ANTONIO JOSÉ RAMÍREZ LONDOÑO

\title{
PRECIPITAÇÃO DE FASES INTERMETÁLICAS E AUSTENITA SECUNDÁRIA NA ZAC DE SOLDAGENS MULTIPASSE DE AÇOS INOXIDÁVEIS DUPLEX
}

\author{
Tese apresentada à Escola Politécnica da \\ Universidade de São Paulo para a obtenção do \\ título de Doutor em Engenharia.
}

SÃO PAULO 


\title{
ANTONIO JOSÉ RAMÍREZ LONDOÑO
}

\section{PRECIPITAÇÃO DE FASES INTERMETÁLICAS E AUSTENITA SECUNDÁRIA NA ZAC DE SOLDAGENS MULTIPASSE DE AÇOS INOXIDÁVEIS DUPLEX}

\author{
Tese apresentada à Escola Politécnica da \\ Universidade de São Paulo para a obtenção do \\ título de Doutor em Engenharia.
}

Área de Concentração:

Engenharia Metalúrgica e de Materiais

Orientador: Prof. Dr. Sérgio Duarte Brandi

SÃO PAULO 
Ramírez-Londoño, Antonio José

Precipitação de fases intermetálicas e austenita secundária na ZAC de soldagens multipasse de aços inoxidáveis duplex. São Paulo, 2001.

$241 \mathrm{p}$.

Tese (Doutorado) - Escola Politécnica da Universidade de São Paulo. Departamento de Engenharia Metalúrgica e de Materiais.

1. Soldagem de aços inoxidáveis duplex. 2. Precipitação de nitreto de cromo e austenita secundária. I. Universidade de São Paulo. Escola Politécnica. Departamento de Engenharia Metalúrgica e de Materiais. II. $\mathrm{t}$ 


\section{AGRADECIMENTOS}

Agradeço sinceramente ao Prof. Dr. Sérgio Duarte Brandi pela inestimável dedicação na orientação desta pesquisa.

Ao Prof. John C. Lippold pela co-orientação deste trabalho e pela cordial acolhida no Welding Metallurgy Group - Welding Eng. Program - The Ohio State University para a utilização do equipamento Gleeble ${ }^{\circledR}$ e para a realização de análises de microscopia eletrônica. Também gostaria de agradece-lhe pelo apoio financeiro para a realização de todas estas análises.

Aos Profs. Célio Taniguchi e André P. Tschiptschin pelos grandes aportes a este trabalho tanto no exame de qualificação como nas diversas discussões tidas ao longo do desenvolvimento da pesquisa.

A todos os integrantes do grupo de soldagem de aços inoxidáveis duplex, os estudantes de Eng. Metalúrgica José Vinicius de Carvalho Gavioli e Francisco de Paula Pinheiro pela enorme colaboração na realização dos ensaios e à M.Sc. Eng. Claudia P. Serna Giraldo pela colaboração na administração do projeto.

À Fundação de Amparo à Pesquisa do Estado de São Paulo (FAPESP), pelo apoio financeiro a traves da bolsa de doutorado (97/05160-1) e do projeto de auxilio a pesquisa (98/02493-2) e aos assessores técnicos da instituição pelos seus valiosos aportes.

À Pró-Reitoria de Pós-Graduação da USP pelo apoio financeiro para a apresentação dos resultados deste trabalho em diversas reuniões cientificas no Brasil, nos EEUU e no México.

À Creusot Loire, pela doação do material $52 \mathrm{~N}^{+}$e os arames de soldagem.

À ACESITA pelas inúmeras análises químicas realizadas, especialmente gostaria de agradecer ao M.Sc. Eng. Ricardo Faria pela sua constante e incondicional ajuda.

Ao Laboratório Nacional de Luz Sincrotron (LNLS), especialmente ao Drs. Daniel Ugarte, Jefferson Bettini e Rogério, e a Paulo, pelo treinamento em microscopia eletrônica e por permitir-me utilizar seus excelentes laboratórios de microscopia eletrónica e de preparação de amostras, assim como por tudo o auxilio prestado durante a realização das análises.

Ao Instituto de Pesquisas Energéticas e Nucleares (IPEN), em particular ao Dr. Waldemar Monteiro e ao Técnico Nildemar por permitir a utilização dos seus equipamentos de microscopia eletrônica e por toda a colaboração prestada durante a utilização dos equipamentos e a análise dos resultados. Também ao Dr. Jesualdo Luís Rossi por permitir a utilização do Lab. de Ensaios Mecânicos.

Ao Electron Microscopy Lab. - Materials Science Dept. - The Ohio State University, especialmente a Cameron Beg, pela colaboração nas análises de microscopia eletrônica. 
Ao Lab. de Caracterização Tecnológica - Dept. Eng. de Minas - Escola Politécnica - USP, especialmente a Antônio Joaquim pela colaboração nas análises de WDS.

Ao Lab. de Processos Eletroquímicos - Dept. Eng. Metalúrgica de Materiais - Escola Politécnica - USP, muito especialmente à Profa. Dra. Neusa Alonso Falleiros pela constante colaboração nos estudos de corrosão desenvolvidos.

Ao Lab. de Análises Térmicas - Dept. Eng. Metalúrgica de Materiais - Escola Politécnica USP, especialmente ao Dr. Alexandre M. Barros, pela realização e colaboração na interpretação das análises térmicas.

A todas as dependências do Departamento de Eng. Metalúrgica e de Materiais - Escola Politécnica - Univ. de São Paulo, os professores, técnicos e servidores que facilitaram a realização deste trabalho. A Márcia, Cristina, Clelia, Ivanete, Lívio, Danilo, Paulão e Rubens pela sua colaboração.

A todos os meus colegas e amigos da pós-graduação tanto na USP como na OSU pela sua colaboração e amizade, em especial aos meus grandes amigos Mane, Alex, Julinho Tasos, Claudia e Risomá.

Às minhas famílias na Colômbia e no Brasil, Luz Helena, Tati, Any, Juanpa, Bibi, Mane e Marcela.

Finalmente quero agradecer a todos aqueles que de certa maneira, ajudaram para que este trabalho fosse concluído. 


\section{CURRÍCULUM VITAE}

\section{ANTONIO JOSÉ RAMÍREZ LONDOÑO}

E-mail: antjosecol@netscape.net

\section{FORMAÇÃO ACADÊMICA}

Candidato a Doutor na Escola Politécnica - Universidade de São Paulo e no Welding Eng. Program -The Ohio State University. 08/1997 - 10/2001

Mestre em Engenharia de Materiais, Escola Politécnica - Universidade de São Paulo. 02/1995 - 08/1997 Dissertação de mestrado: Soldagem de aços inoxidáveis duplex.

Engenheiro Mecânico, Faculdade Nacional de Minas - Universidade Nacional da Colômbia. 02/1987 - 12/1992

Trabalho de formatura: Desenvolvimento de Software de engenharia para aplicação em caldeiraria.

\section{ATIVIDADES PROFISSIONAIS}

Eng. de Riscos. Integral S.A. (Companhia de eng. de consulta especializada no projeto e operação de usinas termo- e hidro-elétricas). Bogotá e Medellín - Colômbia. 01/1994 - 01/1995. Atividades: Coordenou a equipe de engenheiros mecânicos e elétricos em diversos projetos de avaliação de risco e de análise de falha realizados junto as maiores seguradoras da Colômbia e re-seguradoras internacionais.

Eng. de Soldagem e Inspeção. Integral S.A. Medellín - Colômbia. 09/1993 - 01/1994. Atividades: Participou na avaliação de propostas para a reposição de equipamentos em diversas usinas. Coordenou a reparação de turbinas de algumas das maiores usinas da Colômbia.

Eng. de Manutenção. Solla S.A. (Empresa líder no mercado Colombiano na produção e comercialização de rações para animais). 02/1993 - 09/1993. Atividades: Participou na elaboração e implantação do novo programa de manutenção industrial. Coordenou a equipe de manutenção preditiva e participou do projeto e montagem de diversos equipamentos industriais.

Eng. Projetista. D \& F Ltda. (Empresa dedicada ao projeto e fabricação de diversos equipamentos industriais). 06/1992 - 02/1993. Auxiliar de Engenharia. 08/1991 - 06/1992. Participou no projeto, inspeção durante a fabricação e montagem de diversos equipamentos industriais. Responsável pelo projeto de automação do corte de chapa (Trabalho de formatura).

\section{DISTINÇÕES E PRÊMIOS}

Menção de Distinção e Louvor na dissertação de mestrado. 08/1997. Universidade de São Paulo, São Paulo-SP.

Prêmio Lincoln Electric 1996 ao melhor trabalho de metalurgia da soldagem apresentado no XXII Encontro Nacional da Tecnologia da Soldagem - X Congresso latino-americano de Soldagem, Blumenau-SC, Brasil.

Melhor Estudante Graduado do Ano, Departamento de Engenharia Mecânica. 02/1993. Universidade Nacional da Colômbia, Medellín, Colômbia.

Matrícula de Honra - Melhor Aluno do Departamento. Depto. Eng. Mecânica, 1988 e 1989. Universidade Nacional da Colômbia, Medellín, Colômbia.

\section{PUBLICAÇÕES MAIS RELEVANTES}

RAMIREZ, A.J.; BRANDI, S.D.; LIPPOLD, J.C. Relação entre a Temperatura de Resistência Nula e Temperatura Solidus nos Aços Inoxidáveis Duplex. In: III Congresso de Estudantes de Ciências e Engenharia de Materiais do Mercosul, Campina Grande-PB, 2001.

RAMIREZ, A.J.; BRANDI, S.D.; LIPPOLD, J.C. HAZ Precipitação de austenita secundária na ZAC de soldas multipasse de aços inoxidáveis duplex: Estudo a partir de microestruturas simuladas. In: XXV Encontro Nacional de Tecnologia da Soldagem, Curitiba-PR, 2000. Proceedings. Brazil, ABS, 2000.

SERNA, C.P.; RAMIREZ, A.J.; BRANDI, S.D. Precipitação de fases intermetálicas e Cr2N na ZACTB durante a soldagem multipasse dos aços inoxidáveis duplex UNS S32304, UNS S32750 e UNS S32760. In: XXV Encontro Nacional de Tecnologia da Soldagem, Curitiba-PR, 2000. Proceedings. Brazil, ABS, 2000.

SERNA, C.P.; RAMIREZ, A.J.; FALLEIROS, N.A.; BRANDI, S.D. Extração de precipitados de aços inoxidáveis duplex através de técnica eletroquímica. In: Congresso Annual da ABM, Rio de Janeiro-RJ, 2000. Proceedings. Brazil, ABM, 2000. 
RAMIREZ, A.J.; BRANDI, S.D.; LIPPOLD, J.C. HAZ secondary austenite formation in duplex stainless steels during multipass welding. In: $81^{\text {th }}$ Annual AWS Convention, Chicago-IL, 2000. Proceedings. USA, AWS, 2000.

RAMÍREZ, A.J; BRANDI, S.D. Aplication of punctual heat source discrete distribution to simulate multipass welding of duplex stainless steels. In: $80^{\text {th }}$ Annual AWS Welding and Fabrication Convention, Abril 12-15, 1999, St. Louis-MO, Proceedings. USA, AWS, 1999.

RAMíREZ, A.J; Defectos en Soldadura, Abordaje Metalúrgico. Universidad Nacional de Colombia, MedellínColômbia, 104 p., 1998.

RAMÍREZ, A.J; BRANDI, S.D. Modificação da solução de Rosenthal para a equação de fluxo de calor para simulação de soldas multipasse. In: XXIV Encontro Nacional de Tecnologia da Soldagem - XI Congresso latino-americano de Soldagem, Frotaleza-CE-Brasil, 1998. Proceedings-CDRom. Brasil, ABS, 1999.

RAMÍREZ, A.J; BRANDI, S.D. A proposed modification of rosenthal's solution of heat transfer equation to simulate multipass welding of duplex stainless steels. In: Fifth International Conference on Trends in Welding Research, June 1-5, 1998, Pine Mountain, Georgia, Proceedings. USA, ASM, 1998.

RAMÍREZ, A.J; BRANDI, S.D. Intermetallic phases precipitation in simulated multipass low temperature heataffected zone of Duplex Stainless Steels In: $79^{\text {th }}$ American Welding Society Annual Meeting, April 26-30, 1998, Detroit, Michigan, Proceedings. USA, AWS, 1998, p. 220-221.

BRANDI, S.D.; RAMÍREZ, A.J. Precipitation of intermatallic phases in the HAZ of multipass welding of duplex and superduplex stainless steels. In: International Conference Duplex Stainless Steels'97, Maastricht-The Netherlands, 1997. Proceedings. The Netherlands, KCl, 1997, p. 411-418.

RAMÍREZ, A.J; BRANDI, S.D.; TANIGUCHI, C. Simulação da ZAC de uma solda multipasse de aços inoxidáveis duplex: Estudo da precipitação de fases e sua influência no desempenho da junta soldada. In: $23^{\circ}$ Seminário de Inspeção de Equipamentos - COTEQ'97, IBP, Rio de Janeiro-Brasil, 1997. Proceedings. Brasil, IBP, 1997, p. 201-204.

RAMÍREZ, A.J.; BRANDI, S.D. Efeito da adição de nitrogênio no gás de proteção na soldagem do aço inoxidável duplex UNS S31803. Soldagem \& Inspeção - Suplemento Técnico. v. 3, n. 4, p. 1-9, 1997.

RAMíREZ, A.J. Estudo da Precipitação de Nitreto de Cromo e Fase Sigma por Simulação Térmica da Zona Afetada Pelo Calor na Soldagem Multipasse de Aços Inoxidáveis Duplex. São Paulo, $1997.151 \mathrm{p}$. Dissertação (Mestrado) - Departamento de Eng. Metalúrgica, Escola Politécnica, U. de São Paulo.

RAMÍREZ, A.J.; BRANDI, S.D. Estudo da precipitação de fases intermetálicas na ZAC de soldas multipasse de aços inoxidáveis duplex e superduplex. In: V Seminário Brasileiro do Aço Inoxidável - Inox'96, São PauloBrasil, 1996. Proceedings. Brasil, Núcleo Inox, 1996, p. 187-200.

RAMÍREZ, A.J; BRANDI, S.D. Efeito da adição de nitrogênio no gás de proteção na soldagem de aço inoxidável duplex UNS S31803. In: XXII Encontro Nacional de Tecnologia da Soldagem - X Congresso latino-americano de Soldagem, Blumenau-Brasil, 1996. Proceedings. Brasil, ABS, 1996, p. 277-287.

RAMÍREZ, A.J. Cálculo e dibujo por computador de plantillas para el corte de laminas usadas en la fabricación de ductos. Trabalho de formatura, Universidad Nacional de Colombia, Medellín, 1992. 


\section{SUMÁRIO}

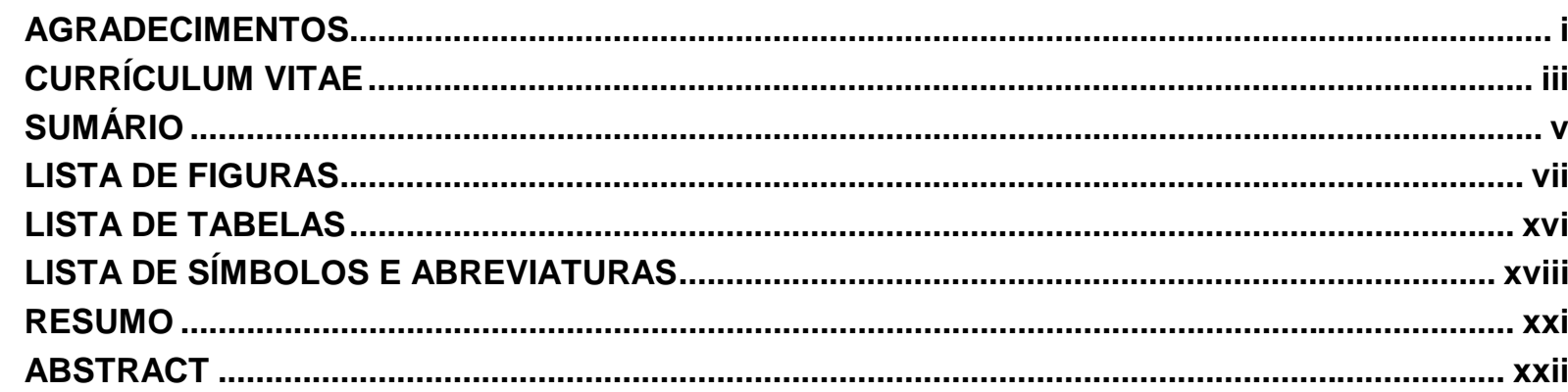

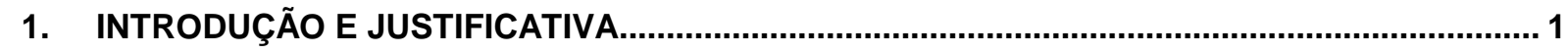

2. TRANSFERÊNCIA DE CALOR NA SOLDAGEM

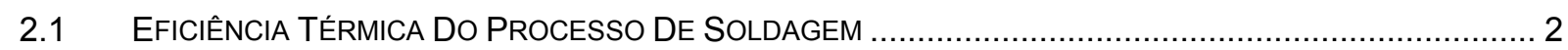

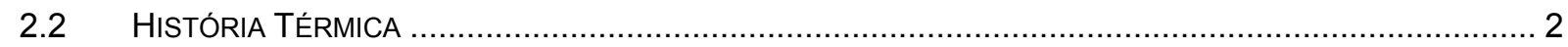

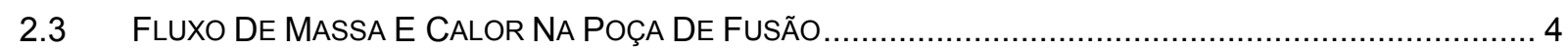

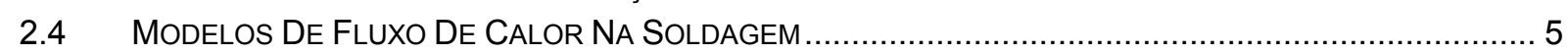

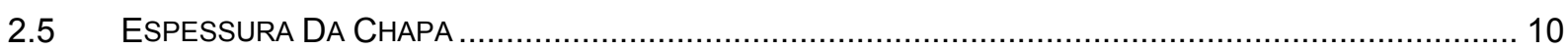

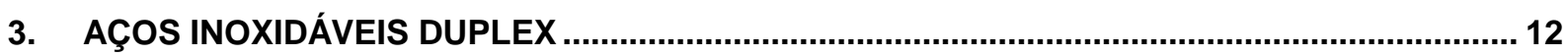

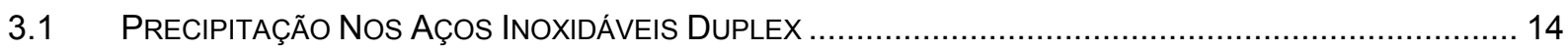

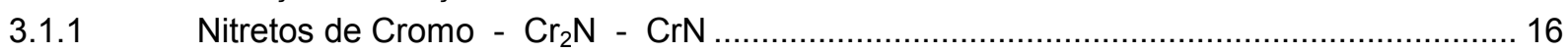

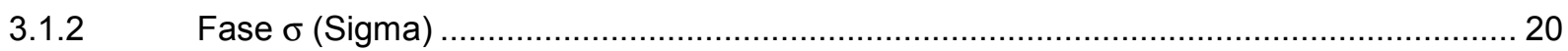

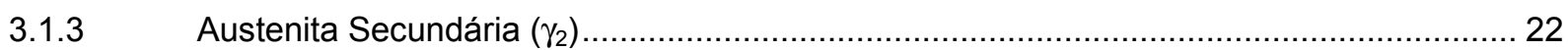

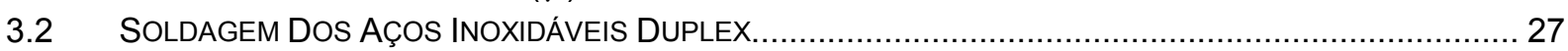

3.2.1 Evolução Microestrutural dos AID Durante a Soldagem................................................. 28

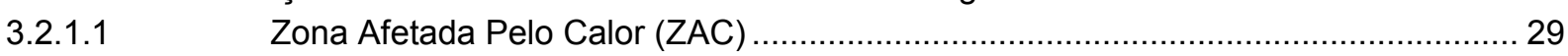

3.2.1.1.1 Zona Afetada Pelo Calor de Temperatura Elevada (ZACTE) ............................... 30

3.2.1.1.2 Zona Afetada Pelo Calor de Temperatura Baixa (ZACTB) ................................ 31

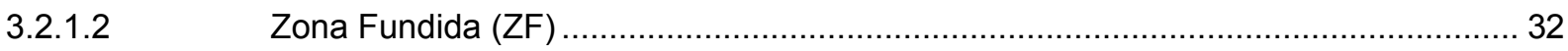

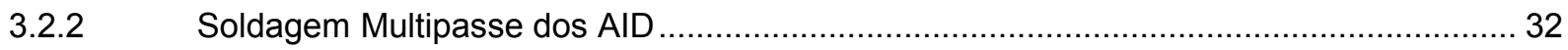

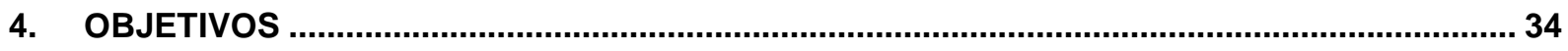

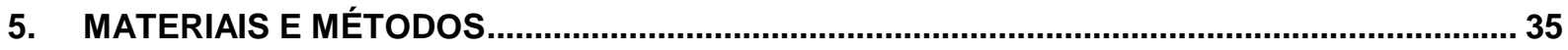

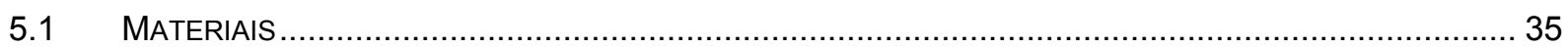

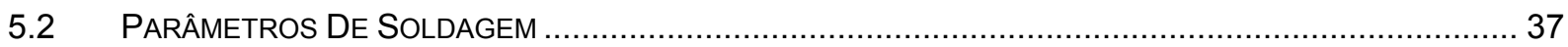

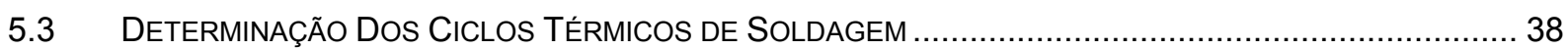

5.3.1 Medidas de Temperatura em Condições Reais de Soldagem ....................................... 38

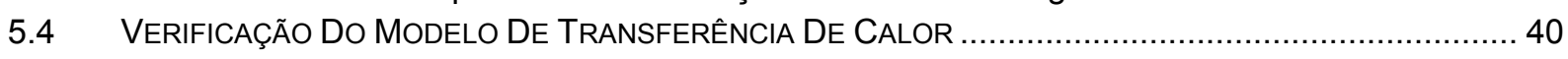

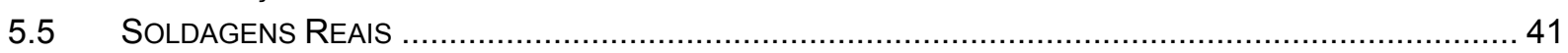

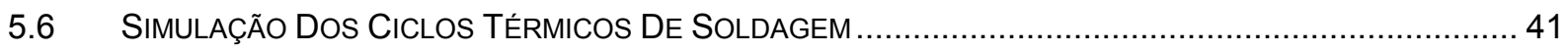

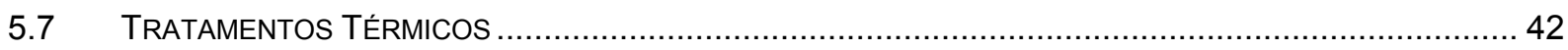

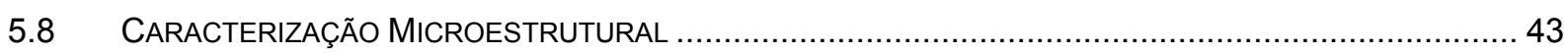

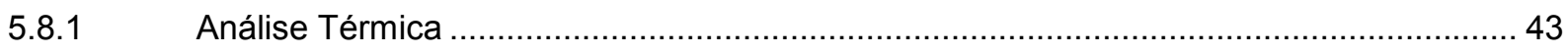

5.8.2 Ensaio de Temperatura de Resistência Nula (TRN) …................................................. 44

5.8.3 Cálculos Termodinâmicos de Equilíbrio entre Fases ........................................................ 44

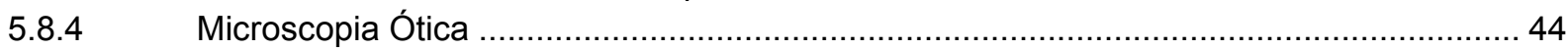

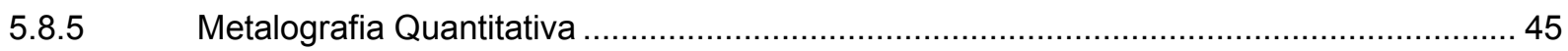

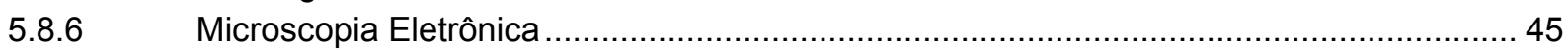

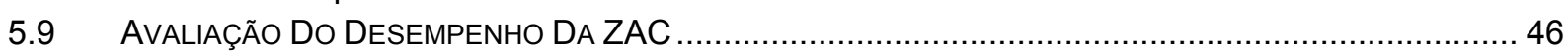

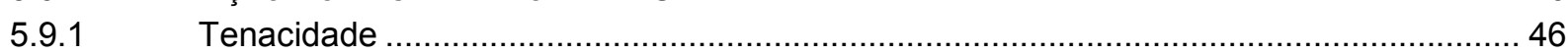




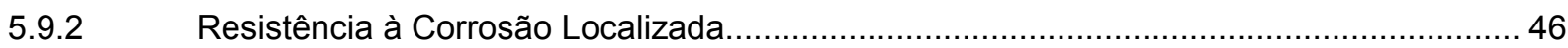

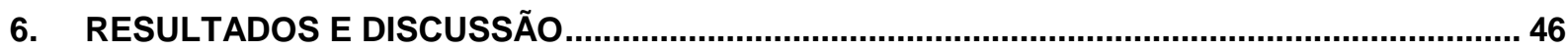

6.1 Modelamento E SIMULAÇÃo Dos CICLOS TÉRMICOS DE SOLDAGEM ......................................... 47

6.1.1 Medida de Temperatura em Condições Reais de Soldagem ........................................ 47

6.1.2 Seleção e Adequação do Modelo de Fluxo de Calor ........................................................ 52

6.1.3 Comparação Entre os Resultados Experimentais e o Modelo ............................................ 54

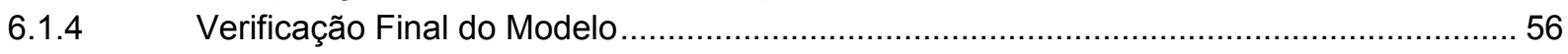

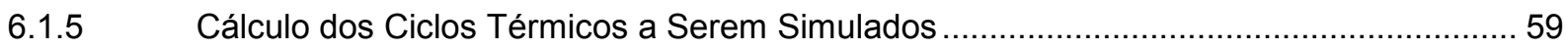

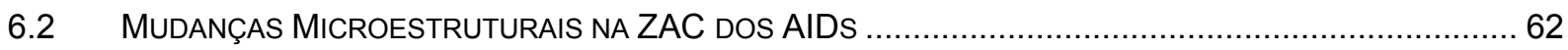

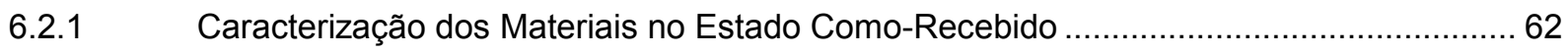

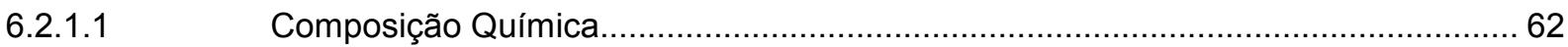

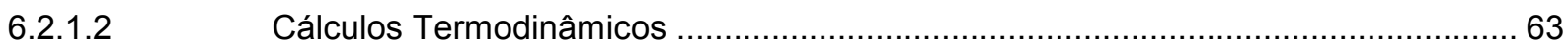

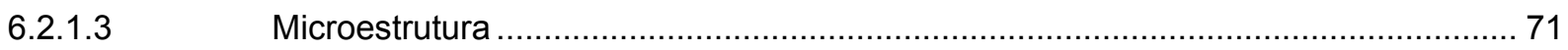

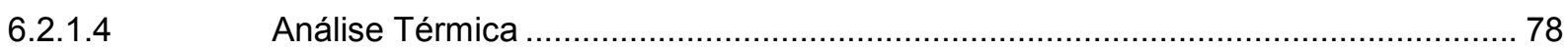

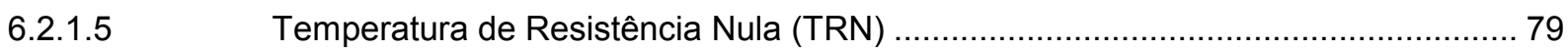

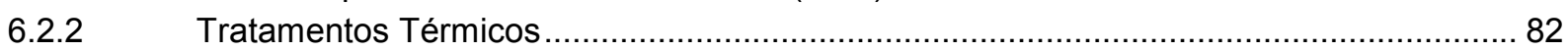

6.2.2.1 Tratamentos Térmicos de Ferritização ............................................................. 82

6.2.2.1.1 Seleção do Tratamento Térmico ................................................................ 82

6.2.2.1.2 Caracterização Microestrutural Detalhada ......................................................... 92

6.2.2.1.2.1 Composição química da ferrita e da austenita ................................................ 92

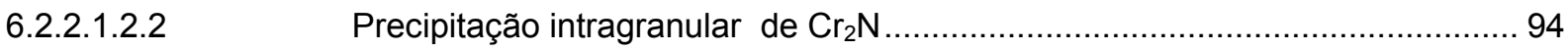

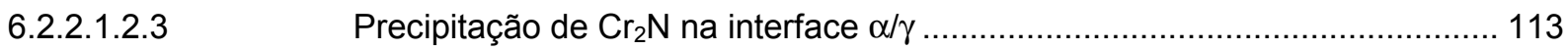

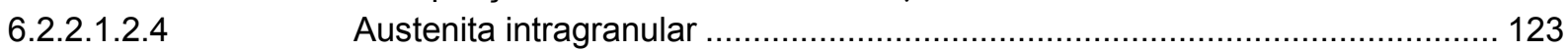

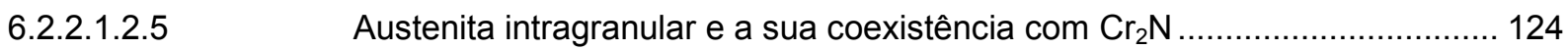

6.2.2.1.2.6 Precipitação de austenita intragranular a partir de inclusões......................... 127

6.2.2.2 Tratamentos Térmicos de Reaquecimento ....................................................... 128

6.2.2.2.1 Precipitação de Austenita Secundária .................................................................. 140

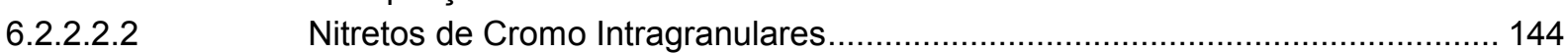

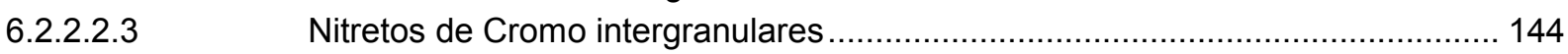

6.2.2.2.4 Austenita intragranular e a sua coexistência com $\mathrm{Cr}_{2} \mathrm{~N}$................................... 152

6.2.2.2.5 Precipitação de austenita intragranular a partir de inclusões .............................. 156

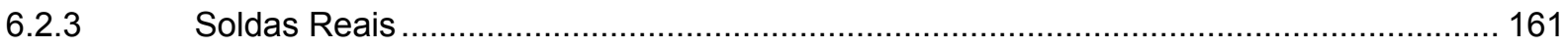

6.2.4 Simulação da ZACTE no Equipamento Gleeble ${ }^{\circledR}$....................................................... 168

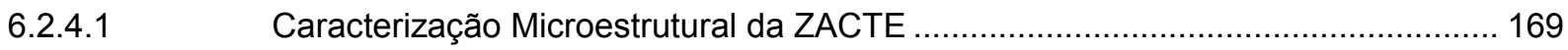

6.3 AVALIAÇÃO DE DESEMPENHO DA ZACTE

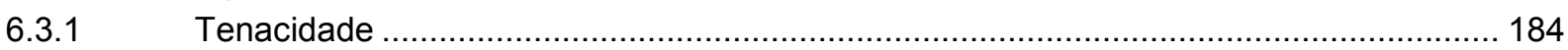

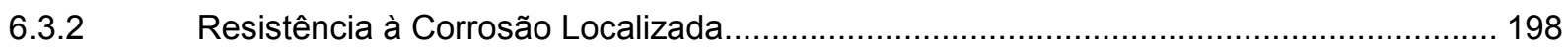

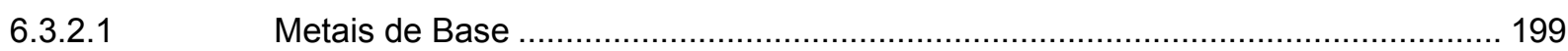

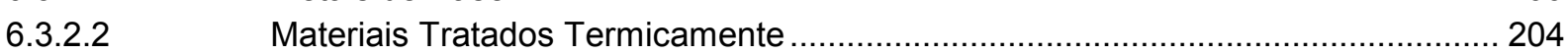

6.3.2.3 Materiais Submetidos à Simulação da ZACTE.................................................... 218

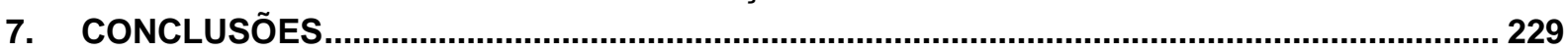

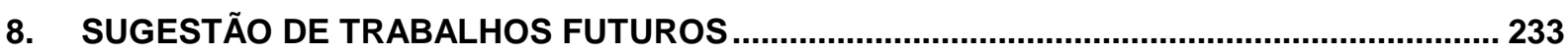

BIBLIOGRAFIA 


\section{LISTA DE FIGURAS}

Figura 1: Ciclos térmicos de soldagem experimentados por diferentes pontos de uma junta soldada.

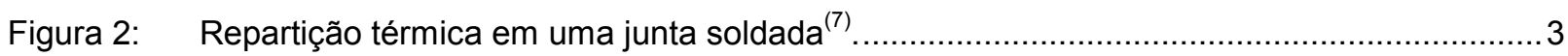

Figura 3: Exemplo dos ciclos térmicos experimentados por um ponto da ZAC perto da raiz de

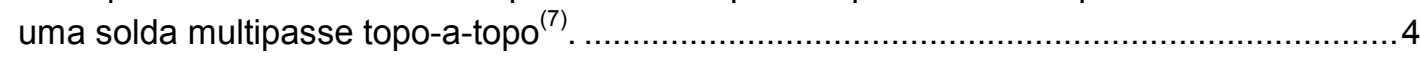

Figura 4: Efeito do padrão de fluxo mássico no formato de uma poça de fusão estacionaria realizada com o processo GTAW ${ }^{(9)}$..................................................................... 5

Figura 5: Coordenadas adotadas para o modelo de fluxo de calor na soldagem............................... 6

Figura 6: Fontes de calor real e imaginárias no caso da chapa de espessura média......................... 8

Figura 7: $\quad$ Modelo geral de fluxo de calor em chapas de espessura média, proposto por MYHR; GRONG ${ }^{(17)}$. Em (a) representação física da distribuição de calor mediante fontes pontuais. Em (b) método de cálculo do campo de temperatura ao redor de uma fonte pontual de calor inserida dentro da chapa.

Figura 8: Formato das isotermas através da espessura da chapa durante a soldagem. Em (a) com fluxo de calor predominantemente bidimensional; em (b) na condição

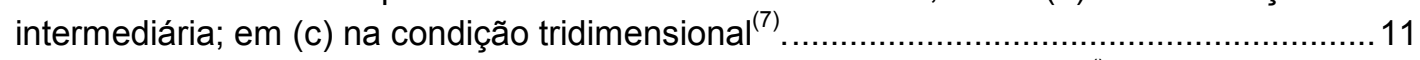

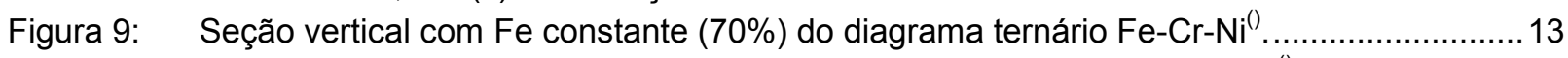

Figura 10: Diagrama TTT esquemático de precipitação de segundas fases nos AID ${ }^{()}$......................... 14

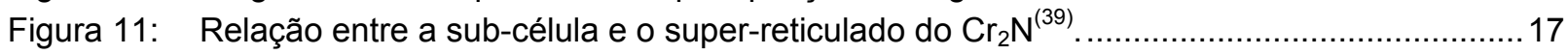

Figura 12: Efeito do teor de nitrogênio e da fração de ferrita na quantidade de $\mathrm{Cr}_{2} \mathrm{~N}$ precipitado na ZAC de um AID ${ }^{(67)}$

Figura 13: Relação entre a energia absorvida no ensaio Charpy $(273 \mathrm{~K})$ e a quantidade de nitretos na ZAC de um AID ${ }^{(67)}$.

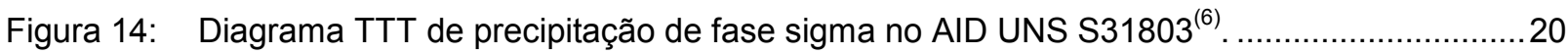

Figura 15: Variação na resistência ao impacto (ensaio Charpy) com o tempo de envelhecimento a $850^{\circ} \mathrm{C}$ das ligas do tipo Fe-22Cr-5,5Ni-0,15 N, com adições de $\mathrm{W}$ e Mo.

Figura 16: Diagrama esquemático mostrando a precipitação cooperativa de $\mathrm{M}_{23} \mathrm{C}_{6}$ e $\gamma_{2}$ a partir da interface $\gamma / \alpha$, seguida da precipitação de $\sigma^{(100)}$.

Figura 17: Precipitação de $\mathrm{M}_{23} \mathrm{C}_{6}$ na interface $\gamma / \alpha$ seguida do crescimento de $\gamma_{2}$ no AID SAF 2205 envelhecido a $800{ }^{\circ} \mathrm{C}$ por 1 hora. $\operatorname{Em~(a)~a~micrografia~eletrônica~de~}$ transmissão com os carbonetos na forma de "larva" precipitados na interface original $\gamma / \alpha$ e o crescimento da $\gamma_{2}$, em (b) o diagrama esquemático da microestrutura ${ }^{(100)} \ldots \ldots \ldots \ldots . . . .24$

Figura 18: Sistema de classificação morfológica proposto por DUBÉ; AARONSON ${ }^{(105)}$.....................25

Figura 19: Diagrama esquemático das mudanças microestruturais acontecidos na junta

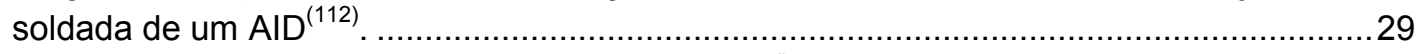

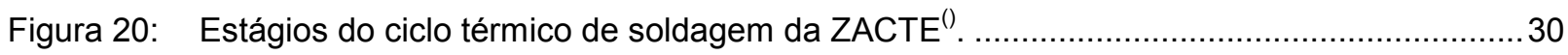

Figura 21: Estágios de um ciclo térmico de soldagem na ZACTB. Em (a) a temperatura máxima acima de $T_{\alpha / \gamma}$ e em (b) dentro do intervalo de precipitação de uma fase ${ }^{(52)}$............32

Figura 22: Geometria da junta soldada. Em (a) preparação da junta e em (b) a junta já

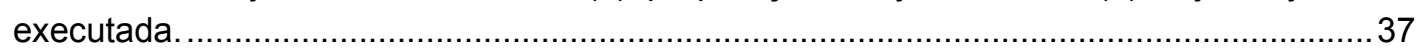

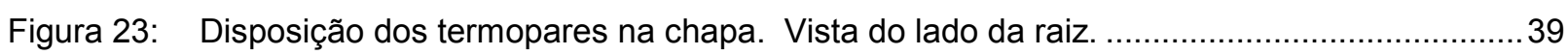

Figura 24: Arranjo experimental utilizado para medir a temperatura durante a soldagem. ..................40

Figura 25: Vista superior da unidade de simulação do equipamento Gleeble ${ }^{\circledR} 1500 \mathrm{com}$ a

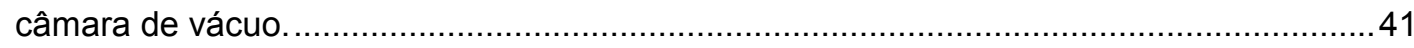

Figura 26: Detalhe da montagem do corpo de prova na unidade de simulação do equipamento Gleeble $^{\circledR} 1500$. 
Figura 27: Ciclos térmicos reais do primeiro passe. Termopares 1,2 e 3 da experiência 3...............49

Figura 28: Ciclos térmicos reais do segundo passe. Termopares 1,2 e 3 da experiência $3 \ldots \ldots \ldots \ldots \ldots . . . .49$

Figura 29: Ciclos térmicos reais do terceiro passe. Termopares 1,2 e 3 da experiência 3...............49

Figura 30: Variação da temperatura máxima com a distância à linha de centro. .................................51

Figura 31: Variação da temperatura máxima com a profundidade do chanfro. ....................................51

Figura 32: Distribuição de fontes de calor no modelo de transferência de calor. .................................53

Figura 33: Comparação entre os ciclos térmicos experimentais (experiência 5) e os calculados segundo o modelo proposto neste trabalho. Pontos a 1,3 e $5 \mathrm{~mm}$ da linha de centro do cordão.

Figura 34: Comparação entre os ciclos térmicos experimentais (experiência 5) e os calculados segundo o modelo proposto neste trabalho. Ponto a $10 \mathrm{~mm}$ da linha de centro do cordão.

Figura 35: Comparação entre os ciclos térmicos de soldagem experimentais medidos no AID UNS S32304 e os calculados segundo o modelo proposto neste trabalho. Pontos a 1,5 e $5 \mathrm{~mm}$ da linha de centro do cordão.

Figura 36: Comparação entre os ciclos térmicos de soldagem experimentais medidos no AID UNS S32304 e os calculados segundo o modelo proposto neste trabalho. Ponto a $10 \mathrm{~mm}$ da linha de centro do cordão.

Figura 37: Ciclos térmicos de soldagem da região da ZACTE com temperatura máxima no primeiro passe de $1400{ }^{\circ} \mathrm{C}$. Estes ciclos foram simulados com energias de soldagem de 0,$6 ; 0,8$ e $1,0 \mathrm{~kJ} / \mathrm{mm}$.

Figura 38: AID UNS S32304, em (a) diagrama de fase pseudo-binário, onde a linha tracejada indica a composição da liga; em (b) variação da fração molar da fases em equilíbrio com a temperatura.

Figura 39: AID UNS S32205, em (a) diagrama de fase pseudo-binário, onde a linha tracejada indica a composição da liga; em (b) variação da fração molar da fases em equilíbrio com a temperatura.

Figura 40: AID UNS S32550, em (a) diagrama de fase pseudo-binário, onde a linha tracejada indica a composição da liga; em (b) variação da fração molar da fases em equilíbrio com a temperatura.

Figura 41: AID UNS S32750, em (a) diagrama de fase pseudo-binário, onde a linha tracejada indica a composição da liga; em (b) variação da fração molar da fases em equilíbrio com a temperatura.

Figura 42: AID UNS S32760, em (a) diagrama de fase pseudo-binário, onde a linha tracejada indica a composição da liga; em (b) variação da fração molar da fases em equilíbrio com a temperatura.

Figura 43: Variação da fração volumétrica das fases em equilíbrio com a temperatura, para as ligas em estudo.

Figura 44: Microestrutura do AID UNS S32304, no estado como-recebido. Microscopia ótica, ataque eletrolítico com solução de $40 \%$ vol de $\mathrm{HNO}_{3}$. 200X.

Figura 45: Microestrutura do AID UNS S32205, no estado como-recebido. Microscopia ótica, ataque eletrolítico com solução de $40 \%$ vol de $\mathrm{HNO}_{3}$. 200X.............................................72

Figura 46: Microestrutura do AISD UNS S32550, no estado como-recebido. Microscopia ótica, ataque eletrolítico com solução de $40 \%$ vol de $\mathrm{HNO}_{3}$. 200X ............................................72

Figura 47: Microestrutura do AISD UNS S32750, no estado como-recebido. Microscopia ótica, ataque eletrolítico com solução de $40 \%$ vol de $\mathrm{HNO}_{3}$. 200X ...........................................73

Figura 48: Microestrutura do AISD UNS S32760, no estado como-recebido. Microscopia ótica,

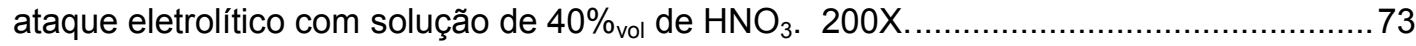

Figura 49: Microestrutura dos AID (a) UNS S32304 e (b) UNS S32205, no estado comorecebido. Microscopia eletrônica de transmissão. 
Figura 50: Microestrutura dos AISD (a) UNS S32550 e (b) UNS S32760, no estado comorecebido. Microscopia eletrônica de transmissão.

Figura 51: Microestrutura do AISD UNS S32750, no estado como-recebido. Microscopia

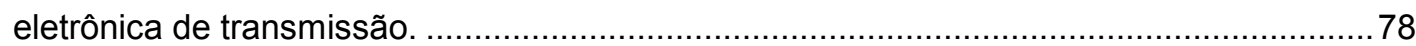

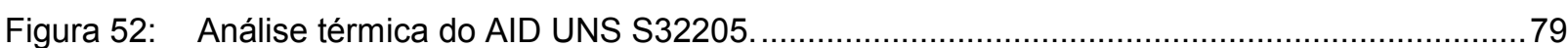

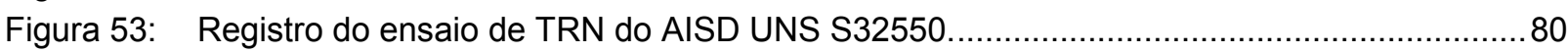

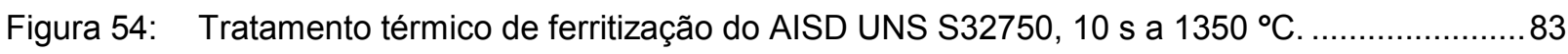

Figura 55: Tamanho de grão ferrítico dos C/P submetidos a TT de ferritização. ................................. 84

Figura 56: Fração volumétrica de austenita dos C/P submetidos a TT de ferritização........................... 86

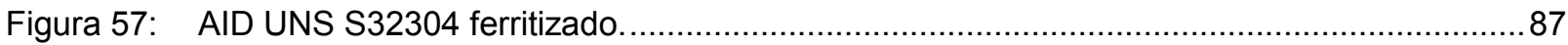

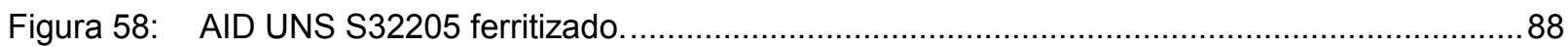

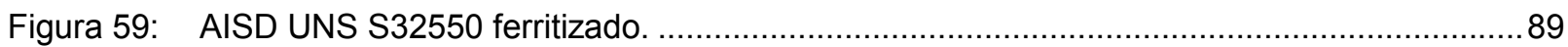

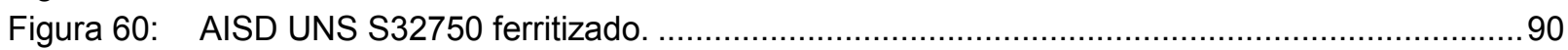

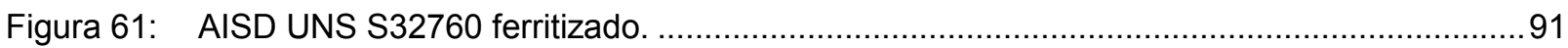

Figura 62: Colônias de $\mathrm{Cr}_{2} \mathrm{~N}$ no interior da ferrita. AID UNS S32205. MEV-EC ..................................94

Figura 63: Colônias de $\mathrm{Cr}_{2} \mathrm{~N}$ no interior da ferrita. AID UNS S32304. MEV-EC .................................94

Figura 64: Colônias de $\mathrm{Cr}_{2} \mathrm{~N}$ no interior da ferrita. AISD UNS S32550. MEV-EC ...............................95

Figura 65: Colônias de $\mathrm{Cr}_{2} \mathrm{~N}$ no interior da ferrita. AISD UNS S32750. MEV-EC ...............................95

Figura 66: Colônias de $\mathrm{Cr}_{2} \mathrm{~N}$ no interior da ferrita. AISD UNS S32760. MEV-EC ..............................95

Figura 67: Precipitação de $\mathrm{Cr}_{2} \mathrm{~N}$ no interior da ferrita. AID UNS S32205. MET ................................96

Figura 68: (a) Bastonete de $\mathrm{Cr}_{2} \mathrm{~N}$ precipitado no interior da ferrita no AID UNS S32304 com a sua respectiva (b) difração de área selecionada e (c) difração com feixe convergente, ambas com o feixe paralelo à direção [0001] do $\mathrm{Cr}_{2} \mathrm{~N}$.

Figura 69: Precipitação de $\mathrm{Cr}_{2} \mathrm{~N}$ ao longo de sub-contornos de grão ferríticos. Em (a) AISD UNS S32750, MEV-EC. Em (b) AID UNS S32205, MET..............................................97

Figura 70: Precipitação de $\mathrm{Cr}_{2} \mathrm{~N}$ no interior da ferrita. AID UNS S32304. MET . ...............................98

Figura 71: Difração de elétrons de área selecionada de diferentes partículas mostrando a relação de orientação $\mathrm{Cr}_{2} \mathrm{~N} / \boldsymbol{\alpha}$, conforme reportada por KOKAWA et al. ${ }^{(58)}$ ou de outro tipo. AID UNS S32304. $1350^{\circ} \mathrm{C}$ por $5 \mathrm{~s}$.

Figura 72: Relação de orientação $\mathrm{Cr}_{2} \mathrm{~N} / \boldsymbol{\alpha}$. Padrão de difração de elétrons e a sua devida indexação. AID UNS S32550. $1350^{\circ} \mathrm{C}$ por $5 \mathrm{~s}$.

Figura 73: Equivalência entre os reticulados trigonal e hexagonal compacto (hcp) do $\mathrm{Cr}_{2} \mathrm{~N}^{(132)} \ldots \ldots . .100$

Figura 74: Relação de orientação $\mathrm{Cr}_{2} \mathrm{~N} / \boldsymbol{\alpha}$. Em (a) imagem do reticulado da interface $\mathrm{Cr}_{2} \mathrm{~N} / \boldsymbol{\alpha}$, na qual é aparente a relação de orientação onde os planos paralelos são os mais compactos das duas fases, (110) $\alpha$ e $(0001) \mathrm{Cr}_{2} \mathrm{~N}$. Em (b) imagem do reticulado filtrada. Em (c) e (d) a transformada de Fourier (equivalente ao padrão de difração de elétrons) da imagem do reticulado e a sua devida indexação. Segundo o padrão de difração existe um pequeno giro de aprox. $1^{\circ}$, ao redor do eixo [ $\left.\overline{1} 100\right]$, entre os planos paralelos. AID UNS S32550. $1350^{\circ} \mathrm{C}$ por $5 \mathrm{~s}$.

Figura 75: Relação de orientação $\mathrm{Cr}_{2} \mathrm{~N} / \boldsymbol{\alpha}$. Em (a) imagem do reticulado da interface $\mathrm{Cr}_{2} \mathrm{~N} / \boldsymbol{\alpha}$, na qual é aparente a relação de orientação onde os planos paralelos são os mais compactos das duas fases, (110) $\alpha$ e $(0001) \mathrm{Cr}_{2} \mathrm{~N}$. Em (b) imagem do reticulado filtrada. Em (c) e (d) a transformada de Fourier (equivalente ao padrão de difração de elétrons) da imagem do reticulado e a sua devida indexação. AID UNS S32550. $1350^{\circ} \mathrm{C}$ por $5 \mathrm{~s}$.

Figura 76: Detalhe das partículas de $\mathrm{Cr}_{2} \mathrm{~N}$ e das regiões das mesmas a partir das quais foram obtidas as imagens de reticulado mostradas nas (a) Figura 74 (b) Figura 75. AISD UNS S32550. 
Figura 77: Difração de elétrons de área selecionada de uma partícula intragranular de $\mathrm{Cr}_{2} \mathrm{~N}$ que apresenta uma relação de orientação $\mathrm{Cr}_{2} \mathrm{~N} / \boldsymbol{\alpha}$. Segundo o padrão de difração existe um pequeno giro de $1,2^{\circ}$ entre os planos paralelos ao redor do eixo [0001]. AID UNS S32304. $1350^{\circ} \mathrm{C}$ por $5 \mathrm{~s}$.

Figura 78: Difração de elétrons de área selecionada de uma partícula intragranular de $\mathrm{Cr}_{2} \mathrm{~N}$ que apresenta uma relação de orientação $\mathrm{Cr}_{2} \mathrm{~N} / \alpha$. Neste caso os planos são perfeitamente paralelos. AID UNS S32304. $1350^{\circ} \mathrm{C}$ por $5 \mathrm{~s}$.

Figura 79: Imagem de reticulado da interface $\mathrm{Cr}_{2} \mathrm{~N} / \alpha$ na qual os planos (110) $\alpha$ não são paralelos com os planos $(0001) \mathrm{Cr}_{2} \mathrm{~N}$. AID UNS S32304. $1350^{\circ} \mathrm{C}$ por $5 \mathrm{~s}$.

Figura 80: Precipitados intragranulares de $\mathrm{Cr}_{2} \mathrm{~N}$. Detalhe da região a partir da qual foi feita a imagem de reticulado mostrada na Figura 79. AID UNS S32304.

Figura 81: Bastonete intragranular de $\mathrm{Cr}_{2} \mathrm{~N}$ apresentando franjas de Moiré. Em (a) vista geral, (b) imagem de reticulado da interface $\mathrm{Cr}_{2} \mathrm{~N} / \alpha$ e (c) detalhe das franjas de Moiré. AID UNS S32304. $1350^{\circ} \mathrm{C}$ por $5 \mathrm{~s}$.

Figura 82: Imagens de reticulado da ferrita (a) e do $\mathrm{Cr}_{2} \mathrm{~N}$ (b) e as suas respectivas transformadas de Fourier em (c) e (d).

Figura 83: Bastonetes de $\mathrm{Cr}_{2} \mathrm{~N}$ precipitados no interior da ferrita no AISD UNS S32550. MEVEC.

Figura 84: Micrografias de alta resolução dos bastonetes de $\mathrm{Cr}_{2} \mathrm{~N}$, com formato bifurcado, precipitados no interior da ferrita e da austenita. AISD UNS S32760. MEV-EC...............110

Figura 85: Precipitação de $\mathrm{Cr}_{2} \mathrm{~N}$ no interior da ferrita. AID UNS S32760. MET . ..............................111

Figura 86: Precipitado bifurcado de $\mathrm{Cr}_{2} \mathrm{~N}$ no interior da ferrita. AID UNS S32760. MET...................111

Figura 87: Precipitação na interface $\gamma / \alpha$. AID UNS S32304. MEV-EC. ........................................... 113

Figura 88: Interface $\alpha / \gamma$ decorada com precipitados de $\mathrm{Cr}_{2} \mathrm{~N}$. AID UNS S32304. MET....................114

Figura 89: Partícula de $\mathrm{Cr}_{2} \mathrm{~N}$ precipitada na interface $\alpha / \gamma$ identificada mediante difração de elétrons com feixe convergente. AID UNS S32304. MET.

Figura 90: Interface $\alpha / \gamma$ decorada com precipitados de $\mathrm{Cr}_{2} \mathrm{~N}$ e detalhe das franjas de Moiré formadas pelos precipitados. AID UNS S32304. MET.

Figura 91: $\mathrm{Cr}_{2} \mathrm{~N}$ precipitado na interface $\alpha / \gamma$, apresentando uma clara relação de orientação com a ferrita. UNS S32304. MET.

Figura 92: Interface $\alpha / \gamma$ decorada com precipitados de $\mathrm{Cr}_{2} \mathrm{~N}$. UNS S32550. MET...........................117

Figura 93: Precipitados de $\mathrm{Cr}_{2} \mathrm{~N}$ na interface $\alpha / \gamma$. AISD UNS S32550. MET. ...................................118

Figura 94: Padrão de difração de elétrons dos precipitados intragranulares de $\mathrm{Cr}_{2} \mathrm{~N}$ mostrados nas duas figuras anteriores. Relação de orientação $\mathrm{Cr}_{2} \mathrm{~N} / \alpha / \gamma$. AISD UNS $\mathrm{S} 32550$. MET.

Figura 95: Esquema dos lugares onde foram feitas as análises químicas ao longo da interface $\alpha / \gamma$. UNS S32304. EDS - MET.

Figura 96: Perfil de composição química da fração metálica ao longo da interface $\alpha / \gamma$. Em (a) Interface contendo precipitado de $\mathrm{Cr}_{2} \mathrm{~N}$ e em (b) interface livre de precipitados. AID UNS S32304 tratado a $1350^{\circ} \mathrm{C}$ por $5 \mathrm{~s}$. EDS-MET.

Figura 97: Partículas de austenita Intragranular. AID UNS S32205. MET......

Figura 98: Partícula de $\gamma$ intragranular apresentando precipitados na sua interface. AISD UNS S32550. MEV-EC.

Figura 99: Partícula de $\gamma$ intragranular com precipitados na sua interface. Um bastonete de $\mathrm{Cr}_{2} \mathrm{~N}$, corta a interface, mostrando-se intimamente ligado, tanto à matriz de $\alpha$, como à partícula de $\gamma$. AISD UNS S32760. MEV-EC.

Figura 100: Partícula de $\gamma$ intragranular contendo bastonetes de $\mathrm{Cr}_{2} \mathrm{~N}$ no seu interior. Os bastonetes de $\mathrm{Cr}_{2} \mathrm{~N}$ apresentam uma bifurcação no seu extremo. AISD UNS S32760. MEV-EC. 
Figura 101: Precipitação de austenita intragranular a partir de uma inclusão rica em $\mathrm{O}, \mathrm{Mg}, \mathrm{Al}$ e Ce. AISD UNS S32760...

Figura 102: Espectro de raios $X$ correspondente à inclusão mostrada na figura anterior. Tensão de aceleração 20kV. AISD UNS S32760.

Figura 103: Tratamento térmico de reaquecimento do AISD $2507,1 \mathrm{~s}$ a $1200^{\circ} \mathrm{C} . \ldots \ldots \ldots \ldots \ldots \ldots \ldots \ldots . . . . . . . . . . . . .128$

Figura 104: Variação da fração volumétrica de austenita com a temperatura e tempo to TT de reaquecimento

Figura 105: Microestruturas do AID UNS S32304 correspondentes aos tratamentos térmicos de reaquecimento a $1200,1100,1000$ e $900^{\circ} \mathrm{C}$ por 1 e $10 \mathrm{~s}$

Figura 106: Microestruturas do AID UNS S32205 correspondentes aos tratamentos térmicos de reaquecimento a $1200,1100,1000$ e $900^{\circ} \mathrm{C}$ por 1 e $10 \mathrm{~s}$.

Figura 107: Microestruturas do AISD UNS S32550 correspondentes aos tratamentos térmicos de reaquecimento a $1200,1100,1000$ e $900^{\circ} \mathrm{C}$ por 1 e $10 \mathrm{~s}$.

Figura 108: Microestruturas do AISD UNS S32750 correspondentes aos tratamentos térmicos de reaquecimento a $1200,1100,1000$ e $900^{\circ} \mathrm{C}$ por 1 e $10 \mathrm{~s}$

Figura 109: Microestruturas do AISD UNS S32760 correspondentes aos tratamentos térmicos de reaquecimento a $1200,1100,1000$ e $900^{\circ} \mathrm{C}$ por 1 e $10 \mathrm{~s}$.

Figura 110: Efeito do tamanho de grão na precipitação de ferrita acicular nos aços altaresistência-baixa-liga ().

Figura 111: Diferenciação entre $\gamma_{1}$ e $\gamma_{2}$ no AID UNS S32205. Em (a) contornos de partículas de $\gamma_{1}$ após tratamento de ferritização a $1350{ }^{\circ} \mathrm{C}$ por $5 \mathrm{~s}$. Em (b) crescimento de $\gamma_{2}$ a partir de partículas preexistentes de $\gamma_{1}$, após reaquecimento a $1000{ }^{\circ} \mathrm{C}$ por $1 \mathrm{~s}$. MEV-EC.

Figura 112: Diferenciação entre $\gamma_{1}$ e $\gamma_{2}$ no AID UNS S32205 após reaquecimento a $1000^{\circ} \mathrm{C}$ por 1 s. MEV-EC.

Figura 113: Falta de uniformidade na camada de $\gamma_{2}$ ao redor das partículas de $\gamma_{1}$. AISD UNS S32750 reaquecido a $1000^{\circ} \mathrm{C}$ por $1 \mathrm{~s}$. MEV-EC.

Figura 114: Camada de $\boldsymbol{\gamma}_{2}$ ao redor de placas laterais de Widmanstätten de $\boldsymbol{\gamma}_{1}$. AID UNS S32205 reaquecido a $1000^{\circ} \mathrm{C}$ por $1 \mathrm{~s}$. MEV-EC.

Figura 115: Bastonete bifurcado de $\mathrm{Cr}_{2} \mathrm{~N}$ próximo a uma partícula de $\gamma_{2}$ intragranular bastante pequena. AISD UNS S32750 reaquecido a $1000^{\circ} \mathrm{C}$ por $1 \mathrm{~s}$. MEV-EC.

Figura 116: Precipitação de partículas de segunda fase na interface $\gamma_{1} / \alpha$. AISD UNS S32760 reaquecido a $1000^{\circ} \mathrm{C}$ por $1 \mathrm{~s}$. Em (a) vista geral e em (b) detalhe das fases precipitadas. MEV-EC

Figura 117: Precipitação de partículas de segunda fase na interface $\gamma_{1} / \alpha$. AISD UNS S32550 reaquecido a $1000{ }^{\circ} \mathrm{C}$ por $1 \mathrm{~s}$. Em (a) vista geral e em (b) detalhe das fases precipitadas. MEV-EC.

Figura 118: Precipitação de partículas de segunda fase na interface $\gamma_{1} / \alpha$. AISD UNS S32205 reaquecido a $900^{\circ} \mathrm{C}$ por $1 \mathrm{~s}$. MEV-EC

Figura 119: Precipitação de partículas de segunda fase na interface $\boldsymbol{\gamma}_{1} / \boldsymbol{\alpha}$. AISD UNS S32550 reaquecido a $900^{\circ} \mathrm{C}$ por $1 \mathrm{~s}$. MEV-EC.

Figura 120: Precipitação de partículas de segunda fase na interface $\gamma_{1} / \alpha$. AISD UNS S32750 reaquecido a $900^{\circ} \mathrm{C}$ por $1 \mathrm{~s}$. MEV-EC.

Figura 121: Precipitação de partículas de segunda fase na interface $\gamma_{1} / \alpha$. AISD UNS S32760 reaquecido a $900^{\circ} \mathrm{C}$ por $1 \mathrm{~s}$. MEV-EC.

Figura 122: Precipitação de partículas de segunda fase no limite entre a $\gamma_{1}$ e a $\gamma_{2}$. AISD UNS S32550 reaquecido a $1000^{\circ} \mathrm{C}$ por $1 \mathrm{~s}$. MEV-EC. 
Figura 123: Precipitação de partículas de segunda fase no limite entre a $\boldsymbol{\gamma}_{1}$ e a $\gamma_{2}$. AISD UNS S32760 reaquecido a $1000^{\circ} \mathrm{C}$ por $1 \mathrm{~s}$. MEV-EC.

Figura 124: Interferência de precipitados crescendo. Em (a) superposição dos campos de difusão e em (b) precipitados pararam de crescer ${ }^{(136)}$.

Figura 125: Diagrama esquemático mostrando a precipitação cooperativa de $\mathrm{Cr}_{2} \mathrm{~N}$ e $\gamma_{2}$ a partir da interface $\alpha / \gamma$, seguida da dissolução do Cr2N.

Figura 126: Diagrama esquemático mostrando os caminhos de difusão na precipitação cooperativa do $\mathrm{Cr}_{2} \mathrm{~N}$ e a $\gamma_{2}$.

Figura 127: Colônia de $\gamma_{2}$ intragranular apresentando orientação preferencial. AID UNS S32205 reaquecido a $1000^{\circ} \mathrm{C}$ por $1 \mathrm{~s}$. MEV-EC.

Figura 128: Colônia de $\gamma_{2}$ intragranular apresentando orientação preferencial. AID UNS S32750 reaquecido a $1000^{\circ} \mathrm{C}$ por $1 \mathrm{~s}$. MEV-EC.

Figura 129: Colônia de $\gamma_{1}$ e $\gamma_{2}$ intragranular apresentando orientação preferencial. AISD UNS S32760 reaquecido a $1000^{\circ} \mathrm{C}$ por $1 \mathrm{~s}$. MEV-EC.

Figura 130: Coexistência de $\mathrm{Cr}_{2} \mathrm{~N}$ e $\gamma$ intragranular nos AIDs UNS S32205, S32550, S32750 e S32760 reaquecidos a $1000{ }^{\circ} \mathrm{C}$ por $1 \mathrm{~s}$. Detalhe de colônias de austenitas secundárias intragranulares. MEV-EC.

Figura 131: Detalhe da coexistência de $\mathrm{Cr}_{2} \mathrm{~N}$ e $\gamma_{2}$ intragranular nos AIDs UNS S32205, S32550, S32750 e $\mathrm{S} 32760$ reaquecidos a $1000^{\circ} \mathrm{C}$ por 1 s. MEV-EC.

Figura 132: Detalhe da precipitação de $\gamma_{2}$ intragranular a partir de nitretos de cromo intragranulares. AISD UNS $S 32750$ reaquecido a $1000^{\circ} \mathrm{C}$ por $1 \mathrm{~s}$. MEV-EC.

Figura 133: Partícula de $\boldsymbol{\gamma}$ intragranular com buracos deixados por partículas de segunda fase removidas durante a preparação do CP. AID UNS S32205 reaquecido a $1000{ }^{\circ} \mathrm{C}$ por $1 \mathrm{~s}$. MEV-EC.

Figura 134: Precipitação de $\gamma_{1}$ intragranular a partir de uma inclusão do tipo $53,4 \%_{a t} \mathrm{O}-31,3 \%_{\mathrm{at}}$ Al-15,3\% at Mg. Parte da inclusão foi dissolvida ou removida durante a preparação do CP. AID UNS S32205. MEV-EC...

Figura 135: Precipitação de $\boldsymbol{\gamma}_{1}$ intragranular a partir de uma inclusão do tipo $51,9 \%_{\text {at }} \mathrm{O}-32,2 \%_{\text {at }}$ $\mathrm{Al}-14,7 \%_{\text {at }} \mathrm{Mg}-1,1 \%_{\text {at }}$ Ce. AISD UNS S32760. MEV-EC.

Figura 136: Precipitação de $\gamma_{1}$ intragranular a partir de uma inclusão do tipo $58,2 \%_{\text {at }}$ O- $21,7 \%_{\text {at }}$ $\mathrm{Al}-18,6 \%$ at $\mathrm{Ce}-1,6 \%$ at Mg. AISD UNS S32760. MEV-EC.

Figura 137: Precipitação de $\boldsymbol{\gamma}_{1}$ intragranular a partir de uma inclusão composta, rica em $\mathrm{O}, \mathrm{Al}, \mathrm{Ce}$ e Mg. AISD UNS S32760. MEV-EC.

Figura 138: Mapeamento por pontos mostrando a distribuição dos elementos $\mathrm{O}, \mathrm{Mg}, \mathrm{Al}$ e Ce na inclusão mostrada na Figura 137. EDS a 10kV. AISD UNS S32760. MEV-EC.

Figura 139: Precipitação de $\gamma_{2}$ intragranular a partir de uma inclusão composta rica em $\mathrm{O}, \mathrm{Al}, \mathrm{Mg}$ e Ca, durante o reaquecimento do AID UNS S32205 a $1000{ }^{\circ} \mathrm{C}$ por $1 \mathrm{~s}$. Mapeamento por pontos mostrando a distribuição dos elementos $\mathrm{O}, \mathrm{Al}, \mathrm{Mg}$ e Ca na inclusão mostrada. EDS a 10kV. MEV-EC.

Figura 140: Precipitação de $\gamma_{2}$ intragranular a partir de uma inclusão rica em O, Al, Mg e Ce. AISD UNS S32760. MEV-EC.

Figura 141: Seção transversal das soldas reais de: a. UNS S32205-0,6 kJ/mm; b. UNS S322050,8 kJ/mm; c. UNS S32205-1,0 kJ/mm; d. UNS S32304-0,6 kJ/mm; e. UNS S32304$0,8 \mathrm{~kJ} / \mathrm{mm} ; \mathrm{f}$. UNS S32304-1,0 kJ/mm.

Figura 142: Seção transversal das soldas reais de: a. UNS S32550-0,6 kJ/mm; b. UNS S325500,8 kJ/mm; c. UNS S32550-1,0 kJ/mm; d. UNS S32570-0,6 kJ/mm; e. UNS S32570$0,8 \mathrm{~kJ} / \mathrm{mm} ; \mathrm{f}$. UNS S32570-1,0 kJ/mm.

Figura 143: Seção transversal das soldas reais de: a. UNS S32760-0,6 kJ/mm; b. UNS S 32760$0,8 \mathrm{~kJ} / \mathrm{mm}$; c. UNS S $32760-1,0 \mathrm{~kJ} / \mathrm{mm}$ 
Figura 144: Microestrutura da ZACTE na região da raiz na junta soldada dos AIDs UNS S32304 e S32205. Energias de soldagem de 0,6-0,8-1,0 kJ/mm. MO.

Figura 145: Microestrutura da ZACTE na região da raiz na junta soldada dos AISDs UNS S32550 e S32750. Energias de soldagem de 0,6-0,8-1,0 kJ/mm. MO.

Figura 146: Microestrutura da ZACTE na região da raiz na junta soldada do AISD UNS S32760. Energias de soldagem de $0,6-0,8-1,0 \mathrm{~kJ} / \mathrm{mm}$. MO.

Figura 147: Efeito do espaçamento entre as "garras" do sistema de fixação do CP na taxa de resfriamento durante a simulação no equipamento Gleeble ${ }^{\circledR}$. (a.) Espaçamento de $20 \mathrm{~mm}$; (b.) Espaçamento de $30 \mathrm{~mm}$.

Figura 148: Experiência de simulação da ZACTE 2-06-1P com temperatura máxima de $1400{ }^{\circ} \mathrm{C}$.....169

Figura 149: Microestruturas do AID UNS S32304, correspondentes à simulação da ZACTE na raiz do cordão, realizado com uma energias de soldagem de 0,6 e $1,0 \mathrm{~kJ} / \mathrm{mm}$.

Figura 150: Microestruturas do AID UNS S32205, correspondentes à simulação da ZACTE na raiz do cordão, realizado com uma energias de soldagem de 0,6 e 1,0 kJ/mm.

Figura 151: Microestruturas do AISD UNS S32550, correspondentes à simulação da ZACTE na raiz do cordão, realizado com uma energias de soldagem de 0,6 e $1,0 \mathrm{~kJ} / \mathrm{mm}$.

Figura 152: Microestruturas do AID UNS S32750, correspondentes à simulação da ZACTE na raiz do cordão, realizado com uma energias de soldagem de 0,6 e $1,0 \mathrm{~kJ} / \mathrm{mm}$.

Figura 153: Microestruturas do AID UNS S32760, correspondentes à simulação da ZACTE na raiz do cordão, realizado com uma energias de soldagem de 0,6 e 1,0 kJ/mm.

Figura 154: Variação do tamanho de grão ferrítico com a energia de soldagem utilizada, na ZACTE das diferentes ligas.

Figura 155: Evolução da fração volumétrica de austenita na ZACTE para energia de soldagem de $0,6 \mathrm{~kJ} / \mathrm{mm}$. Corpos de prova simulados das diversas ligas.

Figura 156: Evolução da fração volumétrica de austenita na ZACTE para energia de soldagem de $0,8 \mathrm{~kJ} / \mathrm{mm}$. Corpos de prova simulados das diversas ligas.

Figura 157: Evolução da fração volumétrica de austenita na ZACTE para energia de soldagem de $1,0 \mathrm{~kJ} / \mathrm{mm}$. Corpos de prova simulados das diversas ligas.

Figura 158: Energia absorvida no ensaio Charpy da região da ZACTE simulada e dos materiais no estado como-recebido.

Figura 159: Vista geral das superfícies de fratura dos CP Charpy do AID UNS S32304. MEV.......... 187

Figura 160: Vista geral das superfícies de fratura dos CP Charpy do AID UNS S32205. MEV...........188

Figura 161: Vista geral das superfícies de fratura dos CP Charpy do AISD UNS S32550. MEV. …...189

Figura 162: Vista geral das superfícies de fratura dos CP Charpy do AISD UNS S32750. MEV. …...190

Figura 163: Vista geral das superfícies de fratura dos CP Charpy do AISD UNS S32760. MEV. .......191

Figura 164: Aspecto da superfície de fratura da trinca secundária formada por splitting no CP Charpy do AISD UNS S32750 no estado como-recebido. MEV.....

Figura 165: Aspecto da superfície de fratura da trinca secundária formada por splitting no $\mathrm{CP}$ Charpy do AISD UNS S32760 no estado como-recebido. MEV. 192

Figura 166: Trinca de liquação no CP submetido a simulação térmica. AISD UNS S32760, simulação $06-1 \mathrm{P}(0,6 \mathrm{~kJ} / \mathrm{mm}$ após o primeiro passe $)$. MEV.

Figura 167: Aspecto dúctil da fratura do CP Charpy do AISD UNS S32750 após o segundo passe para uma energia de soldagem de $1,0 \mathrm{~kJ} / \mathrm{mm}$. Observam-se dimples de tamanhos diferentes. MEV.

Figura 168: Aspecto da fratura do CP Charpy do AID UNS S32304 após o primeiro passe para uma energia de soldagem de $0,6 \mathrm{~kJ} / \mathrm{mm}$. MEV.

Figura 169: Aspecto da fratura do CP Charpy do AID UNS S32205 após o terceiro passe para uma energia de soldagem de $0,6 \mathrm{~kJ} / \mathrm{mm}$. Detalhe de região que sofreu fusão dos contornos de grão. MEV. 
Figura 170: Aspecto da fratura do CP Charpy do AID UNS S32550 após o primeiro passe para uma energia de soldagem de $0,6 \mathrm{~kJ} / \mathrm{mm}$. Fratura intergranular, devido à fusão dos contornos de grão. MEV.

Figura 171: Aspecto da fratura do CP Charpy do AID UNS S32550 após o terceiro passe para uma energia de soldagem de $1,0 \mathrm{~kJ} / \mathrm{mm}$. Trinca de liquação formada durante a simulação. MEV.

Figura 172: Aspecto da fratura do CP Charpy do AID UNS S32750 após o terceiro passe para uma energia de soldagem de $0,6 \mathrm{~kJ} / \mathrm{mm}$. Trinca de liquação formada durante a simulação. MEV.

Figura 173: Curvas de polarização dos materiais de base, levantadas mediante ensaio potenciodinâmico realizado numa solução aquosa naturalmente areada de 3,5 \% de $\mathrm{NaCl}$, na temperatura de $25^{\circ} \mathrm{C}$.

Figura 174: Curvas de polarização dos materiais de base, levantadas mediante ensaio potenciodinâmico realizado numa solução aquosa naturalmente areada de $3,5 \%_{\text {peso }}$ de $\mathrm{NaCl}$, na temperatura de $35^{\circ} \mathrm{C}$.

Figura 175: Curvas de polarização dos materiais de base, levantadas mediante ensaio potenciodinâmico realizado numa solução aquosa naturalmente areada de $3,5 \%_{\text {peso }}$ de $\mathrm{NaCl}$, na temperatura de $50^{\circ} \mathrm{C}$.

Figura 176: Curvas de polarização dos materiais de base, levantadas mediante ensaio potenciodinâmico realizado numa solução aquosa naturalmente areada de $3,5 \%_{\text {peso }}$ de $\mathrm{NaCl}$, na temperatura de $75^{\circ} \mathrm{C}$.

Figura 177: Relação entre o potencial de pite e o PREW para duas diferentes temperaturas de ensaio.

Figura 178: Curvas de polarização do AIDs UNS S32304, S32205, S32550, S32750, S32760 submetido a tratamentos térmicos a $1350^{\circ} \mathrm{C}$ por 5 e $10 \mathrm{~s}$.

Figura 179: Aparência dos pites formados nos ensaios de polarização cíclica nos CPs submetidos a tratamento térmicos de reaquecimento no AID UNS S32304.

Figura 180: Curvas de polarização do AID UNS S32304 submetido a tratamentos térmicos de reaquecimento.

Figura 181: Aparência dos pites formados nos ensaios de polarização cíclica nos CPs submetidos a tratamento térmicos de reaquecimento no AID UNS S32205.

Figura 182: Curvas de polarização do AID UNS S32205 submetido a tratamentos térmicos de reaquecimento.

Figura 183: Aparência dos pites formados nos ensaios de polarização cíclica nos CPs submetidos a tratamento térmicos de reaquecimento no AID UNS S32550.

Figura 184: Curvas de polarização do AID UNS S32550 submetido a tratamentos térmicos de reaquecimento.

Figura 185: Aparência dos pites formados nos ensaios de polarização cíclica nos CPs submetidos a tratamento térmicos de reaquecimento no AID UNS S32750.

Figura 186: Aparência dos pites formados nos ensaios de polarização cíclica nos CPs submetidos a tratamento térmicos de reaquecimento no AID UNS S32760.

Figura 187: Curvas de polarização do AID UNS $\$ 32750$ submetido a tratamentos térmicos de reaquecimento.

Figura 188: Curvas de polarização do AID UNS S32760 submetido a tratamentos térmicos de reaquecimento.

Figura 189: Curvas de polarização dos CPs submetidos a simulação térmica da região da raiz da ZACTE do AID UNS S32304.

Figura 190: Curvas de polarização dos CPs submetidos a simulação térmica da região da raiz da ZACTE do AID UNS S32205. 
Figura 191: Curvas de polarização dos CPs submetidos a simulação térmica da região da raiz da ZACTE do AID UNS S32550......

Figura 192: Curvas de polarização dos CPs submetidos a simulação térmica da região da raiz da ZACTE do AID UNS S32750.

Figura 193: Curvas de polarização dos CPs submetidos a simulação térmica da região da raiz da ZACTE do AID UNS S32760.

Figura 194: Aparência dos pites formados na ZACTE do AID UNS S32304 ...................................225

Figura 195: Aparência dos pites formados na ZACTE do AID UNS S32205.............................226

Figura 196: Aparência dos pites formados na ZACTE do AID UNS S32550.............................226

Figura 197: Aparência dos pites formados na ZACTE do AID UNS S32750.............................226

Figura 198: Aparência dos pites formados na ZACTE do AID UNS S32760............................227

Figura 199: Lugares preferenciais de formação de pites durante o ensaio de polarização cíclica.......228 


\section{LISTA DE TABELAS}

Tabela 1: Economia em peso alcançada pela substituição do aço inoxidável austenítico AISI 316 L pelo AID UNS S31803, com a aplicação de diversos códigos ${ }^{(22)}$.

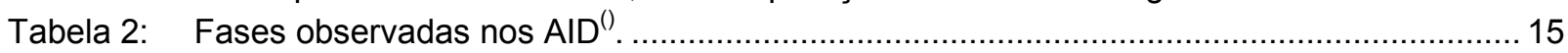

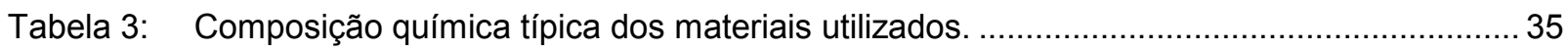

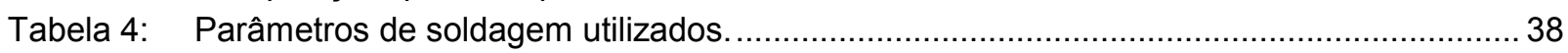

Tabela 5: Parâmetros de soldagem empregados nas soldagens reais............................................. 40

Tabela 6: Matriz de experiências de simulação dos ciclos térmicos de soldagem, com a

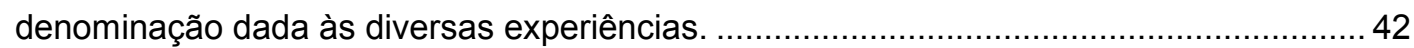

Tabela 7: Resultados da experiência 1 de medida de temperatura. .............................................. 47

Tabela 8: Resultados das experiências 2 e 3 de medida de temperatura.............................................. 48

Tabela 9: Resultados das experiências 4 e 5 de medida de temperatura........................................... 48

Tabela 10: Sumário das temperaturas máximas médias medidas durante a soldagem do aço

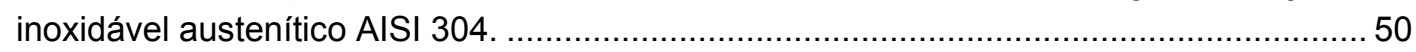

Tabela 11: Resultados utilizados para o cálculo dos dados apresentados na Tabela 10 ...................50

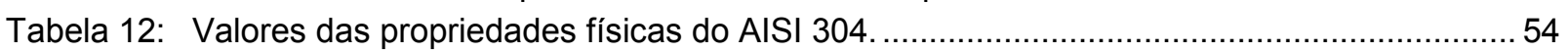

Tabela 13: Propriedades físicas dos AIDs aplicadas no modelo..................................................... 57

Tabela 14: Posição das regiões da ZAC a serem estudadas e temperaturas máximas

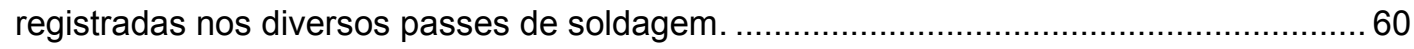

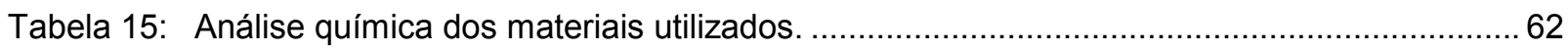

Tabela 16: Valores de $\mathrm{Cr}_{\text {eq }}$, $\mathrm{Ni}_{\text {eq }}$ e PREW para as diversas ligas estudadas. ....................................63

Tabela 17: Temperaturas solidus, liquidus e de início de precipitação das fases, calculadas com o Thermo-Calc ${ }^{\circledR}$.

Tabela 18: Fração volumétrica das fases presentes a $600^{\circ} \mathrm{C}$. Cálculos realizados com o

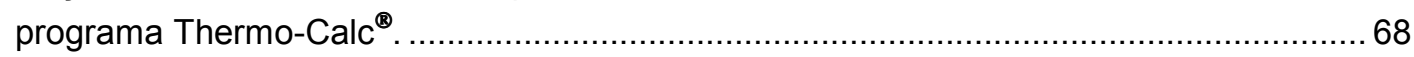

Tabela 19: Composição química das fases presentes no equilíbrio a $600{ }^{\circ} \mathrm{C}$. Cálculos

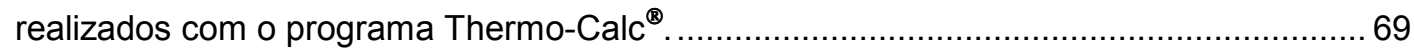

Tabela 20: Composição química das fases presentes no equilíbrio a 1100 e $1200{ }^{\circ} \mathrm{C}$. Cálculos realizados com o programa Thermo-Calc ${ }^{\circledR}$.

Tabela 21: Fração volumétrica das fases presentes a 1100 e $1200^{\circ} \mathrm{C}$. Cálculos realizados com

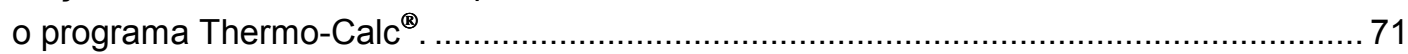

Tabela 22: Fração volumétrica de ferrita no estado como-recebido. ................................................ 74

Tabela 23: Composição química das fases presentes no material no estado como-recebido. Medidas por WDS no MEV e calculadas com o programa Thermo-Calc ${ }^{\circledR}$........................... 76

Tabela 24: Resultados das análises térmicas diferenciais. ............................................................... 78

Tabela 25: Temperatura de resistência nula (TRN) dos materiais no estado como-recebido. ............. 79

Tabela 26: Comparação dos resultados de análise térmica e TRN. .................................................. 80

Tabela 27: Comparação das temperaturas liquidus e solidus calculadas e medidas com a TRN........ 81

Tabela 28: Tamanho de grão e fração de austenita dos C/P submetidos a tratamentos térmicos de ferritização.

Tabela 29: Fração volumétrica das fases presentes a 1350 e $1380^{\circ} \mathrm{C}$. Cálculos realizados com o programa Thermo-Calc ${ }^{\circledR}$.

Tabela 30: Tratamentos térmicos de ferritização selecionados para serem realizados no equipamento Gleeble ${ }^{\circledR}$.

Tabela 31: Composição química da ferrita e da austenita dos corpos de prova tratados termicamente a $1350{ }^{\circ} \mathrm{C}$ por 5 e $10 \mathrm{~s}$. Composição química das mesmas fases calculada com o Thermo-Calc ${ }^{\circledast}$ para a temperatura de $1350^{\circ} \mathrm{C}$. 
Tabela 32: Composição química da fração metálica dos nitretos de cromo $\left(\mathrm{Cr}_{2} \mathrm{~N}\right)$ precipitados no interior da ferrita dos AIDs UNS S32304, S32550 e S32760.

Tabela 33: Composição química da fração metálica dos nitretos de cromo $\left(\mathrm{Cr}_{2} \mathrm{~N}\right)$ precipitados nas interfaces $\alpha / \gamma$ dos AIDs UNS S32304 e S32550 tratados a $1350{ }^{\circ} \mathrm{C}$ por $5 \mathrm{~s}$.

Tabela 34: Perfil de composição química da fração metálica ao longo da interface $\alpha / \gamma$, contendo precipitados de $\mathrm{Cr}_{2} \mathrm{~N}$. AID UNS S32304 tratado a $1350^{\circ} \mathrm{C}$ por $5 \mathrm{~s}$. EDS-MET.

Tabela 35: Perfil de composição química da fração metálica ao longo da interface $\alpha / \gamma$ livre de precipitados de $\mathrm{Cr}_{2} \mathrm{~N}$. AID UNS S32304 tratado a $1350{ }^{\circ} \mathrm{C}$ por $5 \mathrm{~s}$. EDS-MET.

Tabela 36: Fração volumétrica de austenita dos CP submetidos a TT de ferritização, seguidos de TT de reaquecimento.

Tabela 37: Evolução microestrutural dos CPs submetidos a tratamentos térmicos. AIDs UNS S32304 e S32205. Observação no MO.

Tabela 38: Evolução microestrutural dos CPs. submetidos a tratamentos térmicos. AISDs UNS S32550, S32750 e S32760. Observação no MO.

Tabela 39: Temperatura de predominância da austenita secundária intragranular.

Tabela 40: Variação do tamanho de grão ferrítico com a energia de soldagem utilizada, na ZACTE das diferentes ligas.

Tabela 41: Fração volumétrica de austenita dos corpos de prova simulados correspondentes à ZACTE das diversas ligas. Resultados da análise de variância.

Tabela 42: Resumo dos dados de máximos tamanhos de grão de frações de austenita obtidas durante os tratamentos térmicos e as simulações da ZACTE.

Tabela 43: Resumo das mudanças microestruturais observadas nos CP simulados.

Tabela 44: Energia absorvida no ensaio Charpy da região da ZACTE simulada e dos materiais no estado como-recebido.

Tabela 45: Evolução do aspecto da fratura dos CP Charpy.

Tabela 46: Potenciais de pite de proteção (ECS) dos materiais de base, determinados mediante ensaio de polarização cíclica.

Tabela 47: Potenciais de pite (ECS) dos materiais submetidos aos tratamentos térmicos de ferritização e reaquecimento. Ensaio de polarização cíclica.

Tabela 48: Potenciais de proteção (ECS) dos materiais submetidos aos tratamentos térmicos de ferritização e reaquecimento. Ensaio de polarização cíclica.

Tabela 49: Fração do potencial de pite no estado como-recebido após o tratamentos térmicos para todas as ligas estudadas.

Tabela 50: Potenciais de pite e proteção (ECS) dos materiais submetidos a simulação térmica. Ensaio de polarização cíclica.

Tabela 51: Fração do potencial de pite no estado como-recebido após o tratamento térmico a $1350^{\circ} \mathrm{C}$ e a simulação da ZACTE, para todas as ligas estudadas. 


\section{LISTA DE SÍMBOLOS E ABREVIATURAS}

a

AID

AISD

$\operatorname{ccc}$

CCPD

cfc

$\mathrm{C}_{\mathrm{p}}$

d

$d_{m}$

$d_{1}, d_{2}$

$E_{a}$

EDS

EELS Espectrometria por perda de energia dos elétrons.

$E_{t}$

$\mathrm{f}$

GTAW

GMAW

hcp

I

k

K-S

$\mathrm{K}_{0}$

MET

MEV

Aço inoxidável duplex

Aço inoxidável superduplex

Cúbica de corpo centrado

Corrente contínua, polaridade direta

Cúbica de face centrada

Calor específico a pressão constante

Espessura da chapa franjas de Moiré

Espectro de energia dispersiva.

Energia total fornecida ao conjunto eletrodo-arco

Soldagem TIG (Gas Tungsten Arc Welding)

Soldagem MIG/MAG (Gas Metal Arc Welding)

Hexagonal compacta.

Corrente

Condutividade térmica

Relação de orientação do tipo Kurdjumov-Sachs

Microscópio(ia) eletrônico(a) de transmissão

Microscópio(ia) eletrônico(a) de varredura
Difusividade térmica $\left(a=\frac{k}{\rho C_{P}}\right)$

Espaçamento entre as franjas de Mioré $\left(d_{m}=\frac{d_{2} d_{1}}{d_{1}-d_{2}}\right)$

Espaçamentos interplanares, utilizados para calcular o espaçamento entre as

Energia efetivamente absorvida pela peça soldada

Fator de correção para a energia de soldagem.

Função modificada de Bessel de segunda espécie e ordem zero 
MEV-EC Microscópio eletrônico de varredura, com canhão de emissão de campo

N-W Relação de orientação do tipo Nishiyama-Wasserman

$\mathrm{p} \quad$ Profundidade do chanfro

PPit Potencial de pite

PProt Potencial de proteção

PRE Índice de resistência à corrosão por pites (Pitting Resistance Equivalent)

PREW Índice de resistência à corrosão por pites (Pitting Resistance Equivalent). Leva em conta o tungstênio da liga.

$\mathrm{q}_{\mathrm{L}}$

Energia de soldagem líquida $\left(q_{L}=\eta \frac{V . I}{V}\right)$

$\mathrm{q}_{\mathrm{T}}$

Energia de soldagem total $\left(q_{T}=\frac{V . I}{V}\right)$

$\mathrm{R}$

Distância da projeção do centro da fonte de calor na superfície da chapa ao ponto de interesse $\left(R=\sqrt{\xi^{2}+y^{2}+z^{2}}\right)$

$r$

Distância da linha de centro do cordão ao ponto de interesse

$\left(r=\sqrt{\xi^{2}+y^{2}}\right)$

T Temperatura

TL Temperatura liquidus

TRN Temperatura de resistência nula

TS Temperatura solidus

TT Tratamento térmico

$\mathrm{T}_{\mathrm{c}} \quad$ Temperatura crítica

To Temperatura de pré-aquecimento

$\mathrm{T}_{\text {máx }} \quad$ Temperatura máxima

$\mathrm{T}_{\alpha / \gamma} \quad$ Temperatura em que as frações volumétricas de ferrita e austenita são as de equilíbrio

V Tensão

ZAC Zona afetada pelo calor

ZACTB Zona afetada pelo calor submetida a temperatura baixa

ZACTE Zona afetada pelo calor submetida a temperatura elevada 
$\%$

$\%_{\text {atm }}$

$\%_{\text {vol }}$

$\alpha$

$\gamma$

$\gamma_{2}$

$\gamma_{1}$

$\eta$

$\rho$

$\xi$

$v$

$\Delta$

$\Delta_{\mathrm{ch}}$

$\Delta_{\mathrm{i}}$

Porcentagem em peso

Porcentagem atômica

Porcentagem volumétrica

Ferrita

Austenita (Geral)

Austenita secundária (Precipitada durante tratamento de reaquecimento)

Austenita primária (Precipitada durante o resfriamento desde a temperatura de ferritização)

Eficiência térmica do processo de soldagem $\left(\eta=\frac{E_{a}}{E_{t}}=\frac{E_{a}}{V . l}\right)$

Densidade

Coordenada na direção $X$ com origem na fonte de calor $(\xi=x-v t)$

Velocidade da fonte de calor

Distância da fonte de calor à superfície da chapa, como apresentado na Figura 7

Profundidade do chanfro

Distância da fonte de calor $\mathbf{i}$ aos eixos de coordenadas, como apresentado na Figura 32. 


\section{RESUMO}

Os aços inoxidáveis duplex (AIDs) são materiais com um excelente desempenho tanto mecânico como à corrosão. Inúmeras pesquisas tem sido desenvolvidas para aprimorar a soldabilidade destas ligas. Algumas transformações de fase, que são passíveis de ocorrer durante o processo de soldagem, podem prejudicar seriamente o desempenho das juntas.

Foram simuladas microestruturas da região da zona afetada pelo calor submetida a temperaturas elevadas (ZACTE), utilizando um modelo proposto de fluxo de calor. Abordaram-se aspectos fundamentais da precipitação de austenita secundária, de nitreto de cromo e as suas interações na ZACTE de soldas multipasse. Finalmente, foram realizados testes de tenacidade e de resistência à corrosão para avaliar o efeito das transformações de fase estudadas no desempenho das juntas soldadas.

Os tratamento térmicos e simulações da ZACTE foram realizadas num equipamento Gleeble $^{\circledR}$. As microestruturas foram analisadas mediante microscopia ótica e eletrônica de varredura e de transmissão. Junto com a microscopia eletrônica foram realizadas microanálises químicas das fases estudadas.

Baseando-se nos resultados obtidos, verificou-se que nem todos os AIDs são susceptíveis de ferritizar. Este fato tem uma grande influência no comportamento metalúrgico e na soldabilidade destes aços. Quanto aos aspectos fundamentais da metalurgia destes aços, observou-se uma estreita interação entre a precipitação da austenita secundária e os nitretos de cromo, chegando-se a propor um mecanismo de nucleação da austenita secundária intragranular a partir dos nitretos. Por último, foi constatado que o efeito deletério da austenita secundária intragranular na resistência à corrosão pode ser evitado mediante a adequada elaboração do procedimento de soldagem. 


\begin{abstract}
Duplex stainless steels (DSS) have excellent mechanical and corrosion properties. Many researches have been developed regarding the weldability of these alloys. There are some phase transformations that take place during the welding process, which may impair the welded joint behavior.

High temperature heat-affected zone (HTHAZ) microstructures were simulated using a proposed heat flow model. Fundamental aspects of the secondary austenite and chromium nitride precipitation, and its interactions in the HTHAZ of multipass welds, were studied. In addition, toughness and corrosion tests were done to evaluate the influence of the studied phase transformations on the weld behavior.

A Gleeble ${ }^{\circledR}$ system was used to do the heat treatments and HTHAZ simulations. The microstructures were analyzed by means of optic and electron microscopy. Along with the electron microscopy it was done chemical microanalysis of the studied phases.

Based on results, it was verified that not all DSSs can be ferritized. This fact has a strong influence on metallurgical behavior and weldability of these alloys. Regarding to the metallurgical fundamental aspects of these steels, it was observed a remarkable interaction between secondary austenite and chromium nitride precipitation. Thus, it was proposed a mechanism of intragranular secondary austenite precipitation from chromium nitrides. It was also verified, how the deleterious effect of intragranular secondary austenite in the corrosion resistance can be avoided by means of appropriate welding procedures.
\end{abstract}




\section{INTRODUÇÃO E JUSTIFICATIVA}

Os aços inoxidáveis duplex (AID) surgiram na década de 30 e adquiriram uma certa importância comercial na década de 40. Desde então, estas ligas têm sofrido inúmeras modificações, que vão desde a sua composição química até as tecnologias usadas na sua produção. Os AID modernos possuem uma excelente resistência à corrosão e boas propriedades mecânicas. Esta combinação de propriedades têm popularizado o seu uso em ambientes altamente agressivos. Com o interesse de melhorar a resistência à corrosão, as ligas mais recentemente introduzidas no mercado, chamadas de aços inoxidáveis superduplex (AISD), possuem uma maior quantidade de elementos de liga. Porém, esta modificação torna estes materiais mais susceptíveis à precipitação de fases intermetálicas.

Uma grande parcela das aplicações industriais dos AID está nos setores químico, petroquímico e de papel e celulose, geralmente em equipamentos cuja fabricação envolve operações de soldagem. Se a soldagem não for executada com os devidos cuidados, as vantagens dos AID e AISD sobre os aços inoxidáveis tradicionais podem ser perdidas. Portanto, uma grande importância tem sido dada a este tema pela comunidade científica e pelos produtores destes aços, principalmente no caso dos AISDs.

Diversos pesquisadores têm estudado as mudanças microestruturais acontecidas na zona afetada pelo calor submetida a temperatura elevada (ZACTE) e seu efeito no desempenho da junta soldada. No entanto, os estudos com soldagens multipasse têm sido poucos e bastante superficiais, indicando a possibilidade de um trabalho inédito na área.

No Departamento de Engenharia Metalúrgica e de Materiais da EPUSP existe uma linha de pesquisa nestes tipos de aços inoxidáveis. Já foram produzidas diversas teses de doutoramento e dissertações de mestrado. Como parte de uma destas pesquisas anteriores foi desenvolvida uma metodologia experimental para estudar, por simulação térmica, a zona afetada pelo calor submetida a temperatura baixa (ZACTB) de uma solda multipasse em chapa fina. Além disso, com o uso desta ferramenta foi realizado um estudo incipiente sobre a precipitação de fases intermetálicas na ZACTB de duas ligas comerciais de AIDs. Baseando-se na revisão de literatura feita pode-se dizer que este tema foi estudado pela primeira vez neste trabalho.

Portanto, a partir dos resultados de trabalhos anteriores visualizou-se a importância e necessidade desta pesquisa. Ela objetiva estudar com mais detalhe as transformações de fase na ZACTE de soldas multipasse realizadas em chapas finas de diversas ligas comerciais de AIDs. O estudo será realizado a partir de soldas reais e microestruturas simuladas. A simulação da ZACTE foi realizada num equipamento Gleeble ${ }^{\circledR}$. 


\section{TRANSFERÊNCIA DE CALOR NA SOLDAGEM}

Na soldagem a arco elétrico, o calor necessário para fundir os metais de base e de adição é gerado pelo arco elétrico. Esta energia determina não só o volume da poça de fusão, como também o seu tempo de solidificação e as velocidades de resfriamento e temperaturas na junta soldada.

\subsection{EFICIÊNCIA TÉRMICA DO PROCESSO DE SOLDAGEM}

Nem toda a energia gerada pelo arco elétrico é transmitida para o metal de base. Uma parte é dissipada por radiação e por convecção para o meio circundante. Por este motivo, definese a eficiência térmica do processo de soldagem $(\eta)$ como razão entre a energia efetivamente transmitida para o metal de base $\left(E_{a}\right)$ e a energia gerada pelo arco elétrico $\left(E_{t}\right)$. A eficiência térmica para o processo GTAW está entre 0,4 e $0,8^{(1-6)}$. Esta dispersão de valores pode ser devida às diferenças nos arranjos e técnicas experimentais utilizadas. Alguns autores reportam que $\eta$ diminui com o aumento da corrente de soldagem ${ }^{(2,4)}$. Este efeito pode ser explicado por uma perda maior de energia através da superfície da peça soldada. Por outro lado, uma diminuição no comprimento do arco acarreta em um aumento de $\eta^{(1)}$. De qualquer maneira, a influência dos parâmetros de soldagem do processo GTAW levam a variações sempre ao redor de 0,6 para a eficiência térmica.

\subsection{HISTÓRIA TÉRMICA}

A história térmica de uma junta soldada é composta por uma repartição térmica e infinitos ciclos térmicos de soldagem. Esta é determinada pelas propriedades físicas do material, pela temperatura inicial do metal de base, pela geometria da junta, pela energia de soldagem líquida e pelo formato da fonte de calor.

O ciclo térmico representa a variação da temperatura com o tempo, para um dado ponto da junta soldada. Ele está relacionado com a microestrutura nas diferentes regiões da junta soldada. A Figura 1 apresenta esquematicamente diversos ciclos térmicos. A linha tracejada une as temperaturas máximas de cada um dos ciclos. Percebe-se que, o ciclo térmico experimentado por um determinado ponto da junta soldada, depende, entre outras coisas, da sua posição relativa à fonte de calor.

Por repartição térmica entende-se a variação da temperatura máxima dos ciclos térmicos em função da distância ao centro do cordão de solda. Ela determina a extensão da zona afetada pelo calor (ZAC). A Figura 2 apresenta esquematicamente a repartição térmica em uma junta topo-a-topo.

No caso de uma solda (de topo) multipasse, uma região da ZAC do passe de raiz (A) é submetida a diversos ciclos térmicos, conforme mostrado na Figura 3. Analisando-se a figura, percebe-se uma diminuição na temperatura máxima do primeiro para o terceiro passe. 
Observa-se também uma redução da velocidade de resfriamento do primeiro para o segundo e o terceiro passe. Da mesma maneira, ocorre um aumento da temperatura da chapa com a seqüência de soldagem.

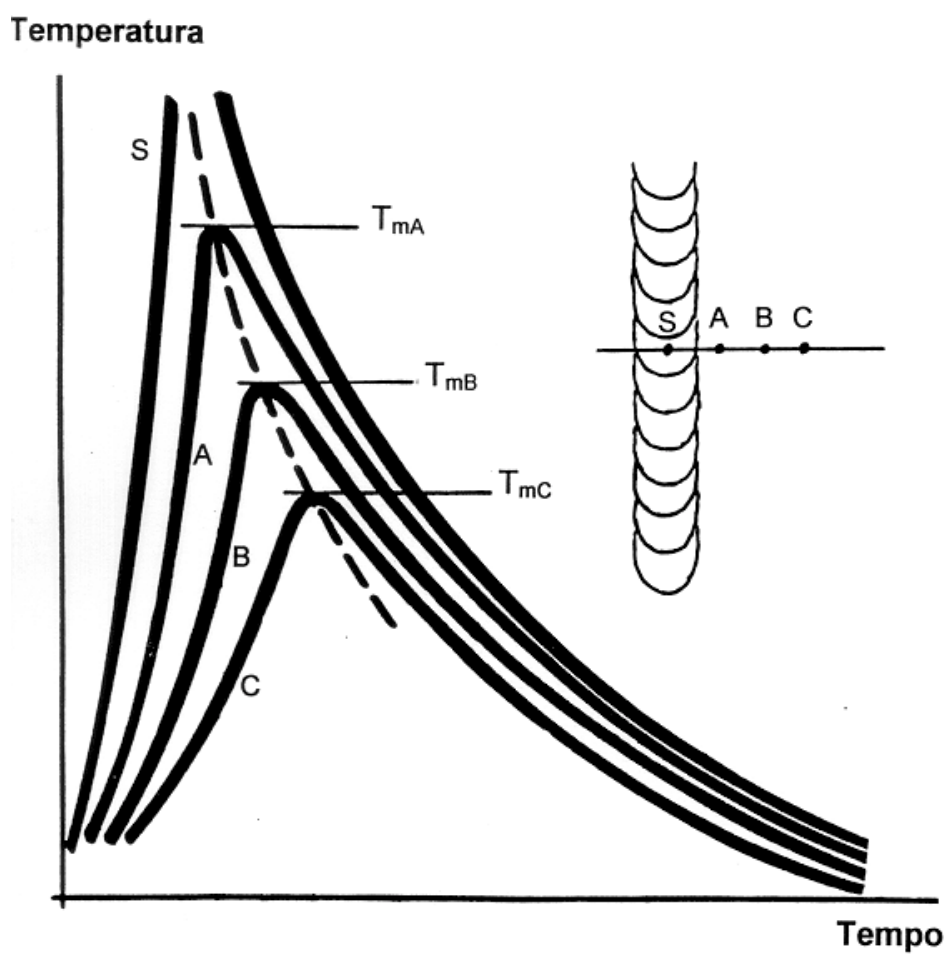

Figura 1: Ciclos térmicos de soldagem experimentados por diferentes pontos de uma junta soldada $^{(7)}$.

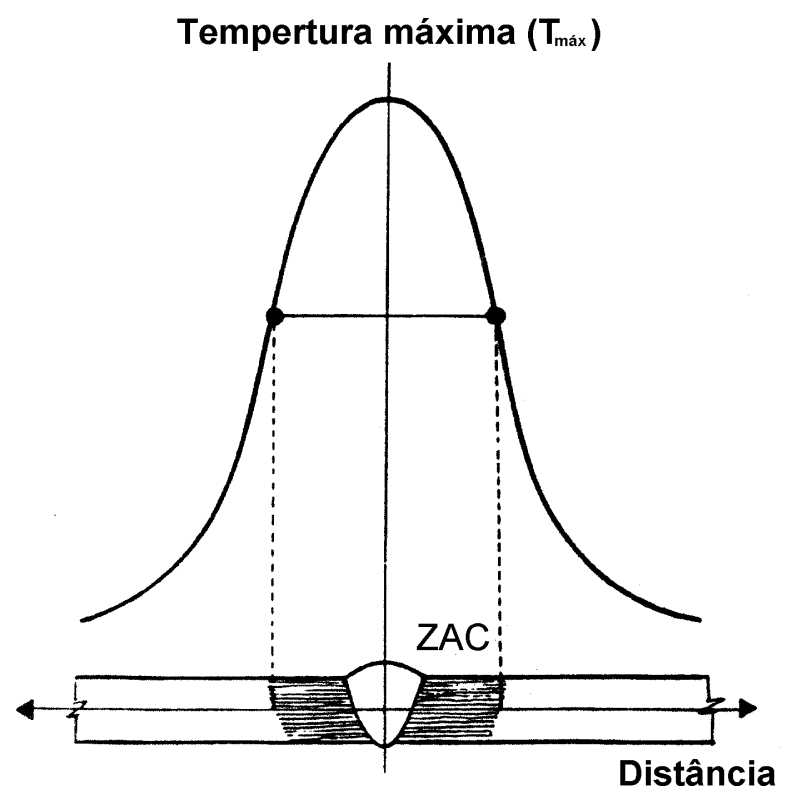

Figura 2: $\quad$ Repartição térmica em uma junta soldada ${ }^{(7)}$. 


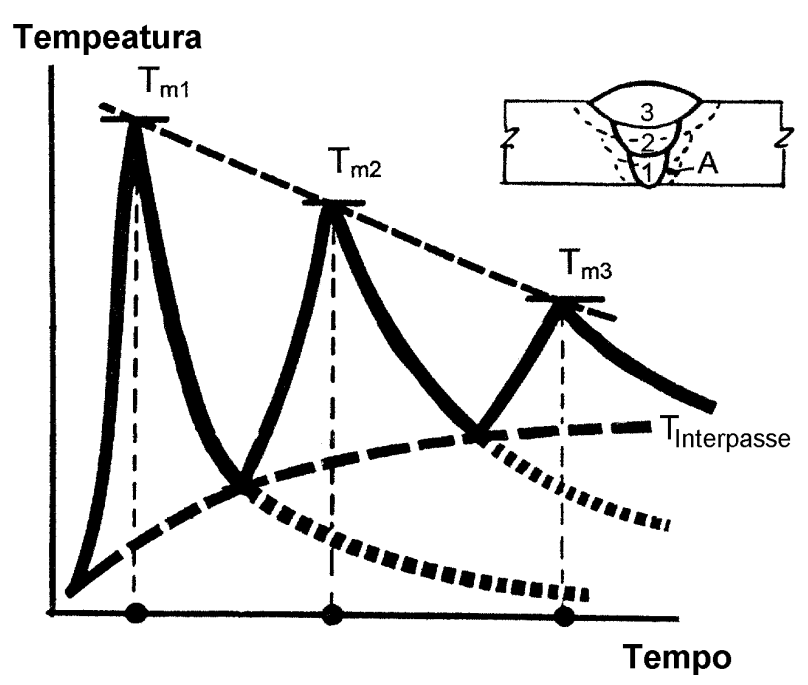

Figura 3: $\quad$ Exemplo dos ciclos térmicos experimentados por um ponto da ZAC perto da raiz de uma solda multipasse topo-a-topo ${ }^{(7)}$.

\subsection{FLUXO DE MASSA E CALOR NA POÇA DE FUSÃO}

Do ponto de vista de fluxo de calor, a região crítica de uma junta soldada é a poça de fusão. O fluxo de massa presente nesta região é suficiente para que fluxo de calor por convecção seja estabelecido. Se este fluxo de massa fosse isotrópico, como é no caso ideal de fluxo toroidal, o gradiente de temperatura na poça cairia, mas a distribuição de temperatura fora dela seria a mesma que na condução pura. No entanto, o fluxo mássico na poça é anisotrópico e, portanto, o formato da poça é modificado.

A movimentação do metal líquido na poça de fusão deve-se principalmente às forças tangenciais geradas pelo gradiente de tensão superficial (efeito Marangoni) e às forças eletromagnéticas que levam a um fluxo convergente instável, que tende a se transformar em toroidal. O sentido do fluxo gerado pelo efeito Marangoni depende da composição química do metal líquido. Geralmente nos aços este efeito leva a um fluxo divergente, mas a adição de elementos tensoativos, como $\mathrm{S}$, Se ou $\mathrm{O}$, pode inverter o sentido do fluxo. Outros fatores de menor peso que levam à movimentação da poça de fusão são a convecção devido às diferenças de temperatura, o arraste devido ao fluxo de gases e à pressão do arco elétrico. $O$ resultado da interação das forças mencionadas pode levar a um fluxo convergente, divergente ou combinado. Devido ao fluxo de calor por convecção na poça de fusão, o padrão de fluxo mássico tem uma grande influência na transferência de calor. Da mesma maneira, o formato da poça de fusão é influenciado por ele, como mostrado na Figura $4^{(8-10)}$. Outro fator que tem uma influência importante na transferência de calor do arco para a poça de fusão é a distribuição da energia no arco elétrico. No caso do processo GTAW, esta distribuição depende principalmente do ângulo de afiação do eletrodo de $W$ e das propriedades físicas do gás de proteção ${ }^{(1,11-12)}$. 


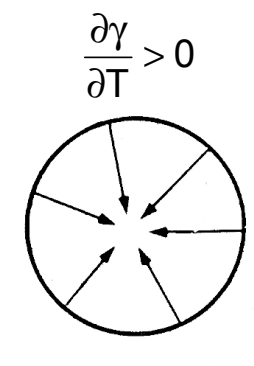

Forças electromagnéticas ajudam à
circulação induzida por tensão superficial

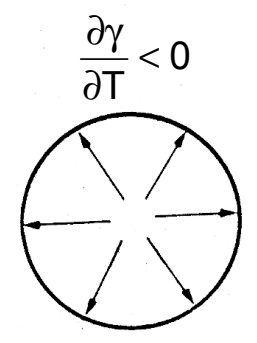

Forças electromagnéticas relativamente fracas

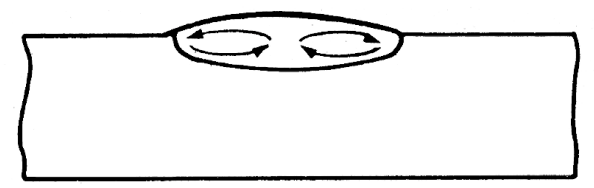

$$
\frac{\partial \gamma}{\partial \mathrm{T}}>0 \quad \frac{\partial \gamma}{\partial \mathrm{T}}<0
$$

região externa região interna

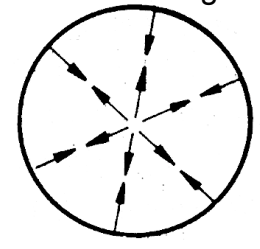

Forças electromagnéticas relativamente fracas
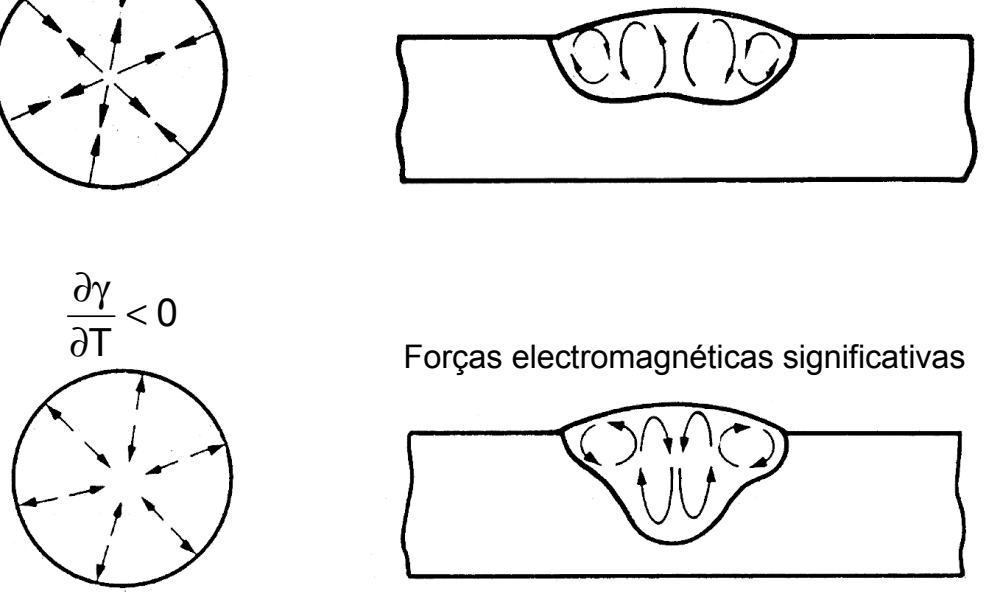

Forças electromagnéticas significativas

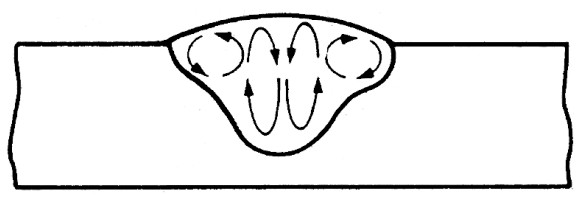

Figura 4: Efeito do padrão de fluxo mássico no formato de uma poça de fusão estacionaria realizada com o processo GTAW $^{(9)}$.

\subsection{MODELOS DE FLUXO DE CALOR NA SOLDAGEM}

Uma grande parte da energia do arco elétrico que atinge a peça que está sendo soldada é dissipada por condução através da mesma ${ }^{(13)}$. Contudo, uma pequena parte é perdida através da(s) superfície(s) da peça em forma de radiação e por convecção para a atmosfera que a circunda. A dissipação de energia por convecção só tem alguma importância no caso em que as chapas soldadas sejam muito finas ${ }^{(14)}$. 
Devido a complexidade dos fenômenos envolvidos no fluxo de calor na poça de fusão, os modelos que visam descrevê-los são bastante elaborados. Já para o estudo da ZAC, são geralmente usados modelos mais simples.

A grande maioria dos modelos físicos de soldagem consistem em uma fonte de calor que se desloca em linha reta com velocidade constante, como mostrado na Figura 5. No começo e no final da soldagem tem-se um regime térmico transiente. Em algum momento após o começo do processo e antes do seu final, a distribuição de temperaturas é estacionária, ou em equilíbrio térmico, em relação às coordenadas móveis com origem no centro da fonte de calor $^{(15)}$.

Para desenvolver um modelo analítico simples de fluxo de calor devido a uma fonte móvel, é preciso fazer as seguintes simplificações:

- A não existência de fontes e sumidouros de calor no interior do material (o calor latente de fusão não é levado em conta).

- As propriedades físicas do material, isto é $\mathbf{k}$ e a são independentes da temperatura.

- A velocidade e potência da fonte de calor são constantes.

- São desprezíveis o aquecimento da peça por efeito Joule, a dissipação viscosa de energia na poça de fusão e a convecção na poça de fusão.

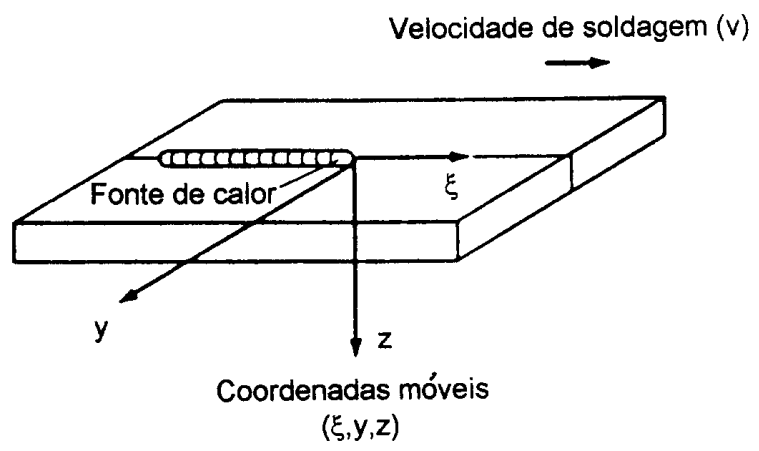

Figura 5: Coordenadas adotadas para o modelo de fluxo de calor na soldagem.

Com isso, a equação diferencial de fluxo de calor, em regime quase-estacionário, expressa em coordenadas cartesianas com origem no centro da fonte móvel é dada por:

$$
\frac{\partial^{2} T}{\partial \xi^{2}}+\frac{\partial^{2} T}{\partial y^{2}}+\frac{\partial^{2} T}{\partial z^{2}}=-\frac{v}{a} \frac{\partial T}{\partial \xi}
$$

ROSENTHAL ${ }^{(16)}$ propôs diversas soluções para esta equação. Entre elas, destacam-se as dadas para o fluxo bidimensional, tridimensional e intermediário de calor, onde são desprezadas as perdas de energia por convecção e radiação através da superfície da chapa. 
Estas soluções permitem obter com uma boa aproximação as condições de fluxo de calor na soldagem de uma chapa, seja fina, média ou grossa. No caso de fluxo bidimensional, admitese uma fonte de calor linear. Já para fluxo tridimensional ela é pontual.

A resolução da Equação 1 para a soldagem topo-a-topo de chapas finas é feita assumindose que a temperatura é constante através da espessura da chapa. No regime quaseestacionário, a temperatura de um ponto que se encontra a uma distância $r\left(r=\sqrt{\xi^{2}+y^{2}}\right)$ da fonte de calor considerada linear, pode ser aproximada pela Equação 2.

$$
\mathrm{T}-\mathrm{T}_{\mathrm{o}}=\frac{\mathrm{q}_{\mathrm{L}}}{2 \pi \mathrm{kd}} \mathrm{e}^{-\frac{v \xi}{2 a}} \mathrm{~K}_{0}\left(\frac{v \mathrm{r}}{2 \mathrm{a}}\right)
$$

Equação 2

Dado que $K_{0}\left(\frac{v r}{2 a}\right)$ tende a $\sqrt{\frac{\pi a}{v r}} e^{-\frac{v r}{2 a}}$ quando $r$ tende a infinito, então a Equação 2 se transforma na Equação 3:

$$
\mathrm{T}-\mathrm{T}_{\mathrm{o}}=\frac{\mathrm{q}_{\mathrm{L}}}{2 \pi \mathrm{kd}} \sqrt{\frac{\pi \mathrm{a}}{v r}} \mathrm{e}^{-\frac{v(\xi-r)}{2 \mathrm{a}}}
$$

Equação 3

Quando a soldagem é realizada em uma chapa grossa, que neste caso é considerada de espessura infinita, a temperatura de um ponto que se encontra a uma distância $R$ $\left(R=\sqrt{\xi^{2}+y^{2}+z^{2}}\right)$ da fonte de calor assumida pontual, pode ser aproximada pela solução da Equação diferencial 1 representada pela Equação 4.

$$
T-T_{0}=\frac{q_{L}}{2 \pi k} e^{-\frac{v \xi}{2 a}} \frac{e^{-\frac{v R}{2 a}}}{R}
$$

No caso de ter uma chapa de espessura média, isto é não ser o suficientemente grossa ou fina, Rosenthal propôs uma fonte pontual que se movimenta com velocidade constante ao longo de uma chapa de largura infinita e espessura d. Ele assumiu que as superfícies da chapa são impermeáveis ao calor, o que é razoável na maioria dos casos. Assim, para manter nulo o fluxo líquido de calor através das superfícies da chapa, é necessário dispor de reflexões especulares da fonte de calor com relação a $z=0$ e $z=d$, como pode ser visto na Figura 6. Este artifício é chamado de método das imagens. 


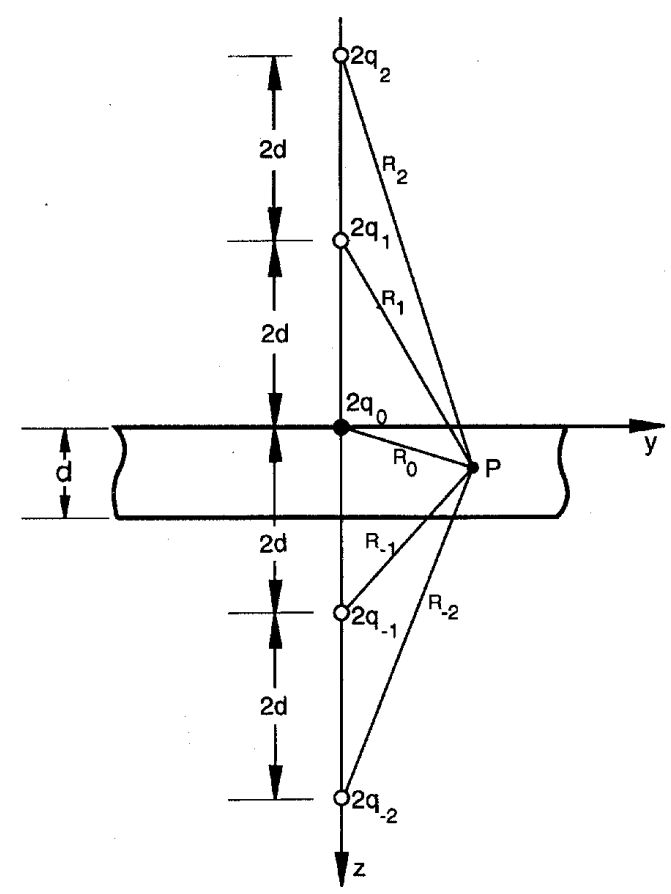

Figura 6: Fontes de calor real e imaginárias no caso da chapa de espessura média.

Desta maneira, levando em conta a contribuição das fontes imaginárias $\ldots .2_{\mathrm{q}-2}, 2_{\mathrm{q}-1}, 2_{\mathrm{q} 1}$, $2_{\mathrm{q} 2}, \ldots$ localizadas simetricamente às distâncias \pm 2 di abaixo e acima da superfície superior da chapa, a distribuição de temperatura no regime quase-estacionário é dada pela série convergente apresentada na Equação 5.

$$
\begin{aligned}
& \mathrm{T}-\mathrm{T}_{0}=\frac{\mathrm{q}_{\mathrm{L}}}{2 \pi \mathrm{k}} \mathrm{e}^{-\frac{v \xi}{2 \mathrm{a}}}\left[\sum_{\mathrm{i}=-\infty}^{\mathrm{i}=+\infty} \frac{\mathrm{e}^{-\mathrm{R}_{\mathrm{i}} \frac{v}{2 \mathrm{a}}}}{\mathrm{R}_{\mathrm{i}}}\right] \\
& \text { Onde: } \quad \mathrm{R}_{\mathrm{i}}=\sqrt{\xi^{2}+\mathrm{y}^{2}+(\mathrm{z}-2 \mathrm{di})^{2}}
\end{aligned}
$$

Posteriormente, na busca de modelos que representassem melhor as condições de transferência de calor durante as condições reais de soldagem MYHR; GRONG ${ }^{(17)}$ desenvolveram um modelo com fonte de calor distribuída. Ele foi baseado no modelo de Rosenthal para chapas de espessura média, previamente apresentado. Como é mostrado na Figura 7-a, o modelo considera duas distribuições discretas de fontes pontuais, as quais se estendem ao longo dos eixos y e $z$ das coordenadas móveis. Desta forma, a contribuição de cada uma destas fontes ao aumento de temperatura em um ponto arbitrário localizado no interior da chapa é calculado a partir do método das imagens, como mostrado na Figura 7-b. Finalmente, o aumento de temperatura deste ponto arbitrário é dado pela somatória do aporte das imagens de cada uma das fontes pontuais da distribuição, segundo a Equação 6. 


$$
T-T_{0}=\sum_{i}\left[T\left(q_{a}^{i}\right)+T\left(q_{b}^{i}\right)\right]
$$

Onde : $\quad q_{0}=\sum_{i}\left(q_{a}^{i}+q_{b}^{i}\right)=\eta V I$

Equação 6

$\mathrm{Na}$ Equação 6, o aporte das distribuições de fontes ao longo dos eixos y e z estão dados pelas Equações 7 e 8, respectivamente.

$$
T\left(q_{a}^{i}\right)=\frac{q_{a}^{i}}{2 \pi k} e^{-\frac{v \xi}{2 a}}\left[\sum_{i=-\infty}^{i=+\infty} \frac{e^{-R_{i} \frac{v}{2 a}}}{R_{i}}\right]
$$

Onde: $\quad R_{i}=\sqrt{\xi^{2}+y^{2}+(z-2 d i)^{2}}$

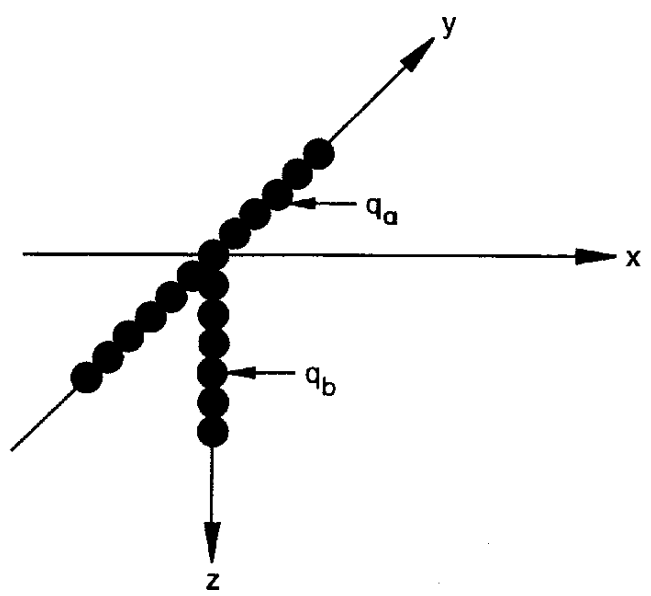

a.

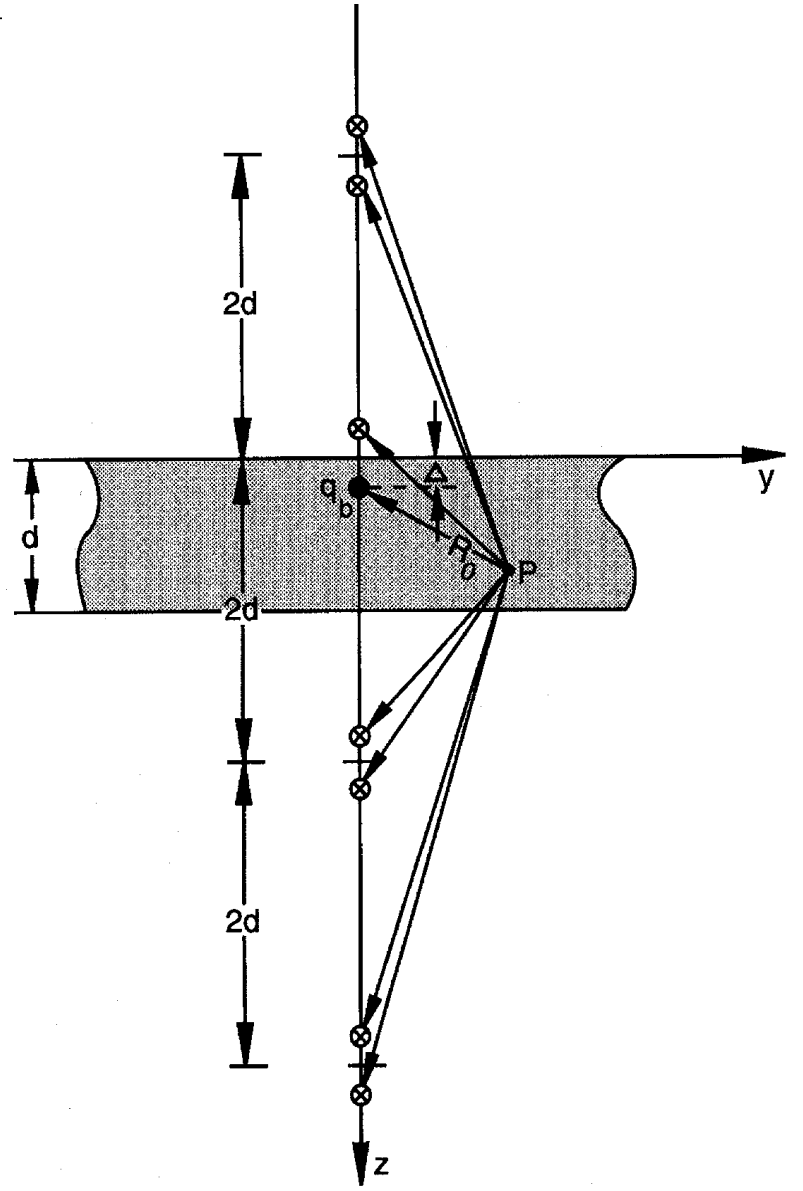

b.

Figura 7: Modelo geral de fluxo de calor em chapas de espessura média, proposto por MYHR; $\mathrm{GRONG}^{(17)}$. Em (a) representação física da distribuição de calor mediante fontes pontuais. Em (b) método de cálculo do campo de temperatura ao redor de uma fonte pontual de calor inserida dentro da chapa. 
$T\left(q_{b}^{i}\right)=\frac{q_{b}^{i}}{4 \pi k} e^{-\frac{v \xi}{2 a}}\left[\sum_{j=-\infty}^{j=+\infty} \frac{e^{-R_{j} \frac{v}{2 a}}}{R_{j}}+\sum_{f=-\infty}^{f=+\infty} \frac{e^{-R_{f} \frac{v}{2 a}}}{R_{f}}\right]$

Onde: $\quad R_{j}=\sqrt{\xi^{2}+y^{2}+(z-2 d j-\Delta)^{2}}$

$$
R_{f}=\sqrt{\xi^{2}+y^{2}+(z-2 d f+\Delta)^{2}}
$$

\subsection{ESPESSURA DA CHAPA}

A diferenciação entre chapa fina e grossa se faz em razão do fluxo de calor ser preponderantemente bidimensional ou tridimensional, respectivamente. No caso de soldagem de aços, LANCASTER ${ }^{(8)}$ propôs que, para chapas com espessura menor de 12 $\mathrm{mm}$ a fonte de calor deve ser tratada como linear e para espessuras maiores que $25 \mathrm{~mm}$, como pontual. Para espessuras intermediárias a distribuição de temperaturas é similar à produzida pela combinação dos regimes bidimensional (2D - fonte linear) e tridimensional (3D - fonte pontual). Todavia, critérios deste tipo são muito vagos e não levam em conta outros fatores que determinam o tipo preponderante de fluxo de calor. Por esta razão foi definido por $\operatorname{ADAMS}^{(18-19)}$ o termo adimensional $(\tau)$ para uma chapa de espessura $(d)^{(2)}$ :

$$
\tau=d \sqrt{\frac{\rho C_{p}\left(T_{c}-T_{o}\right)}{q_{L}}}
$$

Equação 9

A chapa é considerada grossa quando $\tau>0,9$ e fina para $\tau<0,6$. Na condição intermediária de $0,9>\tau>0,6$ o fluxo de calor muda de preponderantemente tridimensional em temperaturas elevadas, para bidimensional em temperaturas mais baixas. Uma divisão arbitrária entre chapa fina e grossa em $\tau=0,75$ não leva a erros superiores a $15 \%$ no cálculo das velocidades de resfriamento. Na Figura 8 são mostrados os formatos das isotermas para estas três condições de fluxo de calor. 
a.

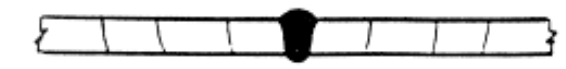

b.

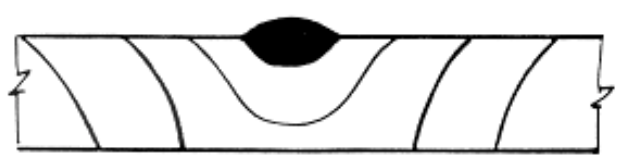

c.

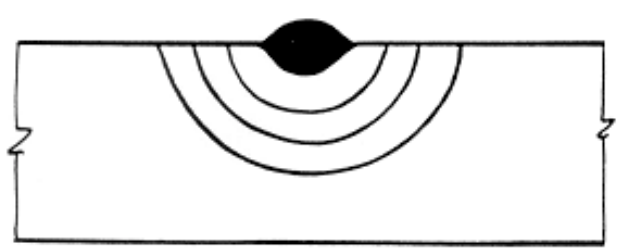

Figura 8: $\quad$ Formato das isotermas através da espessura da chapa durante a soldagem. Em (a) com fluxo de calor predominantemente bidimensional; em (b) na condição intermediária; em (c) na condição tridimensional ${ }^{(7)}$.

Como foi exposto, as condições de fluxo de calor na soldagem determinam os ciclos térmicos experimentados pelas diferentes regiões da junta soldada. Dependendo do material e do seu estado inicial, estes ciclos térmicos podem acarretar diversas mudanças microestruturais. Nos itens seguintes serão descritas as características gerais dos aços inoxidáveis duplex e as principais alterações microestruturais que o processo de soldagem pode ocasionar neles. 


\section{AÇOS INOXIDÁVEIS DUPLEX}

Os aços inoxidáveis duplex (AID) são materiais baseados no sistema Fe-Cr-Ni. Sua composição química e processamento termomecânico conferem-lhes uma microestrutura bifásica com proporções aproximadamente iguais de ferrita e austenita. Tipicamente possuem 20 a $30 \%$ de cromo e 5 a $10 \%$ de níquel, com teores muito baixos de carbono (menores de $0,03 \%$ ) e com adições de nitrogênio, molibdênio, tungstênio e cobre ${ }^{(20)}$.

Os AID apresentam numerosas vantagens sobre os aços inoxidáveis austeníticos e ferríticos tradicionais. A resistência mecânica dos AID é aproximadamente o dobro da dos aços inoxidáveis austeníticos, combinada com uma boa tenacidade. Apresentam uma elevada resistência ao trincamento por corrosão-sob-tensão e à corrosão localizada em meios contendo cloretos. A sua soldabilidade é superior à dos aços inoxidáveis ferríticos ${ }^{(21)}$.

A maior resistência à tração dos AID permite importantes reduções na seção resistente, obtendo-se grandes economias de peso. Além disso, devido à excelente resistência à corrosão, a vida útil do equipamento pode ser prolongada, dependendo da aplicação e do material que está sendo substituído pelo AID. Desta forma, estes materiais tornam-se bastante atrativos do ponto de vista econômico. Dependendo da norma de fabricação aplicada e do material substituído, a economia em peso pode chegar a $50 \%{ }^{(22)}$. A Tabela 1 mostra a economia em peso alcançada quando o aço inoxidável austenítico AISI $316 \mathrm{~L}$ é substituído pelo AID UNS S31803.

Tabela 1: Economia em peso alcançada pela substituição do aço inoxidável austenítico AISI $316 \mathrm{~L}$ pelo AID UNS S31803, com a aplicação de diversos códigos ${ }^{(22)}$.

\begin{tabular}{|c|c|c|c|c|}
\hline \multirow{2}{*}{ Código } & \multirow{2}{*}{ País } & \multicolumn{2}{|c|}{ Esforço Admissível $\left(\mathrm{e}>5 \mathrm{~mm}, 20^{\circ} \mathrm{C}\right)[\mathrm{MPa}]$} & \multirow{2}{*}{$\begin{array}{c}\text { Economia em } \\
\text { peso [\%] }\end{array}$} \\
\cline { 3 - 4 } & & AISI $316 \mathrm{~L}$ & UNS S31803 & 26 \\
\hline ASME VIII & E.U.A. & 115 & 155 & 38 \\
\hline CODAP 90, f.1 & França & 170 & 275 & 48 \\
\hline BS 5.500 & Inglaterra & 150 & 289 & 50 \\
\hline ADW 2 & Dinamarca & 150 & 300 & 5 \\
\hline
\end{tabular}

A microestrutura típica de um AID laminado é formada por lamelas (policristalinas) alternadas de ferrita $(\alpha)$ e austenita $(\gamma)$. As suas fases em equilíbrio podem ser avaliadas usando uma seção vertical com Fe constante do diagrama ternário Fe-Cr-Ni. A Figura 9 mostra esquematicamente, no diagrama pseudo-binário $70 \% \mathrm{Fe}-\mathrm{Cr}-\mathrm{Ni}$, a solidificação ferrítica de um AID de composição química típica. À medida que avança o resfriamento, parte dessa ferrita se transforma, no estado sólido, em austenita. Deste modo, na temperatura ambiente, tem- 
se a estrutura bifásica $\alpha / \gamma$, caso as condições de resfriamento impeçam a formação de outras fases, as quais serão discutidas adiante.

O mecanismo de decomposição da ferrita em austenita nos AID depende da temperatura na qual esta se dá. Em temperaturas elevadas $\left(650-1200^{\circ} \mathrm{C}\right)$, que é como acontece nas condições normais de fabricação dos AID, a austenita é formada por nucleação e crescimento e segue uma curva de cinética em "C". Já em temperaturas mais baixas (300$650^{\circ} \mathrm{C}$ ) a transformação pode ser por um processo atérmico tipo martensítico ${ }^{(23)}$.

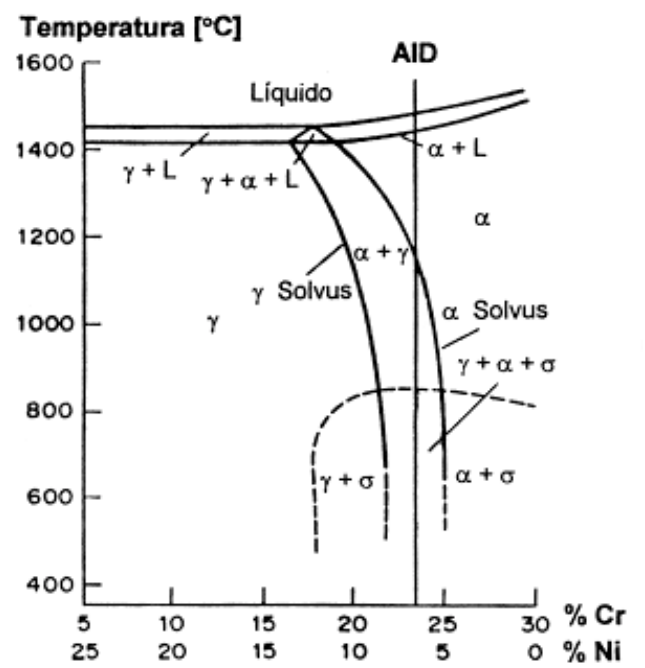

Figura 9: Seção vertical com Fe constante $(70 \%)$ do diagrama ternário $\mathrm{Fe}-\mathrm{Cr}-\mathrm{Ni}^{(24)}$.

A microestrutura formada depende da composição química da liga, do tratamento termomecânico e das condições de resfriamento ${ }^{(20,25)}$. Caso uma liga seja resfriada rapidamente desde o campo ferrítico, a formação de austenita pode ser parcialmente impedida.

Os AID quando comparados com os aços inoxidáveis austeníticos e ferríticos convencionais, possuem uma excelente combinação de propriedades mecânicas. A resistência à tração dos AID é quase o dobro da dos aços inoxidáveis austeníticos, além de possuírem tenacidades comparáveis. Esta combinação de propriedades mecânicas nos AID é devida as frações comparáveis de ferrita e austenita, condição que é alcançada mediante tratamento de solubilização, seguido de resfriamento rápido, a fim de evitar a precipitação de outras fases. Esta precipitação, a partir da ferrita, pode levar a uma séria redução da tenacidade e da resistência à corrosão destes aços. Segundo a temperatura na qual acontece, a fragilização dos AID pode ser dividida em dois grupos:

Fragilização de baixa temperatura: Também chamada de fragilização de $475^{\circ} \mathrm{C}$, que normalmente acontece numa faixa de temperatura de 300 a $500{ }^{\circ} \mathrm{C}$. Este tipo de fragilização limita a temperatura máxima de aplicação em serviço dos $\operatorname{AID}^{(20,26)}$.

Fragilização de alta temperatura: Ocorre na faixa de temperatura de 600 a $1000^{\circ} \mathrm{C}$, onde precipitam diversas fases intermetálicas $\left(\sigma, \chi, \tau, \mathrm{R}, \mathrm{Cr}_{2} \mathrm{~N} \ldots\right)$. 
A fragilização em baixa temperatura normalmente ocorre durante a utilização do equipamento em serviço. Por outro lado, a fragilização em temperatura elevada geralmente acontece durante a fabricação e/ou tratamento térmico pós-soldagem do equipamento. Em ambos os tipos de fragilização, as propriedades mecânicas podem ser deterioradas.

A precipitação das fases intermetálicas, da $\alpha$ ' e da $\gamma_{2}$ também pode causar uma importante diminuição na resistência à corrosão dos AID, comprometendo o desempenho do material ${ }^{(27}$, 28).

A ampla utilização que os AID vem tendo nas últimas décadas deve-se principalmente a sua excelente resistência à corrosão localizada (pites e frestas) e a corrosão-sob-tensão ${ }^{(20,28-30)}$, aliada às suas propriedades mecânicas. Entre a grande variedade de AID disponíveis hoje no mercado tem-se ligas com uma gama de resistência à corrosão similar a dos aços inoxidáveis austeníticos tradicionais, às ligas com Mo elevado e mesmo algumas ligas à base de $\mathrm{Ni}^{(31)}$.

\subsection{PRECIPITAÇÃO NOS AÇOS INOXIDÁVEIS DUPLEX}

Como já foi mencionado, além da ferrita e a austenita, outras fases podem precipitar nos AID numa faixa de temperatura de 300 a $1000^{\circ} \mathrm{C}$. A exposição do material nestas temperaturas pode acontecer como resultado de condições de serviço, de ciclos térmicos de soldagem ou de tratamentos térmicos. A Figura 10 apresenta, esquematicamente, uma curva TTP para fases que podem precipitar na ZAC, como: fases intermetálicas, austenita secundária $\left(\gamma_{2}\right)$ e $\alpha$ '. A Tabela 2 resume as principais características de algumas das fases mais comuns que podem precipitar nos AID. Tanto as propriedades mecânicas, principalmente a tenacidade, como as de resistência à corrosão podem ser prejudicadas de diversas formas, dependendo da fase presente.

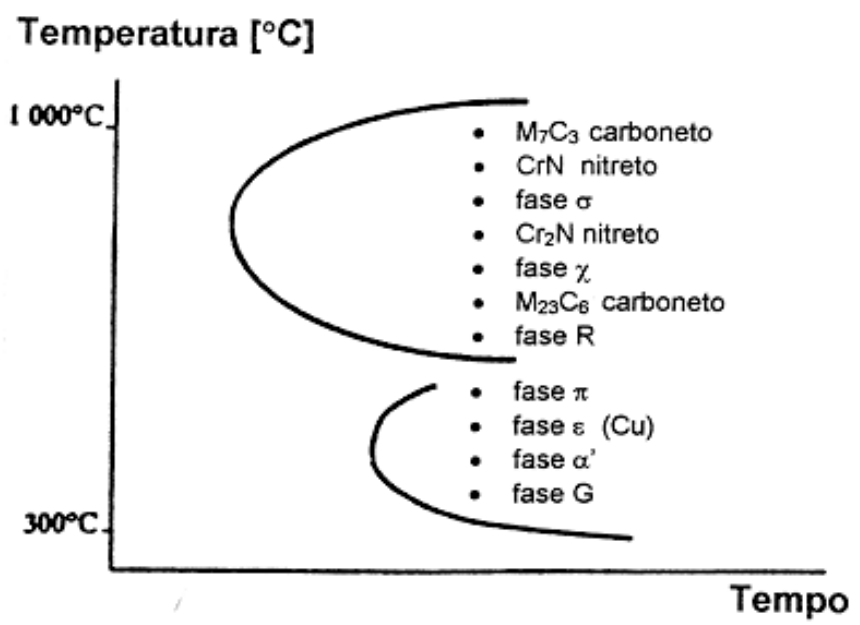

Figura 10: Diagrama TTT esquemático de precipitação de segundas fases nos $\operatorname{AID}^{(32)}$. 
Tabela 2: Fases observadas nos AID ${ }^{(52)}$.

\begin{tabular}{|c|c|c|c|c|c|c|c|c|c|}
\hline \multirow{2}{*}{$\begin{array}{c}\text { Fase } \\
\text { (Formula } \\
\text { química) }\end{array}$} & \multirow{2}{*}{$\begin{array}{c}\text { Est. Cristalina } \\
\text { [Grupo } \\
\text { espacial] }\end{array}$} & \multirow{2}{*}{$\begin{array}{c}\text { Parâmetro de } \\
\text { rede } \\
{[\AA]}\end{array}$} & \multirow{2}{*}{$\begin{array}{c}\text { Faixa de } \\
\text { temperatura } \\
{\left[{ }^{\circ} \mathrm{C}\right]}\end{array}$} & \multicolumn{5}{|c|}{$\begin{array}{c}\text { Composição Química } \\
{[\%]}\end{array}$} & \multirow[t]{2}{*}{ Ref. } \\
\hline & & & & $\mathrm{Fe}$ & $\mathrm{Cr}$ & $\mathrm{Ni}$ & Mo & Outros & \\
\hline Ferrita $(\alpha)^{(a)}$ & $\begin{array}{c}\text { ccc } \\
{[\operatorname{lm} 3 \mathrm{~m}(229)]}\end{array}$ & $a=2,86-2,88$ & - & 54,5 & 27,9 & 8,4 & 2,9 & $0,05 \mathrm{~N}$ & 33 \\
\hline Austenita $(\gamma)^{(a)}$ & $\begin{array}{c}\text { cfc } \\
{[\mathrm{Fm} 3 \mathrm{~m}(225)]}\end{array}$ & $a=3,58-3,62$ & - & 55,5 & 27,0 & 10,0 & 3,6 & $0,54 \mathrm{~N}$ & 33 \\
\hline $\begin{array}{c}\text { Austenita } \\
\text { Secundária }\left(\gamma_{2}\right)^{(a)}\end{array}$ & $\begin{array}{c}\mathrm{cfc} \\
{[\mathrm{Fm} 3 \mathrm{~m}(225)]}\end{array}$ & $a=3,539$ & $600-1000$ & 56,8 & 25,3 & 11,2 & 2,4 & $0,19 \mathrm{~N}$ & $33-36,49$ \\
\hline $\begin{array}{l}\text { Nitreto }^{(b)} \\
\left(\mathrm{Cr}_{2} \mathrm{~N}\right) \\
\end{array}$ & $\begin{array}{c}\text { trigonal } \\
{\left[\mathrm{P} 3_{1} \mathrm{~m}(162)\right]}\end{array}$ & $\begin{array}{l}a=4,750-4,796 \\
c=4,429-4,470\end{array}$ & $550-1000$ & 4,6 & 85,5 & - & 4,8 & $\begin{array}{c}5,1 \mathrm{~V} \\
\mathrm{~N}\end{array}$ & $37-39$ \\
\hline $\begin{array}{l}\text { Nitreto }^{(\mathrm{b})} \\
(\mathrm{CrN})\end{array}$ & $\begin{array}{c}\mathrm{cfc} \\
{[\mathrm{Fm} 3 \mathrm{~m}(225)]}\end{array}$ & $a=4,140$ & $550-1000$ & 5,8 & 83,1 & - & 9,3 & $\begin{array}{c}1,8 \mathrm{Mn} \\
\mathrm{N} \\
\end{array}$ & 40,41 \\
\hline $\begin{array}{c}\pi^{(\mathrm{b})} \\
\left(\mathrm{Mo}_{13} \mathrm{Fe}_{7} \mathrm{~N}_{4}\right)\end{array}$ & $\begin{array}{l}\text { cúbica prim. } \\
{[\mathrm{P} 4,32(213)]}\end{array}$ & $a=6,47$ & $500-600$ & 28,4 & 34,9 & 2,8 & 33,9 & $\mathrm{~N}$ & 42 \\
\hline $\begin{array}{c}\text { Carboneto }^{(\mathrm{b})} \\
\left(\mathrm{M}_{23} \mathrm{C}_{6}\right)\end{array}$ & $\begin{array}{c}\mathrm{cfc} \\
{[\mathrm{Fm} 3 \mathrm{~m}(225)]}\end{array}$ & $a=10,56-10,68$ & $550-1000$ & 35 & 60 & 2 & 3 & C & $43-44$ \\
\hline $\begin{array}{l}\text { Carboneto } \\
\left(\mathrm{M}_{7} \mathrm{C}_{3}\right)\end{array}$ & $\begin{array}{l}\text { ortorrômbico } \\
\text { [Pnma (62)] }\end{array}$ & $\begin{array}{c}a=4,52 \\
b=6,99 \\
c=12,11\end{array}$ & $950-1100$ & & & & & & 42 \\
\hline $\begin{array}{c}\chi \\
\left(\mathrm{Fe}_{18} \mathrm{Cr}_{6} \mathrm{Mo}_{5}\right)\end{array}$ & $\begin{array}{c}\text { ccc } \\
{[143 m(217)]}\end{array}$ & $\begin{array}{c}a=8,920 \\
a=8,862-8,878\end{array}$ & $400-950$ & 48,2 & 26,7 & 3,3 & 21,8 & - & 42,43 \\
\hline $\begin{array}{c}\sigma \\
(\mathrm{FeCr}) \\
\end{array}$ & $\begin{array}{c}\text { tetragonal } \\
{\left[\mathrm{P} 4_{2} / \mathrm{mnm}(136)\right]}\end{array}$ & $\begin{array}{l}a=8,799-8,828 \\
c=4,544-4,597\end{array}$ & $650-1000$ & 55 & 29 & 5 & 11 & - & $43,45,46$ \\
\hline $\begin{array}{c}\varepsilon \\
\text { (rica em } \mathrm{Cu})\end{array}$ & $\begin{array}{c}\mathrm{cfc} \\
{[\mathrm{Fm} 3 \mathrm{~m}(225)]}\end{array}$ & $a=3,615$ & $400-650$ & - & - & - & - & $\mathrm{Cu}$ & 47 \\
\hline $\mathrm{G}^{(\mathrm{c})}$ & $\begin{array}{c}\text { cúbica } \\
{[\mathrm{Fm} 3 \mathrm{~m}(225)]}\end{array}$ & $a=10,9-11,6$ & $300-500$ & 16 & 25 & 26 & 16 & $14 \mathrm{Si}$ & 48 \\
\hline $\begin{array}{c}\alpha^{\prime} \\
(\alpha \text { rica em } \mathrm{Cr}) \\
\end{array}$ & $\begin{array}{c}\mathrm{ccc} \\
{[14 / \mathrm{m} 32 / \mathrm{m}]} \\
\end{array}$ & $a=2,87-2,89$ & $350-750$ & 12 & 72 & 3 & 10 & $3 \mathrm{Si}$ & 42,48 \\
\hline $\begin{array}{c}\mathrm{R} \\
\left(\mathrm{Fe}_{28} \mathrm{Cr}_{13} \mathrm{Mo}_{12}\right)\end{array}$ & $\begin{array}{c}\text { trigonal } \\
\text { romboédrica } \\
\text { hexagonal } \\
{[\mathrm{R} 3(146: \mathrm{H})]}\end{array}$ & $\begin{array}{c}a=9,01 \alpha=74^{\circ} 30^{\prime} \\
a=10,937 \\
c=19,346\end{array}$ & $550-800$ & 44,8 & 25,6 & - & 27,8 & 1,8 Co & $49-50$ \\
\hline $\begin{array}{c}\tau \\
(\mathrm{Fe}-\mathrm{Cr}-\mathrm{Mo})\end{array}$ & $\begin{array}{c}\text { ortorrômbica } \\
\text { [Frmmm } \\
(69)] \\
\end{array}$ & $\begin{array}{l}a=4,054 \\
b=3,436 \\
c=2,867\end{array}$ & $550-650$ & 43,4 & 23,9 & 5,9 & 22,8 & $3,6 \mathrm{Mn}$ & 51 \\
\hline $\begin{array}{l}\text { Laves } \\
\left(\mathrm{Fe}_{2} \mathrm{Mo}\right)\end{array}$ & hcp & $\begin{array}{l}a=4,73 \\
c=7,72\end{array}$ & $650-815$ & & & & & & 43 \\
\hline
\end{tabular}

Notas: a: As composições da ferrita, $\gamma$ e $\gamma_{2}$ são ilustrativas para a liga $25,66 \% \mathrm{Cr}-9,24 \% \mathrm{Ni}-3,8 \% \mathrm{Mo}-0,26 \% \mathrm{~N}$.

b: Medidos só os elementos metálicos

c: \% atômica

Dentro destas fases destacam-se: Os nitretos (devido a vasta e comum presença nas soldas dos AIDs); a fase sigma (pelos seus perniciosos efeitos na tenacidade e nas resistência à corrosão dos materiais); e por último, $\gamma_{2}$ intragranular (a qual precipita durante o reaquecimento de regiões da ZF ou ZAC com elevados teores de ferrita).

No caso dos AISD, a sua composição química os faz mais susceptíveis à precipitação de $\gamma_{2}$. Dadas as fortes quedas na resistência à corrosão localizada que a presença desta fase causa, o seu estudo se torna importante. 
Este trabalho é enfocado basicamente no estudo da precipitação em temperaturas relativamente elevadas (acima de $600^{\circ} \mathrm{C}$ ). Portanto, fases como $\alpha, \mathrm{G}$, $\varepsilon$, e $\tau$ não serão tratadas. Mas é importante saber que, em determinadas condições, estas fases podem estar presentes nas microestruturas dos AIDs.

Nos trabalhos científicos apresentados nas Conferências Internacionais Duplex Stainless Steels até o ano de 1994, tinha-se como inadmissível a presença de fases intermetálicas nos AIDs. No entanto, devido à importância que os AISD estão tomando e a sua propensão à precipitação deste tipo de fase, vem sendo publicados trabalhos onde a quantidade de precipitados admitida tem sido paulatinamente incrementada. Por exemplo, NILSSON; WILSON $^{(53)}$ tem afirmado que para frações volumétricas de fase $\sigma$ menores de $4 \%$, o valor de tenacidade convencionalmente aceitado entre os usuários dos AIDs de $27 \mathrm{~J} / \mathrm{cm}^{2}$ é facilmente alcançado. VAN NASSAU et al. ${ }^{(54)}$ afirmam que frações de intermetálicos precipitados, de $0 \%$ na superfície de 1 até $2 \%$ no meio da espessura são admissíveis, tanto para soldas como para chapas. Segundo GINN; $\mathrm{GOOCH}^{(55)}$, teores de fases intermetálicas ao redor de $1,5 \%$ não causam redução na temperatura crítica de pite, mas teores superiores a $5 \%$ reduzem significativamente a resistência à corrosão por pites. Eles ainda recomendam que a qualificação de um procedimento de soldagem para estes materiais deve ser baseada na medida das propriedades de interesse, sejam estas mecânicas ou de resistência à corrosão.

\subsubsection{Nitretos de Cromo - $\mathrm{Cr}_{2} \mathrm{~N}-\mathrm{CrN}$}

Nos aços inoxidáveis que não tem na sua composição química elementos com uma elevada capacidade de formação de nitretos ( $\mathrm{Ti}, \mathrm{Nb}$ ou $\mathrm{V}$ ), o limite de solubilidade do nitrogênio é dado pelo equilíbrio entre a matriz e o $\mathrm{Cr}_{2} \mathrm{~N}$. Portanto, quando o teor de nitrogênio supera esse limite, a liga se torna termodinamicamente instável e nitretos podem precipitar entre 600 e $1050^{\circ} \mathrm{C}^{(56)}$.

$\mathrm{O} \mathrm{Cr}_{2} \mathrm{~N}$ foi reportado pela primeira vez por UHRLAUB e UFER apud SERVI; FORGENG ${ }^{(57)}$ em 1859, sintetizado a partir de amônia e sais de cromo. Apresenta uma estrutura cristalina trigonal $\left(\mathrm{a}_{\mathrm{SR}}=4,760 \AA, \mathrm{c}=4,438 \AA\right.$ ), na qual os átomos metálicos adotam uma estrutura hexagonal compacta, a qual define a chamada sub-célula (SC) da estrutura. Nesta estrutura os átomos não metálicos ( $\mathrm{N}, \mathrm{C})$ ocupam a metade dos interstícios octaédricos. Desta forma, a minimização da energia de deformação proveniente do preenchimento destes interstícios leva à formação de um super-reticulado (SR) trigonal $\left(a_{S R}=a_{S c}{ }^{-} 3\right)$, em termos do qual são geralmente reportados todos os resultados relativos a este composto. Na Figura 11 é apresentada a relação entre a sub-célula e o super-reticulado do $\mathrm{Cr}_{2} \mathrm{~N}$. As relações de orientação adotadas entre o super-reticulado do $\mathrm{Cr}_{2} \mathrm{~N}$, a ferrita ${ }^{(58)}$ e a austenita ${ }^{(59)}$ são: 


$$
\begin{aligned}
& (0001)_{\mathrm{Cr}_{2} \mathrm{~N}} \mathrm{II}(\overline{1} 10) \alpha \quad[0 \overline{1} 10]_{\mathrm{Cr}_{2} \mathrm{~N}} \mathrm{II}[001] \alpha \quad[2 \overline{1} \overline{1} 0]_{\mathrm{Cr}_{2} \mathrm{~N}} \mathrm{I}[110] \alpha \\
& \{0001\}_{\mathrm{Cr}_{2} \mathrm{~N}}\left\|\{111\} \gamma \quad\langle 1100\rangle_{\mathrm{Cr}_{2} \mathrm{~N}}\right\|\langle 110\rangle \gamma
\end{aligned}
$$

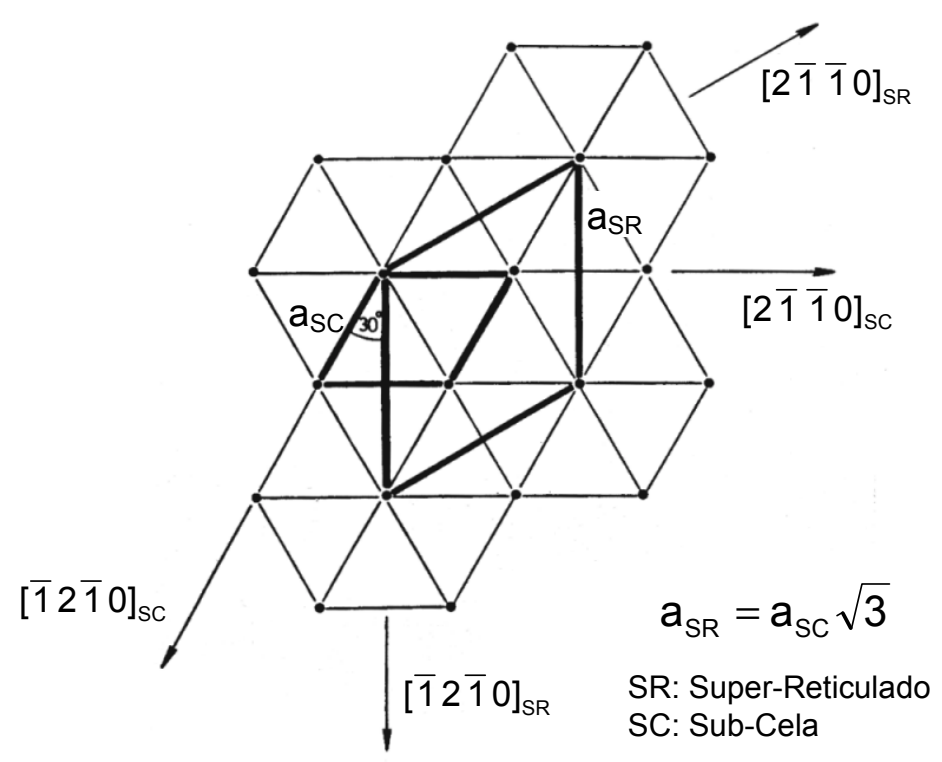

Figura 11: Relação entre a sub-célula e o super-reticulado do $\mathrm{Cr}_{2} \mathrm{~N}^{(39)}$.

A direção de crescimento do $\mathrm{Cr}_{2} \mathrm{~N}$ na ferrita depende da relação entre os parâmetros de rede do precipitado e da matriz, que por sua vez, muda com a temperatura. Em temperaturas elevadas (ao redor de $827^{\circ} \mathrm{C}$ ) a direção de crescimento é $\langle 113\rangle \alpha$ e em temperaturas mais baixas (ao redor de $527^{\circ} \mathrm{C}$ ) na direção $\langle 100\rangle \alpha^{(58)}$.

Quanto a composição química do $\mathrm{Cr}_{2} \mathrm{~N}$, KIKUCHI; KAJIHARA; FRISK reportaram uma solubilidade baixa de $\mathrm{Fe}$ e do Ni nele. Finalmente, a sua dureza está próxima dos 1300 Vickers $^{(60)}$.

Os nitretos de cromo precipitam por nucleação e crescimento, seguindo uma curva de cinética em "C". A nucleação se dá nas discordâncias, inclusões, contornos de grão $(\alpha / \alpha)$ e interfaces $(\alpha / \gamma)^{(61-62)}$. A cinética de precipitação é altamente dependente da temperatura, da composição química da liga e da sua história térmica.

O nitreto de cromo pode precipitar a partir da ferrita ou da austenita. Nos AIDs, bastonetes de $\mathrm{Cr}_{2} \mathrm{~N}$, ou plaquetas de $\mathrm{CrN}$ precipitam a partir da ferrita ${ }^{(63)}$. Durante o resfriamento a partir do campo ferrítico, ocorre uma competição entre a precipitação de austenita e de nitreto de cromo. Se a quantidade de austenita formada for próxima do valor de equilíbrio, praticamente todo o nitrogênio estará dissolvido nela. Como conseqüência, a quantidade de 
nitreto de cromo precipitado na ferrita é praticamente nula. Por outro lado, se a precipitação da austenita for retardada ou impedida, a ferrita torna-se supersaturada em nitrogênio, precipitando nitreto de cromo. Cálculos termodinâmicos mediante a utilização do programa de computador Thermo-Calc ${ }^{\circledR}$ verificaram que, no caso do AID UNS S31803, ainda que as condições de resfriamento permitissem a formação da austenita, $0 \quad \mathrm{Cr}_{2} \mathrm{~N}$ é termodinamicamente estável a temperaturas abaixo de $900{ }^{\circ} \mathrm{C}^{(33)}$. Portanto, a presença dos nitretos é esperada quando o material é submetido por longos períodos de tempo a temperaturas abaixo dos $900^{\circ} \mathrm{C}$.

Quanto à influência dos elementos de liga na cinética de precipitação dos nitretos nos AIDs, o $\mathrm{Cr}$, Mo e W aceleram a sua cinética de precipitação. Da mesma maneira, o Mo e o W estendem o campo de precipitação destas fases para temperaturas mais elevadas ${ }^{(25)}$. O Ni aumenta a fração de austenita, e portanto diminui e retarda a precipitação de nitretos. Já o efeito do $\mathrm{N}$ deve ser visto com maior cuidado. Como este é um elemento fortemente austenitizante, pode chegar a retardar e diminuir a precipitação de nitretos ${ }^{(64,65)}$. Mas, por outro lado, este elemento faz parte do nitreto, e portanto pode ter o efeito contrário ${ }^{(29,66)}$. A Figura 12 mostra a quantidade de nitreto extraído da ZAC de um AID (Fe-27,5\%Cr-3,8\%Mo$\mathrm{Ni}-\mathrm{N})$ em função do teor de nitrogênio e da fração volumétrica de ferrita na liga ${ }^{(67)}$. Observando a Figura 12 nota-se que, para uma dada fração volumétrica de ferrita, a quantidade de nitretos precipitados na ZAC aumenta com o teor de nitrogênio no aço.

A grande maioria dos autores reporta a precipitação do $\mathrm{Cr}_{2} \mathrm{~N}$ nos AIDs na faixa de temperatura de 700 a $900^{\circ} \mathrm{C}^{(29,68)}$. No entanto, a sua precipitação a $400{ }^{\circ} \mathrm{C}$ foi verificada na liga fundida CF8M (Fe-20\%Cr-10\%Ni-2\%Mo-0,15\%N) nas interfaces $\alpha / \gamma$, após tempos de 30.000 horas. Assim, a precipitação de $\mathrm{Cr}_{2} \mathrm{~N}$ pode-se converter em um outro tipo de fragilização a baixas temperaturas ${ }^{(69)}$.

A precipitação de nitretos de cromo pode levar à diminuição da resistência à corrosão dos AIDs, sendo que, ao redor destes precipitados pode-se iniciar um tipo de corrosão localizada ${ }^{(70-75)}$. O teor de cromo da matriz ferrítica adjacente aos nitretos é aproximadamente $3 \%$ menor que no restante da matriz ${ }^{(75)}$. Como a difusão do cromo na ferrita é facilitada, esta diferença tende a diminuir para velocidades de resfriamento menores durante a soldagem. Este pequeno empobrecimento em $\mathrm{Cr}$ não parece justificar totalmente a corrosão localizada gerada nestas regiões. Portanto, outros fenômenos como a corrosão galvânica entre a zona empobrecida e a matriz, o desarranjo interfacial nitreto-matriz ou os esforços internos podem contribuir para que a corrosão localizada aconteça ${ }^{(76)}$. 


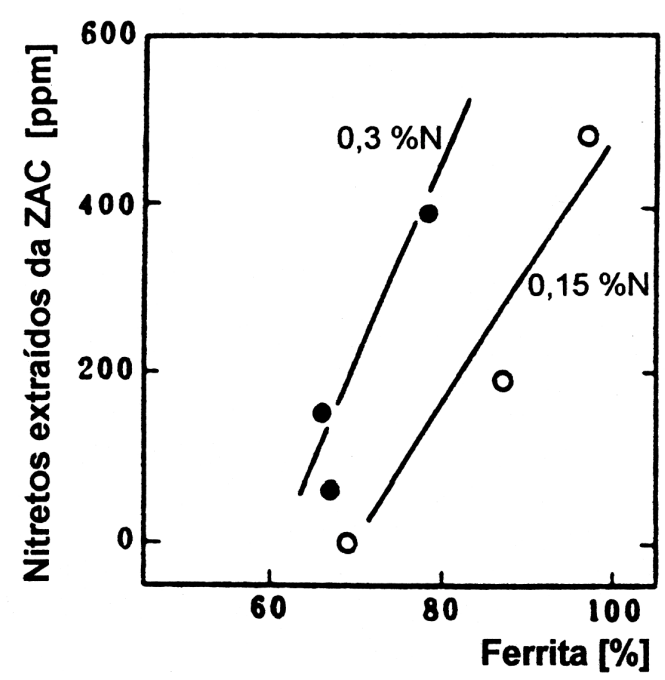

Figura 12: Efeito do teor de nitrogênio e da fração de ferrita na quantidade de $\mathrm{Cr}_{2} \mathrm{~N}$ precipitado na ZAC de um AID ${ }^{(67)}$.

As propriedades mecânicas dos AIDs também podem ser afetadas pela precipitação dos nitretos. Esta precipitação pode levar a uma redução significativa da tenacidade ${ }^{(52-56,67,71,77-}$ 79). A Figura 13 apresenta a energia absorvida no ensaio Charpy de um AID (Fe-27,5\%Cr$3,8 \% \mathrm{Mo}-\mathrm{Ni}-\mathrm{N}$ ) em função da massa de nitreto extraída da ZAC, para frações volumétricas de ferrita maiores que $70 \%$ vol. Em corpos de prova Charpy de AIDs testados a baixas temperaturas $\left(-200,-20^{\circ} \mathrm{C}\right)$, fraturas por clivagem tem sido observadas na presença de $\mathrm{Cr}_{2} \mathrm{~N}^{(6,77-79)}$. O trabalho de SIMMONS et al. ${ }^{(59)}$ com um aço inoxidável austenítico mostrou que é necessária uma certa cobertura dos contornos de grão com $\mathrm{Cr}_{2} \mathrm{~N}$ para que a tenacidade seja sensivelmente afetada.

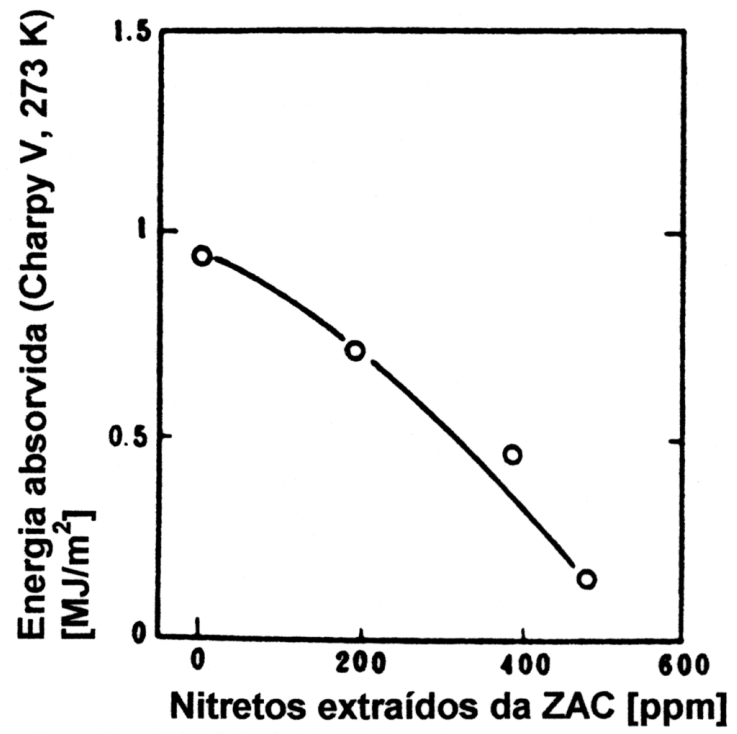

Figura 13: Relação entre a energia absorvida no ensaio Charpy $(273 \mathrm{~K})$ e a quantidade de nitretos na ZAC de um AID ${ }^{(67)}$. 
De uma maneira geral, devido às suas frações volumétricas menores, a presença dos nitretos de cromo nos AIDs é menos prejudicial que a de outras fases intermetálicas, como a fase sigma ${ }^{(80)}$.

\subsubsection{Fase $\sigma$ (Sigma)}

A faixa de temperatura de precipitação de fase sigma depende da composição química da liga. Geralmente encontra-se na faixa de temperatura de 600 a $950^{\circ} \mathrm{C}$. Nos AID, a ferrita é termodinamicamente metaestável na faixa de temperatura de precipitação da fase sigma ${ }^{(33,}$ 81). A ferrita também possui um teor mais elevado dos elementos formadores de fase sigma (por exemplo $\mathrm{Cr}$ e Mo). Dessa maneira, a precipitação da fase sigma dá-se principalmente pela decomposição da ferrita. Essa decomposição geralmente ocorre através de uma reação eutetóide, formando sigma e austenita, esta com teores mais baixos dos elementos $\mathrm{Cr}$ e Mo. A reação ocorre por nucleação e crescimento, apresentando uma curva de transformação em C. A Figura 14 mostra o diagrama TTT de precipitação de fase sigma no AID UNS S31803.

Não é a difusão o fator que controla a precipitação da fase sigma, mas sim o rearranjo atômico em pequena escala para formar a complexa estrutura desta fase ${ }^{(82)}$. O local preferencial para a nucleação da sigma nos AID são as interfaces $\alpha / \gamma$. Devido ao pequeno desarranjo atômico que gera a relação de orientação adotada entre a sigma e a austenita ${ }^{(83)}$, a fase sigma nucleia epitaxialmente na austenita e cresce para a ferrita.

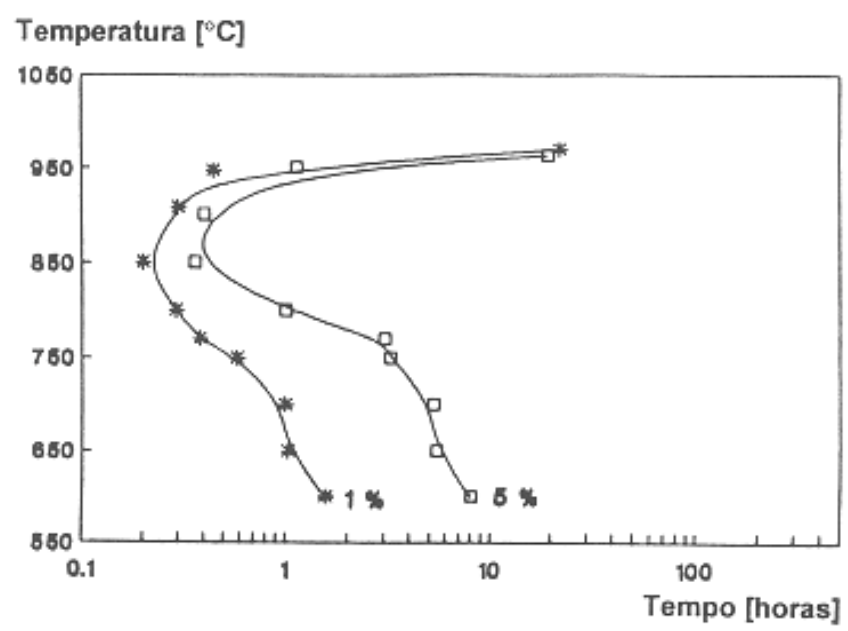

Figura 14: Diagrama TTT de precipitação de fase sigma no AID UNS S31803 ${ }^{(6)}$.

A morfologia da fase sigma precipitada é resultante de uma reação eutetóide. Para temperaturas de transformação mais baixas, a morfologia é lamelar, decorrente do crescimento competitivo. Para temperaturas mais elevadas, a morfologia é não lamelar, produto de uma reação eutetóide divorciada ${ }^{(84)}$. 
As adições de W e Cu aos AID aceleram a cinética de precipitação de fases intermetálicas como $\sigma$ e $\chi$. No caso da fase sigma, este comportamento tem sido explicado pela mudança na morfologia da fase sigma com a adição do $W^{(85)}$. Segundo HERTZMAN et al. ${ }^{(85)}$, em metais de solda com composição química do tipo Fe-25,5Cr-(3-4)Mo-9,5Ni-0,25N um com adição de $2,2 \%$ de $\mathrm{W}$ e o outro com $0,9 \%$ de $\mathrm{W}$ e $0,7 \%$ de $\mathrm{Cu}$, a cinética de precipitação de fases intermetálicas foi acelerada pela presença do W. O material com o maior teor de W teve a sua curva TTT deslocada para tempos menores e expandida para temperaturas maiores. Assim, a temperatura de início de dissolução destas mesmas fases é aumentada, devido a:

- O efeito termodinâmico do $\mathrm{W}$ ao estabilizar as fases intermetálicas, o qual expande a faixa de temperatura de estabilidade e aumenta o potencial termodinâmico para a precipitação.

- Favorece a nucleação da fase metaestável $\chi$, que é bastante mais rápida que a da fase $\sigma$, levando a menores tempos de incubação. Sabe-se, além disso, que na liga SAF $2507 \mathrm{em}$ temperaturas entre 800 e $850^{\circ} \mathrm{C}$ a fase $\chi$ precipita primeiro e subseqüentemente, transforma-se para fase $\sigma$, que é mais estável termodinamicamente ${ }^{(86)}$.

- Dado que as taxas de difusão são muito maiores a altas temperaturas, a extensão da faixa de precipitação favorece bastante este processo.

As observações realizadas na liga SAF 2507 envelhecida isotermicamente mostraram que a precipitação mais rápida de fase $\chi$, quando comparada com a fase $\sigma$, pode estar associada com as baixas deformações de coerência ${ }^{(86)}$.

Por outro lado, resultados de outras pesquisas mostraram que as adições de $\mathrm{W}$ podem reduzir a cinética de precipitação da fase sigma e outras fases intermetálicas. OKAMOTO(87) reportou que para o AISD Fe-24,9Cr-7,2Ni-3,4Mo-0,26N-1,9W teve a precipitação da fase sigma retardada em relação a um aço composição similar, mas com $0,2 \% \mathrm{~W}$. Desta forma, segundo o autor, é possível aumentar a resistência à corrosão localizada dos AISD agregando $\mathrm{W}$ ao contrário do Mo, de forma que a cinética de precipitação da fase sigma não seja incrementada. Um resultado similar foi encontrado por KONDO et al. ${ }^{(88)}$ trabalhando com ligas do tipo Fe-25Cr-7Ni-3Mo-0,3N-(0-4W). Eles concluíram que para pequenas adições de W (até $1 \%$ ) a cinética de precipitação da fase sigma foi incrementada no caso de envelhecimentos de curta duração. No entanto, esta precipitação foi suprimida para conteúdos intermediários de W (1-3\%). Este fenômeno está associado à mudança do mecanismo de precipitação da fase sigma. Isto é, para teores de $W$ entre 0 e $1 \%$ a nucleação acontece nas interfaces $\alpha / \gamma$, mas para teores maiores de $W$, a nucleação da fase sigma ocorre no interior dos grãos de $\alpha$. 
Um outro resultado intermediário entre os anteriormente apresentados foi reportado por $\mathrm{OH}$ et al. ${ }^{\left({ }^{89)}\right.}$, que estudaram a resistência à corrosão e susceptibilidade à precipitação de fase sigma na família de AIDs Fe-22Cr-5,5Ni-0,15N-(0-8)W, além das ligas Fe-22Cr-5,5Ni-0,15N2,7W-1Mo e Fe-22Cr-5,5Ni-0,15N-2,8Mo. Foi encontrado que o aumento do teor de $\mathrm{W}$ acelera a cinética de precipitação da fase sigma, mas o seu efeito é muito menos marcante que o do Mo. Na Figura 15 é mostrada a variação na tenacidade destas juntas com o tempo de envelhecimento a $850^{\circ} \mathrm{C}$. Com relação à resistência à corrosão, parte do Mo da liga pode ser substituído por $W$, podendo-se assim, obter um AID com uma resistência à corrosão adequada, mas com uma cinética reduzida de precipitação da fase sigma.

A precipitação da fase sigma reduz a resistência à corrosão dos AIDs. A presença desta fase pode aumentar a velocidade de corrosão de um AID em até oito vezes ${ }^{(84)}$. Quando submetido a ambientes ácidos $\left(\mathrm{HNO}_{3}, \mathrm{H}_{2} \mathrm{SO}_{4}\right)$, o ataque preferencial da matriz empobrecida em $\mathrm{Cr}$ e Mo perto das partículas de fase sigma tem sido uma das explicações mais comuns para este comportamento ${ }^{(90,91)}$. A resistência à corrosão-sob-tensão também é reduzida pela precipitação de fase sigma ${ }^{(92)}$.

As propriedades mecânicas dos AIDs também são seriamente prejudicadas com a precipitação da fase sigma. O limite de escoamento e o limite de resistência à tração aumentam ligeiramente, mas o alongamento pode cair de $40 \%$ para $7 \%$, com a precipitação desta fase ${ }^{(81,93)}$. A tenacidade também é bastante afetada pela precipitação da fase sigma. A precipitação de $1 \%$ de fase sigma, leva a energia absorvida no ensaio Charpy a cair a $50 \%$ do valor inicial ${ }^{(94)}$.

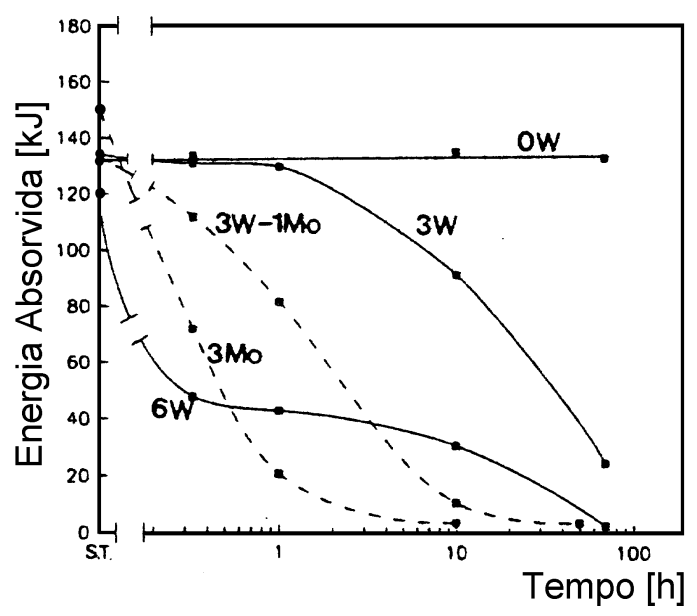

Figura 15: Variação na resistência ao impacto (ensaio Charpy) com o tempo de envelhecimento a $850^{\circ} \mathrm{C}$ das ligas do tipo Fe-22Cr-5,5Ni-0,15 N, com adições de $\mathrm{W}$ e Mo.

\subsubsection{Austenita Secundária $\left(\gamma_{2}\right)$}

Como já foi apresentado, os AID ligeiramente abaixo da temperatura solidus são totalmente ferríticos. Assim, durante o resfriamento a partir do campo ferrítico parte desta fase 
transforma-se em austenita primária $\left(\gamma_{1}\right)$. Caso este resfriamento seja muito rápido, a formação de $\gamma_{1}$ pode ser prejudicada, obtendo-se uma microestrutura metaestável com elevados teores de ferrita. Desta forma, durante o reaquecimento, seja por um tratamento isotérmico ou por reaquecimento devido ao processo de soldagem, a austenita secundária $\left(\gamma_{2}\right)$ precipita a partir da ferrita.

Segundo Nilsson ${ }^{(34)}$, no metal de solda de AID são distinguidos dois tipos de $\gamma_{2}$. Uma delas é formada nas interfaces $\alpha / \gamma$, na faixa de temperatura de 800 a $900^{\circ} \mathrm{C}$, não sendo outra coisa mais do que o crescimento das partículas preexistentes de $\gamma$, porém com diferente composição química. O outro tipo é formado no interior da ferrita, na forma de finas partículas aciculares, na faixa de temperatura de 800 a $1000^{\circ} \mathrm{C}$. Segundo este autor, o processo de nucleação e crescimento desta austenita acicular mostra uma cinética de curva em "C", indicando que a transformação é controlada por difusão. A nucleação intragranular ocorre nas discordâncias e inclusões ${ }^{(35-36,95-96)}$.

A formação de $\gamma_{2}$ na ZAC de soldas multipasse do AID SAF 2507 está intimamente relacionada com a dissolução dos precipitados de $\mathrm{Cr}_{2} \mathrm{~N}$. O nitrogênio liberado da dissolução de $\mathrm{Cr}_{2} \mathrm{~N}$ na faixa de temperatura entre 1000 e $1200{ }^{\circ} \mathrm{C}$, atuando como elemento estabilizador da austenita, promove a formação de $\gamma_{2}{ }^{(97-98)}$. No entanto, um outro estudo realizado com a mesma liga, submetida a tratamentos isotérmicos $\left(700-900{ }^{\circ} \mathrm{C}\right)$, mostrou a precipitação cooperativa de $\gamma_{2}$ e pequenas partículas eqüiaxiais (menores de $1 \mu \mathrm{m}$ ) de $\operatorname{Cr}_{2} \mathrm{~N}$ nas interfaces $\alpha / \gamma_{1}$. Estes nitretos exercem o efeito de ancoramento (Zener pinning) da interface $\alpha / \gamma$ quando do crescimento da $\gamma$, na forma de $\gamma_{2}{ }^{(53)}$.

Os teores de $\mathrm{Cr}$, Mo e $\mathrm{N}$ da $\gamma_{2}$ formada no metal de solda de um AID são menores que os da austenita previamente existente na microestrutura ${ }^{(34,36)}$. Acredita-se que a precipitação cooperativa do $\mathrm{Cr}_{2} \mathrm{~N}$ e da $\gamma_{2}$ tem uma relação direta com os baixos teores de $\mathrm{Cr}$ e $\mathrm{N}$ da $\gamma_{2}$, dado que o nitreto retira estes elementos da $\alpha$, que posteriormente transformar-se-á em $\gamma_{2}$. Desta maneira, a precipitação da $\gamma_{2}$ leva a uma diminuição na resistência à corrosão localizada ${ }^{(53)}$. Por um outro lado, devido à excelente tenacidade da $\gamma$, a precipitação da $\gamma_{2}$ causa uma melhora na tenacidade das juntas soldadas dos AIDs ${ }^{(98)}$.

Outra pesquisa, a qual submeteu o AID SAF 2205 a tratamentos isotérmicos (800 e $\left.900{ }^{\circ} \mathrm{C}\right)$ encontrou a precipitação cooperativa de $\mathrm{M}_{23} \mathrm{C}_{6}$ e $\gamma_{2}$. Foram observadas duas morfologias diferentes:

- Na primeira delas tem-se a precipitação lamelar de carbonetos e $\gamma$ a partir da interface $\gamma / \alpha$, dando origem à reação eutetoide $\alpha \rightarrow \mathrm{M}_{23} \mathrm{C}_{6}+\gamma_{2}$, como esquematizado na Figura 16. A precipitação dos carbonetos retira $\mathrm{Cr}$ da $\alpha$, e desta forma a $\alpha$ empobrecida em $\mathrm{Cr}$ transforma para $\gamma_{2}$, transformação que, por sua vez, rejeita $\mathrm{Cr}$ para a $\alpha$ adjacente, permitindo o crescimento dos carbonetos. Estabelecendo-se portanto o crescimento 
cooperativo das duas fases. Posteriormente, devido ao reduzido teor de $\mathrm{C}$ nos AIDs, a precipitação de carbonetos é limitada, dando origem a uma segunda reação eutetoide do tipo $\alpha \rightarrow \sigma+\gamma^{(99,100)}$.

- A outra morfologia observada nesta pesquisa foi a precipitação de carbonetos no formato de larva na interface original $\gamma / \alpha$, seguida do crescimento de $\gamma_{2}$ dentro da $\alpha$, como mostrado na Figura 17. Uma morfologia similar a esta última foi reportada por KURODA; MATSUDA $^{(101)}$ em diversas regiões da ZAC simulada do AID Fe-25Cr-4,6Ni-2Mo envelhecida a $650^{\circ} \mathrm{C}$ por $72 \mathrm{ks}$.

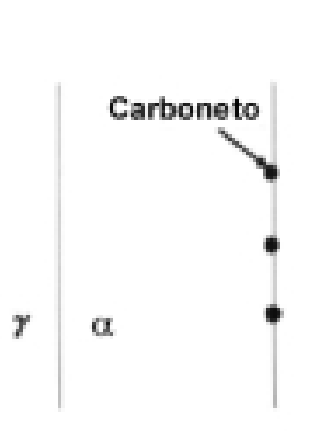

(a) (b)

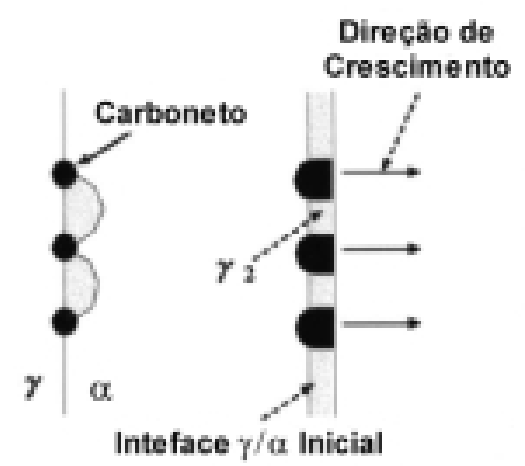

(c)

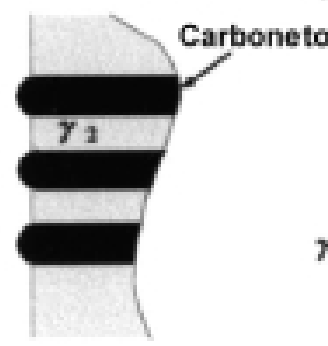

(e)

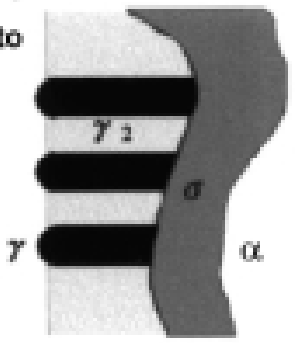

(f)

Figura 16: Diagrama esquemático mostrando a precipitação cooperativa de $\mathrm{M}_{23} \mathrm{C}_{6}$ e $\gamma_{2}$ a partir da interface $\gamma / \alpha$, seguida da precipitação de $\sigma^{(99)}$.

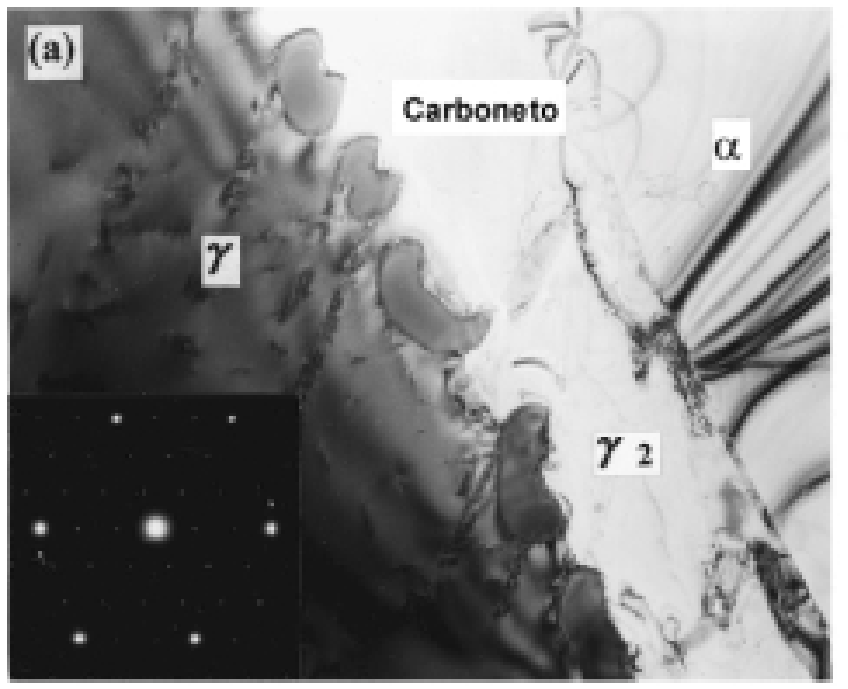

(b)

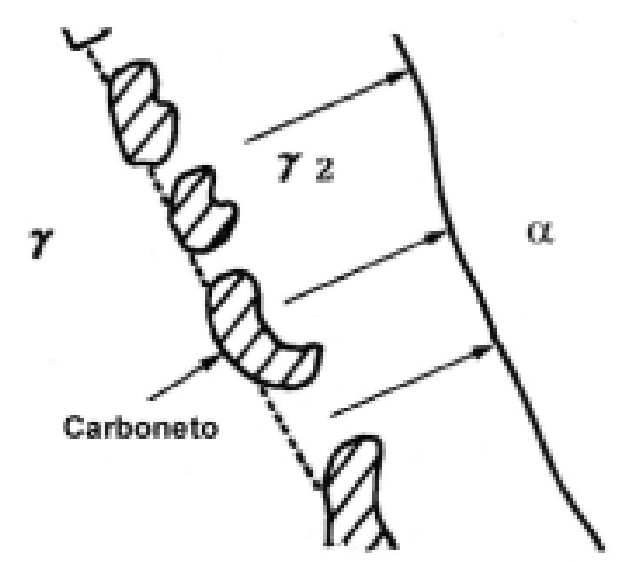

Figura 17: Precipitação de $\mathrm{M}_{23} \mathrm{C}_{6}$ na interface $\gamma / \alpha$ seguida do crescimento de $\gamma_{2}$ no AID SAF 2205 envelhecido a $800{ }^{\circ} \mathrm{C}$ por 1 hora. Em (a) a micrografia eletrônica de transmissão com os carbonetos na forma de "larva" precipitados na interface original $\gamma / \alpha$ e o crescimento da $\gamma_{2}$, em (b) o diagrama esquemático da microestrutura ${ }^{(99)}$.

NILSSON et al. ${ }^{(86)}$ em estudo realizado no metal de solda de diversos AISDs, alguns deles contendo $\mathrm{Cu}$ e/ou W verificaram que a tendência a formar $\gamma_{2}$ é altamente dependente da composição química. As ligas com adições de $\mathrm{W}$ e $\mathrm{Cu}$ ou somente $\mathrm{W}$ apresentaram uma 
maior tendência à formação de $\gamma_{2}$. Comportamento explicado do ponto de vista termodinâmico pelo aumento na energia de ativação para a precipitação desta fase, causado pela adição destes elementos químicos. No entanto, não se descarta a possibilidade do Cu e o W influenciarem na nucleação da $\gamma_{2}$. Nesta pesquisa foram reportadas duas diferentes morfologias da $\gamma_{2}$ intragranular:

- Tipo Widmanstätten com cantos agudos. Em alguns casos estas partículas contém uma espécie de nervura central. Neste caso trata-se de dois cristais de austenita, os quais apresentam uma relação de orientação do tipo K-S com a matriz $\alpha$, separados por um contorno de macla ${ }^{(102)}$. Vale a pena ressaltar que tem sido verificada uma menor concentração de $\mathrm{Cr}$ nestas partículas macladas quando comparadas com outros tipos de $\gamma_{2}$.

- Tipo globular.

Na descrição das diferentes morfologias da austenita nos AID é usualmente empregada ${ }^{(103)}$ a classificação morfológica de DUBÉ apud AARONSON ${ }^{(104)}$ para a ferrita nos aços de baixo carbono, mostrada na Figura 18.

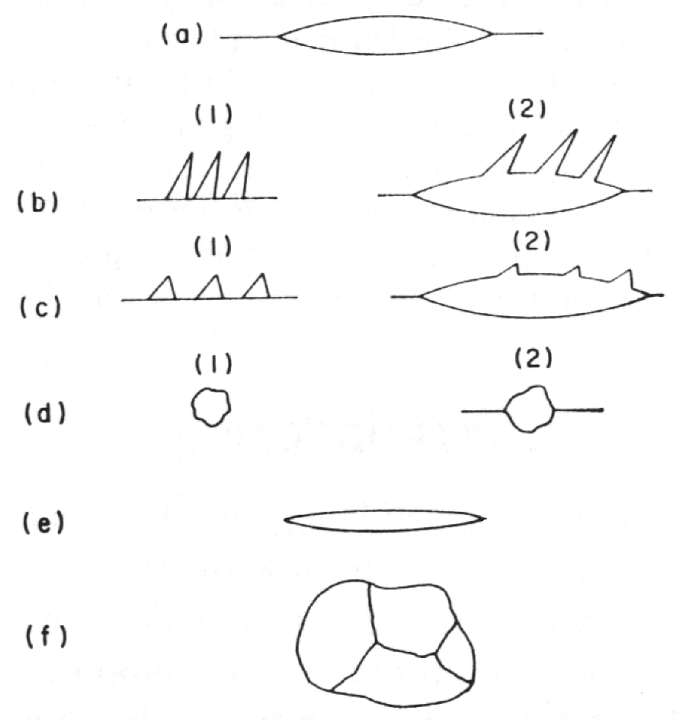

Figura 18: Sistema de classificação morfológica proposto por DUBÉ; AARONSON ${ }^{(104)}$.

a- Alotrimórfica no contorno de grão: Nucleia nos contornos de grão da austenita e cresce preferencialmente ao longo destes contornos bastante rápido, mas engrossa mais devagar. É a primeira ferrita a precipitar ao longo de praticamente todos os contornos de grão das austenitas.

b- Placas laterais de Widmanstätten: Têm um formato de placas ou agulhas bastante finas, as quais crescem dentro da austenita, a partir dos contornos de grão da austenita ou das ferritas alotrimórficas de contorno de grão. Estas placas têm uma orientação preferencial 
com relação à matriz de austenita (plano $\{111\} \gamma$ ). A relação de orientação entre a ferrita e a austenita é do tipo Kurdjumov-Sachs (K-S). Podem ser diferenciados dois tipos:

1- Placas laterais primárias: Crescem diretamente a partir do contorno de grão

2- Placas laterais secundárias: Se desenvolvem a partir de outra morfologia da mesma fase, geralmente a partir de ferritas alotrimórficas de contorno de grão.

c- Widmanstätten serrilhadas: São partículas de ferrita de formato triangular, em forma de dente de serra as quais crescem a partir dos contornos de grão da austenita ou das ferritas alotrimórficas de contorno de grão. Podem ser diferenciados dois diferentes tipos:

1- Serrilhado primário: As partículas crescem diretamente a partir dos contornos de grão de austenita.

2- Serrilhado secundário: As partículas se desenvolvem a partir de outra morfologia da mesma fase, geralmente a partir de ferritas alotrimórficas de contorno de grão.

As estruturas de Widmanstätten dos tipos placa lateral e serrilhada apresentam uma série de diferenças. Ambas as faces das placas laterais são aproximadamente paralelas entre si, com a sua orientação preferencial paralela à família de planos $\{111\}$ da austenita. Já no caso da estrutura serrilhada, no caso de um dos dentes de serra, as faces deste formam uma ângulo apreciável entre si e nenhuma destas faces é paralela ao plano $\{111\}$ da austenita. No entanto, a maioria das faces destes dentes de serra são paralelos aos seus equivalentes em outros dentes de serra que cresceram a partir do mesmo contorno. Além disso, os eixos de simetria de dentes de serra que cresceram a partir do mesmo contorno são aproximadamente paralelos entre si e ao mesmo tempo a um plano comum da família $\{111\}$ da matriz austenítica.

d- Idiomórficas: Partículas de formato aproximadamente eqüiaxial precipitadas no interior dos grãos de austenita ou nos contornos de grão. Esta morfologia pode ser encontrada em aços com teores de $\mathrm{C}$ abaixo de $0,1 \%$. As partículas formadas em temperaturas elevadas apresentam um formato mais regular.

e- Widmanstätten intergranulares: Podem ser placas ou agulhas formadas no interior dos grãos de austenita. A sua precipitação é favorecida por grandes tamanhos de grão austeníticos, baixas temperaturas de transformação e baixos teores de C. Similarmente às outras estruturas do tipo Widmanstätten, apresentam orientação preferencial e relação de orientação com a austenita.

f- Estrutura massiva: Esta resulta da interação (Impingement) de cristais de outras morfologias e do crescimento de grão do agregado formado deste modo. Assim, o resultado final é uma estrutura policristalina grosseiramente eqüiaxial.

Nem todas estas morfologias foram reportadas no caso da $\gamma$ nos AIDs. As usualmente reportadas são: Alotrimórfica de contorno de grão, placas laterais de Widmanstätten (primárias e secundárias) e Widmanstätten intragranulares. 
ATAMERT; KING ${ }^{(36)}$ relacionaram a precipitação da $\gamma_{2}$ intragranular no metal de solda dos AIDs com a precipitação de ferrita acicular no metal de solda dos aços de baixa liga. Em ambos os casos as inclusões tem um papel importante na nucleação destas fases. A nucleação nas inclusões é energeticamente mais favorável que a nucleação homogênea, no entanto é menos favorável do que a nucleação nos contornos de grão. Desta forma, nos AIDs os contornos de grão ferríticos são inicialmente saturados por austenita do tipo alotrimórfica e após esta saturação toma lugar a precipitação da austenita intragranular. Assim, utilizando-se dos resultados experimentais prévios de precipitação de ferrita acicular nos aços de baixa liga e somando a isto, o trabalho experimental com os AIDs, propuseram os seguintes mecanismos de nucleação para a $\gamma_{2}$ intragranular nos AIDs ${ }^{(36)}$ :

- Heterogênea a partir de inclusões: Estas atuariam como um substrato inerte para a nucleação heterogênea. No entanto, pode existir algum tipo de reação química na interface que pode influir no processo.

- Nucleação simpática: Uma partícula de $\gamma_{2}$ atua como substrato para a nucleação de uma nova partícula de $\gamma_{2}$. Este tipo de nucleação acontece preferencialmente em interfaces de baixa mobilidade, onde a nova partícula adota uma determinada relação de orientação com a partícula substrato, resultando em uma interface de baixa energia. Nestas condições, a energia de ativação para os processos de nucleação homogênea, heterogênea e simpática chegam a ser comparáveis ${ }^{(105)}$.

- Nucleação autocatalítica: Novas placas de $\gamma_{2}$ nucleiam dentro do campo de tensões e de difusão das partículas existentes. Este mecanismo mostra-se dominante no caso em que a energia de ativação para a nucleação homogênea é baixa.

SOUTHWICK; HONEYCOMBE ${ }^{(23)}$ estudando os AIDs reportaram a precipitação de austenita mediante um processo de cizalhamento do tipo martensítico em temperaturas abaixo de 650 ${ }^{\circ} \mathrm{C}$. Acima desta temperatura seriam formadas partículas de $\gamma$ com morfologia do tipo Widmanstätten. O processo de cizalhamento resultaria na ausência de diferenças de composição química entre o precipitado e a matriz e numa relação de orientação do tipo Nishiyama-Wasserman (N-W). No entanto, no caso da precipitação de $\gamma_{2}$ do tipo Widmanstätten em AISDs esta apresenta uma relação de orientação Kurdjumov-Sachs (K-S) com a ferrita, além de um maior teor de $\mathrm{Ni}$, mostrando que a formação desta fase foi acompanhada por difusão(102). Por um outro lado, no estudo do AID 25Cr-2Mo-6Ni envelhecido a $600{ }^{\circ} \mathrm{C}$ ROSCOE et al. ${ }^{(106)}$ encontraram uma relação de orientação do tipo $\mathrm{N}$ W entre a $\gamma_{2}$ e a $\alpha$, junto com diferenças de composição química entre a $\gamma_{2}, \gamma$ e $\alpha$.

\subsection{SOLDAGEM DOS AÇOS INOXIDÁVEIS DUPLEX}

Grande parte das aplicações atuais dos AID envolvem algum processo de soldagem. Por este motivo a soldabilidade dos AID tem sido objeto de ampla investigação. Desta forma, os 
AID modernos têm sido desenvolvidos para terem uma excelente soldabilidade. No entanto, existem alguns cuidados que devem ser tomados durante a soldagem, para manter as propriedades mecânicas e de resistência à corrosão que estes materiais possuem.

Praticamente todos os processos de soldagem a arco convencionais podem ser usados na soldagem de AID. Por outro lado, o uso de processos com uma fonte de energia de alta densidade, como o feixe de elétrons ou o laser, tem a sua aplicação limitada. Nestes casos a precipitação da austenita é impedida devido às elevadas velocidades de resfriamento da junta ${ }^{(6,107)}$. O mesmo acontece nos processos de soldagem como por resistência e por atrito.

Com o intuito de facilitar a formação de austenita na ZF geralmente são usados metais de adição com um teor de $\mathrm{Ni}$ de 2,5 a 3,5\% acima do teor do metal de base. Com o uso destas adições e o controle da diluição, os teores de ferrita podem ser mantidos ao redor de $50 \%$. Uma outra forma de controlar o teor de austenita da ZF é mediante a introdução de $\mathrm{N}$ na poça de fusão através do metal de adição ou do gás de proteção.

A mistura gasosa geralmente utilizada com os processos que precisam de proteção gasosa tem como base o argônio. A adição de $1-10 \%$ em volume de $N_{2}$ ao gás tem como fim aumentar o teor de nitrogênio na ZF. Como o nitrogênio é um elemento de liga gamagênico, o seu aumento acarreta em uma fração volumétrica maior de austenita na ZF. Além disto, o nitrogênio aumenta o potencial de ionização da mistura gasosa, estabilizando o arco elétrico ${ }^{(108-110)}$.

O balanço microestrutural na junta soldada dos AIDs também é influenciado pela história térmica do processo de soldagem utilizado.

\subsubsection{Evolução Microestrutural dos AID Durante a Soldagem}

A estrutura obtida na ZF e na ZAC dependem entre outros fatores da história térmica a qual é submetida cada uma destas regiões. As mudanças microestruturais que ocorrem durante 0 aquecimento e o resfriamento de uma solda de um AID, devem ser controladas de modo que as propriedades da junta sejam as melhores possíveis. Conforme discutido anteriormente, este controle pode ser exercido através da composição química e/ou da história térmica. A composição química da ZF pode ser mudada através do metal de adição e/ou do gás de proteção. Por outro lado, a história térmica determinará basicamente a microestrutura da ZAC dos AIDs e, eventualmente, da ZF.

A Figura 19 apresenta algumas das modificações microestruturais ocorridas na junta soldada de um AID. Observando-se esta figura, notam-se 5 regiões na junta soldada: zona fundida, zona parcialmente fundida, zona de crescimento de grão de ferrita, zona bifásica parcialmente transformada e zona bifásica similar ao metal de base. Nesta figura não foi representada a precipitação de outras fases além da ferrita e da austenita. 


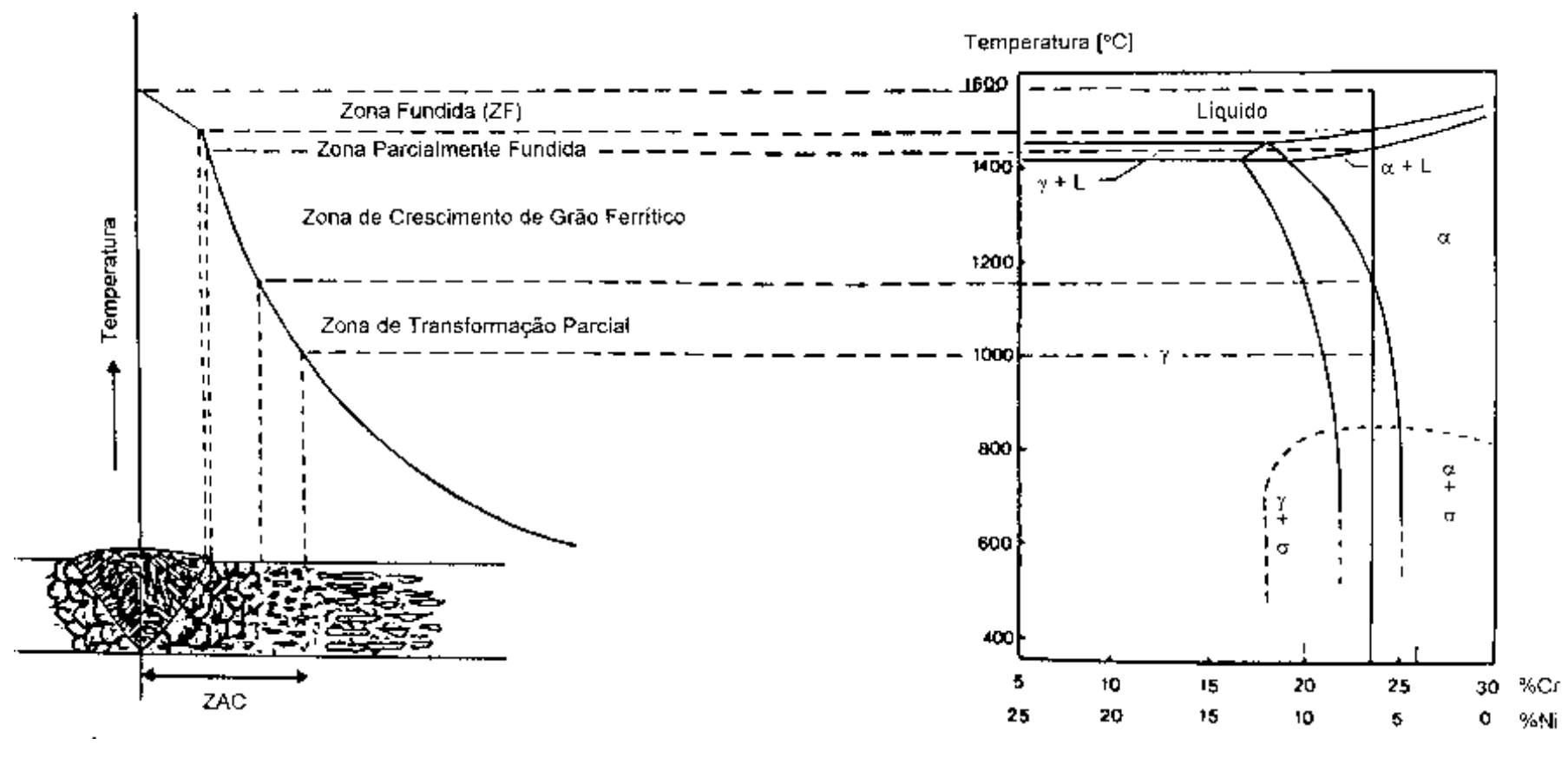

Figura 19: Diagrama esquemático das mudanças microestruturais acontecidos na junta soldada de um $\operatorname{AID}^{(111)}$.

Uma energia de soldagem elevada tende a produzir uma velocidade de resfriamento menor da junta, dependendo da espessura da chapa. Como conseqüência, promove a precipitação de austenita, balanceando, em parte, a microestrutura. Da mesma maneira, pode favorecer a precipitação de fases intermetálicas e o crescimento de grão, dependendo da temperatura máxima atingida na ZAC. Na situação contrária, uma energia de soldagem baixa leva a uma velocidade de resfriamento elevada. Assim, a precipitação de austenita é dificultada, gerando uma fração elevada de ferrita, o que pela sua vez acarreta a precipitação de uma grande quantidade de nitretos de cromo no interior da ferrita. Em ambos os casos tem-se como resultado uma severa diminuição na tenacidade e na resistência à corrosão do material.

\subsubsection{Zona Afetada Pelo Calor (ZAC)}

A ZAC dos AID pode ser dividida em duas sub-regiões ${ }^{(111,112)}$ : A região submetida a temperaturas elevadas (ZACTE) e a região submetida a temperaturas baixas (ZACTB). A primeira é delimitada pelas temperaturas solvus da ferrita, e a temperatura solidus da liga, onde o aço está completamente ferritizado. A segunda apresenta como limite superior a temperatura solvus da ferrita. Nesta última região da ZAC o AID permanece no campo bifásico, porém, com uma fração volumétrica final de austenita que pode ser bem diferente da do metal de base original.

Cabe ressaltar que as definições de ZACTE e ZACTB aqui apresentadas são baseadas no conhecimento prévio ao desenvolvimento desta tese, onde verificou-se que nem todos os 
AIDs são susceptíveis de ferritizar. Desta forma, as definições de ZACTB e ZACTE deverão ser reformuladas para serem compatíveis com as novas evidências experimentais.

\subsection{Zona Afetada Pelo Calor de Temperatura Elevada (ZACTE)}

A extensão da ZACTE é determinada pelos parâmetros de soldagem, pela geometria da junta e pela composição química do AID. Conforme apresentado na Figura 20 no ciclo térmico genérico na ZACTE podem ser distingidos três diferentes estágios: $O$ estágio I descreve o aquecimento até a temperatura solvus da ferrita. Durante o estágio II o material encontra-se dentro do campo ferrítico. O estágio III consiste no resfriamento desde a temperatura solvus da ferrita até a temperatura ambiente.

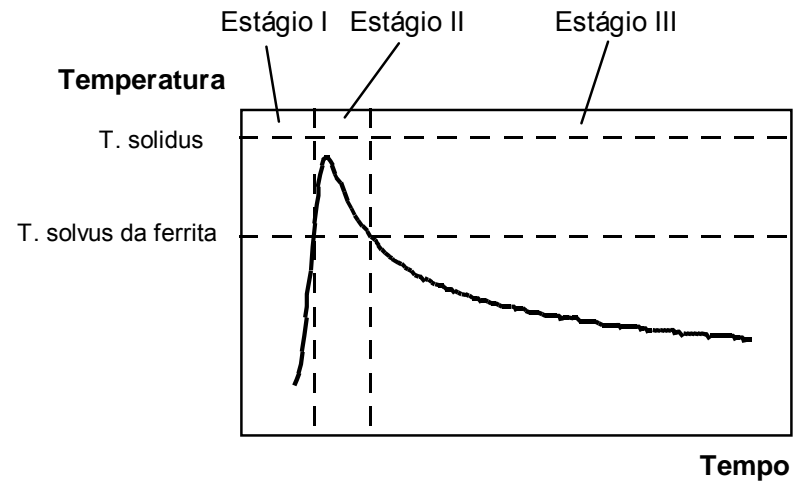

Figura 20: Estágios do ciclo térmico de soldagem da $\operatorname{ZACTE}^{(113)}$.

Durante o estágio I a austenita transforma-se em ferrita, assistida pela difusão de elementos intersticiais e substitucionais. A cinética da dissolução da austenita depende da taxa de aquecimento. Se a velocidade de aquecimento for muito elevada, a dissolução da austenita pode ser impedida, inclusive em temperaturas acima da solvus da ferrita ${ }^{(111,113)}$. Alguns precipitados como nitretos, carbonetos, ou intermetálicos também podem dissolver durante o aquecimento, dependendo da taxa de aquecimento.

Durante o estágio II os precipitados e a austenita continuam dissolvendo, porém com a cinética acelerada pela temperatura mais elevada. Caso a velocidade de aquecimento não seja muito alta, estas transformações se completam, restando somente a ferrita. A partir deste momento os grãos de ferrita começarão a crescer e coalescer. O crescimento de grão depende da temperatura e do tempo de permanência do material acima da temperatura solvus da ferrita. Este tempo acima da temperatura solvus depende da energia de soldagem, da geometria da junta e da composição química da liga, a qual determina o intervalo de temperatura onde o material é totalmente ferrítico. Diversos modelos têm sido propostos para prever o tamanho de grão na ZAC dos AID a partir do tempo acima da temperatura 
solvus ou do $\Delta \mathrm{t}_{12-8}{ }^{(111,114)}$. Este crescimento de grão pode levar a uma severa queda na tenacidade do material.

No resfriamento no estágio III tem-se a precipitação da austenita a partir da ferrita. Com altas velocidades de resfriamento a austenita precipitada nos contornos de grão da ferrita pode ser descontínua. À medida que a velocidade de resfriamento diminui, a austenita nos contornos torna-se cada vez mais contínua. A partir da saturação dos sítios para nucleação nos contornos de grão, a austenita cresce em direção ao centro do grão de ferrita, como austenita de Widmanstätten. Para velocidades de resfriamento mais baixas pode ocorrer a precipitação de austenita intragranular.

A quantidade e morfologia da austenita precipitada depende não só da velocidade de resfriamento, mas também da composição química da liga e do tamanho de grão ferrítico. $O$ teor de nitrogênio altera a posição da temperatura solvus da ferrita. Desta forma, aumentando-se o teor de nitrogênio, aumenta-se a temperatura solvus. Neste caso a precipitação da austenita começa em temperaturas mais elevadas, produzindo uma quantidade maior de austenita de Widmanstätten. Por outro lado, a diminuição do teor de nitrogênio da liga gera uma fração volumétrica maior de austenita intragranular ${ }^{(115)}$.

Durante o resfriamento podem precipitar outras fases como, os nitretos, carbonetos e carbonitretos. A cinética de precipitação destas fases depende basicamente da composição química da liga, do ciclo térmico experimentado e da fração volumétrica de austenita formada.

\subsection{Zona Afetada Pelo Calor de Temperatura Baixa (ZACTB)}

Abaixo da temperatura solvus da ferrita, que delimita o começo da ZACTB, encontra-se a

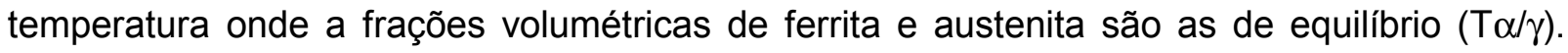
Além disso, podem ser definida(s) a(s) faixa(s) de temperatura de precipitação de alguma(s) fase(s) de interesse ${ }^{(116)}$. Assim, dependendo da temperatura máxima atingida pela região em estudo, no ciclo térmico podem ser delimitados até dois estágios principais ${ }^{(52)}$.

No estágio I tem-se a dissolução parcial da austenita e, dependendo da velocidade de resfriamento, a sua posterior precipitação. Neste caso, os grãos de austenita não dissolvidos inibem o crescimento de grão ferrítico ${ }^{(111)}$. Já durante o resfriamento posterior a austenita cresce continuamente a partir das ilhas intergranulares de austenita não dissolvidas $^{(107)}$. A fração final de austenita nesta zona é maior que na ZACTE, portanto a precipitação intragranular de nitretos é significativamente menor.

O estágio II é delimitado pelas temperaturas máxima e mínima de precipitação da(s) fase(s) de interesse. A precipitação desta(s) fase(s) depende da cinética da transformação e do tempo de permanência nesta faixa.

A Figura 21 apresenta, a título de exemplo, os ciclos térmicos em duas regiões diferentes da ZACTB. Na primeira região (Figura 21.a) atingiu-se uma temperatura máxima acima da $\mathrm{T}_{\alpha / \gamma}$. 
Neste caso podem-se distinguir os dois estágios do ciclo térmico. O segundo ciclo térmico (Figura 21.b) representa uma região da ZACTB onde a temperatura máxima atingida está compreendida dentro do intervalo de precipitação da(s) fase(s) de interesse. Neste caso tem-se somente o estágio II do ciclo, praticamente sem modificação na fração volumétrica da austenita.

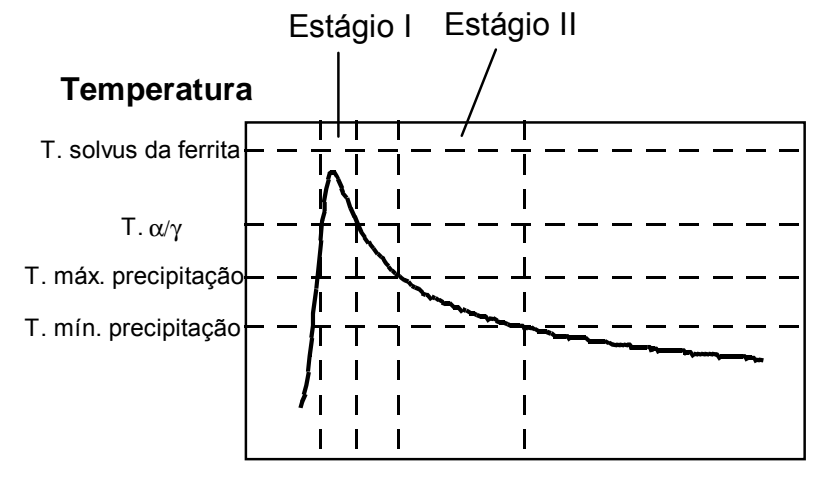

a.

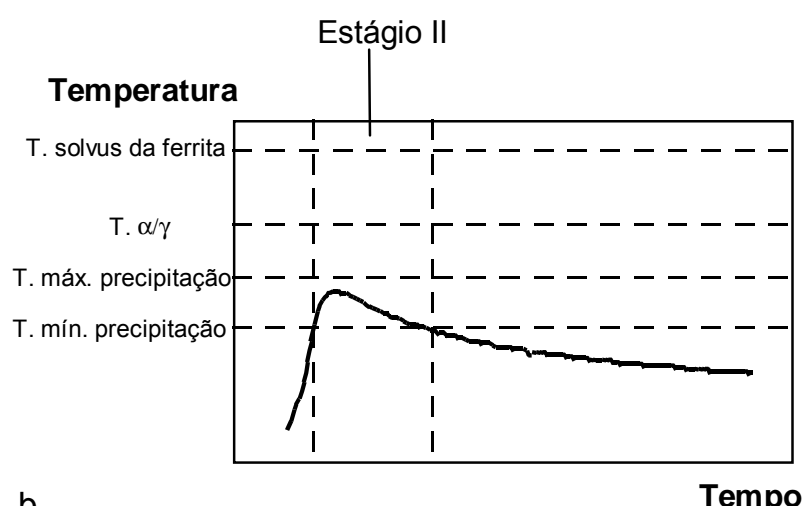

b.

Tempo

Figura 21: Estágios de um ciclo térmico de soldagem na ZACTB. Em (a) a temperatura máxima acima de $T_{\alpha / \gamma}$ e em (b) dentro do intervalo de precipitação de uma fase ${ }^{(52)}$.

\subsubsection{Zona Fundida (ZF)}

Durante a solidificação da poça de fusão, o crescimento epitaxial e competitivo ${ }^{(117-118)}$ a partir dos grãos de ferrita da zona parcialmente fundida, produzem uma estrutura colunar grosseira de grãos de ferrita na ZF. Assim, o tamanho de grão da ZACTE tem uma influência direta na microestrutura da ZF. Posteriormente, durante o resfriamento, similar ao que acontece na ZACTE, ocorre a precipitação da austenita e das demais fases possíveis. Os mecanismos das transformações no estado sólido dentro da ZF são basicamente os mesmos descritos para a $\mathrm{ZAC}^{(107)}$.

Conforme foi apresentado anteriormente, a composição química da ZF pode ser ajustada através do metal de adição e do gás de proteção, junto com o controle da diluição. Isto permite o controle da fração da austenita e, portanto, da precipitação de nitretos de cromo ${ }^{(108-}$ 109). Além disso, o controle do ciclo térmico não deve ser esquecido, principalmente quando são realizadas soldas autógenas ou com metal de adição com a mesma composição química do metal de base.

\subsubsection{Soldagem Multipasse dos AID}

Durante a soldagem multipasse, tanto a ZF como a ZAC são reaquecidas. Isto pode levar a mudanças microestruturais nestas duas regiões, que dependem da microestrutura gerada em cada região pelos ciclos térmicos precedentes. O reaquecimento repetido da $Z F$ e da ZAC pode levar à precipitação de nitretos e fases intermetálicas, como a fase sigma e fase 
$\mathrm{R}^{(52,61-62,119-120)}$. Por outro lado, a fração de austenita da ZAC aumenta quando a junta é reaquecida pelos passes sucessivos. O reaquecimento da ZACTE em temperaturas elevadas, pode levar ao crescimento da austenita intergranular e à precipitação de austenita intragranular ${ }^{(95-96)}$. Da mesma maneira, os nitretos são parcial ou totalmente dissolvidos, gerando um aumento no teor de nitrogênio na matriz. Como resultado, a precipitação da austenita é favorecida. Já no reaquecimento em temperaturas mais baixas, ao redor de $900^{\circ} \mathrm{C}$, pode ocorrer a precipitação de nitretos de cromo tanto na ZACTE como na ZACTB ${ }^{(36}$, $75,111,113)$.

Para obter uma resistência à corrosão ótima no passe de raiz de uma solda multipasse, recomenda-se o uso da técnica do passe frio. Esta técnica consiste no emprego de uma energia de soldagem elevada no passe de raiz e uma baixa no segundo passe. Com isto, se obtém uma fração volumétrica elevada de austenita e pouca precipitação de nitretos, tanto na ZF como na ZAC do passe de raiz. Assim, durante o reaquecimento do passe de raiz causado pela aplicação do segundo passe, a precipitação de austenita intragranular, ou de outras fases, na ZF e ZAC do passe de raiz será diminuída ${ }^{(121)}$.

No caso de soldagem multipasse, o controle da temperatura entre os passes é mais crítico ainda. Caso esta temperatura esteja muito acima de $100{ }^{\circ} \mathrm{C}$, pode ocorrer a precipitação de $\alpha^{\prime}, \gamma_{2}$ e fases intermetálicas ${ }^{(122)}$. A $\alpha^{\prime}$ pode acarretar uma perda de tenacidade no material. A presença de $\gamma_{2}$ e de fases intermetálicas podem prejudicar a resistência à corrosão localizada e a tenacidade dos AIDs.

No entanto, os AIDs são ligas relativamente recentes, os conhecimentos que se tem sobre a sua metalurgia e a sua aplicação à soldagem são vastos, isto devido principalmente à ampla utilização destes materiais na industria de base, o que tem impulsionado fortemente a pesquisa neste campo. Porém, o conhecimento que se tem até o momento não é suficiente para explicar os fenômenos observados, com o qual o projeto de procedimentos de soldagem para estas ligas por parte dos engenheiros não é um assunto trivial. Desta forma, este trabalho encara os problemas da soldabilidade dos AIDs desde dois flancos. Inicialmente o fundamental, no qual se estudam alguns aspectos fundamentais sobre as transformações de fase envolvidas. Mas o tema também é abordado desde um ponto de vista prático, de modo tal que os resultados obtidos na primeira parte são aplicados para explicar alguns dos fenômenos observados na prática. Assim, o conhecimento adquirido com esta pesquisa vem a facilitar as tomadas de decisões dos engenheiros quanto à elaboração de procedimentos de soldagem para uma gama bastante ampla de AIDs. 


\section{OBJETIVOS}

Os objetivos gerais deste trabalho são:

- Propor um modelo de transferência de calor que represente adequadamente a zona afetada pelo calor submetida a temperatura elevada (ZACTE) de uma solda multipasse.

- Estudar a partir de simulações térmicas da ZACTE, tratamentos térmicos e soldagens reais, as mudanças microestruturais na ZACTE de soldagens multipasse de AIDs.

- Esclarecer as possíveis interações entre a precipitação da austenita secundária e a precipitação dos nitretos de cromo.

- Avaliar a soldabilidade metalúrgica de cinco diferentes ligas comerciais de aços inoxidáveis duplex (AIDs) a partir de medidas de desempenho da junta soldada e da evolução microestrutural durante a soldagem multipasse. 


\section{MATERIAIS E MÉTODOS}

Foi desenvolvida a metodologia experimental para estudar por simulação térmica a ZAC de soldas multipasse de AIDs. Baseando-se no uso desta ferramenta foi estudada a precipitação de $\gamma_{2}$ e a sua relação com o $\mathrm{Cr}_{2} \mathrm{~N}$ na ZACTE de soldas multipasse, realizadas em cinco diferentes ligas comerciais de AIDs. Finalmente foi avaliado o efeito destas mudanças microestruturais no desempenho da junta soldada.

O estudo foi realizado a partir CPs submetidos a tratamentos térmicos, de soldas reais e microestruturas simuladas. Para os tratamentos térmicos e a simulação da ZACTE foi utilizado um equipamento Gleeble ${ }^{\circledR} 1500$.

\subsection{MATERIAIS}

Com a seleção dos materiais utilizados pretendeu-se ter uma cobertura razoável das diferentes ligas disponíveis no mercado. Os materiais utilizados e a sua composição química típica são listados na Tabela 3.

Os materiais utilizados foram:

- AID de baixa liga e sem molibdênio, UNS S 32304;

- AID de baixa liga, UNS S 32205;

- AID de alta liga ou superduplex (AISD) contendo cobre UNS S 32550;

- AID de alta liga ou superduplex UNS S 32750;

- AID de alta liga ou superduplex contendo tungstênio e cobre UNS S 32760.

Tabela 3: Composição química típica dos materiais utilizados.

\begin{tabular}{|c|c|c|c|c|c|c|c|}
\hline $\begin{array}{c}\text { Designação } \\
\text { UNS }\end{array}$ & Tipo & $\% \mathrm{Ni}$ & $\% \mathrm{Cr}$ & $\%$ Mo & $\% \mathrm{~N}$ & $\% \mathrm{Cu}$ & $\% W$ \\
\hline S 32304 & \multirow{2}{*}{ Duplex } & 4 & 23 & 0,2 & 0,1 & - & - \\
\hline S 32205 & & 5 & 22 & 2,8 & 0,15 & - & - \\
\hline S 32550 & \multirow{3}{*}{ Superduplex } & 7 & 25 & 3,5 & 0,25 & 1,5 & - \\
\hline S 32750 & & 7 & 25 & 3,8 & 0,28 & - & - \\
\hline S 32760 & & 7 & 25 & 3,5 & 0,24 & 0,7 & 0,7 \\
\hline
\end{tabular}

O UNS S32205 (anteriormente UNS S31803) é o AID mais amplamente utilizado e conhecido no mercado. Este material supera o desempenho do aço inoxidável austenítico AISI 316L na maioria das aplicações. Durante este trabalho será dada continuidade ao estudo já iniciado em trabalhos anteriores. Além disto, este material será usado como ponto de referência para os outros materiais. 
O UNS S32304 é o AID de menor valor no mercado e devido ao seu superior desempenho, quando comparado com o aço inoxidável austenítico AISI 304L, vem tomando uma importante parcela do mercado deste material. No entanto, além da importância tecnológica da inclusão deste material no grupo a ser estudado, existe um outro fator de cunho científico, o qual faz com que esta liga tenha sido selecionada. Devido ao baixo teor de $\mathrm{Ni}$ e $\mathrm{N}$ neste material, a precipitação de $\gamma_{1}$ na ZF e na ZAC são dificultadas, fazendo com que o fenômeno da precipitação da $\gamma_{2}$, durante a soldagem multipasse, seja altamente favorecida.

O UNS S32550 é um AISD com uma considerável adição de $\mathrm{Cu}$, o que faz com que o material apresente uma elevada resistência à corrosão em ambiente contendo sulfetos. Por outro lado, um estudo anterior ${ }^{(52)}$ com esta liga revelou a sua acelerada cinética de precipitação de fases intermetálicas na ZACTB. Deste modo neste estudo, será dada continuidade a este trabalho.

O UNS S32750 apresenta a composição típica de um aço inoxidável superduplex (AISD). Esta liga está sendo amplamente usada em aplicações onde os aços inoxidáveis austeníticos convencionais não são aplicáveis. Desta forma, este AISD consegue substituir diversos aços inoxidáveis super-austeníticos, com inúmeras vantagens tecnológicas e econômicas. No entanto, nos mais recentes encontros internacionais a soldabilidade dos AISDs vem sendo seriamente questionada devido à favorável cinética de precipitação de fases intermetálicas. Assim, o estudo da precipitação de intermetálicos na ZAC destes materiais é um tema de grande relevância tanto tecnológica como científica. Por outro lado, também devido à sua composição química, o fenômeno da precipitação da $\gamma_{2}$ nestes materiais é dificultada. Portanto, a sua comparação com os AID UNS 32205 e 32304 torna-se bastante interessante.

Finalmente, o AISD UNS S32760, pertence à mais nova família de AID disponíveis no mercado. Estes materiais possuem a composição química típica de um AISD, mas com pequenas adições de $\mathrm{Cu}$ e/ou W. Estes elementos de liga tem diversas funções, como: aumentar a resistência à corrosão em ambientes contendo sulfetos no caso do $\mathrm{Cu}$ e a de aumentar a resistência à corrosão localizada no caso do W. No entanto, um dos principais motivadores para a adição de W nos AISD é a possibilidade de substituir, pelo menos em parte, o Mo da liga. Desta forma, pretende-se reduzir a cinética de precipitação de algumas fases intermetálicas, principalmente da fase sigma. Portanto, a inclusão deste material no trabalho visa verificar o aperfeiçoamento da soldabilidade dos AISD com a adição de W e por outra parte, estudar o efeito desta adição na precipitação de $\gamma_{2}$, aspecto que não foi estudado anteriormente.

Pelo exposto, este grupo de cinco materiais permitiu desenvolver um trabalho que engloba praticamente toda a família dos AIDs. Assim, foi possível comparar a soldabilidade destes materiais e sua relação com a precipitação de $\gamma_{2}$ e fases intermetálicas. 


\subsection{PARÂMETROS DE SOLDAGEM}

Como já foi exposto, o trabalho experimental foi baseado no estudo de microestruturas da ZAC de soldas multipasse simuladas. Estas microestruturas foram comparadas com as de soldas reais, obtidas em laboratório. Os parâmetros de soldagem utilizados na execução das soldas reais e nas simulações, correspondem a uma junta topo-a-topo, com preparação de chanfro em V, sem face de raiz, em uma chapa de $6 \mathrm{~mm}$ de espessura, cuja geometria é mostrada na Figura 22. A soldagem foi completada mediante três passes executados com o processo GTAW com adição. Na Tabela 4 são mostrados os parâmetros de soldagem utilizados.

a.

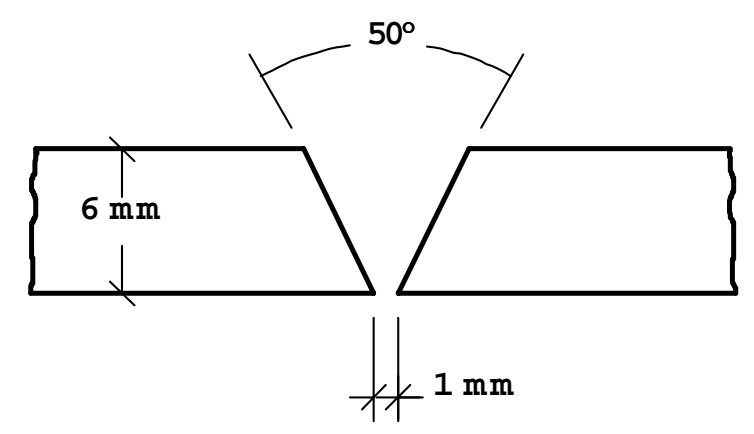

b.

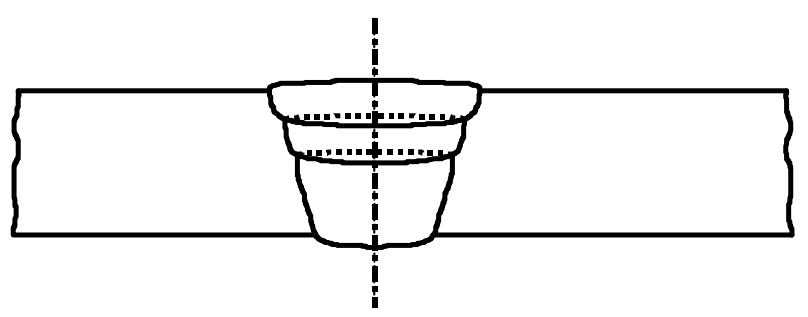

Figura 22: Geometria da junta soldada. Em (a) preparação da junta e em (b) a junta já executada.

Com a finalidade de estudar a influência da energia de soldagem na evolução microestrutural, foram utilizadas três correntes de soldagem diferentes.

É importante ressaltar que as energias de soldagem empregadas neste trabalho podem ser consideradas baixas para a espessura da chapa utilizada. Na seleção das energias de soldagem foi seguida a recomendação dada pelos fabricantes destes materiais, a qual é o uso de energias de soldagem o mais baixas possíveis, desde que seja obtida uma fração de austenita aceitável na junta soldada (aproximadamente de 20 a $25 \%$ no mínimo). 
Tabela 4: Parâmetros de soldagem utilizados.

\begin{tabular}{|l|l|}
\hline Processo & GTAW \\
\hline Tensão & $10 \mathrm{~V}$ \\
\hline Tipo de corrente & CCPD \\
\hline Intensidade de corrente & $135-170-211 \mathrm{~A}$ \\
\hline Velocidade de soldagem & $2,11 \mathrm{~mm} / \mathrm{s}$ \\
\hline Energia de soldagem & $0,6-0,8-1,0 \mathrm{~kJ} / \mathrm{mm}$ \\
\hline Gás de proteção & $\mathrm{Ar}-10 \mathrm{l} / \mathrm{min}$ \\
\hline Temp. pré-aquecimento & $25^{\circ} \mathrm{C}$ \\
\hline Temp. Interpasse $\left(1^{\circ}-2^{\circ}\right)$ & $75^{\circ} \mathrm{C}$ \\
\hline Temp. Interpasse $\left(2^{\circ}-3^{\circ}\right)$ & $100^{\circ} \mathrm{C}$ \\
\hline Metal de Adição & AID alto Ni, Arame $\varnothing 1,2 \mathrm{~mm}$ \\
\hline
\end{tabular}

\subsection{DETERMINAÇÃO DOS CICLOS TÉRMICOS DE SOLDAGEM}

O foco deste trabalho é o estudo da ZAC na superfície da chapa correspondente ao passe de raiz de uma solda multipasse. Esta região foi escolhida devido à sua posição crítica no que diz respeito ao reaquecimento. Além disso, por ficar na superfície da chapa, esta região é exposta ao ambiente de trabalho do componente, que no caso dos AIDs, geralmente é agressivo. Portanto, é o ciclo térmico desta região que deve ser determinado.

Conforme foi apresentado na introdução teórica, existe uma diversidade de modelos para o fluxo de calor na soldagem. A complexidade destes modelos aumenta à medida que estes representam melhor a realidade. Inicialmente pretendeu-se usar o modelo de transferência de calor desenvolvido por RAMIREZ-LONDOÑO(52), originalmente desenvolvido para a simulação da ZACTB. No entanto, este modelo não representou de forma adequada a distribuição de temperaturas na ZACTE. Desta forma foram testados outros modelos analíticos e verificou-se que o modelo proposto por MYHR; GRONG ${ }^{(17)}$ poderia ser adaptado, de modo que pudesse ser aplicado para as condições do trabalho.

Para verificar as condições do fluxo de calor no arranjo proposto, foram feitas medidas de temperatura durante soldagens reais. Com estes dados foram feitos diversos testes com diferentes distribuições da fonte de calor. Desta forma, verificou-se a necessidade de generalizar mais ainda o modelo, de forma que a distribuição da fonte de calor pudesse ser adaptada para as condições de soldagem multipasse.

\subsubsection{Medidas de Temperatura em Condições Reais de Soldagem}

Este trabalho foi executado em duas etapas. Inicialmente foram realizadas medidas de temperatura durante a soldagem de chapas do aço inoxidável AISI 304. Desta maneira, o modelo de transferência de calor foi adequado às condições de trabalho. Posteriormente foram realizadas algumas soldas reais com o AID UNS S32304, durante as quais foram 
registrados os ciclos térmicos de soldagem da ZAC. Assim, mediante a comparação destes ciclos com os das simulações, foi verificado o funcionamento adequado do modelo de fluxo de calor proposto.

Desta forma, foram realizados cordões de solda sobre chapas de AISI 304 de $6 \mathrm{~mm}$ de espessura. As chapas foram dimensionadas $(150 \times 150 \mathrm{~mm})$ para garantir condições de regime quase-estacionário, na região central da chapa, e condições de chapa infinita durante o tempo de duração da experiência.

Para a medida da temperatura foram dispostos oito (8) termopares tipo $\mathrm{K}$ de $0,2 \mathrm{~mm}$ de diâmetro. Os termopares foram soldados por resistência à superfície da chapa e isolados com lã de alumina. Todos os termopares foram colocados na superfície inferior da chapa, a distâncias de 1,3; 5 e $10 \mathrm{~mm}$ da linha de centro do chanfro ou do cordão, como mostrado na Figura 23. A distância do termopar ao centro do cordão de solda foi medida com paquímetro para cada uma das experiências realizadas.

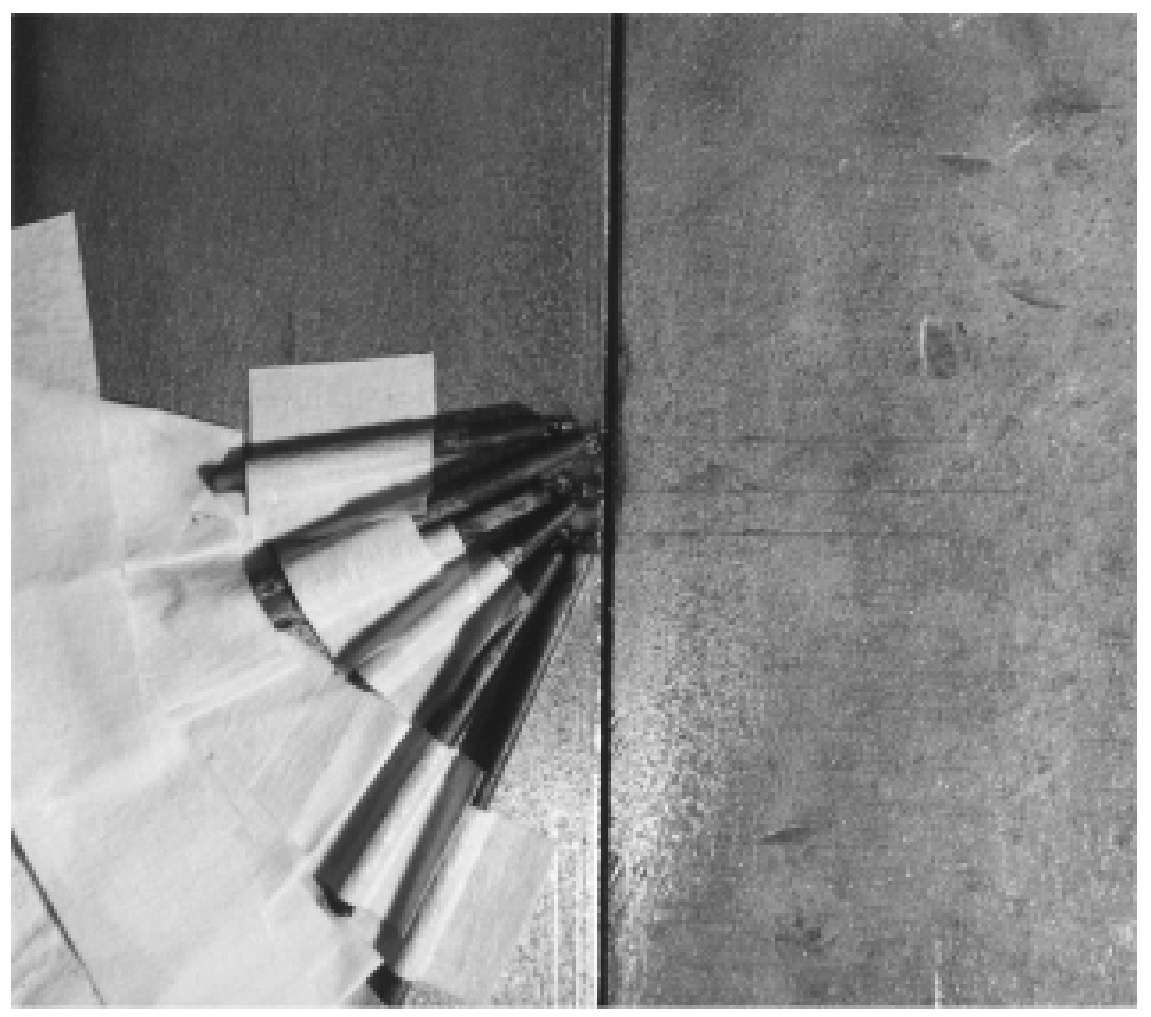

Figura 23: Disposição dos termopares na chapa. Vista do lado da raiz.

Para o registro da temperaturas foi usado o sistema para adquisição de dados por computador, INTERDAT ${ }^{\circledR}$. Os parâmetros de soldagem utilizados estão apresentados na Tabela 5. 
Tabela 5: Parâmetros de soldagem empregados nas soldagens reais.

\begin{tabular}{|l|l|}
\hline Processo & GTAW \\
\hline Tensão & $10 \mathrm{~V}$ \\
\hline Corrente & $135 \mathrm{~A}-\mathrm{CCPD}$ \\
\hline Velocidade de soldagem & $2,00-2,20 \mathrm{~mm} / \mathrm{s}^{*}$ \\
\hline Energia de soldagem & $0,613-0,675 \mathrm{~kJ} / \mathrm{mm}$ * \\
\hline Gás de proteção & $\mathrm{Ar}-10 \mathrm{l} / \mathrm{min}$ \\
\hline Temperatura de pré-aquecimento & $22-100^{\circ} \mathrm{C}$ * \\
\hline Eletrodo (tipo - diâmetro) & $\mathrm{EWTh}-2-3,2 \mathrm{~mm}$ \\
\hline Ângulo de afiação do eletrodo & $60^{\circ}$ \\
\hline Diâmetro interno do bocal & $12,8 \mathrm{~mm}$ (Bocal No. 4) \\
\hline
\end{tabular}

Nota: *: Determinada ou medida para cada ensaio.

O equipamento de soldagem empregado é da marca HOBART, modelo VP-300-S. Para o controle automático da tensão do arco foi usado um AVC (Automatic Voltage Control) da JETLINE, modelo ALC 201. A chapa a ser soldada foi fixada e a tocha de soldagem foi montada em um sistema de deslocamento com velocidade regulável. É importante ressaltar que a chapa foi isolada termicamente. Na Figura 24 é apresentado o arranjo experimental.

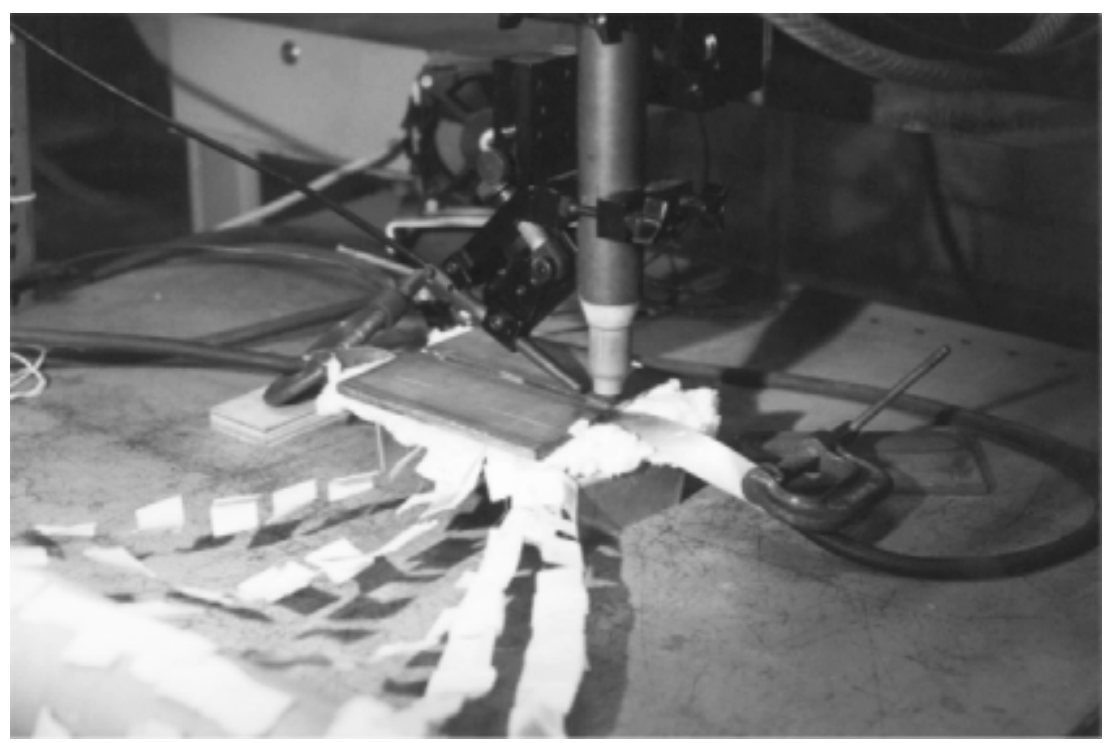

Figura 24: Arranjo experimental utilizado para medir a temperatura durante a soldagem.

\subsection{VERIFICAÇÃO DO MODELO DE TRANSFERÊNCIA DE CALOR}

A comparação dos ciclos térmicos de soldagem registrados na ZACTE e ZACTB do aço AISI 304 , com os ciclos térmicos calculados com o modelo permitiu verificar que o modelo proposto representa adequadamente as condições do trabalho. Esta constatação definitiva 
foi obtida através da confrontação do modelo com os resultados obtidos nas medidas de temperatura durante as soldas reais do AID UNS S32304.

\subsection{SOLDAGENS REAIS}

Com o intuito de comparar as microestruturas da região da ZAC simulada com as das soldas reais, foram realizadas as soldagens reais com os cinco diferentes AIDs, usando-se os mesmos parâmetros apresentados na Tabela 4 (página 38). Cada um dos 15 experimentos foi repetido três vezes, produzindo $45 \mathrm{CPs}$.

\subsection{SIMULAÇÃO DOS CICLOS TÉRMICOS DE SOLDAGEM}

Utilizando-se os ciclos térmicos calculados com o modelo de transferência de calor desenvolvido, realizou-se a simulação dos ciclos térmicos de soldagem no equipamento Gleeble $^{\circledR}$ 1500. Na Figura 25 é apresentada a unidade de simulação com atmosfera controlada do equipamento Gleeble ${ }^{\circledR}$. Neste equipamento o ciclo térmico é controlado por computador através de um termopar tipo $\mathrm{K}$ ou $\mathrm{S}$ soldado à superfície do corpo de prova, de dimensões $6 \times 6 \times 90 \mathrm{~mm}$. O sistema de aquecimento por efeito Joule atinge velocidades de aquecimento de até $20.000{ }^{\circ} \mathrm{C} / \mathrm{s}$. O resfriamento é feito por condução através das peças de cobre refrigeradas que compõem o dispositivo de fixação do corpo de prova, permitindo velocidades de resfriamento de até $100{ }^{\circ} \mathrm{C} / \mathrm{s}$. Na Figura 26 é mostrado o detalhe da montagem do corpo de prova no sistema. Nesta mesma figura é evidente o gradiente térmico gerado no corpo de prova durante a simulação.

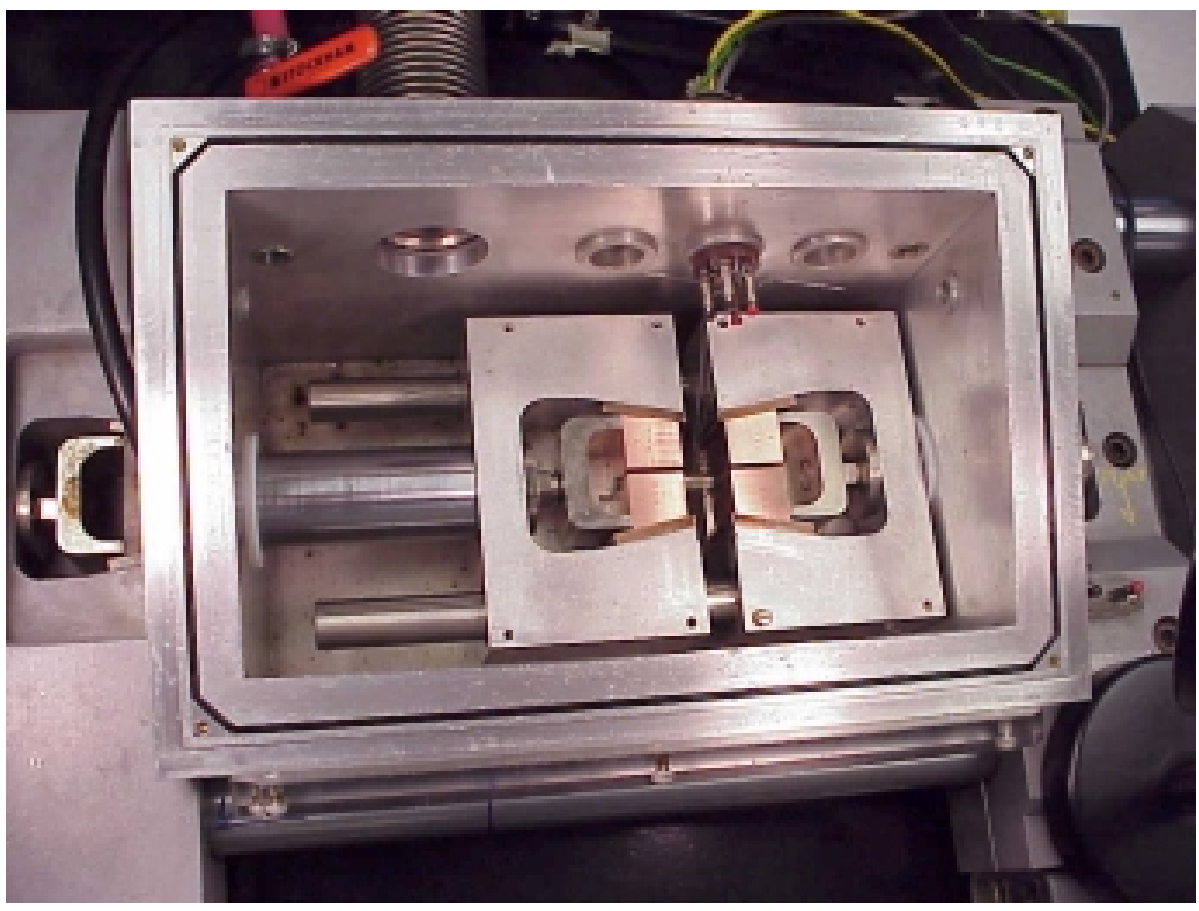

Figura 25: Vista superior da unidade de simulação do equipamento Gleeble ${ }^{\circledR} 1500$ com a câmara de vácuo. 


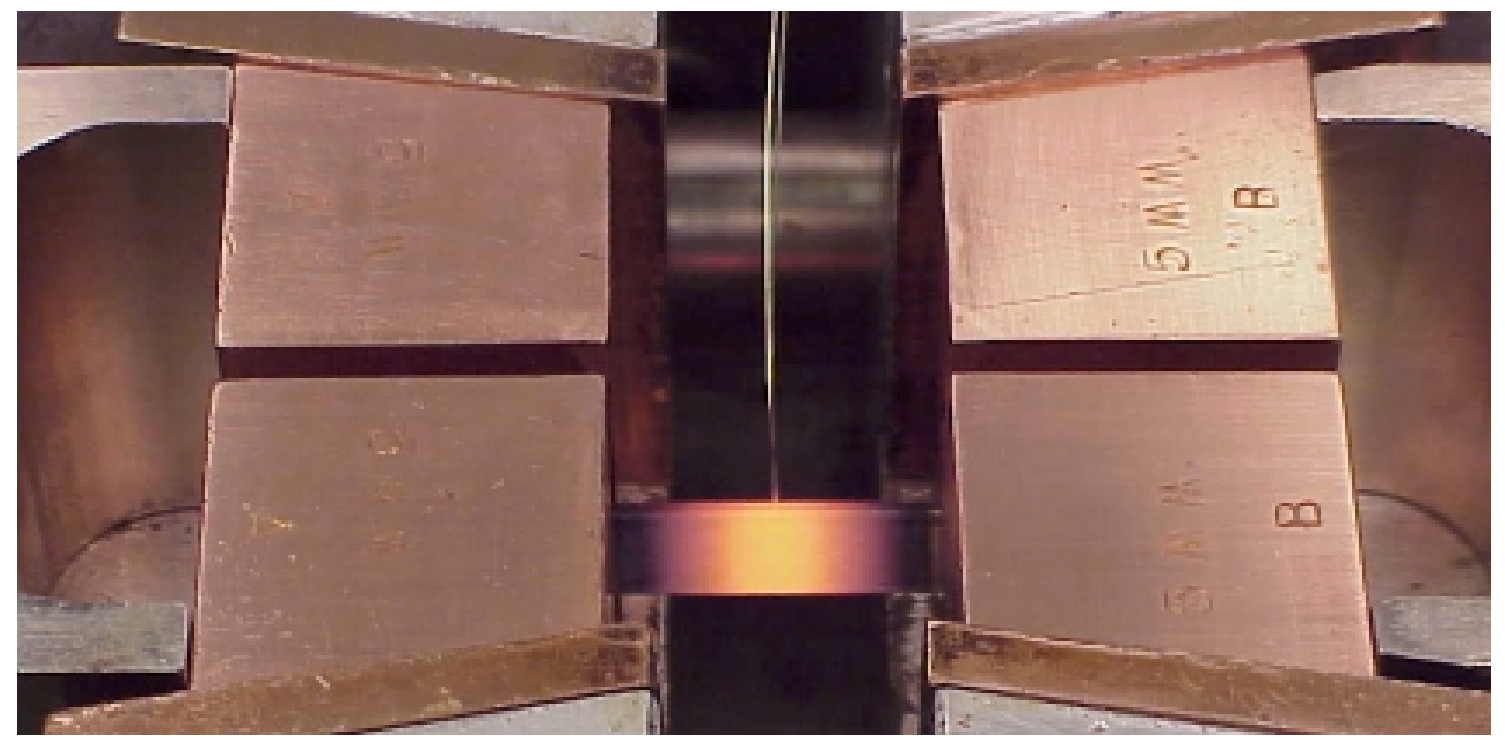

Figura 26: Detalhe da montagem do corpo de prova na unidade de simulação do equipamento Gleeble $^{\circledR} 1500$.

Na Tabela 6 é mostrada a matriz de experiências de simulação dos ciclos térmicos de soldagem. A denominação apresentada nesta tabela para as experiências será usada a partir desta parte do texto. A nomenclatura das experiências está composta por três partes $x-y-z$. A primeira parte indica o material empregado. A segunda parte define a energia de soldagem utilizada. A terceira designa o número de passes.

Tabela 6: Matriz de experiências de simulação dos ciclos térmicos de soldagem, com a denominação dada às diversas experiências.

\begin{tabular}{|c|l|l|l|l|l|l|c|}
\hline \multirow{2}{*}{$\begin{array}{c}\text { Energia de } \\
\text { Soldagem }\end{array}$} & Número de & \multicolumn{5}{|c|}{ Designação UNS do Material } & \multirow{2}{*}{ Geral } \\
\cline { 2 - 7 } & Passes & S32304 & S32205 & S32550 & S32750 & S32760 & \\
\hline \multirow{3}{*}{$0,6 \mathrm{~kJ} / \mathrm{mm}$} & $1^{\circ}$ & $1-06-1 \mathrm{P}$ & $2-06-1 \mathrm{P}$ & $3-06-1 \mathrm{P}$ & $4-06-1 \mathrm{P}$ & $5-06-1 \mathrm{P}$ & $06-1 \mathrm{P}$ \\
\cline { 2 - 8 } & $1^{\circ}+2^{\circ}$ & $1-06-2 \mathrm{P}$ & $2-06-2 \mathrm{P}$ & $3-06-2 \mathrm{P}$ & $4-06-2 \mathrm{P}$ & $5-06-2 \mathrm{P}$ & $06-2 \mathrm{P}$ \\
\cline { 2 - 8 } & $1^{\circ}+2^{\circ}+3^{\circ}$ & $1-06-3 \mathrm{P}$ & $2-06-3 \mathrm{P}$ & $3-06-3 \mathrm{P}$ & $4-06-3 \mathrm{P}$ & $5-06-3 \mathrm{P}$ & $06-3 \mathrm{P}$ \\
\hline \multirow{3}{*}{$0,8 \mathrm{~kJ} / \mathrm{mm}$} & $1^{\circ}$ & $1-08-1 \mathrm{P}$ & $2-08-1 \mathrm{P}$ & $3-08-1 \mathrm{P}$ & $4-08-1 \mathrm{P}$ & $5-08-1 \mathrm{P}$ & $08-1 \mathrm{P}$ \\
\cline { 2 - 8 } & $1^{\circ}+2^{\circ}$ & $1-08-2 \mathrm{P}$ & $2-08-2 \mathrm{P}$ & $3-08-2 \mathrm{P}$ & $4-08-2 \mathrm{P}$ & $5-08-2 \mathrm{P}$ & $08-2 \mathrm{P}$ \\
\cline { 2 - 8 } & $1^{\circ}+2^{\circ}+3^{\circ}$ & $1-08-3 \mathrm{P}$ & $2-08-3 \mathrm{P}$ & $3-08-3 \mathrm{P}$ & $4-08-3 \mathrm{P}$ & $5-08-3 \mathrm{P}$ & $08-3 \mathrm{P}$ \\
\hline \multirow{3}{*}{$1,0 \mathrm{~kJ} / \mathrm{mm}$} & $1^{\circ}$ & $1-10-1 \mathrm{P}$ & $2-10-1 \mathrm{P}$ & $3-10-1 \mathrm{P}$ & $4-10-1 \mathrm{P}$ & $5-10-1 \mathrm{P}$ & $10-1 \mathrm{P}$ \\
\cline { 2 - 8 } & $1^{\circ}+2^{\circ}$ & $1-10-2 \mathrm{P}$ & $2-10-2 \mathrm{P}$ & $3-10-2 \mathrm{P}$ & $4-10-2 \mathrm{P}$ & $5-10-2 \mathrm{P}$ & $10-2 \mathrm{P}$ \\
\cline { 2 - 8 } & $1^{\circ}+2^{\circ}+3^{\circ}$ & $1-10-3 \mathrm{P}$ & $2-10-3 \mathrm{P}$ & $3-10-3 \mathrm{P}$ & $4-10-3 \mathrm{P}$ & $5-10-3 \mathrm{P}$ & $10-3 \mathrm{P}$ \\
\hline
\end{tabular}

\subsection{TRATAMENTOS TÉRMICOS}

Com o intuito de facilitar o estudo de precipitação de $\gamma_{2}$ e as suas relações com o $\mathrm{Cr}_{2} \mathrm{~N}$ nos AIDs, foram realizados tratamentos isotérmicos no equipamento Gleeble ${ }^{\circledR}$. Inicialmente 
foram realizados tratamentos térmicos com os quais se pretendia ferritizar os 5 AIDs. Estes tratamentos foram:

- $1350{ }^{\circ} \mathrm{C}$ por $5 \mathrm{~s}-$ Resfriamento $50^{\circ} \mathrm{C} / \mathrm{s}$;

- $1350{ }^{\circ} \mathrm{C}$ por $10 \mathrm{~s}-$ Resfriamento $50{ }^{\circ} \mathrm{C} / \mathrm{s}$;

- $1350^{\circ} \mathrm{C}$ por $5 \mathrm{~s}-$ Resfriamento $75^{\circ} \mathrm{C} / \mathrm{s}$;

- $1350^{\circ} \mathrm{C}$ por $10 \mathrm{~s}-$ Resfriamento $75^{\circ} \mathrm{C} / \mathrm{s}$;

- $1370^{\circ} \mathrm{C}$ por $5 \mathrm{~s}-$ Resfriamento $75^{\circ} \mathrm{C} / \mathrm{s}$.

Com estes tratamentos procurou-se determinar as condições para obter tamanho de grão ferrítico e fração de austenita similares nos cinco materiais.

Posteriormente ao tratamento de pretendida ferritização, os CPs foram submetidos aos seguintes tratamentos:

- Reaquecimento a $1200^{\circ} \mathrm{C}$ por $1 \mathrm{~s}$

- Reaquecimento a $1200^{\circ} \mathrm{C}$ por $10 \mathrm{~s}$

- Reaquecimento a $1100{ }^{\circ} \mathrm{C}$ por $1 \mathrm{~s}$

- Reaquecimento a $1100{ }^{\circ} \mathrm{C}$ por $10 \mathrm{~s}$

- Reaquecimento a $1000^{\circ} \mathrm{C}$ por $1 \mathrm{~s}$

- Reaquecimento a $1000^{\circ} \mathrm{C}$ por $10 \mathrm{~s}$

- Reaquecimento a $900{ }^{\circ} \mathrm{C}$ por $1 \mathrm{~s}$

- Reaquecimento a $900^{\circ} \mathrm{C}$ por $10 \mathrm{~s}$

\subsection{CARACTERIZAÇÃO MICROESTRUTURAL}

A caracterização microestrutural foi realizada nos materiais nos estados como-recebido, tratado termicamente e simulado termicamente, bem como nas juntas soldadas reais dos AIDs. A seguir são descritas as diversas técnicas utilizadas.

\subsubsection{Análise Térmica}

Foram realizados ensaios de análise térmica diferencial (DTA) nas diferentes ligas no estado como-recebido, de modo a determinar as temperaturas nas quais as transformações de fusão e solidificação acontecem. Para isto foi utilizado um sistema de análise térmica NETZSCH ${ }^{\circledR}$, com célula do tipo STA 409.

Foram feitas medidas na faixa de temperatura de 1000 até $1500{ }^{\circ} \mathrm{C}$, tanto no aquecimento como no resfriamento. A taxa de aquecimento e resfriamento foi de $10{ }^{\circ} \mathrm{C} / \mathrm{min}$. Para minimizar as perdas de nitrogênio do material, todos os ensaios foram realizados numa atmosfera de nitrogênio de alta pureza. 


\subsubsection{Ensaio de Temperatura de Resistência Nula (TRN)}

Poderia-se pensar que uma vez determinada a temperatura solidus do material mediante a análise térmica, esta temperatura poderia ser tomada como o limite máximo de trabalho para a realização dos tratamentos térmicos e as simulações no equipamento Gleeble ${ }^{\circledR}$. No entanto, o dado obtido da análise térmica fornece a temperatura solidus do material como um todo e no caso do equipamento Gleeble ${ }^{\circledR}$, devido as elevadas velocidades de aquecimento, a micro-segregação leva à fusão dos contornos dos grãos bem abaixo da temperatura solidus da liga. Desta forma, este ensaio fornece a temperatura máxima de trabalho no equipamento Gleeble $^{\circledR}$, dentro do estado sólido.

Para a determinação da TRN, os corpos de prova foram montados no equipamento Gleeble ${ }^{\circledR}$ e aquecidos a uma taxa de $150^{\circ} \mathrm{C} / \mathrm{s}$ ao mesmo tempo que uma carga de tração mínima foi aplicada. Uma vez que os contornos de grão fundem, a resistência à tração do material torna-se nula, levando a ruptura instantânea do corpo de prova. Assim, a temperatura na qual o material perdeu a sua resistência é registrada como a Temperatura de Resistência Nula (TRN).

\subsubsection{Cálculos Termodinâmicos de Equilíbrio entre Fases}

Foram realizados cálculos termodinâmicos para a determinação dos diagramas de fase multicomponentes e dos diagramas de variação da fração volumétrica das fases presentes em função da temperatura. Para estes diagramas foi utilizado o programa de computador Thermo-Calc $^{\circledR}$ (version L PC / Windows NT) da Foundation for Computational Thermodynamics, Stockholm, Sweden.

\subsubsection{Microscopia Ótica}

Os corpos de prova para análise metalográfica foram montados a quente em baquelite e lixados até lixa de grana 1000. Em seguida, foi realizado o polimento automático com pasta de diamante na seqüência 6,3 e $1 \mu \mathrm{m}$ de tamanho médio de partícula. Posteriormente, foi realizado um polimento automático usando uma suspensão coloidal de sílica, com tamanho médio de partícula de $0,06 \mu \mathrm{m}$.

Como parte deste trabalho foi desenvolvido um ataque eletrolítico especialmente adaptado para AIDs, o qual permite a observação tanto no MO como no MEV. No caso do MO o ataque confere uma clara diferenciação entre a ferrita e a austenita e, para um observador experiente, é possível diferenciar as austenitas primária e secundária em grandes aumentos (1000X). No caso do MEV, este ataque é o suficientemente profundo para conferir à imagem de elétrons secundários um contraste adequado. Além disso, dado que o ataque das austenitas primária e secundária é diferenciado, a identificação de cada uma destas faces torna-se bastante fácil. Finalmente, este ataque tem as vantagens de ser altamente reprodutível e não super-atacar as regiões adjacentes aos nitretos de cromo e, assim evitar 
que estes sejam arrancados do CP. Este ataque eletrolítico utiliza uma solução de $40 \%$ vol de $\mathrm{HNO}_{3}$ em água destilada, sendo utilizada a mesma solução para as duas etapas do ataque. Na primeira etapa, na qual visa-se revelar as interfaces e contornos de grão, aplicase uma tensão de 1-1,2 V por 2 minutos. Já na segunda etapa, a qual visa diferenciar a ferrita e as austenitas primária e secundária entre si, aplica-se uma tensão de 0,7-0,8 V durante aproximadamente 7 minutos. As faixas de tensão dadas permitem obter um resultado final igual para as 5 ligas utilizadas.

\subsubsection{Metalografia Quantitativa}

Toda a caracterização da microestrutura dos AIDs foi realizada sobre um corte ao longo da espessura da chapa, paralelo à direção de laminação desta.

$\mathrm{O}$ ataque eletrolítico descrito no item anterior permite uma excelente diferenciação entre $\alpha \mathrm{e}$ $\gamma$. Desta forma a medida da fração de ferrita foi realizada mediante contagem de pontos e com o auxílio de um sistema digital de análise de imagens.

\subsubsection{Microscopia Eletrônica}

Devido a pequena fração volumétrica e tamanho das fases precipitadas durante a simulação térmica é preciso a observação dos corpos de prova em grandes aumentos, através da microscopia eletrônica de varredura (MEV) e transmissão (MET). Para facilitar a identificação dos precipitados e completar a sua caracterização, foi realizada microanálise química mediante espectrometria por energia dispersiva (EDS) com sistemas acoplados aos microscópios eletrônicos de varredura e transmissão.

A identificação inequívoca das fases, a determinação da sua estrutura cristalina e das direções de orientação entre os precipitados e a matriz foi realizada mediante de difração de elétrons de área selecionada (DAS) e difração de elétrons por feixe convergente (DFC).

Os equipamentos utilizados foram:

- MEV-EC (Emissão de Campo); EDS: PHILIPS EXL-30-FG (The Ohio State University)

- MEV (Filamento de Tungstênio); EDS: CAMBRIDGE Stereoscan-240 (Universidade de São Paulo)

- MEV (Filamento de Tungstênio); EDS; WDS: CAMBRIDGE Stereoscan-440 (Universidade de São Paulo)

- MET (Filamento de tungstênio): JEOL 200-C (Inst. de Pesquisas Energéticas e Nucleares)

- $\operatorname{MET}\left(\operatorname{LaB}_{6}\right)$; EDS: JEOL JEM 3010 (Lab. Nacional de Luz Síncrotron)

A técnica de espectrometria por comprimento de onda dispersiva (WDS), foi empregada para determinar a composição química da ferrita e austenita presentes nos CPs no estado como- 
recebido e tratados termicamente. Esta análise além de permitir uma maior precisão, possibilita a análise quantitativa do nitrogênio. Para facilitar estas análises, foram preparados dois materiais de referência, com as seguintes composições químicas:

- Aço inoxidável austenítico 18,2Cr-15,1Mn-0,0026C-0,4167N.

- Aço inoxidável austenítico 25,1Cr-1,5Si-1,9Mo-0,08V-5,5Ni-1,2Mn-0,03C-0,8808N.

\subsection{AVALIAÇÃO DO DESEMPENHO DA ZAC}

A avaliação da influência da precipitação da $\gamma_{2}$ e fases intermetálicas e nas propriedades mecânicas e de resistência à corrosão da ZAC dos AIDs, não é o ponto central deste trabalho. No entanto, é a influência destas transformações de fase no desempenho do material o fator que justifica a realização deste tipo de trabalho. Portanto, considera-se pertinente realizar ensaios simples que permitam ter uma idéia do efeito da precipitação destas fases no desempenho dos materiais estudados.

\subsubsection{Tenacidade}

Sendo a tenacidade a propriedade mecânica mais seriamente afetada pelas mudanças microestruturais em estudo, esta propriedade foi avaliada mediante o ensaio Charpy. Foram empregados corpos de prova reduzidos de $5 \times 5 \times 55 \mathrm{~mm}$, com entalhe em "V", segundo a norma ASTM E-23. Os ensaios foram realizados na temperatura de $-40{ }^{\circ} \mathrm{C}$. A orientação do plano da trinca segundo a norma AWS B 4.0 (92) é LT, que é a direção na qual são normalmente ensaiadas as juntas soldadas.

\subsubsection{Resistência à Corrosão Localizada}

A resistência à corrosão localizada nos AIDs é seriamente comprometida pela precipitação de fases intermetálicas ${ }^{(70-75)}$ e $\gamma_{2}{ }^{(53)}$. Desta forma, a resistência à corrosão por pites, que é um tipo de corrosão localizada, foi avaliada mediante ensaio potenciodinâmico realizado numa solução aquosa naturalmente areada de $3,5 \%$ peso de $\mathrm{NaCl}$, nas temperaturas de 25 , 35,50 e $75^{\circ} \mathrm{C}$. 


\section{RESULTADOS E DISCUSSÃO}

Este capítulo será dividido em duas partes. Na primeira delas serão tratados os resultados relacionados com a medida e o modelamento dos ciclos térmicos de soldagem. Na segunda parte serão apresentados e discutidos os resultados relativos ao estudo da precipitação de $\gamma_{2}$ e fases intermetálicas na ZACTE dos AIDs.

\subsection{MODELAMENTO E SIMULAÇÃO DOS CICLOS TÉRMICOS DE SOLDAGEM}

Nesta seção serão apresentados e discutidos os resultados relativos à determinação dos ciclos térmicos reais, o seu modelamento e a sua simulação. Esta etapa é o ponto de partida para o estudo da precipitação de fases na ZACTE dos AIDs.

\subsubsection{Medida de Temperatura em Condições Reais de Soldagem}

Inicialmente foram registrados os ciclos térmicos durante a soldagem multipasse do aço inoxidável austenítico AISI 304. A energia de soldagem utilizada foi de 0,6 kJ/mm. Nas Tabelas 7 a 9 são resumidos os resultados destas experiências. A título de exemplo, nas Figuras 27 a 29 são mostrados os ciclos térmicos registrados pelos termopares 1,2 e 3 durante a experiência No. 3.

Tabela 7: Resultados da experiência 1 de medida de temperatura.

\begin{tabular}{|c|c|c|c|c|}
\hline \multicolumn{2}{|r|}{ Experiência No. } & \multicolumn{3}{|c|}{1} \\
\hline \multicolumn{2}{|c|}{ Velocidade de soldagem $[\mathrm{mm} / \mathrm{s}]$} & \multicolumn{3}{|c|}{2,10} \\
\hline \multicolumn{2}{|l|}{ Passe } & 1 & 2 & 3 \\
\hline \multicolumn{2}{|c|}{ Temperatura de pré-aquecimento $\left[{ }^{\circ} \mathrm{C}\right]$} & 26 & 70 & 100 \\
\hline \multicolumn{2}{|c|}{ Profundidade final do chanfro [mm] } & 2,6 & $0,8-1,0$ & - \\
\hline \multicolumn{2}{|c|}{ Vel. de alimentação do arame [cm/min] } & 50 & 70 & 90 \\
\hline \multicolumn{5}{|l|}{ Termopar } \\
\hline \multirow[t]{2}{*}{1} & Temperatura máxima $\left[{ }^{\circ} \mathrm{C}\right]$ & 1217 & 1053 & 868 \\
\hline & Distância** $[\mathrm{mm}]$ & \multicolumn{3}{|c|}{2,10} \\
\hline \multirow[t]{2}{*}{2} & Temperatura máxima $\left[{ }^{\circ} \mathrm{C}\right]$ & $840^{*}$ & $812^{*}$ & $687^{*}$ \\
\hline & Distância** [mm] & \multicolumn{3}{|c|}{4,85} \\
\hline \multirow[t]{2}{*}{3} & Temperatura máxima $\left[{ }^{\circ} \mathrm{C}\right]$ & 1305 & 1102 & 904 \\
\hline & Distância** $[\mathrm{mm}]$ & \multicolumn{3}{|c|}{1,30} \\
\hline \multirow[t]{2}{*}{4} & Temperatura máxima $\left[{ }^{\circ} \mathrm{C}\right]$ & 977 & 923 & 782 \\
\hline & Distância** $[\mathrm{mm}]$ & \multicolumn{3}{|c|}{4,70} \\
\hline \multirow[t]{2}{*}{5} & Temperatura máxima $\left[{ }^{\circ} \mathrm{C}\right]$ & 1222 & 1041 & 902 \\
\hline & Distância** $[\mathrm{mm}]$ & \multicolumn{3}{|c|}{2,00} \\
\hline \multirow[t]{2}{*}{6} & Temperatura máxima $\left[{ }^{\circ} \mathrm{C}\right]$ & 961 & 872 & 788 \\
\hline & Distância** $[\mathrm{mm}]$ & \multicolumn{3}{|c|}{4,70} \\
\hline Notas: & $\begin{array}{l}\text { Apresentaram-se problemas } \\
\text { soldagem no termopar } \\
\text { Distância do termopar à linha }\end{array}$ & istro & $m p$ & \\
\hline
\end{tabular}


Tabela 8: Resultados das experiências 2 e 3 de medida de temperatura.

\begin{tabular}{|c|c|c|c|c|c|c|c|}
\hline \multicolumn{2}{|r|}{ Experiência No. } & \multicolumn{3}{|c|}{2} & \multicolumn{3}{|c|}{3} \\
\hline \multicolumn{2}{|c|}{ Velocidade de soldagem $[\mathrm{mm} / \mathrm{s}]$} & \multicolumn{3}{|c|}{2,19} & \multicolumn{3}{|c|}{2,11} \\
\hline \multicolumn{2}{|l|}{ Passe } & 1 & 2 & 3 & 1 & 2 & 3 \\
\hline \multicolumn{2}{|c|}{ Temperatura de pré-aquecimento $\left[{ }^{\circ} \mathrm{C}\right]$} & 30 & 70 & 100 & 28 & 75 & 100 \\
\hline \multicolumn{2}{|c|}{ Profundidade final do chanfro [mm] } & 3,0 & $1,2-1,3$ & - & $2,5-2,8$ & $0,9-1,1$ & $-1,3$ \\
\hline \multicolumn{2}{|c|}{ Vel. de alimentação do arame [cm/min] } & 50 & 70 & 90 & 50 & 70 & 90 \\
\hline \multicolumn{8}{|c|}{ Termopar } \\
\hline \multirow[t]{2}{*}{1} & Temperatura máxima $\left[{ }^{\circ} \mathrm{C}\right]$ & $865^{*}$ & $547^{*}$ & $410^{*}$ & 1381 & 1118 & 929 \\
\hline & Distância** $[\mathrm{mm}]$ & \multicolumn{3}{|c|}{1,70} & \multicolumn{3}{|c|}{1,35} \\
\hline \multirow[t]{2}{*}{2} & Temperatura máxima $\left[{ }^{\circ} \mathrm{C}\right]$ & $810^{*}$ & - & - & 961 & 864 & 780 \\
\hline & Distância** $[\mathrm{mm}]$ & \multicolumn{3}{|c|}{4,90} & \multicolumn{3}{|c|}{4,65} \\
\hline \multirow[t]{2}{*}{3} & Temperatura máxima $\left[{ }^{\circ} \mathrm{C}\right]$ & 478 & 530 & 532 & 586 & 569 & 561 \\
\hline & Distância** $[\mathrm{mm}]$ & \multicolumn{3}{|c|}{10,00} & \multicolumn{3}{|c|}{10,00} \\
\hline \multirow[t]{2}{*}{4} & Temperatura máxima $\left[{ }^{\circ} \mathrm{C}\right]$ & 1113 & 975 & 889 & 1348 & 1089 & 916 \\
\hline & Distância** $[\mathrm{mm}]$ & \multicolumn{3}{|c|}{2,10} & \multicolumn{3}{|c|}{1,40} \\
\hline \multirow[t]{2}{*}{5} & Temperatura máxima $\left[{ }^{\circ} \mathrm{C}\right]$ & $786^{*}$ & $496^{*}$ & $437^{*}$ & $793^{*}$ & $696^{*}$ & $638^{*}$ \\
\hline & Distância** $[\mathrm{mm}]$ & \multicolumn{3}{|c|}{5,00} & \multicolumn{3}{|c|}{4,85} \\
\hline \multirow[t]{2}{*}{6} & Temperatura máxima $\left[{ }^{\circ} \mathrm{C}\right]$ & $1051^{*}$ & $721^{*}$ & $581^{*}$ & 1379 & 1101 & 929 \\
\hline & Distância** $[\mathrm{mm}]$ & \multicolumn{3}{|c|}{1,80} & \multicolumn{3}{|c|}{1,30} \\
\hline \multirow[t]{2}{*}{7} & Temperatura máxima $\left[{ }^{\circ} \mathrm{C}\right]$ & 861 & 853 & 750 & 911 & 806 & 780 \\
\hline & Distância** [mm] & \multicolumn{3}{|c|}{5,00} & \multicolumn{3}{|c|}{4,90} \\
\hline \multirow[t]{2}{*}{8} & Temperatura máxima $\left[{ }^{\circ} \mathrm{C}\right]$ & 504 & 550 & 529 & 571 & 552 & 555 \\
\hline & Distância** $[\mathrm{mm}]$ & \multicolumn{3}{|c|}{10,00} & & 10,00 & \\
\hline
\end{tabular}

Notas: *: Apresentaram-se problemas de registro de temperatura ou na soldagem do termopar.

**: Distância do termopar à linha de centro do cordão.

Tabela 9: Resultados das experiências 4 e 5 de medida de temperatura.

\begin{tabular}{|c|c|c|c|c|c|c|c|}
\hline & Experiência No. & \multicolumn{3}{|c|}{4} & \multicolumn{3}{|c|}{5} \\
\hline \multicolumn{2}{|c|}{ Velocidade de soldagem [mm/s] } & \multicolumn{3}{|c|}{2,05} & \multicolumn{3}{|c|}{2,11} \\
\hline \multicolumn{2}{|l|}{ Passe } & 1 & 2 & 3 & 1 & 2 & 3 \\
\hline \multicolumn{2}{|c|}{ Temperatura de pré-aquecimento $\left[{ }^{\circ} \mathrm{C}\right]$} & 27 & 75 & 100 & 23 & 75 & 100 \\
\hline \multicolumn{2}{|c|}{ Profundidade final do chanfro [mm] } & 2,3 & 0,7 & $-1,2$ & 2,4 & $0,6-0,8$ & $-1,4$ \\
\hline \multicolumn{2}{|c|}{ Vel. de alimentação do arame [cm/min] } & 50 & 80 & 90 & 50 & 80 & 80 \\
\hline \multicolumn{8}{|c|}{ Termopar } \\
\hline \multirow[t]{2}{*}{1} & Temperatura máxima $\left[{ }^{\circ} \mathrm{C}\right]$ & 1339 & 1048 & 896 & 1309 & 1109 & 974 \\
\hline & Distância** $[\mathrm{mm}]$ & \multicolumn{3}{|c|}{1,30} & \multicolumn{3}{|c|}{1,30} \\
\hline \multirow[t]{2}{*}{2} & Temperatura máxima $\left[{ }^{\circ} \mathrm{C}\right]$ & $804^{*}$ & $734^{*}$ & $647^{*}$ & 924 & 926 & 878 \\
\hline & Distância** $[\mathrm{mm}]$ & \multicolumn{3}{|c|}{5,00} & \multicolumn{3}{|c|}{5,00} \\
\hline \multirow[t]{2}{*}{3} & Temperatura máxima $\left[{ }^{\circ} \mathrm{C}\right]$ & $551^{*}$ & $563^{*}$ & $520^{*}$ & 531 & 592 & 610 \\
\hline & Distância** [mm] & \multicolumn{3}{|c|}{9,90} & \multicolumn{3}{|c|}{10,00} \\
\hline \multirow[t]{2}{*}{4} & Temperatura máxima $\left[{ }^{\circ} \mathrm{C}\right]$ & 1294 & 1026 & 890 & 1292 & 1099 & 957 \\
\hline & Distância** $[\mathrm{mm}]$ & \multicolumn{3}{|c|}{1,45} & \multicolumn{3}{|c|}{1,40} \\
\hline \multirow[t]{2}{*}{5} & Temperatura máxima $\left[{ }^{\circ} \mathrm{C}\right]$ & 914 & 836 & 738 & $866^{*}$ & $871^{*}$ & $836^{*}$ \\
\hline & Distância** [mm] & \multicolumn{3}{|c|}{4,90} & \multicolumn{3}{|c|}{5,00} \\
\hline \multirow[t]{2}{*}{6} & Temperatura máxima $\left[{ }^{\circ} \mathrm{C}\right]$ & 1276 & 998 & 870 & 1235 & 1042 & 929 \\
\hline & Distância** $[\mathrm{mm}]$ & \multicolumn{3}{|c|}{1,45} & \multicolumn{3}{|c|}{1,75} \\
\hline \multirow[t]{2}{*}{7} & Temperatura máxima $\left[{ }^{\circ} \mathrm{C}\right]$ & 951 & 852 & 762 & 914 & 897 & 864 \\
\hline & Distância** $[\mathrm{mm}]$ & \multicolumn{3}{|c|}{4,90} & \multicolumn{3}{|c|}{5,10} \\
\hline \multirow[t]{2}{*}{8} & Temperatura máxima $\left[{ }^{\circ} \mathrm{C}\right]$ & 564 & 575 & 540 & 542 & 594 & 615 \\
\hline & Distância** $[\mathrm{mm}]$ & \multicolumn{3}{|c|}{9,90} & \multicolumn{3}{|c|}{9,60} \\
\hline
\end{tabular}

Notas: *: Apresentaram-se problemas de registro de temperatura ou na soldagem do termopar.

**: Distância do termopar à linha de centro do cordão. 


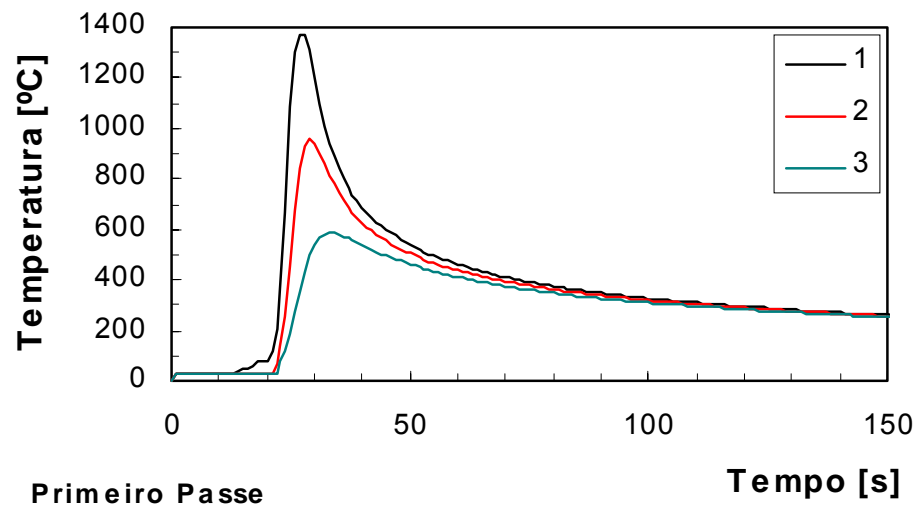

Figura 27: Ciclos térmicos reais do primeiro passe. Termopares 1,2 e 3 da experiência 3.

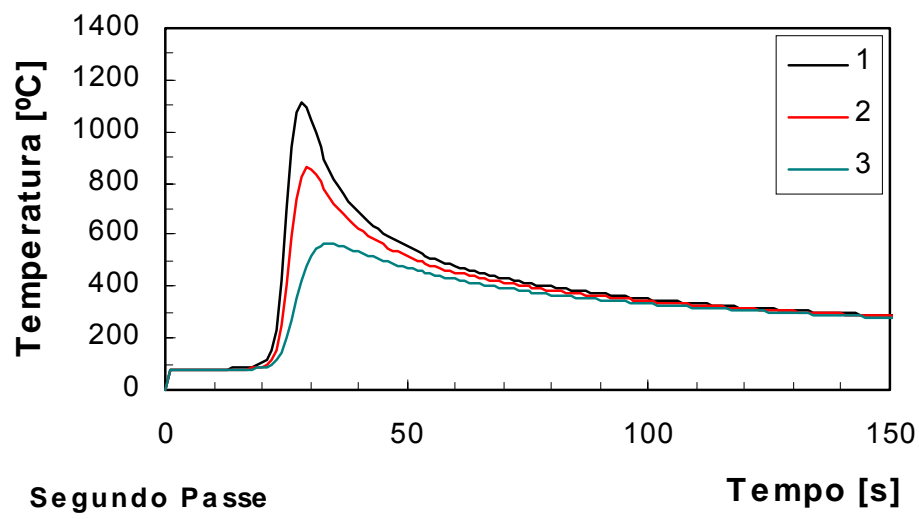

Figura 28: Ciclos térmicos reais do segundo passe. Termopares 1,2 e 3 da experiência 3.

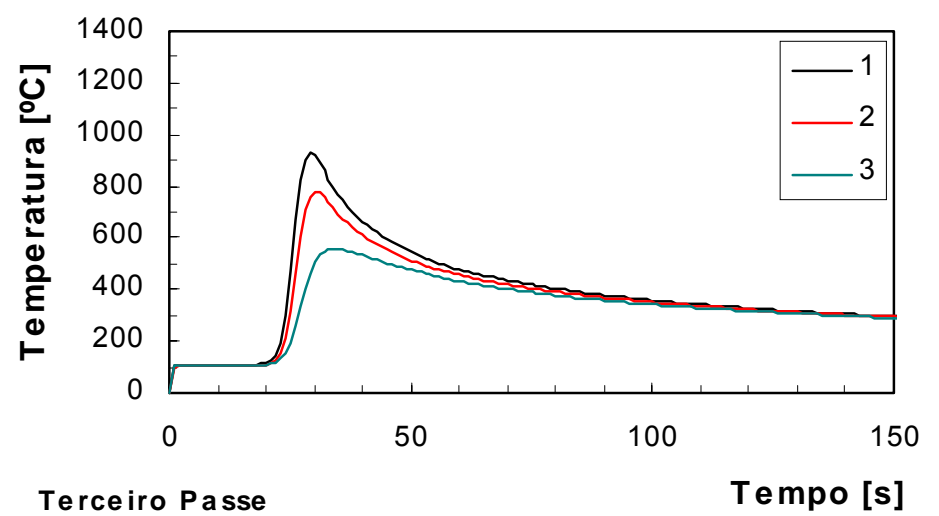

Figura 29: Ciclos térmicos reais do terceiro passe. Termopares 1,2 e 3 da experiência 3.

Nas tabelas e figuras anteriores pode-se observar como as temperaturas máximas mudam de um passe para o seguinte. A tendência é de que a temperatura máxima seja menor à medida que a junta é preenchida. Isto indica que o modelo escolhido para representar o fluxo de calor nestas soldas, deve levar em conta de algum modo a variável z. Mais especificamente, deve de algum modo permitir mudar a posição da fonte de calor em relação à superfície inferior da chapa. 
Na Tabela 10 é apresentado o resumo das Tabelas 7 a 9 . O símbolo \# nesta tabela representa o número de medidas utilizadas no tratamento estatístico. Devido às diversas dificuldades experimentais inerentes à medida de ciclos térmicos de soldagem, a confiabilidade de alguns dos resultados é questionável. Portanto, nem todos os valores foram utilizados no tratamento estatístico, sendo descartadas as medidas onde verificou-se uma inadequada soldagem do termopar e também aquelas medidas que tiveram um nível maior de ruído eletrônico. Desta forma, na Tabela 11 são listados os resultados que foram levados em conta para a obtenção dos valores apresentados na Tabela 10.

Tabela 10: Sumário das temperaturas máximas médias medidas durante a soldagem do aço inoxidável austenítico AISI 304.

\begin{tabular}{|c|c|c|c|c|c|c|}
\hline \multirow{2}{*}{$\begin{array}{c}\text { Distância à } \\
\text { linha de centro } \\
{[\mathrm{mm}]}\end{array}$} & \multicolumn{2}{|c|}{ Primeiro passe } & \multicolumn{2}{c|}{ Segundo passe } & Terceiro passe & \multirow{2}{*}{ \# } \\
\cline { 2 - 7 } & $\mathrm{T}_{\text {máx }}\left[{ }^{\circ} \mathrm{C}\right]$ & Prof. $[\mathrm{mm}]$ & $\mathrm{T}_{\text {máx }}\left[{ }^{\circ} \mathrm{C}\right]$ & Prof. [mm] & $\mathrm{T}_{\text {máx }}\left[{ }^{\circ} \mathrm{C}\right]$ & \\
\hline $1.36 \pm 0.02$ & $1325 \pm 13$ & $2.47 \pm 0.05$ & $1077 \pm 14$ & $0.82 \pm 0.05$ & $918 \pm 11$ & 9 \\
\hline $1.99 \pm 0.08$ & $1197 \pm 28$ & $2.70 \pm 0.10$ & $1028 \pm 18$ & $0.90 \pm 0.10$ & $897 \pm 13$ & 4 \\
\hline $4.87 \pm 0.05$ & $930 \pm 12$ & $2.54 \pm 0.07$ & $870 \pm 13$ & $0.87 \pm 0.06$ & $791 \pm 16$ & 9 \\
\hline $9.93 \pm 0.06$ & $539 \pm 15$ & $2.60 \pm 0.10$ & $566 \pm 9$ & $0.94 \pm 0.09$ & $563 \pm 14$ & 6 \\
\hline
\end{tabular}

Tabela 11: Resultados utilizados para o cálculo dos dados apresentados na Tabela 10.

\begin{tabular}{|c|c|c|}
\hline $\begin{array}{c}\text { Distância à } \\
\text { linha de centro } \\
{[\mathrm{mm}]}\end{array}$ & \multicolumn{1}{|c|}{ Resultados utilizados [n-m] } & Total \\
\hline $1.36 \pm 0.02$ & $1-3,3-1,3-4,3-6,4-1,4-4,4-6,5-1,5-4$ & 9 \\
\hline $1.99 \pm 0.08$ & $1-1,1-5,2-4,5-6$ & 4 \\
\hline $4.87 \pm 0.05$ & $1-4,1-6,2-7,3-2,3-7,4-5,4-7,5-2,5-7$ & 9 \\
\hline $9.93 \pm 0.06$ & $2-3,2-8,3-3,3-8,4-8,5-3,5-8$ & 6 \\
\hline Nota: *: Número de experiência e termopar [n-m] segundo as Tabelas 7 a 9. \\
Onde n representa o número da experiência e m o número do termopar.
\end{tabular}

Os dados apresentados na Tabela 10 mostram como a temperatura máxima para um mesmo ponto diminui de um passe para o seguinte. No entanto, está diminuição é maior para os termopares que se encontram mais perto da linha de centro. Este fato fica mais evidente na Figura 30 onde os dados são apresentados graficamente.

Com exceção da temperatura de pré-aquecimento, não foi mudado durante as experiências nenhum parâmetro de soldagem de um passe para o seguinte. Assim, o fator que mudou de um passe para o seguinte foi a profundidade do chanfro, isto é a coordenada $Z$ da posição da fonte de calor (ver Figura 5). Na Figura 31 é apresentada a variação da temperatura máxima com a profundidade do chanfro. Como pode ser visto nesta figura, a influência da 
profundidade do chanfro na temperatura máxima sofrida por um ponto da junta é bastante importante para pontos perto da linha de centro do cordão, mas vai perdendo esta influência à medida que se afasta da linha de centro.

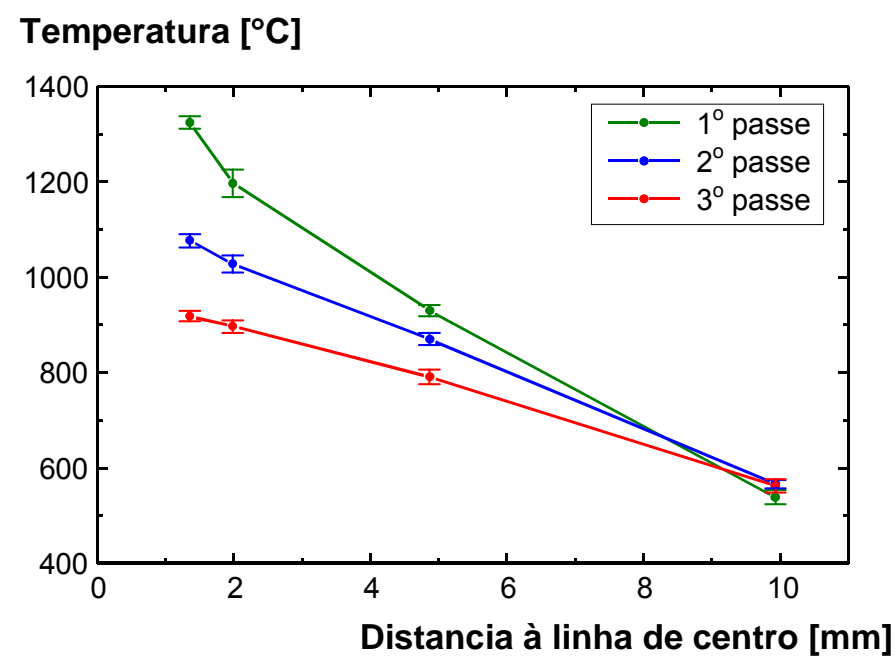

Figura 30: Variação da temperatura máxima com a distância à linha de centro.

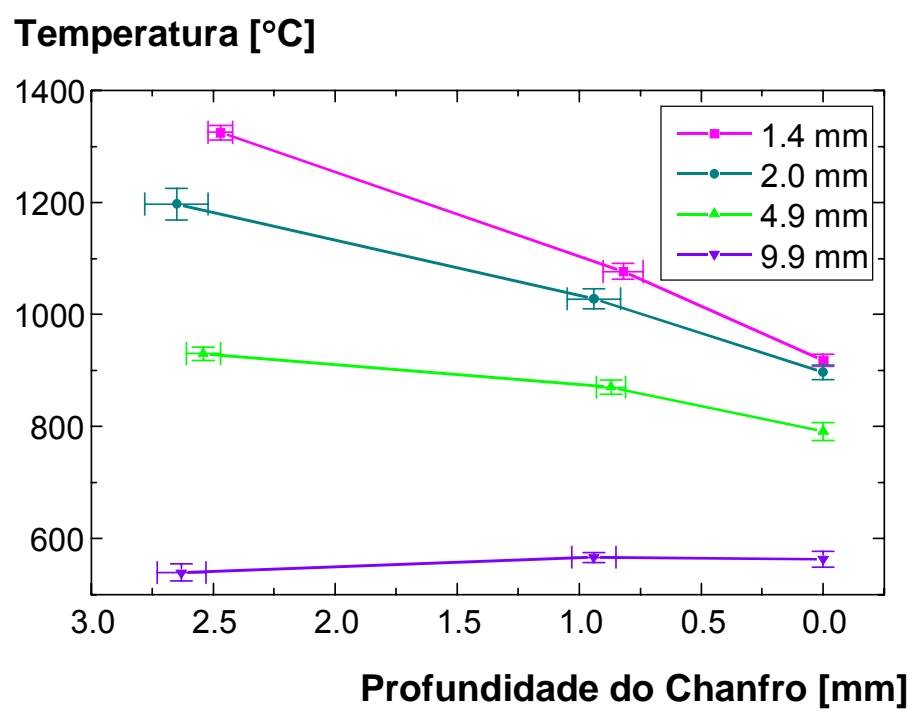

Figura 31: Variação da temperatura máxima com a profundidade do chanfro.

Portanto, a partir destes resultados verifica-se como o fluxo de calor tende para regime tridimensional perto da fonte de calor, onde a profundidade do chanfro, isto é a coordenada $z$ tem influência na temperatura máxima atingida. Quanto para pontos longe da fonte de calor, a profundidade do chanfro perde qualquer influência na temperatura máxima atingida, o que configura condições de fluxo bidimensional de calor. Assim, o padrão de fluxo de calor para as condições utilizadas é intermediário entre o bidimensional e o tridimensional. 


\subsubsection{Seleção e Adequação do Modelo de Fluxo de Calor}

Inicialmente foi testado o modelo proposto por RAMIREZ-LONDOÑO ${ }^{(52)}$ para o estudo da ZACTB de soldas multipasse sobre chapas finas. Este modelo foi desenvolvido a partir de medidas de temperatura em soldagens autógenas, realizadas sobre chapas com chanfros retangulares, produzindo resultados bastante adequados para a ZACTB. No entanto, os ciclos térmicos da ZACTE calculados com este modelo apresentaram temperaturas máximas bem acima dos valores experimentais. Por este motivo, o modelo não se mostrou adequado para a representação do fluxo de calor na região da ZAC em estudo.

Sendo assim, foi necessário buscar outros modelos, tendo sempre bem claro que, não sendo este o foco central do trabalho, procurou-se um modelo simples. Foram testados os modelos de Rosenthal para chapas fina e grossa e nenhum dos dois foi satisfatório. Foi então, verificado o modelo de Rosenthal para chapas de espessura média, apresentando resultados levemente animadores. Mas a utilização deste modelo na representação de uma solda multipasse é limitada pelo fato da fonte de calor pontual sempre se encontrar na superfície superior da chapa. Além disso, esta fonte de calor pontual não representa muito bem as condições de fluxo de calor na sua vizinhança. Pensou-se então num modelo de fonte distribuída, e desta forma, foi testado o modelo proposto por MYHR; GRONG ${ }^{(17)}$. Este modelo mostrou-se adequado, pois além de ter uma fonte distribuída permitia a variação da sua posição na direção $z$, permitindo assim representar o preenchimento sucessivo do chanfro em uma soldagem multipasse.

Foram testadas inúmeras distribuições da fonte de calor, mas não foi possível encontrar uma que fosse adequada às condições experimentais do trabalho. Decidiu-se então fazer algumas modificações neste modelo, de forma que fosse possível ter uma configuração de fonte de calor um pouco mais generalizada. Com o novo desenvolvimento proposto conseguiu-se ter uma fonte de calor constituída por diversas fontes pontuais localizadas em qualquer parte do plano perpendicular à direção de soldagem, mas dentro ou sobre a chapa, como mostrado na Figura 32. Assim, este novo modelo é representado pela Equação 10.

$$
\begin{gathered}
T-T_{0}=\sum_{i}\left[T\left(q_{a}^{i}\right)+T\left(q_{b}^{i}\right)\right] \\
q_{0}=\sum_{i}\left(q_{a}^{i}+q_{b}^{i}\right)=\eta V I
\end{gathered}
$$

$\mathrm{Na}$ Equação 10, o aporte das distribuições de fontes que estão fora e sob o eixo $z$ são dados pelas Equações 11 e 12, respectivamente.] 


$$
\begin{aligned}
& T\left(q_{a}^{i}\right)=\frac{q_{a}^{i}}{4 \pi k} e^{-\frac{v \xi}{2 a}}\left[\sum_{i=-\infty}^{i=+\infty} \frac{e^{-R_{i} \frac{v}{2 a}}}{R_{i}}+\sum_{w=-\infty}^{w=+\infty} \frac{e^{-R_{w} \frac{v}{2 a}}}{R_{w}}\right] \\
& R_{i}=\sqrt{\xi^{2}+\left(y-\Delta_{a h}\right)^{2}+\left(z-2 i d-\Delta_{a v}\right)^{2}} \\
& R_{w}=\sqrt{\xi^{2}+\left(y-\Delta_{a h}\right)^{2}+\left(z-2 w d+\Delta_{a v}\right)^{2}} \\
& T\left(q_{b}^{i}\right)=\frac{q_{b}^{i}}{4 \pi k} e^{-\frac{v \xi}{2 a}}\left[\sum_{j=-\infty}^{j=+\infty} \frac{e^{-R_{j} \frac{v}{2 a}}}{R_{j}}+\sum_{f=-\infty}^{f=+\infty} \frac{e^{-R_{f} \frac{v}{2 a}}}{R_{f}}\right] \\
& R_{j}=\sqrt{\xi^{2}+y^{2}+\left(z-2 j d-\Delta_{b v}\right)^{2}} \\
& R_{f}=\sqrt{\xi^{2}+y^{2}+\left(z-2 f d+\Delta_{b v}\right)^{2}}
\end{aligned}
$$

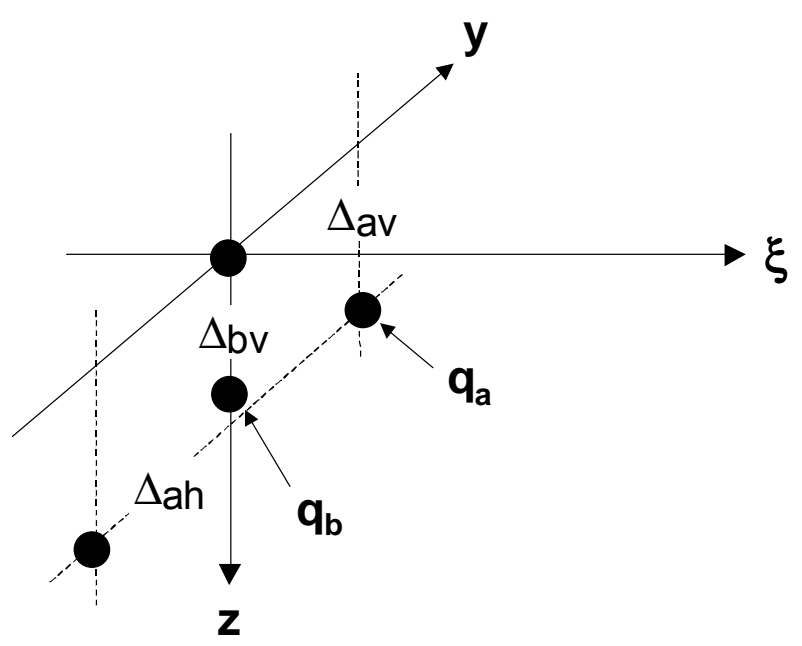

Figura 32: Distribuição de fontes de calor no modelo de transferência de calor.

Com esta adequação, os resultados do modelo se ajustaram bem às condições reais de fluxo de calor. No entanto, em trabalhos anteriores foi verificado que a eficiência térmica do processo de soldagem muda com a profundidade do chanfro. Isto, ao que parece, é devido ao confinamento do arco no chanfro ${ }^{(52)}$. Assim, dada a tendência quase-linear desta mudança, foi utilizado o fator de correção "f" para a energia de soldagem ( $\left.q_{o}=\bigvee / \eta\right)$, como definido na Equação 13. 


$$
f=1+\left(\frac{\theta}{180-\theta}\right) \frac{\Delta_{c h}}{d}
$$

Nesta equação, " $\theta$ " é o ângulo do chanfro, " $\Delta_{\mathrm{ch}}$ " é a profundidade do chanfro e "d" é a espessura da chapa. Portanto, no passe de raiz o fator " $f$ " corrige a área efetiva para difusão do calor, originalmente proposta por RYKALIN ${ }^{(123)}$ para uma junta em V. Por outro lado, para o passe de acabamento, onde se assume uma profundidade do chanfro de zero (0), o fator "f" torna-se igual a 1. Desta maneira, a energia de soldagem qo a ser aplicada na Equação 10, é dada pela Equação 14.

$$
q_{0}=\eta f \vee I
$$

Equação 14

\subsubsection{Comparação Entre os Resultados Experimentais e o Modelo}

Para a verificação do modelo proposto, este foi empregado para calcular os ciclos térmicos de soldagem correspondentes às experiências de soldagem das chapas do aço AISI 304 . Desta forma, os resultados desta simulação foram comparados com os dos ciclos térmicos medidos. Para a aplicação do modelo foi usada uma fonte de calor distribuída em três pontos, com potências relativas de 0,4;0,2 e 0,4. A profundidade na qual estas fontes foram localizadas é a média da profundidade do chanfro real após o respectivo passe, ou seja 2,4; 1,0 e $0 \mathrm{~mm}$ para o primeiro, segundo e terceiro passes, respectivamente. A eficiência térmica utilizada foi de 0,735 . Os valores das propriedades físicas do AISI 304 empregados são apresentados na Tabela 12.

Tabela 12: Valores das propriedades físicas do AISI 304.

\begin{tabular}{|c|c|}
\hline Densidade $-\rho\left[\mathrm{g} / \mathrm{mm}^{3}\right]$ & 0,00792 \\
\hline Calor Específico $-\mathrm{Cp}[\mathrm{J} / \mathrm{g} . \mathrm{K}]$ & 0,569 \\
\hline Condutividade Térmica $-\mathrm{k}[\mathrm{J} / \mathrm{mm} . \mathrm{s} . \mathrm{K}]$ & 0,0201 \\
\hline
\end{tabular}

Nas Figuras 33 e 34 é mostrada a comparação entre os ciclos térmicos reais correspondentes aos termopares 1, 2 e 3 da experiência 5 e os calculados com o modelo, correspondentes aos mesmos pontos. Como pode ser observado nestas figuras, o modelo representa bastante bem a realidade, principalmente em pontos da ZACTE. À medida que a região simulada se afasta da fonte de calor, isto é, pontos longe da linha de centro do cordão e também no caso do terceiro passe, o modelo vai perdendo paulatinamente a sua capacidade de representar adequadamente a realidade. 

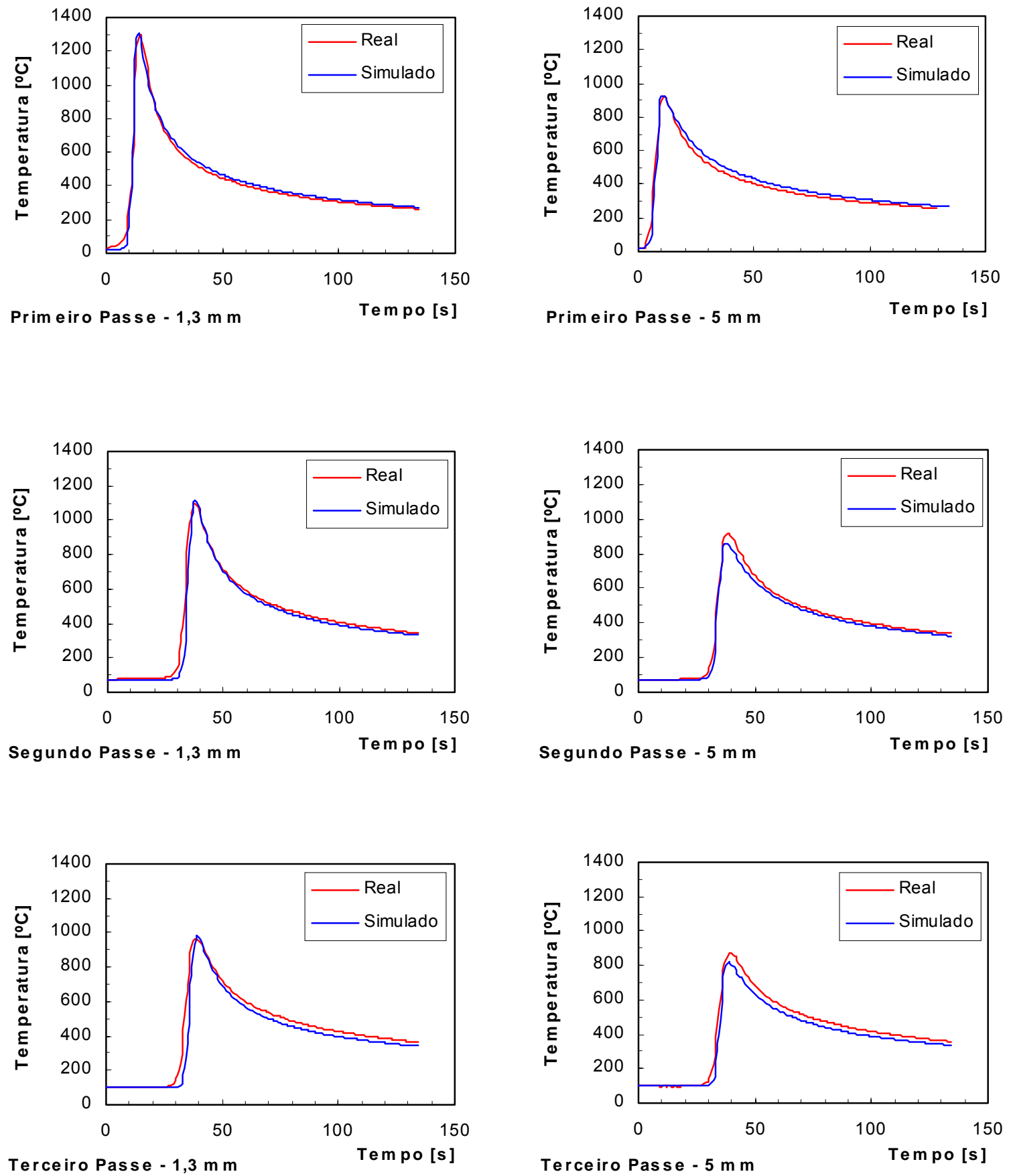

Figura 33: Comparação entre os ciclos térmicos experimentais (experiência 5) e os calculados segundo o modelo proposto neste trabalho. Pontos a 1,3 e $5 \mathrm{~mm}$ da linha de centro do cordão.

Como este trabalho todo é desenvolvido em regiões bastante próximas da fonte de calor, a ligeira perda de qualidade do modelo para pontos muito distantes da fonte de calor, como pode ser visto na Figura 34, não vem a comprometer a sua aplicação nesta pesquisa. 

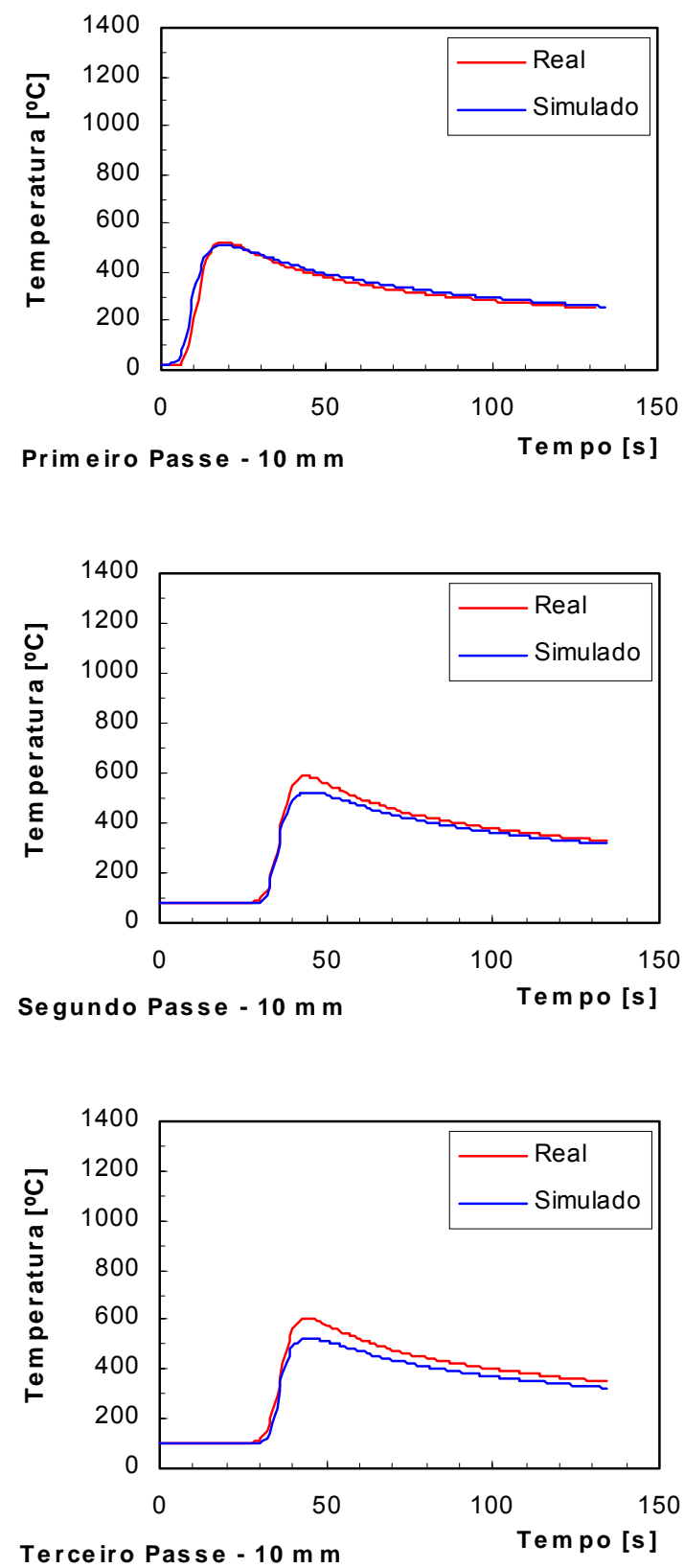

Figura 34: Comparação entre os ciclos térmicos experimentais (experiência 5) e os calculados segundo o modelo proposto neste trabalho. Ponto a $10 \mathrm{~mm}$ da linha de centro do cordão.

\subsubsection{Verificação Final do Modelo}

O modelo proposto foi desenvolvido e calibrado a partir de dados experimentais de ciclos térmicos de soldagem do aço inoxidável austenítico AISI 304. No entanto, a calibração final deste modelo foi realizada a partir de dados experimentais de soldagem de AIDs.

Para isto foram realizadas soldas multipasse no AID UNS S32304, onde foram registrados os ciclos térmicos de soldagem. Os parâmetros de soldagem utilizados foram os mesmos no caso do AISI 304, que correspondem a uma energia de soldagem de 0,64 kJ/mm. Foi feito 
um ajuste final nos parâmetros do modelo a partir dos dados obtidos durante estas experiências, de modo a se ajustar melhor às condições determinadas experimentalmente. Foi conservada a distribuição da fonte de calor em três fontes com potências relativas de 0,4 ; 0,2 e 0,4 com profundidade de 3,0; 1,6 e $0 \mathrm{~mm}$ para o primeiro, segundo e terceiro passes , respectivamente. A eficiência térmica usada foi de 0,652. Os valores das propriedades físicas para o AID são apresentados na Tabela 13.

Tabela 13: Propriedades físicas dos AIDs aplicadas no modelo.

\begin{tabular}{|c|c|}
\hline Densidade $-\rho\left[\mathrm{g} / \mathrm{mm}^{3}\right]$ & 0,0078 \\
\hline Calor Específico $-\mathrm{Cp}[\mathrm{J} / \mathrm{g} . \mathrm{K}]$ & 0,492 \\
\hline Condutividade Térmica $-\mathrm{k}[\mathrm{J} / \mathrm{mm} . \mathrm{s} . \mathrm{K}]$ & 0,0214 \\
\hline
\end{tabular}

Pela comparação apresentada nas Figuras 35 e 36 pode-se verificar que o modelo representa bastante bem os ciclos térmicos de soldagem de uma solda multipasse AID. No entanto, à medida que o ponto de interesse se afasta da fonte de calor, o modelo vai perdendo a sua precisão. Este fato é apresentado na Figura 36 para um ponto a $10 \mathrm{~mm}$ da linha de centro, no qual a temperatura máxima do primeiro passe está abaixo de $600{ }^{\circ} \mathrm{C}$. Este modelo será usado neste projeto no estudo da ZACTE (temperatura máxima no primeiro passe acima de $1350^{\circ} \mathrm{C}$ ) e em outro projeto anexo a este, no estudo de uma região da ZACTB com temperatura máxima no primeiro passe de $950^{\circ} \mathrm{C}$. 

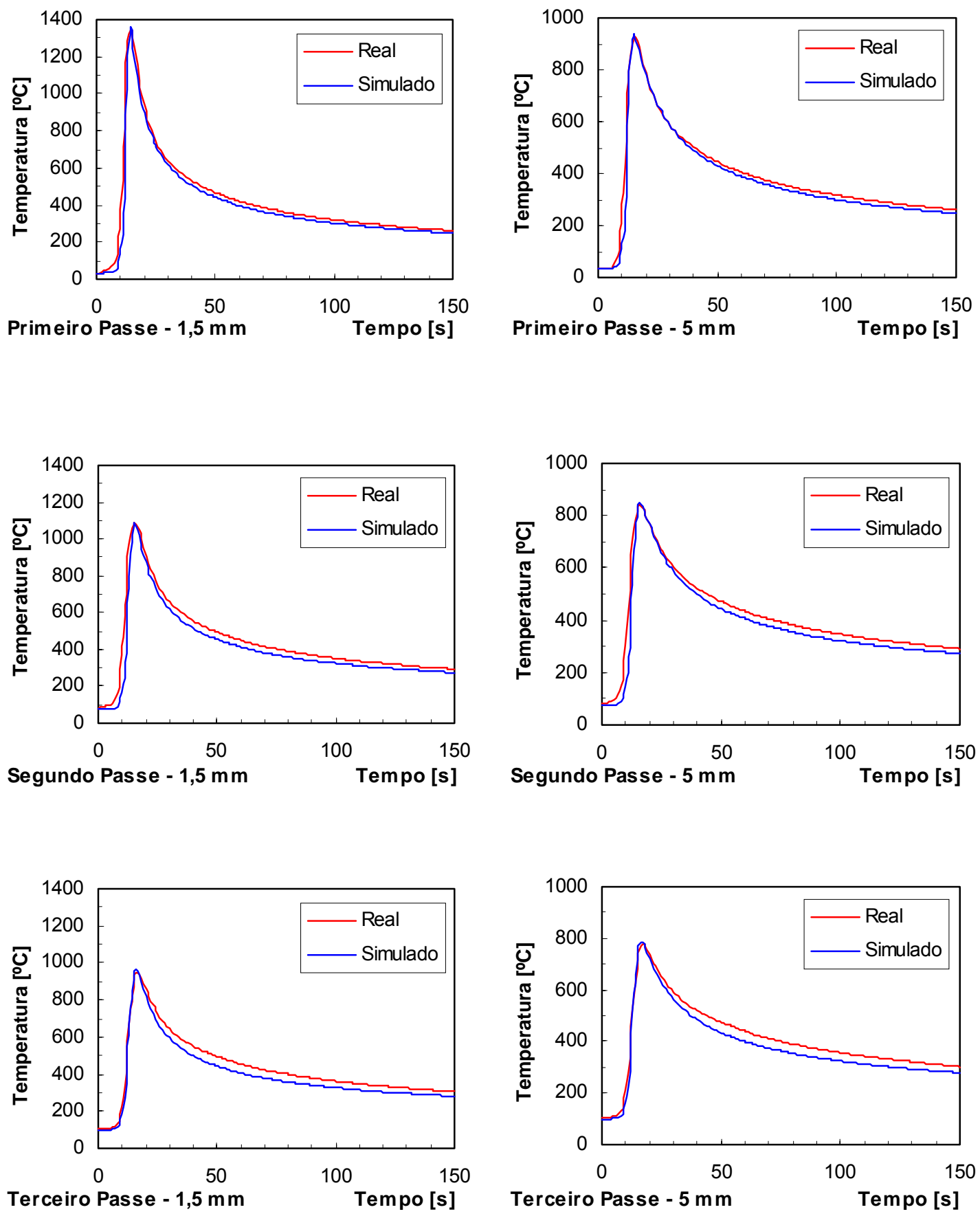

Figura 35: Comparação entre os ciclos térmicos de soldagem experimentais medidos no AID UNS S32304 e os calculados segundo o modelo proposto neste trabalho. Pontos a 1,5 e $5 \mathrm{~mm}$ da linha de centro do cordão. 

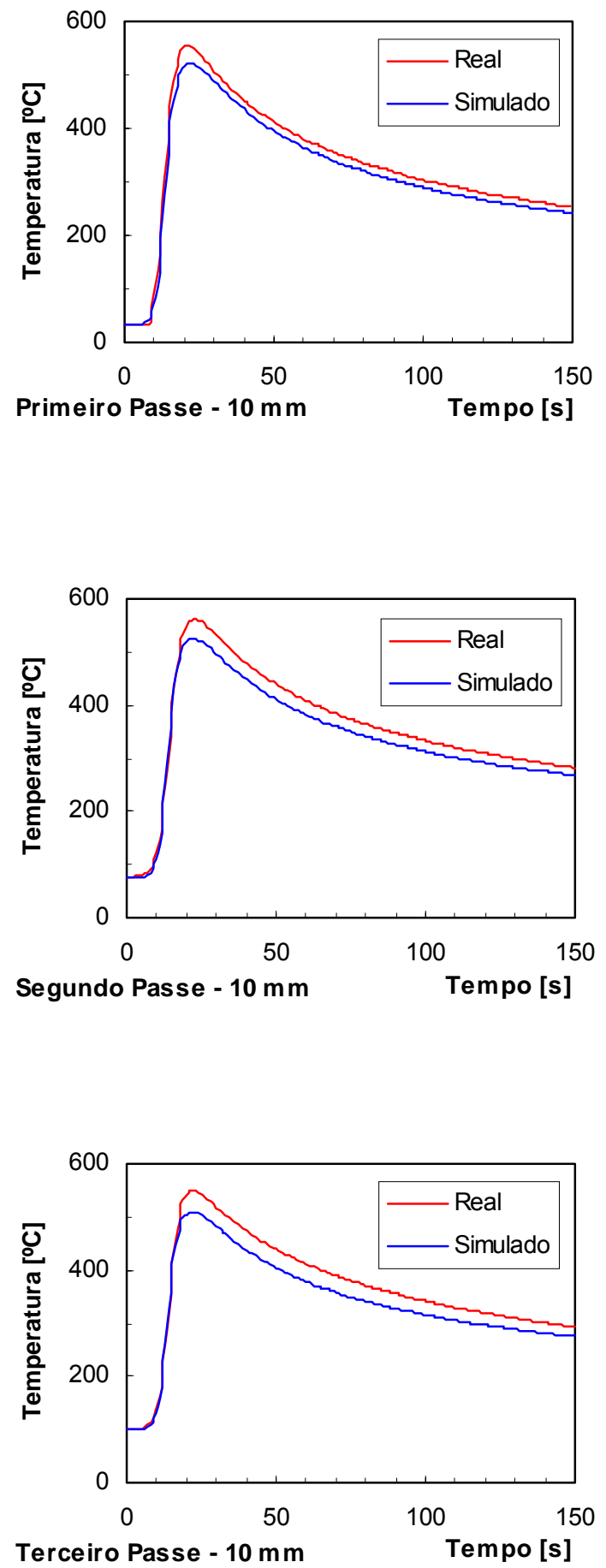

Figura 36: Comparação entre os ciclos térmicos de soldagem experimentais medidos no AID UNS S32304 e os calculados segundo o modelo proposto neste trabalho. Ponto a $10 \mathrm{~mm}$ da linha de centro do cordão.

\subsubsection{Cálculo dos Ciclos Térmicos a Serem Simulados}

Foram simulados os ciclos térmicos de soldagem correspondentes a energias de soldagem de 0,$6 ; 0,8$ e $1,0 \mathrm{~kJ} / \mathrm{mm}$. 
Para os cálculos com o modelo foram utilizados os valores de propriedades físicas do AID UNS S31803 apresentados na Tabela 13. A eficiência térmica empregada foi de 0,652 e as profundidades da fonte de calor para o primeiro, segundo e terceiro passes foram de 3,0; 1,6 e $0 \mathrm{~mm}$, respectivamente. Assim, com estes valores foram determinadas as distâncias da linha de centro do cordão às regiões da ZAC que apresentam temperaturas máximas de $1400,1390,1380,1370,1350$ e $950^{\circ} \mathrm{C}$ no primeiro passe. Na Tabela 14 são apresentadas as posições das regiões a serem estudadas e as temperaturas máximas para cada um dos passes.

Tabela 14: Posição das regiões da ZAC a serem estudadas e temperaturas máximas registradas nos diversos passes de soldagem.

\begin{tabular}{|c|c|c|c|c|c|c|c|}
\hline \multicolumn{2}{|c|}{ Energia de soldagem } & \multicolumn{7}{|c|}{$0,640 \mathrm{~kJ} / \mathrm{mm}$} \\
\hline \multicolumn{2}{|c|}{ Distância à linha de centro $[\mathrm{mm}]$} & 1,15 & 1,44 & 1,68 & 1,86 & 2,17 & 5,02 \\
\hline \multirow{2}{*}{$\begin{array}{c}\text { Temperatura } \\
\text { Máxima } \\
{\left[{ }^{\circ} \mathrm{C}\right]}\end{array}$} & $1^{\circ}$ Passe & 1400 & 1390 & 1380 & 1370 & 1350 & 950 \\
\cline { 2 - 9 } & $2^{\circ}$ Passe & 1130 & 1121 & 1111 & 1103 & 1087 & 862 \\
\cline { 2 - 9 } & $3^{\circ}$ Passe & 996 & 988 & 981 & 975 & 963 & 797 \\
\hline
\end{tabular}

\begin{tabular}{|c|c|c|c|c|c|c|c|}
\hline \multicolumn{2}{|c|}{ Energia de soldagem } & \multicolumn{7}{|c|}{$0,806 \mathrm{~kJ} / \mathrm{mm}$} \\
\hline \multicolumn{2}{|c|}{ Distância à linha de centro $[\mathrm{mm}]$} & 4,01 & 4,05 & 4,12 & 4,16 & 4,23 & 6,51 \\
\hline \multirow{2}{*}{$\begin{array}{c}\text { Temperatura } \\
\text { Máxima } \\
{\left[{ }^{\circ} \mathrm{C}\right]}\end{array}$} & $1^{\circ}$ Passe & 1400 & 1390 & 1380 & 1370 & 1350 & 950 \\
\cline { 2 - 8 } & $2^{\circ}$ Passe & 1179 & 1175 & 1167 & 1163 & 1155 & 910 \\
\cline { 2 - 8 } & $3^{\circ}$ Passe & 1063 & 1060 & 1054 & 1051 & 1045 & 851 \\
\hline
\end{tabular}

\begin{tabular}{|c|c|c|c|c|c|c|c|}
\hline \multicolumn{2}{|c|}{ Energia de soldagem } & \multicolumn{7}{|c|}{$1,000 \mathrm{~kJ} / \mathrm{mm}$} \\
\hline \multicolumn{2}{|c|}{ Distância à linha de centro $[\mathrm{mm}]$} & 5,34 & 5,39 & 5,43 & 5,48 & 5,57 & 8,25 \\
\hline $\begin{array}{c}\text { Temperatura } \\
\text { Máxima } \\
{\left[{ }^{\circ} \mathrm{C}\right]}\end{array}$ & $1^{\circ}$ Passe & 1400 & 1390 & 1380 & 1370 & 1350 & 950 \\
\cline { 2 - 8 } & $2^{\circ}$ Passe & 1262 & 1255 & 1250 & 1243 & 1231 & 927 \\
\cline { 2 - 8 } & $3^{\circ}$ Passe & 1155 & 1150 & 1146 & 1140 & 1131 & 873 \\
\hline
\end{tabular}

Nem todos estes pontos da ZAC foram estudados, mas foi necessário realizar simulações de diversos deles para determinar a região ideal para o desenvolvimento desta pesquisa. $\mathrm{Na}$ Figura 37 são apresentados, a título de exemplo, os ciclos térmicos de soldagem simulados correspondentes à região da raiz que atinge uma temperatura máxima de $1400{ }^{\circ} \mathrm{C}$. 

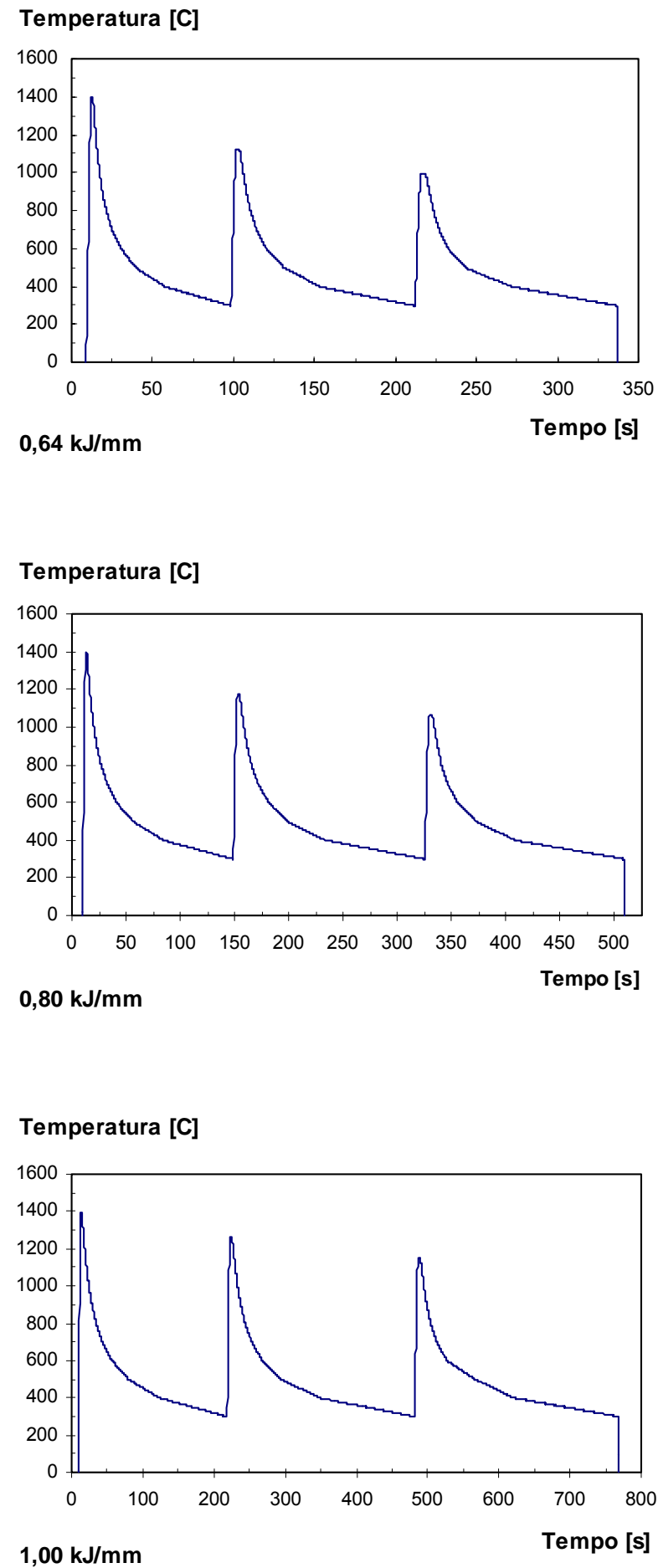

Figura 37: Ciclos térmicos de soldagem da região da ZACTE com temperatura máxima no primeiro passe de $1400^{\circ} \mathrm{C}$. Estes ciclos foram simulados com energias de soldagem de 0,6;0,8 e $1,0 \mathrm{~kJ} / \mathrm{mm}$. 


\subsection{MUDANÇAS MICROESTRUTURAIS NA ZAC DOS AIDS}

Nesta seção é tratada a caracterização dos materiais utilizados e o estudo da precipitação de $\gamma_{2}$ e fases intermetálicas e as suas inter-relações na ZACTE de soldagens multipasse de chapas finas de AIDs. Finalmente é apresentado o estudo do efeito destas mudanças microestruturais no desempenho desta região.

\subsubsection{Caracterização dos Materiais no Estado Como-Recebido}

Nesta seção são apresentados a composição química, resultados dos ensaios de análise térmica, de temperatura de resistência nula e, finalmente, do estudo microestrutural das cinco ligas usadas nesta pesquisa.

\subsubsection{Composição Química}

$\mathrm{Na}$ Tabela 15 são apresentadas as análises químicas dos materiais. Para todas as ligas, com exceção do AISD UNS S32550, as análises foram fornecidas pelos fabricantes do material. No caso do AISD UNS S32550, e do Vanádio para todas as ligas, as análises foram realizada nos laboratórios de pesquisa e desenvolvimento da ACESITA ${ }^{\circledR}$.

Tabela 15: Análise química dos materiais utilizados.

\begin{tabular}{|c|c|c|c|c|c|c|c|c|c|c|c|c|c|}
\hline $\begin{array}{c}\text { Designação } \\
\text { UNS }\end{array}$ & \%C & \%Si & \%Mn & \%P & \%S & \%V & \%Cr & \%Ni & $\% \mathbf{M o}$ & \%W & $\% \mathbf{C u}$ & $\% \mathbf{C o}$ & $\% \mathbf{N}$ \\
\hline S 32304 & 0,014 & 0,41 & 1,53 & 0,022 & 0,001 & 0,057 & 22,64 & 4,81 & 0,3 & - & 0,33 & 0,08 & 0,100 \\
\hline S 32205 & 0,015 & 0,45 & 1,50 & 0,023 & 0,001 & 0,057 & 21,90 & 5,80 & 3,06 & - & - & 0,11 & 0,179 \\
\hline S 32550 & 0,023 & 0,28 & 0,91 & 0,023 & 0,001 & 0,082 & 25,11 & 6,08 & 3,78 & 0,02 & 1,53 & 0,07 & 0,245 \\
\hline S 32750 & 0,016 & 0,21 & 0,81 & 0,022 & 0,001 & 0,075 & 25,08 & 6,86 & 3,82 & - & 0,20 & 0,10 & 0,300 \\
\hline S 32760 & 0,022 & 0,19 & 0,51 & 0,022 & 0,001 & 0,118 & 25,14 & 6,86 & 3,61 & 0,61 & 0,59 & - & 0,250 \\
\hline
\end{tabular}

Ao comparar os valores da Tabela anterior com os da Tabela 3 verifica-se que todas as ligas encontram-se dentro da especificação.

$\mathrm{Na}$ Tabela 16 são apresentados os valores de cromo equivalente $\left(\mathrm{Cr}_{\text {eq }}\right)$ e níquel equivalente $\left(\mathrm{Ni}_{\text {eq }}\right.$ ) calculados segundo Hull ${ }^{(124)}$, Espy ${ }^{(125)}$ e o diagrama WRC-1992 ${ }^{(126)}$ e relação $\mathrm{Cr}_{\text {eq }} / \mathrm{Ni}_{\text {eq. }}$. Estes diagramas de forma geral não conseguem representar muito bem os AIDs. No entanto, os valores de $\mathrm{Cr}_{\mathrm{eq}}$ e $\mathrm{Ni}_{\text {eq }}$ dão uma idéia bastante boa da tendência da liga para formar austenita ou ferrita. O diagrama de Hull, que foi obtido a partir de estruturas fundidas resfriadas rapidamente, leva em conta uma grande quantidade de elementos de liga. Por outro lado, o diagrama do Espy não leva em conta tantos elementos de liga como o anterior, mas em compensação, avalia muito bem o efeito do nitrogênio, que é um dos elementos de liga mas importantes nos AIDs. Finalmente, foi utilizado o diagrama WRC-1992, que é um dos diagramas com mais ampla utilização em soldagem. No entanto, este último diagrama é bastante simplificado, levando em conta somente o efeito de alguns elementos de liga. Também nesta tabela é apresentado o índice de resistência à corrosão por pites $(\mathrm{PREW})^{(30)}$ 
para cada uma das ligas estudadas. Este índice é utilizado como uma primeira aproximação da resistência à corrosão localizada do material.

Tabela 16: Valores de $\mathrm{Cr}_{\text {eq }}, \mathrm{Ni}_{\text {eq }}$ e PREW para as diversas ligas estudadas.

\begin{tabular}{|c|c|c|c|c|c|c|c|c|c|c|}
\hline \multirow{2}{*}{$\begin{array}{c}\text { Diagrama } \\
\text { Designação } \\
\text { UNS }\end{array}$} & \multicolumn{3}{|c|}{ Hull $^{1}$} & \multicolumn{3}{|c|}{ Espy $^{2}$} & \multicolumn{3}{|c|}{ WRC-1992 ${ }^{3}$} & \multirow[b]{2}{*}{ PREW $^{4}$} \\
\hline & $\mathrm{Cr}_{\mathrm{eq}}$ & $\mathrm{Ni}_{\text {eq }}$ & $\mathrm{Cr}_{\text {eq }} / \mathrm{Ni}_{\mathrm{eq}} \mid$ & $\mathrm{Cr}_{\text {eq }}$ & $\mathrm{Ni}_{\text {eq }}$ & $\mathrm{Cr}_{\text {eq }} / \mathrm{Ni}_{\text {eq }} \mid$ & $\mathrm{Cr}_{\text {eq }}$ & $\mathrm{Ni}_{\text {eq }}$ & $\mathrm{Cr}_{\mathrm{eq}} / \mathrm{Ni}_{\mathrm{eq}} \mid$ & \\
\hline S 32304 & 23,33 & 7,31 & 3,19 & 23,84 & 8,32 & 2,87 & 22,94 & 7,38 & 3,11 & 25,23 \\
\hline S 32205 & 25,95 & 9,63 & 2,70 & 25,92 & 11,58 & 2,24 & 24,96 & 9,91 & 2,52 & 34,86 \\
\hline S 32550 & 30,02 & 11,92 & 2,52 & 29,72 & 12,47 & 2,38 & 28,89 & 12,17 & 2,37 & 41,54 \\
\hline S 32750 & 29,97 & 12,95 & 2,31 & 29,59 & 13,21 & 2,24 & 28,90 & 13,47 & 2,15 & 42,49 \\
\hline S 32760 & 30,31 & 12,31 & 2,46 & 29,63 & 12,67 & 2,34 & 28,75 & 12,78 & 2,25 & 42,06 \\
\hline \multicolumn{11}{|c|}{ 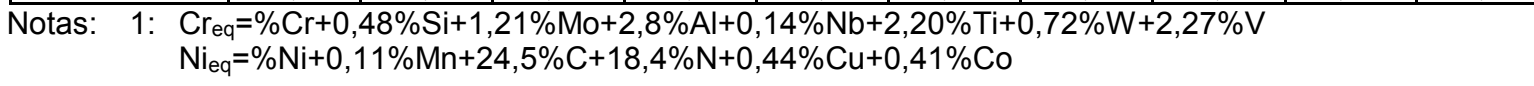 } \\
\hline 2: C & $\begin{array}{l}\% \mathrm{Cr}+1 \\
\% \mathrm{Ni}+0, \\
\text { para } \%\end{array}$ & $\begin{array}{c}\% \mathrm{Si}+\% \\
\% \mathrm{Mn}+ \\
0,0-0,\end{array}$ & $\begin{array}{l}\text { Mo+3\%Al+C } \\
30 \% \mathrm{C}+0,33 \\
2 \mathrm{x}=30, \text { par }\end{array}$ & $\begin{array}{l}0,5 \% \mathrm{Nb} \\
\% \mathrm{Cu}+\mathrm{x} \\
\mathrm{a} \% \mathrm{~N} 0,\end{array}$ & $\begin{array}{l}5 \% \mathrm{~V} \\
6 \mathrm{~N}-0,0 \\
1-0,25\end{array}$ & 22 e pa & م & r & & \\
\hline \multicolumn{11}{|c|}{ 3: $\begin{aligned} \mathrm{Cr}_{\text {eq }}=\% \mathrm{Cr}+\% \mathrm{Mo}+0,7 \% \mathrm{Nb} \\
\mathrm{Ni}_{\text {eq }}=\% \mathrm{Ni}+35 \% \mathrm{C}+20 \% \mathrm{~N}+0,25 \% \mathrm{Cu}\end{aligned}$} \\
\hline 4: $\mathrm{PI}$ & $=\%$ & $3(\%$ & $0,5 \%$ & $+16 \%$ & & & & & & \\
\hline
\end{tabular}

\subsubsection{Cálculos Termodinâmicos}

Foram realizados cálculos termodinâmicos para determinar os diagramas de fase pseudobinários das ligas utilizadas e os diagramas de variação da fração molar das fases presentes com a temperatura. Nos cálculos foram levados em conta os elementos de liga: $\mathrm{Fe}, \mathrm{Cr}, \mathrm{Ni}$, Mo, W, Cu, N, C, Si e Mn; e as fases: Liquido, ferrita, austenita, $\mathrm{Cr}_{2} \mathrm{~N}$, Sigma e $\mathrm{M}_{23} \mathrm{C}_{6}$.

Nos diagramas apresentados nas Figuras 38 a 42, o teor de nitrogênio é variado entre 0 e 1 $\%$, e a linha vermelha representa o teor da liga em estudo. Nos diagramas de variação de fração com a temperatura é utilizada a fração molar para facilitar a apresentação, pois no caso de apresentar a fração volumétrica as fases com frações muito pequenas, como $\mathrm{Cr}_{2} \mathrm{~N}$ e $\mathrm{M}_{23} \mathrm{C}_{6}$, não podem mais ser observadas. No entanto, dada a maior familiaridade com a fração volumétrica estes diagramas são apresentados na Figura 43.

$\mathrm{Na}$ Tabela 17 são apresentadas as temperaturas liquidus e solidus e de começo de precipitação da austenita, $\mathrm{Cr}_{2} \mathrm{~N}, \mathrm{M}_{23} \mathrm{C}_{6}$ e fase sigma. No caso da ferrita, a sua temperatura de começo de transformação é a temperatura liquidus. 


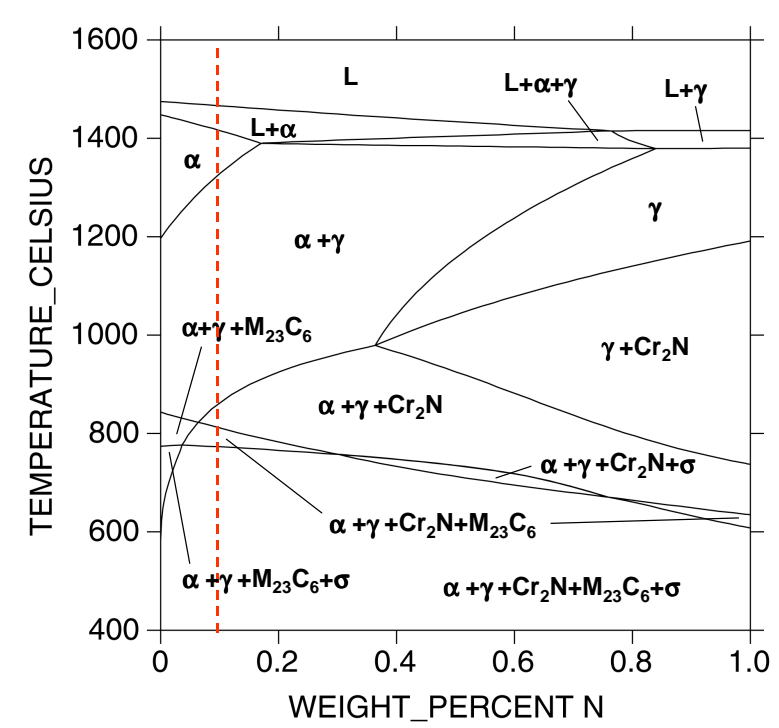

a.

Figura 38: AID UNS S32304, em (a) diagrama de fase pseudo-binário, onde a linha tracejada indica a composição da liga; em (b) variação da fração molar da fases em equilíbrio com a temperatura.

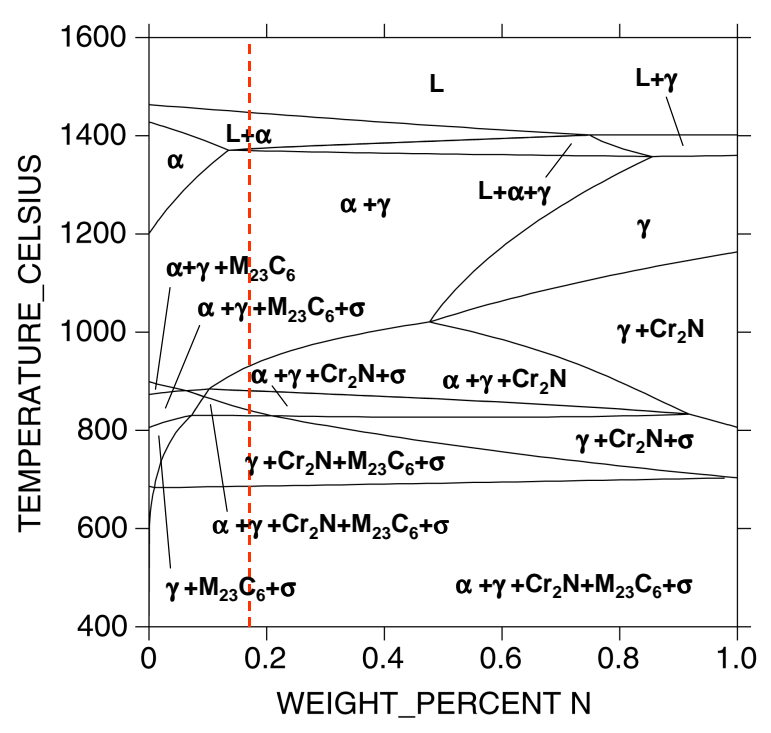

a.

Figura 39: AID UNS S32205, em (a) diagrama de fase pseudo-binário, onde a linha tracejada indica a composição da liga; em (b) variação da fração molar da fases em equilíbrio com a temperatura.

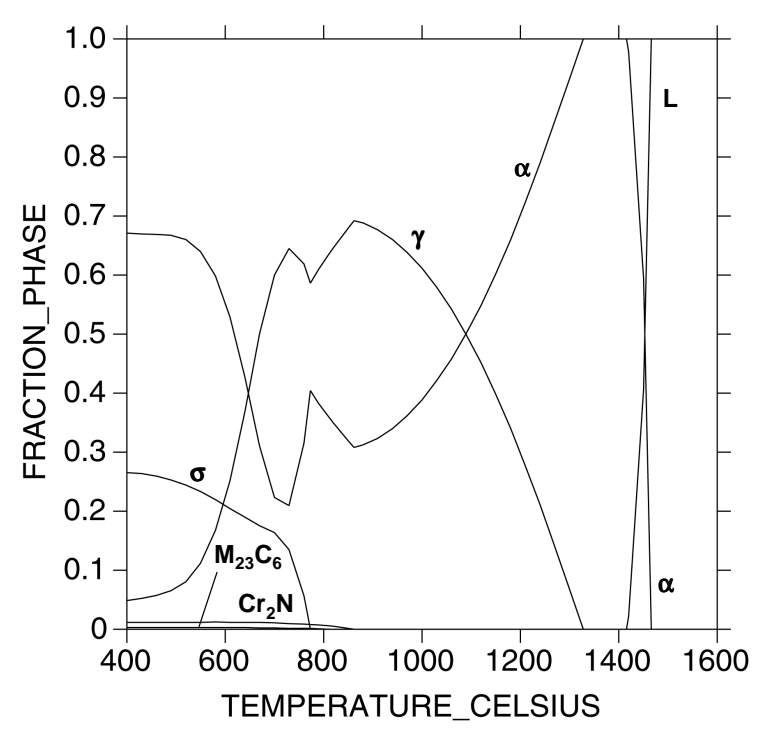

b.

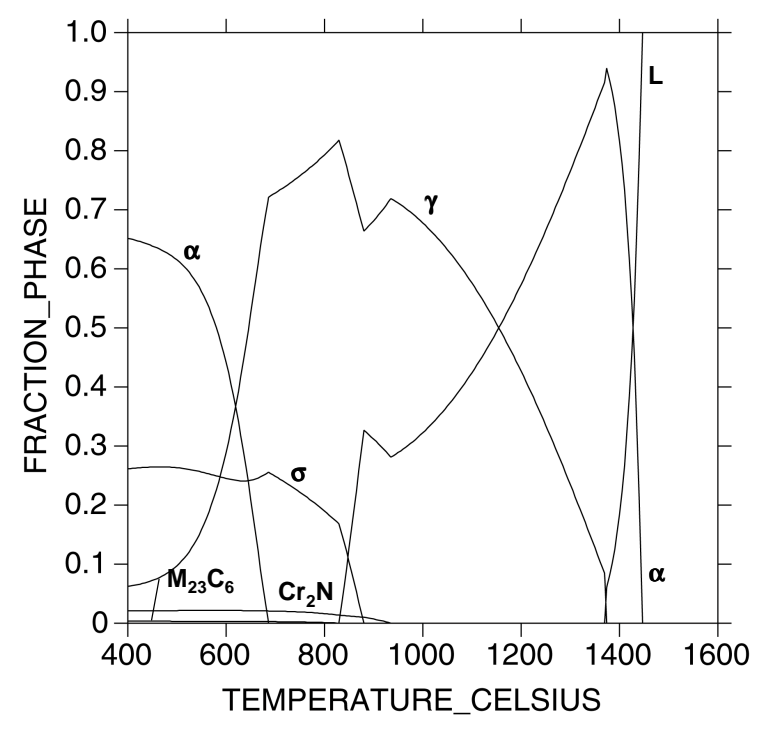

b. 


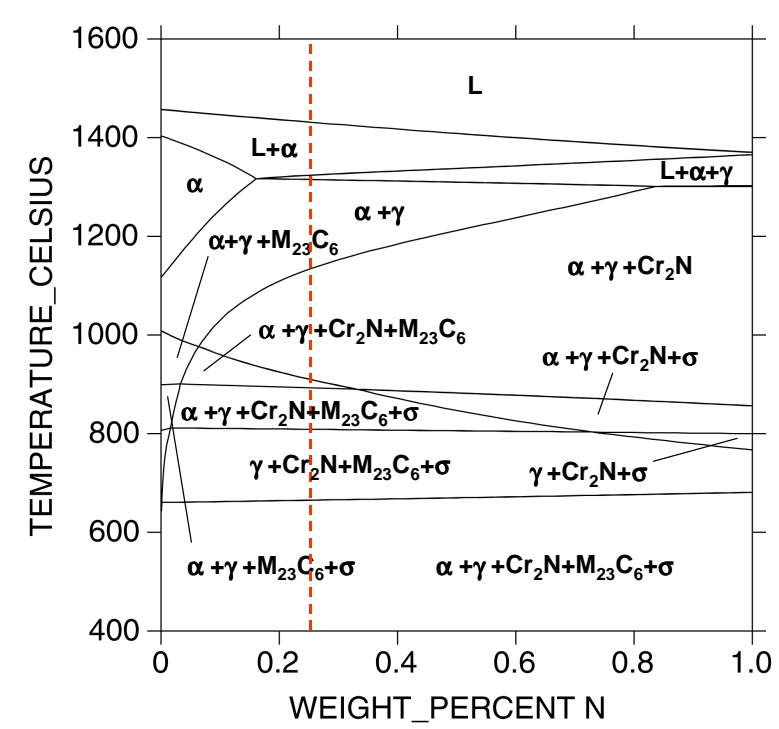

a.

Figura 40: AID UNS S32550, em (a) diagrama de fase pseudo-binário, onde a linha tracejada indica a composição da liga; em (b) variação da fração molar da fases em equilíbrio com a temperatura.

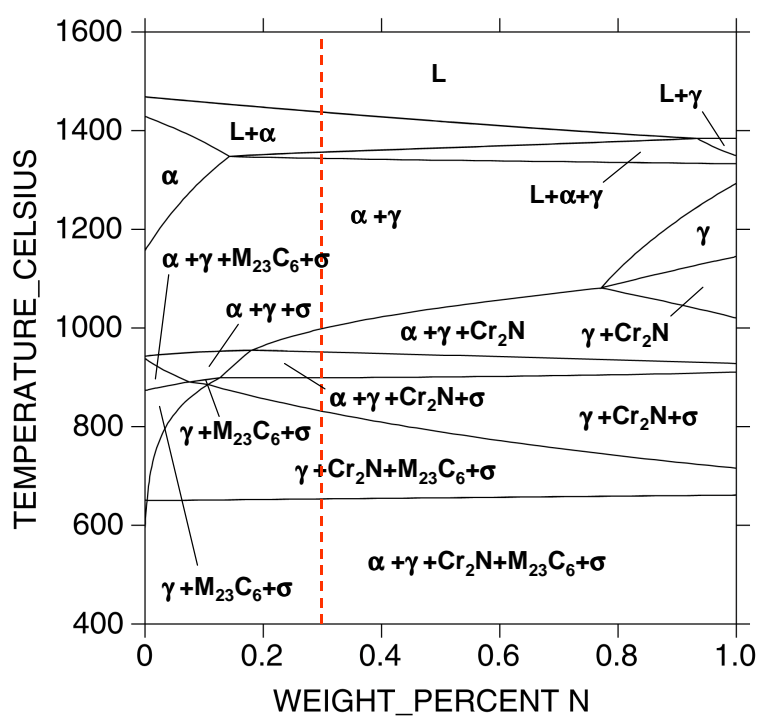

a.

Figura 41: AID UNS S32750, em (a) diagrama de fase pseudo-binário, onde a linha tracejada indica a composição da liga; em (b) variação da fração molar da fases em equilíbrio com a temperatura.

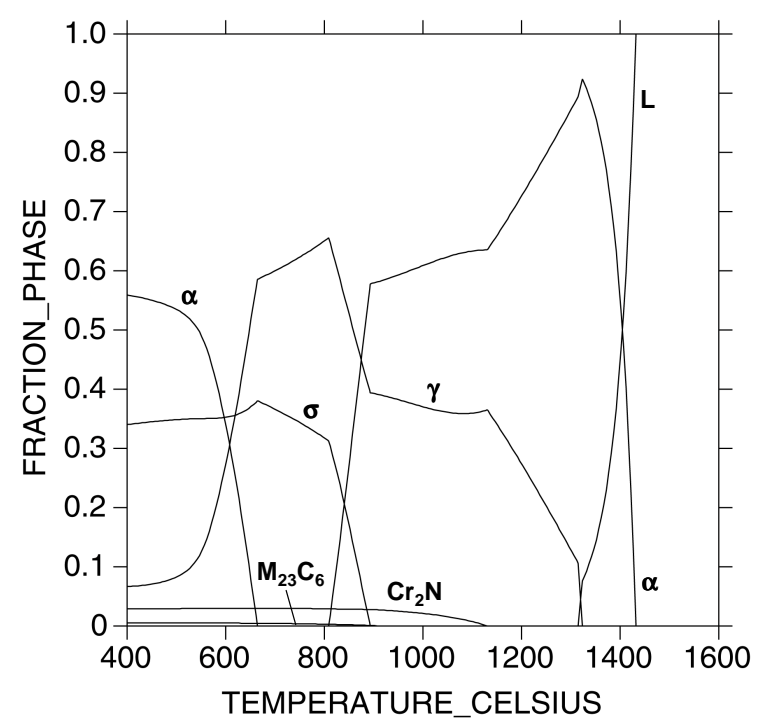

b.

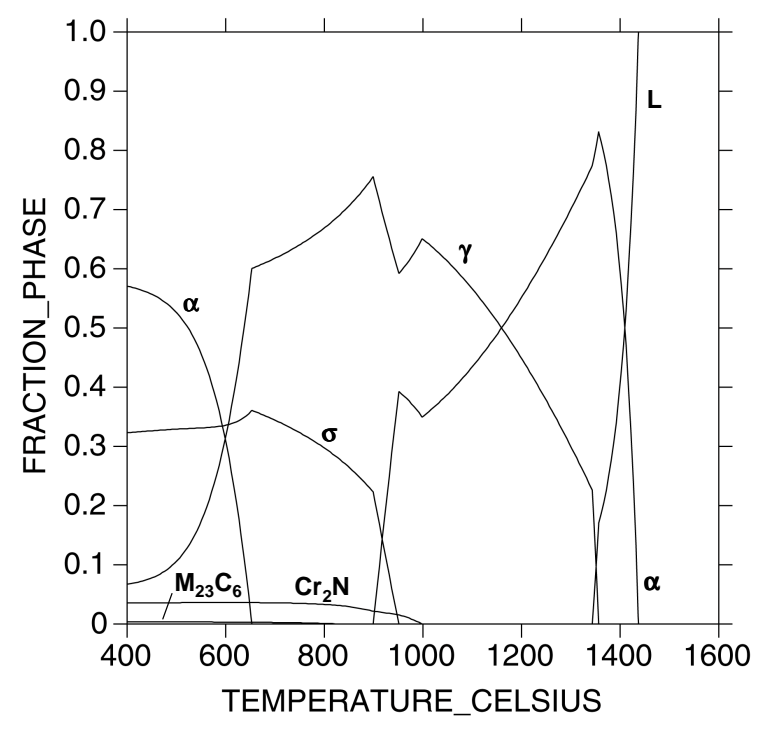

b. 


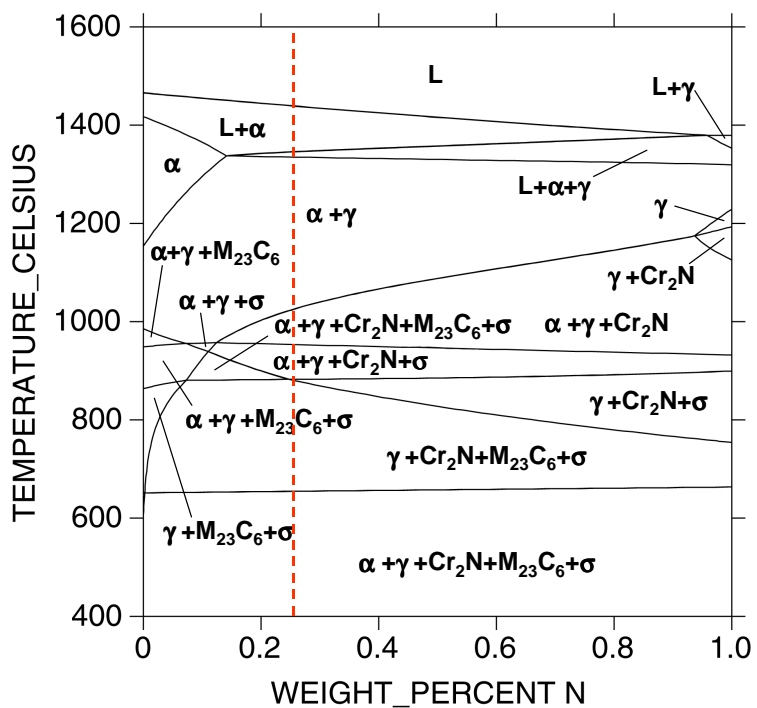

a.

Figura 42: AID UNS S32760, em (a) diagrama de fase pseudo-binário, onde a linha tracejada indica a composição da liga; em (b) variação da fração molar da fases em equilíbrio com a temperatura.

Deve-se chamar a atenção para a seqüência de solidificação das ligas sugerida pelos diagramas mostrados anteriormente. No caso da liga UNS S32304, a solidificação é totalmente ferrítica, tendo-se ainda a possibilidade de ferritizar a liga. Mas, no caso das outras quatro ligas, a solidificação é do tipo ferrítico-austenítica, de modo que segundo estes cálculos não existe uma faixa de temperatura na qual o material seja totalmente ferrítico. Mais adiante serão feitos mais alguns comentários a respeito deste assunto.

Tabela 17: Temperaturas solidus, liquidus e de início de precipitação das fases, calculadas com o Thermo-Calc ${ }^{\circledR}$.

\begin{tabular}{|c|c|c|c|c|c|c|}
\hline \multirow{2}{*}{$\begin{array}{c}\text { Designação } \\
\text { UNS }\end{array}$} & \multicolumn{2}{|c|}{ Temperatura $\left[{ }^{\circ} \mathbf{C}\right]$} & \multicolumn{4}{|c|}{ Temperatura de Início de Precipitação ${ }^{\circ} \mathbf{C}$ ] } \\
\cline { 2 - 7 } & Liquidus & Solidus & Austenita & $\mathbf{C r}_{2} \mathbf{N}$ & $\mathbf{M}_{23} \mathbf{C}_{6}$ & Sigma \\
\hline S32304 & 1466 & 1416 & 1328 & 862 & 814 & 778 \\
\hline S32205 & 1447 & 1369 & 1374 & 935 & 953 & 774 \\
\hline S32550 & 1432 & 1315 & 1323 & 1131 & 912 & 889 \\
\hline S32750 & 1437 & 1344 & 1356 & 999 & 831 & 957 \\
\hline S32760 & 1439 & 1335 & 1345 & 1023 & 882 & 953 \\
\hline
\end{tabular}



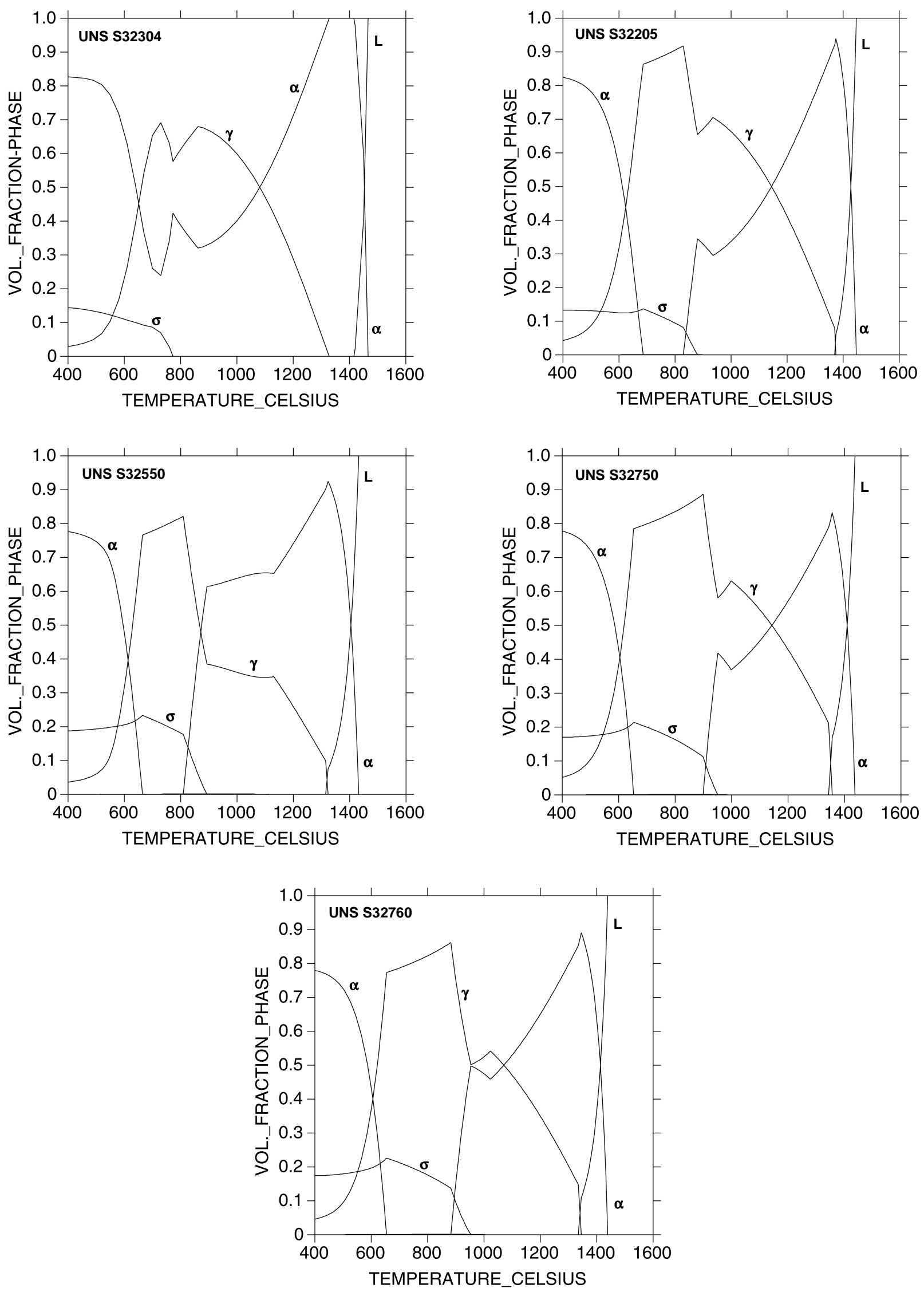

Figura 43: Variação da fração volumétrica das fases em equilíbrio com a temperatura, para as ligas em estudo. 
O Thermo-Calc ${ }^{\circledR}$ calcula as propriedades termodinâmicas das espécies a partir de modelos ajustados mediante a utilização de dados experimentais. Porém, os resultados obtidos neste trabalho, no que corresponde as temperaturas solidus e liquidus, estão bastante perto dos obtidos experimentalmente, dando uma maior confiabilidade aos resultados com ele obtidos nesta pesquisa.

$\mathrm{Na}$ Tabela 18 são mostradas as frações volumétricas calculadas das fases em equilíbrio a $600{ }^{\circ} \mathrm{C}$. A cinética de transformação abaixo desta temperatura torna-se bastante lenta e, portanto, as frações volumétricas máximas de fases como o $\mathrm{Cr}_{2} \mathrm{~N}, \circ \mathrm{M}_{23} \mathrm{C}_{6}$ e a sigma, que poderiam ser atingidas na prática, podem ser aproximadas pelos valores obtidos nesta temperatura. Mas deve-se ter em mente que estes resultados são calculados para condições de equilíbrio. Porém, se por alguma circunstância a fração de austenita for diminuída, a fração de $\mathrm{Cr}_{2} \mathrm{~N}$ e $\mathrm{M}_{23} \mathrm{C}_{6}$ poderia vir a ser maior. Isto é explicado pela maior solubilidade do nitrogênio e do carbono na austenita. Desta forma, no caso da microestrutura da ZACTE, onde a fração de austenita pode vir a ser bastante reduzida, pode-se esperar frações maiores de $\mathrm{Cr}_{2} \mathrm{~N}$ e $\mathrm{M}_{23} \mathrm{C}_{6}$.

Tabela 18: Fração volumétrica das fases presentes a $600{ }^{\circ} \mathrm{C}$. Cálculos realizados com o programa Thermo-Calc ${ }^{\circledR}$.

\begin{tabular}{|c|c|c|c|c|c|}
\hline \multirow{2}{*}{$\begin{array}{c}\text { Designação } \\
\text { UNS }\end{array}$} & \multicolumn{5}{|c|}{ Fração Volumétrica a $\mathbf{6 0 0}{ }^{\circ} \mathbf{C}[\%]$} \\
\cline { 2 - 6 } & Ferrita & Austenita & $\mathbf{C r}_{2} \mathbf{N}$ & $\mathbf{M}_{\mathbf{2 3}} \mathbf{C}_{6}$ & Sigma \\
\hline S32304 & 66,4 & 22,6 & 0,025 & 0,007 & 11,0 \\
\hline S32205 & 55,8 & 31,7 & 0,035 & 0,001 & 12,5 \\
\hline S32550 & 47,8 & 31,6 & 0,057 & 0,002 & 20,5 \\
\hline S32750 & 43,0 & 38,1 & 0,067 & 0,001 & 18,8 \\
\hline S32760 & 43,5 & 36,8 & 0,057 & 0,002 & 19,6 \\
\hline
\end{tabular}

$\mathrm{Na}$ Tabela 19 é apresentada a composição química das fases presentes nas diversas fases no estado de equilíbrio a $600{ }^{\circ} \mathrm{C}$. Em relação a esta tabela vale a pena comentar que as composições químicas correspondentes à ferrita e à austenita, são bastante diferentes das composições medidas nestas mesmas fases, quando o material encontra-se no estado como-recebido. Neste ultimo caso as únicas fases presentes são a austenita e a ferrita. Além disso, os materiais no estado como-recebido foram solubilizados em temperaturas entre 1100 e $1200^{\circ} \mathrm{C}$ e, posteriormente, resfriados rapidamente. Desta forma, a composição química destas fases encontra-se bastante perto da sua composição no equilíbrio nesta temperatura. Nas Tabelas 20 e 21 são apresentadas as composições químicas da ferrita e da austenita e as suas frações volumétricas, respectivamente, calculadas no estado de equilíbrio a 1100 e $1200^{\circ} \mathrm{C}$. 
Tabela 19: Composição química das fases presentes no equilíbrio a $600^{\circ} \mathrm{C}$. Cálculos realizados com o programa Thermo-Calc ${ }^{\circledR}$.

\begin{tabular}{|c|c|c|c|c|c|c|}
\hline \multirow{2}{*}{$\begin{array}{c}\text { Designação } \\
\text { UNS }\end{array}$} & \multirow{2}{*}{ Elemento } & \multicolumn{5}{|c|}{ Composição Química a 600 C [\%] } \\
\hline & & Ferrita & Austenita & $\mathrm{Cr}_{2} \mathrm{~N}$ & $\mathrm{M}_{23} \mathrm{C}_{6}$ & Sigma \\
\hline \multirow{9}{*}{ S32304 } & C & 0,00004 & 0,00041 & 0,09 & 5,25 & 0,00 \\
\hline & $\mathbf{N}$ & 0,00003 & 0,00278 & 11,31 & 0,00 & 0,00 \\
\hline & Si & 0,38 & 0,30 & 0,00 & 0,00 & 0,63 \\
\hline & Mo & 0,15 & 0,14 & 3,34 & 15,43 & 0,56 \\
\hline & $\mathrm{Cr}$ & 17,65 & 13,49 & 84,28 & 71,68 & 42,74 \\
\hline & Mn & 0,56 & 3,61 & 0,80 & 0,13 & 1,95 \\
\hline & $\mathrm{Fe}$ & 78,00 & 69,79 & 0,15 & 7,30 & 51,65 \\
\hline & $\mathrm{Ni}$ & 3,02 & 11,74 & 0,005 & 0,18 & 2,44 \\
\hline & $\mathrm{Cu}$ & 0,23 & 0,90 & 0,00 & 0,00 & 0,00 \\
\hline \multirow{8}{*}{ S32205 } & C & 0,00001 & 0,00020 & 0,06 & 5,13 & 0,00 \\
\hline & $N$ & 0,00002 & 0,00256 & 10,71 & 0,00 & 0,00 \\
\hline & Si & 0,51 & 0,43 & 0,00 & 0,00 & 0,39 \\
\hline & Mo & 1,39 & 1,30 & 16,78 & 19,84 & 7,02 \\
\hline & $\mathrm{Cr}$ & 15,48 & 12,71 & 71,94 & 67.91 & 40,35 \\
\hline & Mn & 0,45 & 3,04 & 0,39 & 0,04 & 1,65 \\
\hline & $\mathrm{Fe}$ & 78,96 & 70,24 & 0,09 & 6,82 & 47,30 \\
\hline & $\mathrm{Ni}$ & 3,21 & 12,26 & 0,01 & 0,22 & 3,27 \\
\hline \multirow{9}{*}{ S32550 } & C & 0,00001 & 0,00007 & 0,06 & 5,14 & 0,00 \\
\hline & $\mathbf{N}$ & 0,00002 & 0,00018 & 10,76 & 0,00 & 0,00 \\
\hline & $\mathrm{Si}$ & 0,33 & 0,17 & 0,00 & 0,00 & 0,33 \\
\hline & Mo & 1,38 & 1,63 & 15,72 & 19,77 & 6,82 \\
\hline & $\mathrm{Cr}$ & 16,28 & 10,71 & 73,18 & 68,35 & 41,29 \\
\hline & Mn & 0,21 & 2,02 & 0,18 & 0,02 & 0,77 \\
\hline & $\mathrm{Fe}$ & 77,77 & 67,12 & 0,08 & 6,50 & 47,52 \\
\hline & $\mathrm{Ni}$ & 3,16 & 13,86 & 0,009 & 0,21 & 3,27 \\
\hline & $\mathrm{Cu}$ & 0,85 & 4,46 & 0,00 & 0,00 & 0,00 \\
\hline \multirow{9}{*}{ S32750 } & C & 0,00001 & 0,00017 & 0,06 & 5,14 & 0,00 \\
\hline & $\mathrm{N}$ & 0,00002 & 0,00205 & 10,77 & 0,00 & 0,00 \\
\hline & $\mathrm{Si}$ & 0,25 & 0,21 & 0,00 & 0,00 & 0,19 \\
\hline & Mo & 1,29 & 1,34 & 15,58 & 19,76 & 7,38 \\
\hline & $\mathrm{Cr}$ & 15,96 & 12,84 & 73,32 & 68,21 & 40,63 \\
\hline & Mn & 0,19 & 1,54 & 0,18 & 0,02 & 0,75 \\
\hline & $\mathrm{Fe}$ & 78,40 & 70,11 & 0,08 & 6,61 & 46,93 \\
\hline & $\mathrm{Ni}$ & 3,76 & 13,46 & 0,01 & 0,25 & 4,12 \\
\hline & $\mathrm{Cu}$ & 0,14 & 0,49 & 0,00 & 0,00 & 0,00 \\
\hline \multirow{10}{*}{ S32760 } & C & 0,00001 & 0,00014 & 0,06 & 5,14 & 0,00 \\
\hline & $N$ & 0,00002 & 0,00113 & 10,81 & 0,00 & 0,00 \\
\hline & Si & 0,24 & 0,18 & 0,00 & 0,00 & 0,17 \\
\hline & W & 0,14 & 0,14 & 0,02 & 0,15 & 1,48 \\
\hline & Mo & 1,18 & 1,30 & 14,67 & 19,59 & 6,85 \\
\hline & $\mathrm{Cr}$ & 16,17 & 12,43 & 74,23 & 6,83 & 40,32 \\
\hline & Mn & 0,12 & 1,01 & 0,11 & 0,01 & 0,45 \\
\hline & $\mathrm{Fe}$ & 77,96 & 69,67 & 0,08 & 6,55 & 46,61 \\
\hline & $\mathrm{Ni}$ & 3,79 & 13,75 & 0,01 & 0,25 & 4,13 \\
\hline & $\mathrm{Cu}$ & 0,40 & 1,51 & 0,00 & 0,00 & 0,00 \\
\hline
\end{tabular}


Tabela 20: Composição química das fases presentes no equilíbrio a 1100 e $1200{ }^{\circ} \mathrm{C}$. Cálculos realizados com o programa Thermo-Calc ${ }^{\circledR}$.

\begin{tabular}{|c|c|c|c|c|c|}
\hline \multirow{3}{*}{$\begin{array}{c}\text { Designação } \\
\text { UNS }\end{array}$} & \multirow{3}{*}{ Elemento } & \multicolumn{4}{|c|}{ Composição Química no Equilíbrio [\% ${ }_{\text {peso] }}$} \\
\hline & & \multicolumn{2}{|c|}{$1100^{\circ} \mathrm{C}$} & \multicolumn{2}{|c|}{$1200^{\circ} \mathrm{C}$} \\
\hline & & Ferrita & Austenita & Ferrita & Austenita \\
\hline \multirow{9}{*}{ S32304 } & C & 0,006 & 0,023 & 0,008 & 0,028 \\
\hline & $\mathbf{N}$ & 0,029 & 0,176 & 0,048 & 0,222 \\
\hline & Si & 0,44 & 0,37 & 0,42 & 0,36 \\
\hline & Mo & 0,37 & 0,23 & 0,34 & 0,22 \\
\hline & Cr & 25,14 & 19,98 & 23,88 & 19,71 \\
\hline & Mn & 1,34 & 1,74 & 1,42 & 1,78 \\
\hline & $\mathrm{Fe}$ & 68,71 & 71,10 & 69,37 & 71,01 \\
\hline & $\mathrm{Ni}$ & 3,63 & 6,06 & 4,15 & 6,35 \\
\hline & $\mathrm{Cu}$ & 0,34 & 0,33 & 0,34 & 0,31 \\
\hline \multirow{8}{*}{ S32205 } & C & 0,005 & 0,022 & 0,007 & 0,026 \\
\hline & $\mathbf{N}$ & 0,035 & 0,286 & 0,058 & 0,343 \\
\hline & $\mathrm{Si}$ & 0,50 & 0,41 & 0,49 & 0,40 \\
\hline & Mo & 3,87 & 2,46 & 3,59 & 3,34 \\
\hline & $\mathrm{Cr}$ & 24,16 & 20,22 & 23,22 & 20,11 \\
\hline & Mn & 1,24 & 1,69 & 1,33 & 1,73 \\
\hline & $\mathrm{Fe}$ & 6,60 & 67,90 & 66,58 & 67,79 \\
\hline & $\mathbf{N i}$ & 4,17 & 7,01 & 4,73 & 7,25 \\
\hline \multirow{9}{*}{ S32550 } & C & 0,010 & 0,041 & 0,013 & 0,050 \\
\hline & $\mathbf{N}$ & 0,051 & 0,440 & 0,093 & 0,657 \\
\hline & Si & 0,31 & 0,24 & 0,30 & 0,22 \\
\hline & Mo & 4,36 & 2,77 & 4,15 & 0,28 \\
\hline & $\mathrm{Cr}$ & 25,87 & 22,90 & 25,43 & 24,23 \\
\hline & Mn & 0,79 & 1,12 & 0,84 & 1,11 \\
\hline & $\mathrm{Fe}$ & 61,90 & 63,15 & 62,00 & 62,16 \\
\hline & $\mathrm{Ni}$ & 4,97 & 8,16 & 5,42 & 7,86 \\
\hline & $\mathrm{Cu}$ & 1,74 & 1,18 & 1,75 & 0,95 \\
\hline \multirow{9}{*}{ S32750 } & C & 0,006 & 0,024 & 0,007 & 0,027 \\
\hline & $\mathbf{N}$ & 0,046 & 0,498 & 0,078 & 0,578 \\
\hline & Si & 0,25 & 0,18 & 0,24 & 0,17 \\
\hline & Mo & 4,79 & 3,06 & 4,50 & 2,97 \\
\hline & $\mathrm{Cr}$ & 26,87 & 23,68 & 26,12 & 23,78 \\
\hline & Mn & 0,66 & 0,92 & 0,71 & 0,94 \\
\hline & $\mathrm{Fe}$ & 62,11 & 63,17 & 62,51 & 62,95 \\
\hline & $\mathrm{Ni}$ & 5,00 & 8,30 & 5,60 & 8,44 \\
\hline & $\mathrm{Cu}$ & 0,25 & 0,16 & 0,24 & 0,15 \\
\hline \multirow{10}{*}{ S32760 } & $\mathbf{C}$ & 0,009 & 0,036 & 0,011 & 0,041 \\
\hline & $\mathbf{N}$ & 0,047 & 0,465 & 0,079 & 0,551 \\
\hline & $\mathrm{Si}$ & 0,22 & 0,16 & 0,21 & 0,15 \\
\hline & $\mathbf{W}$ & 0,74 & 0,47 & 0,69 & 0,47 \\
\hline & Mo & 4,38 & 2,79 & 4,12 & 2,71 \\
\hline & $\mathrm{Cr}$ & 26,69 & 23,50 & 25,98 & 23,67 \\
\hline & Mn & 0,43 & 0,60 & 0,45 & 0,61 \\
\hline & $\mathrm{Fe}$ & 61,59 & 62,88 & 61,99 & 62,62 \\
\hline & $\mathrm{Ni}$ & 5,18 & 8,63 & 5,79 & 8,74 \\
\hline & $\mathrm{Cu}$ & 0,71 & 0,46 & 0,69 & 0,42 \\
\hline
\end{tabular}


Tabela 21: Fração volumétrica das fases presentes a 1100 e $1200^{\circ} \mathrm{C}$. Cálculos realizados com o programa Thermo-Calc ${ }^{\circledR}$.

\begin{tabular}{|c|c|c|c|c|}
\hline \multirow{2}{*}{$\begin{array}{c}\text { Designação } \\
\text { UNS }\end{array}$} & \multicolumn{4}{|c|}{ Fração Volumétrica [\%] } \\
\cline { 2 - 5 } & \multicolumn{2}{|c|}{$\mathbf{1 1 0 0}^{\circ} \mathbf{C}$} & \multicolumn{2}{c|}{$\mathbf{1 2 0 0}{ }^{\circ} \mathbf{C}$} \\
\hline & Ferrita & Austenita & Ferrita & Austenita \\
\hline S32304 & 52,7 & 47,3 & 71,0 & 29,0 \\
\hline S32205 & 43,9 & 56,1 & 58,8 & 41,2 \\
\hline S32550 & 65,4 & 34,5 & 74,1 & 25,9 \\
\hline S32750 & 45,4 & 54,6 & 57,1 & 42,9 \\
\hline S32760 & 53,0 & 47,0 & 65,0 & 35,0 \\
\hline
\end{tabular}

\subsubsection{Microestrutura}

A observação das diversas ligas no estado como-recebido no microscópio ótico revelou como todas elas apresentam a microestrutura típica dos AID laminados. Ela é formada por uma matriz de ferrita (fase escura) com ilhas alongadas de austenita (fase clara). Nas Figuras 44 a 48 são mostradas as microestruturas destes materiais em três diferentes direções ortogonais. Durante a observação destes materiais no $\mathrm{MO}$ a $1000 \mathrm{X}$ não foi evidente a presença de nenhum tipo de precipitado.

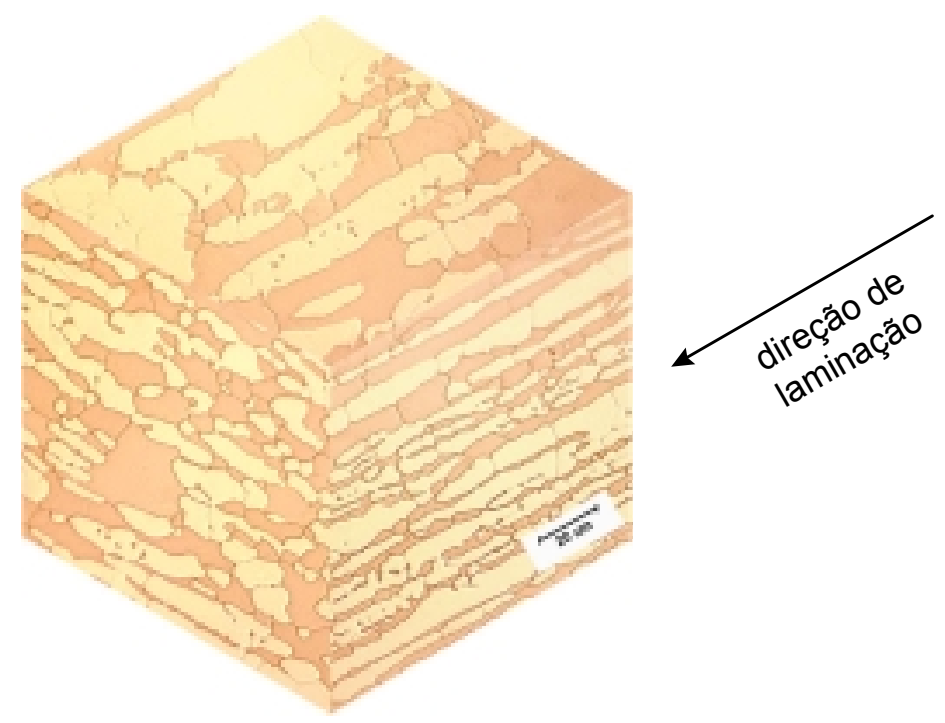

Figura 44: Microestrutura do AID UNS S32304, no estado como-recebido. Microscopia ótica, ataque eletrolítico com solução de $40 \%$ vol de $\mathrm{HNO}_{3}$. 200X. 


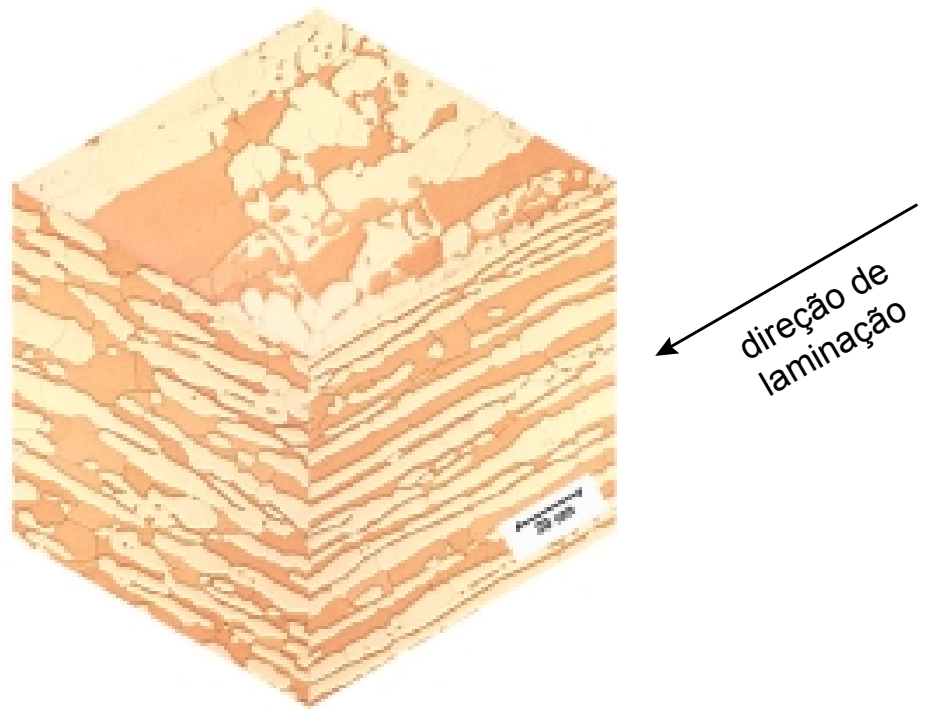

Figura 45: Microestrutura do AID UNS S32205, no estado como-recebido. Microscopia ótica, ataque eletrolítico com solução de $40 \%$ vol de $\mathrm{HNO}_{3}$. 200X.

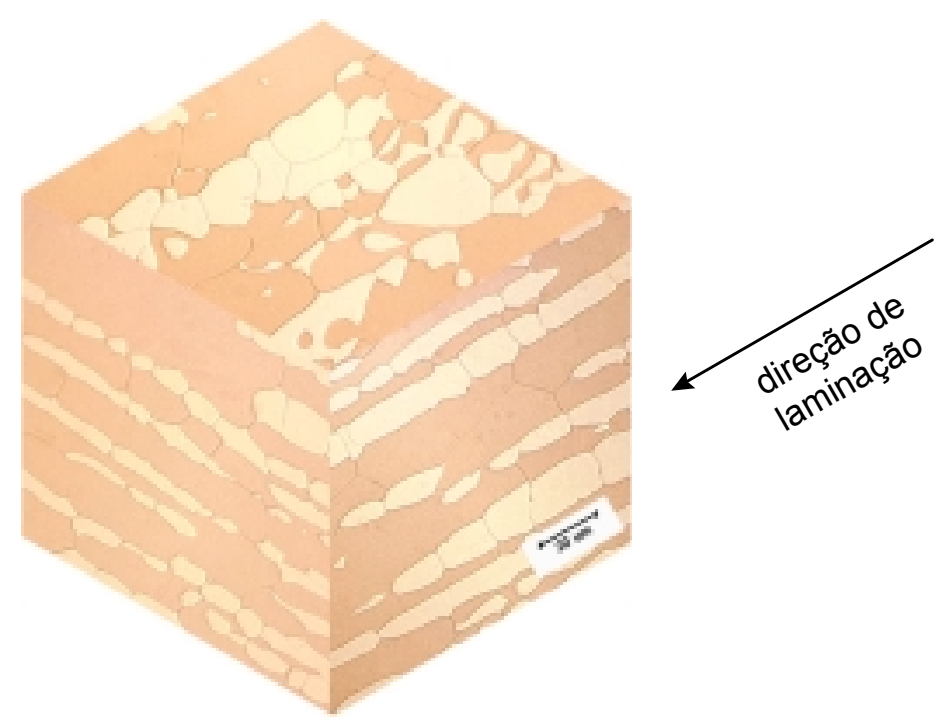

Figura 46: Microestrutura do AISD UNS S32550, no estado como-recebido. Microscopia ótica, ataque eletrolítico com solução de $40 \%$ vol de $\mathrm{HNO}_{3}$. 200X. 


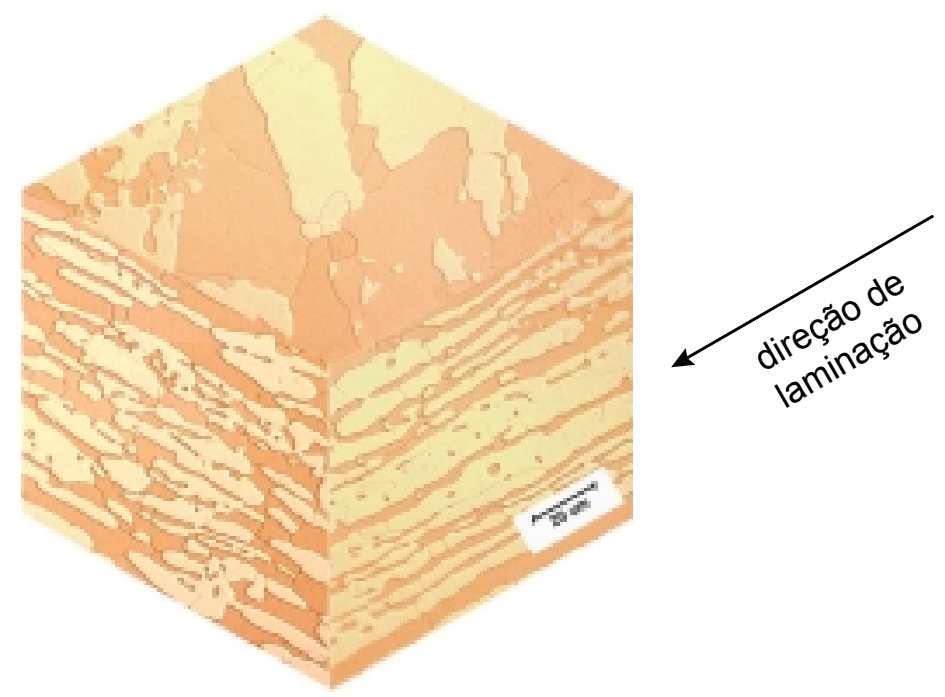

Figura 47: Microestrutura do AISD UNS S32750, no estado como-recebido. Microscopia ótica, ataque eletrolítico com solução de $40 \%$ vol de $\mathrm{HNO}_{3}$. 200X.

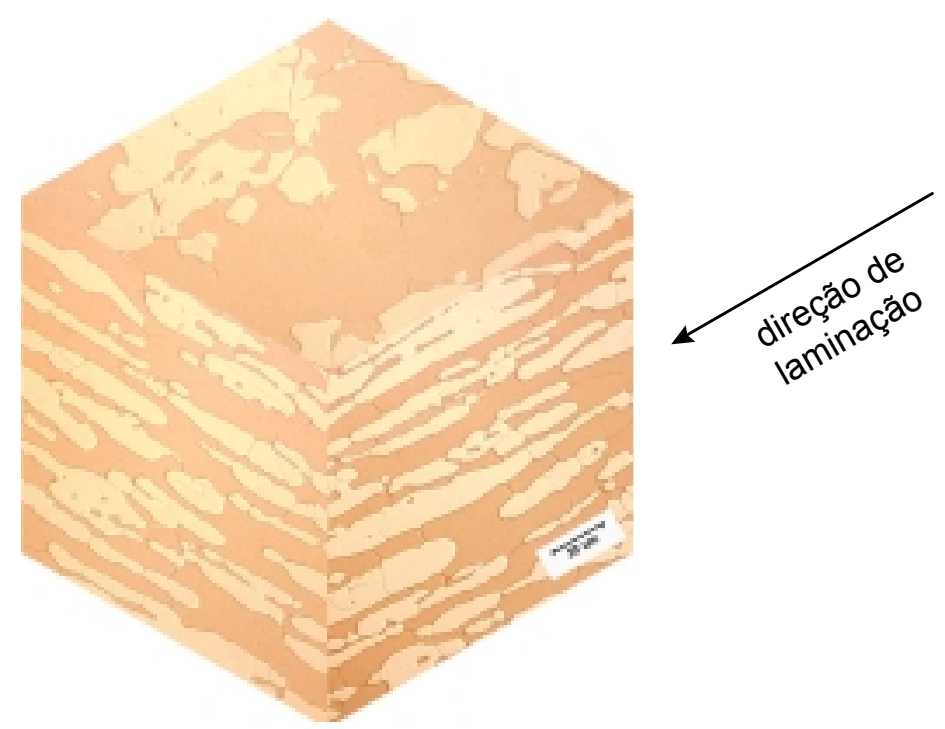

Figura 48: Microestrutura do AISD UNS S32760, no estado como-recebido. Microscopia ótica, ataque eletrolítico com solução de $40 \%$ vol de $\mathrm{HNO}_{3}$. 200X. 
Foi medida a fração volumétrica de ferrita mediante análise digital de imagens em seções normais à superfície da chapa, tanto no corte longitudinal TL (paralelo à direção de laminação) como no transversal TT (normal à direção de laminação). Os valores obtidos são apresentados na Tabela 22. Assim, junto com a observação no MO, confirmou-se que os materiais foram fornecidos no estado solubilizado. A comparação dos dados de fração volumétrica de austenita no estado como-recebido (Tabela 22) e no estado de equilíbrio a $1100{ }^{\circ} \mathrm{C}$ (Tabela 21), verifica-se que os valores medidos de austenita foram sempre maiores que os valores preditos no equilíbrio na temperatura de solubilização. Este fato é explicado pela ferrita que transforma para austenita durante o processo de resfriamento após a solubilização, pois como pode ser visto na Figura 43, para temperaturas menores que 1100 ${ }^{\circ} \mathrm{C}$, as ligas apresentam frações de $\gamma$ maiores na condição de equilíbrio.

Tabela 22: Fração volumétrica de ferrita no estado como-recebido.

\begin{tabular}{|c|c|c|}
\hline \multirow{2}{*}{$\begin{array}{c}\text { Designação } \\
\text { UNS }\end{array}$} & \multicolumn{2}{|c|}{ Fração de Austenita [\% } \\
\cline { 2 - 3 } vol]
\end{tabular}

A observação das Figuras 44 a 48 permite classificar os materiais no estado como-recebido segundo o seu tamanho de grão, que neste caso refere-se principalmente à espessura das lamelas, do maior para o menor:

UNS S32550 > UNS S32760 > UNS S32750 > UNS S32205 > UNS S32304

A diferença significativa de tamanho de grão do AISD UNS S32550 em relação aos outros materiais pode ser devida à temperatura de tratamento de solubilização notoriamente superior requerida para este material. Fato este suportado, pela sua maior temperatura de início de precipitação de $\mathrm{Cr}_{2} \mathrm{~N}$ (ver Tabela 17). Além disso, este material apresenta uma fração volumétrica de ferrita maior na faixa de temperatura na qual deve ser solubilizado. Assim, levando em conta o favorecimento da cinética de crescimento de grão pela estrutura ccc da ferrita, é de se esperar um tamanho de grão maior nesta liga. 
Aliás, deve-se ressaltar que, se as ligas fossem ordenadas segundo a temperatura de início de precipitação de $\mathrm{Cr}_{2} \mathrm{~N}$, do maior para o menor, a ordem é a mesma apresentada acima. Desta forma, caso os tempos dos tratamentos de solubilização e os processos de laminação utilizados fossem semelhantes, o tamanho de grão poderia vir a ser uma indicação da temperatura utilizada no tratamento de solubilização.

A composição química das fases presentes foi determinada mediante WDS no MEV. Na Tabela 23 são apresentados os resultados desta medidas junto com a composição química predita pelo programa Thermo-Calc ${ }^{\circledR}$ para uma temperatura de $1100{ }^{\circ} \mathrm{C}$. Da observação desta tabela verifica-se a partição dos elementos de liga entre a ferrita e a austenita, como reportado por CHARLES ${ }^{(21)}$. As composições químicas previstas pelo Thermo-Calc ${ }^{\circledR}$ são bastante similares às medidas, assim como os coeficientes de partição $(X \alpha / X \gamma)$. A única exceção é o $\mathrm{Cu}$, caso no qual os cálculos termodinâmicos predizem uma partição deste elemento entre a ferrita e austenita, que é inversa ao valor previamente reportado por outros

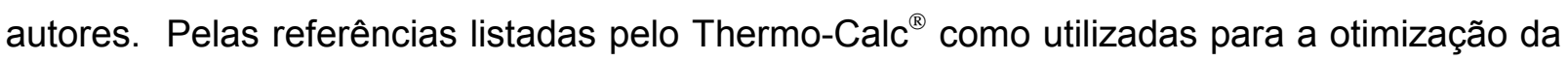
base de dados utilizada (TCFe), parece que existissem dados suficientes para conseguir modelar de modo adequado ligas contendo $\mathrm{Cu}$. Por isso, existem duas possíveis explicações para este resultado:

- Algum problema com o modelo utilizado para a fases em estudo com relação ao elemento $\mathrm{Cu}$ ou algum problema na interação dos diversos elementos utilizados nos cálculos.

- O fato dos corpos de prova estudados encontrarem-se fora do estado de equilíbrio. Esta possibilidade é bastante remota, pois o tempo de permanência na temperatura de solubilização destes materiais deve ser suficiente para chegar bastante perto das condições de equilíbrio. 
Tabela 23: Composição química das fases presentes no material no estado como-recebido. Medidas por WDS no MEV e calculadas com o programa Thermo-Calc ${ }^{\circledR}$.

\begin{tabular}{|c|c|c|c|c|c|c|c|}
\hline \multirow{3}{*}{$\begin{array}{c}\text { Designação } \\
\text { UNS }\end{array}$} & \multirow{3}{*}{ Elemento } & \multicolumn{6}{|c|}{ Composição Química [\%peso] } \\
\hline & & \multicolumn{3}{|c|}{ Equilíbrio $1100^{\circ} \mathrm{C}$ (Thermo-Calc $\left.{ }^{\circledR}\right)$} & \multicolumn{3}{|c|}{ Como-Recebido (Medido com WDS) } \\
\hline & & Ferrita & Austenita & $\mathrm{X} \alpha / \mathbf{X}_{\gamma}$ & Ferrita & Austenita & $\mathrm{X} \alpha / \mathrm{X}_{\gamma}$ \\
\hline \multirow{9}{*}{ S32304 } & C & 0,006 & 0,023 & 0,26 & - & - & - \\
\hline & $\mathbf{N}$ & 0,029 & 0,176 & 0,16 & $0,00 \pm 0,00$ & $0,33 \pm 0,04$ & 0,00 \\
\hline & $\mathrm{Si}$ & 0,44 & 0,37 & 1,19 & $0,58 \pm 0,02$ & $0,42 \pm 0,02$ & 1,38 \\
\hline & Mo & 0,37 & 0,23 & 1,61 & $0,35 \pm 0,03$ & $0,22 \pm 0,02$ & 1,59 \\
\hline & $\mathrm{Cr}$ & 25,14 & 19,98 & 1,26 & $25,49 \pm 0,09$ & $21,85 \pm 0,30$ & 1,17 \\
\hline & Mn & 1,34 & 1,74 & 0,77 & - & - & - \\
\hline & $\mathrm{Fe}$ & 68,71 & 71,10 & 0,97 & $69,56 \pm 0,11$ & $70,99 \pm 0,19$ & 0,98 \\
\hline & $\mathrm{Ni}$ & 3,63 & 6,06 & 0,60 & $3,78 \pm 0,09$ & $5,87 \pm 0,13$ & 0,64 \\
\hline & $\mathrm{Cu}$ & 0,34 & 0,33 & 1,03 & $0,24 \pm 0,08$ & $0,32 \pm 0,07$ & 0,75 \\
\hline \multirow{8}{*}{ S32205 } & C & 0,005 & 0,022 & 0,23 & - & - & - \\
\hline & $\mathbf{N}$ & 0,035 & 0,286 & 0,12 & $0,00+0,00$ & $0,39 \pm 0,06$ & 0,00 \\
\hline & Si & 0,50 & 0,41 & 1,22 & $0,40 \pm 0,02$ & $0,33 \pm 0,02$ & 1,21 \\
\hline & Mo & 3,87 & 2,46 & 1,57 & $3,67 \pm 0,09$ & $2,34 \pm 0,08$ & 1,57 \\
\hline & $\mathrm{Cr}$ & 24,16 & 20,22 & 1,19 & $24,88 \pm 0,26$ & $21,85 \pm 0,18$ & 1,14 \\
\hline & Mn & 1,24 & 1,69 & 0,73 & - & - & - \\
\hline & $\mathrm{Fe}$ & 66,01 & 67,90 & 0,97 & $66,64 \pm 0,31$ & $68,31 \pm 0,22$ & 0,98 \\
\hline & $\mathrm{Ni}$ & 4,17 & 7,01 & 0,59 & $4,42 \pm 0,16$ & $6,78 \pm 0,13$ & 0,65 \\
\hline \multirow{9}{*}{ S32550 } & C & 0,010 & 0,042 & 0,24 & - & - & - \\
\hline & $\mathbf{N}$ & 0,055 & 0,535 & 0,10 & $0,00 \pm 0,00$ & $0,53 \pm 0,05$ & 0,00 \\
\hline & Si & 0,31 & 0,23 & 1,35 & $0,31 \pm 0,01$ & $0,22 \pm 0,02$ & 1,41 \\
\hline & Mo & 4,42 & 2,81 & 1,57 & $4,36 \pm 0,14$ & $2,64 \pm 0,04$ & 1,65 \\
\hline & $\mathrm{Cr}$ & 25,97 & 23,81 & 1,09 & $28,41 \pm 0,12$ & $24,77 \pm 0,18$ & 1,15 \\
\hline & Mn & 7,86 & 1,10 & 7,15 & - & - & - \\
\hline & $\mathrm{Fe}$ & 61,73 & 62,52 & 0,99 & $60,69 \pm 0,22$ & $62,42 \pm 0,21$ & 0,97 \\
\hline & $\mathbf{N i}$ & 4,91 & 7,87 & 0,62 & $4,88 \pm 0,10$ & $7,54 \pm 0,13$ & 0,65 \\
\hline & $\mathrm{Cu}$ & 1,82 & 1,08 & 1,69 & $1,35 \pm 0,08$ & $1,88 \pm 0,10$ & 0,72 \\
\hline \multirow{9}{*}{ S32750 } & C & 0,006 & 0,024 & 0,25 & - & - & - \\
\hline & $\mathbf{N}$ & 0,046 & 0,498 & 0,09 & $0,00 \pm 0,00$ & $0,53 \pm 0,08$ & 0,00 \\
\hline & Si & 0,25 & 0,18 & 1,39 & $0,24 \pm 0,01$ & $0,19 \pm 0,02$ & 1,26 \\
\hline & Mo & 4,79 & 3,06 & 1,57 & $4,86 \pm 0,12$ & $2,97 \pm 0,07$ & 1,64 \\
\hline & $\mathrm{Cr}$ & 26,87 & 23,68 & 1,13 & $28,14 \pm 0,12$ & $25,01 \pm 0,34$ & 1,13 \\
\hline & Mn & 0,66 & 0,92 & 0,72 & - & - & - \\
\hline & $\mathrm{Fe}$ & 62,11 & 63,17 & 0,98 & $61,93 \pm 0,20$ & $63,65 \pm 0,33$ & 0,97 \\
\hline & $\mathbf{N i}$ & 5,00 & 8,30 & 0,60 & $4,83 \pm 0,10$ & $7,65 \pm 0,14$ & 0,63 \\
\hline & $\mathrm{Cu}$ & 0,25 & 0,16 & 1,56 & - & - & - \\
\hline \multirow{10}{*}{ S32760 } & C & 0,009 & 0,036 & 0,25 & - & - & - \\
\hline & $\mathbf{N}$ & 0,047 & 0,465 & 0,10 & $0,01 \pm 0,01$ & $0,51 \pm 0,08$ & 0,02 \\
\hline & Si & 0,22 & 0,16 & 1,38 & $0,21 \pm 0,01$ & $0,16 \pm 0,01$ & 1,31 \\
\hline & $\mathbf{W}$ & 0,74 & 0,47 & 1,57 & $0,73 \pm 0,06$ & $0,43 \pm 0,03$ & 1,70 \\
\hline & Mo & 4,38 & 2,79 & 1,57 & $4,40 \pm 0,05$ & $2,57 \pm 0,06$ & 1,71 \\
\hline & $\mathrm{Cr}$ & 26,69 & 23,50 & 1,14 & $28,20 \pm 0,22$ & $24,20 \pm 0,21$ & 1,17 \\
\hline & Mn & 0,43 & 0,60 & 0,72 & - & - & - \\
\hline & $\mathrm{Fe}$ & 61,59 & 62,88 & 0,98 & $60,77 \pm 0,22$ & $63,31 \pm 0,34$ & 0,96 \\
\hline & $\mathrm{Ni}$ & 5,18 & 8,63 & 0,60 & $5,19 \pm 0,10$ & $8,12 \pm 0,19$ & 0,64 \\
\hline & $\mathrm{Cu}$ & 0,71 & 0,46 & 1,54 & $0,50 \pm 0,08$ & $0,70 \pm 0,11$ & 0,71 \\
\hline
\end{tabular}


As diversas ligas no estado como-recebido também foram estudadas no MET. Como pode ser visto nas Figuras 49 a 51, estes materiais não apresentam fases intermetálicas na sua microestrutura.

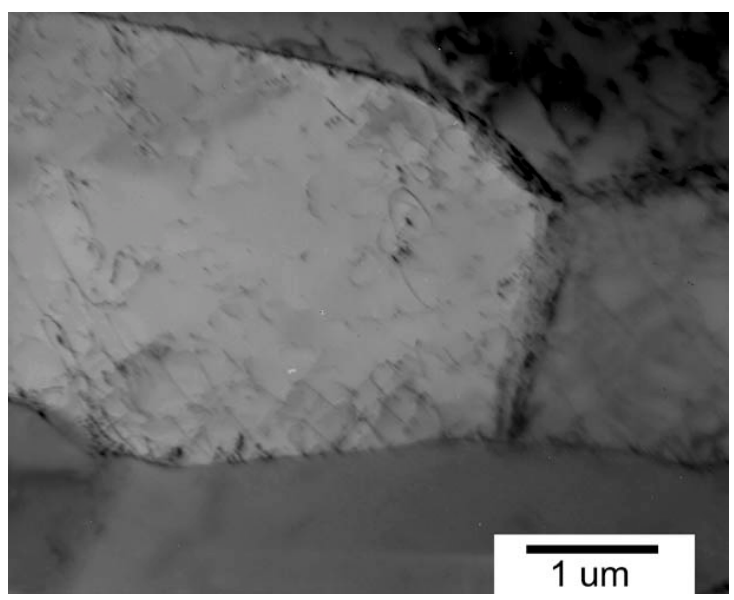

a. UNS S32304

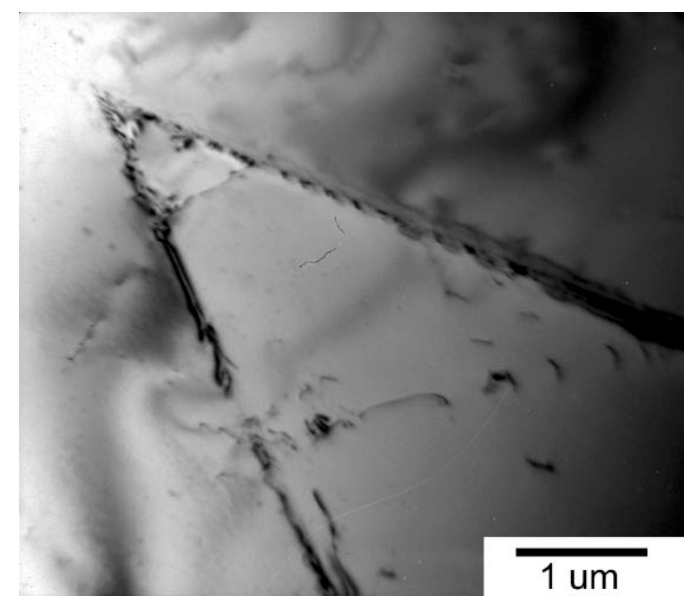

b. UNS S32205

Figura 49: Microestrutura dos AID (a) UNS S32304 e (b) UNS S32205, no estado como-recebido. Microscopia eletrônica de transmissão.

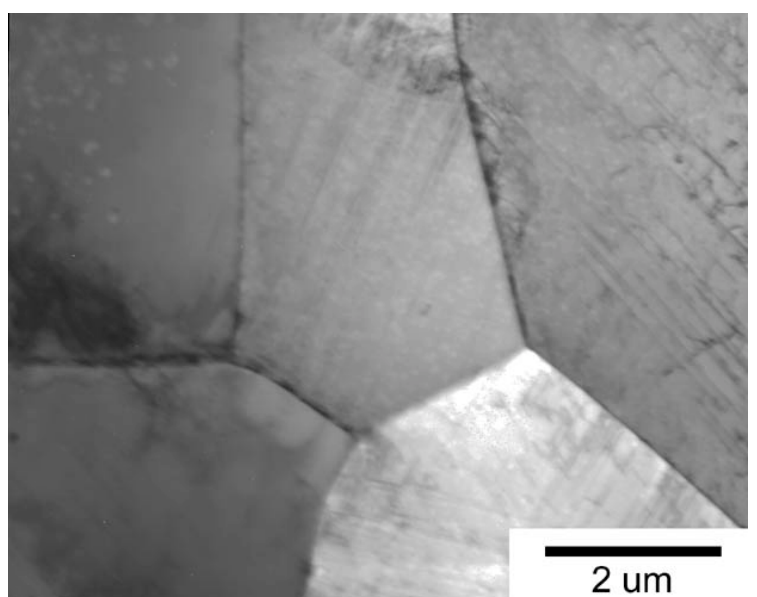

a. UNS S32550

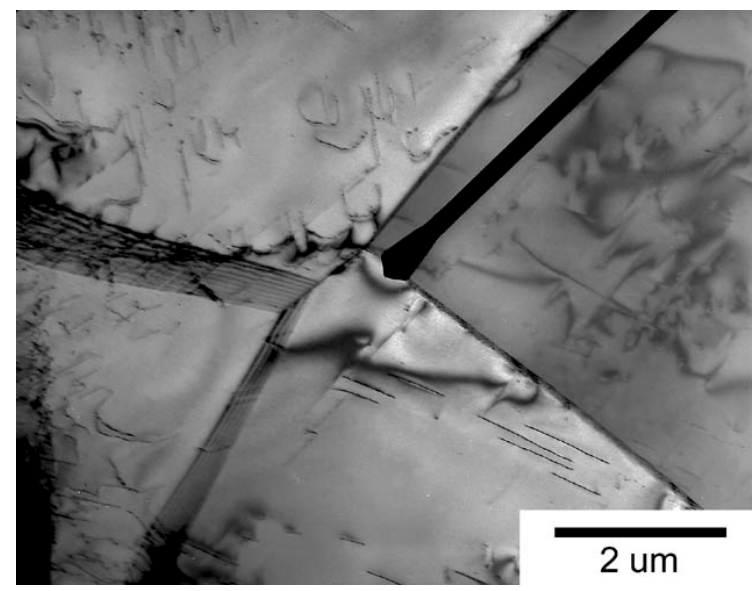

b. UNS S32760

Figura 50: Microestrutura dos AISD (a) UNS S32550 e (b) UNS S32760, no estado como-recebido. Microscopia eletrônica de transmissão. 


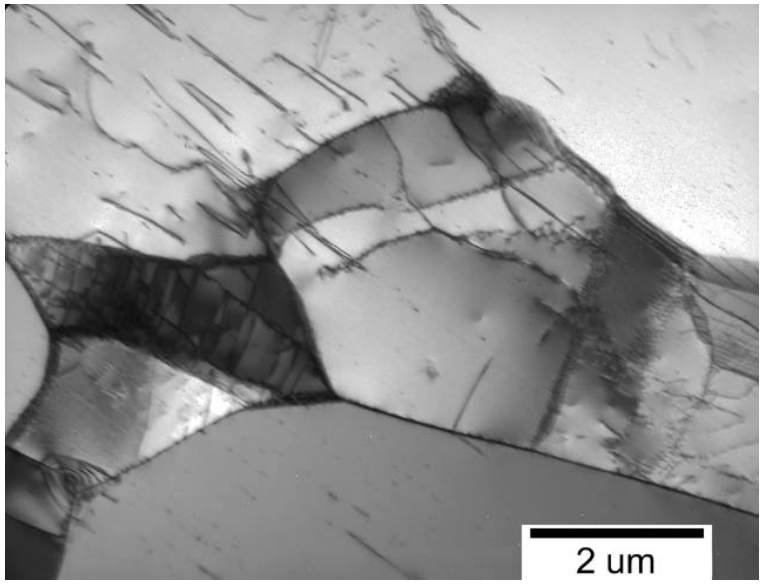

a. UNS S32750

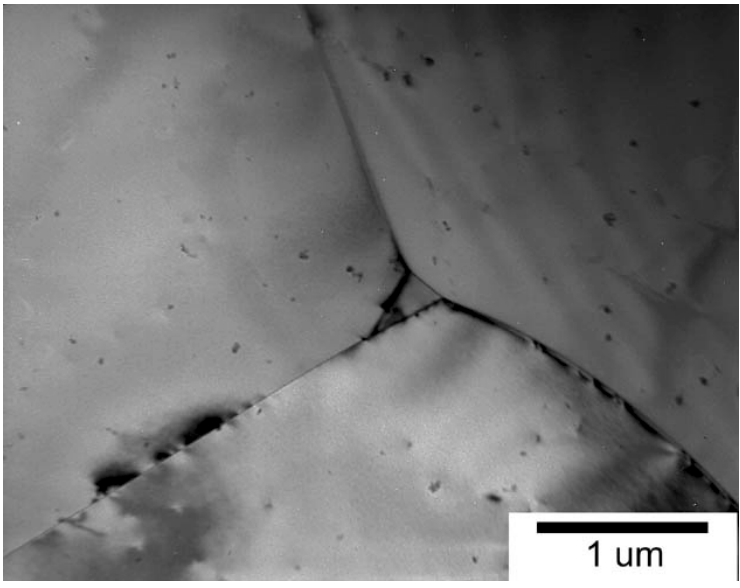

b. UNS S32750

Figura 51: Microestrutura do AISD UNS S32750, no estado como-recebido. Microscopia eletrônica de transmissão.

\subsubsection{Análise Térmica}

$\mathrm{Na}$ Tabela 24 são apresentados os resultados de análise térmica diferencial das diversas ligas. Foram determinadas a temperatura solidus (TS) e a temperatura liquidus (TL) durante $o$ aquecimento e o resfriamento. A diferença nas temperaturas medidas no aquecimento e no resfriamento são inerentes ao ensaio e ao método empregado para a determinação destas temperaturas, a partir dos dados aportados pelos ensaios. A extrapolação da temperatura de início da transformação (onset) vem a ser a temperatura solidus e o pico a temperatura liquidus, para o aquecimento. No caso do resfriamento ocorre o contrário.

Tabela 24: Resultados das análises térmicas diferenciais.

\begin{tabular}{|c|c|c|c|c|c|c|c|}
\hline \multirow{2}{*}{$\begin{array}{c}\text { Designação } \\
\text { UNS }\end{array}$} & \multicolumn{3}{|c|}{ Temperatura Solidus $\left[{ }^{\circ} \mathrm{C}\right]$} & \multicolumn{3}{|c|}{ Temperatura Liquidus $\left[{ }^{\circ} \mathrm{C}\right]$} & \multirow{2}{*}{$\begin{array}{l}\text { I.S. } \\
{\left[{ }^{\circ} \mathrm{C}\right]}\end{array}$} \\
\hline & $\uparrow$ & $\downarrow$ & Média & $\uparrow$ & $\downarrow$ & Média & \\
\hline S 32304 & 1465,6 & 1465,1 & $1465,4 \pm 0,5$ & 1486,9 & 1471,3 & $1479,1 \pm 15,3$ & 14 \\
\hline S 32205 & 1448,1 & 1450,0 & $1449,1 \pm 1,9$ & 1472,4 & 1455,6 & $1464,0 \pm 16,5$ & 15 \\
\hline S 32550 & 1446,8 & 1443,8 & $1445,3 \pm 2,9$ & 1469,9 & 1446,7 & $1458,3 \pm 22,7$ & 13 \\
\hline S 32750 & 1449,2 & 1454,1 & $1451,7 \pm 4,8$ & 1472,9 & 1462,7 & $1467,8 \pm 10,0$ & 16 \\
\hline S 32760 & 1447,5 & 1455,8 & $1451,7 \pm 8,1$ & 1472,2 & 1468,3 & $1470,3 \pm 3,8$ & 19 \\
\hline
\end{tabular}

Na Figura 52 é mostrado a título de exemplo o resultado do ensaio de análise térmica do AID UNS S32205. 


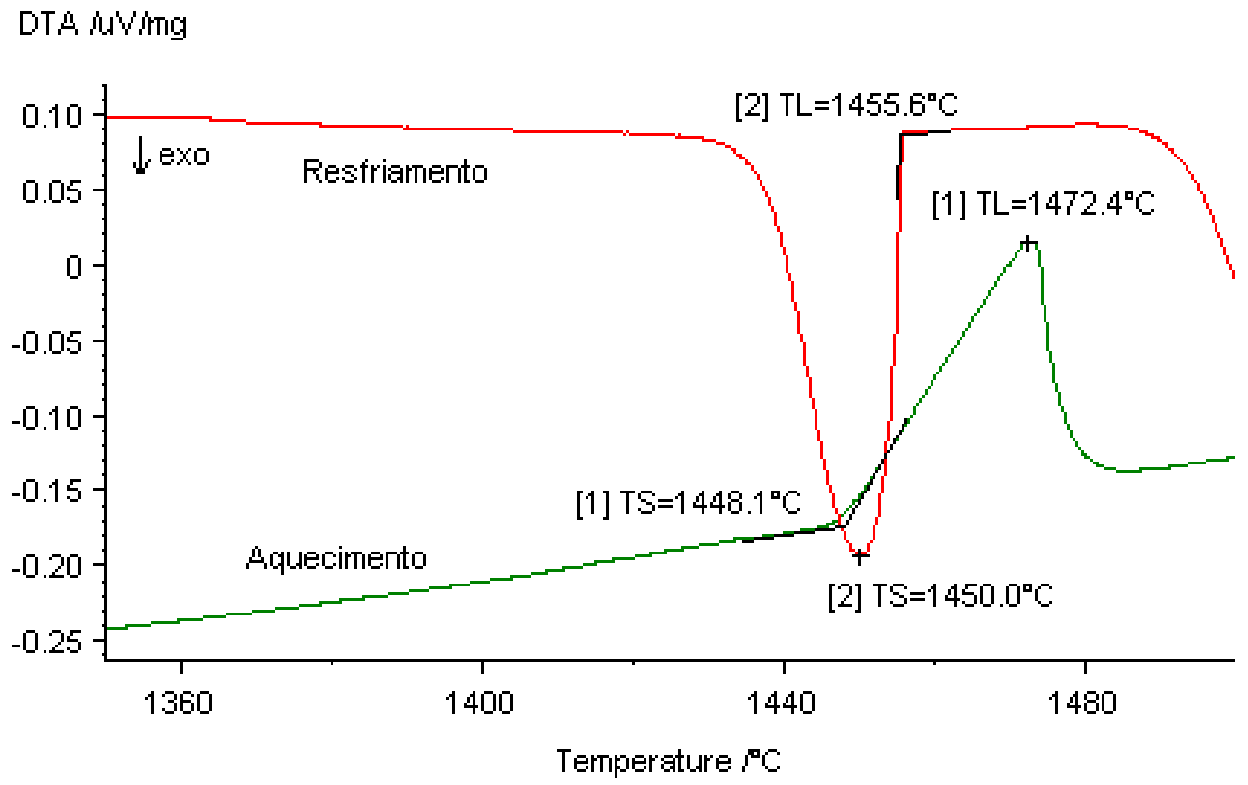

Figura 52: Análise térmica do AID UNS S32205.

\subsubsection{Temperatura de Resistência Nula (TRN)}

Foram realizados três testes de TRN para cada liga. Na Tabela 25 são apresentados os resultados obtidos. $\mathrm{Na}$ Tabela 26 são comparados os valores de temperatura solidus e liquidus determinados mediante análise térmica da Tabela 24 e os dados de TRN da Tabela 25. Desta comparação pode ser observada uma diferença média de 83 e $99{ }^{\circ} \mathrm{C}$ entre as temperaturas solidus e liquidus com relação à TRN, respectivamente. Estes resultados mostram que existe, para estas ligas, uma relação bastante bem definida entre a TRN e as temperaturas solidus e liquidus, sendo esta de 0,943 e 0,933, respectivamente. Portanto, conhecendo-se um destes valores o outro pode ser facilmente estimado a partir desta relação. No entanto, este comportamento não deve ser generalizado para outras ligas sem uma verificação experimental prévia.

Tabela 25: Temperatura de resistência nula (TRN) dos materiais no estado como-recebido.

\begin{tabular}{|c|c|c|c|c|}
\hline \multirow{2}{*}{$\begin{array}{c}\text { Designação } \\
\text { UNS }\end{array}$} & \multicolumn{4}{|c|}{ Temperatura de Resistência Nula $\left[{ }^{\circ} \mathrm{C}\right]$} \\
\cline { 2 - 5 } & Teste 1 & Teste 2 & Teste 3 & Média \\
\hline S 32304 & 1393,0 & 1383,8 & 1383,8 & $1387 \pm 6,1$ \\
\hline S 32205 & 1372,5 & 1369,8 & 1369,5 & $1371 \pm 2,0$ \\
\hline S 32550 & 1350,6 & 1353,0 & 1350,9 & $1352 \pm 1,6$ \\
\hline S 32750 & 1361,0 & 1365,8 & 1379,0 & $1369 \pm 10,6$ \\
\hline S 32760 & 1375,0 & 1365,8 & 1364,0 & $1368 \pm 6,7$ \\
\hline
\end{tabular}


Tabela 26: Comparação dos resultados de análise térmica e TRN.

\begin{tabular}{|c|c|c|c|c|c|c|c|}
\hline \multirow{2}{*}{$\begin{array}{c}\text { Designação } \\
\text { UNS }\end{array}$} & \multicolumn{2}{|c|}{ Análise Térmica } & \multirow{2}{*}{$\begin{array}{l}\text { TRN } \\
{\left[{ }^{\circ} \mathrm{C}\right]} \\
\end{array}$} & \multirow{2}{*}{$\begin{array}{c}\text { TS-TRN } \\
{\left[{ }^{\circ} \mathrm{C}\right]}\end{array}$} & \multirow{2}{*}{$\begin{array}{c}\text { TL-TRN } \\
{\left[{ }^{\circ} \mathrm{C}\right]} \\
\end{array}$} & \multirow{2}{*}{ TRN / TS } & \multirow{2}{*}{ TRN / TL } \\
\hline & TS $\left[{ }^{\circ} \mathrm{C}\right]$ & $\mathrm{TL}\left[{ }^{\circ} \mathrm{C}\right]$ & & & & & \\
\hline S 32304 & 1465 & 1479 & 1387 & 78 & 92 & 0,946 & 0,938 \\
\hline S 32205 & 1449 & 1464 & 1371 & 78 & 93 & 0,946 & 0,936 \\
\hline S 32550 & 1445 & 1458 & 1352 & 94 & 107 & 0,935 & 0,927 \\
\hline S 32750 & 1452 & 1468 & 1369 & 83 & 99 & 0,943 & 0,932 \\
\hline S 32760 & 1452 & 1470 & 1368 & 83 & 102 & 0,943 & 0,931 \\
\hline \multicolumn{4}{|c|}{ Média } & $83 \pm 5$ & $99 \pm 5$ & $0,943 \pm 0,004$ & $0,933 \pm 0,004$ \\
\hline
\end{tabular}

Na Figura 53 é mostrado, a título de exemplo, o resultado de um dos ensaios de TRN do AISD UNS S32550. Neste ensaio foi determinada uma TRN de $1353^{\circ} \mathrm{C}$.

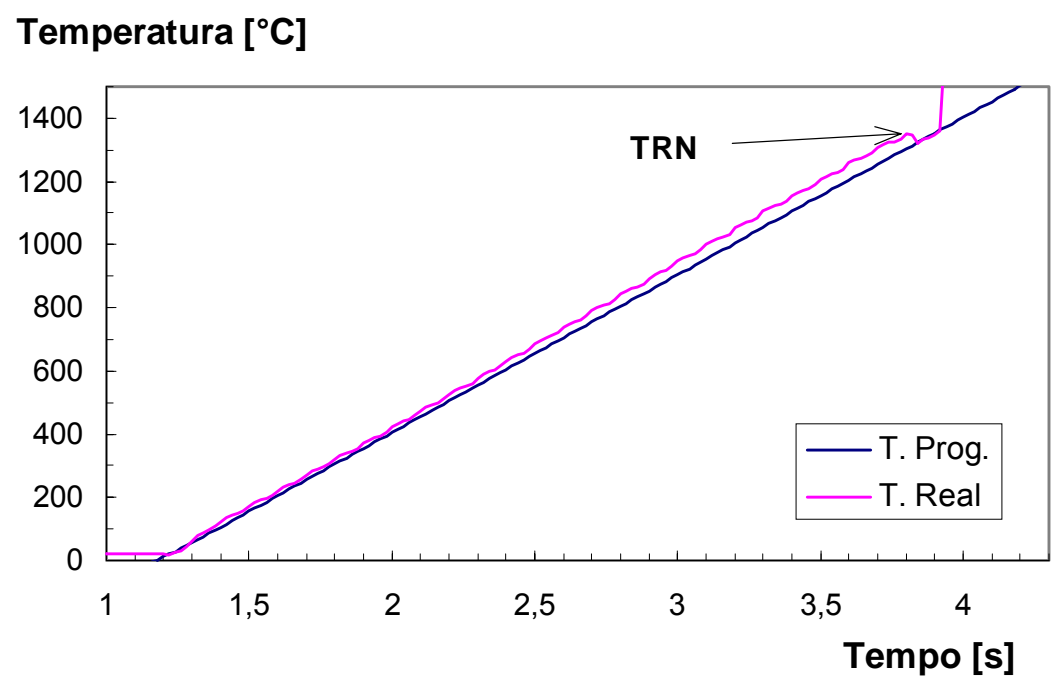

Figura 53: Registro do ensaio de TRN do AISD UNS S32550.

No caso da determinação da temperatura solidus mediante análise térmica, o aquecimento da amostra foi de $10{ }^{\circ} \mathrm{C} / \mathrm{min}$. Esta taxa permite uma homogeneização química da mostra à medida que esta vai sendo aquecida. Por isso, a temperatura de início de fusão medida corresponde à composição química média da liga. No caso do ensaio de TRN, a amostra é aquecida a uma taxa de $150{ }^{\circ} \mathrm{C} / \mathrm{s}$, até atingir a temperatura de liquação dos contornos dos grãos. Assim, a velocidade de aquecimento é tal que não há tempo para a homogeneização química da amostra, de modo que pode-se determinar a temperatura de fusão dos contornos 
dos grãos. Desta forma, devido à segregação para os contornos dos grãos e interfaces de elementos que abaixam a temperatura de fusão do material, a TRN vem a ser menor que a temperatura solidus da liga determinada mediante análise térmica.

Devido à grande influência que tem os teores de $\mathrm{S}$ e $\mathrm{P}$ no material na sua tendência ao trincamento a quente ${ }^{(127)}$, a relação TRN/TS deve ser fortemente influenciada pelo conteúdo deste elementos na liga. Neste trabalho, o teor destes dois elementos é aproximadamente o mesmo para todas as ligas, o que permite ter uma relação TRN/TS bastante similar entre estas.

Ao comparar a diferença TS-TRN, mostrada na Tabela 26, com as microestruturas dos materiais no estado como-recebido, pode-se verificar que existe uma relação direta entre as mesmas. Isto é, quanto maior o tamanho de grão (que no nosso caso vem a ser a espessura das lamelas), maior a diferença TS-TRN. Quanto maior o tamanho de grão de um material, menor é a quantidade de contornos (ou interfaces) por unidade de volume e desta forma, será maior a concentração dos elementos de liga segregados para estas regiões.

A diferença da relação TRN/TS da liga UNS S32550 com relação às outras é bastante notória. Acredita-se que esta diferença esteja relacionada com o maior tamanho de grão desta liga. Mas existe um outro fator importante para o qual deve ser chamada a atenção, sendo este o conteúdo de $\mathrm{Cu}$ da liga $(1,53 \%)$. É um fenômeno conhecido o trincamento intragranular a quente causado pela contaminação com cobre ${ }^{(128-129)}$. Desta forma, o Cu segregado para os contornos de grão, poderia ser o fator que está abaixando a TRN do AISD UNS S32550. Porém, a verificação desta hipótese está fora do alcance deste trabalho.

A comparação dos dados de temperaturas liquidus, solidus determinadas mediante análise térmica e calculadas com o Thermo-Calc ${ }^{\circledR}$, junto com os dados de TRN das Tabelas 24, 25 e 17, é apresentada na Tabela 27. Da análise desta tabela verifica-se que a temperatura solidus experimental foi em média $7 \%$ maior do que a calculada. Por outro lado, a temperatura liquidus experimental foi maior que a calculada apenas $2 \%$ em média. Deve-se notar que os dados aportados pelo programa Thermo-Calc ${ }^{\circledR}$ são mais confiáveis em temperaturas mais elevadas. Quanto a comparação da TRN com a temperatura solidus calculada, verificou-se que estas são praticamente iguais, com uma diferença de apenas $1 \%$ em média.

Tabela 27: Comparação das temperaturas liquidus e solidus calculadas e medidas com a TRN. 


\begin{tabular}{|c|c|c|c|c|c|c|c|c|c|}
\hline \multirow{2}{*}{$\begin{array}{c}\text { Designação } \\
\text { UNS }\end{array}$} & \multicolumn{2}{|c|}{$\begin{array}{c}\text { Análise Térmica } \\
{\left[{ }^{\circ} \mathrm{C}\right]}\end{array}$} & \multicolumn{2}{|c|}{$\begin{array}{c}\text { Thermo-Calc }^{(1)} \\
{\left[{ }^{\circ} \mathrm{C}\right]}\end{array}$} & \multirow{2}{*}{$\begin{array}{l}\text { TRN } \\
{\left[{ }^{\circ} \mathrm{C}\right]}\end{array}$} & \multirow[t]{2}{*}{ TSe / TSc } & \multirow[t]{2}{*}{ TLe / TLc } & \multirow[t]{2}{*}{ TRN / TSc } & \multirow[t]{2}{*}{ TRN / TLc } \\
\hline & TSe & TLe & TSc & TLc & & & & & \\
\hline S 32304 & 1465 & 1479 & 1416 & 1466 & 1387 & 1,03 & 1,01 & 0,98 & 0,95 \\
\hline S 32205 & 1449 & 1464 & 1369 & 1447 & 1371 & 1,06 & 1,01 & 1,00 & 0,95 \\
\hline S 32550 & 1445 & 1458 & 1315 & 1432 & 1352 & 1,10 & 1,02 & 1,03 & 0,94 \\
\hline S 32750 & 1452 & 1468 & 1344 & 1437 & 1369 & 1,08 & 1,02 & 1,02 & 0,95 \\
\hline S 32760 & 1452 & 1470 & 1335 & 1439 & 1368 & 1,09 & 1,02 & 1,02 & 0,95 \\
\hline \multicolumn{6}{|c|}{ Média } & $1,07 \pm 0,02$ & $1,02 \pm 0,01$ & $1,01 \pm 0,02$ & $0,95 \pm 0,003$ \\
\hline \multicolumn{10}{|c|}{$\begin{array}{ll}\text { Nota: } & \text { TS: Temperatura solidus; } \\
& \text { TL: Temperatura liquidus; } \\
& \text { e: } \quad \text { Determinado experimentalmente - Análise Térmica } \\
& \text { c: Determinado mediante cálculos termodinâmicos - Thermo-Calc }{ }^{\circledR} . \\
& \text { TRN: Temperatura de resistência nula. }\end{array}$} \\
\hline
\end{tabular}

\subsubsection{Tratamentos Térmicos}

Foram realizados dois tipos de tratamentos térmicos (TT). O primeiro deles teve como objetivo determinar as condições de tempo e temperatura necessárias para ferritizar as cinco ligas, de maneira a obter microestruturas similares em todos os materiais. Deve-se mencionar que estes TTs são chamados de ferritização, mas como foi exposto no item anterior, em quatro das ligas não é possível dissolver totalmente a austenita sem entrar no campo líquido. Posteriormente, foram realizados os TTs chamados de ferritização, seguidos de tratamentos isotérmicos de envelhecimento. O objetivo deste segundo tipo de TTs foi estudar a precipitação de $\gamma_{2}$ e fases intermetálicas em condições isotérmicas. Desta forma, a partir destes resultados, obtidos em condições simplificadas, será possível interpretar com maior facilidade os fenômenos acontecidos na ZACTE de soldas multipasse.

\subsubsection{Tratamentos Térmicos de Ferritização}

É importante mencionar que os cálculos termodinâmicos para a determinação dos diagramas de fase foram realizados após os tratamentos térmicos, pois foram os resultados obtidos com estes TTs os que motivaram a utilização do recurso do Thermo-Calc ${ }^{\circledR}$ para tentar esclarecer os fenômenos envolvidos.

\subsection{Seleção do Tratamento Térmico}

Após a realização dos TT de ferritização descritos no item 5.7 , os corpos de prova foram preparados para observação no MO. Utilizou-se metalografia quantitativa para determinar a fração volumétrica de $\gamma$ e o tamanho de grão ferrítico. Na Tabela 28 é apresentado o resultado destas medidas. Como pode ser visto nesta tabela, com as limitações experimentais do equipamento Gleeble ${ }^{\circledR}$, não foi possível obter a mesma fração de $\gamma$ e tamanho de grão ferrítico nos cinco materiais. Isto se deve principalmente às diferenças na composição química das ligas, da qual depende o diagrama de fases do material e a própria cinética de precipitação da $\gamma$. 
Na Figura 54 é mostrado o registro de temperatura durante o TT do AISD UNS S32750 a $1350{ }^{\circ} \mathrm{C}$ por $10 \mathrm{~s}$.

\section{Temperatura $\left[{ }^{\circ} \mathrm{C}\right]$}

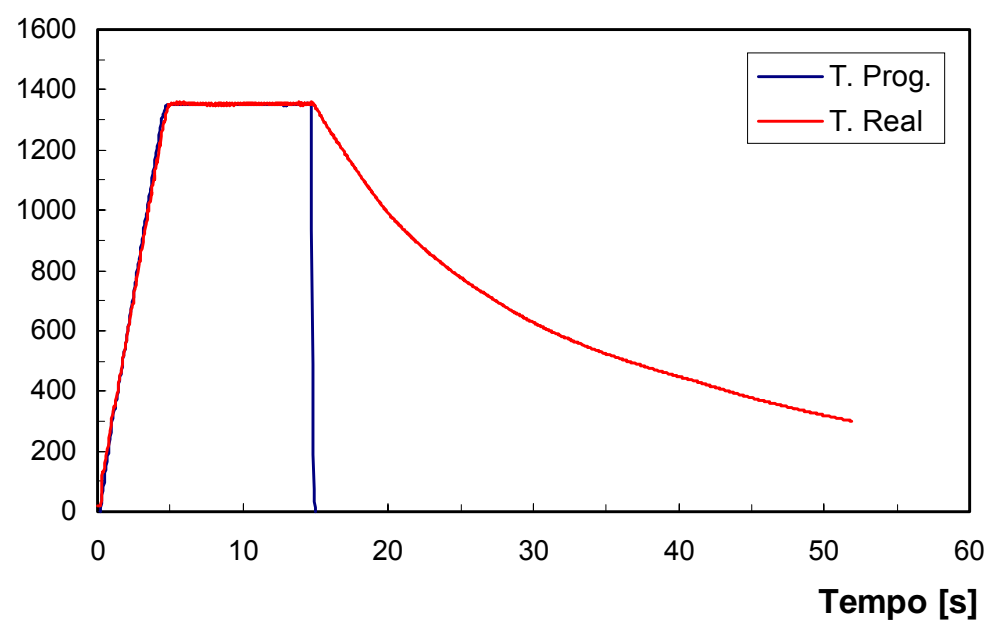

Figura 54: Tratamento térmico de ferritização do AISD UNS S32750, 10 s a $1350{ }^{\circ} \mathrm{C}$.

Tabela 28: Tamanho de grão e fração de austenita dos C/P submetidos a tratamentos térmicos de ferritização.

\begin{tabular}{|c|c|c|c|c|c|c|}
\hline \multirow{2}{*}{$\begin{array}{c}\text { Designação } \\
\text { UNS }\end{array}$} & \multirow{2}{*}{ TRN } & \multicolumn{5}{|c|}{ Tratamento Térmico } \\
\hline & & \begin{tabular}{|c} 
Temperatura \\
{$\left[{ }^{\circ} \mathrm{C}\right]$}
\end{tabular} & $\begin{array}{c}\text { Tempo } \\
\text { [s] }\end{array}$ & $\begin{array}{c}\text { Tamanho } \\
\text { grão } \alpha[\mu \mathrm{m}]\end{array}$ & $\begin{array}{c}\text { Fração } \gamma \\
{[\%]}\end{array}$ & $\begin{array}{c}\text { Resfriamento } \\
{\left[{ }^{\circ} \mathrm{C} / \mathrm{s}\right]}\end{array}$ \\
\hline \multirow{4}{*}{ S32304 } & \multirow{4}{*}{$1387 \pm 6$} & 1350 & $5 \mathrm{~s}$ & $238 \pm 23$ & $16 \pm 2$ & 55 \\
\hline & & 1356 & $5 \mathrm{~s}$ & $244 \pm 17$ & $12 \pm 1$ & 55 \\
\hline & & 1375 & $5 \mathrm{~s}$ & $266 \pm 23$ & $19 \pm 2$ & 80 \\
\hline & & 1355 & $10 \mathrm{~s}$ & $296 \pm 30$ & $14 \pm 2$ & 55 \\
\hline \multirow{4}{*}{ S32205 } & \multirow{4}{*}{$1371 \pm 2$} & 1348 & $5 \mathrm{~s}$ & $193 \pm 11$ & $26 \pm 3$ & 55 \\
\hline & & 1375 & $5 \mathrm{~s}$ & $230 \pm 15$ & $33 \pm 4$ & 80 \\
\hline & & 1384 & $5 \mathrm{~s}$ & $175 \pm 13$ & $37 \pm 3$ & 55 \\
\hline & & 1355 & $10 \mathrm{~s}$ & $220 \pm 18$ & $26 \pm 2$ & 55 \\
\hline \multirow{5}{*}{ S32550 } & \multirow{5}{*}{$1352 \pm 2$} & 1350 & $5 \mathrm{~s}$ & $167 \pm 9$ & $27 \pm 2$ & 55 \\
\hline & & 1366 & $5 \mathrm{~s}$ & $134 \pm 6$ & $22 \pm 2$ & 55 \\
\hline & & 1374 & $5 \mathrm{~s}$ & $135 \pm 15$ & $33 \pm 3$ & 80 \\
\hline & & 1375 & $5 \mathrm{~s}$ & $128 \pm 7$ & $30 \pm 4$ & 55 \\
\hline & & 1364 & $10 \mathrm{~s}$ & $163 \pm 11$ & $21 \pm 3$ & 55 \\
\hline \multirow{4}{*}{ S32750 } & \multirow{4}{*}{$1369 \pm 11$} & 1363 & $5 \mathrm{~s}$ & $142 \pm 7$ & $28 \pm 3$ & 55 \\
\hline & & 1372 & $5 \mathrm{~s}$ & $140 \pm 26$ & $42 \pm 2$ & 55 \\
\hline & & 1376 & $5 \mathrm{~s}$ & $125 \pm 9$ & $38 \pm 3$ & 80 \\
\hline & & 1351 & $10 \mathrm{~s}$ & $145 \pm 7$ & $33 \pm 3$ & 55 \\
\hline \multirow{4}{*}{ S32760 } & \multirow{4}{*}{$1368 \pm 7$} & 1350 & $5 \mathrm{~s}$ & $173 \pm 20$ & $33 \pm 3$ & 55 \\
\hline & & 1367 & $5 \mathrm{~s}$ & $120 \pm 6$ & $23 \pm 2$ & 55 \\
\hline & & 1380 & $5 \mathrm{~s}$ & $126 \pm 12$ & $27 \pm 2$ & 80 \\
\hline & & 1356 & $10 \mathrm{~s}$ & $224 \pm 15$ & $24 \pm 2$ & 55 \\
\hline
\end{tabular}


Com relação ao tamanho de grão ferrítico, em termos gerais pode-se dizer que o aumento do tempo de permanência no patamar de 5 para 10 segundos, levou a um ligeiro aumento no tamanho de grão, como pode ser observado na Figura 55.

Os AID UNS S32304 e UNS S32205 apresentaram comportamento similar entre se, com os maiores tamanhos de grão. Fato que é explicado pelos diagramas de fase destes materiais. No caso do AID UNS S32304, os TT foram realizados dentro do campo ferrítico (sólido), pelo qual é de se esperar um significativo crescimento de grão. No caso do AID UNS S32205, os TT realizados em temperaturas mais baixas (1348 e $\left.1355{ }^{\circ} \mathrm{C}\right)$ permaneceram dentro do campo ferrita+austenita, com frações de austenita bastante baixas, ao redor de $10 \%$, o que permitiu um considerável crescimento de grão. Já com o aumento de temperatura para 1384 ${ }^{\circ} \mathrm{C}$, a quantidade de líquido tornou-se importante (aproximadamente $10 \%$ vol segundo o Thermo-Calc ${ }^{\circledR}$ ). Desta forma, o crescimento de grão foi bastante limitado, explicando a abrupta queda no tamanho de grão final.

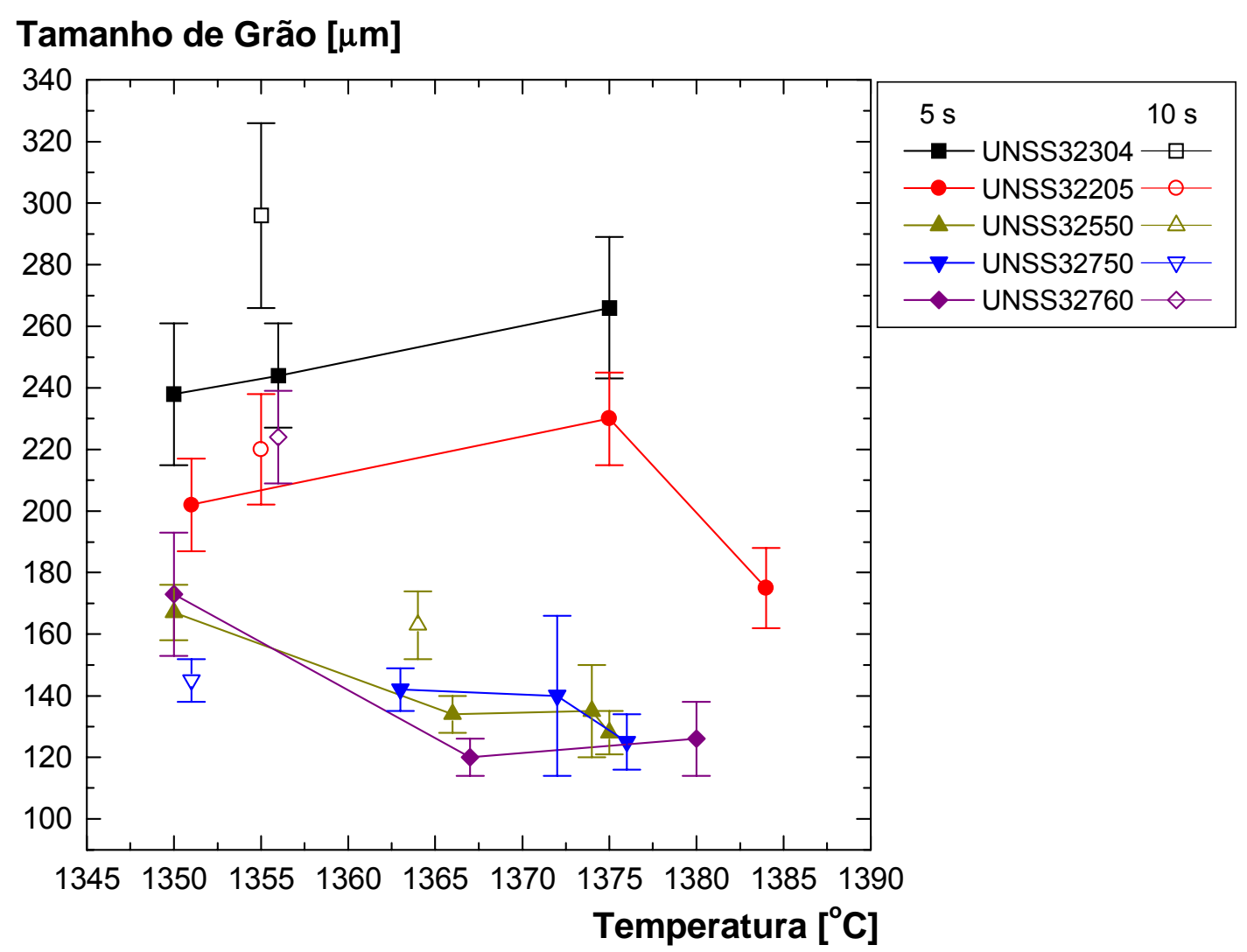

Figura 55: Tamanho de grão ferrítico dos C/P submetidos a TT de ferritização. 
Os AISD UNS S32550, S32750 e S32760 tiveram também um comportamento similar entre si, com tamanhos de grão menores e uma clara tendência à sua diminuição com o aumento da temperatura. Levando-se em conta os cálculos realizados com o programa Thermo-Calc ${ }^{\circledR}$ e mostrados na Tabela 29, na faixa de temperatura utilizada, determinou-se a quantidade de líquido, que dificultou o crescimento de grão ferrítico. Este fato é reforçado, por duas observações. Primeiro, a presença esporádica de microtrincas nas microestruturas, as quais na verdade poderiam ser microrechupes, constatando a presença de fase líquida. Segundo, foi também observado que a região com maior tamanho de grão não se encontrava no centro dos $\mathrm{C} / \mathrm{P}$, onde se atinge a maior temperatura, mas sim em regiões um pouco deslocadas do centro. Desta forma, nestas regiões onde não foi presumivelmente ultrapassada a temperatura solidus, o crescimento de grão ferrítico foi ligeiramente superior. Por outro lado, este comportamento também pode estar influenciado pelas taxas de resfriamento utilizadas.

$\mathrm{Na}$ Figura 56 é apresentada a variação da fração volumétrica de austenita com a temperatura de TT e com o tempo de permanência no patamar. Não se observou nesta figura uma tendência clara no comportamento dos materiais.

Nas Figuras 57 a 61 são mostradas as microestruturas dos materiais tratados termicamente a $1350{ }^{\circ} \mathrm{C}$ por 5 e 10 segundos e a $1380{ }^{\circ} \mathrm{C}$ durante 5 segundos, em todos os casos seguidos de resfriamento rápido (aproximadamente $75^{\circ} \mathrm{C} / \mathrm{s}$ ).

Tabela 29: Fração volumétrica das fases presentes a 1350 e $1380^{\circ} \mathrm{C}$. Cálculos realizados com o programa Thermo-Calc ${ }^{\circledR}$.

\begin{tabular}{|c|c|c|c|c|c|}
\hline \multirow{3}{*}{$\begin{array}{c}\text { Designação } \\
\text { UNS }\end{array}$} & \multicolumn{5}{|c|}{ Fração Volumétrica das Fases [\%] } \\
\hline & \multicolumn{3}{|c|}{$1350^{\circ} \mathrm{C}$} & \multicolumn{2}{|c|}{$1380^{\circ} \mathrm{C}$} \\
\hline & Líquido & Ferrita & Austenita & Líquido & Ferrita \\
\hline S32304 & - & 100 & - & - & 100 \\
\hline S32205 & - & 88 & 12 & 8 & 92 \\
\hline S32550 & 14 & 86 & - & 28 & 72 \\
\hline S32750 & 8 & 81 & 11 & 26 & 74 \\
\hline S 32760 & 12 & 88 & - & 23 & 77 \\
\hline
\end{tabular}

Mediante a observação no MO dos corpos ferritizados e do estudo do efeito das variáveis do tratamento térmico na fração final de $\gamma$, no tamanho de grão e na formação de microtrincas, foram determinadas as melhores condições para os tratamentos térmicos de ferritização das diversas ligas. $\mathrm{Na}$ Tabela 30 são apresentadas as condições de TT selecionadas para conferir microestruturas similares às diversas ligas. É importante notar que a taxa de resfriamento à qual se faz referência nesta tabela é a taxa média de resfriamento entre 1350 e $1000{ }^{\circ} \mathrm{C}$. Em todos os tratamentos térmicos foi utilizada uma taxa de aquecimento de 350 ${ }^{\circ} \mathrm{C} / \mathrm{s}$. 


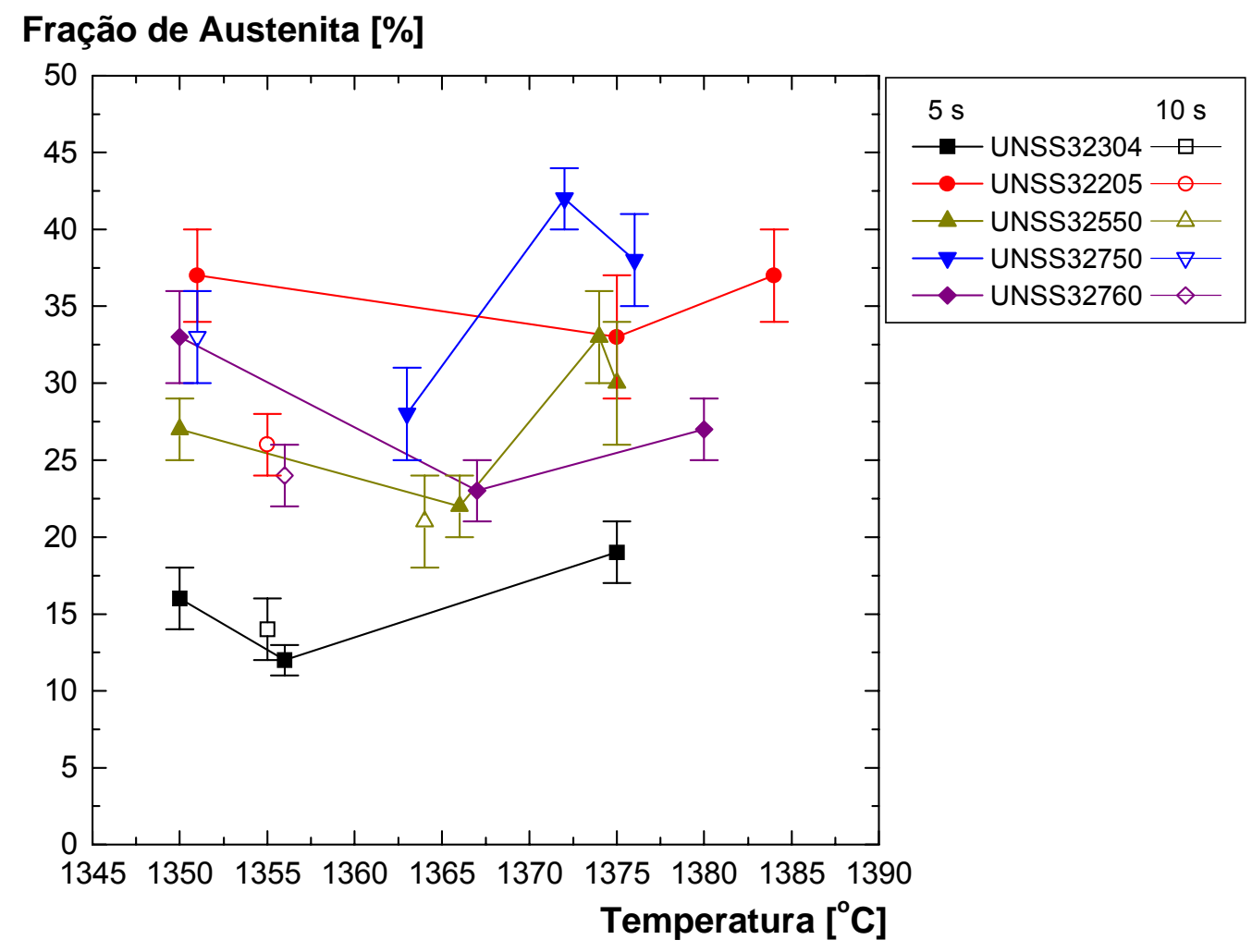

Figura 56: Fração volumétrica de austenita dos C/P submetidos a TT de ferritização.

Tabela 30: Tratamentos térmicos de ferritização selecionados para serem realizados no equipamento Gleeble $^{\circledR}$.

\begin{tabular}{|c|c|c|c|}
\hline $\begin{array}{c}\text { Designação } \\
\text { UNS }\end{array}$ & $\begin{array}{c}\text { Temperatura } \\
{\left[{ }^{\circ} \mathbf{C}\right]}\end{array}$ & $\begin{array}{c}\text { Tempo } \\
{[\mathbf{s}]}\end{array}$ & $\begin{array}{c}\text { Taxa de Resfriamento } \\
{\left[{ }^{\circ} \mathbf{C} / \mathbf{s}\right]}\end{array}$ \\
\hline S32304 & & & \\
S32205 & 1350 & 5 & 75 \\
S32550 & & 10 & 75 \\
\hline S32760 & 1350 & 10 & \\
\hline S32750 & & & \\
\hline
\end{tabular}

Vale a pena ressaltar que as microestruturas obtidas são similares, mas não iguais, devido às grandes diferenças de composição química e às limitações experimentais. Entre estas limitações destaca-se a máxima velocidade de resfriamento possível e reprodutível no equipamento Gleeble ${ }^{\circledR}$. 


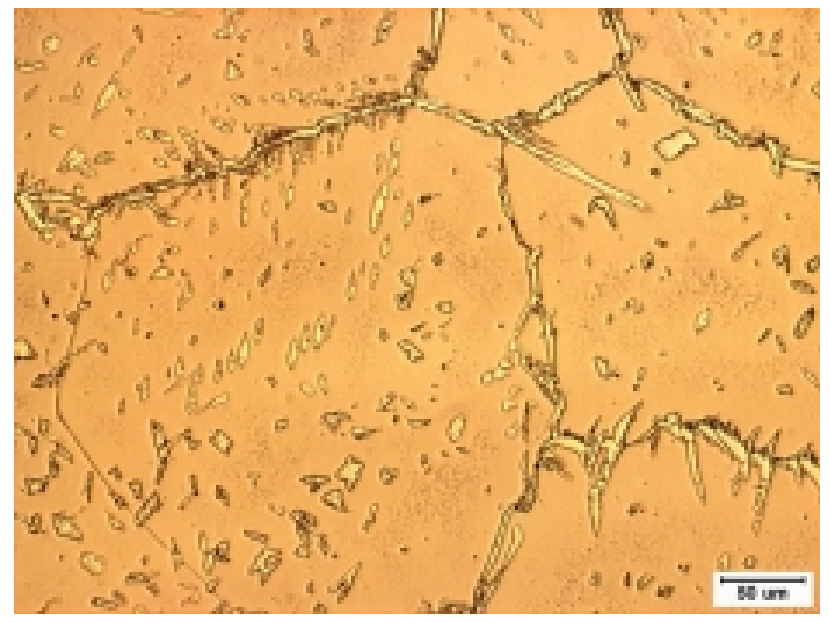

$1350{ }^{\circ} \mathrm{C}$ por $5 \mathrm{~s}$

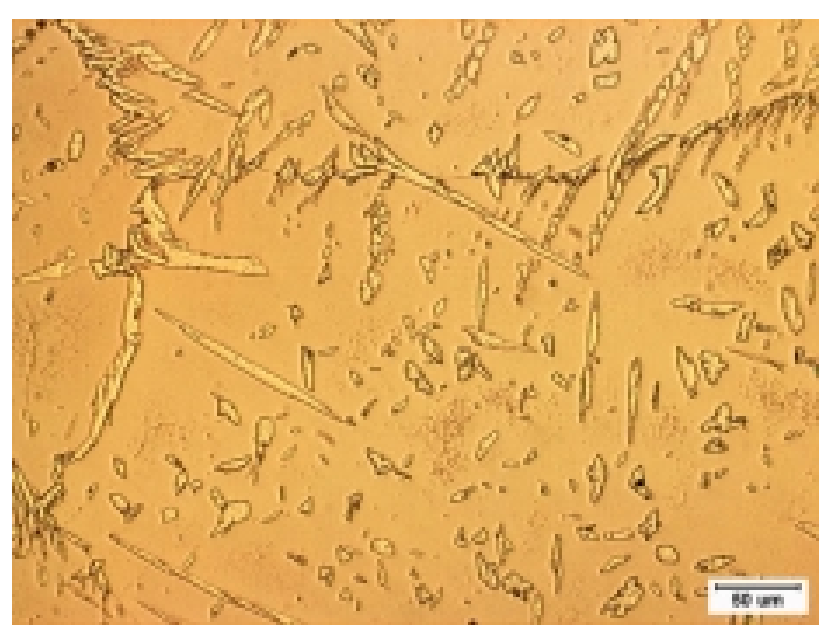

$1350^{\circ} \mathrm{C}$ por $10 \mathrm{~s}$

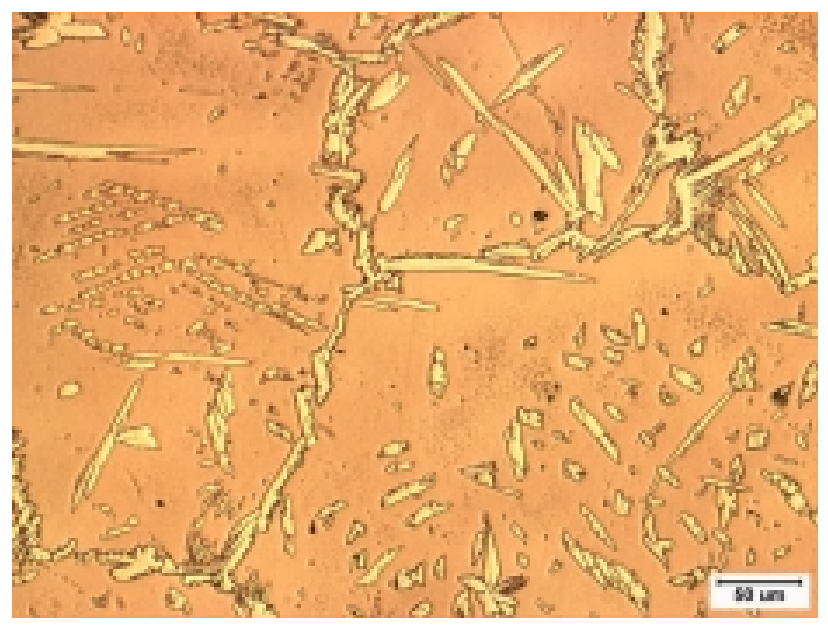

$1380^{\circ} \mathrm{C}$ por $5 \mathrm{~s}$

Figura 57: AID UNS S32304 ferritizado. 


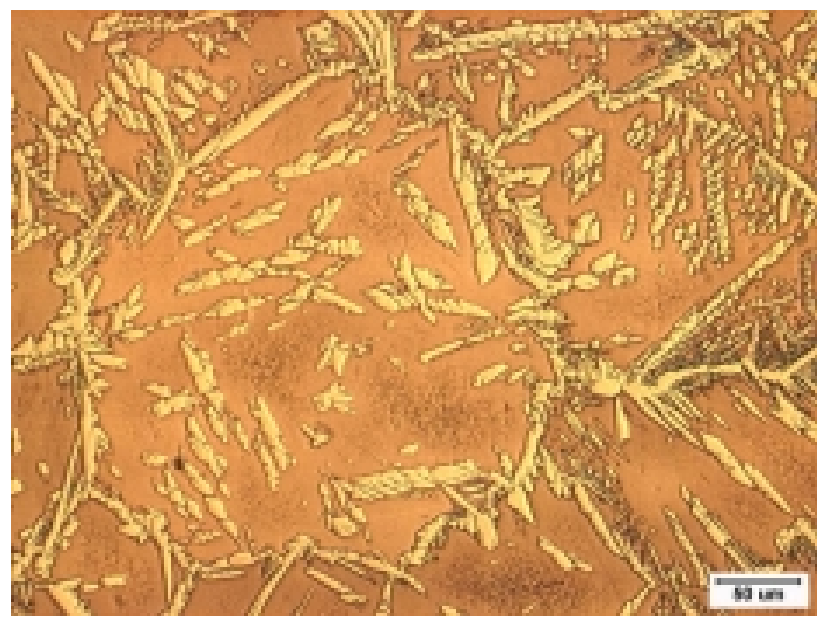

$1350{ }^{\circ} \mathrm{C}$ por $5 \mathrm{~s}$

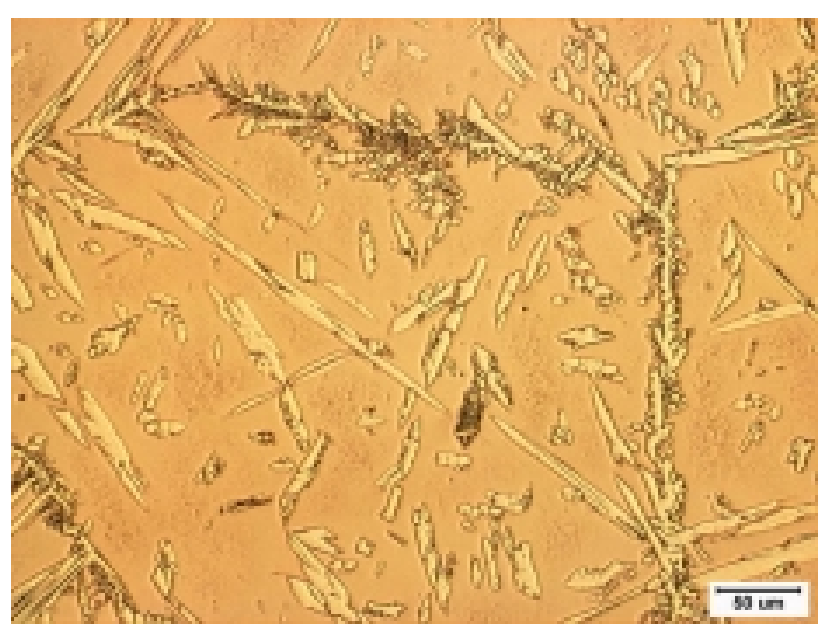

$1350^{\circ} \mathrm{C}$ por $10 \mathrm{~s}$

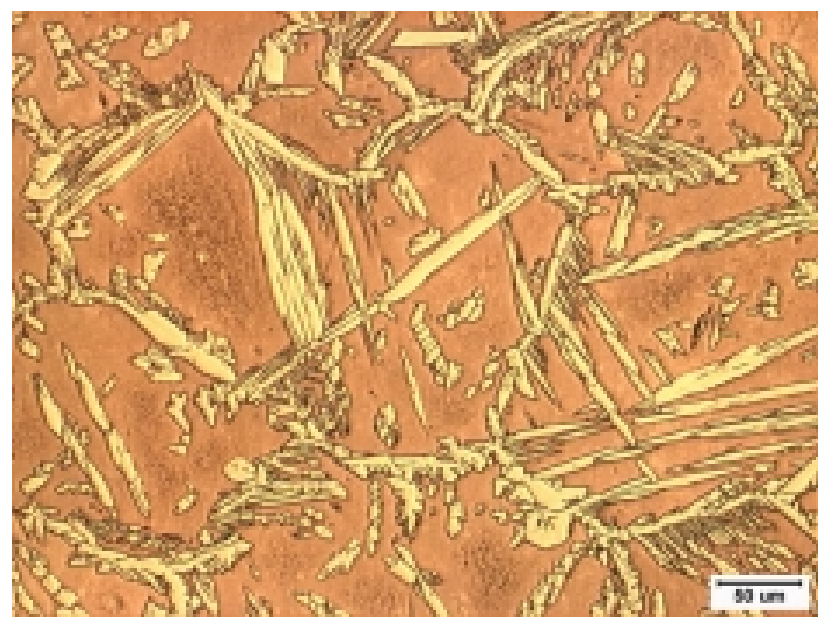

$1380{ }^{\circ} \mathrm{C}$ por $5 \mathrm{~s}$

Figura 58: AID UNS S32205 ferritizado. 


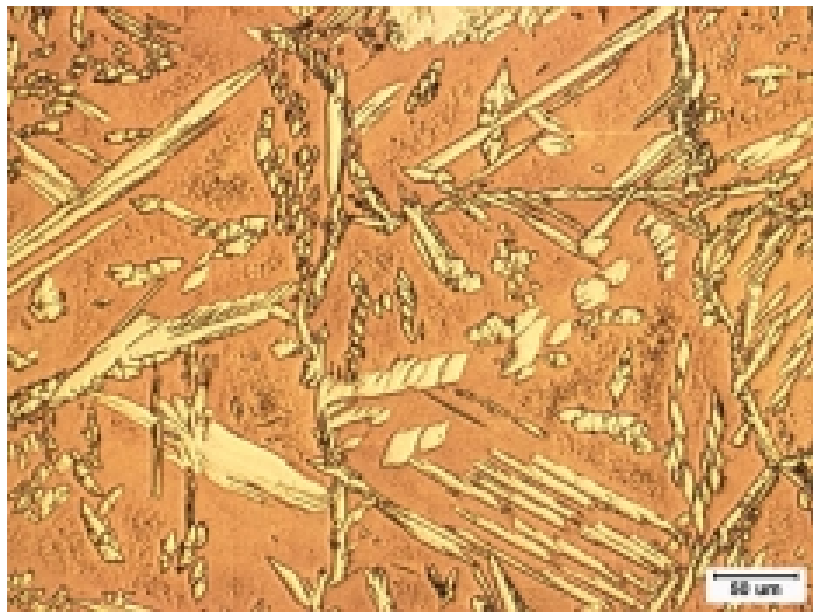

$1350{ }^{\circ} \mathrm{C}$ por $5 \mathrm{~s}$

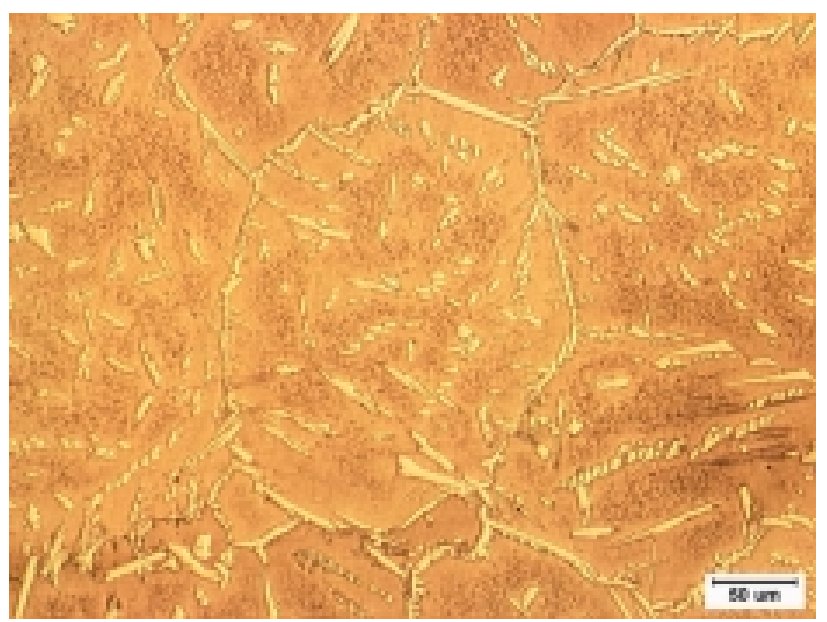

$1350{ }^{\circ} \mathrm{C}$ por $10 \mathrm{~s}$

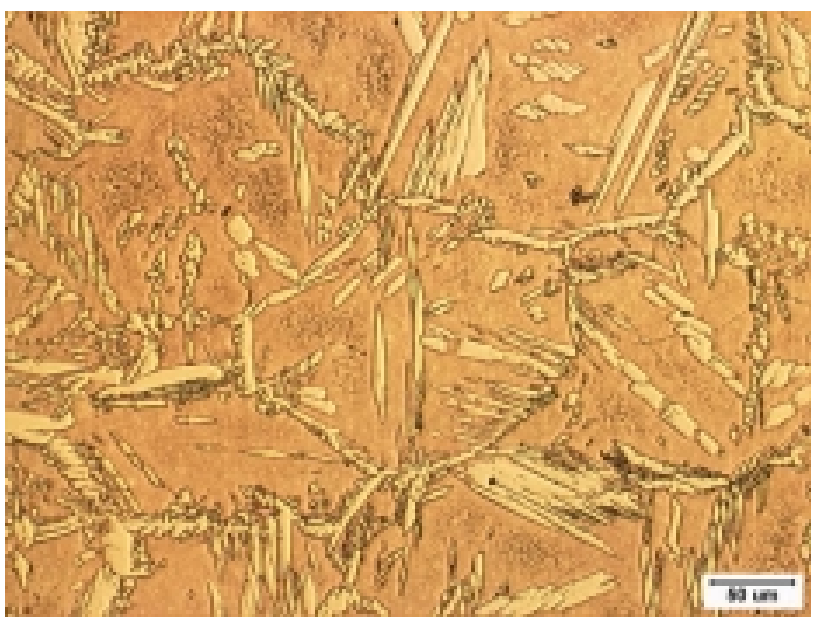

$1380{ }^{\circ} \mathrm{C}$ por $5 \mathrm{~s}$

Figura 59: AISD UNS S32550 ferritizado. 


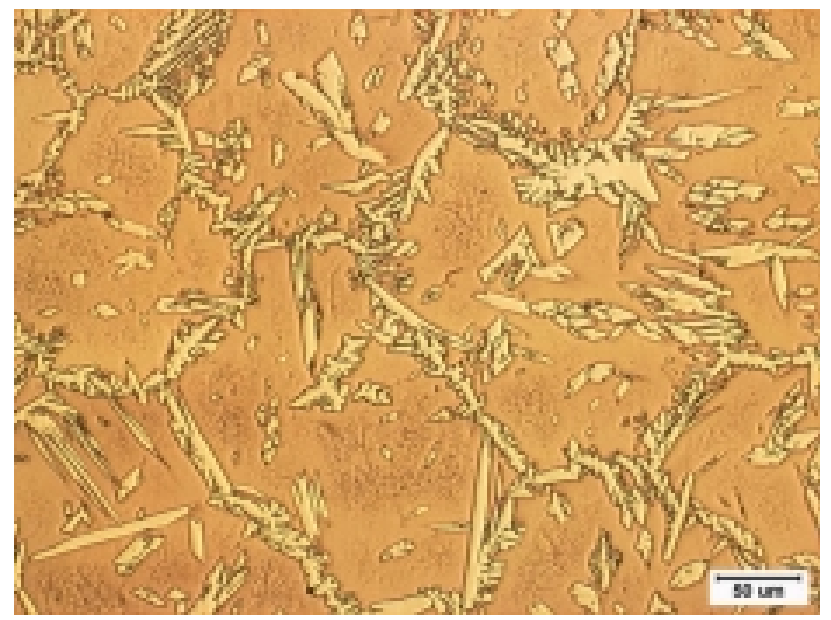

$1350^{\circ} \mathrm{C}$ por $5 \mathrm{~s}$

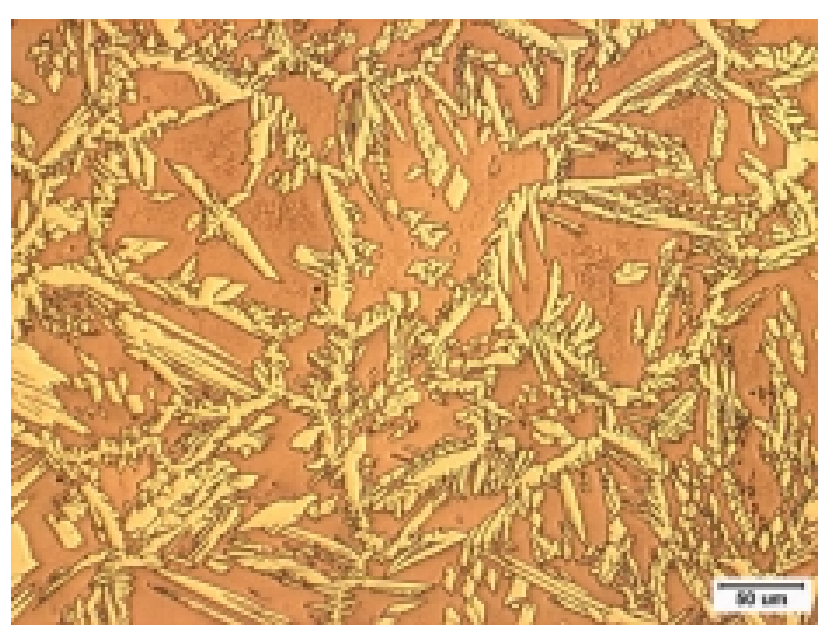

$1350{ }^{\circ} \mathrm{C}$ por $10 \mathrm{~s}$

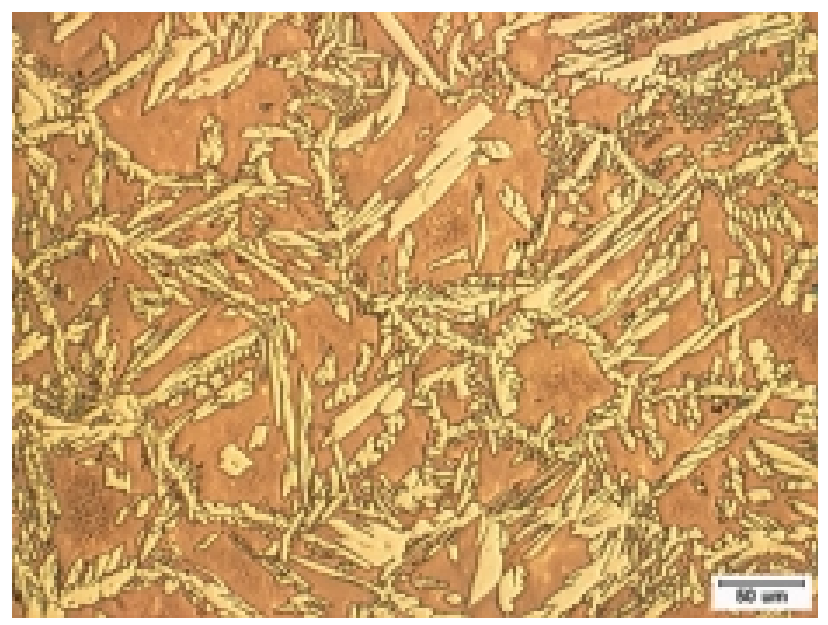

$1380^{\circ} \mathrm{C}$ por $5 \mathrm{~s}$

Figura 60: AISD UNS S32750 ferritizado. 


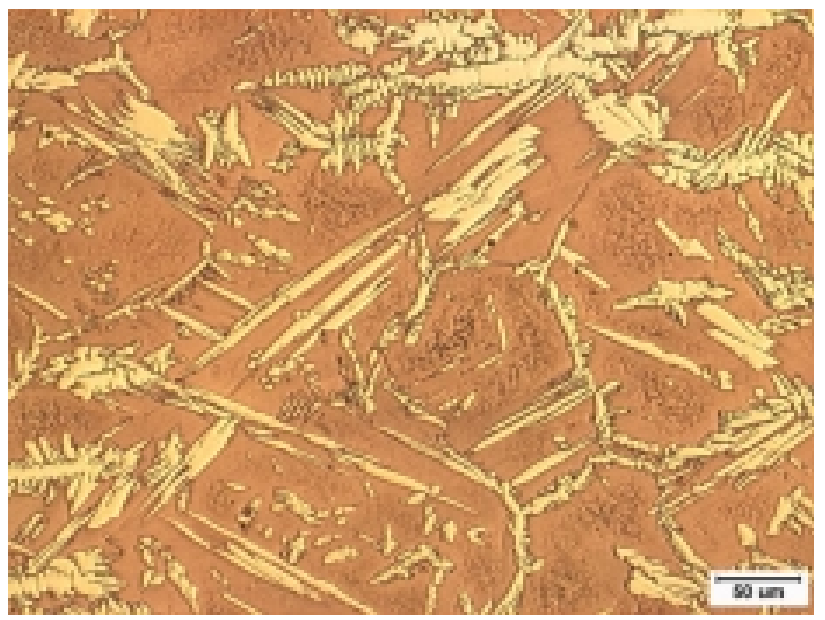

$1350{ }^{\circ} \mathrm{C}$ por $5 \mathrm{~s}$

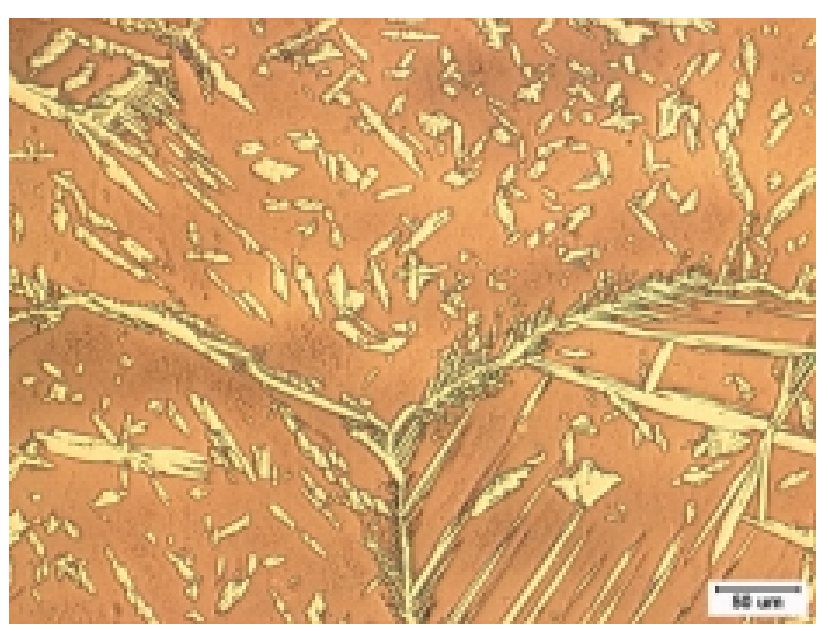

$1350{ }^{\circ} \mathrm{C}$ por $10 \mathrm{~s}$

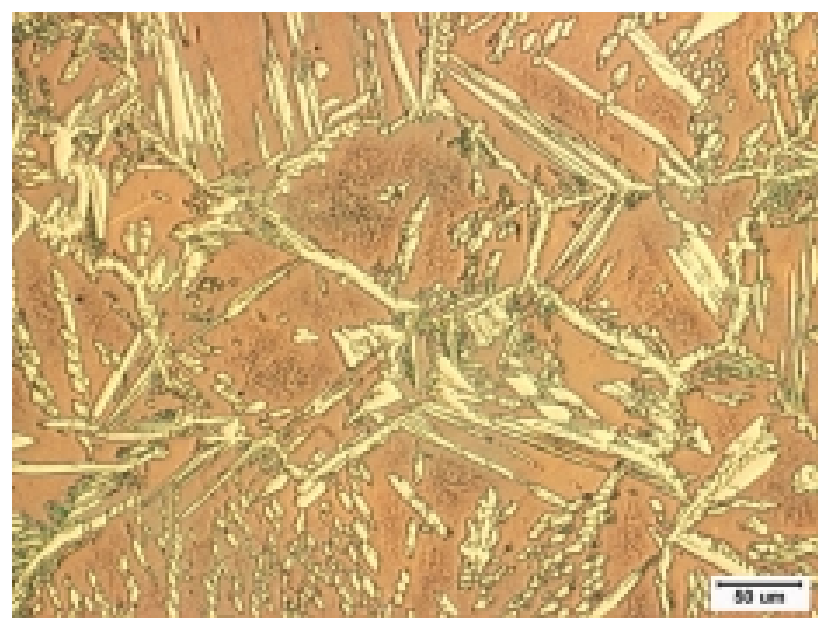

$1380{ }^{\circ} \mathrm{C}$ por $5 \mathrm{~s}$

Figura 61: AISD UNS S32760 ferritizado. 


\subsection{Caracterização Microestrutural Detalhada}

Como já foi mencionado, durante o aquecimento e manutenção no patamar todas as ligas experimentaram a dissolução parcial ou total (como o AID UNS S32304) da austenita, seguida de um importante crescimento de grão ferrítico. Já durante o resfriamento obteve-se a re-precipitação da austenita com as seguintes morfologias:

- Alotrimórfica ao longo dos contornos de grão de ferrita

- Placas laterais do tipo Widmanstätten, as quais crescem a partir das primeiras.

- Austenitas intragranulares.

Além da re-precipitação da austenita, verificou-se:

- Extensa precipitação de bastonetes de nitreto de cromo $\left(\mathrm{Cr}_{2} \mathrm{~N}\right)$ no interior da ferrita.

- Esporádica precipitação de nitretos de cromo $\left(\mathrm{Cr}_{2} \mathrm{~N}\right)$ nas interfaces $\alpha / \gamma$.

Estes corpos de prova foram submetidos a um estudo mais aprofundado mediante microscopia eletrônica de varredura e transmissão.

\subsection{Composição química da ferrita e da austenita}

A composição química da ferrita e da austenita foi determinada mediante WDS no MEV com uma tensão de aceleração de $12 \mathrm{KV}$. Como pode ser visto na Tabela 31, os elementos de liga apresentaram partição preferencial entre as fases presentes. Contudo, esta partição foi bastante pequena para a maioria dos elementos devido à temperatura elevada na qual os TTs foram realizados.

A presença do nitrogênio foi verificada quase que exclusivamente na austenita, o que é explicado pela maior solubilidade deste elemento nesta fase. Para todas as ligas, o teor de nitrogênio medido na ferrita foi menor que o previsto pelo Thermo-Calc ${ }^{\circledR}$. O resfriamento dos $\mathrm{CPs}$ foi bastante rápido $\left(75^{\circ} \mathrm{C} / \mathrm{s}\right)$. Porém, a difusividade do nitrogênio na ferrita é bastante elevada. Associado a este fato, o limite de solubilidade deste elemento na ferrita cai drasticamente com a temperatura. Assim, ou o nitrogênio migra para a austenita que está sendo formada, ou então causa a precipitação de $\mathrm{Cr}_{2} \mathrm{~N}$ no interior da ferrita. Consequentemente o teor final de nitrogênio na ferrita, após o resfriamento, vem a ser bem menor que o calculado a $1350{ }^{\circ} \mathrm{C}$ pelo Thermo-Calc ${ }^{\circledR}$.

Para o restante dos elementos de liga analisados, as partições medidas foram em geral bem menores que as previstas pelo Thermo-Calc $^{\circledR}$ para as condições de equilíbrio nesta temperatura. A exceção foram o Si e o Mo (este somente para algumas das ligas) cuja partição medida dos elementos de liga foi desprezível, como foi previamente reportado por CHARLES $^{(21)}$. A diferença entre os coeficientes de partição de equilíbrio e os medidos pode ser devida ao tempo curto do tratamento, isto é 5 ou $10 \mathrm{~s}$. 
Tabela 31: Composição química da ferrita e da austenita dos corpos de prova tratados termicamente a $1350{ }^{\circ} \mathrm{C}$ por 5 e $10 \mathrm{~s}$. Composição química das mesmas fases calculada com o Thermo-Calc ${ }^{\circledR}$ para a temperatura de $1350{ }^{\circ} \mathrm{C}$.

\begin{tabular}{|c|c|c|c|c|c|c|c|}
\hline \multirow{3}{*}{$\begin{array}{l}\text { Designação } \\
\text { UNS }\end{array}$} & \multirow{3}{*}{ Elemento } & \multicolumn{6}{|c|}{ Composição Química [\%peso] } \\
\hline & & \multicolumn{3}{|c|}{ Equilíbrio $1350{ }^{\circ} \mathrm{C}$ (Thermo-Calc $\left.{ }^{\circledR}\right)$} & \multicolumn{3}{|c|}{$\begin{array}{l}\text { TT } 1350^{\circ} \mathrm{C} \text { por } 5 \text { ou } 10 \mathrm{~s} \\
\text { (Medido com WDS) }\end{array}$} \\
\hline & & Ferrita & Austenita & $\mathrm{X} \alpha / \mathrm{X} \gamma$ & Ferrita & Austenita & $\mathrm{X} \alpha / \mathrm{X} \gamma$ \\
\hline \multirow{9}{*}{ S32304 } & C & 0,014 & \multirow{9}{*}{ NA } & \multirow{9}{*}{ NA } & - & - & - \\
\hline & $\mathbf{N}$ & 0,100 & & & $0,00 \pm 0,00$ & $0,48 \pm 0,10$ & 0,00 \\
\hline & Si & 0,41 & & & $0,36 \pm 0,01$ & $0,27 \pm 0,03$ & 1,33 \\
\hline & Mo & 0,30 & & & $0,29 \pm 0,04$ & $0,25 \pm 0,04$ & 1,16 \\
\hline & $\mathrm{Cr}$ & 22,64 & & & $23,98 \pm 0,23$ & $23,29 \pm 0,24$ & 1,03 \\
\hline & Mn & 1,53 & & & - & - & - \\
\hline & $\mathrm{Fe}$ & 69,87 & & & $70,37 \pm 0,18$ & $70,43 \pm 0,34$ & 1,00 \\
\hline & $\mathrm{Ni}$ & 4,81 & & & $4,64 \pm 0,09$ & $4,87 \pm 0,09$ & 0,95 \\
\hline & $\mathrm{Cu}$ & 0,33 & & & $0,37 \pm 0,07$ & $0,43 \pm 0,06$ & 0,86 \\
\hline \multirow{8}{*}{ S32205 } & $\mathrm{C}$ & 0,012 & 0,037 & 0,32 & - & - & - \\
\hline & $\mathbf{N}$ & 0,130 & 0,516 & 0,25 & $0,00 \pm 0,00$ & $0,71 \pm 0,08$ & 0,00 \\
\hline & Si & 0,46 & 0,37 & 1,24 & $0,41 \pm 0,02$ & $0,36 \pm 0,02$ & 1,14 \\
\hline & Mo & 3,18 & 2,19 & 1,45 & $3,04 \pm 0,14$ & $2,88 \pm 0,08$ & 1,06 \\
\hline & $\mathrm{Cr}$ & 22,13 & 20,29 & 1,09 & $23,32 \pm 0,27$ & $22,56 \pm 0,37$ & 1,03 \\
\hline & Mn & 1,46 & 1,81 & 0,81 & - & - & - \\
\hline & $\mathrm{Fe}$ & 67,07 & 67,28 & 1,00 & $67,37 \pm 0,42$ & $68,07 \pm 0,36$ & 0,99 \\
\hline & $\mathbf{N i}$ & 5,55 & 7,50 & 0,74 & $5,86 \pm 0,23$ & $5,68 \pm 0,22$ & 1,03 \\
\hline \multirow{9}{*}{ S32550 } & C & 0,011 & \multirow{9}{*}{ NA } & \multirow{9}{*}{ NA } & - & - & - \\
\hline & $\mathbf{N}$ & 0,143 & & & $0,02 \pm 0,03$ & $0,91 \pm 0,13$ & 0,02 \\
\hline & Si & 0,28 & & & $0,26 \pm 0,02$ & $0,22 \pm 0,01$ & 1,18 \\
\hline & Mo & 3,65 & & & $3,74 \pm 0,10$ & $3,34 \pm 0,10$ & 1,12 \\
\hline & $\mathrm{Cr}$ & 24,62 & & & $27,01 \pm 0,29$ & $26,24 \pm 0,23$ & 1,03 \\
\hline & Mn & 0,88 & & & - & - & - \\
\hline & $\mathrm{Fe}$ & 63,00 & & & $61,27 \pm 0,22$ & $61,31 \pm 0,22$ & 1,00 \\
\hline & $\mathrm{Ni}$ & 5,93 & & & $6,08 \pm 0,23$ & $6,36 \pm 0,30$ & 0,96 \\
\hline & $\mathrm{Cu}$ & 1,47 & & & $1,63 \pm 0,14$ & $1,62 \pm 0,10$ & 1,01 \\
\hline \multirow{9}{*}{ S32750 } & $\mathrm{C}$ & 0,009 & 0,027 & 0,33 & - & - & - \\
\hline & $\mathbf{N}$ & 0,160 & 0,717 & 0,22 & $0,01 \pm 0,01$ & $0,79 \pm 0,04$ & 0,01 \\
\hline & Si & 0,22 & 0,16 & 1,38 & $0,19 \pm 0,02$ & $0,16 \pm 0,01$ & 1,19 \\
\hline & Mo & 3,87 & 2,70 & 1,43 & $3,62 \pm 0,09$ & $3,42 \pm 0,07$ & 1,06 \\
\hline & $\mathrm{Cr}$ & 24,89 & 23,49 & 1,06 & $26,21 \pm 0,20$ & $25,63 \pm 0,26$ & 1,02 \\
\hline & Mn & 0,77 & 0,98 & 0,79 & - & - & - \\
\hline & $\mathrm{Fe}$ & 63,36 & 63,10 & 1,00 & $63,45 \pm 0,23$ & $63,54 \pm 0,33$ & 1,00 \\
\hline & $\mathrm{Ni}$ & 6,51 & 8,72 & 0,75 & $6,52 \pm 0,12$ & $6,46 \pm 0,14$ & 1,01 \\
\hline & $\mathrm{Cu}$ & 0,20 & 0,12 & 1,67 & - & - & - \\
\hline \multirow{10}{*}{ S32760 } & C & 0,011 & \multirow{10}{*}{ NA } & \multirow{10}{*}{ NA } & - & - & - \\
\hline & $\mathbf{N}$ & 0,148 & & & $0,02 \pm 0,05$ & $0,86 \pm 0,13$ & 0,02 \\
\hline & Si & 0,19 & & & $0,19 \pm 0,02$ & $0,16 \pm 0,01$ & 1,19 \\
\hline & $\mathbf{W}$ & 0,60 & & & $0,55 \pm 0,05$ & $0,47 \pm 0,04$ & 1,17 \\
\hline & Mo & 3,51 & & & $3,49 \pm 0,10$ & $3,14 \pm 0,04$ & 1,11 \\
\hline & $\mathrm{Cr}$ & 24,65 & & & $26,20 \pm 0,35$ & $25,94 \pm 0,28$ & 1,01 \\
\hline & Mn & 0,50 & & & - & - & - \\
\hline & $\mathrm{Fe}$ & 63,12 & & & $62,39 \pm 0,25$ & $61,91 \pm 0,32$ & 1,01 \\
\hline & $\mathrm{Ni}$ & 6,71 & & & $6,52 \pm 0,19$ & $6,92 \pm 0,34$ & 0,94 \\
\hline & $\mathrm{Cu}$ & 0,57 & & & $0,65 \pm 0,08$ & $0,60 \pm 0,07$ & 1,08 \\
\hline
\end{tabular}

Nota: 1: AIDs UNS S32304, UNS S32205, UNS S32550 e UNS S32760 foram tratados a $1350{ }^{\circ} \mathrm{C}$ por 5 segundos. O AID UNS S 32750 foi tratado a $1350^{\circ} \mathrm{C}$ por 10 segundos. NA: Não aplica, pois a fase não é estável nessa temperatura. 


\subsection{Precipitação intragranular $\mathrm{de} \mathrm{Cr}_{2} \mathrm{~N}$}

A observação no MEV-EC revelou a precipitação em colônias de pequenas partículas com formato de bastonete no interior da ferrita, principalmente nos lugares livres de austenita. Pela localização destas partículas na microestrutura e pelo seu formato, pode-se deduzir que estas são $\mathrm{Cr}_{2} \mathrm{~N}$. Nas Figuras 62 a 66 são mostradas estas colônias de $\mathrm{Cr}_{2} \mathrm{~N}$ nas diversas ligas estudadas.

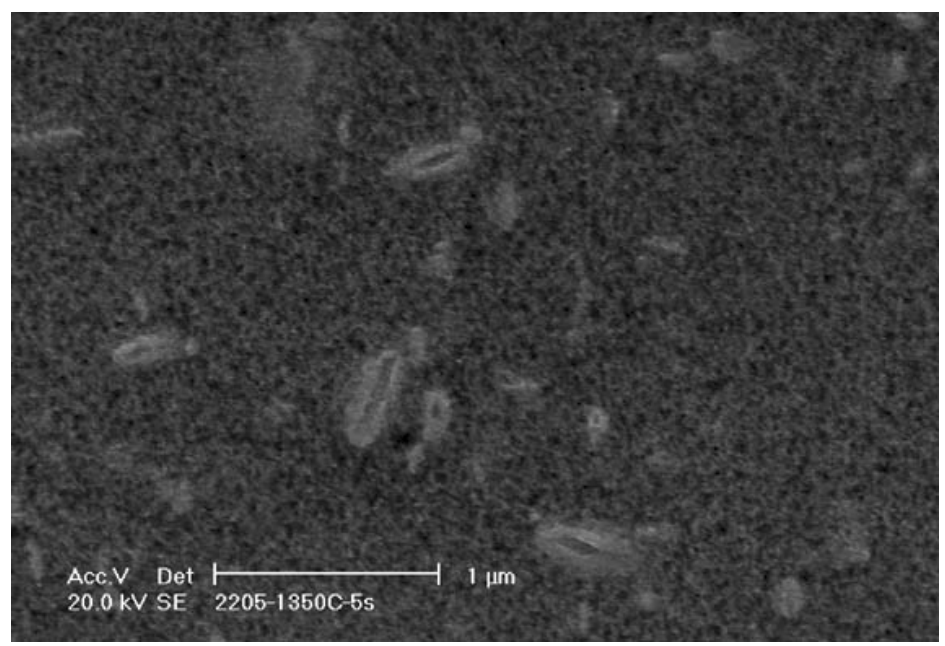

Figura 62: Colônias de $\mathrm{Cr}_{2} \mathrm{~N}$ no interior da ferrita. AID UNS S32205. MEV-EC

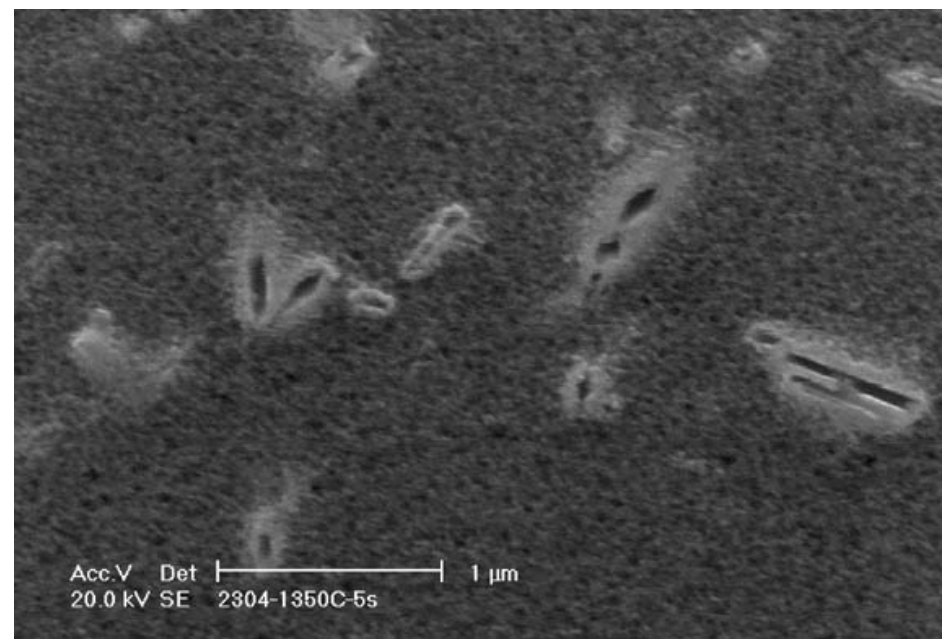

Figura 63: Colônias de $\mathrm{Cr}_{2} \mathrm{~N}$ no interior da ferrita. AID UNS S32304. MEV-EC. 


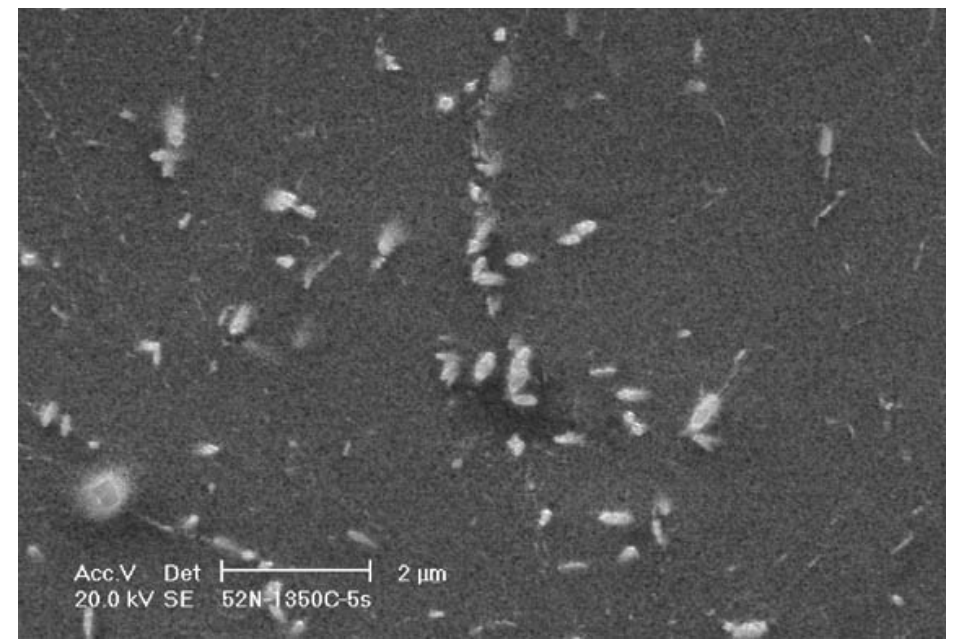

Figura 64: Colônias de $\mathrm{Cr}_{2} \mathrm{~N}$ no interior da ferrita. AISD UNS S32550. MEV-EC.

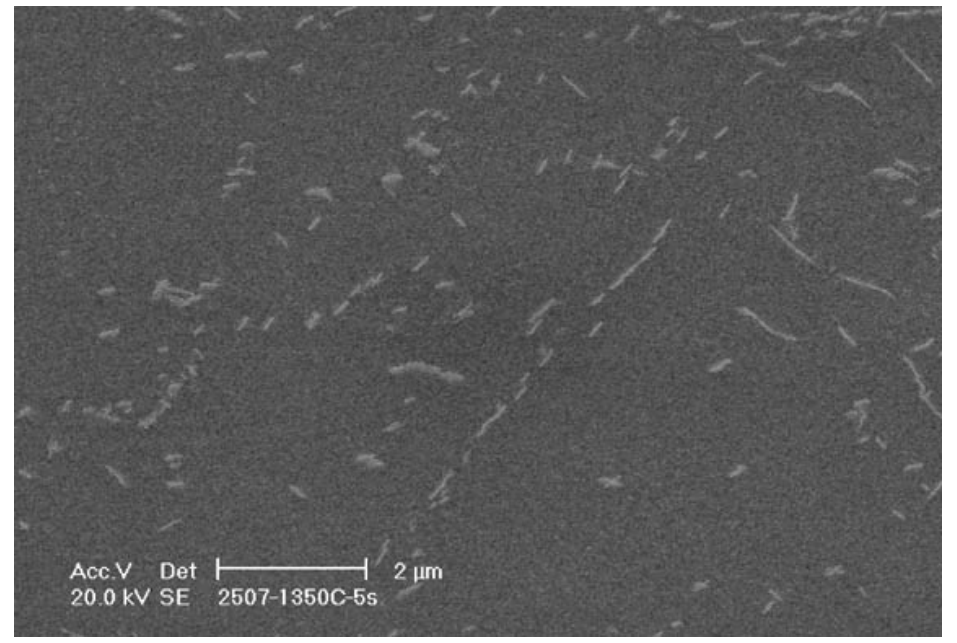

Figura 65: Colônias de $\mathrm{Cr}_{2} \mathrm{~N}$ no interior da ferrita. AISD UNS S32750. MEV-EC.

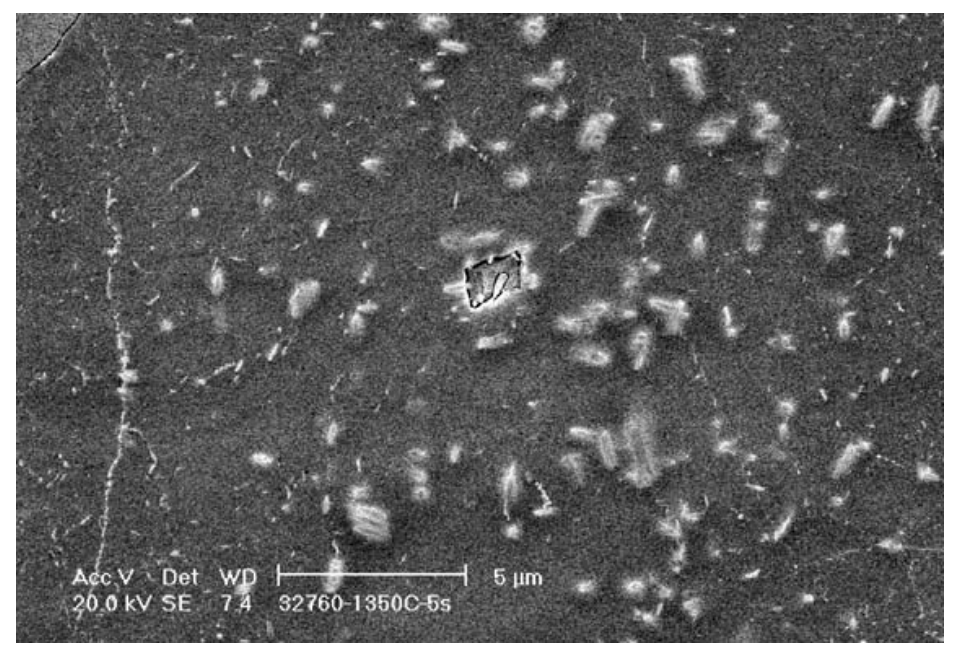

Figura 66: Colônias de $\mathrm{Cr}_{2} \mathrm{~N}$ no interior da ferrita. AISD UNS S32760. MEV-EC. 
As colônias de $\mathrm{Cr}_{2} \mathrm{~N}$ apresentadas nas figuras anteriores também foram observadas no MET. Os precipitados foram identificados inequivocamente mediante difração de elétrons de área selecionada (SAD) e com feixe convergente (CBD) como sendo $\mathrm{Cr}_{2} \mathrm{~N}$. Na Figura 67 são mostrados os bastonetes de $\mathrm{Cr}_{2} \mathrm{~N}$ precipitados no interior da ferrita do AID UNS S32205, observados no MET. Na Figura 68 é apresentado um bastonete de $\mathrm{Cr}_{2} \mathrm{~N}$ precipitado no interior da ferrita do AID UNS S32304, junto com a sua difração de elétrons com feixe convergente (CBD) e a difração de elétrons de área selecionada (SAD).
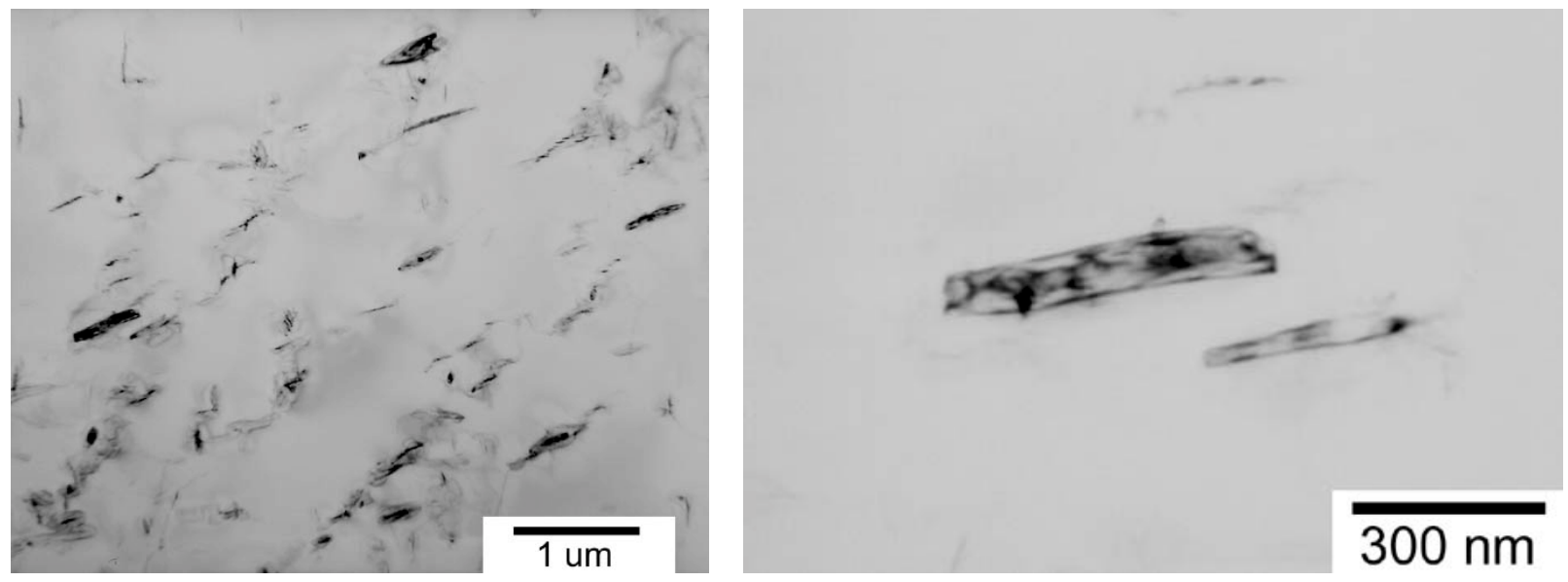

Figura 67: Precipitação de $\mathrm{Cr}_{2} \mathrm{~N}$ no interior da ferrita. AID UNS S32205. MET.

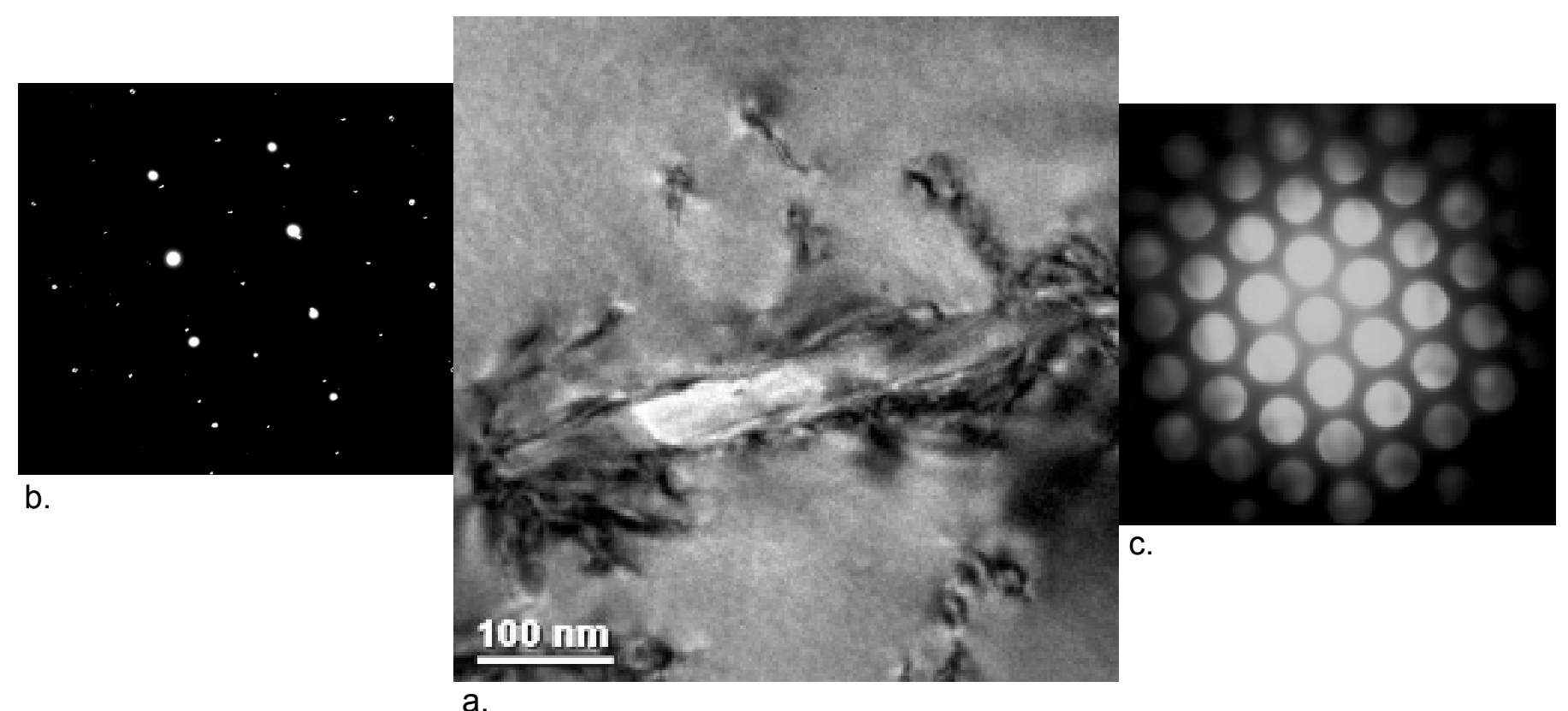

Figura 68: (a) Bastonete de $\mathrm{Cr}_{2} \mathrm{~N}$ precipitado no interior da ferrita no AID UNS S32304 com a sua respectiva (b) difração de área selecionada e (c) difração com feixe convergente, ambas com o feixe paralelo à direção [0001] do $\mathrm{Cr}_{2} \mathrm{~N}$. 
Como já foi reportado por outros autores, os nitretos de cromo precipitam no interior da ferrita, a partir de discordâncias, inclusões, e sub-contornos de grão ${ }^{(39)}$. Talvez devido à pequena quantidade de inclusões presentes nos materiais estudados, não foi observada a precipitação de nitretos a partir destas. Por outro lado, a grande maioria dos bastonetes de $\mathrm{Cr}_{2} \mathrm{~N}$ observados precipitaram a partir de discordâncias, como sugerem as duas figuras anteriores. Foi comum também a observação de sub-contornos de grão quase que totalmente preenchidos por nitretos, como mostrado na Figura 69, para os AIDs UNS S32205 e S32750.
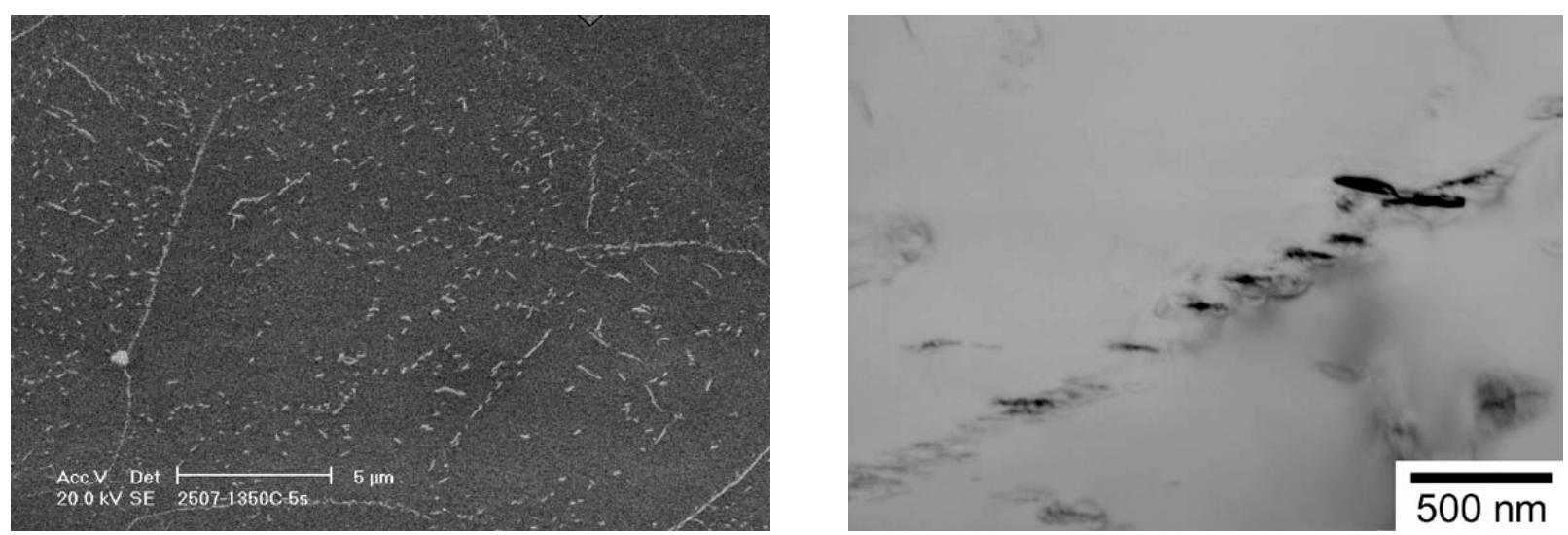

Figura 69: Precipitação de $\mathrm{Cr}_{2} \mathrm{~N}$ ao longo de sub-contornos de grão ferríticos. Em (a) AISD UNS S32750, MEV-EC. Em (b) AID UNS S32205, MET.

Os bastonetes intragranulares de $\mathrm{Cr}_{2} \mathrm{~N}$ apresentam claramente um relação de orientação com a ferrita. Como pode ser visto na Figura 70, o ângulo formado entre os eixos dos precipitados é de aproximadamente $60^{\circ}$. A imagem mostrada nesta figura é uma projeção no plano de objetos no espaço, portanto o ângulo entre os eixos está sujeito a deformações se os eixos não estiverem no mesmo plano da projeção. Neste caso, o formato dos bastonetes indica que o plano definido pelos seus eixos não se encontra muito fora do plano da projeção.

Existem duas relações de orientação mais freqüentemente reportadas entre fases ccc e hcp $^{(130)}$ :

\section{Relação de orientação do tipo Pitsch-Scharrer:}

$$
\begin{aligned}
& (110)_{\mathrm{CCC}} \text { II }(0001)_{\mathrm{HCP}} \\
& {[\overline{1} 10]_{\mathrm{CCC}} \text { II }[01 \overline{1} 0]_{\mathrm{HCP}}}
\end{aligned}
$$


Relação de orientação do tipo Burgers:

$$
\begin{aligned}
& (110)_{\mathrm{CCC}} \|(0001)_{\mathrm{HCP}} \\
& {[\overline{1} 11]_{\mathrm{CCC}} \|[\overline{1} 2 \overline{1} 0]_{\mathrm{HCP}}}
\end{aligned}
$$

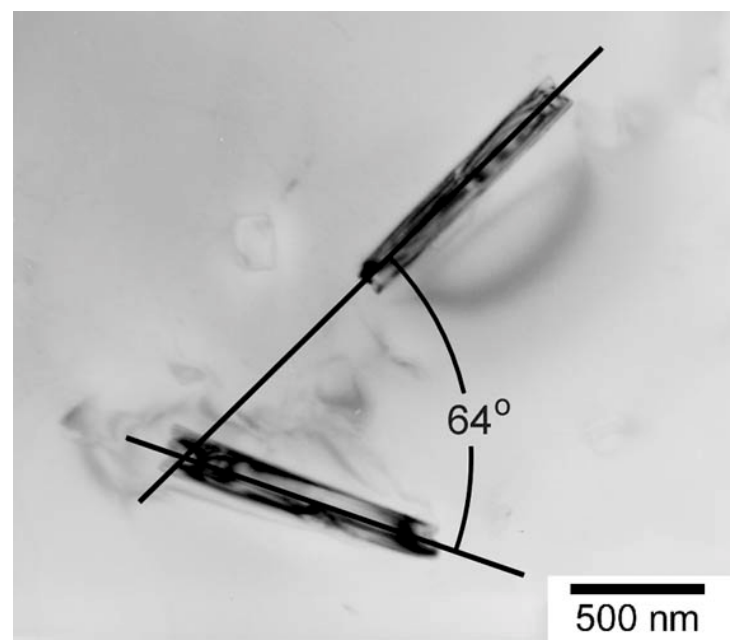

Figura 70: Precipitação de $\mathrm{Cr}_{2} \mathrm{~N}$ no interior da ferrita. AID UNS S32304. MET.

Em 1967 LAGNEBORG apud BYWATER; DYSON ${ }^{(39)}$ reportaram uma relação de orientação entre o super-reticulado (trigonal) do $\mathrm{Cr}_{2} \mathrm{~N}$ e a ferrita num aço com $30 \%$ de $\mathrm{Cr}$, a qual é equivalente à relação de Burgers entre a ferrita e a sub-célula hexagonal formada pelos átomos metálicos do $\mathrm{Cr}_{2} \mathrm{~N}$. Posteriormente em 1975 BYWATER; DYSON ${ }^{(39)}$ confirmaram esta mesma relação de orientação num aço inoxidável ferrítico com $17 \%$ de Cr. Recentemente, KOKAWA; TSORY; NORTH ${ }^{(58)}$ reportaram uma relação de orientação diferente:

$$
\begin{aligned}
& (\overline{1} 10)_{\alpha} \|(0001)_{\mathrm{Cr}_{2} \mathrm{~N}} \\
& {[110]_{\alpha}\left\|[2 \overline{1} \overline{1} 0]_{\mathrm{Cr}_{2} \mathrm{~N}},[001]_{\alpha}\right\|[0 \overline{1} 10]_{\mathrm{Cr}_{2} \mathrm{~N}}}
\end{aligned}
$$

Recentemente KOBAYASHI; NAKAI; OHMORI ${ }^{(131)}$ estudaram a precipitação do $\mathrm{Cr}_{2} \mathrm{~N}$ num AID $(25 \mathrm{Cr}-7 \mathrm{Ni}-0,14 \mathrm{~N})$ a temperaturas entre 450 e $600{ }^{\circ} \mathrm{C}$. Eles verificaram a precipitação de plaquetas de $\mathrm{Cr}_{2} \mathrm{~N}$ com a seguinte relação de orientação: 


$$
\begin{aligned}
& (\overline{1} 01)_{\alpha} I I(0001)_{\mathrm{Cr}_{2} \mathrm{~N}} \\
& {[101]_{\alpha} \mathrm{II}[1 \overline{2} 10]_{\mathrm{Cr}_{2} \mathrm{~N}}}
\end{aligned}
$$

Uma das relações de orientação $\mathrm{Cr}_{2} \mathrm{~N} / \alpha$ determinada mediante difração de elétrons no MET, apresenta (110) $\alpha$ e (0002) $\mathrm{Cr}_{2} \mathrm{~N}$ paralelos, mas devido ao pequeno tamanho das partículas não foi possível obter um padrão completo do $\mathrm{Cr}_{2} \mathrm{~N}$. Assim, o eixo de zona desta fase não pode ser determinado e portanto esta relação de orientação pode ser a reportada por KOKAWA et al. ${ }^{(58)}$ ou até alguma outra. Na Figura 71 é mostrado o padrão de difração de elétrons da ferrita junto com o do $\mathrm{Cr}_{2} \mathrm{~N}$, no qual é apresentada a mencionada relação de orientação.
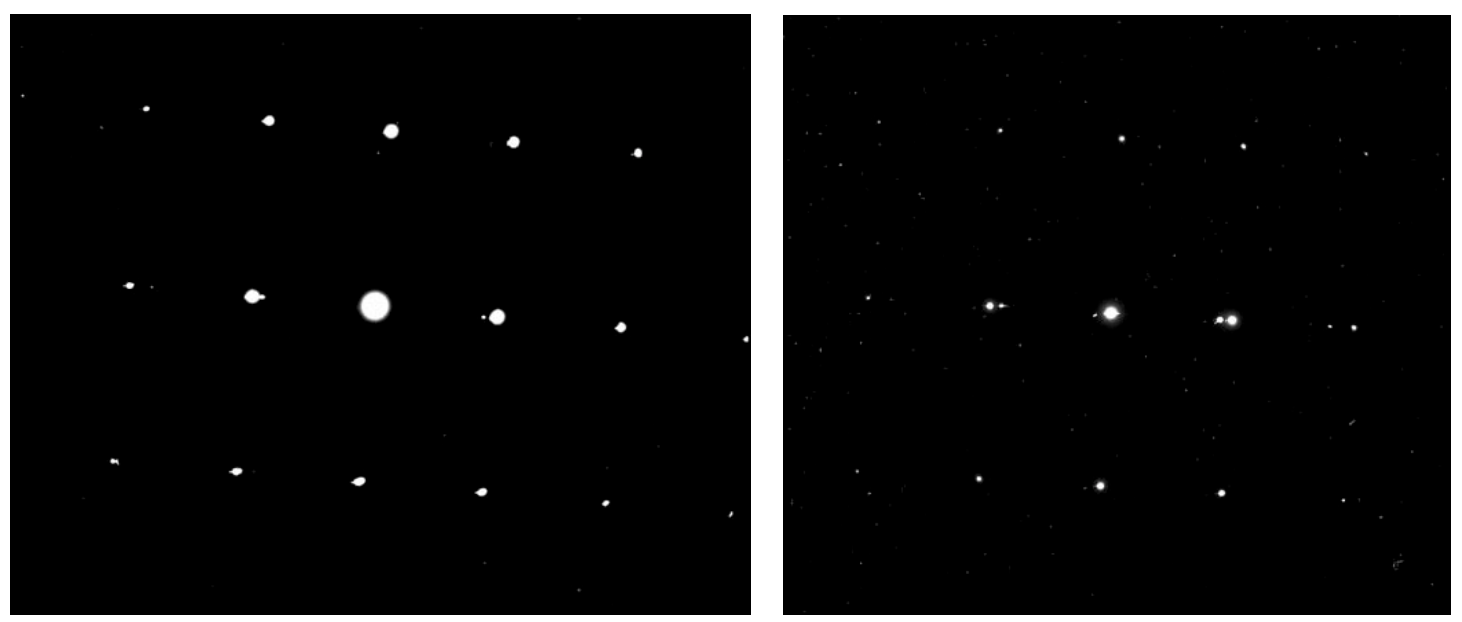

$$
\begin{aligned}
& (\overline{1} 10)_{\alpha} \text { II }(0001)_{\mathrm{Cr}_{2} \mathrm{~N}} \\
& {[110]_{\alpha} \text { II }[2 \overline{1} \overline{1} 0]_{\mathrm{Cr}_{2} \mathrm{~N}} \text { ou }[\overline{1} 100]_{\mathrm{Cr}_{2} \mathrm{~N}}}
\end{aligned}
$$

Figura 71: Difração de elétrons de área selecionada de diferentes partículas mostrando a relação de orientação $\mathrm{Cr}_{2} \mathrm{~N} / \alpha$, conforme reportada por KOKAWA et al. ${ }^{(58)}$ ou de outro tipo. AID UNS S32304. $1350{ }^{\circ} \mathrm{C}$ por $5 \mathrm{~s}$.

Foi registrada uma outra relação de orientação $\mathrm{Cr}_{2} \mathrm{~N} / \alpha$, onde se tem os mesmos planos paralelos da relação de orientação anteriormente mencionada. Na Figura 72 é apresentado o padrão de difração de elétrons com esta relação de orientação, qual é definida:

$$
\begin{aligned}
& (110)_{\alpha} \mathrm{II}(0001)_{\mathrm{Cr}_{2} \mathrm{~N}} \\
& {[\overline{1} 11]_{\alpha} \mathrm{II}[\overline{1} 100]_{\mathrm{Cr}_{2} \mathrm{~N}}}
\end{aligned}
$$

Tanto está relação de orientação como as outras que serão mencionadas de aqui para frente são apresentadas com relação ao super-reticulado do $\mathrm{Cr}_{2} \mathrm{~N}$, que apresenta uma estrutura trigonal. No entanto, como já foi apresentado na página 16 e mostrado na Figura 11, as informações cristalográficas desta fase também podem ser apresentadas com relação a uma 
sub-célula, formada pelos átomos metálicos da estrutura, que apresenta estrutura hexagonal compacta (hcp), como mostrado na Figura 73.
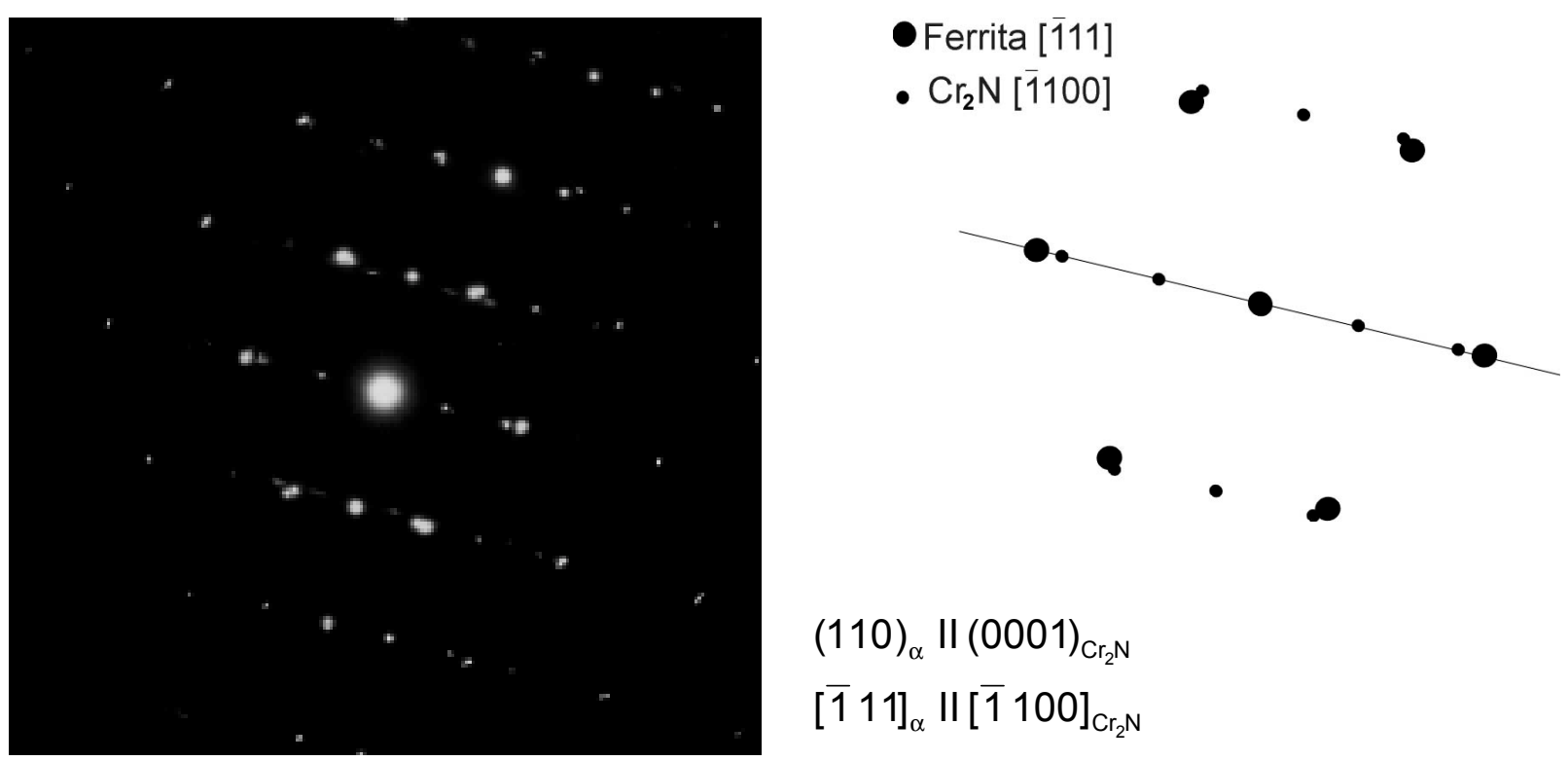

Figura 72: Relação de orientação $\mathrm{Cr}_{2} \mathrm{~N} / \alpha$. Padrão de difração de elétrons e a sua devida indexação. AID UNS S32550. $1350^{\circ} \mathrm{C}$ por $5 \mathrm{~s}$.

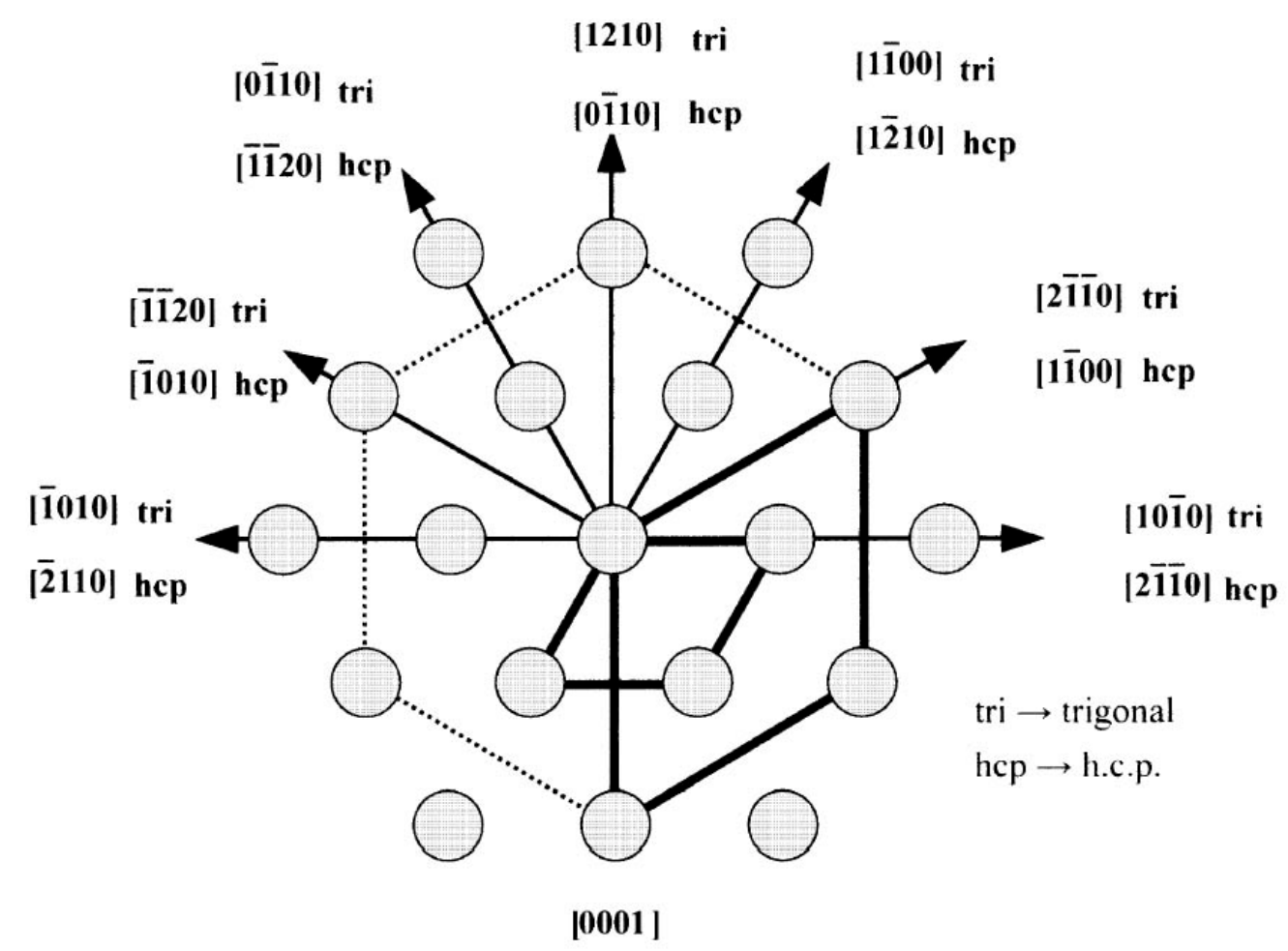

Figura 73: Equivalência entre os reticulados trigonal e hexagonal compacto (hcp) do $\mathrm{Cr}_{2} \mathrm{~N}^{(131)}$. 
Desta forma, a direção $[\overline{1} 100]_{\mathrm{Cr}_{2} \mathrm{~N}(\mathrm{Trigonal})}$ é equivalente à direção $[\overline{1} 2 \overline{1} 0]_{\mathrm{Cr}_{2} \mathrm{~N}(\mathrm{hcp})}$ e a relação de orientação anterior, quando colocada em termos do reticulado hcp, passa a ser a relação de Burgers. Isto é a mesma previamente reportada por BYWATER; DYSON ${ }^{(39)}$.

Na Figura 74 é apresentada uma imagem de reticulado (alta resolução) onde é mostrada a interface $\mathrm{Cr}_{2} \mathrm{~N} / \alpha$ no AISD UNS S32550. Nesta imagem podem-se observar os planos paralelos (110) $\alpha$ e (0001) $\mathrm{Cr}_{2} \mathrm{~N}$ os quais definem a relação de orientação. Também pode ser observada esta mesma imagem após uma filtração digital onde os planos são ressaltados. A partir desta imagem de alta resolução foi calculado, mediante a transformada de Fourier da imagem, o padrão de difração de elétrons correspondente, no qual verifica-se a relação de orientação descrita acima.

Na Figura 75 é mostrado um outro exemplo da imagem de reticulado de uma interface $\mathrm{Cr}_{2} \mathrm{~N} / \alpha$ no AISD UNS S32550. Ela apresenta a mesma relação de orientação anteriormente mencionada. Nesta figura pode-se ver claramente como na interface cada plano (0001) $\mathrm{Cr}_{2} \mathrm{~N}$ acomoda dois planos $(110) \alpha$, o que produz interface semicoerente.

$\mathrm{Na}$ Figura 76 são apresentadas as partículas de $\mathrm{Cr}_{2} \mathrm{~N}$ e as respectivas regiões a partir das quais foram obtidas as imagens de reticulado mostradas nas Figuras 74 e 75. Nestas duas micrografias, os bastonetes foram cortados transversalmente, de modo que todas as interfaces presentes nos corpos de prova deveriam ser semicoerentes. Este fato foi confirmado em algumas seções destas interfaces. Deve-se chamar a atenção para o formato das partículas, pois é bastante claro que as interfaces coerentes e semicoerentes tendem a ser planas. Desta forma, as facetas bem definidas das partículas sugerem um certo grau de coerência do restante das interfaces. 


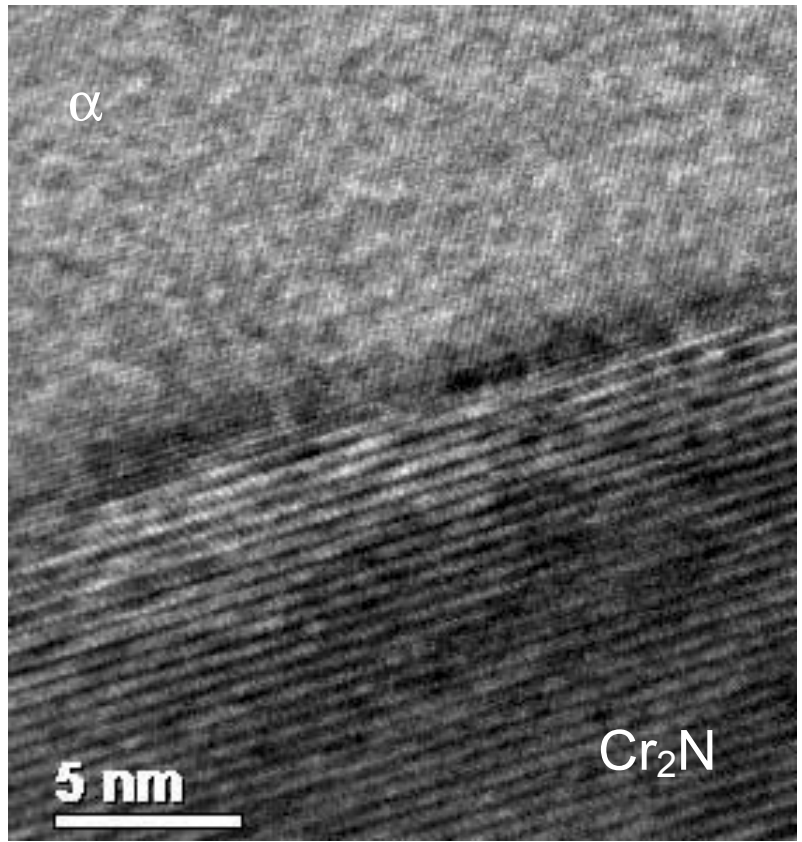

a.

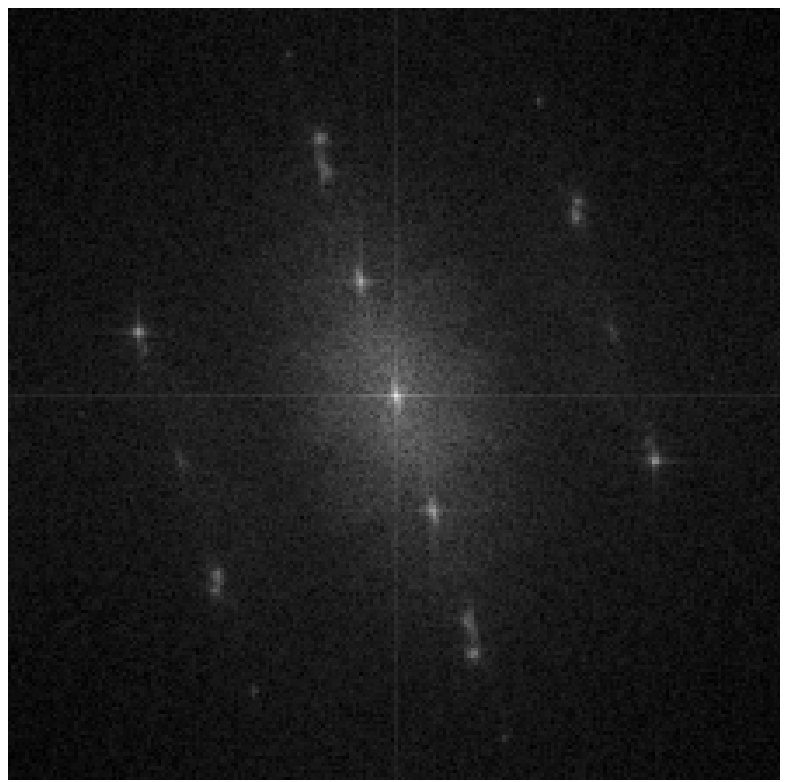

C.

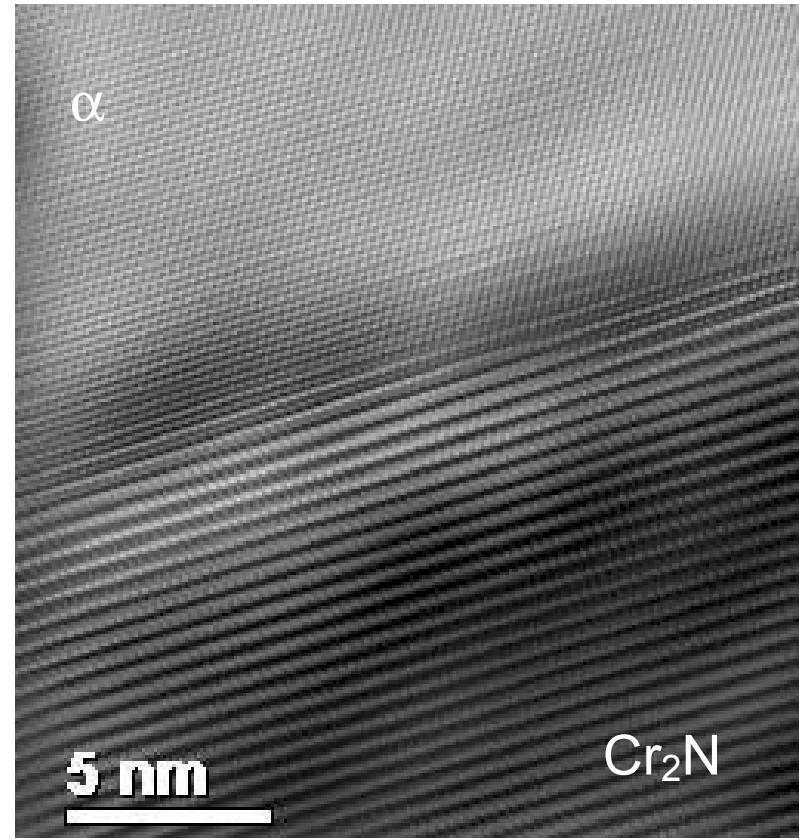

b.

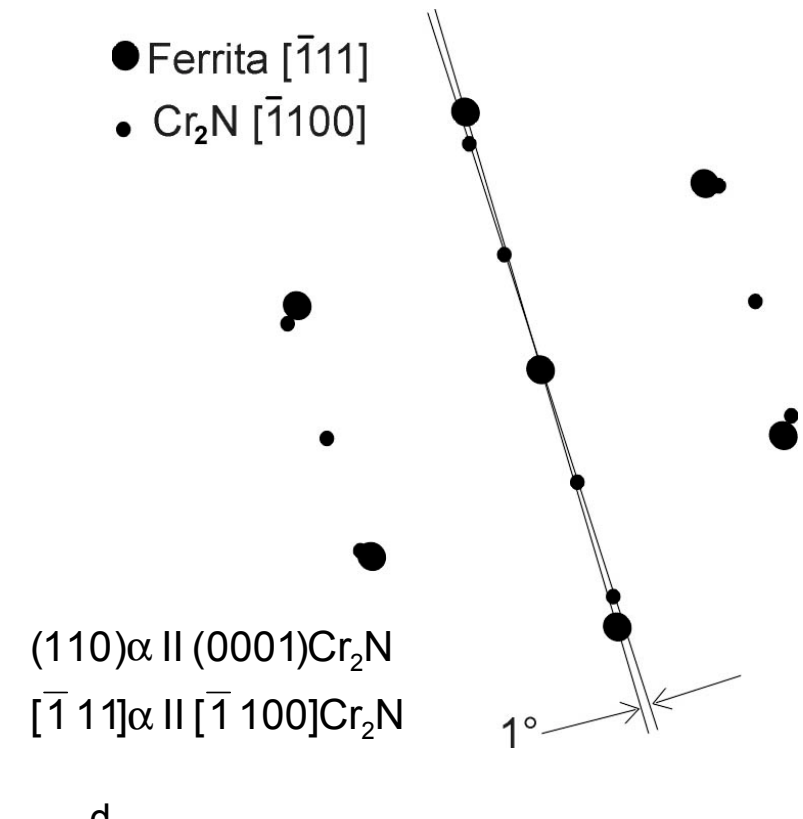

d.

Figura 74: Relação de orientação $\mathrm{Cr}_{2} \mathrm{~N} / \alpha$. Em (a) imagem do reticulado da interface $\mathrm{Cr}_{2} \mathrm{~N} / \alpha$, na qual é aparente a relação de orientação onde os planos paralelos são os mais compactos das duas fases, (110) $\alpha$ e (0001) $\mathrm{Cr}_{2} \mathrm{~N}$. Em (b) imagem do reticulado filtrada. Em (c) e (d) a transformada de Fourier (equivalente ao padrão de difração de elétrons) da imagem do reticulado e a sua devida indexação. Segundo o padrão de difração existe um pequeno giro de aprox. $1^{\circ}$, ao redor do eixo [ $\left.\overline{1} 100\right]$, entre os planos paralelos. AID UNS S32550. $1350^{\circ} \mathrm{C}$ por $5 \mathrm{~s}$. 


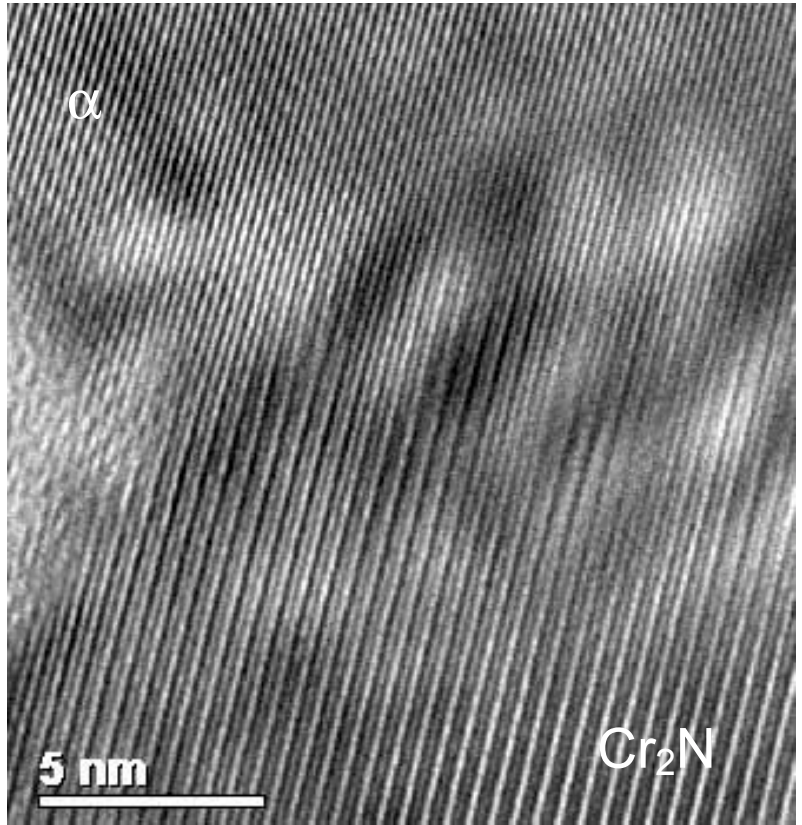

a.

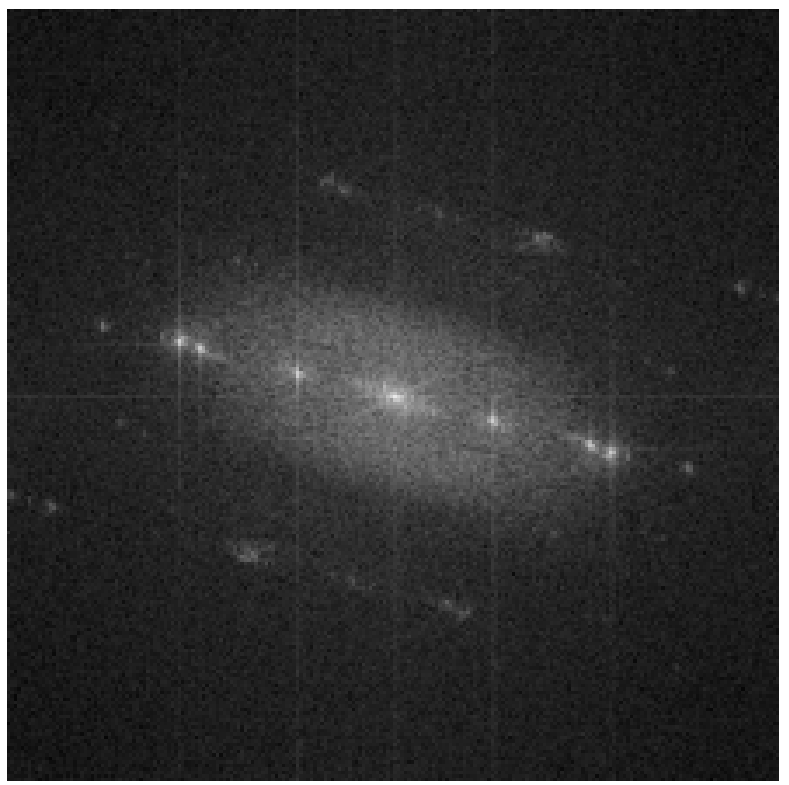

C.

Figura 75: Relação de orientação $\mathrm{Cr}_{2} \mathrm{~N} / \alpha$. Em (a) imagem do reticulado da interface $\mathrm{Cr}_{2} \mathrm{~N} / \alpha$, na qual é aparente a relação de orientação onde os planos paralelos são os mais compactos das duas fases, (110) $\alpha$ e (0001) $\mathrm{Cr}_{2} \mathrm{~N}$. Em (b) imagem do reticulado filtrada. Em (c) e (d) a transformada de Fourier (equivalente ao padrão de difração de elétrons) da imagem do reticulado e a sua devida indexação. AID UNS S32550. $1350{ }^{\circ} \mathrm{C}$ por $5 \mathrm{~s}$. 


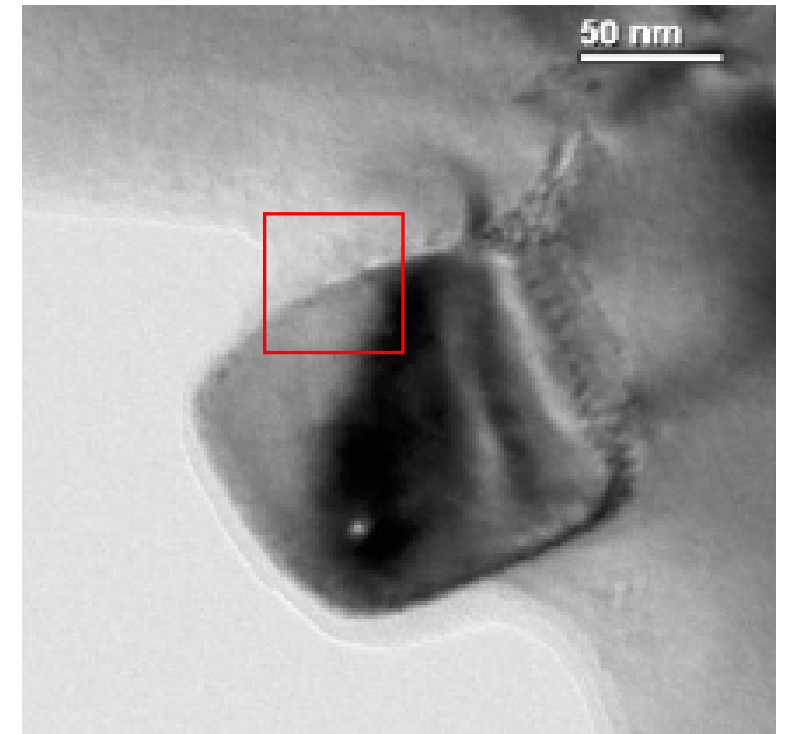

a.

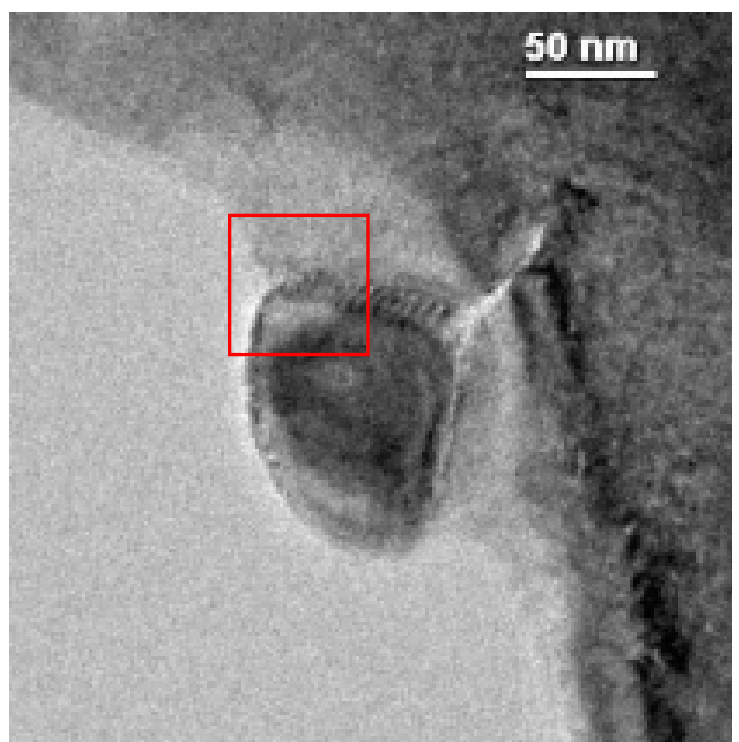

b.

Figura 76: Detalhe das partículas de $\mathrm{Cr}_{2} \mathrm{~N}$ e das regiões das mesmas a partir das quais foram obtidas as imagens de reticulado mostradas nas (a) Figura 74 (b) Figura 75. AISD UNS S32550.

A outra relação de orientação $\mathrm{Cr}_{2} \mathrm{~N} / \alpha$ verificada, foi registrada com o feixe paralelo as direções [110] $\alpha$ e [0001] $\mathrm{Cr}_{2} \mathrm{~N}$. Esta relação de orientação é:

$$
\begin{aligned}
& (\overline{1} 1 \overline{2})_{\alpha} \text { II }(2 \overline{1} \overline{1} 0)_{\mathrm{Cr}_{2} \mathrm{~N}} \\
& {[110]_{\alpha} \text { II }[0001]_{\mathrm{Cr}_{2} \mathrm{~N}}}
\end{aligned}
$$

Nas Figuras 77 e 78 são apresentadas difrações de elétrons de área selecionada com esta última relação de orientação.

Como foi mencionado anteriormente, as faces planas dos precipitados são uma indicação da existência de uma relação de orientação de baixa energia entre as fases. No entanto, não se pode afirmar que todas as interfaces ao longo destes precipitados apresentem uma interface semicoerente com uma mesma relação de orientação. Alias, neste trabalho duas das relações de orientação verificadas apresentam como planos paralelos (110) $\alpha$ e $(0001) \mathrm{Cr}_{2} \mathrm{~N} \mathrm{e}$ foram obtidas imagens de reticulado de interfaces $\mathrm{Cr}_{2} \mathrm{~N} / \alpha$ nas quais estes mesmos planos não se apresentam paralelos. Na Figura 79 é apresentada esta interface na qual os planos (110) $\alpha$ e (0001) $\mathrm{Cr}_{2} \mathrm{~N}$ não são paralelos, mas se conserva aquela relação previamente mencionada de cada plano (0001) $\mathrm{Cr}_{2} \mathrm{~N}$ acomodar dois planos (110) $\alpha$ na interface. Na Figura 80 é mostrado o precipitado e a região do mesmo a partir da qual foi feita a imagem de reticulado da interface $\mathrm{Cr}_{2} \mathrm{~N} / \alpha$ mencionada acima. 

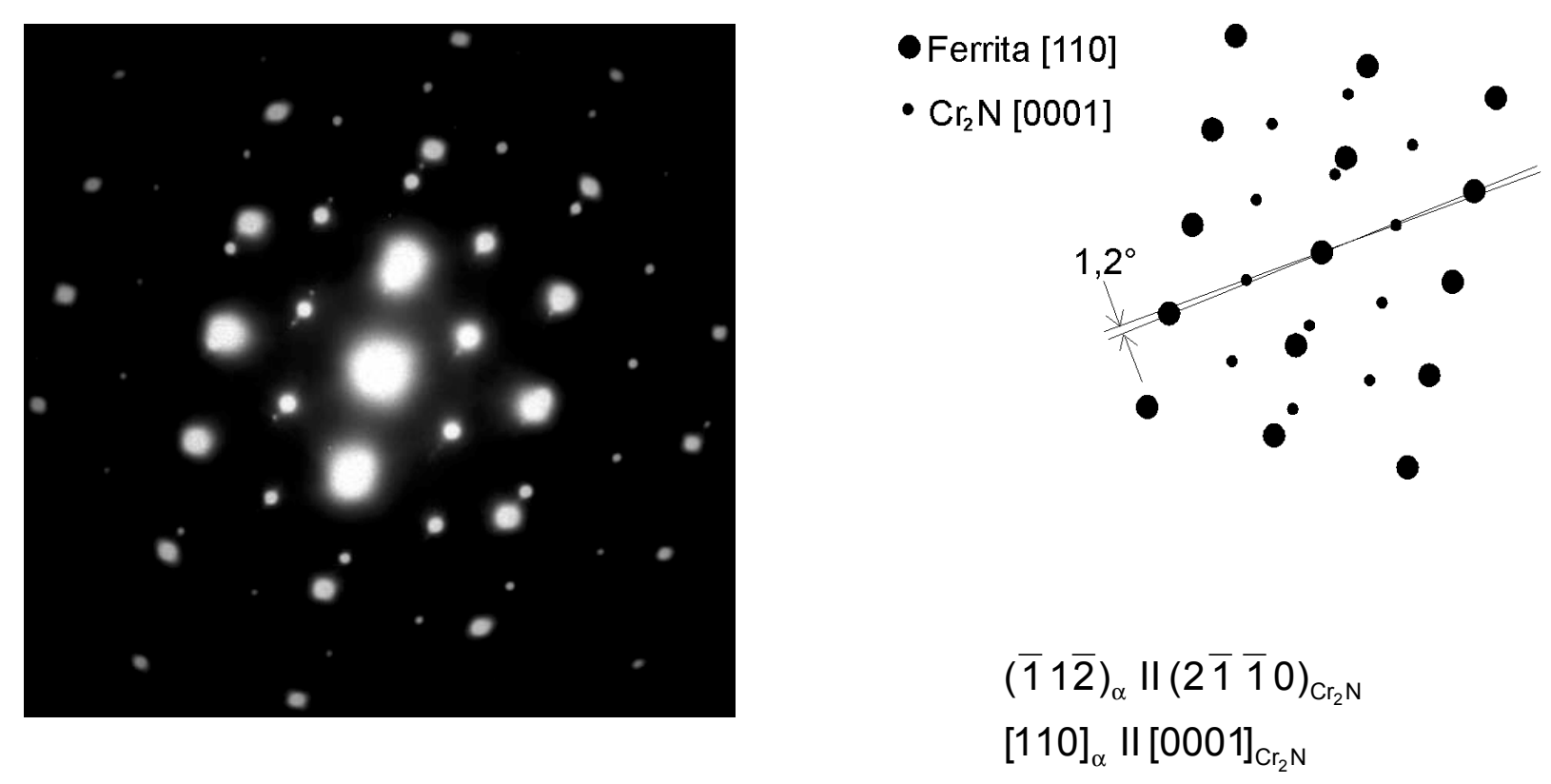

Figura 77: Difração de elétrons de área selecionada de uma partícula intragranular de $\mathrm{Cr}_{2} \mathrm{~N}$ que apresenta uma relação de orientação $\mathrm{Cr}_{2} \mathrm{~N} / \alpha$. Segundo o padrão de difração existe um pequeno giro de $1,2^{\circ}$ entre os planos paralelos ao redor do eixo [0001]. AID UNS S32304. $1350^{\circ} \mathrm{C}$ por $5 \mathrm{~s}$.
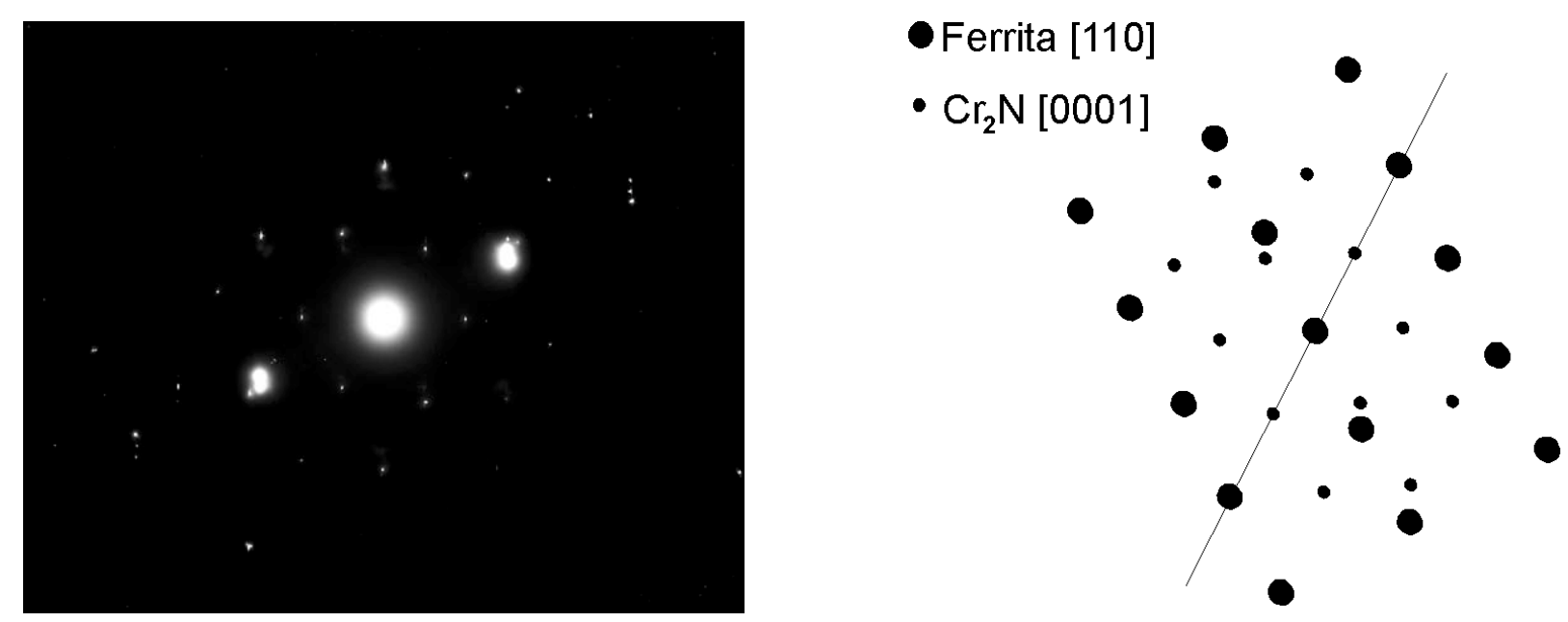

$$
\begin{aligned}
& (\overline{1} 1 \overline{2})_{\alpha} \|(2 \overline{1} \overline{1} 0)_{\mathrm{Cr}_{2} \mathrm{~N}} \\
& {[110]_{\alpha} \|[0001]_{\mathrm{Cr}_{2} \mathrm{~N}}}
\end{aligned}
$$

Figura 78: Difração de elétrons de área selecionada de uma partícula intragranular de $\mathrm{Cr}_{2} \mathrm{~N}$ que apresenta uma relação de orientação $\mathrm{Cr}_{2} \mathrm{~N} / \alpha$. Neste caso os planos são perfeitamente paralelos. AID UNS S32304. $1350^{\circ} \mathrm{C}$ por $5 \mathrm{~s}$. 

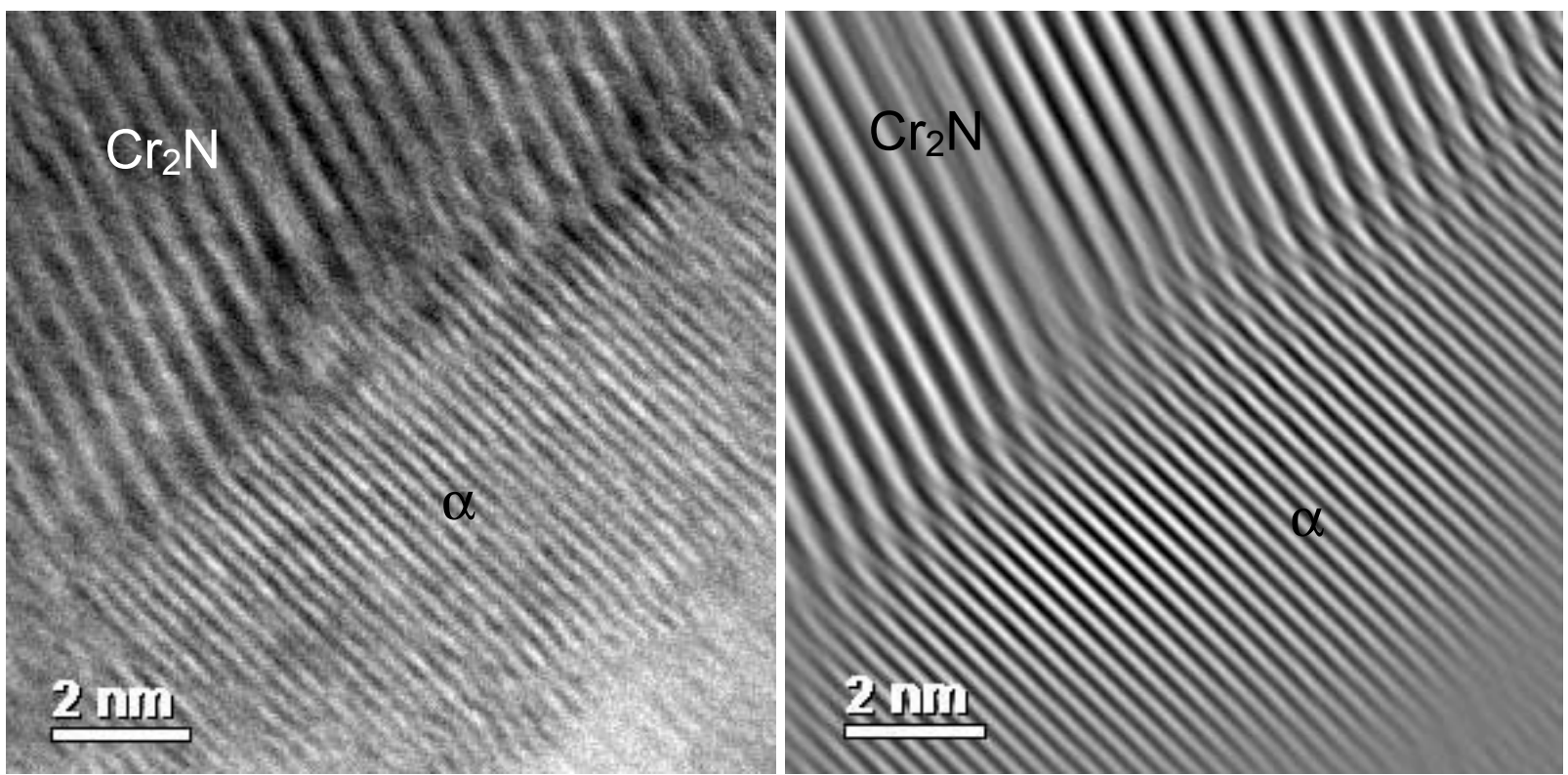

a.

b.
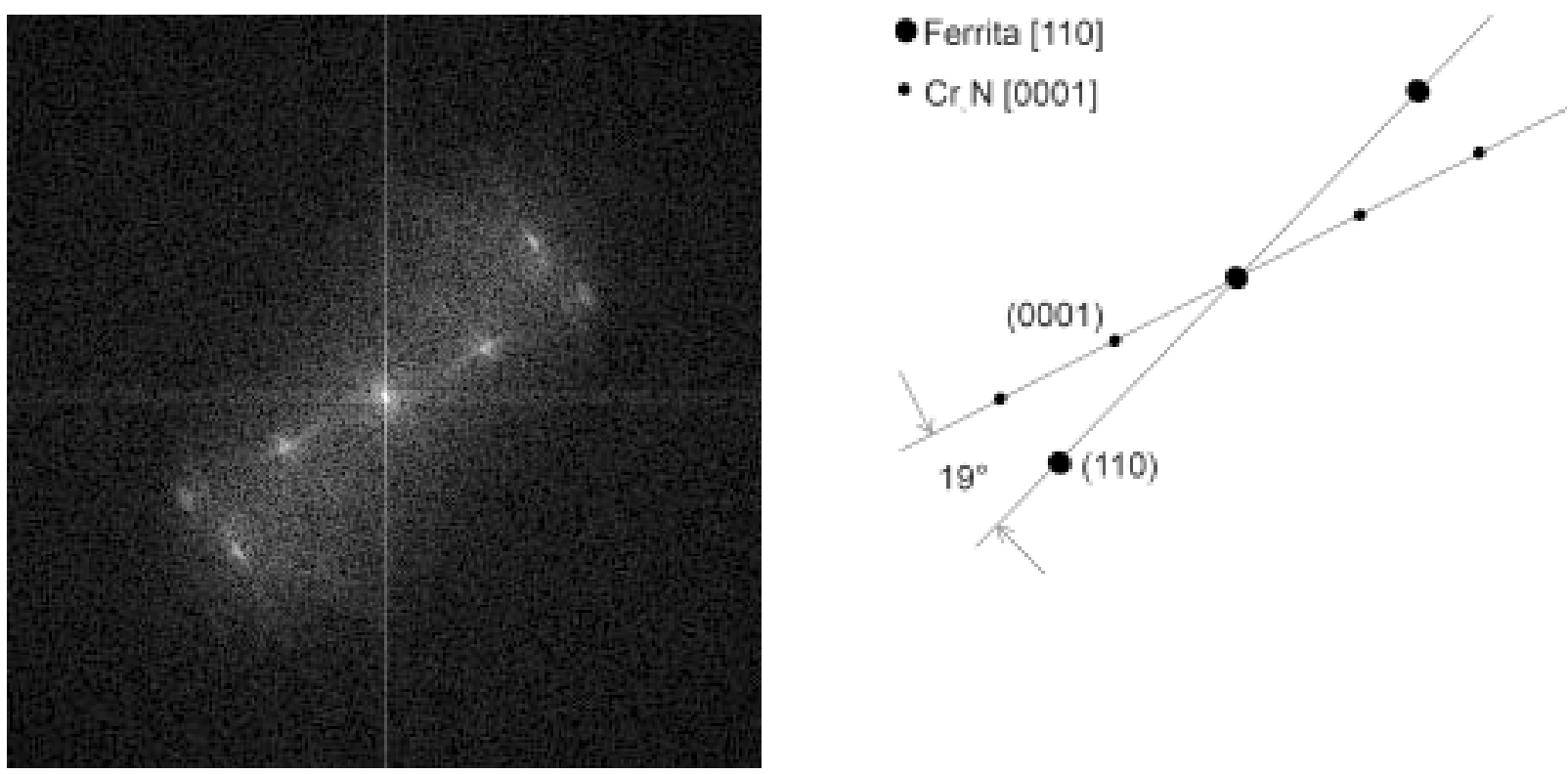

c.

d.

Figura 79: Imagem de reticulado da interface $\mathrm{Cr}_{2} \mathrm{~N} / \alpha$ na qual os planos (110) $\alpha$ não são paralelos com os planos (0001) $\mathrm{Cr}_{2} \mathrm{~N}$. AID UNS S32304. $1350{ }^{\circ} \mathrm{C}$ por $5 \mathrm{~s}$. 


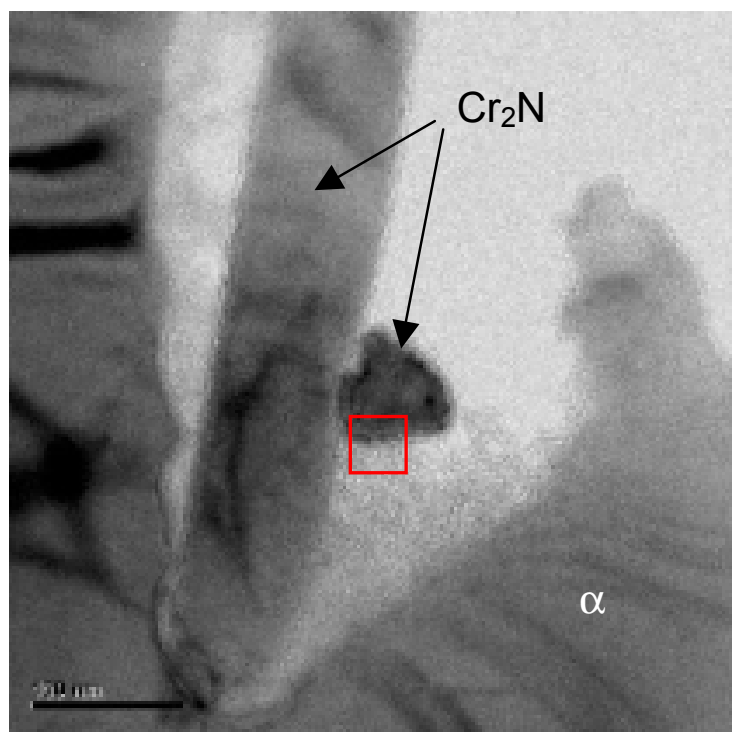

Figura 80: Precipitados intragranulares de $\mathrm{Cr}_{2} \mathrm{~N}$. Detalhe da região a partir da qual foi feita a imagem de reticulado mostrada na Figura 79. AID UNS S32304.

Uma outra técnica utilizada para verificar a relação de orientação dos bastonetes de $\mathrm{Cr}_{2} \mathrm{~N}$ com a ferrita foi através das franjas de Moiré formadas pela superposição dos reticulados do nitreto e da ferrita. O espaçamento entre estas franjas $\left(d_{m}\right)$ está relacionado com os espaçamentos entre os planos paralelos $\left(d_{1}\right.$ e $\left.d_{2}\right)$ segundo a Equação 15.

$$
d_{m}=\frac{d_{2} d_{1}}{d_{1}-d_{2}}
$$

Desta forma, o valor de $d_{m}$ para os planos (110) $\alpha$ e $(0002) \mathrm{Cr}_{2} \mathrm{~N}$ foi calculado como sendo $2,29 \mathrm{~nm}$. Para o calculo foram utilizados $d_{2}=0.20418 \mathrm{~nm}$ para o plano $(110) \alpha$, determinado através de difração de raios $X$ desta liga ${ }^{(132)}$, e $d_{1}=0,22420 \mathrm{~nm}$ para o plano $(0002) \mathrm{Cr}_{2} \mathrm{~N}$, obtido da tabela JCPDS No. 35-803). Na Figura 81 é apresentado um bastonete intragranular de $\mathrm{Cr}_{2} \mathrm{~N}$, o qual apresenta franjas de Moiré. O espaçamento médio entre estas foi medido, obtendo-se um valor de aproximadamente $2,3 \mathrm{~nm}$, isto é, igual ao valor calculado. Desta forma, este resultado vem reforçar o fato da relação de orientação $\mathrm{Cr}_{2} \mathrm{~N} / \alpha$ basear-se no paralelismo dos planos (110) $\alpha$ e (0001) $\mathrm{Cr}_{2} \mathrm{~N}$. Além desta verificação pelas franjas de Moiré, imagens de reticulado da interface deste precipitado com a ferrita e a sua respectiva transformada de Fourier confirmaram os planos paralelos. É importante chamar a atenção para o grande número de discordâncias ao redor do precipitado mostrado nesta figura. 


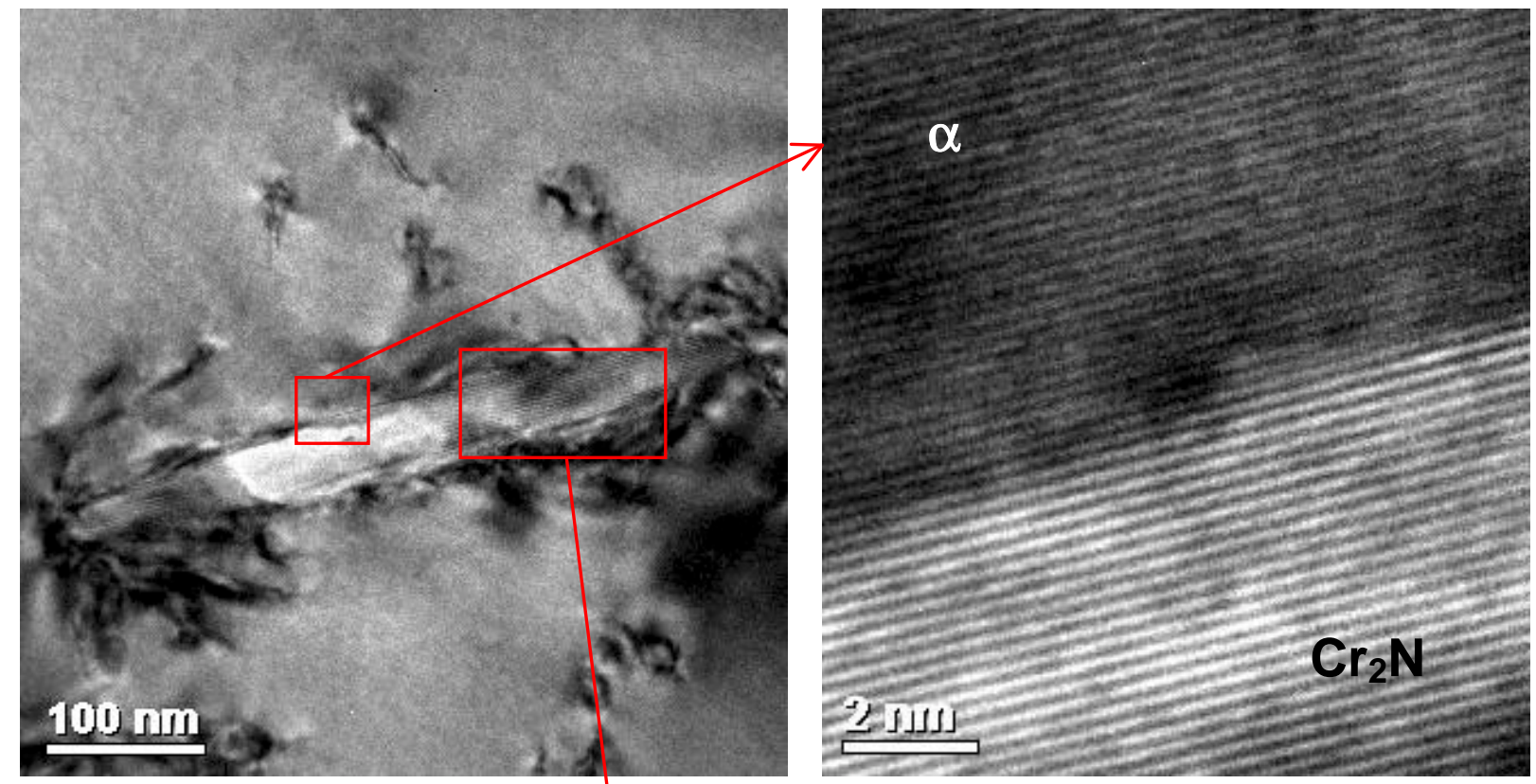

a.

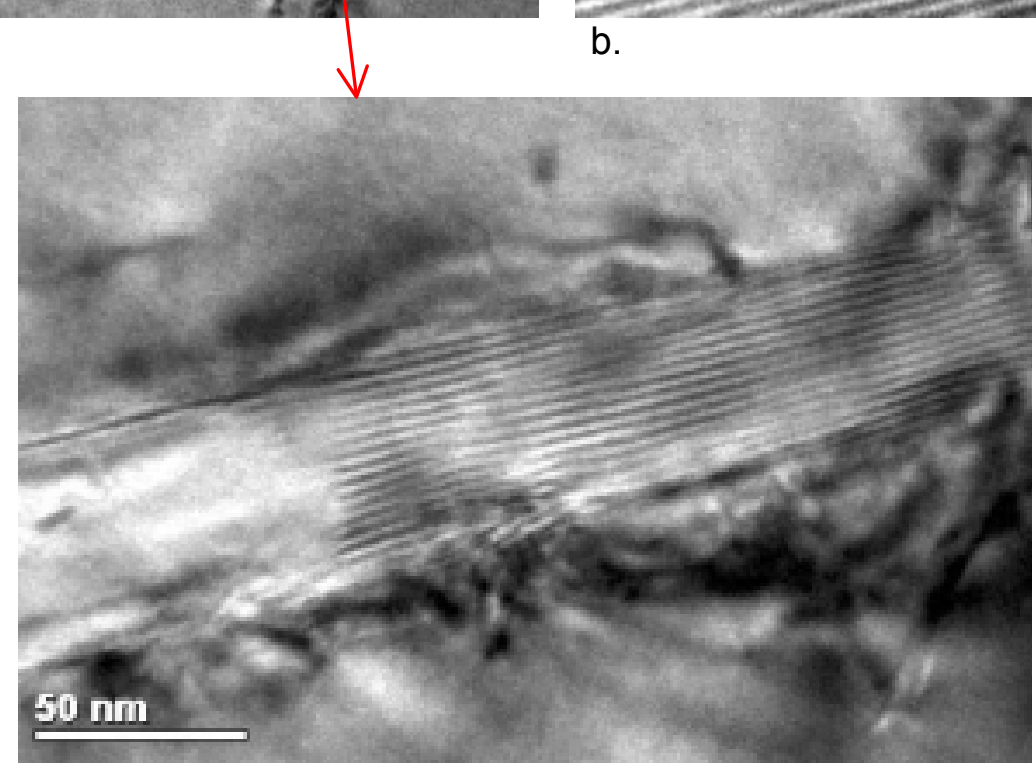

c.

Figura 81: Bastonete intragranular de $\mathrm{Cr}_{2} \mathrm{~N}$ apresentando franjas de Moiré. Em (a) vista geral, (b) imagem de reticulado da interface $\mathrm{Cr}_{2} \mathrm{~N} / \alpha$ e (c) detalhe das franjas de Moiré. AID UNS S32304. $1350^{\circ} \mathrm{C}$ por $5 \mathrm{~s}$.

Além das imagens de reticulado das interfaces $\mathrm{Cr}_{2} \mathrm{~N} / \alpha$, foram feitas imagens de melhor qualidade de cada uma destas fases em separado. Na Figura 82 são apresentadas as imagens da ferrita [111] e do $\mathrm{Cr}_{2} \mathrm{~N}$ [11100] com as suas respectivas transformadas de Fourier. No caso da imagem da ferrita é evidente a resolução atômica. 


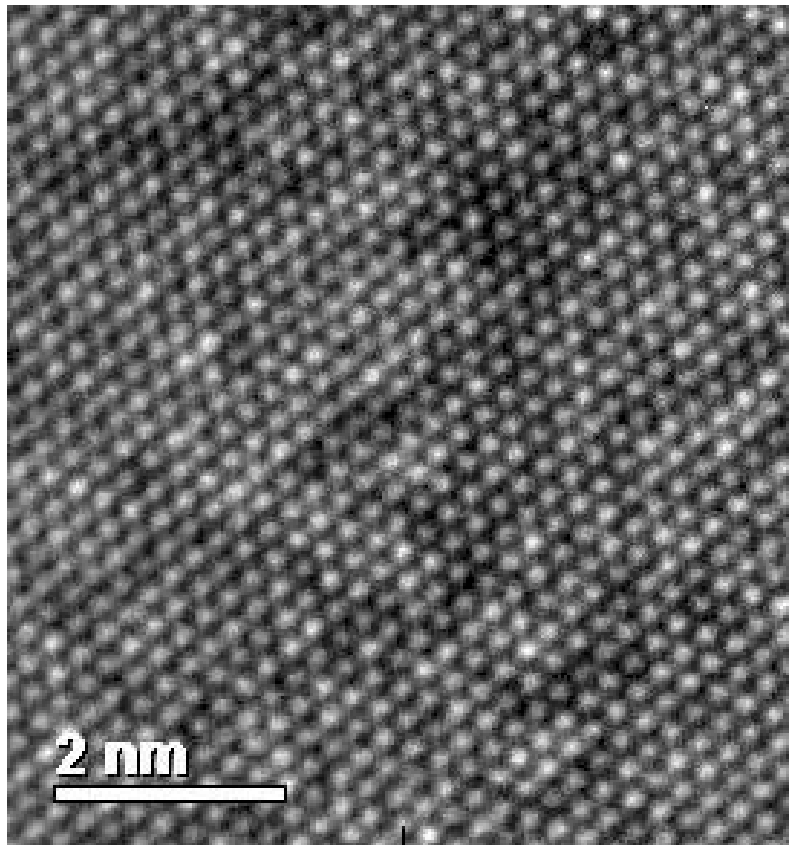

a.

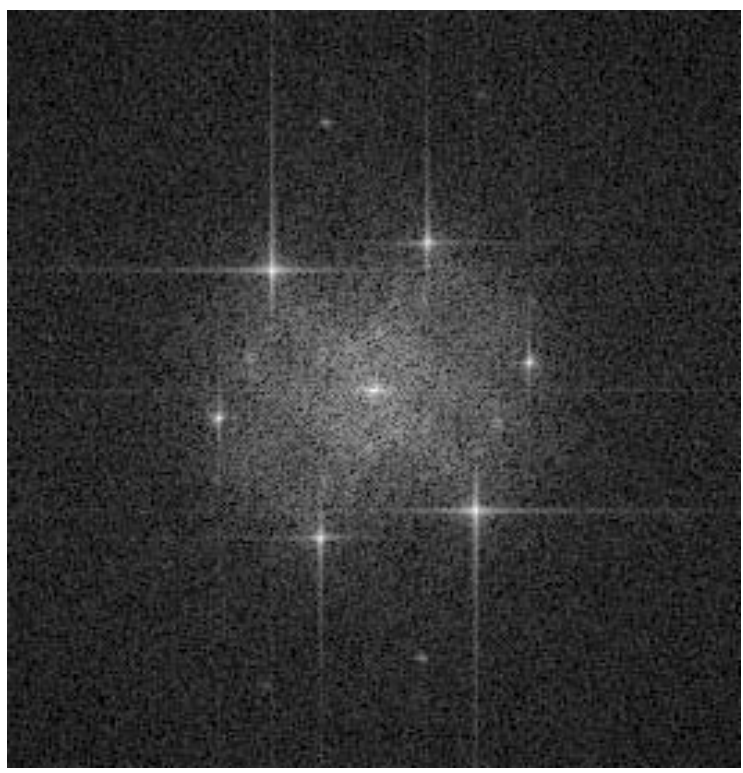

Ferrita [111]

c.

Figura 82: Imagens de reticulado da ferrita (a) e do $\mathrm{Cr}_{2} \mathrm{~N}$ (b) e as suas respectivas transformadas de Fourier em (c) e (d).

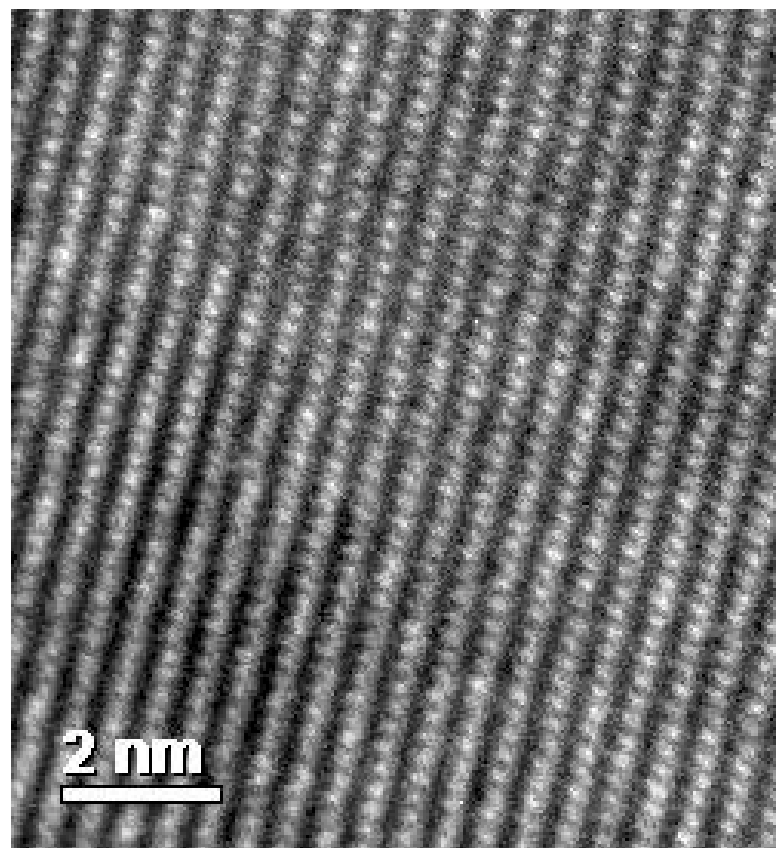

b.

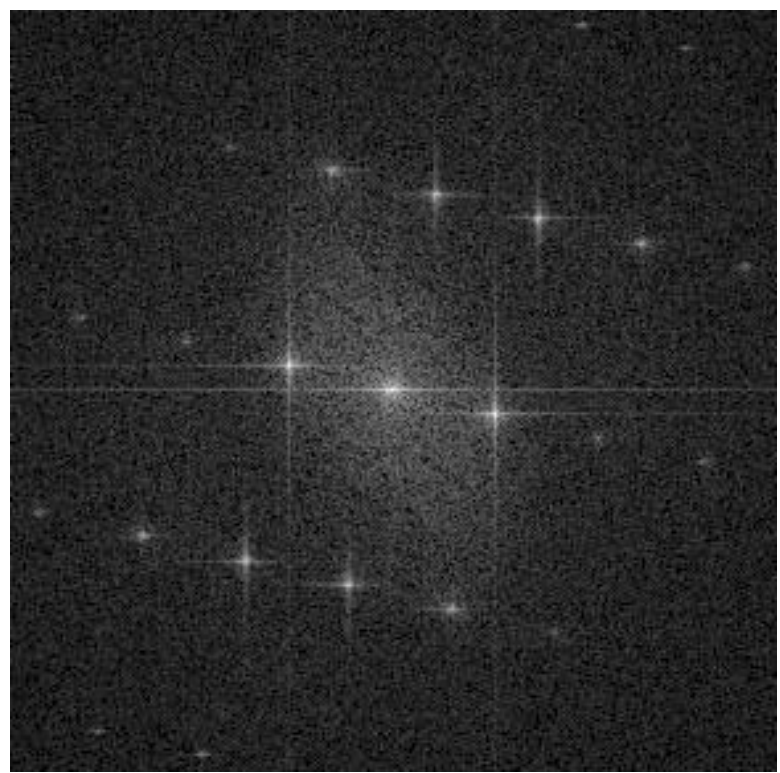

$\mathrm{Cr}_{2} \mathrm{~N}[\overline{1} 100]$

d.

Os bastonetes de $\mathrm{Cr}_{2} \mathrm{~N}$ apresentaram diferentes formatos. Nas micrografias apresentadas nas Figuras 83 e 84, são mostrados os dois formatos observados de bastonetes de $\mathrm{Cr}_{2} \mathrm{~N}$. Na primeira figura os $\mathrm{Cr}_{2} \mathrm{~N}$ têm um formato de bastonetes simples. Já na segunda figura, estes bastonetes apresentam uma clara bifurcação nas suas extremidades. Nas Figuras 85 e 86 são mostrados estes mesmos formatos dos bastonetes com uma maior definição, possibilitada pelo MET. 


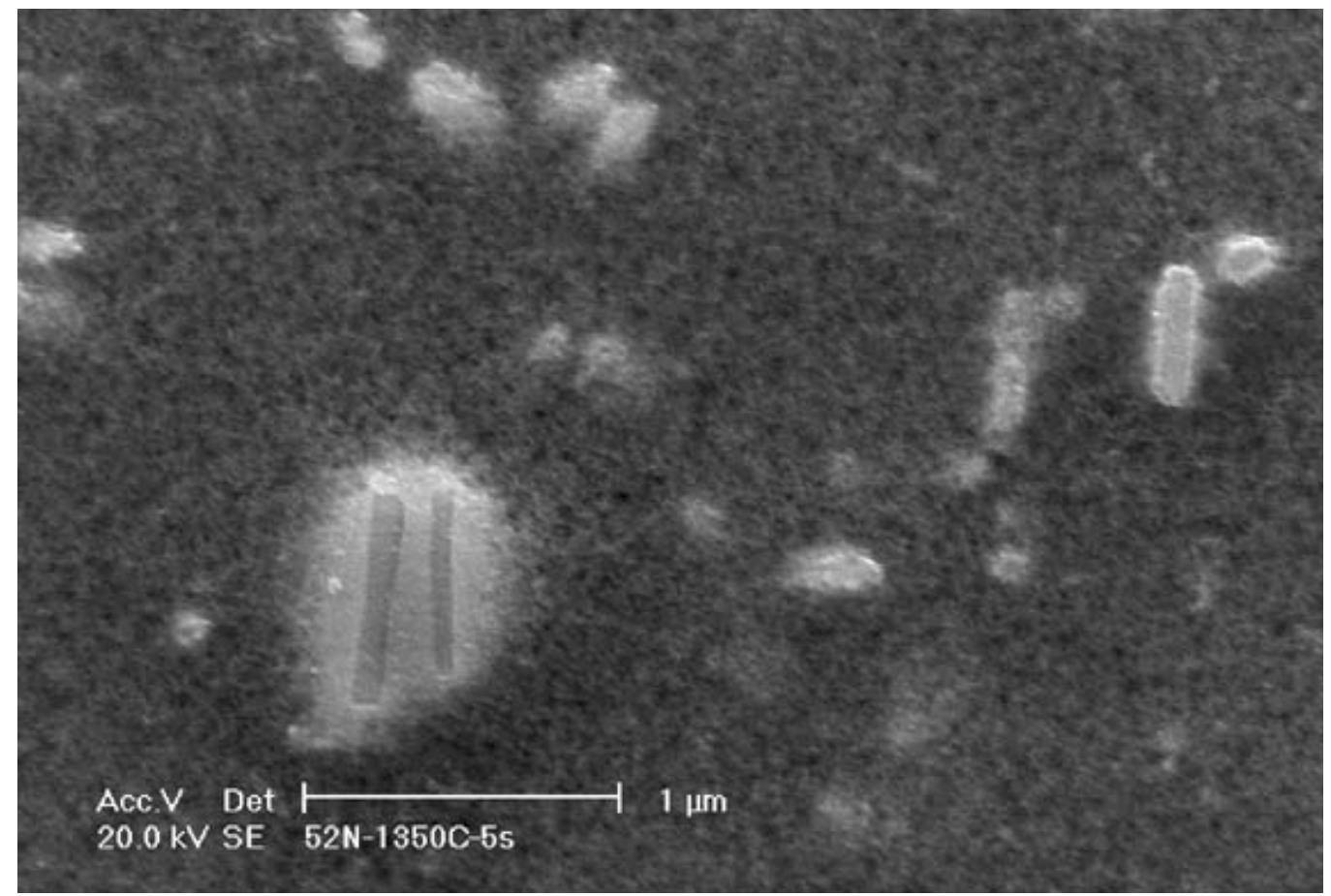

Figura 83: Bastonetes de $\mathrm{Cr}_{2} \mathrm{~N}$ precipitados no interior da ferrita no AISD UNS S32550. MEV-EC.

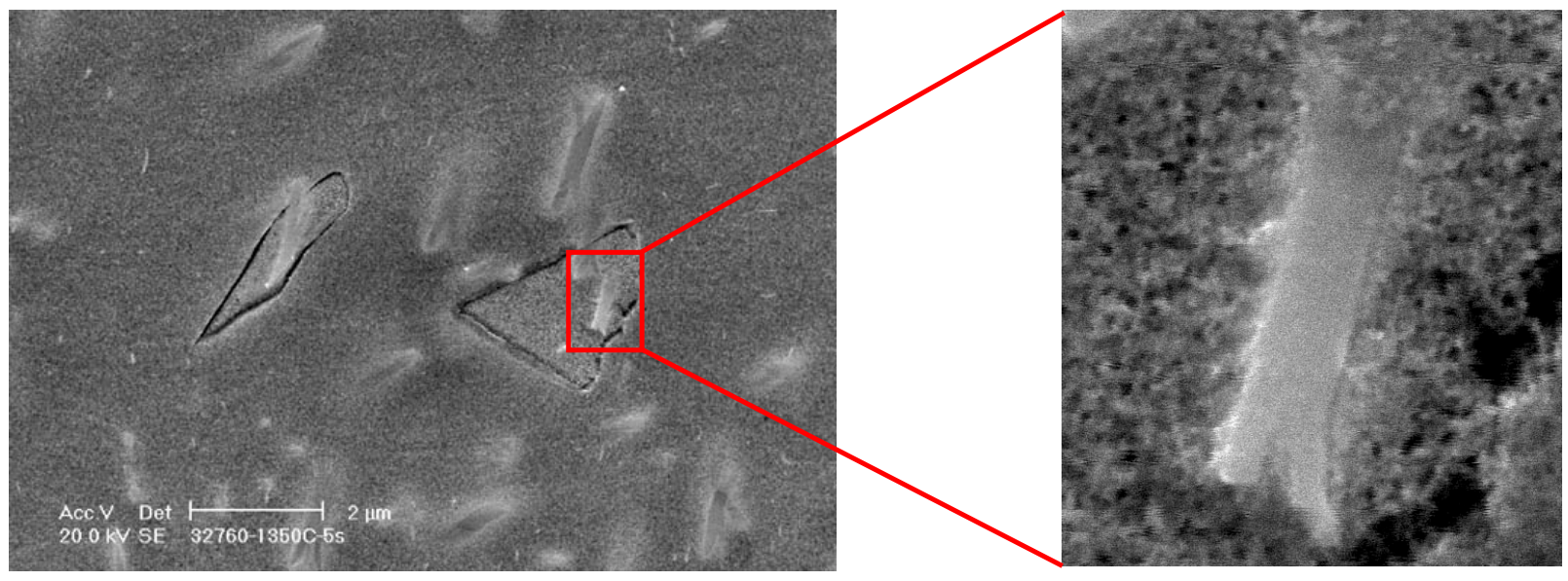

Figura 84: Micrografias de alta resolução dos bastonetes de $\mathrm{Cr}_{2} \mathrm{~N}$, com formato bifurcado, precipitados no interior da ferrita e da austenita. AISD UNS S32760. MEV-EC. 


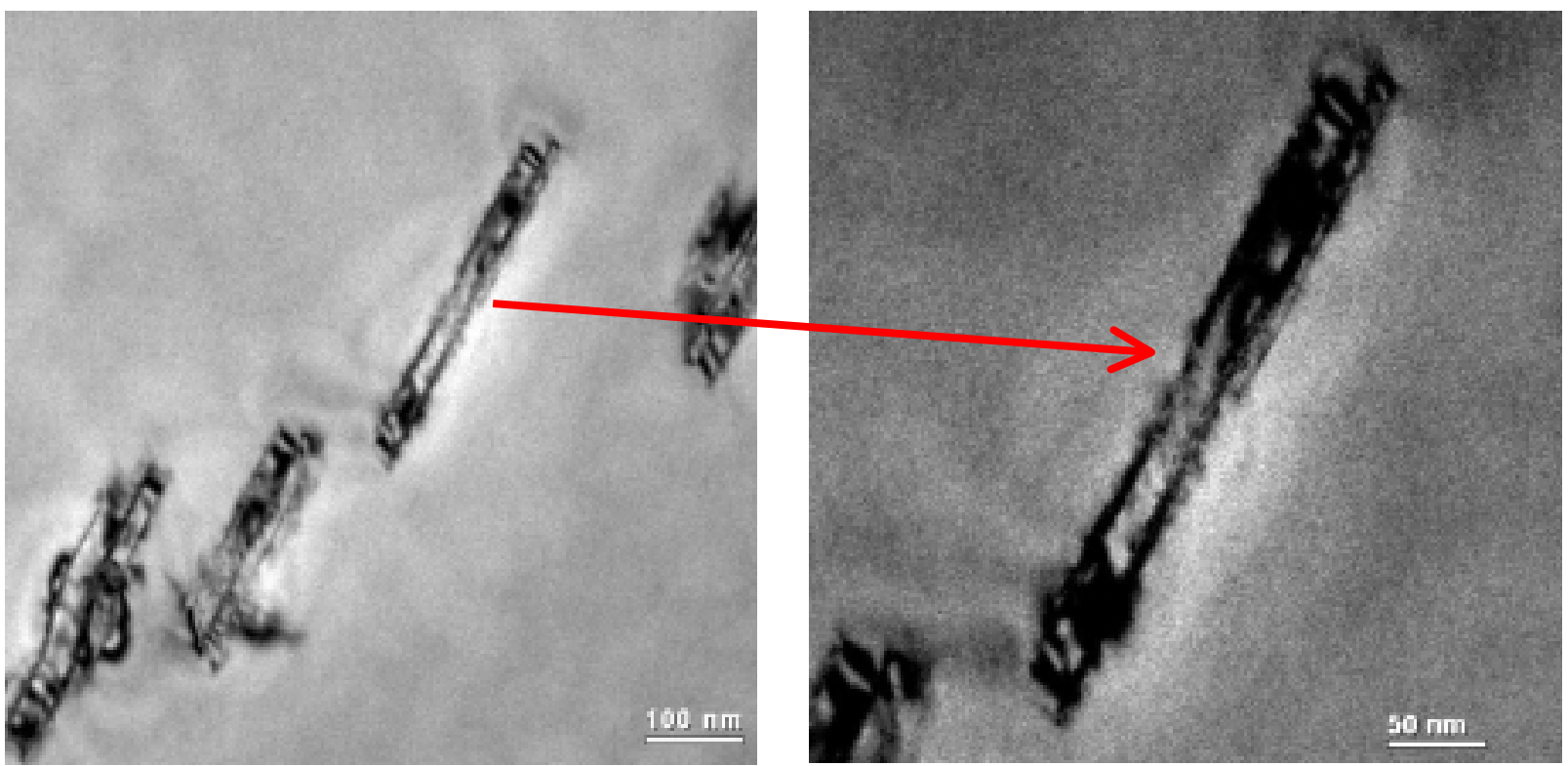

Figura 85: Precipitação de $\mathrm{Cr}_{2} \mathrm{~N}$ no interior da ferrita. AID UNS S32760. MET.

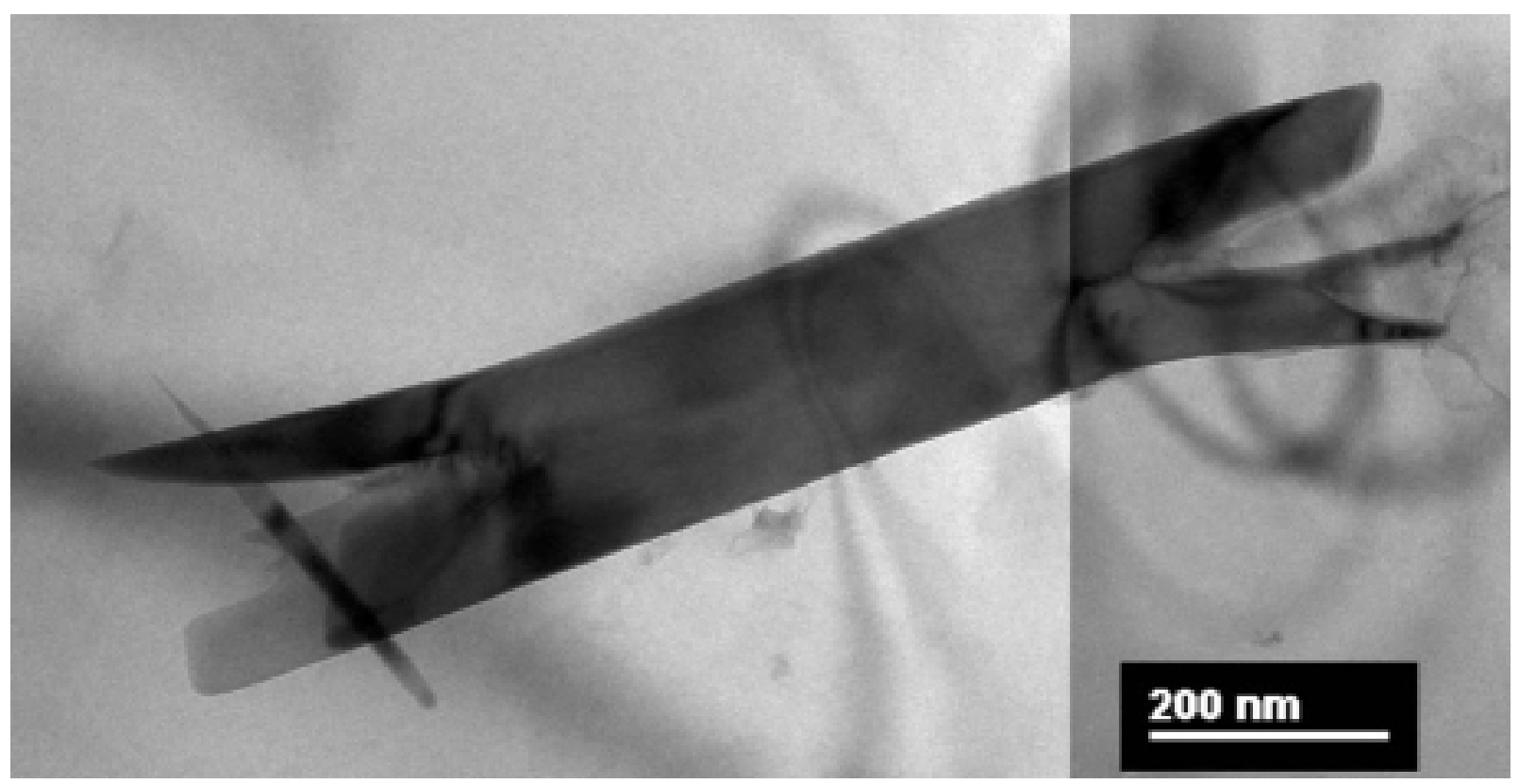

Figura 86: Precipitado bifurcado de $\mathrm{Cr}_{2} \mathrm{~N}$ no interior da ferrita. AID UNS S32760. MET.

Em termos gerais, o formato de bastonete dos precipitados de $\mathrm{Cr}_{2} \mathrm{~N}$ é devido à maior coerência da interface $\mathrm{Cr}_{2} \mathrm{~N} / \alpha$ ao longo do comprimento do bastonete, a qual está diretamente relacionada com a relação de orientação entre as duas faces. No caso da relação de orientação previamente reportada por KOKAWA et al. ${ }^{(58)}$, mostrada na Figura 71 , a direção [1 $\overline{2} 10$ ] do $\mathrm{Cr}_{2} \mathrm{~N}$ coincide com o eixo do bastonete e é paralelo as direções [001] ou [113] da ferrita, que resulta em uma interface com um grau de coerência maior ao longo do 
comprimento do precipitado do que nas suas extremidades. Isto explica a morfologia bifurcada apresentada pelos maiores bastonetes de $\mathrm{Cr}_{2} \mathrm{~N}$, nos quais a energia total associada à interface precipitado/matriz é diminuída mediante a redução da área dos extremos do bastonete. Área esta que é minimizada mediante a bifurcação do bastonete.

Além da redução da energia associada à interface, o formato de bastonete também pode vir a reduzir a deformação causada pelo precipitado no reticulado da matriz. Deformação que é evidenciada na Figura 86 pelos campos de tensão associados ao precipitado, que se estendem além da própria interface.

A composição química dos nitretos de cromo intragranulares foi determinada mediante análise de EDS no MET. Para poder realizar uma análise quantitativa do conteúdo metálico do $\mathrm{Cr}_{2} \mathrm{~N}$ no $\mathrm{MET}$ utilizou-se a própria ferrita de cada um dos CPs como material de referência. Desta forma, junto com os espectros de energia dispersiva correspondentes aos nitretos, foram adquiridos espectros das matrizes ferríticas, isto com as mesmas condições de operação do MET, de forma tal que a correção se torna mais precisa. Estas análises foram realizadas com feixes de 5, 10 e $25 \mathrm{~nm}$ de diâmetro, dependendo do tamanho da partícula e da região que estava sendo analisada. Aqui vale a pena chamar a atenção para o fato da estatística e a resolução espacial da medida serem antagônicas. Portanto, o menor tamanho de feixe somente foi utilizado nos casos nos quais foi considerado absolutamente necessário, por exemplo, para a análise das interfaces. Na Tabela 32 são apresentados os resultados destas medidas. Dependendo do tamanho do precipitado analisado, da sua localização no CP e da própria espessura do $C P$, as medidas são mais ou menos contaminadas pelo sinal da matriz. No caso das medidas realizadas, a do AID UNS S32550 foi a que apresentou a menor contaminação, seguida pelas medidas no AISD UNS S32304. Nestes casos foi possível analisar precipitados que se encontravam exatamente na borda da amostra (ver Figuras 76 e 80). Assim, a contaminação da medida com sinal da matriz foi quase totalmente eliminada. Já no caso do AISD UNS S32760, as partículas analisadas eram bastante grandes, mas não foram encontradas na borda da amostra (ver Figura 86). Desta forma, os teores de $\mathrm{Fe}$ e $\mathrm{Ni}$ medidos nestes precipitados mostram que houve uma grande influência da matriz na medida.

Como pode ser observado na Tabela 32 no caso do AID UNS S32304 (baixo teor de Mo), a parte metálica do $\mathrm{Cr}_{2} \mathrm{~N}$ é formada de $90 \%$ de $\mathrm{Cr}, 9 \%$ de $\mathrm{Fe}$ e o $1 \%$ restante de outros elementos. Já nos AISD UNS S32550 e S32760, uma parte importante do Cr é substituído por Mo. Quanto ao Ni e Cu, a sua solubilidade no nitreto mostrou-se bastante baixa. O W e o Si não apresentaram uma partição preferencial, ao contrário do $\mathrm{V}$, elemento cujo teor no nitreto foi 10 vezes maior que na matriz, chegando a teores ao redor de $1 \%$ para os AISD. 
Tabela 32: Composição química da fração metálica dos nitretos de cromo $\left(\mathrm{Cr}_{2} \mathrm{~N}\right)$ precipitados no interior da ferrita dos AIDs UNS S32304, S32550 e S32760.

\begin{tabular}{|c|c|c|c|c|c|c|}
\hline \multirow{2}{*}{ Elemento } & \multicolumn{2}{|c|}{ UNS S32304 } & \multicolumn{2}{c|}{ UNS S32550 } & \multicolumn{2}{c|}{ UNS S32760 } \\
\cline { 2 - 7 } & Ferrita & $\mathbf{C r}_{2} \mathbf{N}$ & Ferrita & $\mathbf{C r}_{2} \mathbf{N}$ & Ferrita & $\mathbf{C r}_{2} \mathbf{N}^{*}$ \\
\hline $\mathrm{Cr}$ & $23,98 \pm 0,23$ & $89,93 \pm 0,87$ & $27,01 \pm 0,29$ & $78,97 \pm 2,47$ & $26,20 \pm 0,35$ & $63,36 \pm 6,09$ \\
\hline $\mathrm{Fe}$ & $70,37 \pm 0,18$ & $8,81 \pm 0,87$ & $61,27 \pm 0,22$ & $11,12 \pm 1,43$ & $62,39 \pm 0,25$ & $26,52 \pm 6,10$ \\
\hline $\mathrm{Ni}$ & $4,64 \pm 0,09$ & $0,18 \pm 0,04$ & $6,08 \pm 0,23$ & $0,70 \pm 0,38$ & $6,52 \pm 0,19$ & $2,39 \pm 0,53$ \\
\hline $\mathrm{Mo}$ & $0,29 \pm 0,04$ & $0,30 \pm 0,10$ & $3,74 \pm 0,10$ & $7,49 \pm 0,69$ & $3,49 \pm 0,10$ & $5,27 \pm 0,86$ \\
\hline $\mathrm{W}$ & - & - & - & - & $0,55 \pm 0,05$ & $0,61 \pm 0,11$ \\
\hline $\mathrm{Cu}$ & $0,37 \pm 0,07$ & $0,04 \pm 0,02$ & $1,63 \pm 0,14$ & $0,36 \pm 0,23$ & $0,65 \pm 0,08$ & $0,28 \pm 0,13$ \\
\hline $\mathrm{Si}$ & $0,36 \pm 0,01$ & $0,32 \pm 0,19$ & $0,26 \pm 0,03$ & $0,37 \pm 0,27$ & $0,19 \pm 0,02$ & $0,08 \pm 0,01$ \\
\hline $\mathrm{V}$ & $0,069 \pm 0,006$ & $0,42 \pm 0,06$ & $0,098 \pm 0,004$ & $0,99 \pm 0,08$ & $0,141 \pm 0,005$ & $1,50 \pm 0,07$ \\
\hline
\end{tabular}

Notas: * Esta medida apresentou uma considerável contaminação com a matriz ferrítica.

\subsection{Precipitação de $\mathrm{Cr}_{2} \mathrm{~N}$ na interface $\alpha / \gamma$}

Além da precipitação de bastonetes de $\mathrm{Cr}_{2} \mathrm{~N}$ no interior da ferrita, a precipitação de nitretos também foi verificada nas interfaces $\alpha / \gamma$. Este tipo de precipitação foi observado esporadicamente nas ligas UNS S32304, S32550 e S32760.

Estes precipitados mostraram-se bastante pequenos para serem identificados no estudo com o MEV-EC dos CPs tratados a $1350{ }^{\circ} \mathrm{C}$ por 5 ou $10 \mathrm{~s}$. Na Figura 87 são mostrados estes precipitados na interface $\gamma / \alpha$, no caso do AID UNS S32304.

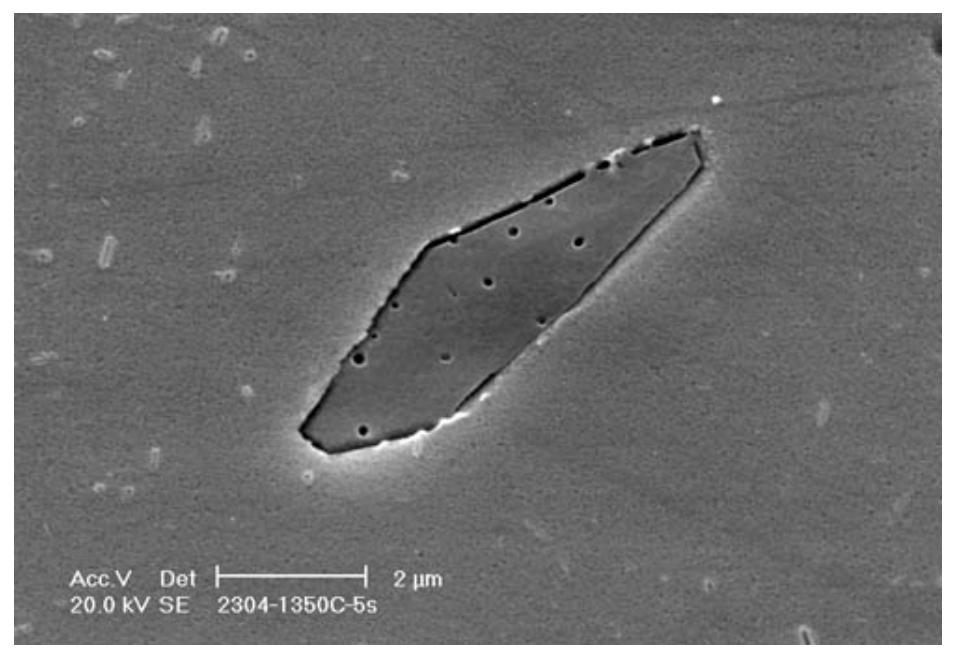

Figura 87: Precipitação na interface $\gamma / \alpha$. AID UNS S32304. MEV-EC.

Estes mesmos precipitados foram observados e identificados mediante difração de elétrons no MET. Na Figura 88 é mostrada uma interface $\alpha / \gamma$ decorada com precipitados de $\mathrm{Cr}_{2} \mathrm{~N}$ e na 
Figura 89 e apresentado o detalhe de uma destas partículas junto com a sua difração de elétrons com feixe convergente, em ambos casos no AID UNS S32304. Nesta última figura pode-se observar como este precipitado, que foi o maior encontrado nesta interface, está exercendo o efeito de ancoramento da interface (Zener Pinning). O espaçamento entre as franjas de Moiré $\left(d_{m}\right)$ formadas pelos precipitados que se encontram do lado da $\gamma$ é de aproximadamente $1,7 \mathrm{~nm}$, que é um valor muito perto do $d_{m}$ calculado de $1,9 \mathrm{~nm}$ quando os planos (111) $\gamma$ e (0002) $\mathrm{Cr}_{2} \mathrm{~N}$ são paralelos. O valor de $\mathrm{d}_{1}=0,25443 \mathrm{~nm}$ (111) $\gamma$ foi determinado para o AID UNS $S 32304$ mediante difração de raios $X^{(132)}$ e o valor de $d_{2}=0,22420 \mathrm{~nm}$ (0002) $\mathrm{Cr}_{2} \mathrm{~N}$ foi determinado a partir dos dados da tabela JCPDS No. 35-803.

Outros precipitados semelhantes aos anteriormente mencionados foram achados em outras interfaces $\alpha / \gamma$ no AID UNS S32304 e são mostrados na Figura 90. Neste caso os precipitados encontram-se parcialmente dentro da ferrita, ao contrário dos mostrados na Figura 88 , que estavam quase totalmente do lado da austenita.

As franjas de Moiré formadas nos precipitados da Figura 90, estão do lado da austenita e o seu $d_{m}$ é de aproximadamente $1,8 \mathrm{~nm}$. O que indica uma possível relação de orientação

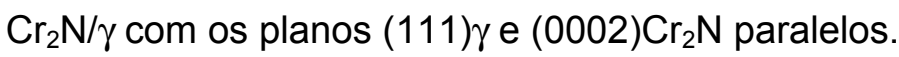

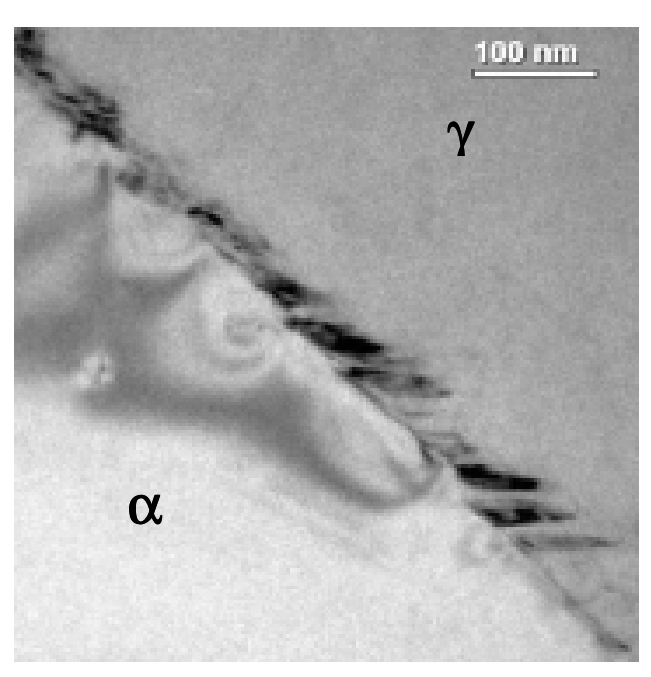

Figura 88: Interface $\alpha / \gamma$ decorada com precipitados de $\mathrm{Cr}_{2} \mathrm{~N}$. AID UNS S32304. MET.

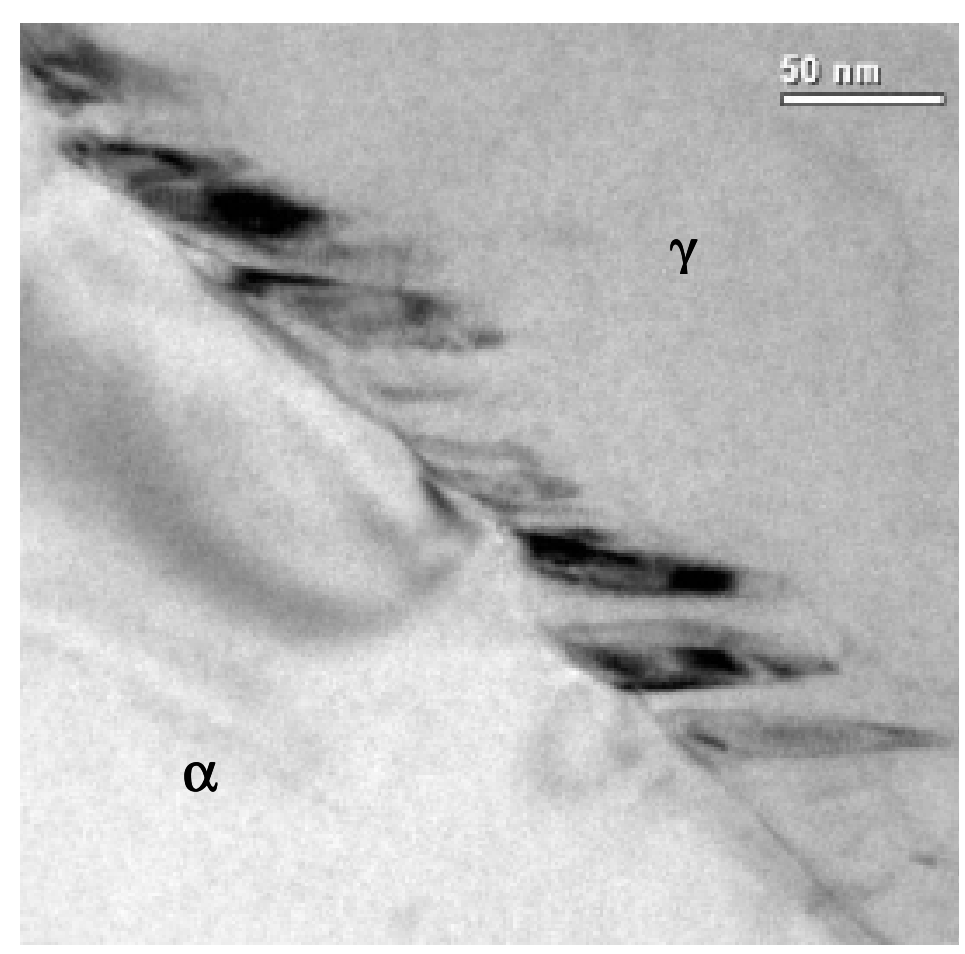



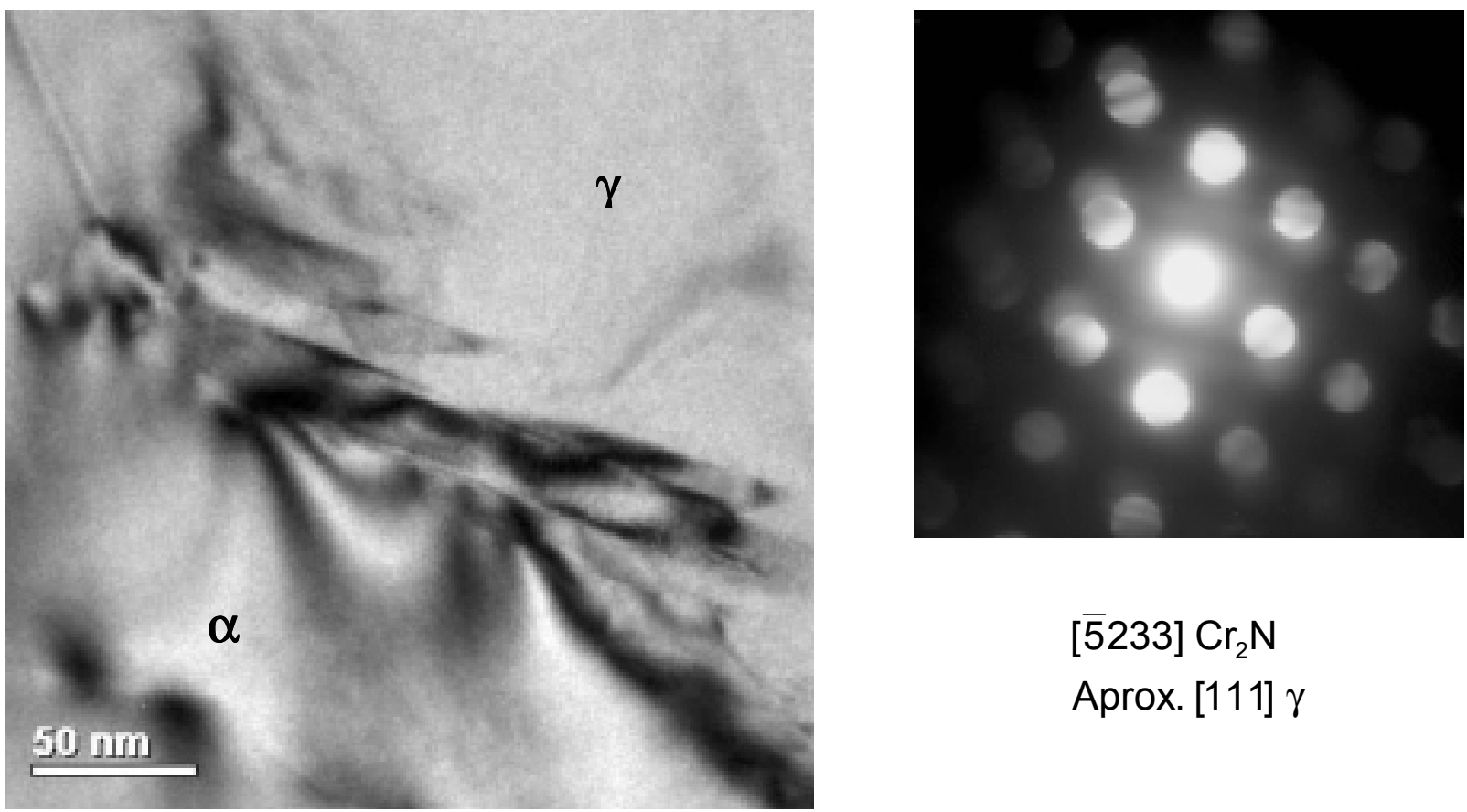

[5233] $\mathrm{Cr}_{2} \mathrm{~N}$

Aprox. [111] $\gamma$

Figura 89: Partícula de $\mathrm{Cr}_{2} \mathrm{~N}$ precipitada na interface $\alpha / \gamma$ identificada mediante difração de elétrons com feixe convergente. AID UNS S32304. MET.
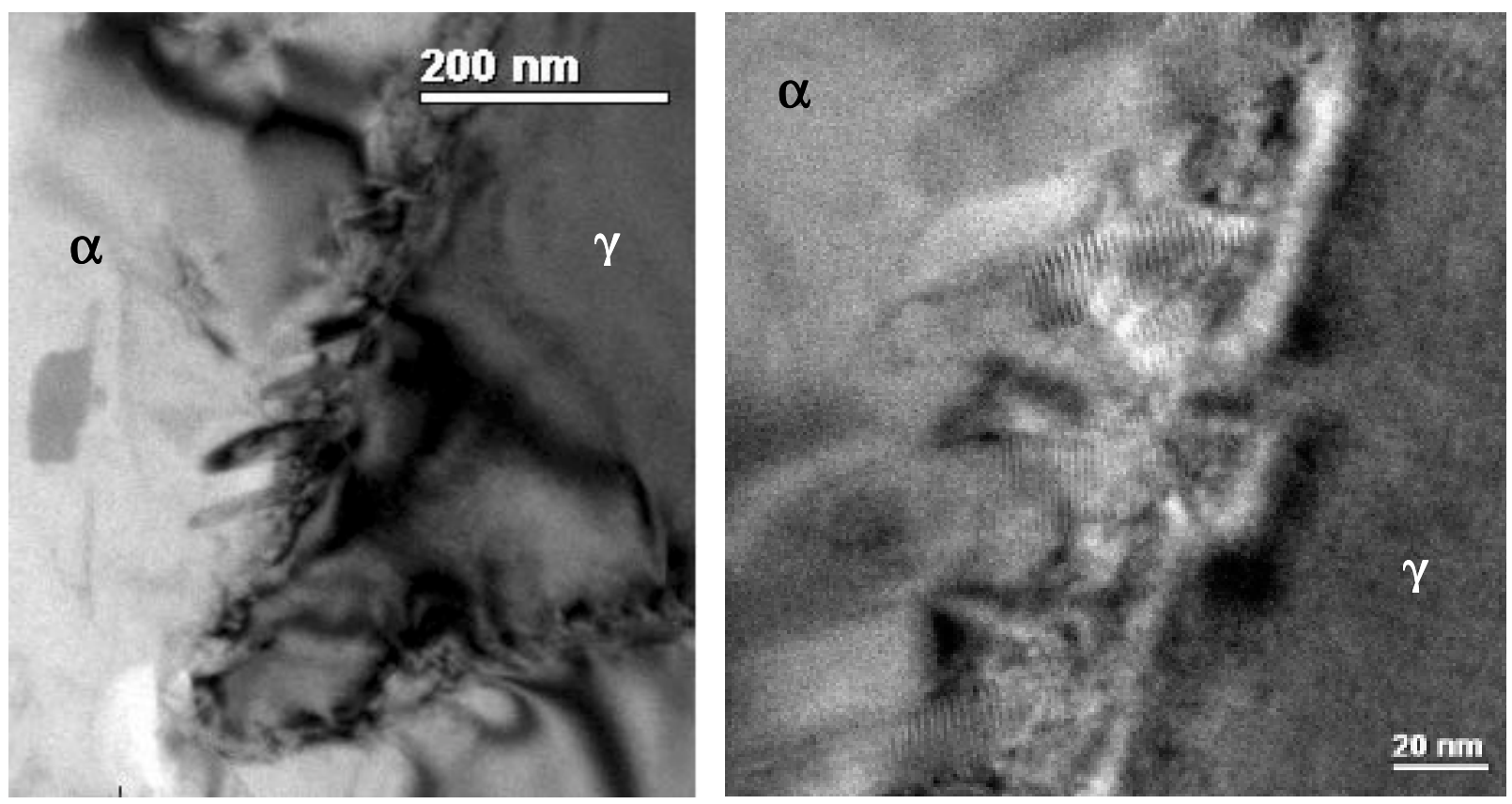

Figura 90: Interface $\alpha / \gamma$ decorada com precipitados de $\mathrm{Cr}_{2} \mathrm{~N}$ e detalhe das franjas de Moiré formadas pelos precipitados. AID UNS S32304. MET.

No mesmo material UNS S32304 foram encontradas partículas de $\mathrm{Cr}_{2} \mathrm{~N}$ precipitadas nas interfaces $\alpha / \gamma$, com um formato ligeiramente diferente do mostrado até agora. Estes podem ser observados na Figura 91. Nesta figura, pode-se ver como o precipitado apresenta uma 
clara relação de orientação com a ferrita. O valor de $d_{m}$ medido é de 2,20 e o $d_{m}$ para os planos (110) $\alpha$ e (0002) $\mathrm{Cr}_{2} \mathrm{~N}$ sendo paralelos é de $2,29 \mathrm{~nm}$, o que vem confirmar a relação de orientação $\mathrm{Cr}_{2} \mathrm{~N} / \alpha$ para estes precipitados.

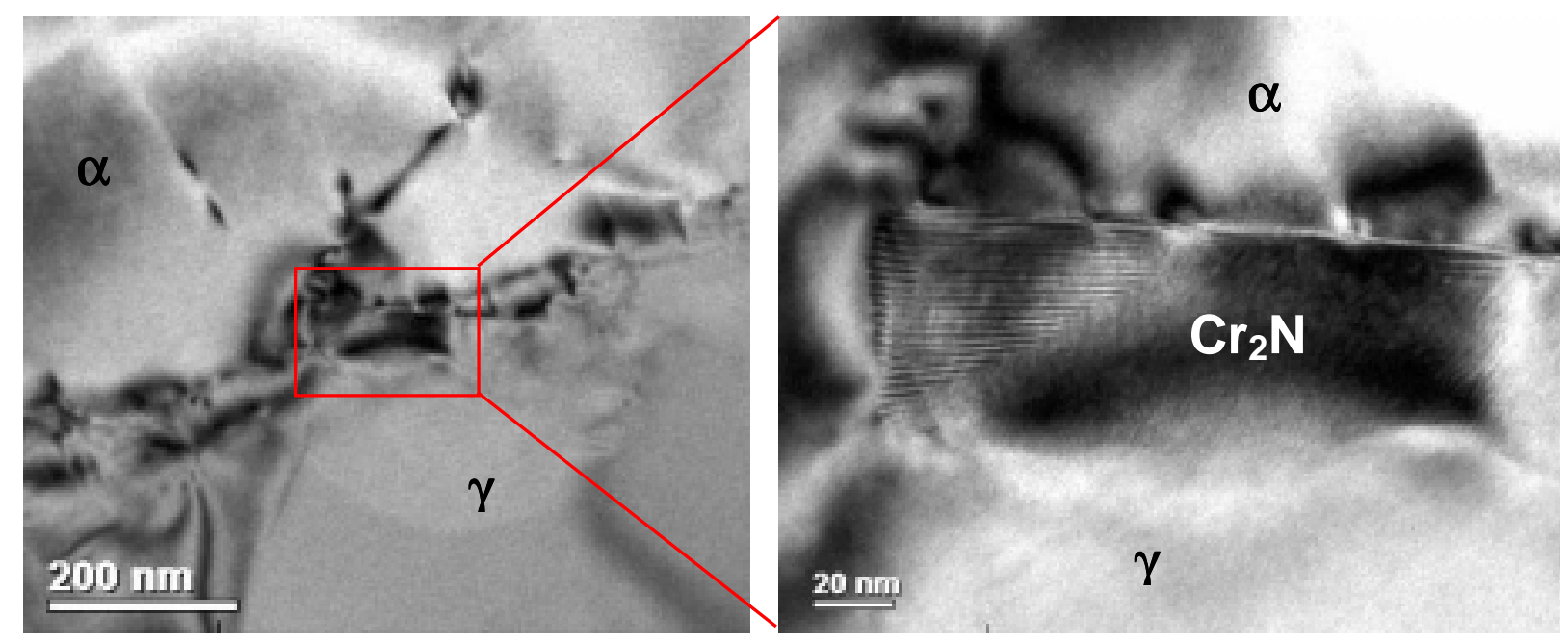

Figura 91: $\mathrm{Cr}_{2} \mathrm{~N}$ precipitado na interface $\alpha / \gamma$, apresentando uma clara relação de orientação com a ferrita. UNS S32304. MET.

No caso do AISD UNS $S 32550$ a precipitação de $\mathrm{Cr}_{2} \mathrm{~N}$ nas interfaces $\alpha / \gamma$ também foi observada no MET. Na Figura 92 é apresentada uma destas interfaces decorada com precipitados de $\mathrm{Cr}_{2} \mathrm{~N}$. Neste caso verifica-se as seguintes relações de orientação entre as fases presentes $\alpha, \gamma$ e $\mathrm{Cr}_{2} \mathrm{~N}$ :

$$
\begin{aligned}
& (110) \alpha \|(0001) \mathrm{Cr}_{2} \mathrm{~N} \\
& {[\overline{1} 11] \alpha \|[\overline{1} 100] \mathrm{Cr}_{2} \mathrm{~N}}
\end{aligned}
$$

- Esta é a mesma relação de orientação $\mathrm{Cr}_{2} \mathrm{~N} / \alpha$ mostrada pelos precipitados intragranulares e quando expressa em termos do reticulado hcp é equivalente à relação de Burgers.

$$
\begin{aligned}
& (111) \gamma \|(0001) \mathrm{Cr}_{2} \mathrm{~N} \\
& {[\overline{1} 10] \gamma \|[\overline{1} 100] \mathrm{Cr}_{2} \mathrm{~N}}
\end{aligned}
$$

- Esta relação de orientação $\mathrm{Cr}_{2} \mathrm{~N} / \gamma$ é a mesma previamente reportada por RAYAPROLU; HENDRY ${ }^{(133)}$ no caso da precipitação celular de $\mathrm{Cr}_{2} \mathrm{~N}$ num aço inoxidável austenítico (Nitronic 50) com elevado teor de nitrogênio, submetido a envelhecimento a $1000^{\circ} \mathrm{C}$. 


$$
\begin{aligned}
& (111) \gamma \|(110) \alpha \\
& {[\overline{1} 10] \gamma \|[\overline{1} 11] \alpha}
\end{aligned}
$$

- Esta é a relação de orientação de Kurdjumov-Sachs. Vale a pena ressaltar que esta mesma relação de orientação $\alpha / \gamma$ foi verificada em outras interfaces estudadas em todas as ligas. No entanto esta não foi a única relação de orientação $\alpha / \gamma$ observada, pois em vários casos foi registrada a relação $\alpha / \gamma$ de Nishiyama-Wasserman.

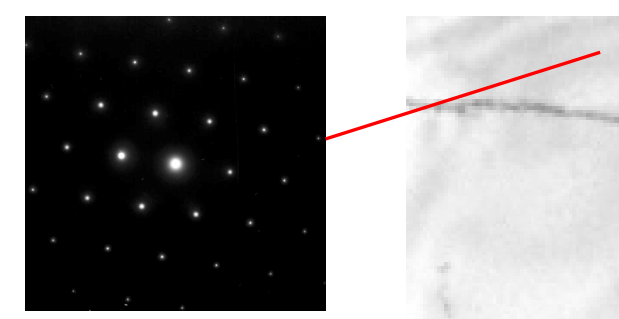

[111] $\alpha$

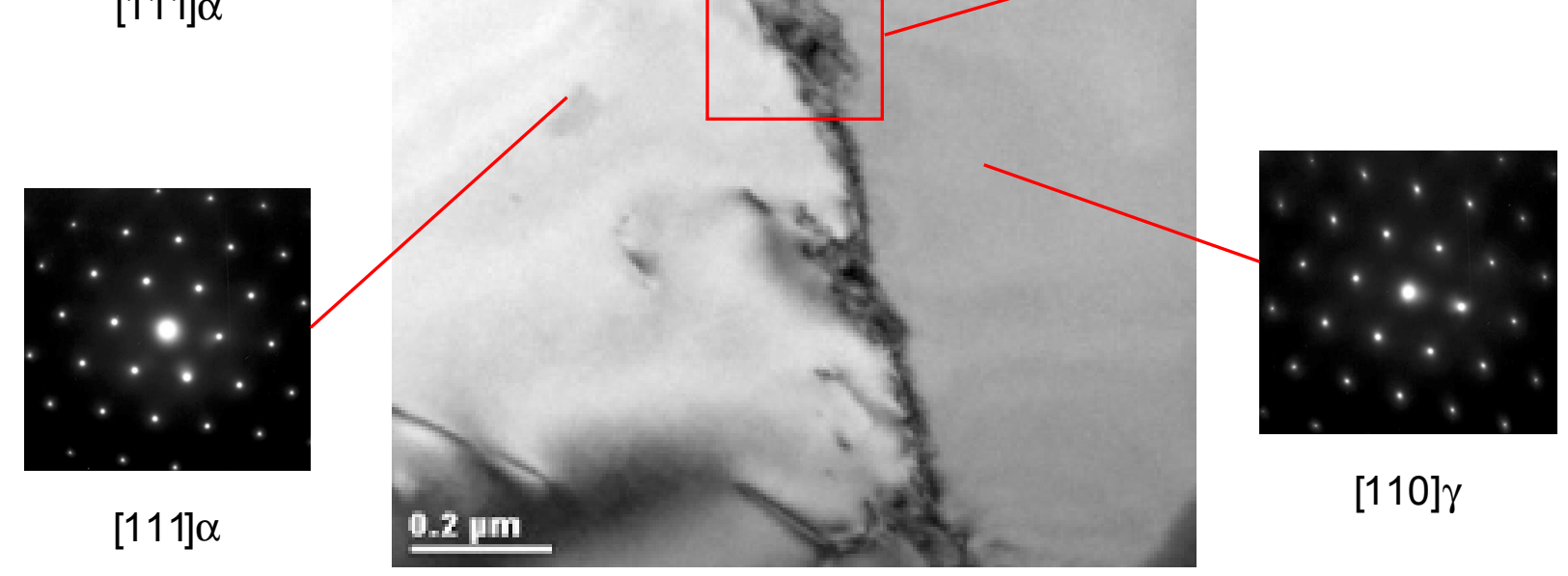

Figura 92: Interface $\alpha / \gamma$ decorada com precipitados de $\mathrm{Cr}_{2} \mathrm{~N}$. UNS S32550. MET.

Na Figura 94 é apresentado o padrão de difração destas partículas (Figuras 92 e 93), junto com a sua indexação, no qual aparecem juntos os padrões da ferrita e a austenita e onde podem-se verificar as relações de orientação mencionadas anteriormente, as quais podem ser resumidas da seguinte forma:

$$
\begin{aligned}
& (111) \gamma\|(110) \alpha\|(0001) \mathrm{Cr}_{2} \mathrm{~N} \\
& {[\overline{1} 10] \gamma\|[\overline{1} 11] \alpha\|[\overline{1} 100] \mathrm{Cr}_{2} \mathrm{~N}}
\end{aligned}
$$

Portanto, existe uma relação de orientação entre as três fases, de modo que os planos mais compactos das três fases $(111) \gamma,(110) \alpha$ e $(0001) \mathrm{Cr}_{2} \mathrm{~N}$ são paralelos. Esta relação de orientação é consistente com os outros resultados apresentados, onde sempre se verificou o paralelismo entre os planos mais compactos das fases $\left(\mathrm{Cr}_{2} \mathrm{~N}, \alpha\right.$ e $\left.\gamma\right)$. 

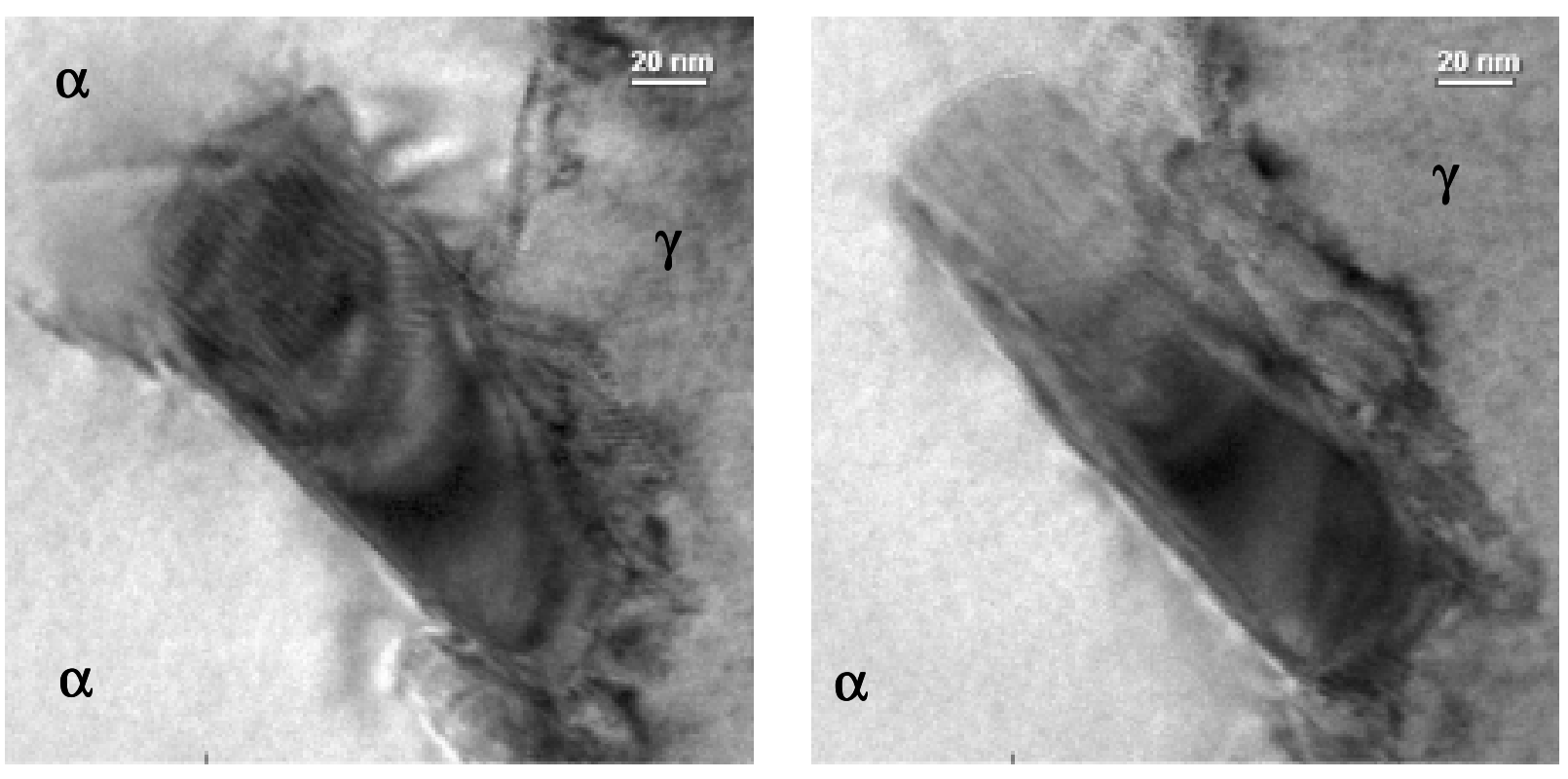

Figura 93: Precipitados de $\mathrm{Cr}_{2} \mathrm{~N}$ na interface $\alpha / \gamma$. AISD UNS S32550. MET.
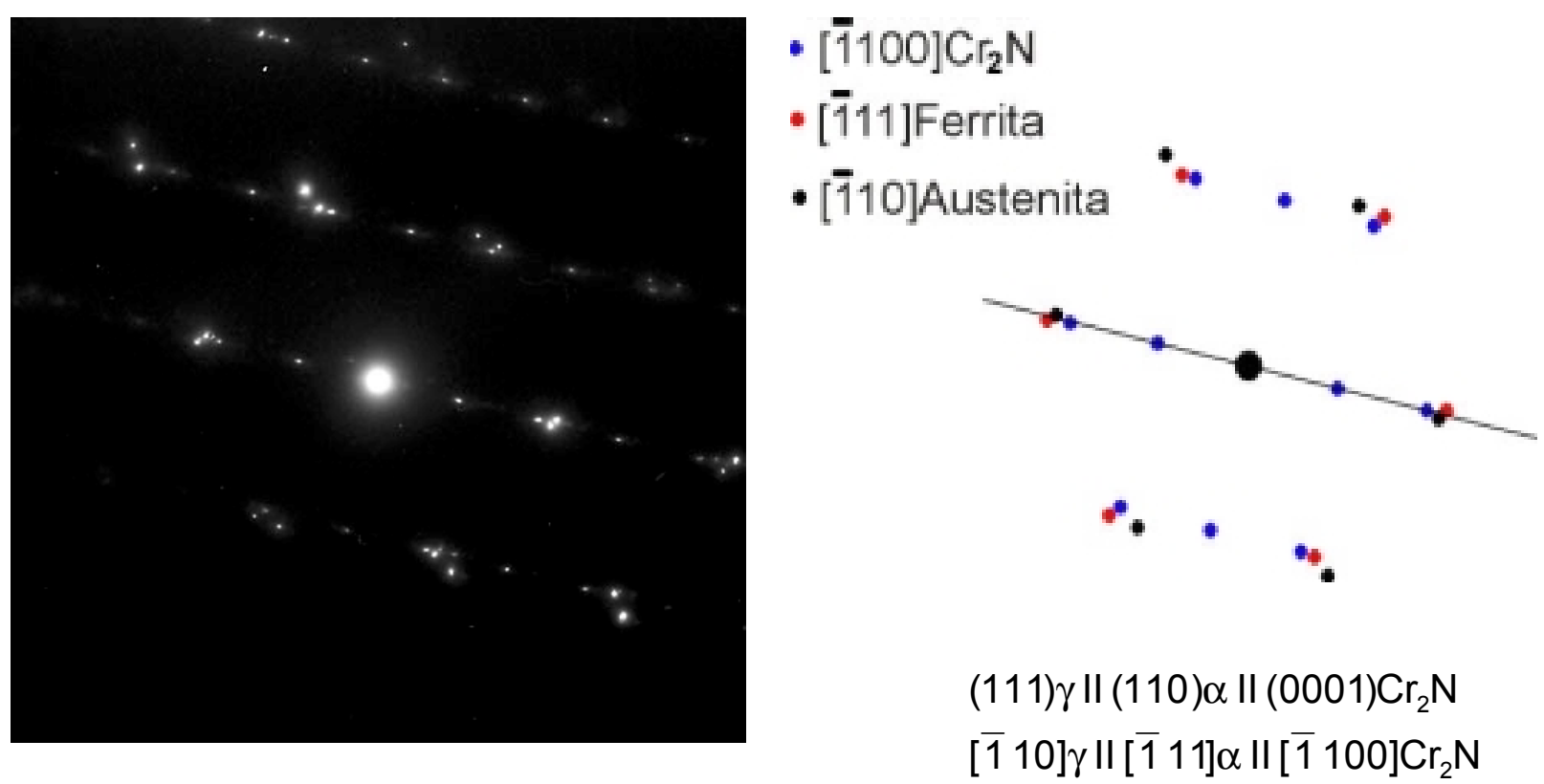

Figura 94: Padrão de difração de elétrons dos precipitados intragranulares de $\mathrm{Cr}_{2} \mathrm{~N}$ mostrados nas duas figuras anteriores. Relação de orientação $\mathrm{Cr}_{2} \mathrm{~N} / \alpha / \gamma$. AISD UNS S32550. MET.

Desta forma, o grau de coerência das interfaces geradas na precipitação de $\mathrm{Cr}_{2} \mathrm{~N}$ nas interfaces $\alpha / \gamma$ vem a facilitar a precipitação desta fase neste sítio.

A composição química da fração metálica dos nitretos de cromo precipitados nas interfaces $\alpha / \gamma$ também foi determinada mediante EDS no MET, conforme mostra a Tabela 33. Devido ao reduzido tamanho destas partículas, as medidas em geral apresentaram contaminação do 
espectro com sinal proveniente da ferrita e da austenita. A interferência da matriz nas medidas dos $\mathrm{Cr}_{2} \mathrm{~N}$ tanto intra- como inter-granulares não permite fazer uma comparação das duas composições químicas para estabelecer possíveis diferenças. No entanto, pode-se apontar facilmente as similaridades na composição química de ambos tipos de nitretos:

- O elemento predominante é o $\mathrm{Cr}$ (ao redor de $80 \%$ );

- Baixíssimo conteúdo de $\mathrm{Ni}$;

- Elevado conteúdo de Mo no caso dos AIDs que contém este elemento;

- Baixo conteúdo de Cu quando comparado com o teor da liga;

- Elevado teor de V. Seu conteúdo é proporcional ao teor deste elemento no aço.

Analisando do pondo de vista da composição química, não foi observada nenhuma diferença importante entre os nitretos intra e inter-granulares.

Tabela 33: Composição química da fração metálica dos nitretos de cromo $\left(\mathrm{Cr}_{2} \mathrm{~N}\right)$ precipitados nas interfaces $\alpha / \gamma$ dos AIDs UNS S32304 e S32550 tratados a $1350^{\circ} \mathrm{C}$ por $5 \mathrm{~s}$.

\begin{tabular}{|c|c|c|c|c|}
\hline \multirow{2}{*}{ Elemento } & \multicolumn{2}{|c|}{ UNS S32304 } & \multicolumn{2}{|c|}{ UNS S32550 } \\
\hline & Ferrita & $\mathrm{Cr}_{2} \mathrm{~N}^{*}$ & Ferrita & $\mathrm{Cr}_{2} \mathrm{~N}^{*}$ \\
\hline $\mathrm{Cr}$ & $23.98 \pm 0.23$ & $81.01 \pm 5.44$ & $27.01 \pm 0.29$ & $78.14 \pm 3.34$ \\
\hline $\mathrm{Fe}$ & $70.37 \pm 0.18$ & $16.41 \pm 5.01$ & $61.27 \pm 0.22$ & $12.85 \pm 3.31$ \\
\hline $\mathrm{Ni}$ & $4.64 \pm 0.09$ & $0.96 \pm 0.43$ & $6.08 \pm 0.23$ & $0.89 \pm 0.32$ \\
\hline Mo & $0.29 \pm 0.04$ & $0.83 \pm 0.42$ & $3.74 \pm 0.10$ & $7.07 \pm 0.57$ \\
\hline $\mathrm{Cu}$ & $0.37 \pm 0.07$ & $0.09 \pm 0.07$ & $1.63 \pm 0.14$ & $0.28 \pm 0.06$ \\
\hline $\mathrm{Si}$ & $0.36 \pm 0.01$ & $0.35 \pm 0.13$ & $0.26 \pm 0.03$ & $0.09 \pm 0.02$ \\
\hline V & $0.069 \pm 0,006$ & $0.35 \pm 0.13$ & $0.098 \pm 0.004$ & $0.68 \pm 0.11$ \\
\hline
\end{tabular}

Além da composição química dos nitretos foi levantado também o perfil de composição através da interface $\alpha / \gamma$ contendo nitretos e também livre dos mesmos. Na Figura 95 são mostrados os pontos nos quais as medidas foram feitas. Os pontos vermelhos correspondem as medidas através da interface $\alpha / \gamma$ contendo um precipitado de $\mathrm{Cr}_{2} \mathrm{~N}$, que foram feitas exatamente nas regiões indicadas. Já no caso dos pontos azuis, isto é, as medidas através da interface $\alpha / \gamma$ (sem nitretos), as medidas foram feitas na mesma interface e às distâncias da interface mostradas esquematicamente na figura. Mas estas medidas foram realizadas numa região bem mais longe dos precipitados. Em cada um dos pontos foi realizada somente uma medida e os resultados são apresentados nas Tabelas 34 e 35. 


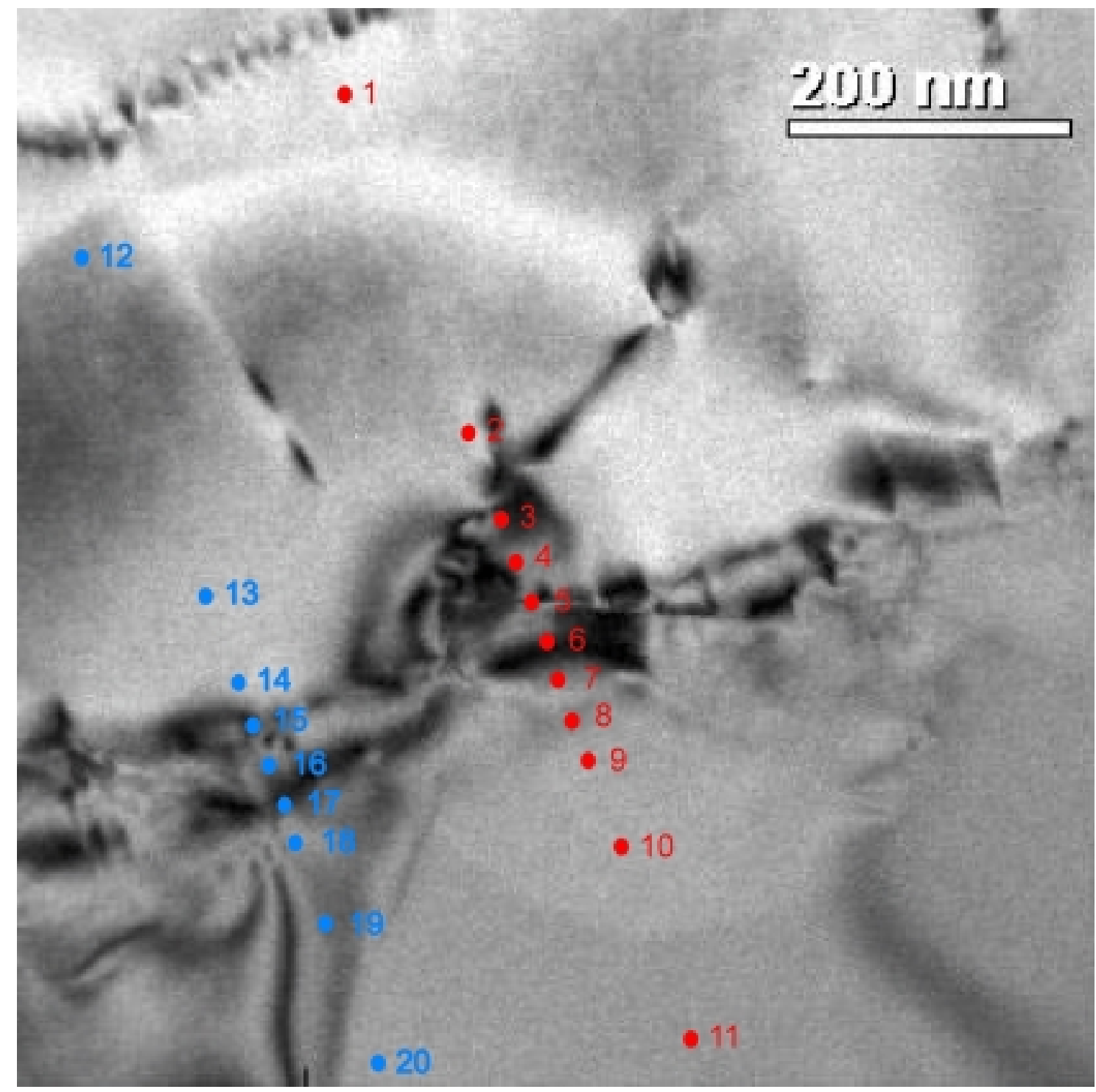

Figura 95: Esquema dos lugares onde foram feitas as análises químicas através da interface $\alpha / \gamma$. UNS S32304. EDS - MET.

Na Figura 96 são apresentados os perfis de composição química de forma gráfica. Deve-se ter cuidado ao analisar estes dados, pois eles são o resultado de uma única medida. Além disso no caso do $\mathrm{Mo}, \mathrm{Cu}$, Si e $\mathrm{V}$ o número de contagens obtidas é muito baixo e portanto, a estatística da medida não é muito boa. Assim, os teores dos elementos devem ser tomados somente como uma indicação e se deve observar as tendências e não os valores absolutos. Todas estas medidas foram realizadas com um feixe de aproximadamente $25 \mathrm{~nm}$ de diâmetro, sugerindo que as regiões analisadas podem estar superpostas. 
Tabela 34: Perfil de composição química da fração metálica ao longo da interface $\alpha / \gamma$, contendo precipitados de $\mathrm{Cr}_{2} \mathrm{~N}$. AID UNS S32304 tratado a $1350^{\circ} \mathrm{C}$ por $5 \mathrm{~s}$. EDS-MET.

\begin{tabular}{|c|c|c|c|c|c|c|c|c|c|c|c|}
\hline & \multicolumn{10}{|c|}{ Distância a partir da interface $\alpha / \gamma[\mathrm{nm}]$} \\
\cline { 2 - 15 } & $-\infty$ & -200 & -120 & -80 & -40 & 0 & 40 & 80 & 120 & 200 & $+\infty$ \\
\hline Ponto & 1 & 2 & 3 & 4 & 5 & 6 & 7 & 8 & 9 & 10 & 11 \\
\hline Fase & $\alpha$ & $\alpha$ & $\alpha$ & $\alpha$ & $\alpha / \mathrm{Cr}_{2} \mathrm{~N}$ & $\mathrm{Cr}_{2} \mathrm{~N}$ & $\mathrm{Cr}_{2} \mathrm{~N} / \gamma$ & $\gamma$ & $\gamma$ & $\gamma$ & $\gamma$ \\
\hline Elemento & \multicolumn{10}{|c|}{ Composição química \%peso } \\
\hline $\mathrm{Cr}$ & 23,96 & 23,76 & 22,28 & 20,02 & 27,57 & 76,35 & 24,00 & 24,21 & 24,56 & 24,64 & 24,51 \\
\hline $\mathrm{Fe}$ & 70,31 & 71,03 & 72,34 & 74,55 & 66,59 & 19,45 & 68,12 & 68,66 & 68,62 & 69,15 & 68,75 \\
\hline $\mathrm{Ni}$ & 4,64 & 4,04 & 4,24 & 4,37 & 4,09 & 1,61 & 6,66 & 6,09 & 5,76 & 5,28 & 5,75 \\
\hline $\mathrm{Mo}$ & 0,29 & 0,28 & 0,36 & 0,25 & 0,80 & 1,48 & 0,21 & 0,00 & 0,10 & 0,00 & 0,02 \\
\hline $\mathrm{Cu}$ & 0,37 & 0,45 & 0,38 & 0,38 & 0,29 & 0,21 & 0,43 & 0,49 & 0,43 & 0,44 & 0,41 \\
\hline $\mathrm{Si}$ & 0,36 & 0,37 & 0,31 & 0,38 & 0,56 & 0,35 & 0,46 & 0,43 & 0,42 & 0,44 & 0,41 \\
\hline $\mathrm{V}$ & 0,069 & 0,072 & 0,098 & 0,046 & 0,092 & 0,543 & 0,129 & 0,111 & 0,106 & 0,046 & 0,158 \\
\hline
\end{tabular}

Tabela 35: Perfil de composição química da fração metálica ao longo da interface $\alpha / \gamma$ livre de precipitados de $\mathrm{Cr}_{2} \mathrm{~N}$. AID UNS S32304 tratado a $1350{ }^{\circ} \mathrm{C}$ por $5 \mathrm{~s}$. EDS-MET.

\begin{tabular}{|c|c|c|c|c|c|c|c|c|c|}
\hline & \multicolumn{10}{|c|}{ Distância a partir da interface $\alpha / \gamma[\mathrm{nm}]$} \\
\cline { 2 - 11 } & $-\infty$ & -160 & -80 & -40 & 0 & 40 & 80 & 160 & $+\infty$ \\
\hline Ponto & 12 & 13 & 14 & 15 & 16 & 17 & 18 & 19 & 20 \\
\hline Fase & $\alpha$ & $\alpha$ & $\alpha$ & $\alpha$ & $\alpha / \gamma$ & $\gamma$ & $\gamma$ & $\gamma$ & $\gamma$ \\
\hline Elemento & \multicolumn{8}{|c|}{ Composição química \%peso } \\
\hline $\mathrm{Cr}$ & 23,96 & 24,49 & 23,96 & 23,48 & 25,40 & 24,66 & 24,48 & 24,81 & 24,51 \\
\hline $\mathrm{Fe}$ & 70,31 & 69,74 & 70,51 & 71,44 & 68,44 & 68,10 & 68,71 & 68,74 & 68,75 \\
\hline $\mathrm{Ni}$ & 4,64 & 4,29 & 3,93 & 3,90 & 4,94 & 6,04 & 5,52 & 5,28 & 5,75 \\
\hline $\mathrm{Mo}$ & 0,29 & 0,48 & 0,57 & 0,35 & 0,32 & 0,06 & 0,14 & 0,00 & 0,02 \\
\hline $\mathrm{Cu}$ & 0,37 & 0,35 & 0,49 & 0,33 & 0,37 & 0,49 & 0,45 & 0,49 & 0,41 \\
\hline $\mathrm{Si}$ & 0,36 & 0,58 & 0,46 & 0,41 & 0,42 & 0,50 & 0,53 & 0,51 & 0,41 \\
\hline $\mathrm{V}$ & 0,069 & 0,058 & 0,085 & 0,084 & 0,116 & 0,139 & 0,171 & 0,175 & 0,158 \\
\hline
\end{tabular}

Nestes perfis de composição verifica-se o empobrecimento em $\mathrm{Cr}$ e enriquecimento em $\mathrm{Fe}$ na ferrita do lado da interface (com ou sem nitreto, Figura 96.a e Figura 96.b, respectivamente). Este comportamento é mais pronunciado no caso da interface contendo o nitreto. Estes perfis indicam que a interface está-se movendo ou pelo menos pode-se mover. Caso as interfaces sejam incoerentes, elas estarão se movendo, mas no caso delas serem semicoerentes, podem estar paradas ou não. Porém, pelas análises de MET realizadas neste trabalho sabe-se que ambas interfaces são semicoerentes. 

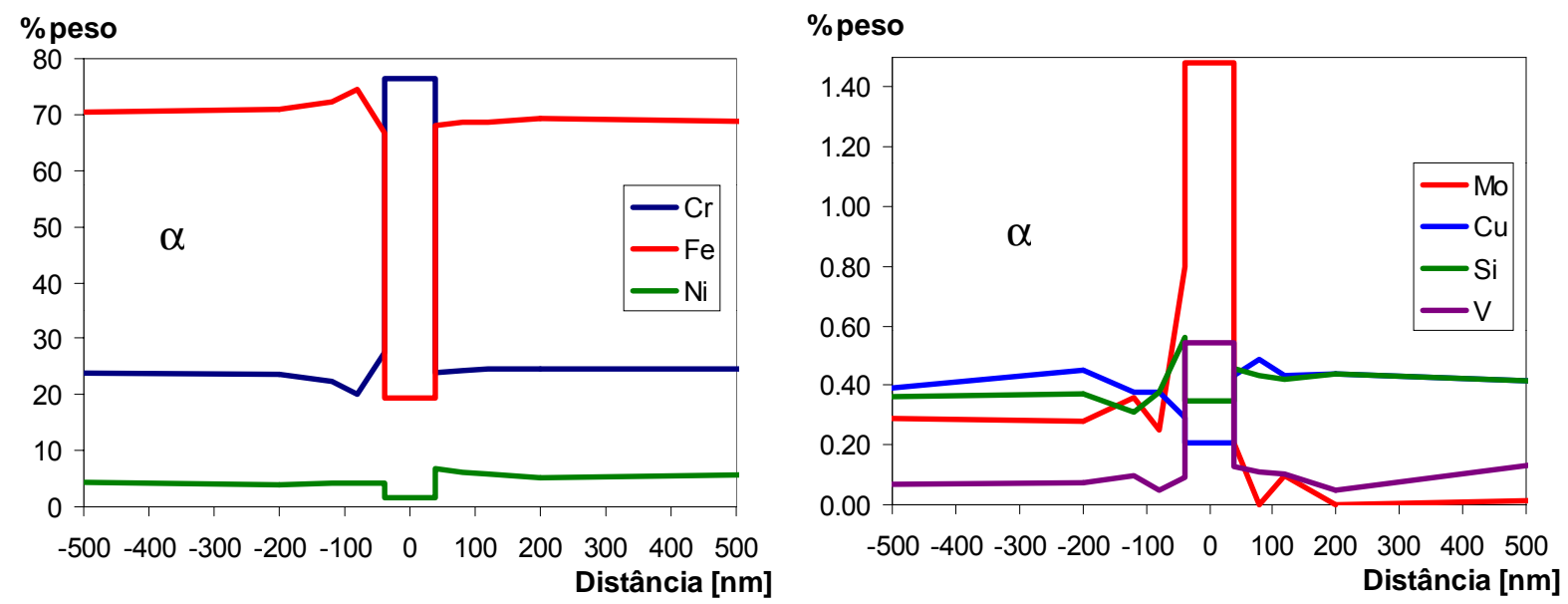

a.
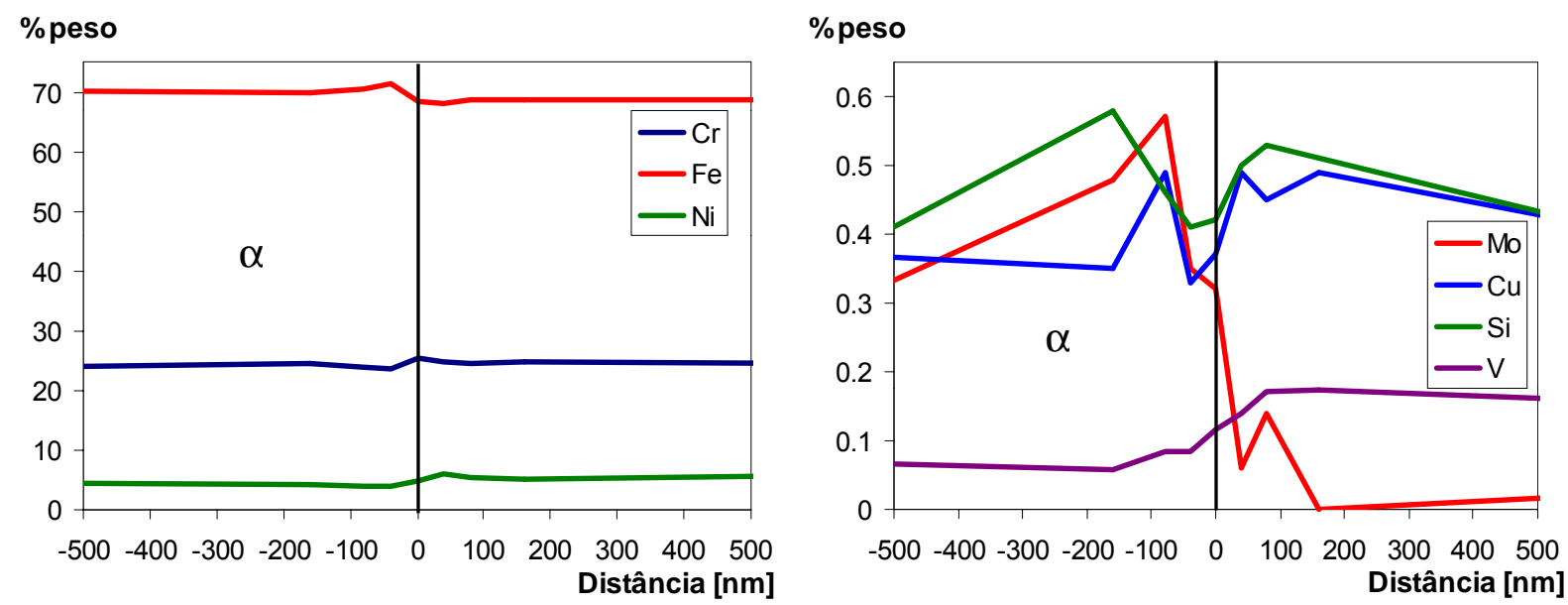

b.

Figura 96: Perfil de composição química da fração metálica ao longo da interface $\alpha / \gamma$. Em (a) Interface contendo precipitado de $\mathrm{Cr}_{2} \mathrm{~N}$ e em (b) interface livre de precipitados. AID UNS S32304 tratado a $1350^{\circ} \mathrm{C}$ por $5 \mathrm{~s}$. EDS-MET.

Todas as interfaces $\alpha / \gamma$ analisadas neste trabalho apresentaram relações de orientação do tipo K-S ou N-W, típicas das placas laterais de Widmanstätten, as quais formam complexas interfaces semicoerentes, que contém degraus estruturais e discordâncias de desarranjo. Com relação à interface $\alpha / \mathrm{Cr}_{2} \mathrm{~N}$, foi verificada neste trabalho a sua natureza semicoerente na direção na qual o perfil foi levantado. O avanço destas interfaces semicoerentes é lento, pois ele acontece pelo mecanismo de degraus, o qual requer difusão para o avanço da borda do $\operatorname{degrau}^{(134)}$.

Quanto à interface $\alpha / \gamma$, devido ao aumento da fração de $\gamma$ durante o resfriamento, é de se esperar que esta interface esteja avançando. Com relação ao nitreto observado nesta interface, ele é muito menor do que os outros observados neste mesmo tipo de interface, nesta mesma liga, portanto acredita-se que ele ainda estava crescendo. $O$ crescimento do 
nitreto dá-se preferencialmente para dentro da ferrita pois é nesta fase onde se tem os maiores teores de $\mathrm{Cr}, \mathrm{V}$ e Mo e menores teores de $\mathrm{Ni}$ e $\mathrm{Cu}$, além de se ter na interface $\alpha / \gamma$ um aporte importante de nitrogênio, que está fluindo da ferrita para a austenita. Além disso, as observações no MEV-EC e MET mostraram que estes nitretos crescem para dentro da ferrita. Assim, estas duas interfaces $\alpha / \gamma$ e $\mathrm{Cr}_{2} \mathrm{~N} / \alpha$ devem estar se deslocando em direção à ferrita.

Foi mencionado acima como os nitretos crescem para dentro da ferrita. Porém, na Figura 88 são observados estes precipitados numa interface $\alpha / \gamma$, do lado da austenita. Isto é devido ao deslocamento da interface $\alpha / \gamma$, deixando os nitretos para trás, causado por um certo mecanismo de cooperação entre a precipitação do $\mathrm{Cr}_{2} \mathrm{~N}$ e a $\gamma$, o qual será tratado em detalhe mais adiante.

\subsection{Austenita intragranular}

Nas Figuras 57 a 61 são apresentadas as microestruturas dos materiais ferritizados onde pode-se observar o comportamento bastante diferente das ligas quanto a precipitação da $\gamma_{\text {intragranular }}$ e a grande influência do tratamento térmico nesta precipitação.

O ordenamento das ligas quanto a sua tendência à formação de $\gamma_{\text {intragranular }}$ de maior a menor é:

UNS S32034 - UNS S32760 - UNS S32205 - UNS S32550 - UNS S32750

Em termos gerais, o tratamento térmico realizado a $1350{ }^{\circ} \mathrm{C}$ por $10 \mathrm{~s}$ causou a maior

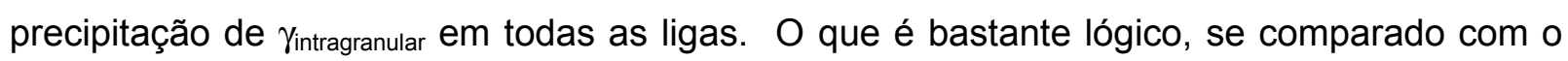
tratamento a esta mesma temperatura por $5 \mathrm{~s}$. O maior tempo de permanência nesta temperatura levou a um tamanho de grão maior o que, consequentemente, facilita a

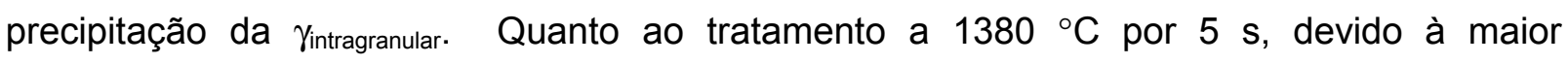
quantidade de liquido presente para a maioria das ligas, o crescimento de grão foi dificultado, com o que a quantidade de $\gamma_{\text {intragranular }}$ foi reduzida.

Um outro fato que é importante ressaltar é a grande variedade de tamanho e formato destas $\gamma_{\text {intragranulares, }}$ tornando a sua diferenciação em grandes aumentos bastante difícil. Isto é, quando se tem uma visão geral da região, com aumento de aproximadamente 200X é fácil diferenciar as $\gamma_{\text {intragranulares }}$ das $\gamma$ alotrimórficas e de Widmanstätten. Porém, quando se está no MET, onde não se tem a possibilidade de utilizar baixos aumentos, a diferenciação torna-se bastante difícil.

$\mathrm{Na}$ Figura 97 são mostradas, a título de exemplo, partículas de $\gamma_{\text {intragranular }}$ precipitadas no AID UNS S32205. 

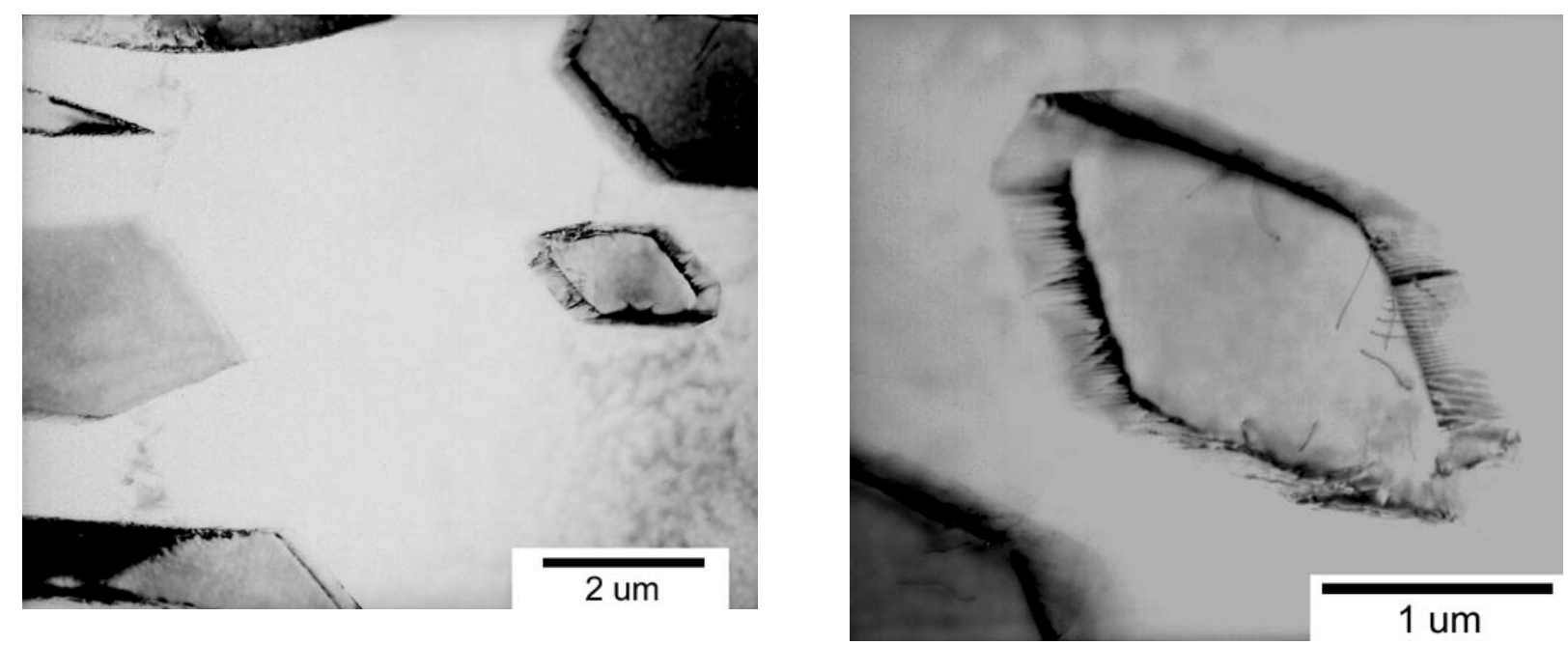

Figura 97: Partículas de austenita Intragranular. AID UNS S32205. MET.

Como foi tratado anteriormente, a partição de elementos de liga entre a ferrita e a austenita nos CPs tratados termicamente a $1350{ }^{\circ} \mathrm{C}$ foi bastante reduzida. Desta forma não era de se esperar uma partição maior destes elementos no caso da $\gamma_{\text {intragranular. }} \mathrm{O}$ único elemento que deve apresentar uma partição importante é o nitrogênio, mas não é possível medir este elemento no MET empregando EDS. Desta forma, devido a estatística mais pobre das medidas de EDS no MET não foi possível detectar diferenças relevantes entre as composições químicas das austenitas alotrimórficas, de Widmanstätten e intragranulares.

\subsection{Austenita intragranular e a sua coexistência com $\mathrm{Cr}_{2} \mathrm{~N}$}

Em geral, em todas as ligas utilizadas neste estudo foi clara a íntima coexistência de $\mathrm{Cr}_{2} \mathrm{~N}$ e a $\gamma$ intragranular (no interior da $\alpha$ ). Nas Figuras 98 a 100 são mostrados exemplos de partículas de $\gamma$ intragranular contendo ou com partículas adjacentes, que parecem ser $\mathrm{Cr}_{2} \mathrm{~N}$.

O ideal teria sido estudar estas regiões no MET. Porém, a sua observação no MEV-EC não foi trivial, pois não foi um acontecimento muito freqüente. Desta forma, devido ao pequeno volume de material que é possível estudar no MET, a probabilidade de encontrar uma destas regiões não era grande. Foram preparados diversos CPs, mas não foi possível observar e estudar esta coexistência no MET, onde teria sido possível a identificação inequívoca dos precipitados e o estudo da sua relação de orientação com a $\gamma$. Na ciência, por sua vez, o caminho direto nem sempre é o mais fácil e, as vezes, ele nem é possível. 


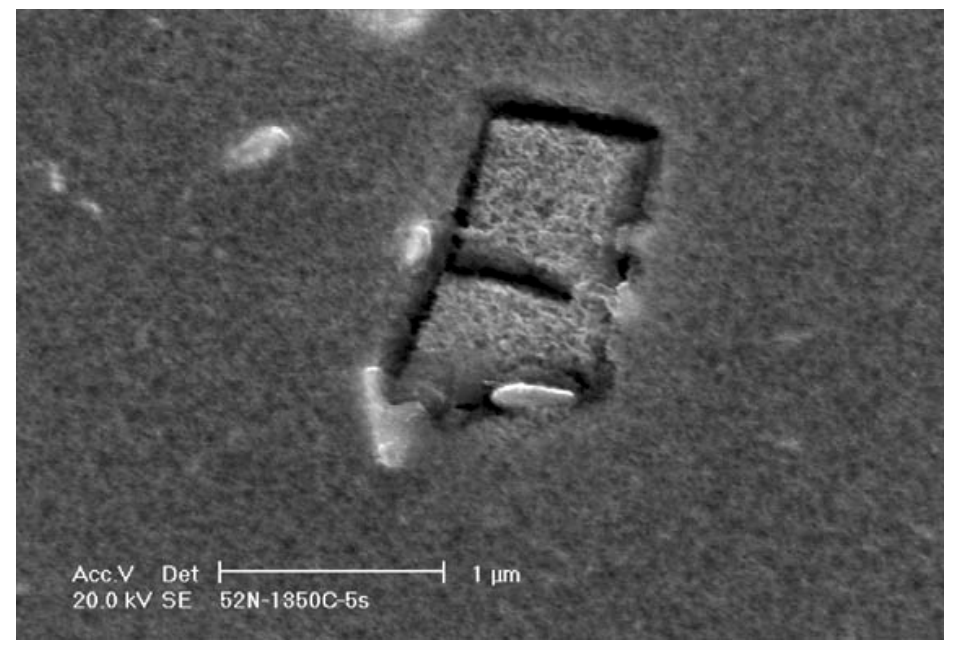

Figura 98: Partícula de $\gamma$ intragranular apresentando precipitados na sua interface. AISD UNS S32550. MEV-EC.

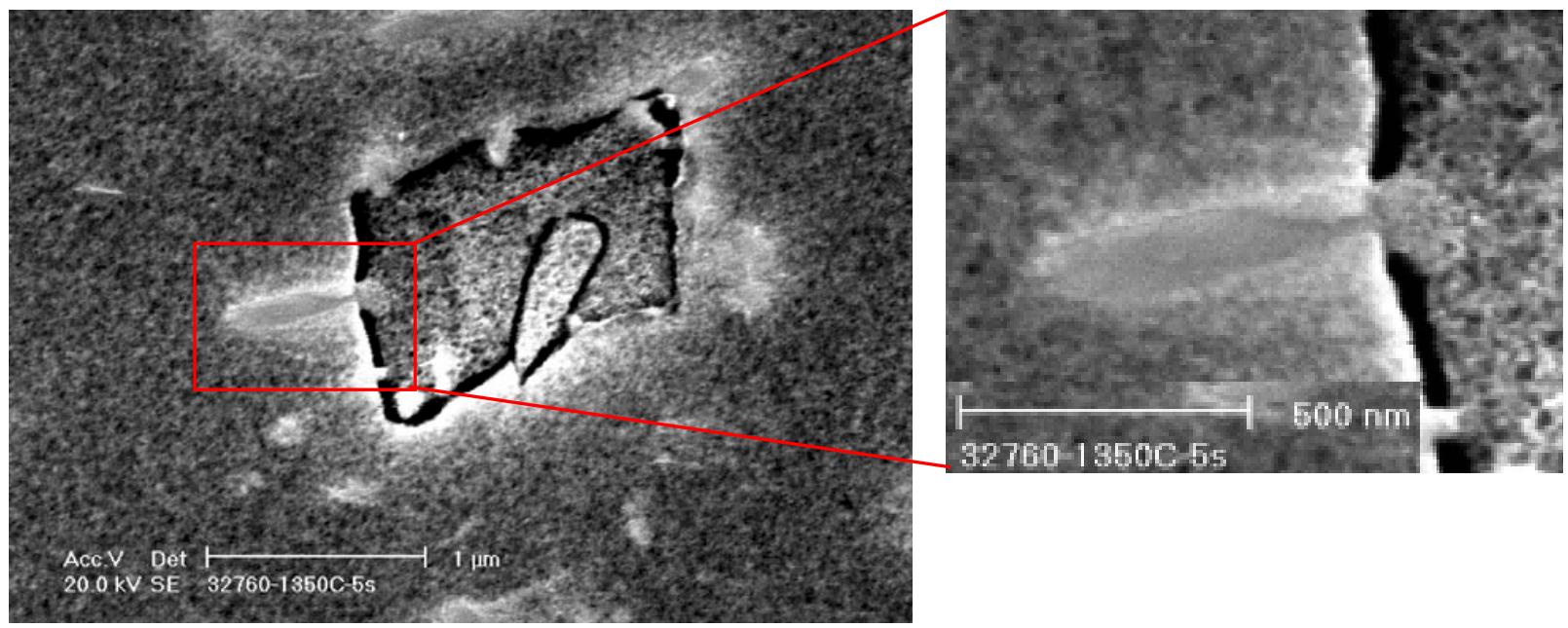

Figura 99: Partícula de $\gamma$ intragranular com precipitados na sua interface. Um bastonete de $\mathrm{Cr}_{2} \mathrm{~N}$, corta a interface, mostrando-se intimamente ligado, tanto à matriz de $\alpha$, como à partícula de $\gamma$. AISD UNS S32760. MEV-EC.

Neste caso, se fez necessário a busca de fatos que permitissem a identificação destes

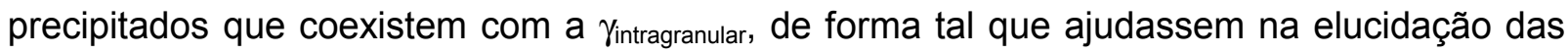
possíveis relações entre estas fases. Isto é, se uma fase participa na precipitação da outra e, se o faz, de que modo isto acontece. 


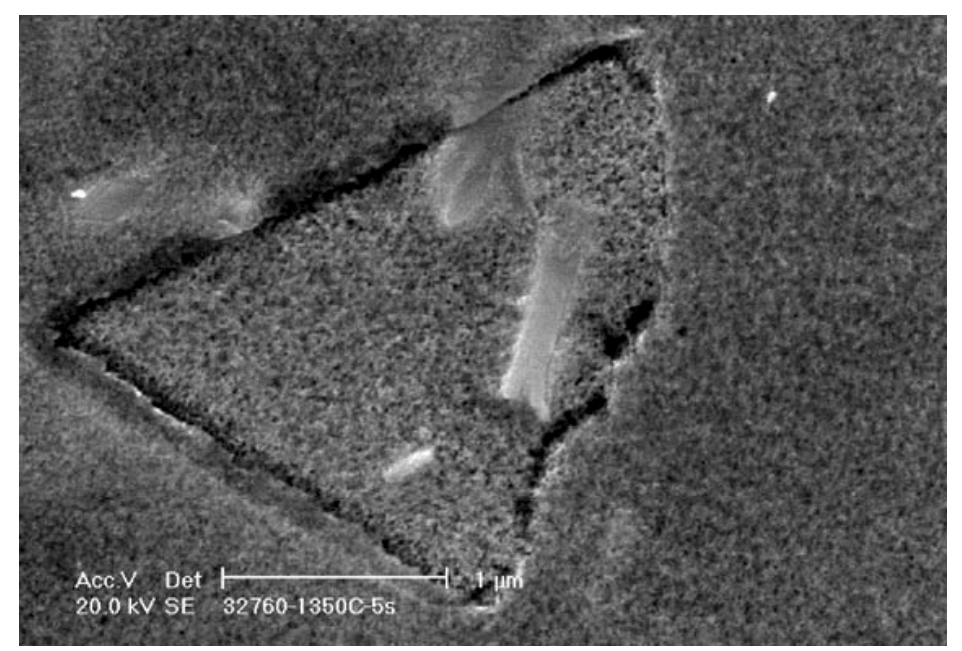

Figura 100: Partícula de $\gamma$ intragranular contendo bastonetes de $\mathrm{Cr}_{2} \mathrm{~N}$ no seu interior. Os bastonetes de $\mathrm{Cr}_{2} \mathrm{~N}$ apresentam uma bifurcação no seu extremo. AISD UNS S32760. MEV-EC.

Como pode ser visto nas figuras anteriores, verifica-se claramente a coexistência da $\gamma_{\text {intragranular }}$ e outros precipitados que se encontram tanto na sua interface com a ferrita como no seu interior. Estes precipitados poderiam ser quaisquer das fases intermetálicas possíveis de precipitar nos AIDs, previamente mencionadas na pagina 14 . No entanto, a grande maioria destas podem ser descartadas, pois requerem tratamentos isotérmicos de duração considerável para a sua precipitação acontecer.

Existe uma similaridade de formato e lugar de precipitação com a precipitação de carbonetos de cromo $\left(\mathrm{M}_{23} \mathrm{C}_{6}\right)$ nas interfaces $\alpha / \gamma$, previamente reportada por diversos autores ${ }^{(98-100,135-136)}$. Portanto, pode-se pensar que os precipitados intergranulares observados neste trabalho sejam carbonetos. Porém, todos os precipitados encontrados nas interfaces $\alpha / \gamma$ foram identificados como sendo nitretos. Além disso, o tempo de duração dos tratamentos térmicos utilizados foi muito curto para se ter precipitação de carbonetos.

É amplamente reconhecido que o nitrogênio retarda a precipitação de $\mathrm{M}_{23} \mathrm{C}_{6}$. Acredita-se que isto esteja relacionado com a dificuldade para nuclear estes carbonetos, devido à sua solubilidade zero de nitrogênio. Além disso, cálculos ab initio mostraram que a estrutura do $\mathrm{M}_{23} \mathrm{C}_{6}$ é desestabilizada se alguns átomos de carbono são substituídos por átomos nitrogênio ${ }^{(137)}$.

Para o tempo de tratamento utilizado, a precipitação de carbonetos é bastante improvável. Além disso, todos os precipitados encontrados nas interfaces $\alpha / \gamma$ foram identificados como $\mathrm{Cr}_{2} \mathrm{~N}$. Também, deve-se ressaltar a grande semelhança entre os bastonetes intragranulares bifurcados de $\mathrm{Cr}_{2} \mathrm{~N}$, como o mostrado na Figura 86, e os precipitados observados no interior das austenitas intragranulares, como o mostrado na Figura 100. Finalmente, é bastante claro o formato de bastonete de um outro precipitado que está junto com uma $\gamma_{\text {intragranular, }}$ como pode ser observado na Figura 99. Portanto, pode-se deduzir que estes precipitados 
observados em intimo contato com as austenitas intragranulares são nitretos de cromo $\left(\mathrm{Cr}_{2} \mathrm{~N}\right)$.

Assim, com o empobrecimento da ferrita em $\mathrm{Cr}$, Mo e $\mathrm{V}$ do lado do nitreto (como verificado pelas medidas de EDS), o suprimento de nitrogênio dos nitretos que estão dissolvendo e a relação de orientação $\alpha / \mathrm{Cr}_{2} \mathrm{~N} / \gamma$ constatada, pode-se sugerir a nucleação (precipitação heterogênea) de austenita intragranular a partir dos bastonetes de $\mathrm{Cr}_{2} \mathrm{~N}$ presentes no interior dos grão ferríticos. Contudo, estes nitretos dificilmente são observados no interior ou em contato com austenitas intragranulares. Mas isto pode ser explicado pela dissolução posterior destes nitretos, que também foi verificada nos tratamentos de reaquecimento que serão mostrados mais adiante. Além disso, é importante mencionar que estes nitretos intragranulares precipitaram devido à super-saturação de $\mathrm{N}$ na ferrita. Mas uma vez que a austenita precipita, o nitrogênio do nitreto pode ser absorvido pela austenita, ajudando no seu crescimento.

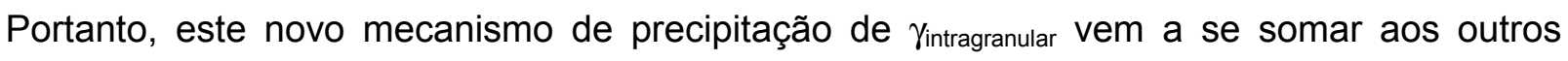
mecanismos propostos de nucleação em discordâncias e inclusões.

\subsection{Precipitação de austenita intragranular a partir de inclusões}

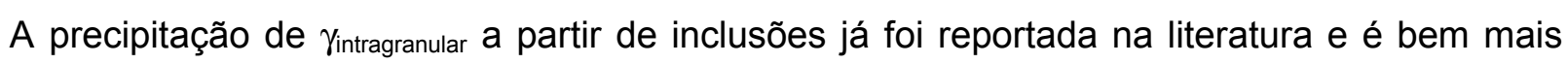
importante na zona fundida da soldas, onde a quantidade de inclusões é bem maior que no metal de base. Assim, este não é o mecanismo preponderante de precipitação da $\gamma_{\text {intragranular }}$ na ZACTE. Porém, foi freqüentemente observado neste trabalho a precipitação heterogênea a partir de inclusões. A título de exemplo é mostrada na Figura 101 a precipitação de $\gamma$ a partir de uma inclusão rica em O, Mg, Al e Ce, no AISD UNS S32760. Na Figura 102 é mostrado o espectro de raios $X$ da inclusão anteriormente mencionada.

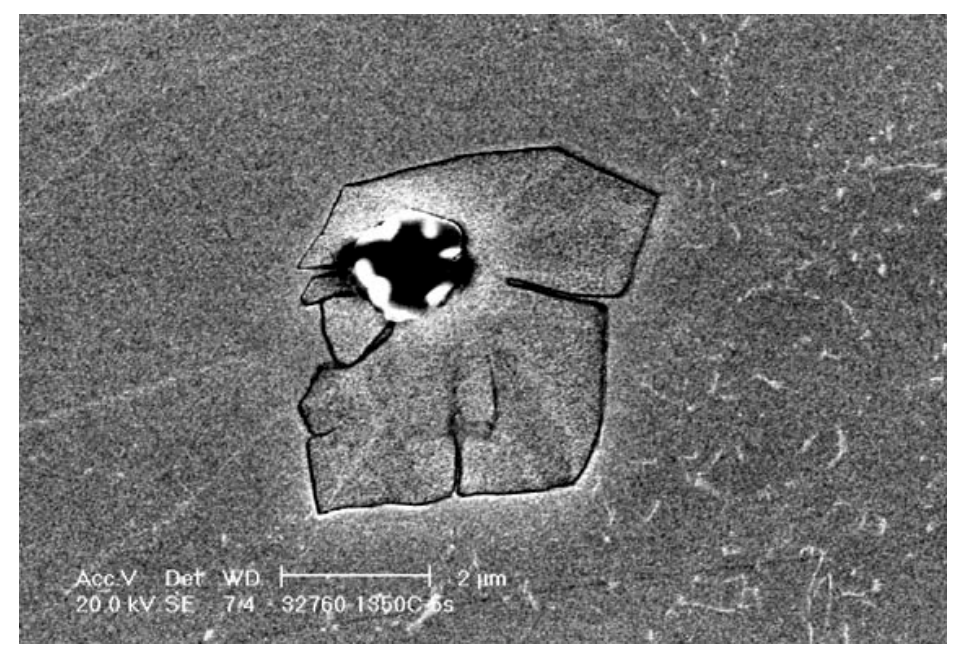

Figura 101: Precipitação de austenita intragranular a partir de uma inclusão rica em $\mathrm{O}, \mathrm{Mg}, \mathrm{Al}$ e Ce. AISD UNS S32760. 


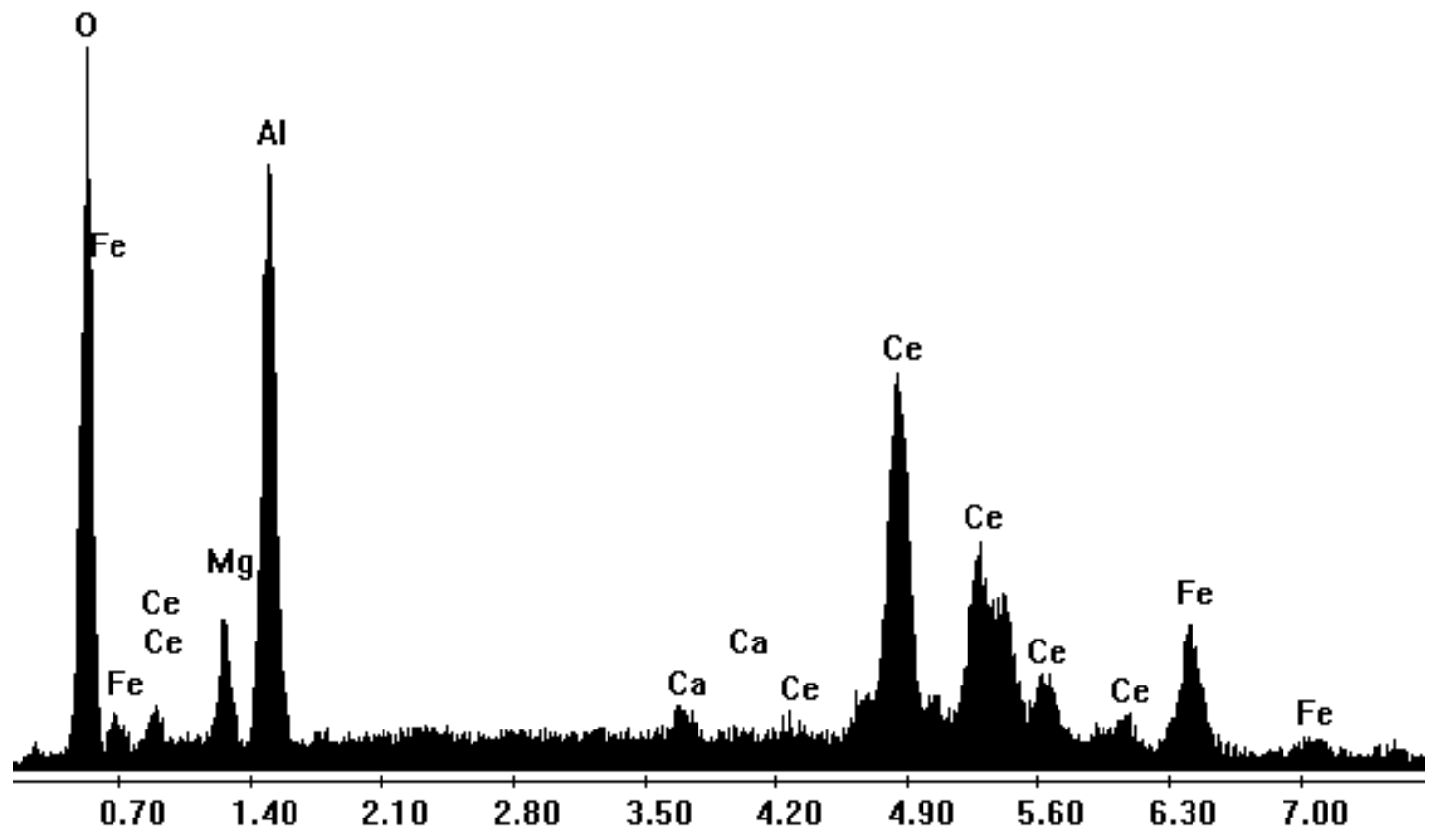

Figura 102: Espectro de raios $X$ correspondente à inclusão mostrada na figura anterior. Tensão de aceleração 20kV. AISD UNS S32760.

\subsubsection{Tratamentos Térmicos de Reaquecimento}

Uma vez determinadas as condições ideais para os TTs de ferritização, foram realizados os TTs de reaquecimento apresentados no Item 5.7.

Na Figura 103 é mostrada, a título de exemplo, a história térmica do tratamento térmico de reaquecimento a $1200^{\circ} \mathrm{C}$ durante $1 \mathrm{~s}$ do AISD UNS S32750.

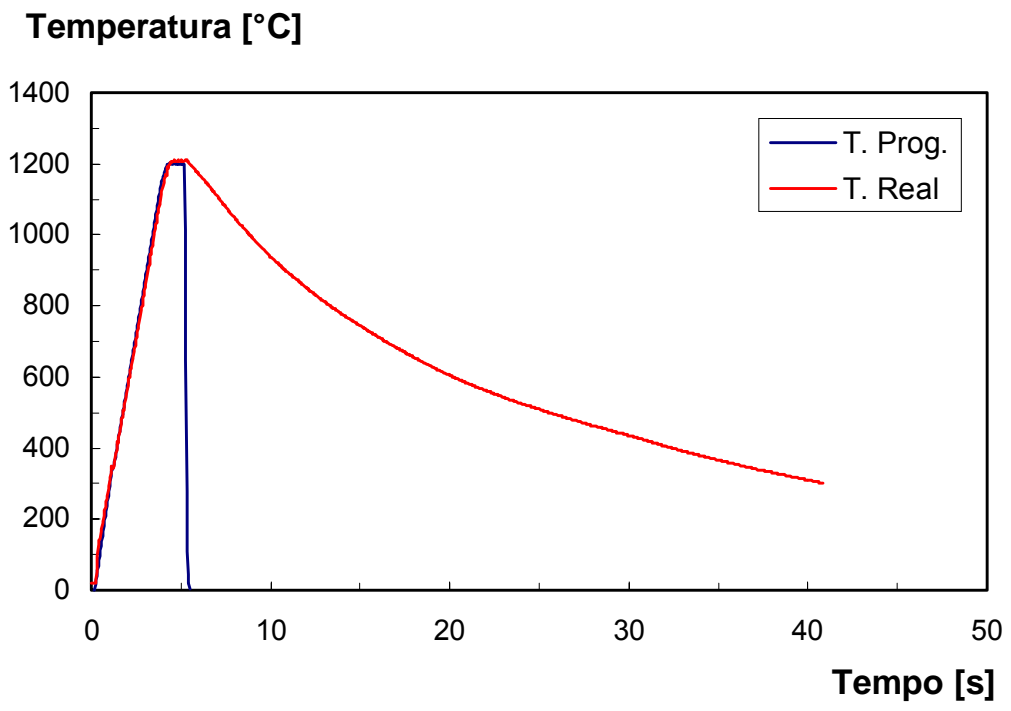

Figura 103: Tratamento térmico de reaquecimento do AISD $2507,1 \mathrm{~s}$ a $1200{ }^{\circ} \mathrm{C}$. 
Como pode ser observado nas Figuras 54 e 103, com os parâmetros de operação utilizados, o equipamento Gleeble ${ }^{\circledR}$ consegue reproduzir bastante bem os ciclos programados durante o aquecimento e o patamar. Por outro lado, a máxima taxa de resfriamento depende das propriedades físicas do material testado, do tamanho do corpo de prova e do seu comprimento livre entre os sistemas de fixação e resfriamento. Portanto, para as condições em que os testes foram realizados, a taxa de resfriamento média de $75^{\circ} \mathrm{C} / \mathrm{s}$ foi a máxima possível.

Após os TT de ferritização e reaquecimento, os CP foram preparados para observação no MO. A Tabela 36 e Figura 104 apresentam as frações volumétricas de austenita medidas por análise de imagens para os diversos tratamentos de reaquecimento. $\mathrm{A}$ análise de variância (ANOVA) destes dados mostrou que a temperatura de reaquecimento influiu na fração final de austenita, com a exceção dos reaquecimentos do AISD UNS S32550 por $1 \mathrm{~s} \mathrm{e}$ do AISD UNS S32760 por 10 s. Nestes casos, onde o fator de variância F, mostrou-se

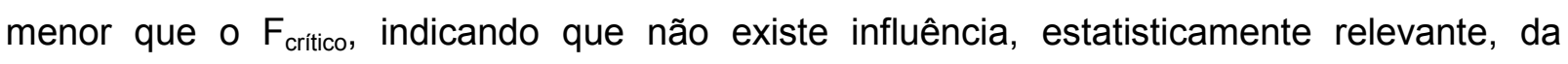
temperatura do TT na fração de $\gamma$. Já os AIDs UNS S32304, S32205 e $\$ 32760$ apresentaram mudanças importantes na fração de $\gamma$ com a temperatura de tratamento.

Tabela 36: Fração volumétrica de austenita dos CP submetidos a TT de ferritização, seguidos de TT de reaquecimento.

\begin{tabular}{|c|c|c|c|c|c|c|c|c|c|}
\hline \multirow{2}{*}{$\begin{array}{c}\text { Designação } \\
\text { UNS }\end{array}$} & \multirow{2}{*}{$\begin{array}{c}\text { Como- } \\
\text { Recebido }\end{array}$} & \multirow{2}{*}{$\begin{array}{c}13500^{\circ} \mathrm{C} \times 5 \\
\text { ou } 10 \mathrm{~s}^{1}\end{array}$} & \multirow{2}{*}{$\begin{array}{c}\text { Tempo } \\
\text { [s] }\end{array}$} & \multicolumn{4}{|c|}{ Temperatura de Reaquecimento $\left[{ }^{\circ} \mathrm{C}\right]$} & \multicolumn{2}{|c|}{ ANOVA } \\
\hline & & & & 900 & 1000 & 1100 & 1200 & $\mathbf{F}_{\text {critico }}$ & $\mathbf{F}$ \\
\hline \multirow{3}{*}{ S32304 } & \multirow{3}{*}{$50 \pm 0,8$} & \multirow{3}{*}{$16 \pm 2$} & 1 & $21 \pm 2,1$ & $22 \pm 2,7$ & $27 \pm 2,7$ & $26 \pm 2,3$ & 4,1 & 6,1 \\
\hline & & & 10 & $22 \pm 2,4$ & $32 \pm 3,2$ & $34 \pm 3,0$ & $33 \pm 2,4$ & 4,1 & 16,9 \\
\hline & & & $\mathbf{F}$ & 0,1 & 23,1 & 12,7 & 15,4 & 7,4 & \\
\hline \multirow{3}{*}{ S32205 } & \multirow{3}{*}{$60 \pm 1,2$} & \multirow{3}{*}{$26 \pm 3$} & 1 & $35 \pm 3,5$ & $37 \pm 3,5$ & $48 \pm 3,7$ & $49 \pm 2,9$ & 4,1 & 17,8 \\
\hline & & & 10 & $37 \pm 5,9$ & $47 \pm 3,9$ & $45 \pm 3,0$ & $48 \pm 3,3$ & 4,1 & 5,4 \\
\hline & & & $\mathbf{F}$ & 0,4 & 14,2 & 1,1 & 0,4 & 7,4 & \\
\hline \multirow{3}{*}{ S32550 } & \multirow{3}{*}{$51 \pm 1,2$} & \multirow{3}{*}{$27 \pm 2$} & 1 & $33 \pm 3,1$ & $34 \pm 3,9$ & $34 \pm 3,0$ & $35 \pm 2,4$ & 4,1 & 0,5 \\
\hline & & & 10 & $30 \pm 3,2$ & $38 \pm 2,6$ & $46 \pm 2,7$ & $31 \pm 2,4$ & 4,1 & 29,7 \\
\hline & & & $\mathbf{F}$ & 1,5 & 3,0 & 37,3 & 6,1 & 7,4 & \\
\hline \multirow{3}{*}{ S32750 } & \multirow{3}{*}{$61 \pm 1,0$} & \multirow{3}{*}{$33 \pm 3$} & 1 & $46 \pm 4,4$ & $42 \pm 3,6$ & $48 \pm 3,3$ & $52 \pm 2,1$ & 4,0 & 9,1 \\
\hline & & & 10 & $44 \pm 2,8$ & $47 \pm 2,6$ & $53 \pm 2,8$ & $52 \pm 2,5$ & 4,0 & 7,8 \\
\hline & & & $F$ & 0,5 & 5,1 & 5,2 & 0,0 & 7,4 & \\
\hline \multirow{3}{*}{ S32760 } & \multirow{3}{*}{$51 \pm 1,1$} & \multirow{3}{*}{$33 \pm 3$} & 1 & $28 \pm 2,5$ & $27 \pm 1,8$ & $34 \pm 3,0$ & $35 \pm 2,2$ & 4,1 & 10,6 \\
\hline & & & 10 & $36 \pm 4,3$ & $37 \pm 2,4$ & $42 \pm 2,8$ & $40 \pm 2,9$ & 4,1 & 2,9 \\
\hline & & & $F$ & 9,6 & 48,1 & 17,3 & 6,1 & 7,4 & \\
\hline $\mathrm{Ve}$ & - & (1) & S327 & ados a & & $\mathrm{S} 32750 \mathrm{tr}$ & a $1350^{\circ}$ & & \\
\hline
\end{tabular}

Em geral todos os materiais apresentaram uma mudança desprezível da fração de $\gamma$ com o tempo na temperatura de reaquecimento de $900{ }^{\circ} \mathrm{C}$. Isto pode ser devido à cinética lenta da reação nesta temperatura. 
A tendência de crescimento da fração de $\gamma$ com a temperatura é reduzida em todas as ligas para a temperatura de $1200^{\circ} \mathrm{C}$. Uma provável explicação é a menor fração de $\gamma$ no equilíbrio nesta temperatura. Como pode ser visto na Figura 43, a partir de aproximadamente 900 a $1100{ }^{\circ} \mathrm{C}$, dependendo da liga, tem-se uma queda abrupta na fração de $\gamma$ em equilíbrio. Da mesma forma, isto também justifica que, tratamentos de maior duração em temperaturas superiores àquelas de queda abrupta da fração de $\gamma$ no equilíbrio, levem a menores frações finais de austenita.

No caso do AID UNS S32304, a fração de $\gamma$ no equilíbrio começa a cair a partir dos $900{ }^{\circ} \mathrm{C}$, mas, nas temperaturas 1000,1100 e $1200^{\circ} \mathrm{C}$ a fração de $\gamma$ de equilíbrio ainda está muito acima da alcançada durante $1 \mathrm{~s}$ de tratamento. Assim, os tratamentos de $10 \mathrm{~s}$ causam um aumento da fração de $\gamma$.

Para o AID UNS S32205, a máxima fração de $\gamma$ no equilíbrio é alcançada aproximadamente a $1000{ }^{\circ} \mathrm{C}$. Portanto, é para esta temperatura que se tem a maior influência do tempo de tratamento na fração final de $\gamma$. A partir desta temperatura se tem uma queda abrupta da fração de $\gamma$ no equilíbrio. Desta forma, o tempo de tratamento não tem mais influência na fração de $\gamma$.

O AISD UNS S32550 alcança a maior fração de austenita no equilíbrio a aproximadamente $1100{ }^{\circ} \mathrm{C}$. Temperatura que coincide com um aumento importante da fração final de austenita para o tratamento de $10 \mathrm{~s}$. A posterior queda na quantidade de $\gamma$ com o aumento da temperatura é explicado da mesma forma que para as outras ligas, pela queda na fração de austenita no equilíbrio. 

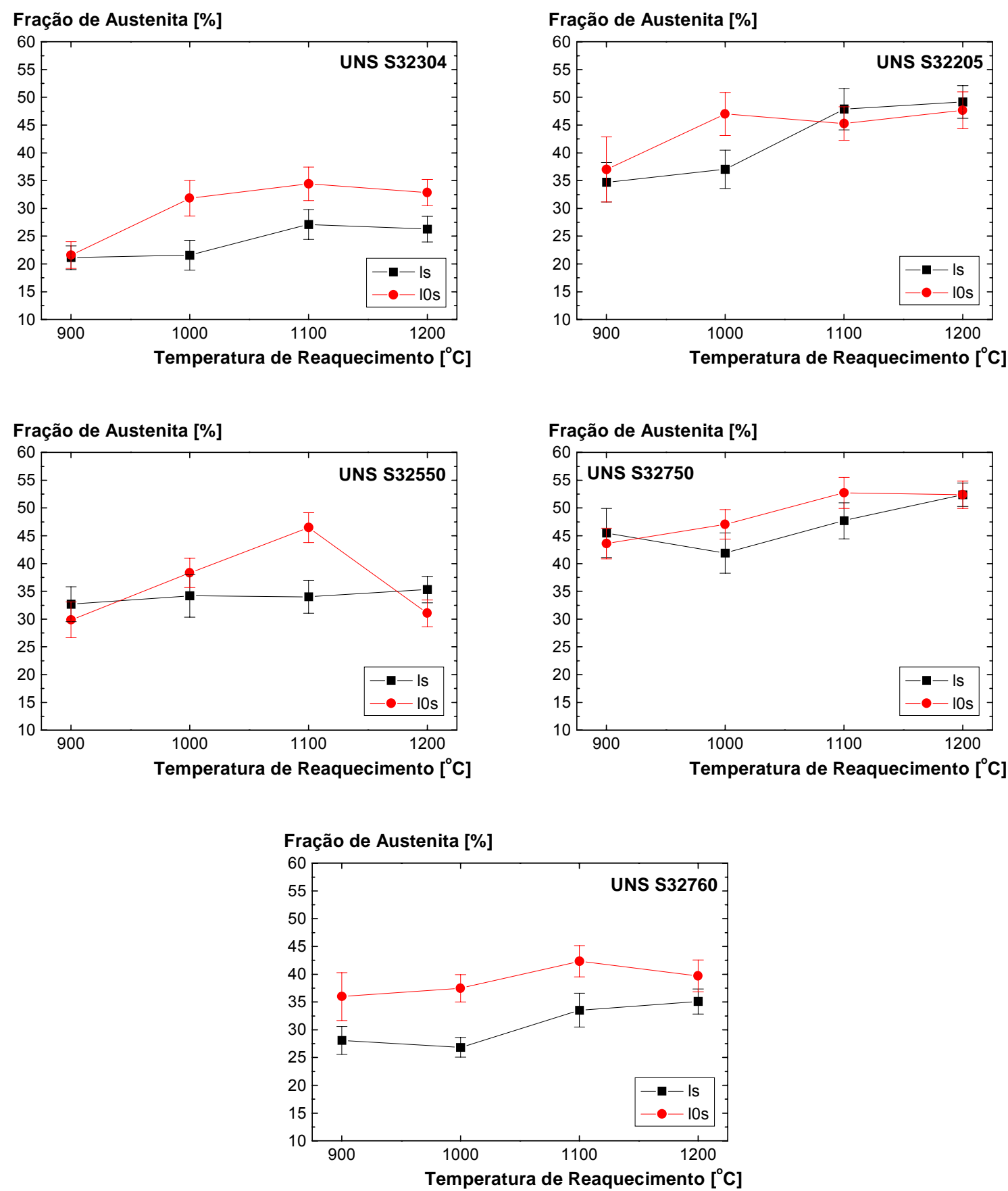

Figura 104: Variação da fração volumétrica de austenita com a temperatura e tempo to TT de reaquecimento.

O AISD S32750 não apresenta mudanças consideráveis na quantidade de $\gamma$, nem em função da temperatura, nem do tempo de tratamento. No entanto, a fração de $\gamma$ foi sempre maior que no $\mathrm{CP}$ ferritizado e, relativamente próxima do valor no estado como-recebido. Comportamento que sugere o consumo do potencial termodinâmico disponível para a transformação já nas temperaturas e tempos menores. 
Finalmente, no caso do AISD UNS S32760, observou-se uma influência importante do tempo de tratamento para as temperaturas de 900,1000 e $1100^{\circ} \mathrm{C}$. A fração máxima de $\gamma$ em equilíbrio desta liga acontece aproximadamente a $1050^{\circ} \mathrm{C}$, o que justifica a maior influência do tempo de tratamento na fração final de $\gamma$, nas temperaturas de 1000 e $1100{ }^{\circ} \mathrm{C}$.

Nas Figuras 105 a 109 são mostradas as microestruturas dos CPs submetidos aos tratamentos térmicos de reaquecimento a $900,1000,1100$ e $1200{ }^{\circ} \mathrm{C}$, por 1 e $10 \mathrm{~s}$. Nas Tabelas 37 e 38 é resumida a evolução microestrutural destes CPs, observada ao microscópio ótico. Nestas tabelas, quando se especifica que uma determinada fase permaneceu constante, cresceu, dissolveu ou dissolveu quase totalmente (fração muito baixa), isto é relativo à condição anterior. Isto é, no caso do tratamento de reaquecimento por $1 \mathrm{~s}$, as mudanças são relativas ao estado após o tratamento aqui chamado de ferritização. Já quando se refere ao tratamento de reaquecimento por $10 \mathrm{~s}$, as mudanças são relativas ao tratamento de reaquecimento por $1 \mathrm{~s}$. É importante mencionar que, por simplicidade, nestas tabelas não se faz diferenciação entre $\gamma_{1}$ e $\gamma_{2}$. Mas é claro que toda a $\gamma$ que se forma durante os reaquecimentos é do tipo secundária.

Como pode ser visto nestas micrografias e como é resumido nas tabelas acima mencionadas, em termos gerais pode-se afirmar:

- Nos reaquecimentos a $900{ }^{\circ} \mathrm{C}$ observou-se mudanças mínimas na microestrutura.

- A $1200{ }^{\circ} \mathrm{C}$ notou-se principalmente o crescimento das austenitas alotrimórficas e de Widmanstätten.

Já nos tratamentos a 1000 e $1100{ }^{\circ} \mathrm{C}$, além do crescimento das austenitas previamente existentes, verificou-se claramente a dissolução dos nitretos de cromo e a precipitação e crescimento das $\gamma_{2}$ intragranulares. A predominância da precipitação da $\gamma_{2}$ intragranular nestas temperaturas é mostrada na Tabela 39. Como pode ser visto nesta tabela, a precipitação desta fase depende da temperatura de reaquecimento e da composição química da liga. Com exceção do AISD UNS S32760, a maior quantidade de $\gamma_{2}$ intragranular foi obtida no reaquecimento a $1000{ }^{\circ} \mathrm{C}$. No caso especifico do AISD UNS S32760, esta condição foi obtida a $1100{ }^{\circ} \mathrm{C}$. 


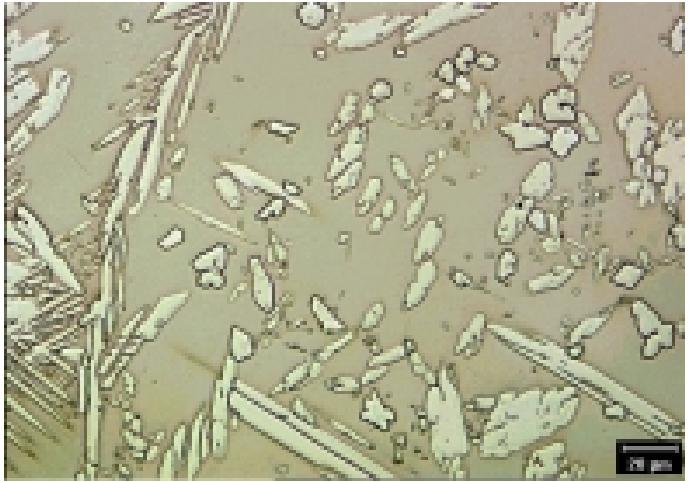

$1200^{\circ} \mathrm{C} \times 1 \mathrm{~s}$

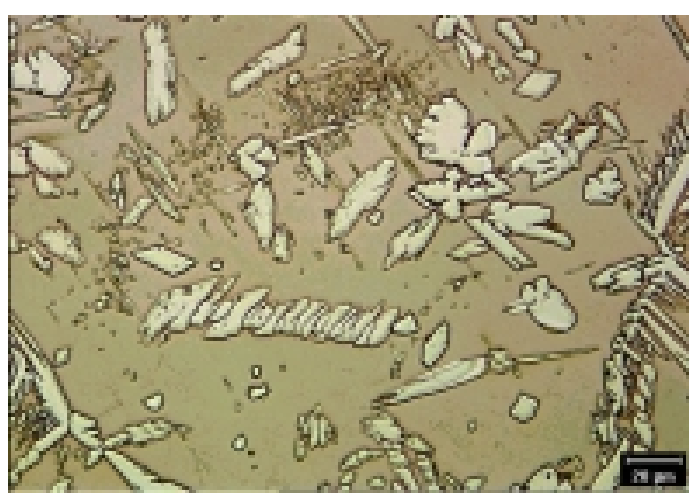

$1100{ }^{\circ} \mathrm{C} \times 1 \mathrm{~s}$

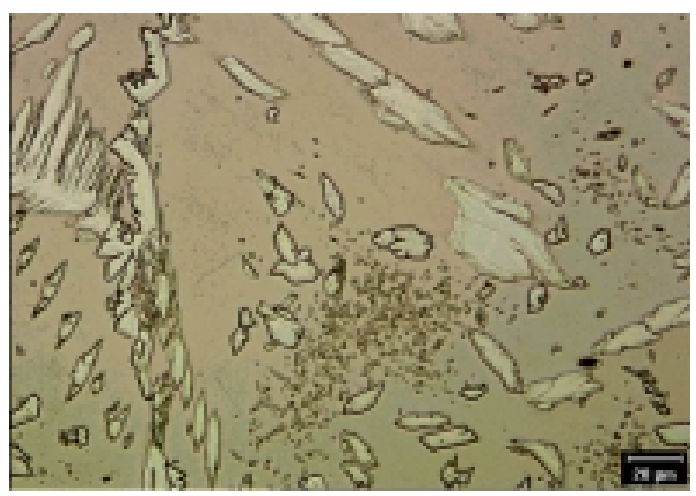

$1000{ }^{\circ} \mathrm{C} \times 1 \mathrm{~s}$

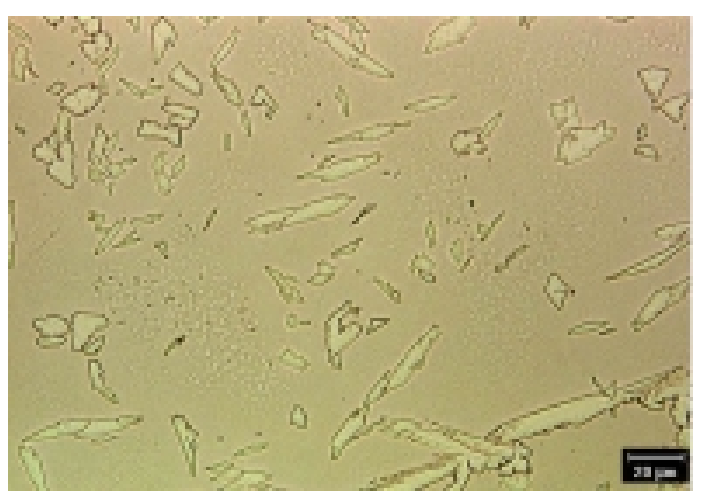

$900{ }^{\circ} \mathrm{C} \times 1 \mathrm{~s}$

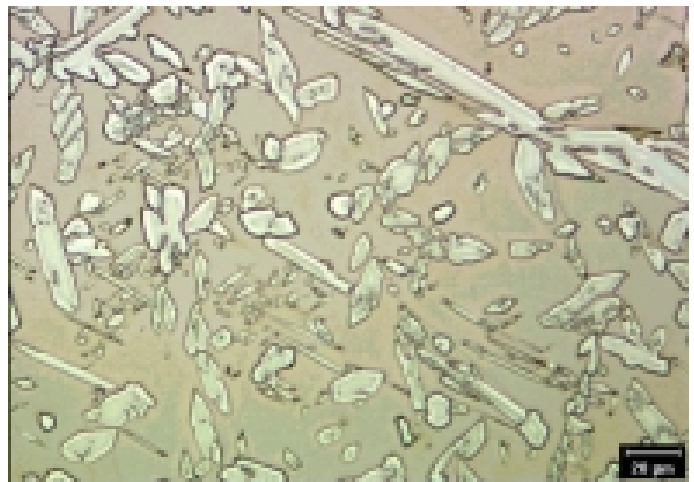

$1200{ }^{\circ} \mathrm{C} \times 10 \mathrm{~s}$

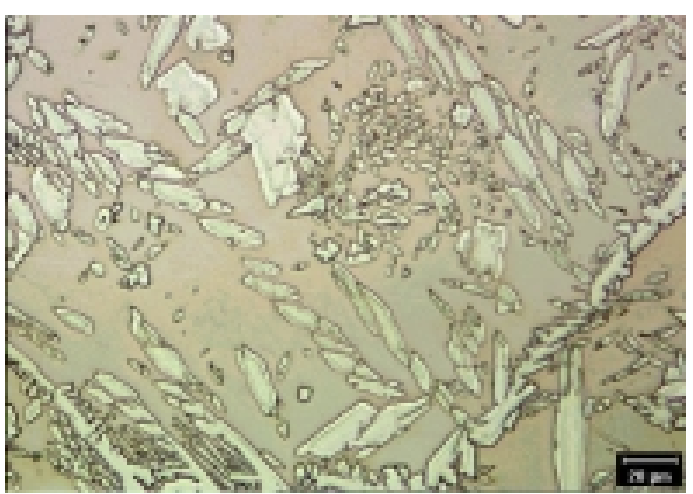

$1100^{\circ} \mathrm{C} \times 10 \mathrm{~s}$

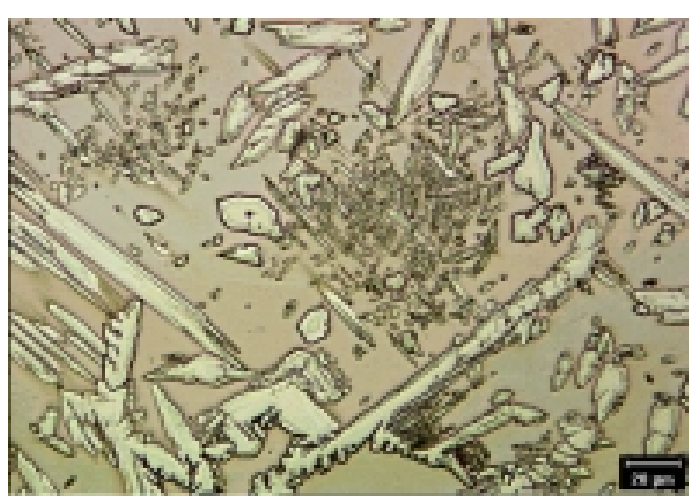

$1000^{\circ} \mathrm{C} \times 10 \mathrm{~s}$

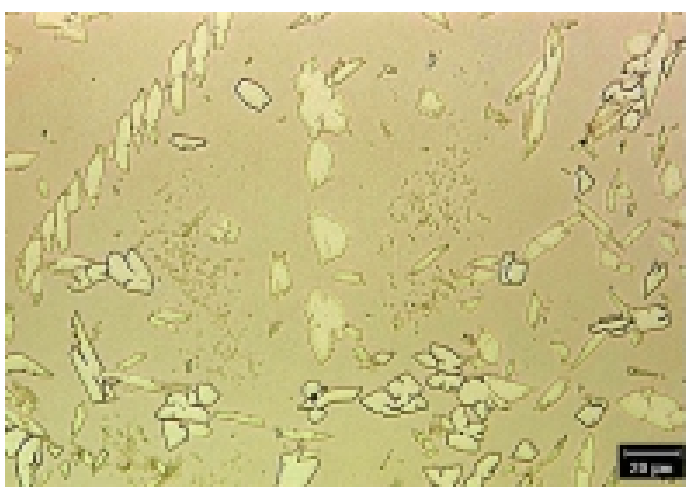

$900{ }^{\circ} \mathrm{C} \times 10 \mathrm{~s}$

Figura 105: Microestruturas do AID UNS S32304 correspondentes aos tratamentos térmicos de reaquecimento a $1200,1100,1000$ e $900^{\circ} \mathrm{C}$ por 1 e $10 \mathrm{~s}$. 

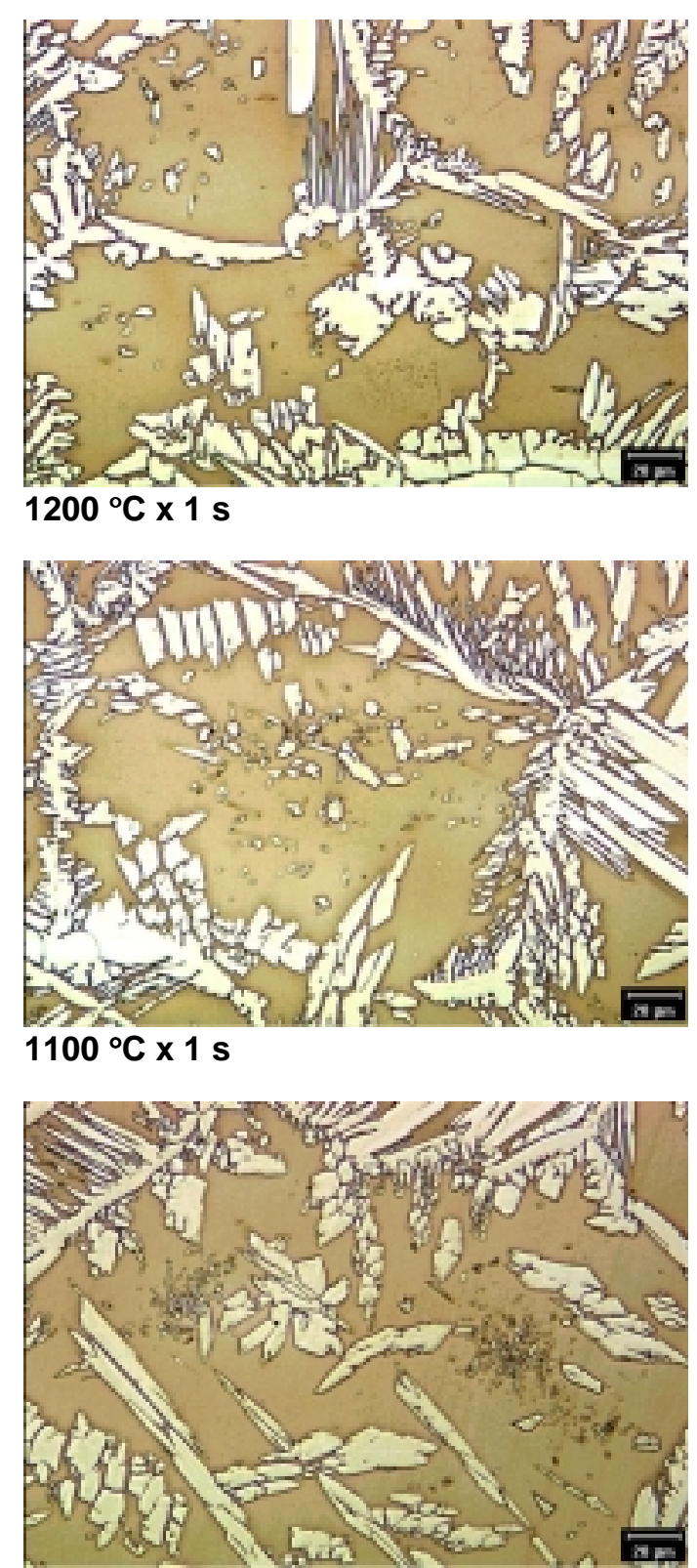

$1000^{\circ} \mathrm{C} \times 1 \mathrm{~s}$

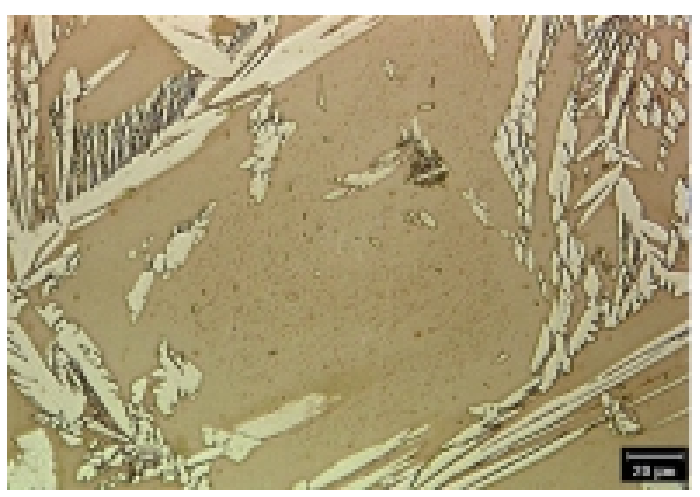

$900{ }^{\circ} \mathrm{C} \times 1 \mathrm{~s}$

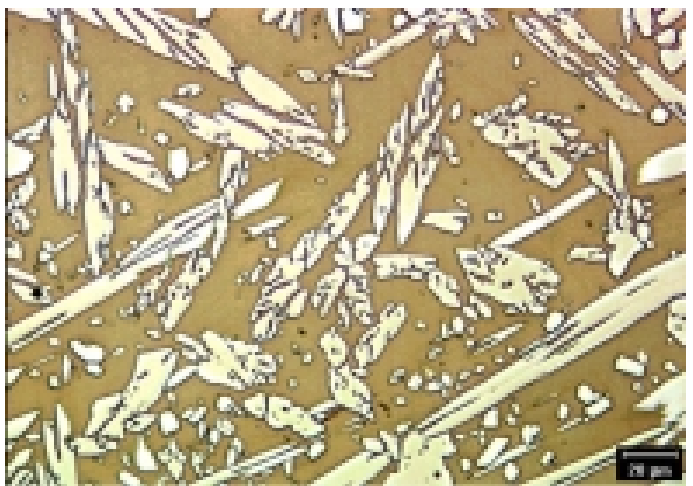

$1200{ }^{\circ} \mathrm{C} \times 10 \mathrm{~s}$

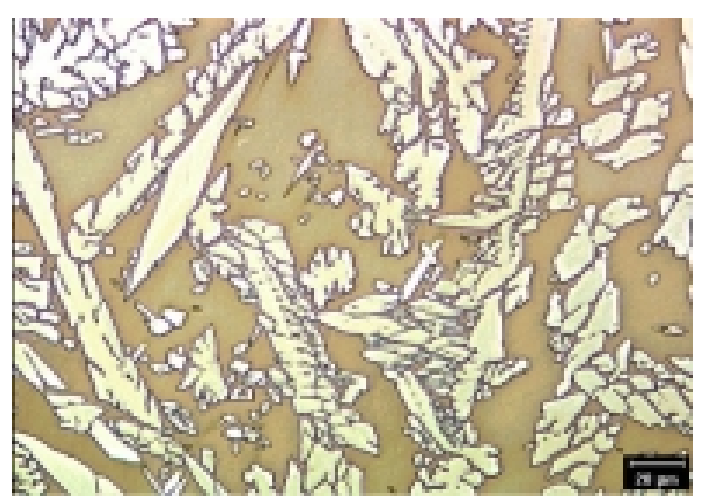

$1100^{\circ} \mathrm{C} \times 10 \mathrm{~s}$

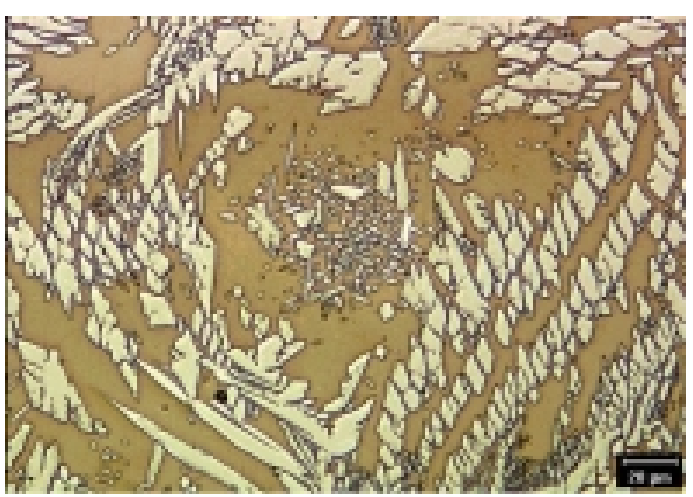

$1000^{\circ} \mathrm{C} \times 10 \mathrm{~s}$

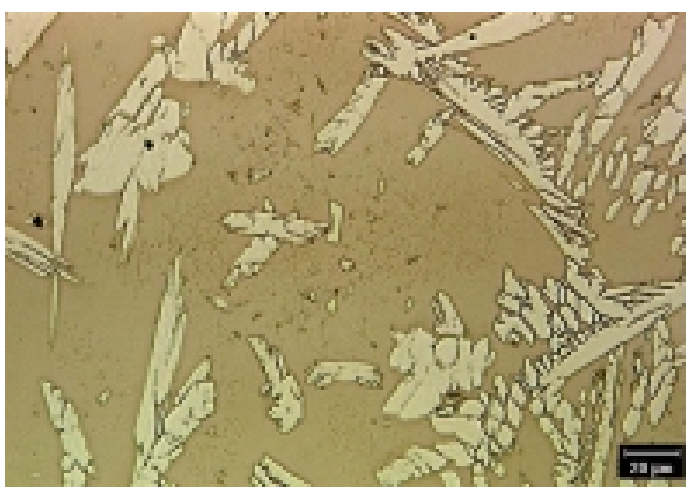

$900{ }^{\circ} \mathrm{C} \times 10 \mathrm{~s}$

Figura 106: Microestruturas do AID UNS S32205 correspondentes aos tratamentos térmicos de reaquecimento a $1200,1100,1000$ e $900^{\circ} \mathrm{C}$ por 1 e $10 \mathrm{~s}$. 


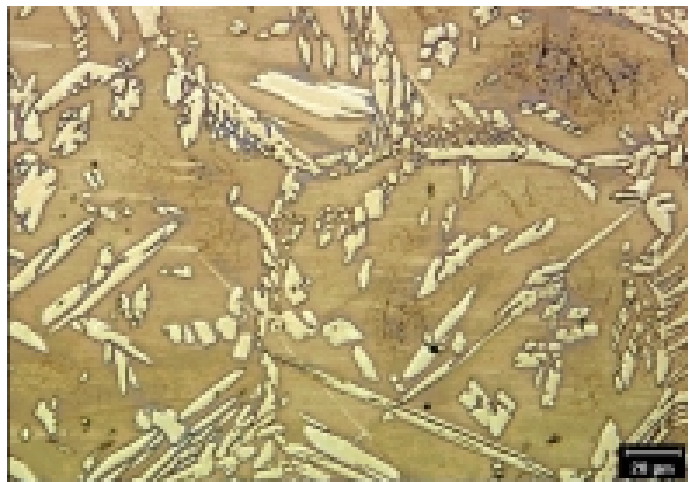

$1200{ }^{\circ} \mathrm{C} \times 1 \mathrm{~s}$

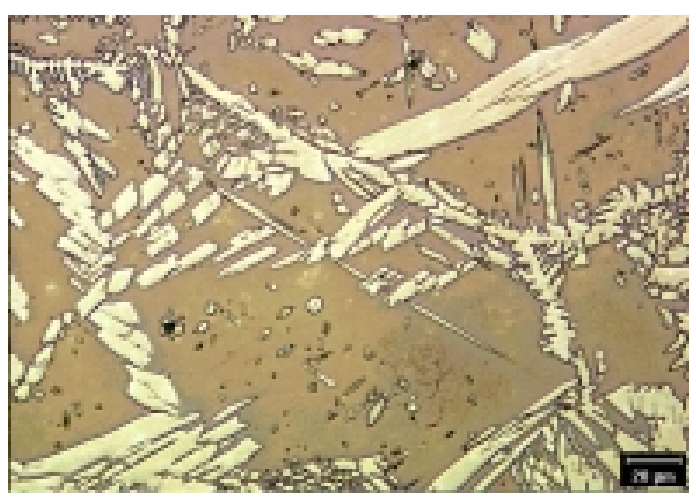

$1100{ }^{\circ} \mathrm{C} \times 1 \mathrm{~s}$

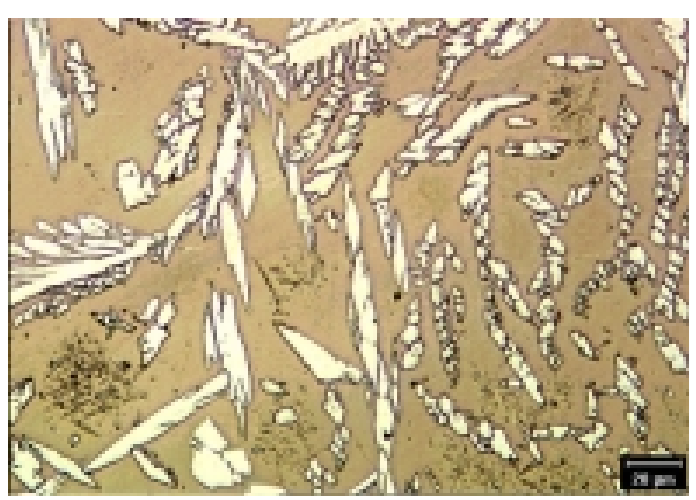

$1000^{\circ} \mathrm{C} \times 1 \mathrm{~s}$

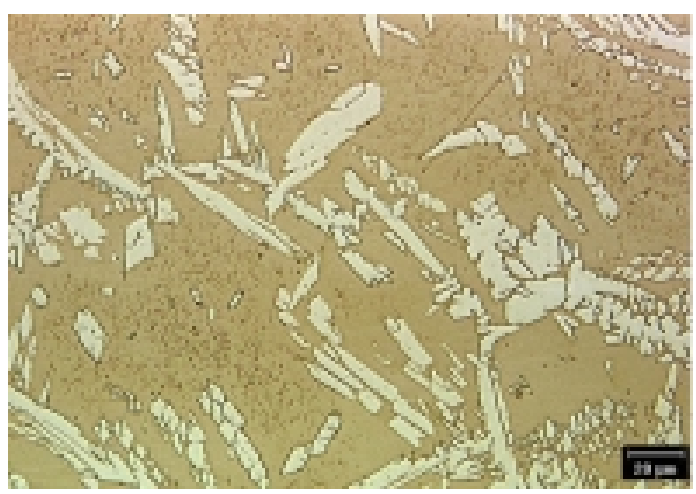

$900{ }^{\circ} \mathrm{C} \times 1 \mathrm{~s}$

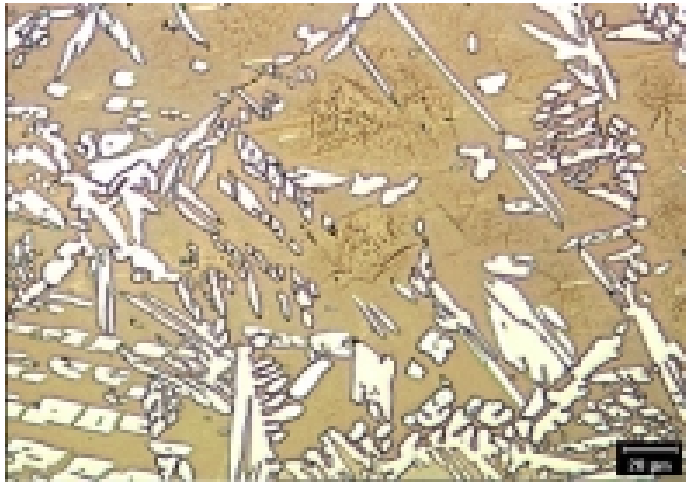

$1200{ }^{\circ} \mathrm{C} \times 10 \mathrm{~s}$

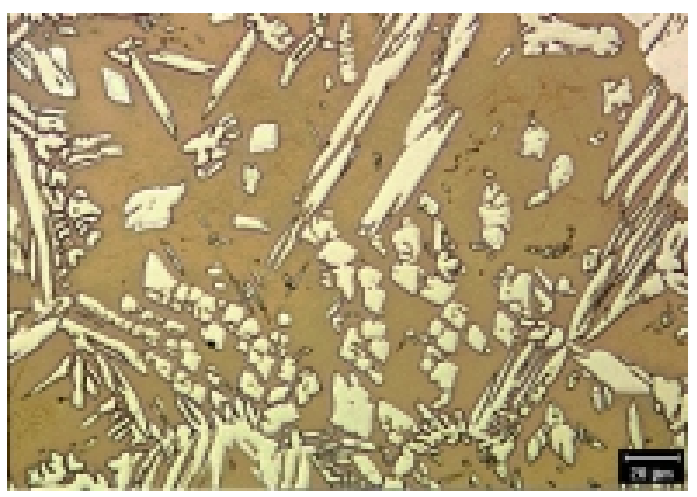

$1100^{\circ} \mathrm{C} \times 10 \mathrm{~s}$

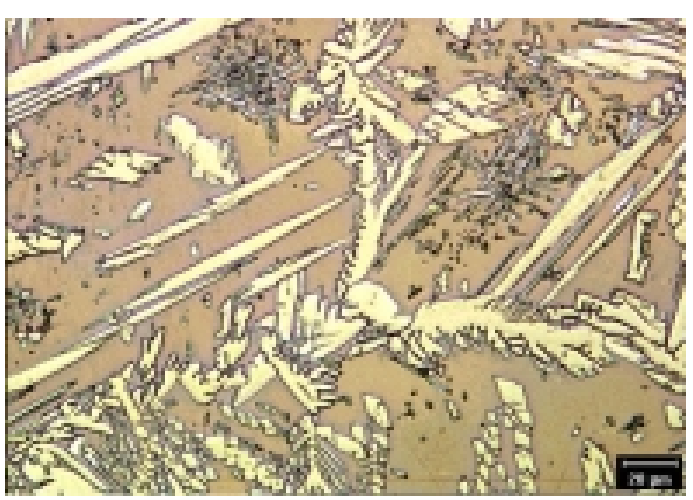

$1000^{\circ} \mathrm{C} \times 10 \mathrm{~s}$

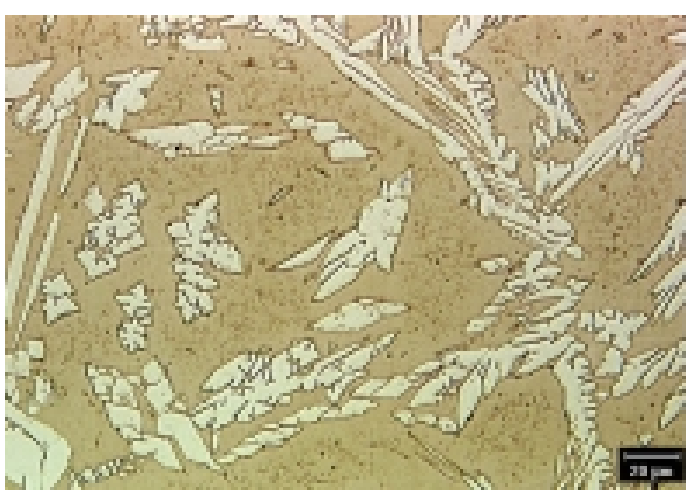

$900^{\circ} \mathrm{C} \times 10 \mathrm{~s}$

Figura 107: Microestruturas do AISD UNS S32550 correspondentes aos tratamentos térmicos de reaquecimento a $1200,1100,1000$ e $900^{\circ} \mathrm{C}$ por 1 e $10 \mathrm{~s}$. 


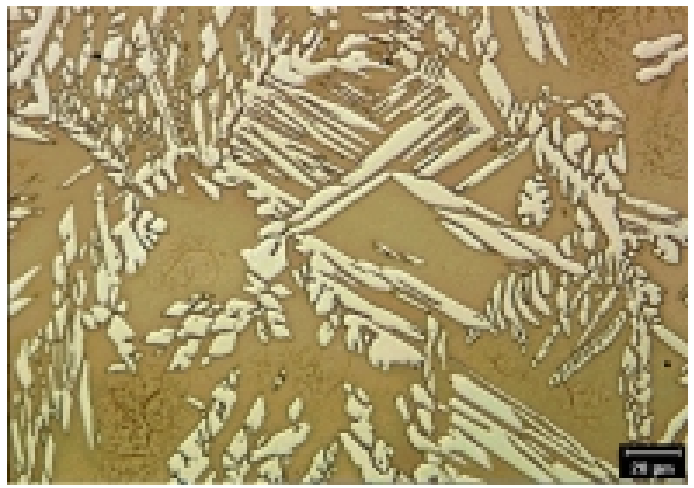

$1200^{\circ} \mathrm{C} \times 1 \mathrm{~s}$

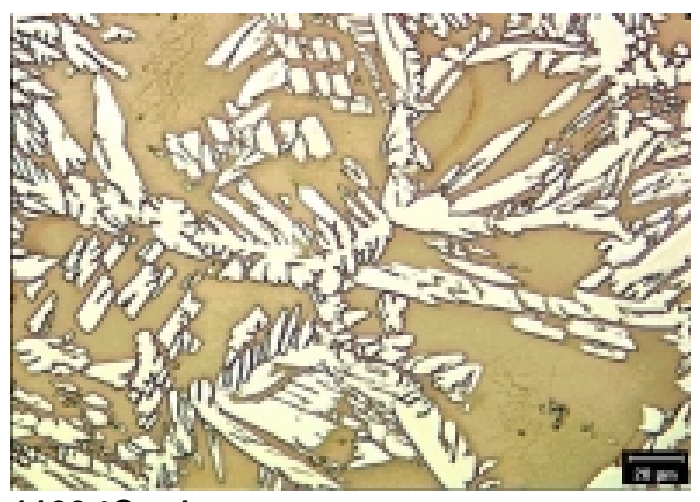

$1100^{\circ} \mathrm{C} \times 1 \mathrm{~s}$

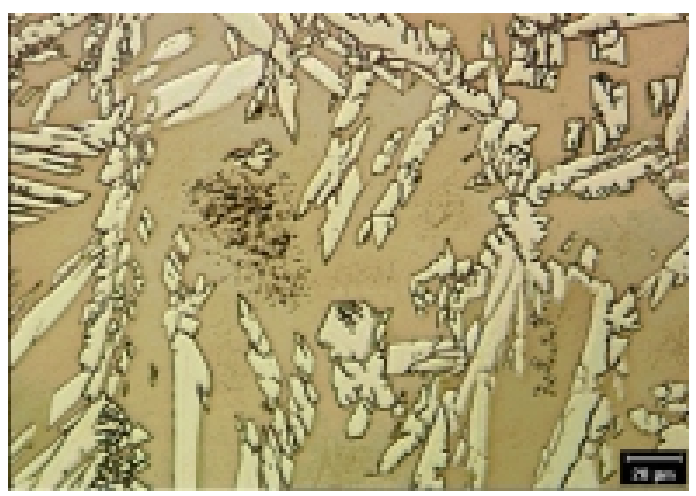

$1000^{\circ} \mathrm{C} \times 1 \mathrm{~s}$

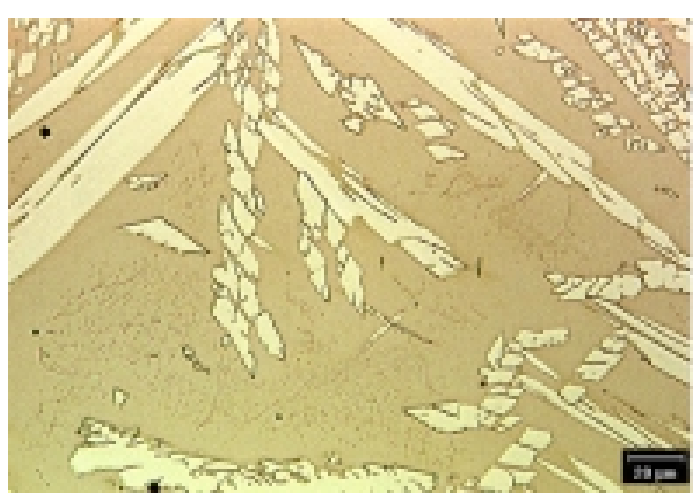

$900{ }^{\circ} \mathrm{C} \times 1 \mathrm{~s}$

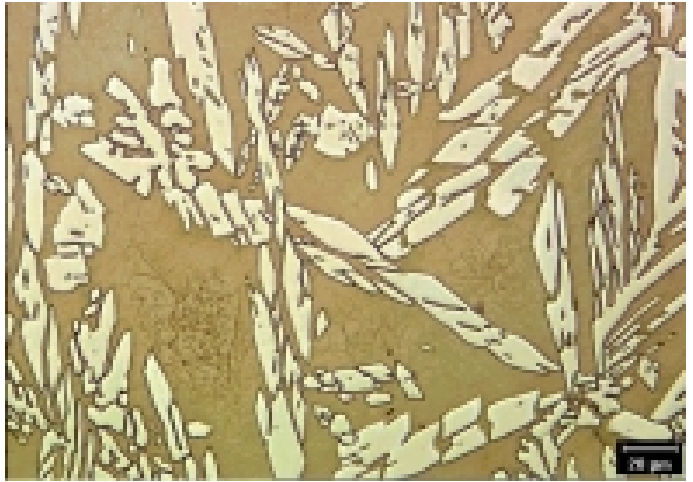

$1200^{\circ} \mathrm{C} \times 10 \mathrm{~s}$

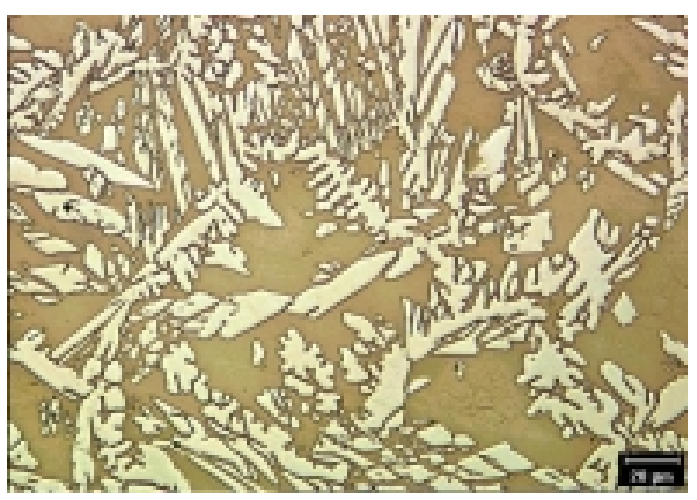

$1100{ }^{\circ} \mathrm{C} \times 10 \mathrm{~s}$

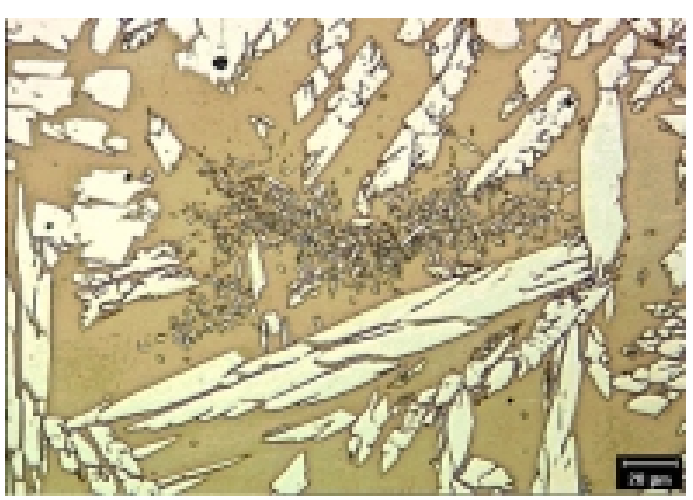

$1000^{\circ} \mathrm{C} \times 10 \mathrm{~s}$

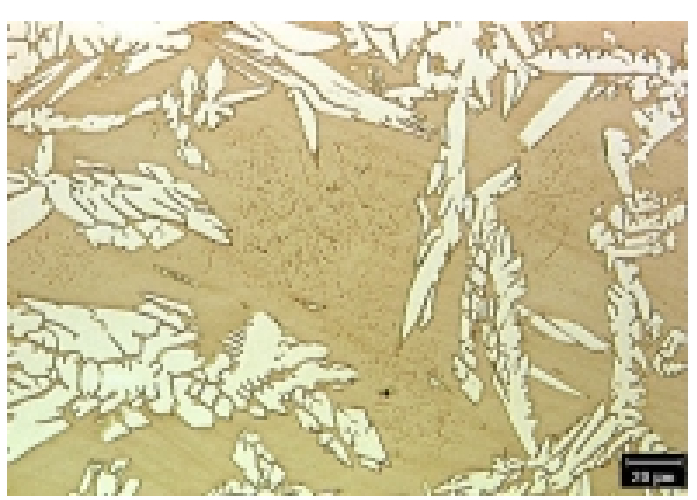

$900{ }^{\circ} \mathrm{C} \times 10 \mathrm{~s}$

Figura 108: Microestruturas do AISD UNS S32750 correspondentes aos tratamentos térmicos de reaquecimento a $1200,1100,1000$ e $900^{\circ} \mathrm{C}$ por 1 e $10 \mathrm{~s}$. 


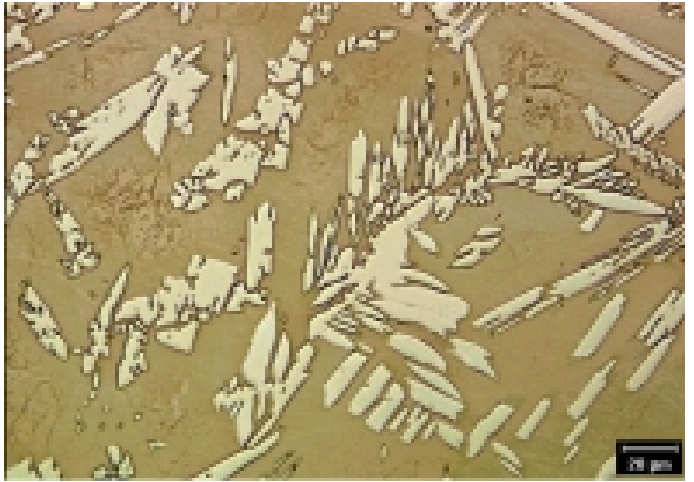

$1200{ }^{\circ} \mathrm{C} \times 1 \mathrm{~s}$

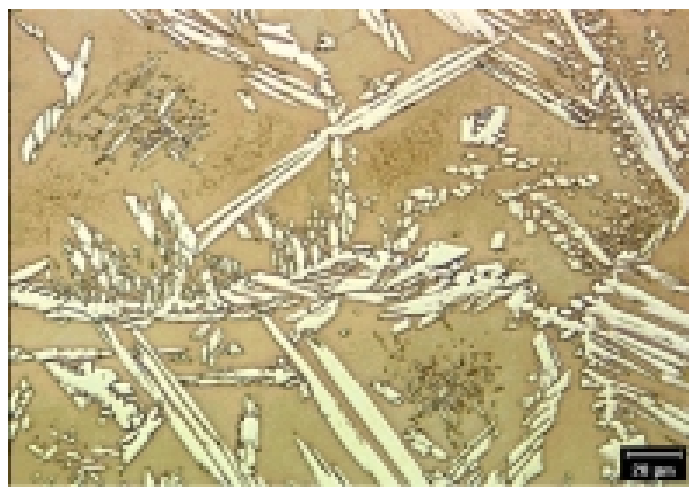

$1100{ }^{\circ} \mathrm{C} \times 1 \mathrm{~s}$

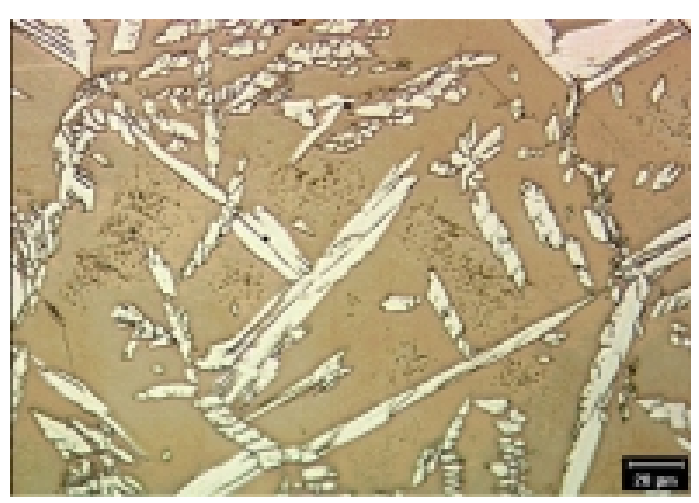

$1000^{\circ} \mathrm{C} \times 1 \mathrm{~s}$

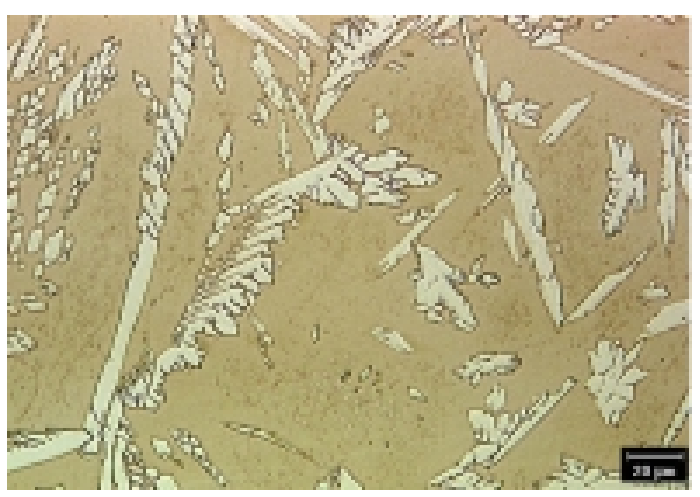

$900{ }^{\circ} \mathrm{C} \times 1 \mathrm{~s}$

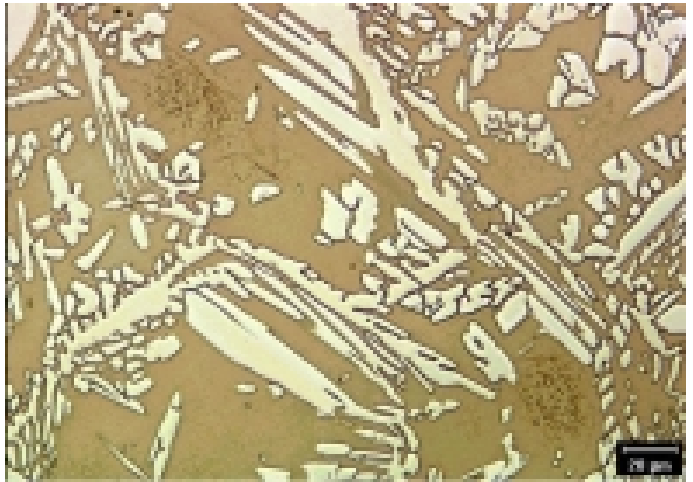

$1200{ }^{\circ} \mathrm{C} \times 10 \mathrm{~s}$

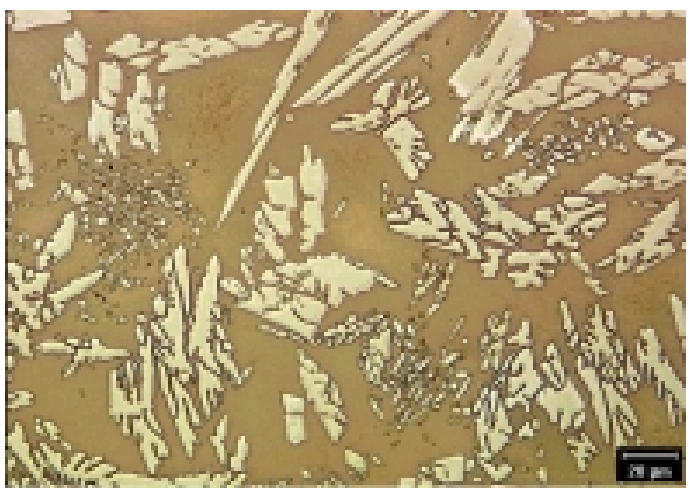

$1100{ }^{\circ} \mathrm{C} \times 10 \mathrm{~s}$

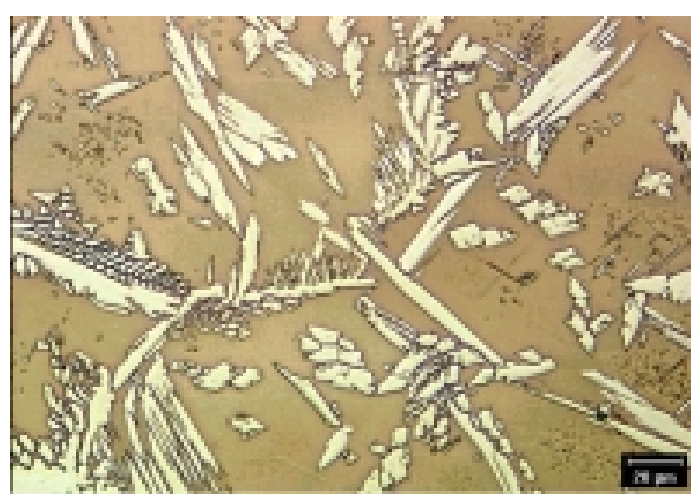

$1000^{\circ} \mathrm{C} \times 10 \mathrm{~s}$

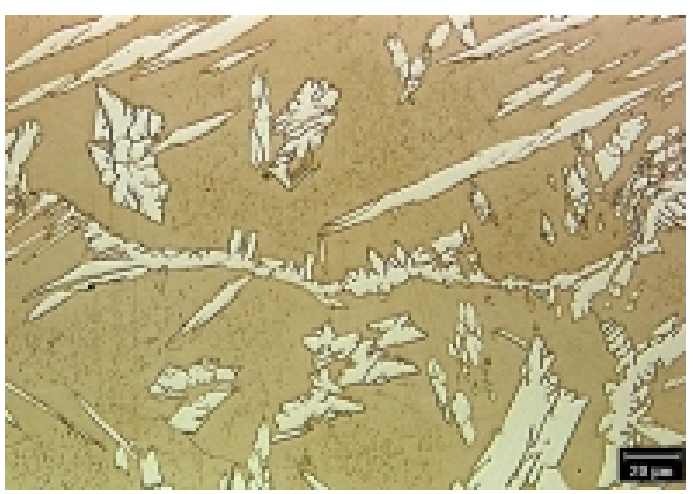

$900{ }^{\circ} \mathrm{C} \times 10 \mathrm{~s}$

Figura 109: Microestruturas do AISD UNS S32760 correspondentes aos tratamentos térmicos de reaquecimento a $1200,1100,1000$ e $900^{\circ} \mathrm{C}$ por 1 e $10 \mathrm{~s}$. 
Tabela 37: Evolução microestrutural dos CPs submetidos a tratamentos térmicos. AIDs UNS S32304 e S32205. Observação no MO.

\begin{tabular}{|c|c|c|c|c|c|}
\hline \multirow{2}{*}{ Condição } & \multirow{2}{*}{ Temperatura } & \multicolumn{4}{|c|}{ Evolução da Microestrutura } \\
\hline & & \multicolumn{2}{|c|}{ UNS S32304 } & \multicolumn{2}{|c|}{ UNS S32205 } \\
\hline Ferritizado & $1350^{\circ} \mathrm{C}$ & \multicolumn{2}{|c|}{$\gamma_{A}-\gamma_{W}-\gamma_{i n t}-C r_{2} N$} & \multicolumn{2}{|c|}{$\gamma_{A}-\gamma_{W}-\gamma_{i n t}-C r_{2} N$} \\
\hline \multicolumn{2}{|c|}{ Tempo Reaquecimento } & $1 \mathrm{~s}$ & $10 \mathrm{~s}$ & $1 \mathrm{~s}$ & $10 \mathrm{~s}$ \\
\hline \multirow{4}{*}{ Reaquecido } & $1200^{\circ} \mathrm{C}$ & $\begin{array}{c}\gamma_{A}-\gamma_{W}-\gamma_{i n t}-C r_{2} N- \\
\gamma_{\text {Int }}\end{array}$ & $\gamma_{A}-\gamma_{W}-\gamma_{1 n t}-\mathrm{Cr}_{2} \mathrm{~N}$ & $\gamma_{\mathrm{A}}-\gamma_{\mathrm{W}}-\gamma_{\gamma_{\mathrm{Int}}}-\mathrm{Cr}_{2} \mathrm{~N}-$ & $\gamma_{A}-\gamma_{W}-\gamma_{1 n t}-C_{2} N$ \\
\hline & $1100^{\circ} \mathrm{C}$ & $\begin{array}{c}\gamma_{A}-\gamma_{W}-\gamma_{i n t}-C_{2} \mathbf{N}- \\
\gamma_{\text {int }}\end{array}$ & $\gamma_{A}-\gamma_{W}-\gamma_{1 n t}-C_{2} N$ & $\gamma_{\mathrm{A}}=\gamma_{\mathrm{W}}-\gamma_{\mathrm{Int}}-\mathrm{Cr}_{2} \mathrm{~N}-$ & $\gamma_{A}-\gamma_{W}-\gamma_{1 n t}$ \\
\hline & $1000^{\circ} \mathrm{C}$ & $\begin{array}{c}\gamma_{A}-\gamma_{W}-\gamma_{\text {Int }}-C r_{2} N- \\
\gamma_{\text {Int }}\end{array}$ & $\gamma_{A}-\gamma_{W}-\gamma_{1 n t}-C_{2} N$ & $\begin{array}{c}\gamma_{\mathrm{A}}-\gamma_{\mathrm{W}}-\gamma_{\mathrm{int}}-\mathrm{Cr}_{2} \mathrm{~N}- \\
\gamma_{\mathrm{int}}\end{array}$ & $\gamma_{A}-\gamma_{W}-\gamma_{i n t}$ \\
\hline & $900{ }^{\circ} \mathrm{C}$ & 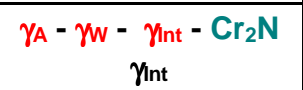 & $\begin{array}{c}\gamma_{A}=\gamma_{W}-\gamma_{i n t}-C_{2} \mathrm{~N}- \\
\alpha / \gamma\end{array}$ & $\gamma_{\mathrm{A}}-\gamma_{\mathrm{W}}-\gamma_{\gamma_{\mathrm{int}}}-\mathrm{Cr}_{2} \mathrm{~N}-$ & $\gamma_{\mathrm{A}}-\gamma_{\mathrm{W}}-\gamma_{\gamma_{\mathrm{Int}}}-\mathrm{Cr}_{2} \mathrm{~N}-$ \\
\hline
\end{tabular}

Nota: $\gamma_{\mathrm{A}}$ : Austenita alotrimórfica de contorno de grão

$\gamma_{w}$ : Placas laterais de austenita de Widmanstätten

Ynt: Austenita intragranular

$\alpha / \gamma$. Precipitados muito pequenos na interface $\alpha / \gamma$

Código de cores: Precipitação - Constante - Crescimento - Dissolução - Fração muito baixa

Tabela 38: Evolução microestrutural dos CPs. submetidos a tratamentos térmicos. AISDs UNS S32550, S32750 e S32760. Observação no MO.

\begin{tabular}{|c|c|c|c|c|c|c|c|}
\hline \multirow{2}{*}{ Condição } & \multirow{2}{*}{ Temperatura } & \multicolumn{6}{|c|}{ Evolução da Microestrutura } \\
\hline & & \multicolumn{2}{|c|}{ UNS S32550 } & \multicolumn{2}{|c|}{ UNS S32750 } & \multicolumn{2}{|c|}{ UNS S32760 } \\
\hline Ferritizado & $1350^{\circ} \mathrm{C}$ & \multicolumn{2}{|c|}{$\gamma_{A}-\gamma_{W}-\gamma_{i n t}-C_{2} N$} & \multicolumn{2}{|c|}{$\gamma_{A}-\gamma_{W}-C_{2} \mathbf{N}$} & \multicolumn{2}{|c|}{$\gamma_{A}-\gamma_{W}-\gamma_{1 n t}-C_{2} N$} \\
\hline \multicolumn{2}{|c|}{ Tempo Reaquecimento } & $1 \mathrm{~s}$ & $10 \mathrm{~s}$ & $1 \mathrm{~s}$ & $10 \mathrm{~s}$ & $1 \mathrm{~s}$ & $10 \mathrm{~s}$ \\
\hline \multirow{4}{*}{ Reaquecido } & $1200^{\circ} \mathrm{C}$ & $\begin{array}{c}\gamma_{\mathrm{A}}-\gamma_{\mathrm{W}}-\gamma_{\mathrm{Int}}- \\
\mathrm{Cr}_{2} \mathrm{~N}\end{array}$ & $\begin{array}{c}\gamma_{A}-\gamma_{W}-\gamma_{i n t}- \\
\mathrm{Cr}_{2} \mathrm{~N}\end{array}$ & $\gamma_{A}-\gamma_{W}-\mathrm{Cr}_{2} \mathbf{N}$ & $\gamma_{A}-\gamma_{W}-\mathrm{Cr}_{2} \mathrm{~N}$ & $\begin{array}{c}\gamma_{A}-\gamma_{W}-\gamma_{\mathrm{lnt}}- \\
\mathrm{Cr}_{2} \mathrm{~N}\end{array}$ & $\gamma_{A}-\gamma_{W}-\gamma_{i n t}-$ \\
\hline & $1100^{\circ} \mathrm{C}$ & $\begin{array}{c}\gamma_{A}-\gamma_{W}-\gamma_{\mathrm{Int}}- \\
\mathrm{Cr}_{2} \mathrm{~N}-\gamma_{\mathrm{Int}}\end{array}$ & $\begin{array}{c}\gamma_{A}-\gamma_{W}-\gamma_{i n t}- \\
C_{2} N-\gamma_{i n t}\end{array}$ & $\begin{array}{c}\gamma_{A}-\gamma_{W}-C_{2} \mathrm{~N}- \\
\gamma_{\mathrm{int}}\end{array}$ & $\begin{array}{c}\gamma_{A}-\gamma_{W}-\gamma_{I n t}- \\
\mathrm{Cr}_{2} \mathrm{~N}\end{array}$ & $\begin{array}{c}\gamma_{A}-\gamma_{W}-\gamma_{1 n t}= \\
C_{2} N-\gamma_{i n t}\end{array}$ & $\begin{array}{c}\gamma_{A}-\gamma_{W}-\gamma_{1 n t}- \\
C_{2} N-\gamma_{i n t}\end{array}$ \\
\hline & $1000^{\circ} \mathrm{C}$ & $\begin{array}{c}\gamma_{A}-\gamma_{W}-\gamma_{1 n t}- \\
C_{2} N-\gamma_{i n t}\end{array}$ & $\gamma_{\mathrm{A}}-\gamma_{\mathrm{W}}-\gamma_{\mathrm{Cr}_{2} \mathrm{~N}}$ & $\begin{array}{c}\gamma_{\mathrm{A}}-\gamma_{\mathrm{W}}-\mathrm{Cr}_{2} \mathrm{~N}- \\
\gamma_{\mathrm{int}}\end{array}$ & $\gamma_{A}-\gamma_{W}-\gamma_{i n t}-$ & $\begin{array}{c}\gamma_{A}-\gamma_{W}-\gamma_{1 n t}= \\
C_{2} N=\gamma_{i n t}\end{array}$ & $\begin{array}{c}\gamma_{\mathrm{A}}-\gamma_{\mathrm{W}}-\gamma_{\mathrm{Int}}- \\
\mathrm{Cr}_{2} \mathrm{~N}-\gamma_{\mathrm{Int}}\end{array}$ \\
\hline & $900^{\circ} \mathrm{C}$ & $\begin{array}{c}\gamma_{A}-\gamma_{W}=\gamma_{i n t}- \\
C r_{2} N=\gamma_{i n t}\end{array}$ & $\begin{array}{c}\gamma_{\mathrm{A}}-\gamma_{\mathrm{W}}-\gamma_{\mathrm{int}}- \\
\mathrm{Cr}_{2} \mathrm{~N}-\alpha / \gamma\end{array}$ & $\begin{array}{c}\gamma_{A}-\gamma_{W}-C_{2} \mathrm{~N}- \\
\gamma_{\text {Int }}-\alpha \gamma\end{array}$ & $\begin{array}{c}\gamma_{\mathrm{A}}-\gamma_{\mathrm{W}}-\gamma_{\mathrm{int}}- \\
\mathrm{Cr}_{2} \mathrm{~N}-\alpha / \gamma\end{array}$ & $\begin{array}{c}\gamma_{A}-\gamma_{W}-\gamma_{\text {Int }}- \\
{C r_{2}}_{2} N-\gamma_{\text {Int }}-\alpha \gamma\end{array}$ & $\begin{array}{c}\gamma_{\mathrm{A}}-\gamma_{\mathrm{W}}-\gamma_{\mathrm{lnt}}- \\
\alpha / \gamma-\mathrm{Cr}_{2} \mathrm{~N}\end{array}$ \\
\hline
\end{tabular}

Nota: $\gamma_{\mathrm{A}}$ : Austenita alotrimórfica de contorno de grão

$\gamma_{\text {w: }}$ Placas laterais de austenita de Widmanstätten

Yint: Austenita intragranular

$\alpha / \gamma$. Precipitados muito pequenos nas interfaces $\alpha / \gamma$

Código de cores: Precipitação - Constante - Crescimento - Dissolução - Fração muito baixa

Vale a pena ressaltar que o AID UNS S32304 foi o material com a maior quantidade de $\gamma_{2}$ intragranular. Este material também apresentou o maior intervalo de temperatura de precipitação desta fase. Isto pode ser devido a:

- O maior tamanho de grão ferrítico e a menor fração de $\gamma$ deste material após o tratamento a $1350^{\circ} \mathrm{C}$ x $5 \mathrm{~s}$, que estão relacionados com a possibilidade de ferritizar este material e com a sua relação $\mathrm{Cr}_{\text {eq }} / \mathrm{Ni}_{\mathrm{eq}}$, respectivamente. O efeito do tamanho de grão é o mesmo experimentado pela precipitação de ferrita acicular nos aços alta-resistência-baixa-liga (HSLA), como mostrado esquematicamente na Figura 110. 
- A maior quantidade de $\mathrm{Cr}_{2} \mathrm{~N}$ precipitada no interior da ferrita. Isto justifica a maior fração

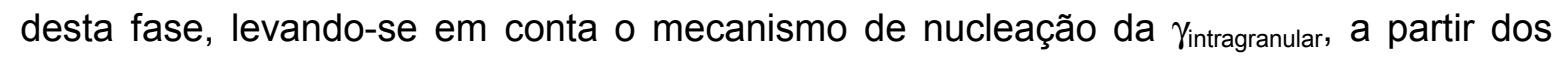
nitretos de cromo, como proposto neste trabalho.

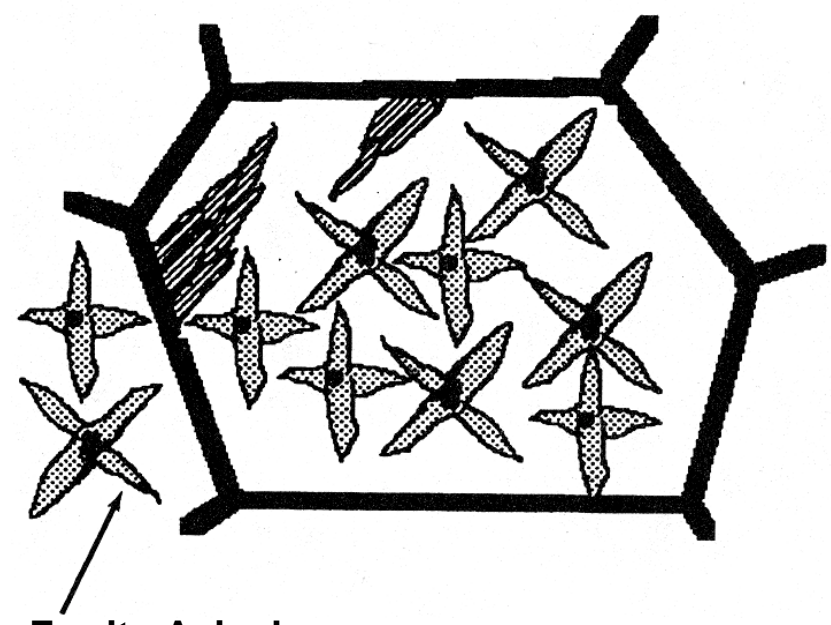

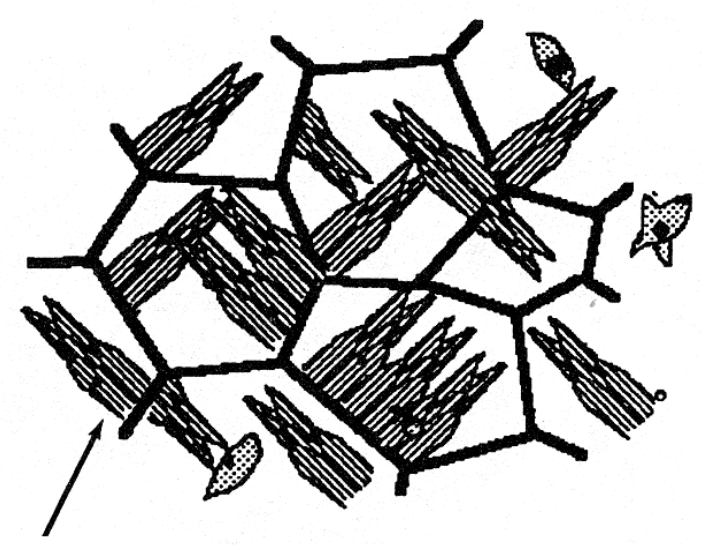

Ferrita de Widmanstätten

\section{Ferrita Acicular}

Figura 110: Efeito do tamanho de grão na precipitação de ferrita acicular nos aços alta-resistênciabaixa-liga (HSLA) ${ }^{(138)}$.

Quanto à diferença de temperatura de reaquecimento na qual as diversas ligas apresentam a maior quantidade de $\gamma_{2}$ intragranular, não se tem ainda uma explicação definitiva, mas acredita-se que esteja estreitamente relacionado com:

- A estabilidade ou taxa de dissolução dos nitretos de cromo na temperatura de reaquecimento.

- Distância de difusão dos elementos formadores da $\gamma_{2}$ intragranular.

- O potencial termodinâmico disponível para a transformação.

Segundo os diagramas de fase das ligas estudadas, apresentados no item 6.2.1.2, à medida que a temperatura de reaquecimento é aumentada, por exemplo a $1200{ }^{\circ} \mathrm{C}$, os nitretos tornam-se mais instáveis e a difusão é facilitada. Como resultado tem-se uma maior taxa de dissolução dos nitretos de cromo. Desta forma, os nitretos dissolvem-se antes de conseguirem servir como sítio para a nucleação das $\gamma_{2}$ intragranulares. Além disso, a alta temperatura facilita a difusão de longo alcance, favorecendo o crescimento das $\gamma$ alotrimórficas e de Widmanstätten. Por outro lado, à medida que as temperaturas de reaquecimento são mais baixas, por exemplo a $900^{\circ} \mathrm{C}$, a cinética das reações torna-se mais lenta, o que não significa que as $\gamma_{2}$ intragranulares não precipitem, mas é provável que isto 
envolva tempos maiores do que os empregados nos tratamentos térmicos aqui apresentados. Além disso, para todas as ligas, com exceção do AID UNS S32304, os nitretos de cromo são termodinamicamente estáveis nesta temperatura, o que por um lado pode manter uma parte deles disponíveis para servir como substrato para a nucleação da $\gamma_{2}$ intragranular, mas ao mesmo tempo a estabilidade destes precipitados pode prejudicar o suprimento do nitrogênio, que viria a facilitar a precipitação desta austenita.

Já no caso das temperaturas intermediárias 1000 e $1100{ }^{\circ} \mathrm{C}$, tem-se as condições adequadas para a precipitação da $\gamma_{2}$ intragranular, onde:

- A difusão de longo alcance, isto é do centro do grão até os contornos, não é tão importante assim, para que o crescimento das austenitas alotrimórficas e de Widmanstätten prevaleça sobre a precipitação e crescimento das pequenas partículas de $\gamma_{2}$ intragranular.

- A estabilidade dos nitretos de cromo é tal que permite que alguns sirvam como substrato para a nucleação e precipitação da $\gamma_{2}$ intragranular mas, ao mesmo tempo, muitos deles conseguem dissolver-se. Assim, a matriz ferrítica destas colônias de nitretos fica momentaneamente enriquecida em nitrogênio, facilitando a precipitação de austenita.

Tabela 39: Temperatura de predominância da austenita secundária intragranular.

\begin{tabular}{|c|c|c|c|c|c|c|c|c|c|c|}
\hline \multirow{3}{*}{$\begin{array}{c}\text { Reaquecimento } \\
\text { Tempo }\end{array}$} & \multicolumn{10}{|c|}{$\gamma_{2}$ intragranular } \\
\hline & \multicolumn{2}{|c|}{$\begin{array}{c}\text { UNS } \\
\text { S32304 }\end{array}$} & \multicolumn{2}{|c|}{$\begin{array}{c}\text { UNS } \\
\text { S32205 }\end{array}$} & \multicolumn{2}{|c|}{$\begin{array}{c}\text { UNS } \\
\text { S32550 }\end{array}$} & \multicolumn{2}{|c|}{$\begin{array}{c}\text { UNS } \\
\text { S32750 }\end{array}$} & \multicolumn{2}{|c|}{$\begin{array}{c}\text { UNS } \\
\text { S32760 }\end{array}$} \\
\hline & $1 \mathrm{~s}$ & $10 \mathrm{~s}$ & $1 \mathrm{~s}$ & $10 \mathrm{~s}$ & $1 \mathrm{~s}$ & $10 \mathrm{~s}$ & $1 \mathrm{~s}$ & $10 \mathrm{~s}$ & $1 \mathrm{~s}$ & $10 \mathrm{~s}$ \\
\hline $1200^{\circ} \mathrm{C}$ & & & & & & & & & & \\
\hline $1100^{\circ} \mathrm{C}$ & & & & & & & & & & \\
\hline $1000^{\circ} \mathrm{C}$ & & & & & & & & & & \\
\hline $900^{\circ} \mathrm{C}$ & & & & & & & & & & \\
\hline
\end{tabular}

Desta forma, após uma detalhada observação no MO dos CPs reaquecidos, foi feita uma seleção dos corpos de prova que apresentaram os estágios incipientes da precipitação das austenitas secundárias intergranular e intragranular. Foram selecionados os CPs reaquecidos a $1000{ }^{\circ} \mathrm{C}$ por $1 \mathrm{~s}$ para serem submetidos a estudo no MEV-EC. A seguir são analisadas as observações realizadas nestes $\mathrm{CP}$ :

\subsection{Precipitação de Austenita Secundária}

A diferenciação entre as austenitas primária $\left(\gamma_{1}\right)$ e secundária $\left(\gamma_{2}\right)$ no MEV-EC foi possibilitada pelo ataque eletrolítico em duas etapas (ver página 44), especialmente desenvolvido neste 
trabalho para este fim. Esta diferenciação foi possível devido à diferença de composição química entre as austenitas primária e secundária, a qual gera comportamentos diferentes frente ao ataque eletrolítico utilizado. Ele forma um degrau no limite entre a $\gamma_{1}$ e a $\gamma_{2}$, que é facilmente observável numa imagem de elétrons secundários, como mostrado na Figura 111.

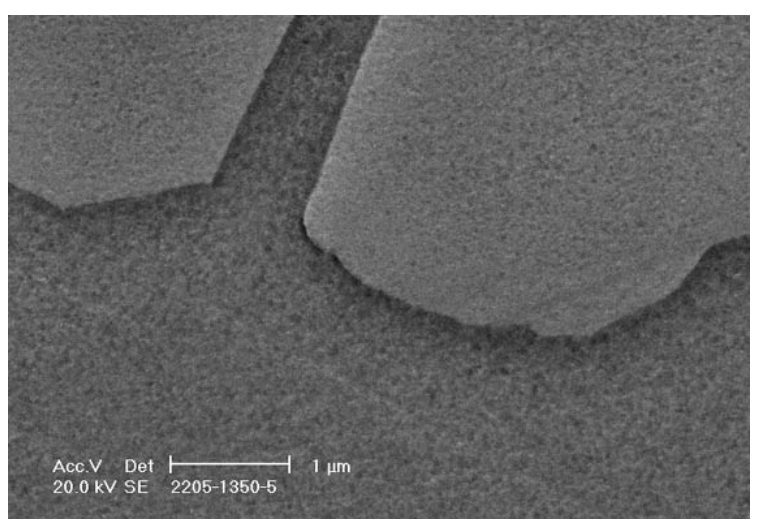

a.

Figura 111: Diferenciação entre $\gamma_{1}$ e $\gamma_{2}$ no AID UNS S32205. Em (a) contornos de partículas de $\gamma_{1}$ após tratamento de ferritização a $1350{ }^{\circ} \mathrm{C}$ por $5 \mathrm{~s}$. Em (b) crescimento de $\gamma_{2}$ a partir de partículas preexistentes de $\gamma_{1}$, após reaquecimento a $1000^{\circ} \mathrm{C}$ por $1 \mathrm{~s}$. MEV-EC.

Esta clara diferenciação entre as austenitas primária e secundária permitiu determinar quando uma austenita intragranular era primária ou secundária. Como pode ser visto na Figura 112, as $\gamma_{1}$ intragranulares apresentam uma camada de $\gamma_{2}$, enquanto que as $\gamma_{2}$ intragranulares não apresentam esta camada. 


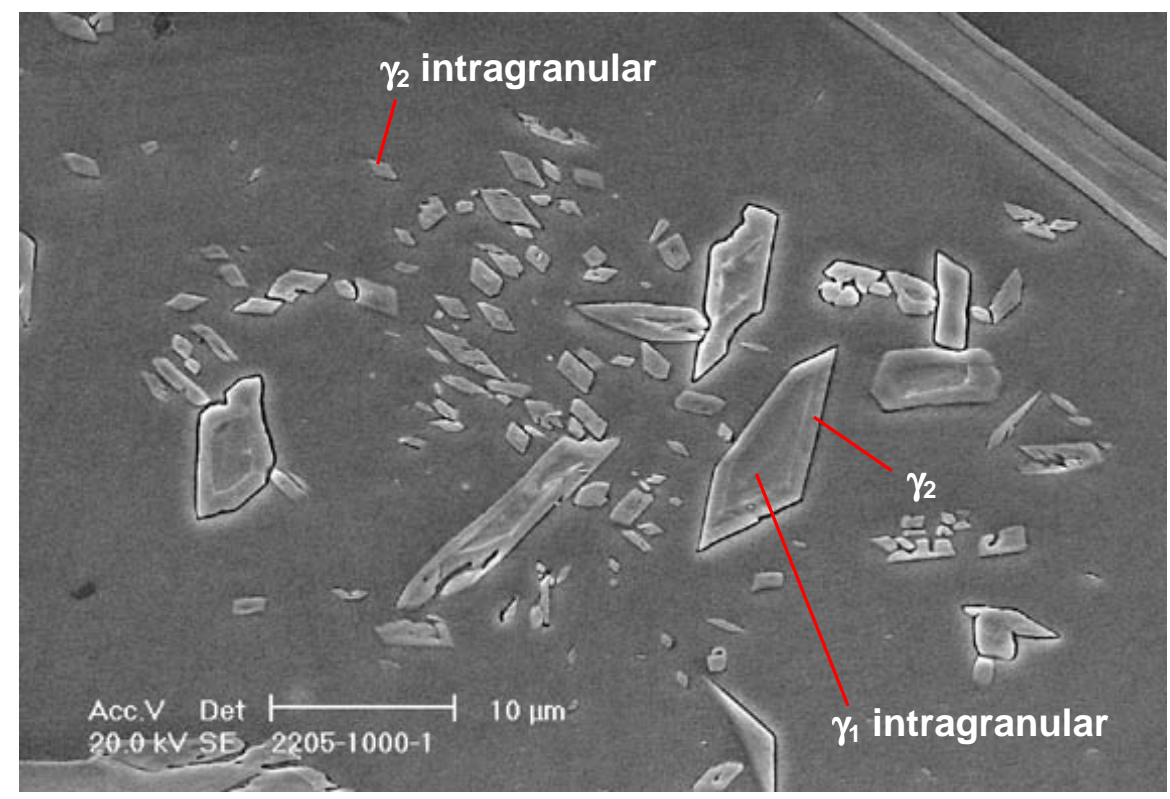

Figura 112: Diferenciação entre $\gamma_{1}$ e $\gamma_{2}$ no AID UNS S32205 após reaquecimento a $1000{ }^{\circ} \mathrm{C}$ por $1 \mathrm{~s}$. MEV-EC.

Esta diferenciação entre $\gamma_{1}$ e $\gamma_{2}$ também permitiu identificar em que interfaces das austenitas primárias se teve o crescimento da $\gamma_{2}$. Foi observado como o crescimento da $\gamma_{2}$ a partir da $\gamma_{1}$, não foi uniforme ao longo de todas as interfaces $\gamma_{1} / \alpha$, isto no plano em que os CP foram preparados, como é mostrado na Figura 113. Esta falta de uniformidade pode estar relacionada com:

- A diferente orientação das partículas de $\gamma_{1}$ em relação ao plano de corte observado no $\mathrm{CP}$, pode em parte, vir a gerar esta falta de uniformidade. No entanto, nem toda ela pode ser justificada deste modo.

- As relações de orientação entre a $\gamma_{1}$ e a $\alpha$. Diferentes planos da interface de uma mesma partícula de $\gamma_{1}$ podem apresentar um comportamento diferente quanto ao crescimento da $\gamma_{2}$. É conhecido que as estruturas do tipo Widmanstätten apresentam interfaces semicoerentes e no caso do par $\gamma / \alpha$ elas formam as relações de orientação do tipo K-S e $\mathrm{N}-\mathrm{W}$. No entanto, as interfaces reais apresentam desvios maiores ou menores destas relações de orientação. Assim, as interfaces apresentam variações no seu grau de coerência e, portanto, na sua mobilidade.

- O caminho de difusão que os elementos formadores das duas fases devem realizar de modo que a transformação $\alpha \rightarrow \gamma$ possa acontecer. Por este motivo, poderia ser explicado que, em geral, as interfaces $\gamma_{1} / \alpha$, ou a porção delas, que se encontram bastante perto de outra partícula de $\gamma$ (ou outra interface $\gamma / \alpha$ da mesma partícula) apresentaram uma quantidade mínima ou não apresentaram $\gamma_{2}$ após o reaquecimento. 
Esta justificativa é respaldada pelo fato das placas laterais de Widmanstätten de $\gamma_{1}$ apresentarem, em geral, camadas mais espessas de $\gamma_{2}$ nas pontas que nos seus cantos e, em muitos casos, a ausência de $\gamma_{2}$ nestes cantos, como pode ser observado na Figura 114.

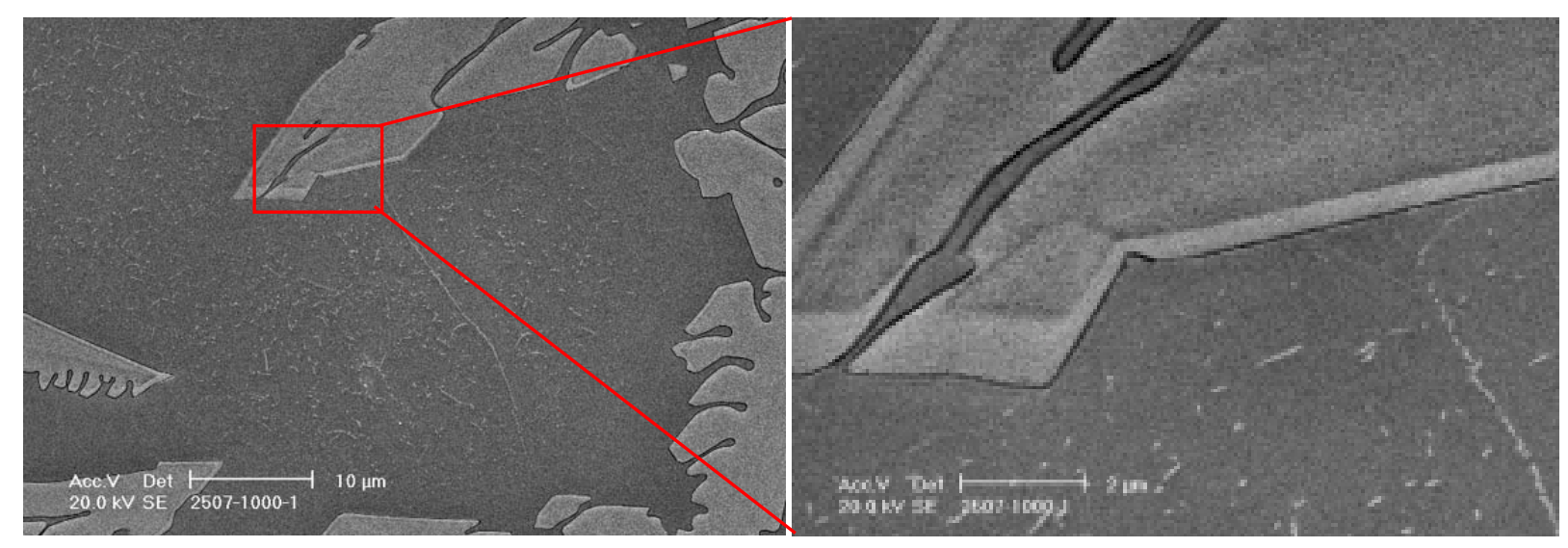

Figura 113: Falta de uniformidade na camada de $\gamma_{2}$ ao redor das partículas de $\gamma_{1}$. AISD UNS S32750 reaquecido a $1000^{\circ} \mathrm{C}$ por $1 \mathrm{~s}$. MEV-EC.

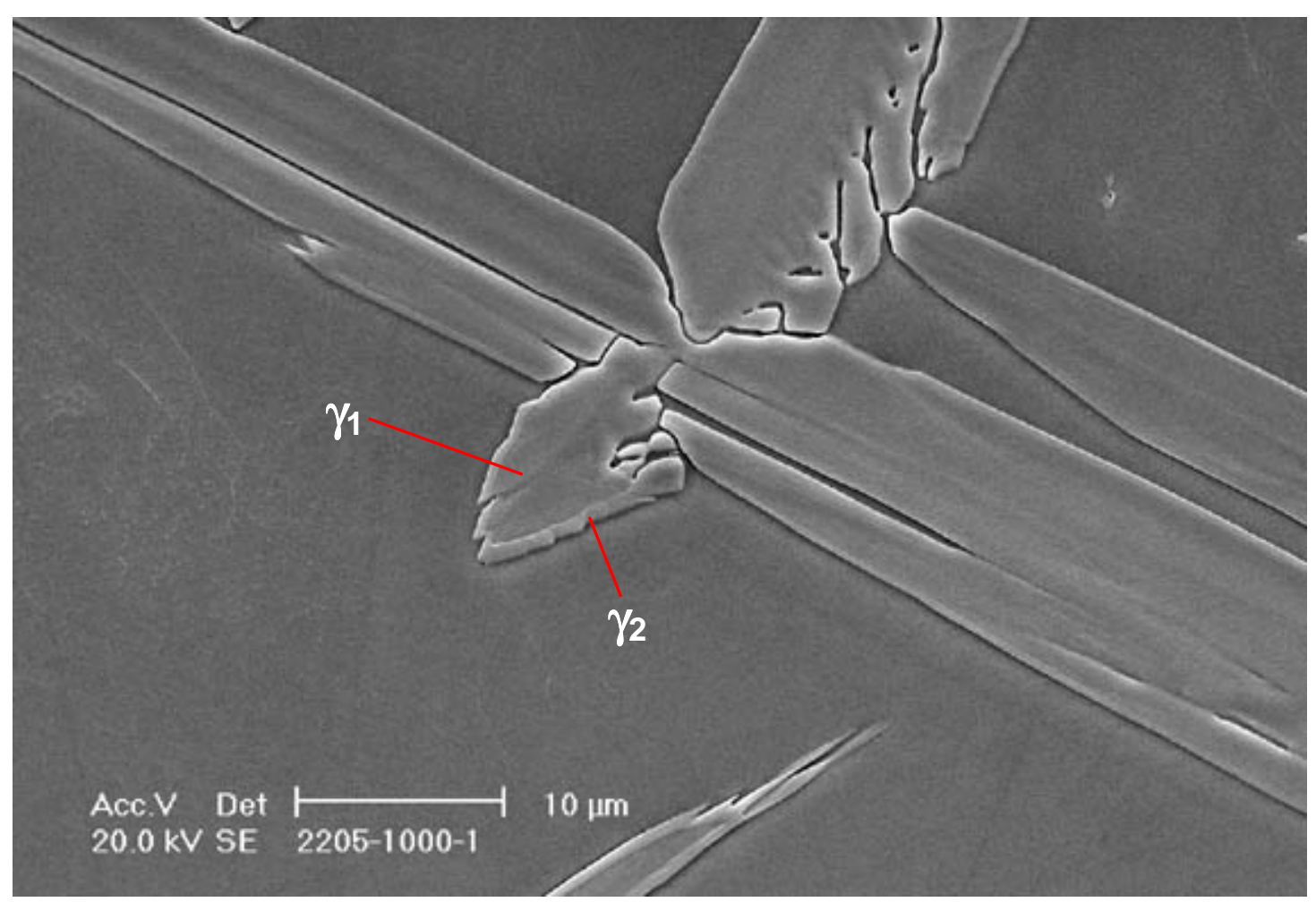

Figura 114: Camada de $\gamma_{2}$ ao redor de placas laterais de Widmanstätten de $\gamma_{1}$. AID UNS S32205 reaquecido a $1000^{\circ} \mathrm{C}$ por $1 \mathrm{~s}$. MEV-EC. 


\subsection{Nitretos de Cromo Intragranulares}

Em termos gerais, a quantidade de nitretos de cromo intragranulares diminui bastante com os tratamentos de reaquecimento. No entanto, após os tratamentos de reaquecimento por $10 \mathrm{~s}$ ainda eram observados nitretos na microestrutura, isto para quase todas as ligas estudadas e para várias temperaturas de tratamento (ver Tabelas 37 e 38).

Similarmente aos CPs submetidos ao tratamento térmico a $1350{ }^{\circ} \mathrm{C}$, também foram observados bastonetes de $\mathrm{Cr}_{2} \mathrm{~N}$ com uma clara bifurcação nos seus extremos. Na Figura 115 é mostrado um destes bastonetes de aparência bifurcada no AISD UNS S32750 reaquecido a $1000^{\circ} \mathrm{C}$ por $1 \mathrm{~s}$.

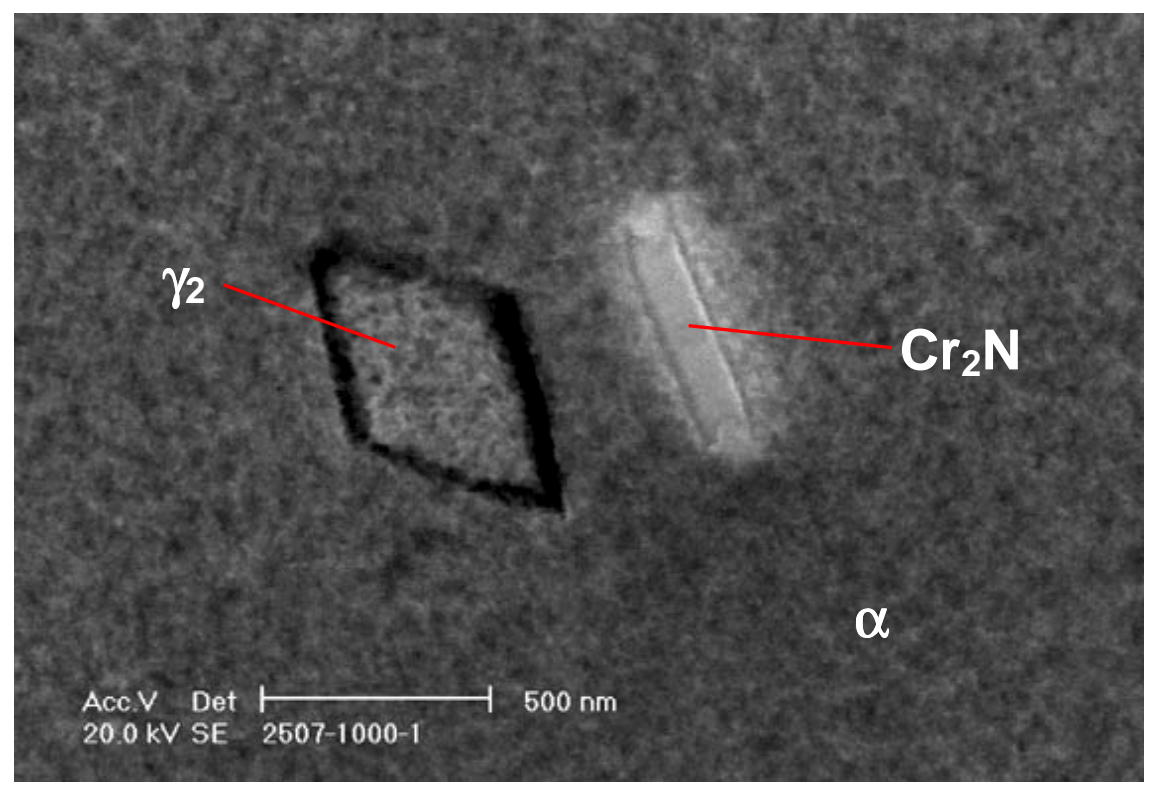

Figura 115: Bastonete bifurcado de $\mathrm{Cr}_{2} \mathrm{~N}$ próximo a uma partícula de $\gamma_{2}$ intragranular bastante pequena. AISD UNS $S 32750$ reaquecido a $1000^{\circ} \mathrm{C}$ por $1 \mathrm{~s}$. MEV-EC.

\subsection{Nitretos de Cromo intergranulares}

Nos CPs reaquecidos a $1000^{\circ} \mathrm{C}$ por $1 \mathrm{~s}$ dos AISD UNS S32550 e S32760 foi observada a precipitação de uma outra fase nas interfaces $\gamma_{1} / \alpha$. Na Figura 116 é mostrada a precipitação destas partículas de segunda fase na interface $\gamma / \alpha$, do lado da $\alpha$, no AISD UNS S32760 reaquecido a $1000{ }^{\circ} \mathrm{C}$ por $1 \mathrm{~s}$. Já na micrografia apresentada na Figura 117 do AISD UNS S32550 reaquecido a $1000{ }^{\circ} \mathrm{C}$ por $1 \mathrm{~s}$, não fica tão claro de que lado da interface ocorreu a precipitação. Porém, a figura sugere que o precipitado está crescendo para o lado da $\alpha$.

Estes precipitados foram identificados mediante MET nos CPs submetidos a tratamentos a $1350{ }^{\circ} \mathrm{C}$, como sendo $\mathrm{Cr}_{2} \mathrm{~N}$. Já durante o tratamento térmico de reaquecimento, estes nitretos cresceram de modo que foram observados no MEV-EC. 


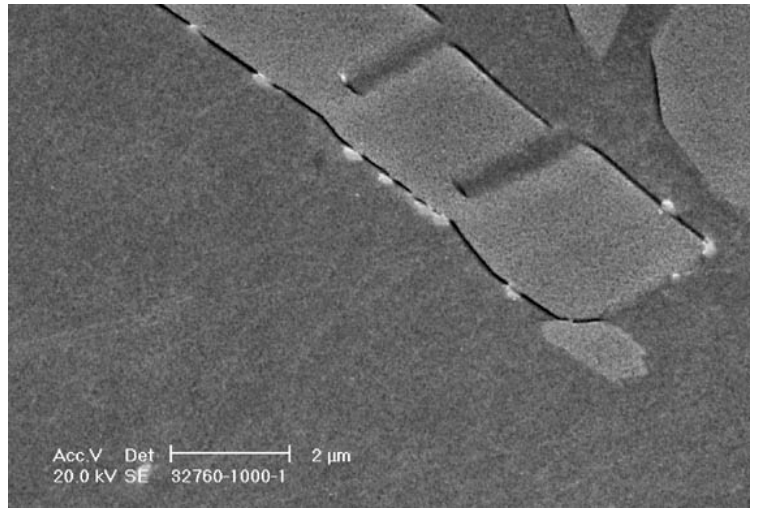

a.

Figura 116: Precipitação de partículas de segunda fase na interface $\gamma_{1} / \alpha$. AISD UNS S32760 reaquecido a $1000{ }^{\circ} \mathrm{C}$ por $1 \mathrm{~s}$. Em (a) vista geral e em (b) detalhe das fases precipitadas. MEV-EC.

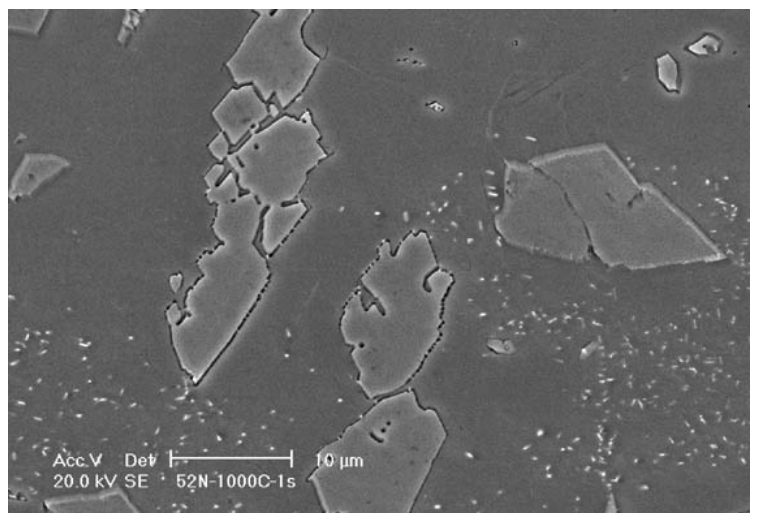

a.

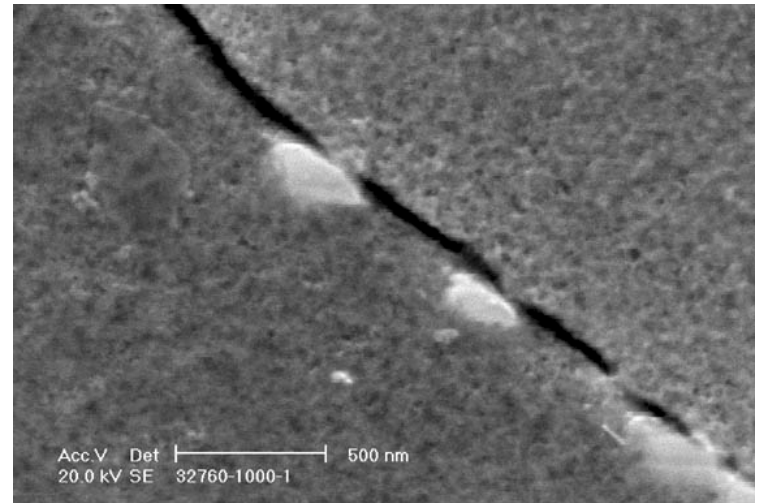

b.

Figura 117: Precipitação de partículas de segunda fase na interface $\gamma_{1} / \alpha$. AISD UNS S32550 reaquecido a $1000^{\circ} \mathrm{C}$ por $1 \mathrm{~s}$. Em (a) vista geral e em (b) detalhe das fases precipitadas. MEV-EC.

Estes mesmos precipitados foram observados no $\mathrm{MO}$ e no MEV-EC nos CPs reaquecidos a $900{ }^{\circ} \mathrm{C}$. Acredita-se que maior incidência desta precipitação durante o tratamento a $900{ }^{\circ} \mathrm{C}$ seja justificada pela maior estabilidade, do ponto de vista termodinâmico, do $\mathrm{Cr}_{2} \mathrm{~N}$ nesta temperatura (Ver diagramas de fase de equilíbrio das ligas estudadas no item 6.2.1.2). Está sendo assumido que estes precipitados sejam os mesmos identificados no MET nos CPs tratados a $1350{ }^{\circ} \mathrm{C}$. Nas Figuras 118 a 121 são apresentados exemplos desta precipitação nos AIDs UNS S32205, S32550, S32750 e S32760.

Como pode ser observado nas figuras anteriores, os precipitados aparecem principalmente nas interfaces $\alpha / \gamma$, onde o crescimento da $\gamma_{2}$ ainda não começou, ou está no seu estágio incipiente (Ver Figura 118). Isto pode ser interpretado da seguinte forma: 
- A precipitação dos nitretos é favorecida nas interfaces $\alpha / \gamma$ onde o crescimento da $\gamma_{2}$ é mais lento.

- A precipitação dos nitretos na interface $\alpha / \gamma$ antecede o crescimento da $\gamma_{2}$. Estes nitretos poderão ser dissolvidos posteriormente.

- A precipitação dos nitretos a partir das interfaces $\alpha / \gamma$ favorece o crescimento da $\gamma$ na forma de $\gamma_{2}$. Este processo pode ser seguido pela dissolução destes nitretos.

Vale a pena ressaltar que a dissolução dos nitretos, proposta acima, é baseada em observações de CPs submetidos a TTs mais longos, onde estes nitretos não foram observados.
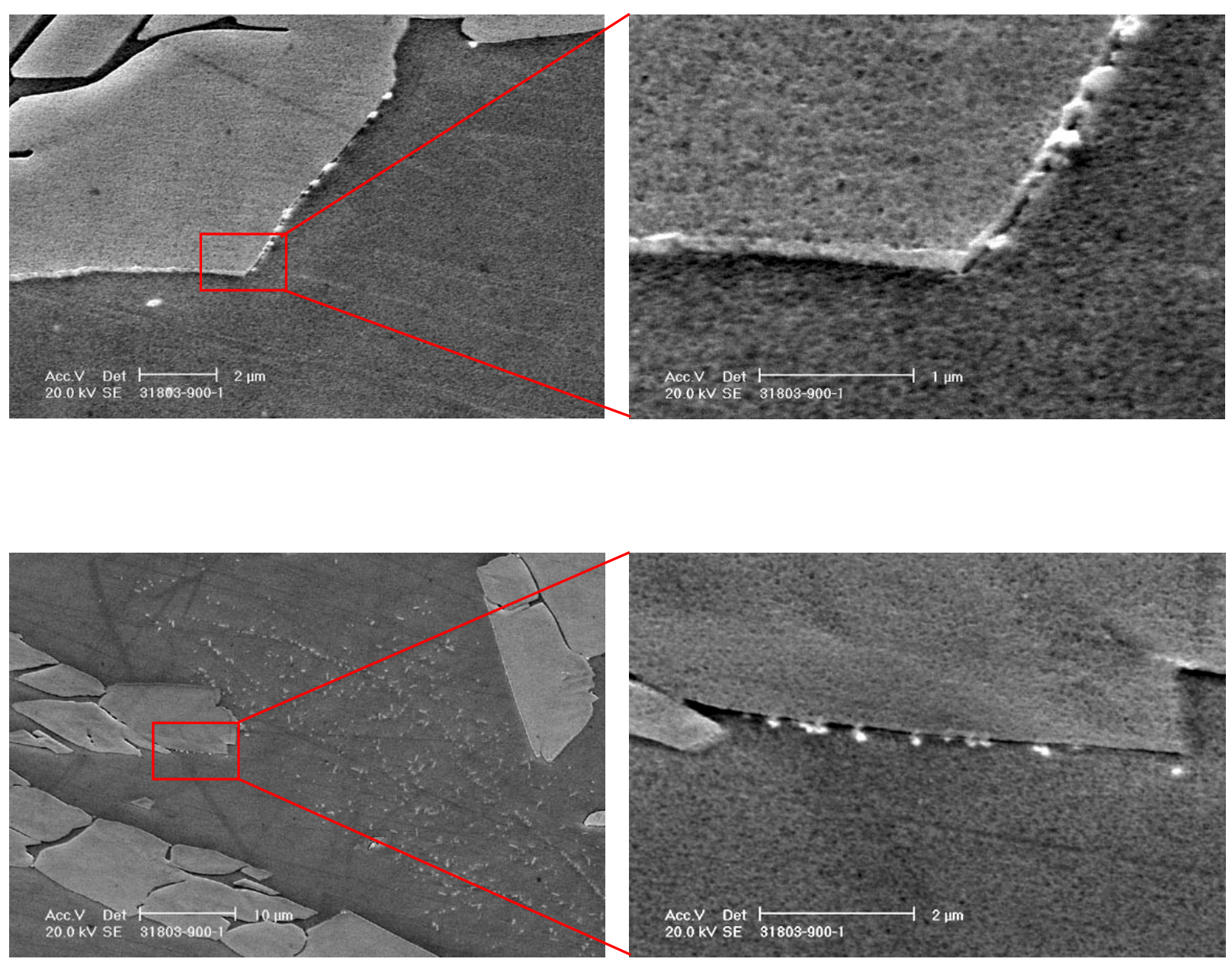

Figura 118: Precipitação de partículas de segunda fase na interface $\gamma_{1} / \alpha$. AISD UNS S32205 reaquecido a $900^{\circ} \mathrm{C}$ por $1 \mathrm{~s}$. MEV-EC. 


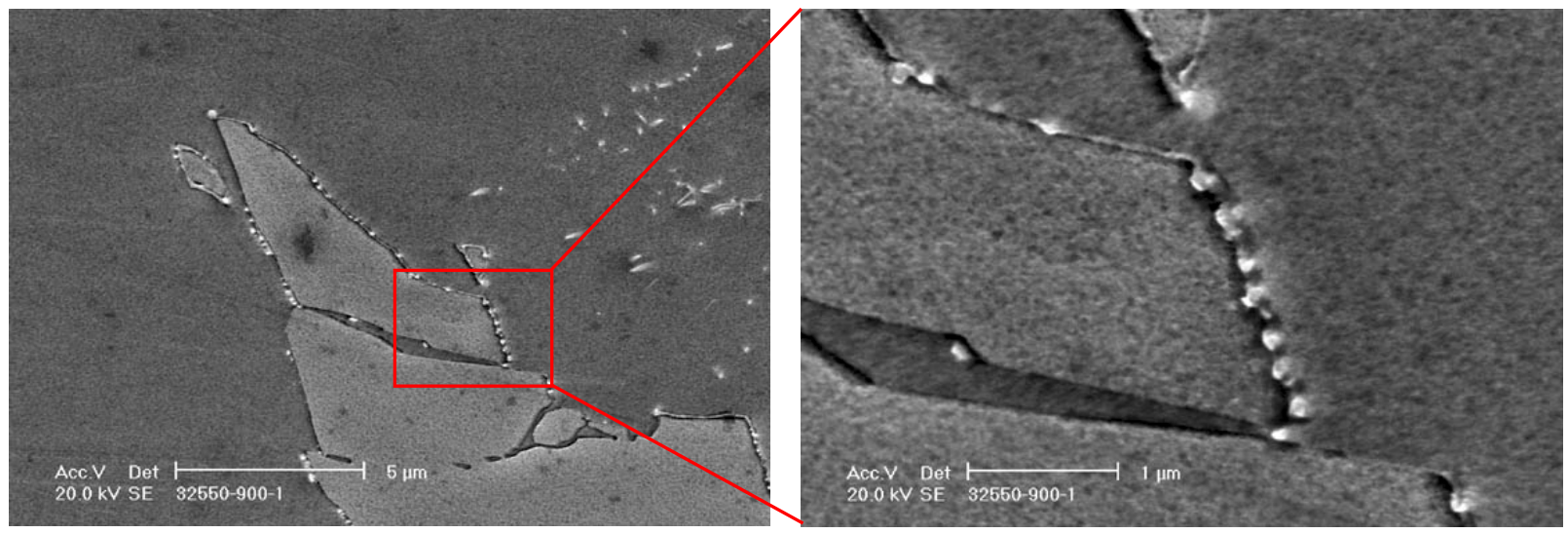

Figura 119: Precipitação de partículas de segunda fase na interface $\gamma_{1} / \alpha$. AISD UNS S32550 reaquecido a $900{ }^{\circ} \mathrm{C}$ por $1 \mathrm{~s}$. MEV-EC.

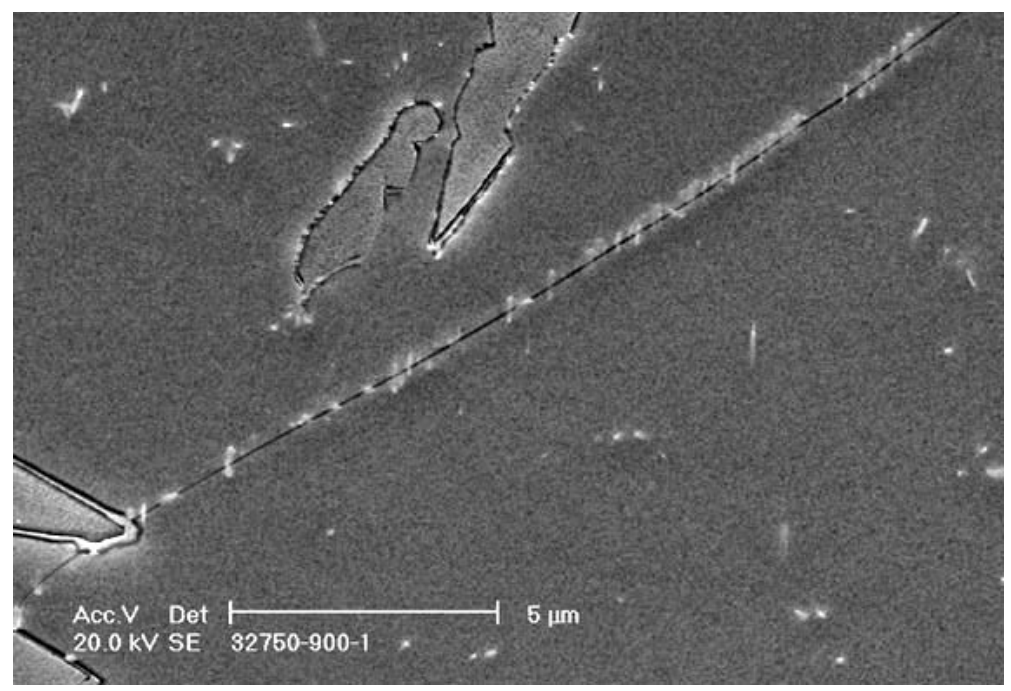

Figura 120: Precipitação de partículas de segunda fase na interface $\gamma_{1} / \alpha$. AISD UNS S32750 reaquecido a $900^{\circ} \mathrm{C}$ por $1 \mathrm{~s}$. MEV-EC.

Além da precipitação destas partículas de segunda fase nas interfaces $\gamma_{1} / \alpha$, nos AISD UNS S32550 e S32760 foi possível observar o estágio subsequente a esta precipitação. Isto é, observou-se como, após a precipitação dos nitretos de cromo na interface $\alpha / \gamma$, a $\gamma_{2}$ cresceu para dentro da $\alpha$. Este comportamento já se insinuara nos $\mathrm{CPs}$ reaquecidos a $900^{\circ} \mathrm{C}$, porém nos CPs tratados a $1000{ }^{\circ} \mathrm{C}$ por $1 \mathrm{~s}$ o processo encontrou-se um pouco mais avançado em algumas interfaces. Nas Figuras 122 e 123 pode ser observado como a interface $\alpha / \gamma$ avançou, deixando os precipitados para trás. 

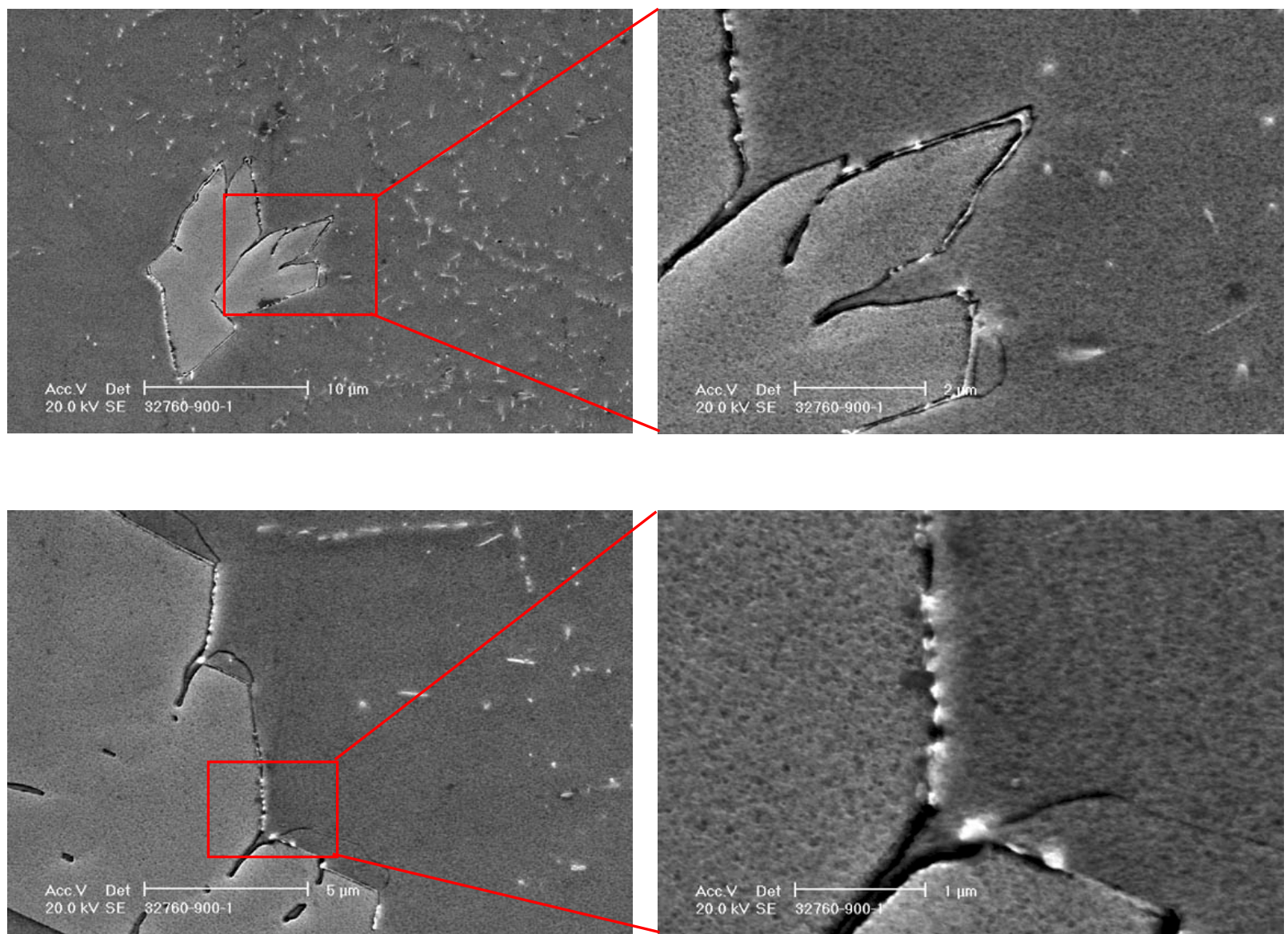

Figura 121: Precipitação de partículas de segunda fase na interface $\gamma_{1} / \alpha$. AISD UNS S32760 reaquecido a $900^{\circ} \mathrm{C}$ por $1 \mathrm{~s}$. MEV-EC.

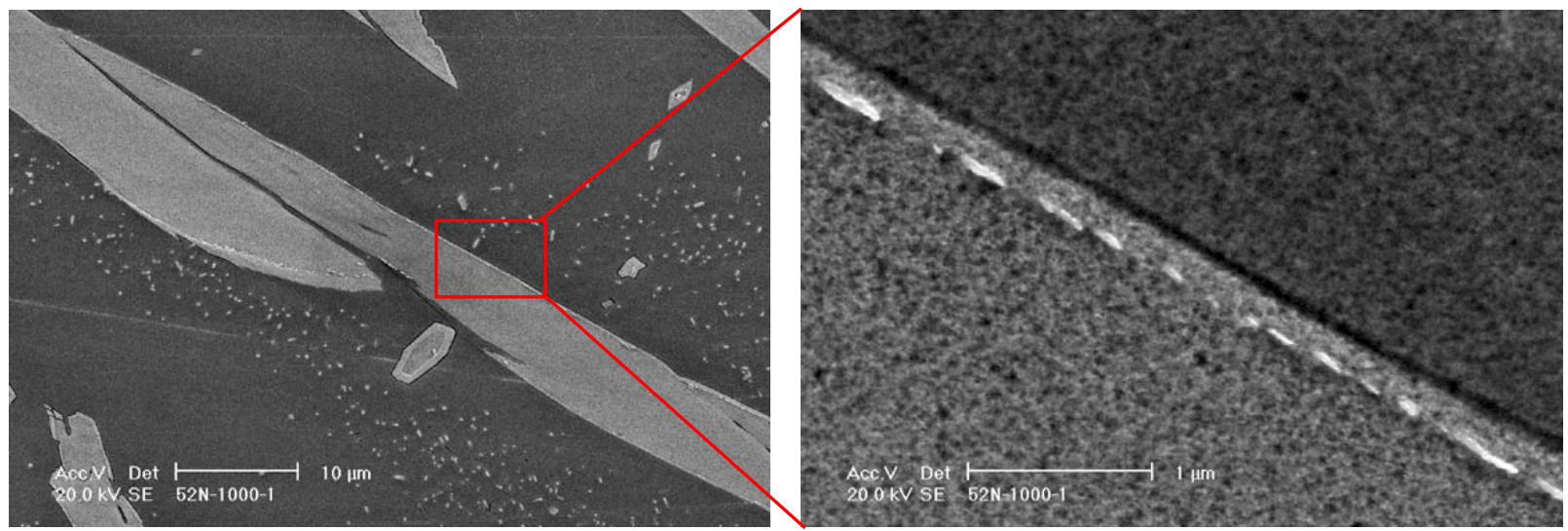

Figura 122: Precipitação de partículas de segunda fase no limite entre a $\gamma_{1}$ e a $\gamma_{2}$. AISD UNS S32550 reaquecido a $1000^{\circ} \mathrm{C}$ por $1 \mathrm{~s}$. MEV-EC. 


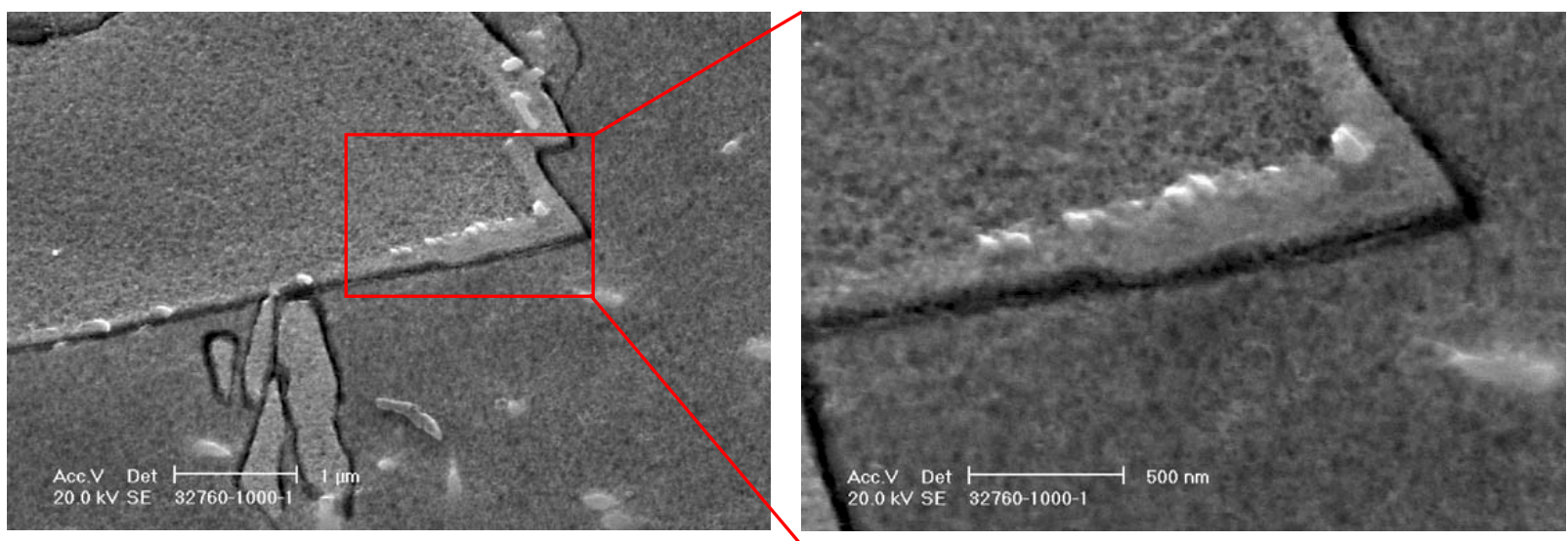

Figura 123: Precipitação de partículas de segunda fase no limite entre a $\gamma_{1}$ e a $\gamma_{2}$. AISD UNS S32760 reaquecido a $1000^{\circ} \mathrm{C}$ por $1 \mathrm{~s}$. MEV-EC.

Retomando as hipóteses feitas anteriormente quanto às relações entre a precipitação dos nitretos nas interfaces $\alpha / \gamma$ e o crescimento da $\gamma_{2}$ a partir destas interfaces, e levando-se em conta a evidência apresentada nas Figuras 122 e 123, é possível propor um modelo mais elaborado para esta transformação, que é apresentado esquematicamente nas Figuras 125 e 126.

Segundo este modelo, durante o reaquecimento, inicialmente tem-se a precipitação de $\mathrm{Cr}_{2} \mathrm{~N}$ (que na verdade é $\mathrm{M}_{2} \mathrm{~N}$ ) na interface $\alpha / \gamma$ (Figura 125-b). Como já foi apresentado no item 6.2.2.1.2.3, a precipitação do $\mathrm{Cr}_{2} \mathrm{~N}$ nesta interface é facilitada pela relação de orientação $\alpha / \mathrm{Cr}_{2} \mathrm{~N} / \gamma$. Este nitretos crescem para dentro da ferrita, empobrecendo a vizinhança em $\mathrm{Cr}$, Mo e $\vee$ (elementos estabilizadores da ferrita). Do nitrogênio necessário para a precipitação destes nitretos, parte já se encontra na interface, mas a grande maioria deve ser suprido principalmente pela ferrita. Devido a elevada difusividade do $\mathrm{N}$, quando comparado com os outros elementos mencionados, o seu suprimento vem tanto da ferrita ao redor dos precipitados como do seio da ferrita, a qual está supersaturada neste elemento. Deve-se notar que a dissolução dos nitretos intragranulares gera uma fonte importante de $\mathrm{N}$ no interior da ferrita. Cálculos de difusão permitiram verificar que, a $1000{ }^{\circ} \mathrm{C}$, a distância de difusão do nitrogênio na ferrita alcança aproximadamente $21 \mu \mathrm{m}$ em $0,5 \mathrm{~s}^{(138)}$. Além disso, a distâncias das interfaces $\alpha / \gamma$ muito menores que esta, já são encontradas quantidades bastante grandes de nitretos, no interior da $\alpha$.

Deve-se ressaltar que estes nitretos crescem principalmente na direção paralela à interface, provavelmente, devido à difusão facilitada nesta direção e ao provável menor grau de coerência desta região da interface $\alpha / \mathrm{Cr}_{2} \mathrm{~N}$.

Assim, com o crescimento dos nitretos se retira $\mathrm{Cr}$, Mo e $\mathrm{V}$ da ferrita e ao mesmo tempo se rejeita $\mathrm{Ni}, \mathrm{Cu}($ elementos estabilizadores da austenita) e Fe para a ferrita adjacente. Desta forma, esta ferrita ao redor dos nitretos fica empobrecida em elementos estabilizadores da 
ferrita e enriquecida em elementos estabilizadores da austenita. Observou-se que estes nitretos não chegam a crescer até preencher totalmente as interfaces $\alpha / \gamma$. Existem duas possíveis explicações para isto:

- A superposição dos campos de difusão dos elementos substitucionais, como mostrado esquematicamente na Figura 124. Isto é, a exaustão do $\mathrm{Mo}, \mathrm{Cr}$ e V e o enriquecimento em Ni e Cu na vizinhança imediata dos nitretos. Acredita-se que o Mo seja um elemento chave nisto, pois a sua difusividade é bastante menor que dos outros elementos envolvidos.

- O crescimento da $\gamma$ na forma de $\gamma_{2}$, isto é o avanço da interface $\alpha / \gamma$.

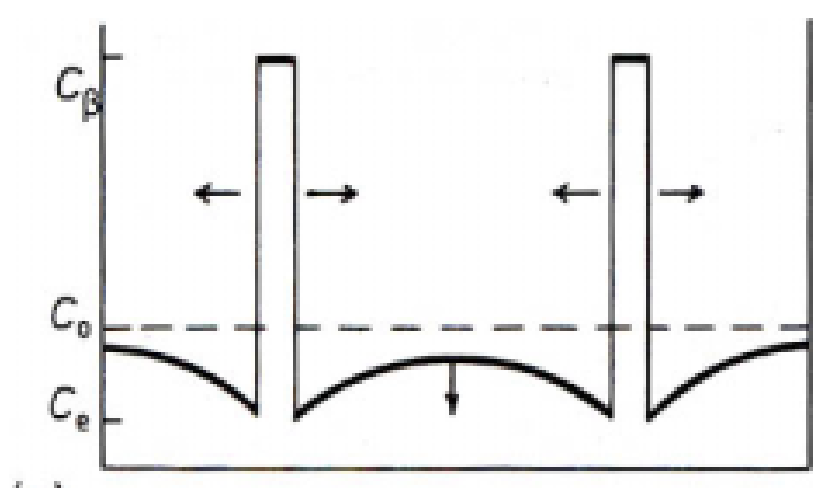

(a)

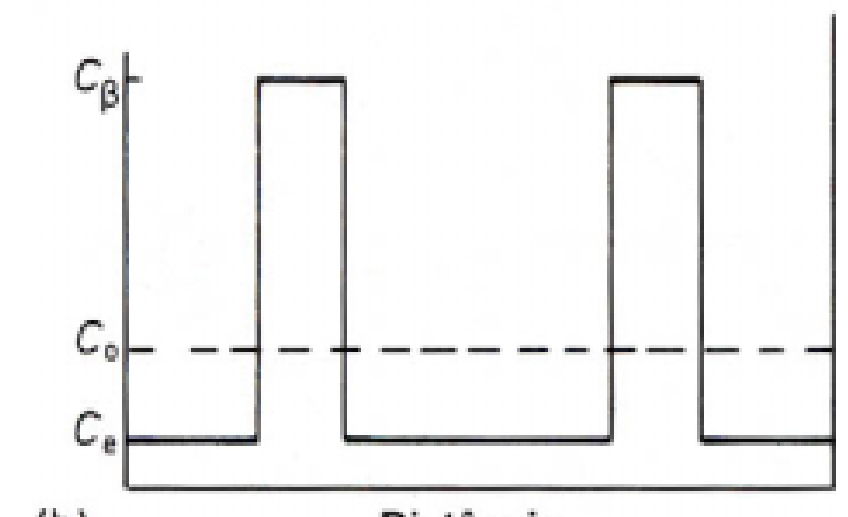

(b)

Distância

Figura 124: Interferência de precipitados crescendo. Em (a) superposição dos campos de difusão e em (b) precipitados pararam de crescer $^{(134)}$.

Além do enriquecimento em $\mathrm{Ni}$ e $\mathrm{Cu}$ da ferrita perto dos nitretos, tem-se o suprimento de nitrogênio (elemento fortemente estabilizador da austenita) do seio da ferrita. Assim, tem-se as condições favoráveis para o crescimento da austenita, na forma de $\gamma_{2}$ (Figura 125-d).

Esta cooperação opera somente durante o início da transformação, pois como já foi mencionado, logo os nitretos deixam de crescer e a $\gamma_{2}$ continua a crescer sozinha (Figura 125-e). Ambas as interfaces $\alpha / \gamma$ como $\alpha / \mathrm{Cr}_{2} \mathrm{~N}$, são semicoerentes, e portanto devem crescer 
pelo mecanismo de degraus, onde o crescimento não é controlado por difusão. Porém, o avanço destas interfaces também requer difusão, pois o avanço da borda dos degraus é controlado por difusão. O crescimento do nitreto requer maior movimentação de elementos substitucionais, como $\mathrm{V}, \mathrm{Cr}$, Ni e Mo, de modo que isto pode influenciar na preponderância do crescimento da $\gamma_{2}$ sobre o $\mathrm{Cr}_{2} \mathrm{~N}$. No entanto, a mobilidade destas duas interfaces pode ser o fator que define o avanço da $\gamma$ por sobre os nitretos.

No caso do reaquecimento a $1000{ }^{\circ} \mathrm{C}$ por $10 \mathrm{~s}$, tem-se evidências experimentais da dissolução posterior destes nitretos (Figura 125-f-g). No entanto, faz-se necessário um estudo mais aprofundado neste campo, utilizando tempos maiores de tratamento para verificar este fato. Por outro lado, após o reaquecimento a $900{ }^{\circ} \mathrm{C}$ por $10 \mathrm{~s}$ estes nitretos ainda subsistem. Portanto, não fica claro se estes nitretos irão dissolver com tempos maiores ou se nesta temperatura, já para estes tempos curtos, eles estão em equilíbrio com as outras fases presentes.

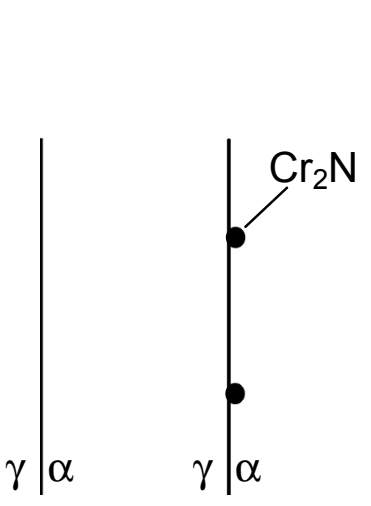

(a) (b)

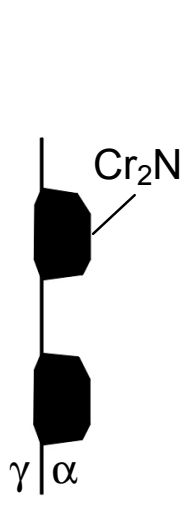

(c)

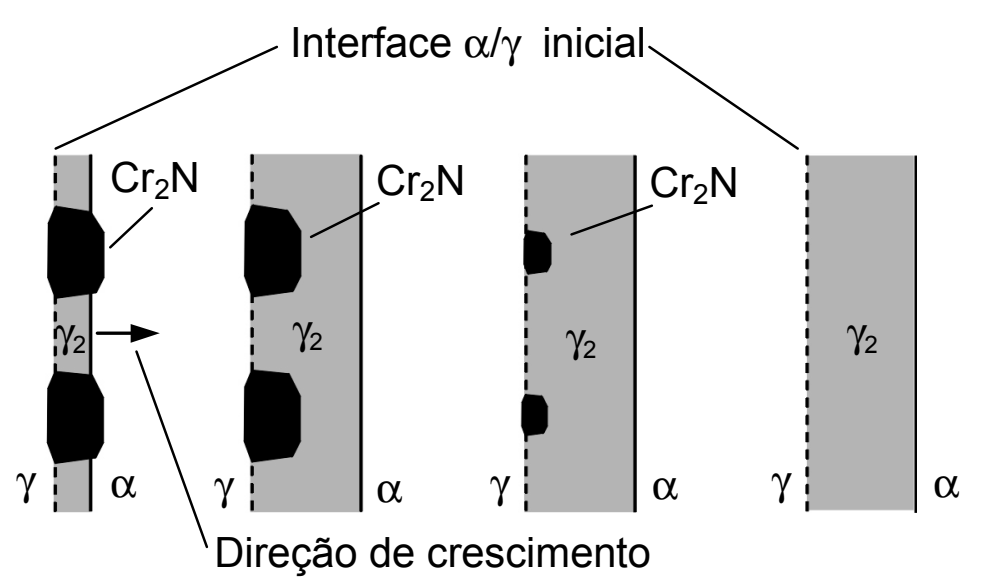

(d) (e) (f) (g)

Figura 125: Diagrama esquemático mostrando a precipitação cooperativa de $\mathrm{Cr}_{2} \mathrm{~N}$ e $\gamma_{2}$ a partir da interface $\alpha / \gamma$, seguida da dissolução do $\mathrm{Cr} 2 \mathrm{~N}$.

Pelo exposto anteriormente, esta cooperação entre a precipitação do nitreto de cromo $\left(\mathrm{Cr}_{2} \mathrm{~N}\right)$ e da $\gamma_{2}$ parece ser devida à difusão dos elementos mais pesados, como $\mathrm{Cr}$, Ni, Mo e V. No caso do nitrogênio, a precipitação das duas fases tornam-se competitivas, mas a elevada difusividade deste elemento e o seu suprimento desde o seio da ferrita, faz com que a difusão deste elemento não seja o fator de controle desta precipitação (Ver Figura 126). 

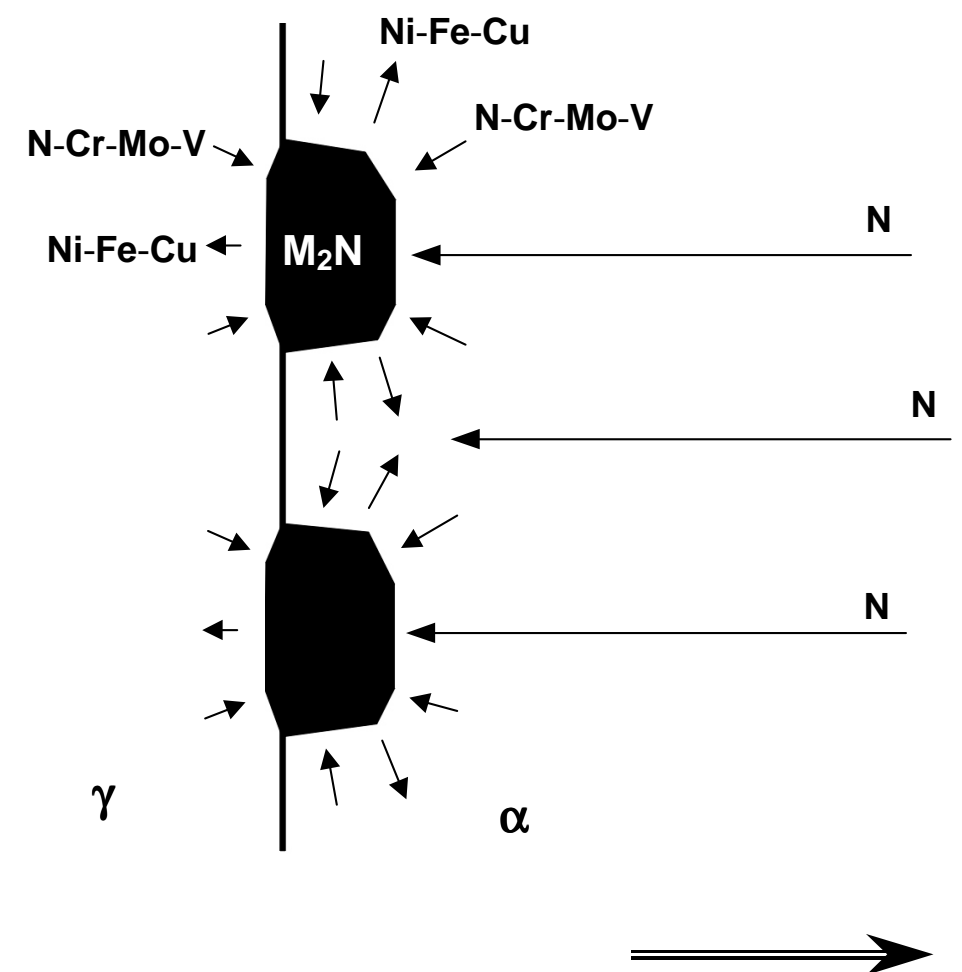

Interface $\alpha / \gamma$ Inicial

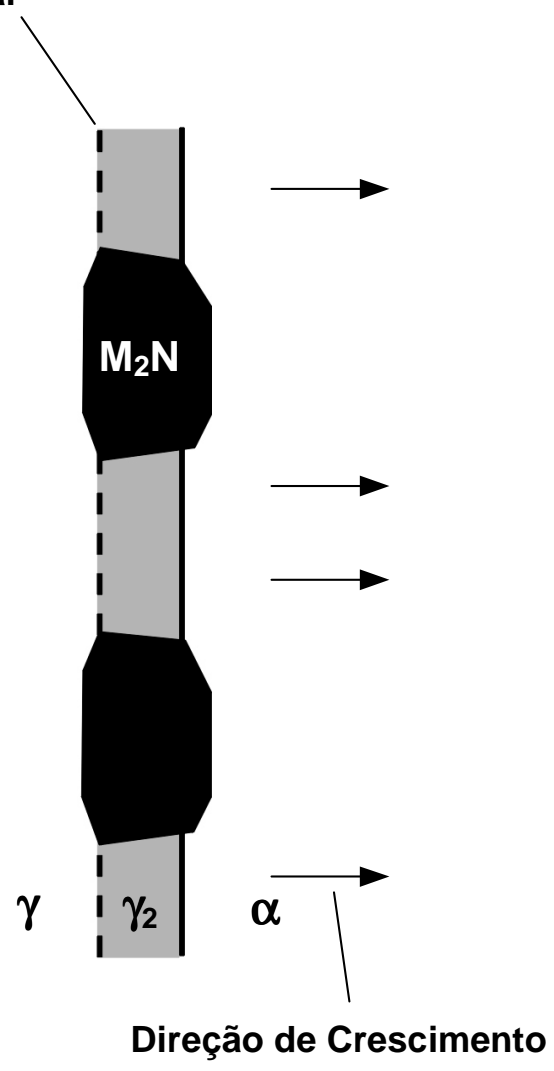

Figura 126: Diagrama esquemático mostrando os caminhos de difusão na precipitação cooperativa do $\mathrm{Cr}_{2} \mathrm{~N}$ e a $\gamma_{2}$

\subsection{Austenita intragranular e a sua coexistência com $\mathrm{Cr}_{2} \mathrm{~N}$}

As colônias de $\gamma_{1}$ e $\gamma_{2}$ intragranular apresentam uma marcada orientação preferencial como pode ser visto nas Figuras 127 a 129 . Este comportamento já foi reportado por outros autores.

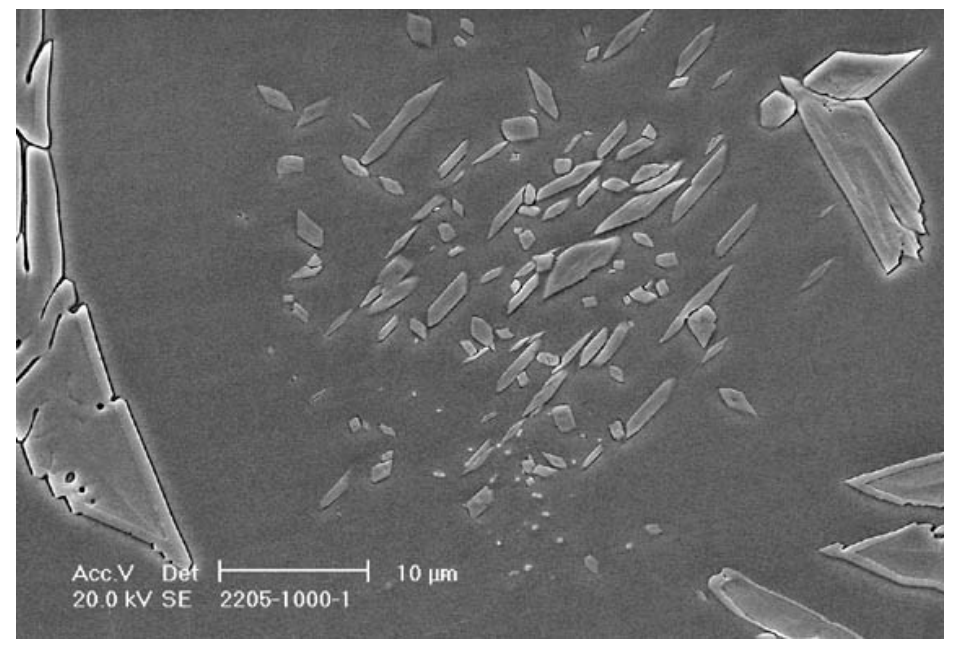

Figura 127:Colônia de $\gamma_{2}$ intragranular apresentando orientação preferencial. AID UNS S32205 reaquecido a $1000^{\circ} \mathrm{C}$ por $1 \mathrm{~s}$. MEV-EC. 


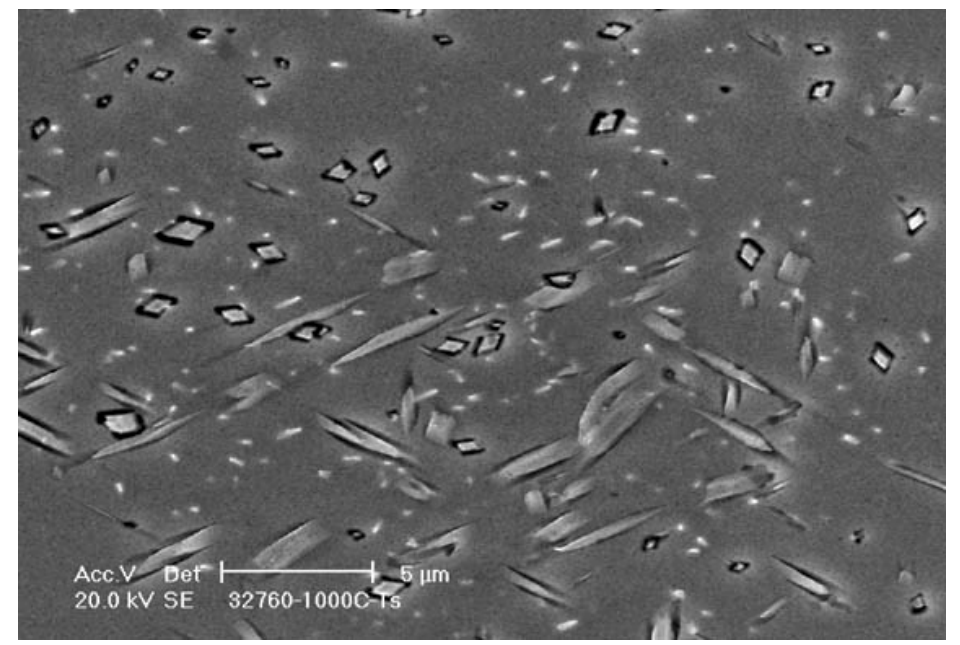

Figura 128: Colônia de $\gamma_{2}$ intragranular apresentando orientação preferencial. AID UNS S32750 reaquecido a $1000^{\circ} \mathrm{C}$ por $1 \mathrm{~s}$. MEV-EC.

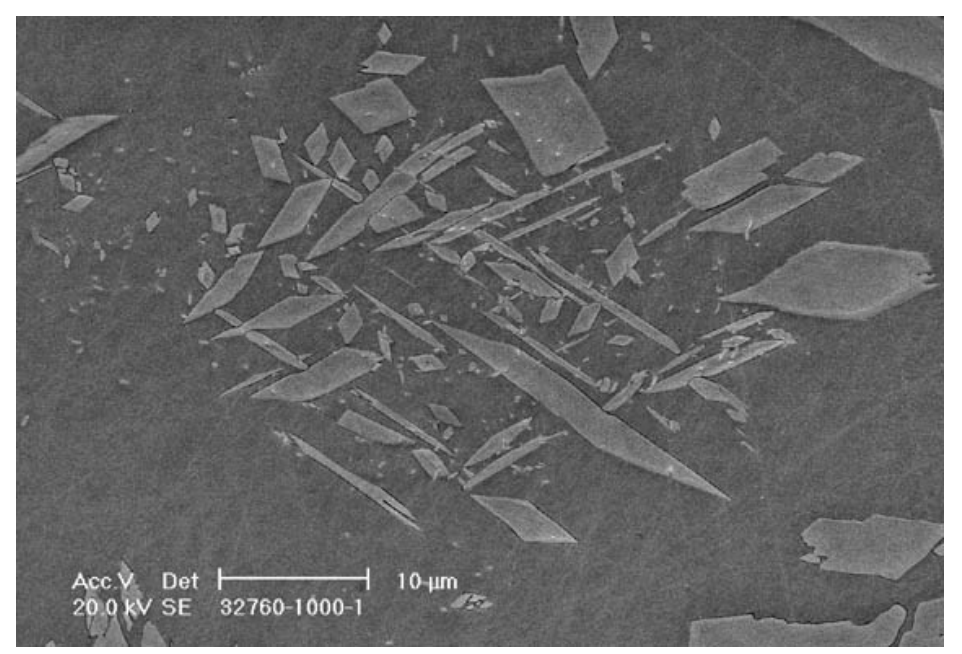

Figura 129: Colônia de $\gamma_{1}$ e $\gamma_{2}$ intragranular apresentando orientação preferencial. AISD UNS S32760 reaquecido a $1000^{\circ} \mathrm{C}$ por $1 \mathrm{~s}$. MEV-EC.

Foi observada a estreita coexistência de partículas de $\mathrm{Cr}_{2} \mathrm{~N}$ e $\gamma_{2}$ intragranular, após o reaquecimento a $1000{ }^{\circ} \mathrm{C}$, da mesma forma que nos $\mathrm{CPs}$ tratados termicamente a $1350{ }^{\circ} \mathrm{C}$. $\mathrm{Na}$ Figura 130 são mostradas colônias de $\gamma_{2}$ intragranular, onde existe ainda uma grande quantidade de $\mathrm{Cr}_{2} \mathrm{~N}$, sendo que algumas destas partículas se encontram em contato direto com a $\gamma$, como apresentado em detalhe na Figura 131. Portanto, deve ser revisto o mecanismo de precipitação de $\gamma_{2}$, previamente sugerido, onde a dissolução dos $\mathrm{Cr}_{2} \mathrm{~N}$ precede a precipitação de $\gamma_{2}$. Por outro lado, mais esta evidência vem reforçar o mecanismo proposto de nucleação da $\gamma_{2}$ intragranular a partir dos nitretos de cromo, como mostrado em detalhe na Figura 132. No entanto, como já foi exposto, nem todos os nitretos darão origem a partículas de $\gamma_{2}$, pois muitos deles dissolverão antes que isto aconteça e é essa dissolução 
que garante o suprimento do nitrogênio que será empregado na precipitação da $\gamma_{2}$ intragranular.

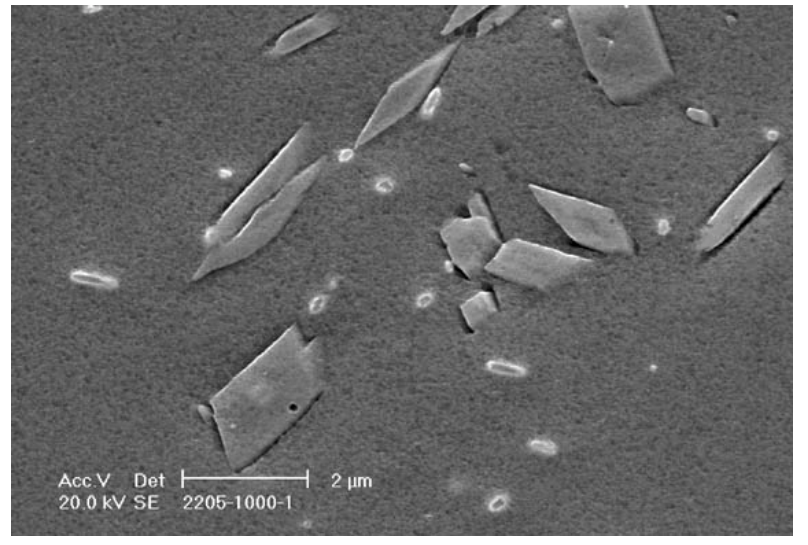

UNS S32205

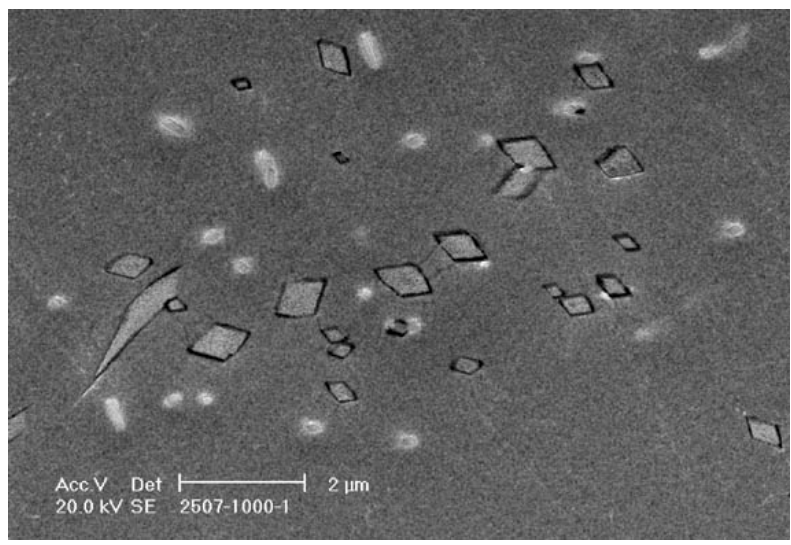

UNS S32750

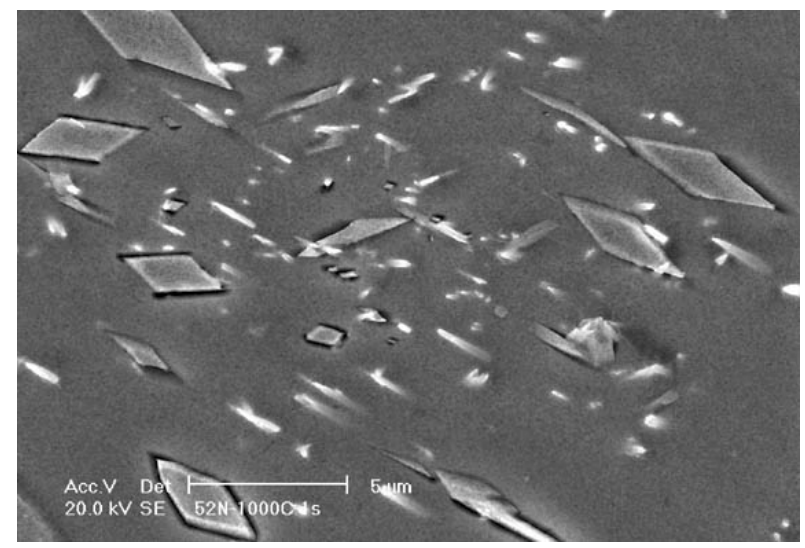

UNS S32550

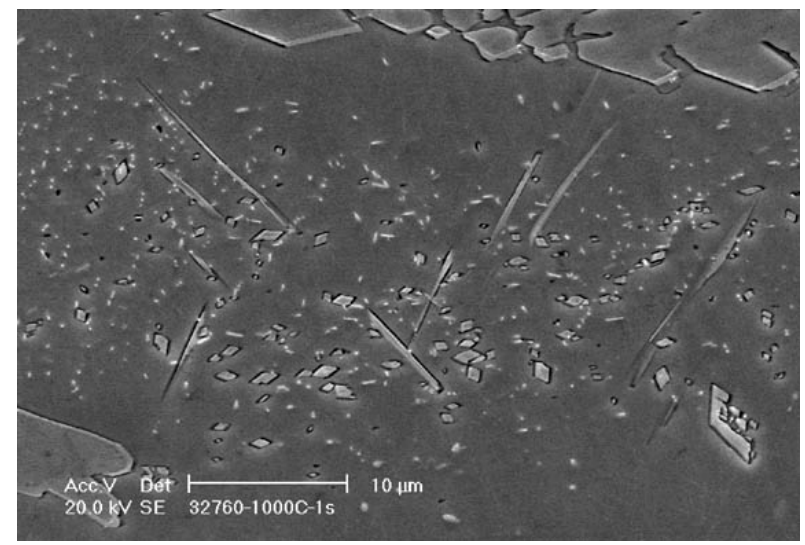

UNS S32760

Figura 130: Coexistência de $\mathrm{Cr}_{2} \mathrm{~N}$ e $\gamma$ intragranular nos AIDs UNS S32205, S32550, S32750 e S32760 reaquecidos a $1000{ }^{\circ} \mathrm{C}$ por $1 \mathrm{~s}$. Detalhe de colônias de austenitas secundárias intragranulares. MEV-EC.

Uma outra evidência importante encontrada foi a presença comum de pequenos buracos nas partículas de $\gamma_{2}$ intragranular (Ver Figura 133), que parecem ser deixados por partículas de segunda fase removidas durante a preparação dos CPs, que poderiam ser bastonetes de $\mathrm{Cr}_{2} \mathrm{~N}$. Estes buracos nas austenitas intragranulares são facilmente observáveis no MO. 


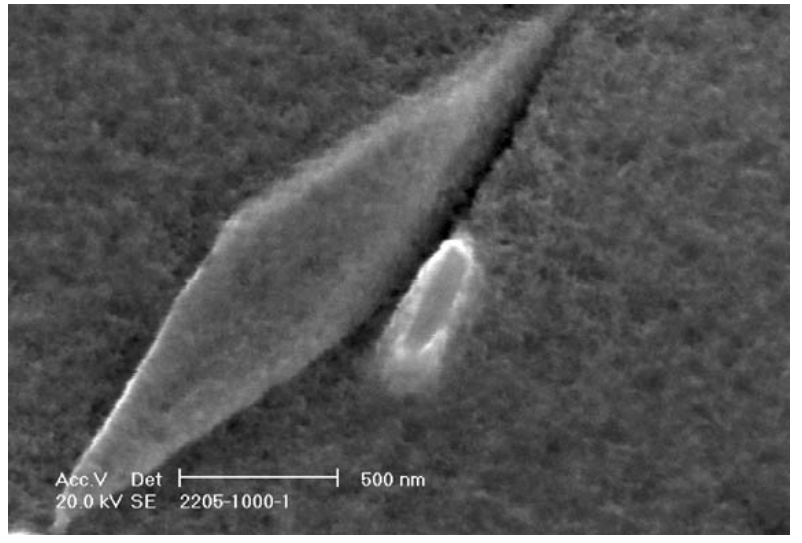

UNS S32205

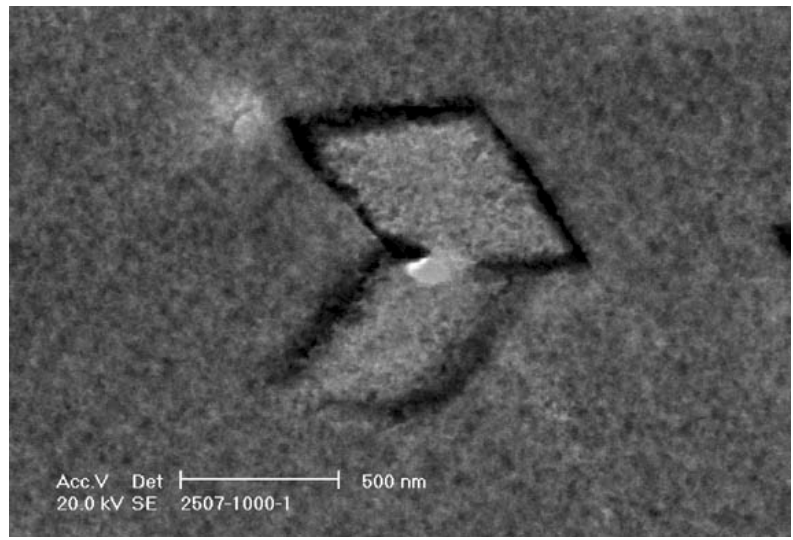

UNS S32750

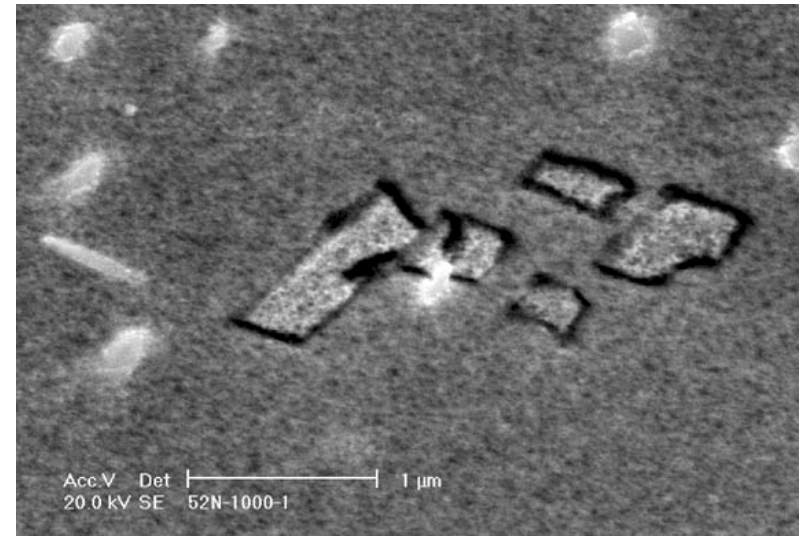

UNS S32550

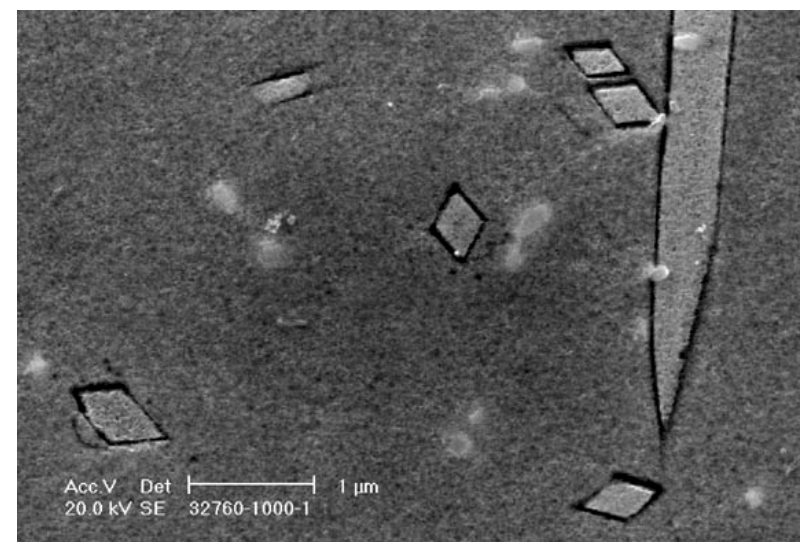

UNS S32760

Figura 131: Detalhe da coexistência de $\mathrm{Cr}_{2} \mathrm{~N}$ e $\gamma_{2}$ intragranular nos AIDs UNS S32205, S32550, $\mathrm{S} 32750$ e $\mathrm{S} 32760$ reaquecidos a $1000^{\circ} \mathrm{C}$ por 1 s. MEV-EC.

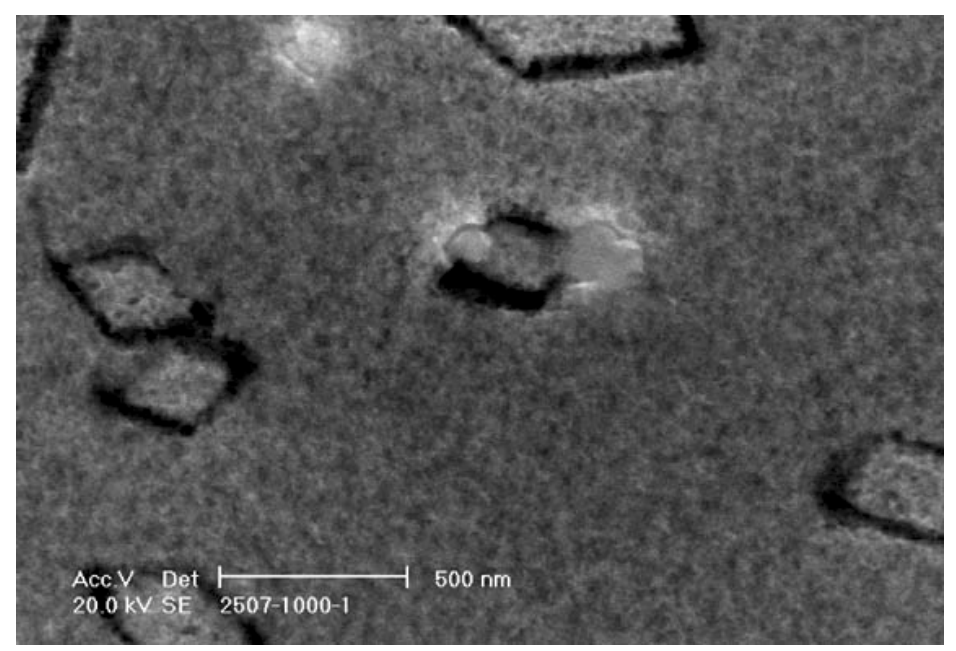

Figura 132: Detalhe da precipitação de $\gamma_{2}$ intragranular a partir de nitretos de cromo intragranulares. AISD UNS $S 32750$ reaquecido a $1000^{\circ} \mathrm{C}$ por $1 \mathrm{~s}$. MEV-EC. 

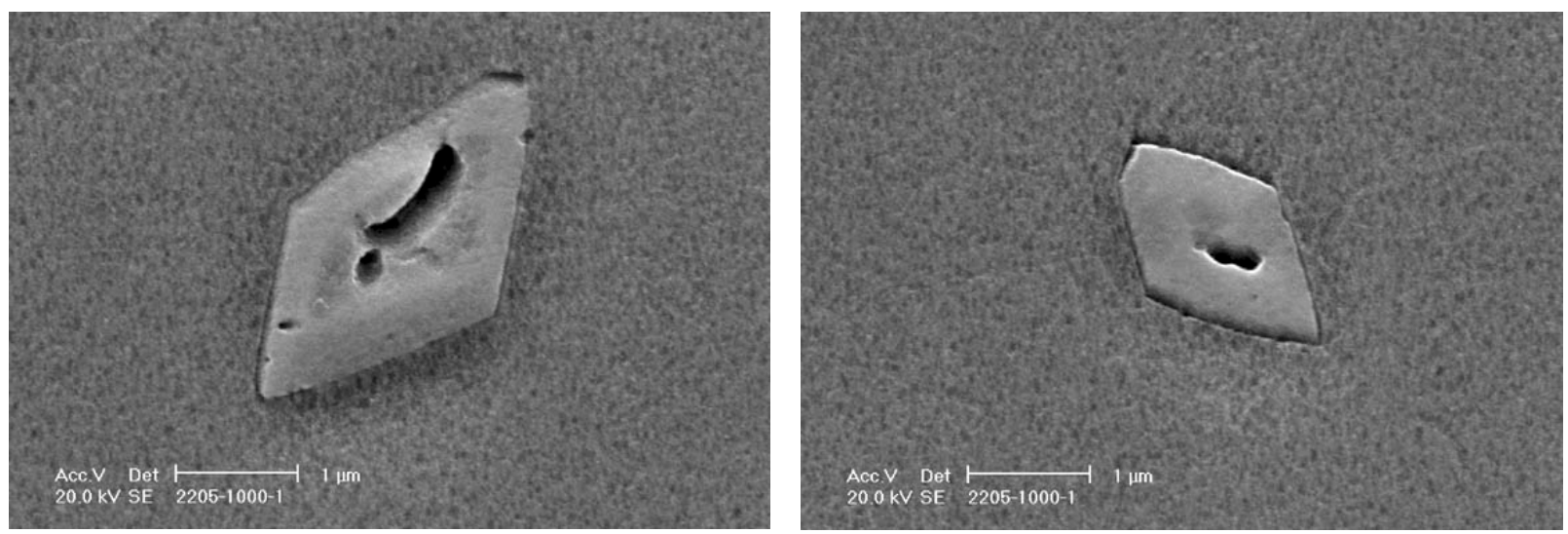

Figura 133: Partícula de $\gamma$ intragranular com buracos deixados por partículas de segunda fase removidas durante a preparação do CP. AID UNS S32205 reaquecido a $1000{ }^{\circ} \mathrm{C}$ por $1 \mathrm{~s}$. MEV-EC.

\subsection{Precipitação de austenita intragranular a partir de inclusões}

Foi verificada a precipitação de austenita primária $\left(\gamma_{1}\right)$ intragranular a partir de inclusões. $\mathrm{Na}$ Figura 134 é mostrada a precipitação de $\gamma_{1}$ intragranular a partir de uma inclusão rica em $\mathrm{O}$, Al e Mg (53,4\% at O-31,3\% at Al-15,3\% at Mg; EDS a 10kV) no AID UNS S32205. Também no caso do AISD UNS S32760 foi observada a precipitação de $\gamma_{1}$ intragranular a partir de inclusões ricas em $\mathrm{O}$, Al e $\mathrm{Mg}$ e com um conteúdo mínimo de Ce $(51,9 \%$ at $\mathrm{O}-32,2 \%$ at $\mathrm{Al}$ $14,7 \%_{\text {at }} \mathrm{Mg}-1,1 \%$ at $\mathrm{Ce}$; EDS a $10 \mathrm{kV}$ ), revelando-se portanto uma inclusão do mesmo tipo que a anterior. Na Figura 135 é mostrado o segundo caso.

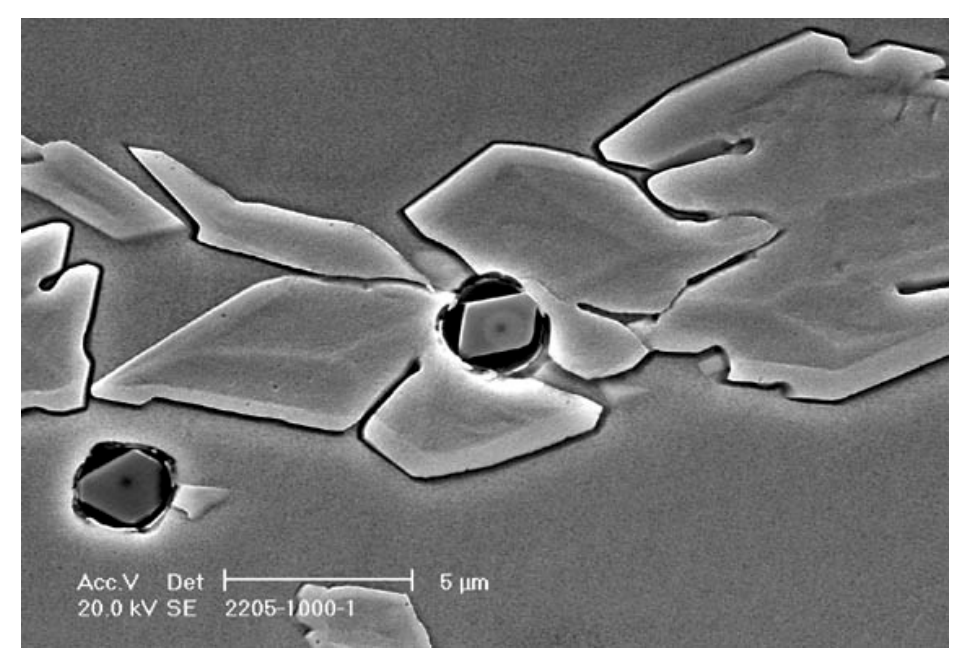

Figura 134: Precipitação de $\gamma_{1}$ intragranular a partir de uma inclusão do tipo $53,4 \%_{\text {at }} \mathrm{O}-31,3 \%_{\text {at }} \mathrm{Al}-$ $15,3 \%$ at Mg. Parte da inclusão foi dissolvida ou removida durante a preparação do CP. AID UNS S32205. MEV-EC. 


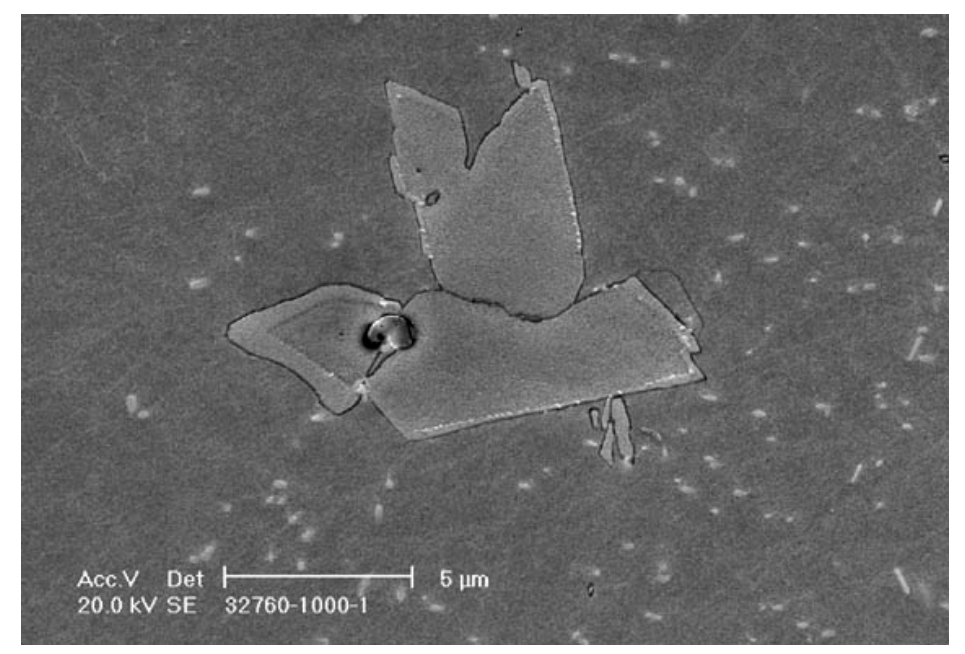

Figura 135: Precipitação de $\gamma_{1}$ intragranular a partir de uma inclusão do tipo $51,9 \%_{\text {at }}$ O-32,2\% at $\mathrm{Al}$ $14,7 \%_{\text {at }} \mathrm{Mg}-1,1 \%{ }_{\text {at }}$ Ce. AISD UNS S32760. MEV-EC.

Outros dois casos de precipitação de $\gamma_{1}$ intragranular, a partir de inclusões, foram encontrados no AISD UNS S32760, sendo que as inclusões foram menos danificadas durante a preparação do CP. Como pode ser observado nas Figuras 136 e 137, estas inclusões são compostas por um núcleo (escuro) e um envoltório (claro) facilmente diferenciáveis. A inclusão da Figura 136 apresenta um núcleo menor e é rica em $\mathrm{O}, \mathrm{Al}$, com um conteúdo mínimo de $\mathrm{Mg}\left(58,2 \%_{\text {at }} \mathrm{O}-21,7 \%_{\text {at }} \mathrm{Al}-18,6 \%_{\text {at }}\right.$ Ce-1,6\% at $\mathrm{Mg}$; EDS a 10kV). No entanto, devido ao tamanho desta partícula, não foi possível analisar a composição química do núcleo e do envoltório separadamente. Foi realizado um mapeamento por pontos da inclusão mostrada na Figura 137. O resultado é apresentado na Figura 138. Foi realizada a microanálise química por EDS do núcleo da inclusão $(55,7 \%$ at $0-30,1 \%$ at $\mathrm{Al}-14,2 \%$ at $\mathrm{Mg}$; EDS a $10 \mathrm{kV}$ ) e do seu envoltório (55,9\%at O-22,7\%at Al-18,2\%at Ce-3,2\%at Mg; EDS a $10 \mathrm{kV}$ ). Devido à espessura reduzida deste envoltório, o espectro obtido para a sua análise química foi contaminado com sinal emitido pelo núcleo da inclusão e, em uma menor quantidade, pela austenita ao seu redor. Portanto, pode-se concluir que o núcleo é formado por $\mathrm{O}, \mathrm{Al}$ e $\mathrm{Mg}$ e o seu envoltório por $\mathrm{O}, \mathrm{Al}$ e Ce. 


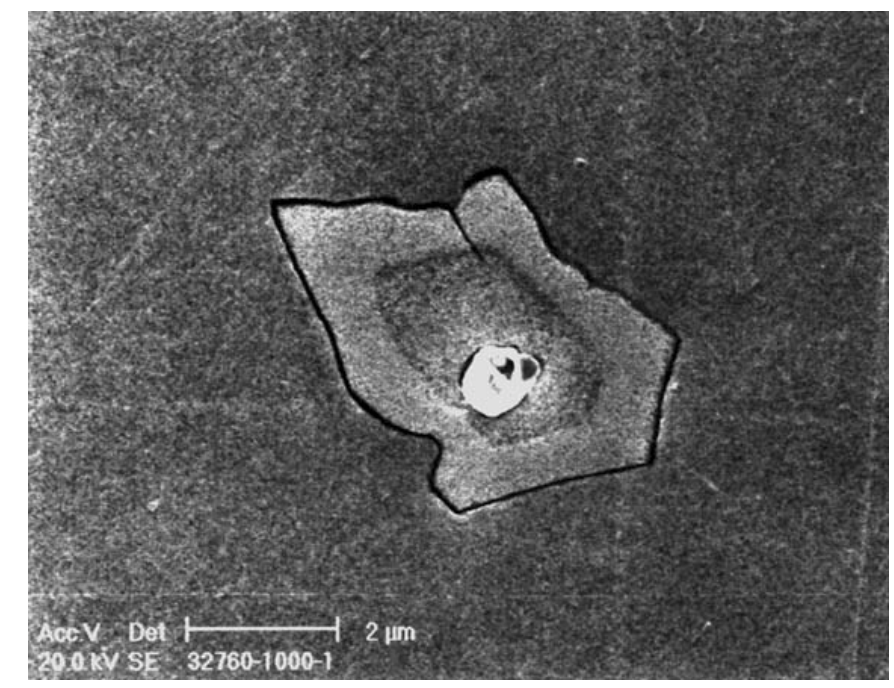

Figura 136: Precipitação de $\gamma_{1}$ intragranular a partir de uma inclusão do tipo $58,2 \%_{\text {at }}$ O- $21,7 \%_{\text {at }} \mathrm{Al}$ $18,6 \%$ at $\mathrm{Ce}-1,6 \%_{\text {at }} \mathrm{Mg}$. AISD UNS S32760. MEV-EC.

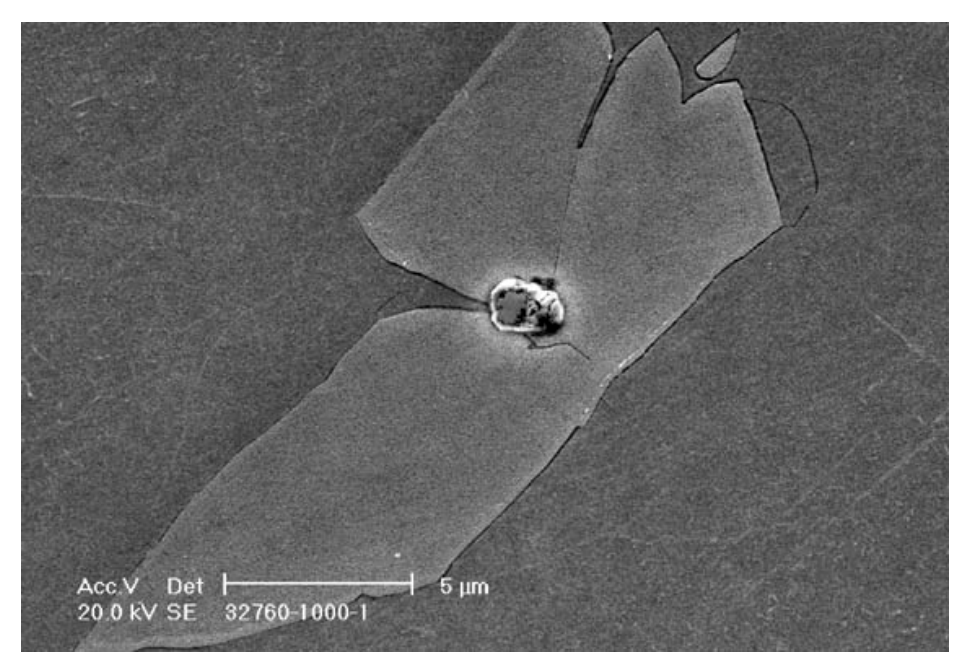

Figura 137: Precipitação de $\gamma_{1}$ intragranular a partir de uma inclusão composta, rica em $\mathrm{O}, \mathrm{Al}, \mathrm{Ce}$ e Mg. AISD UNS S32760. MEV-EC.

Também foi verificada a precipitação de $\gamma_{2}$ intragranular a partir de inclusões. Na Figura 139 é mostrada a precipitação de duas pequenas partículas de $\gamma_{2}$ intragranular a partir de uma inclusão rica em O, Al, Mg e Ca, no AID UNS S32205. Como pode ser visto nesta figura, parte desta inclusão composta foi removida ou dissolvida durante a preparação do CP. O mapeamento por pontos desta inclusão é apresentado nesta mesma figura. Esta inclusão concentra o Mg no seu núcleo e o Ca no seu envoltório. A microanálise química do núcleo (53,0\%at O-32,0\%at Al-15,0\%at Mg; EDS a $10 \mathrm{kV}$ ) e do seu envoltório (56,9\%at O-34,1\%at Al-9,0\%at Ca; EDS a 10k) confirmaram que se trata de uma inclusão composta, onde o seu núcleo apresenta a mesma composição química da inclusão mostrada na Figura 137. 

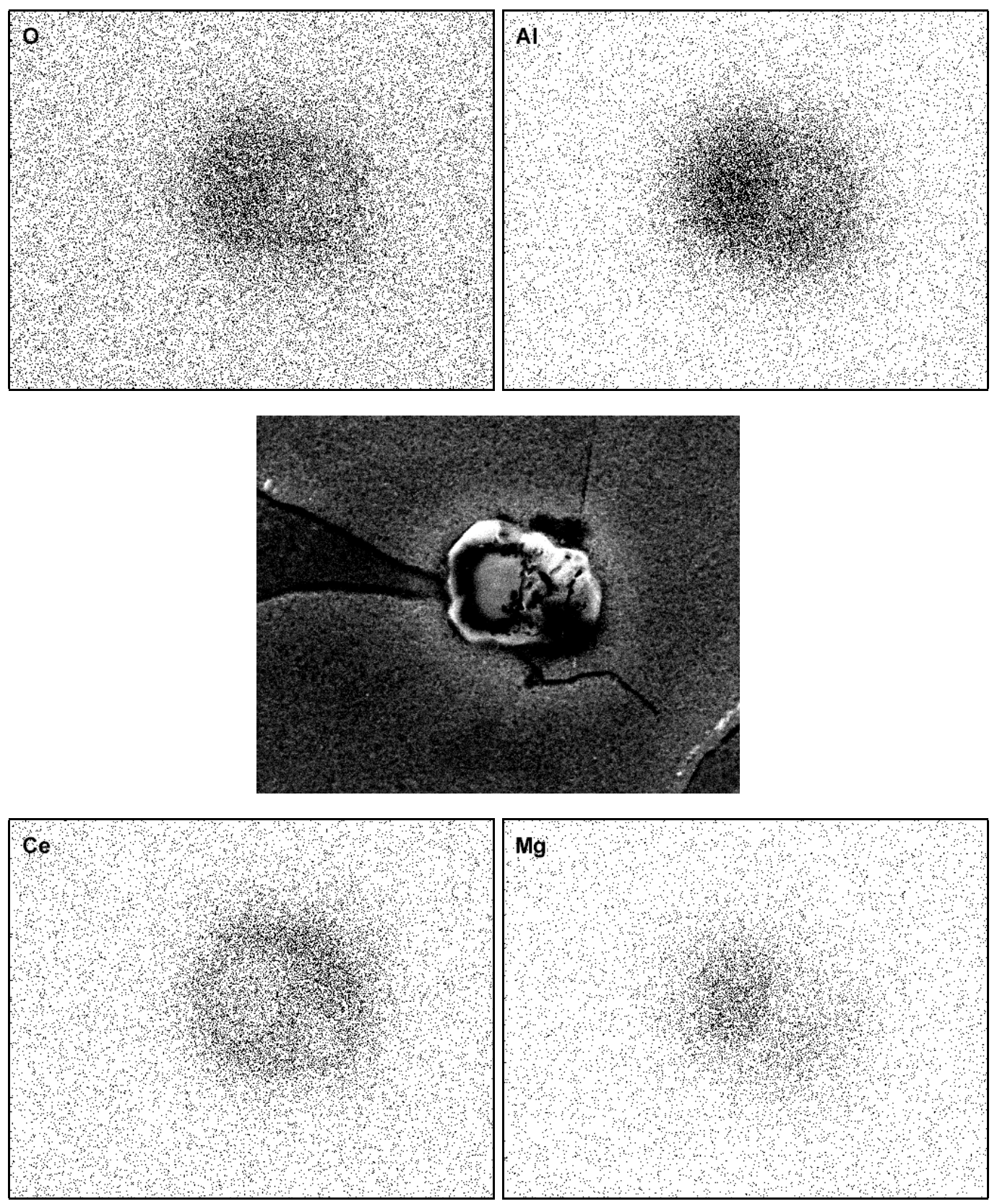

Figura 138: Mapeamento por pontos mostrando a distribuição dos elementos $\mathrm{O}, \mathrm{Mg}, \mathrm{Al}$ e $\mathrm{Ce}$ na inclusão mostrada na Figura 137. EDS a 10kV. AISD UNS S32760. MEV-EC.

No caso do AID UNS S32304, verificou-se a precipitação de $\gamma_{2}$ intragranular a partir de inclusões ricas em Ti, as quais devem ser do tipo TiN. Já no caso do AISD UNS S32760, foram encontradas partículas de $\gamma_{2}$ intragranular precipitando a partir de inclusões compostas ricas em O, Al, Mg e Ce (Ver Figura 140). Nesta última inclusão verificou-se que é uma inclusão composta do mesmo tipo apresentado na Figura 137. 

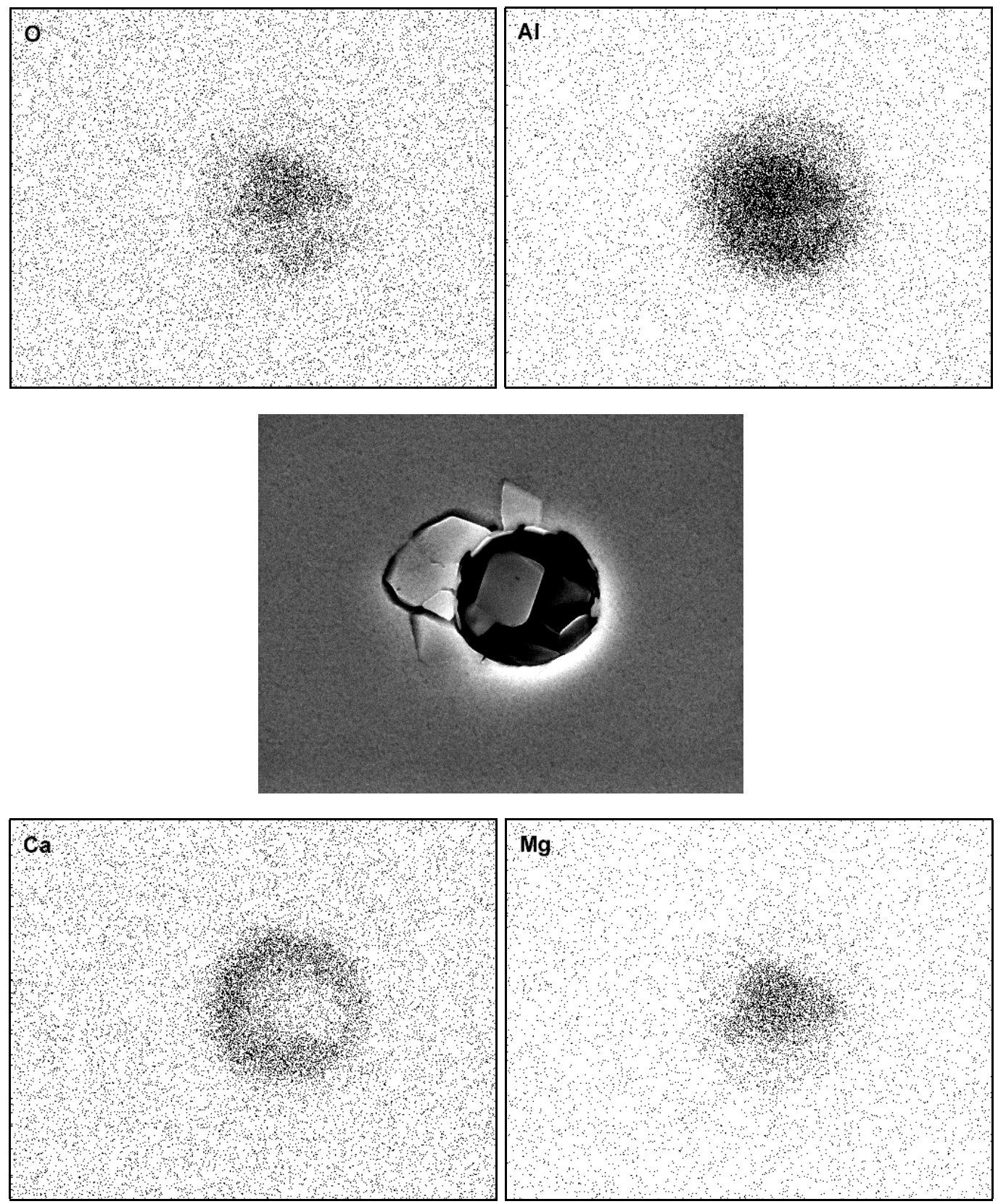

Figura 139: Precipitação de $\gamma_{2}$ intragranular a partir de uma inclusão composta rica em $\mathrm{O}, \mathrm{Al}, \mathrm{Mg} \mathrm{e} \mathrm{Ca}$, durante o reaquecimento do AID UNS S32205 a $1000{ }^{\circ} \mathrm{C}$ por $1 \mathrm{~s}$. Mapeamento por pontos mostrando a distribuição dos elementos $\mathrm{O}, \mathrm{Al}, \mathrm{Mg}$ e Ca na inclusão mostrada. EDS a 10kV. MEV-EC. 


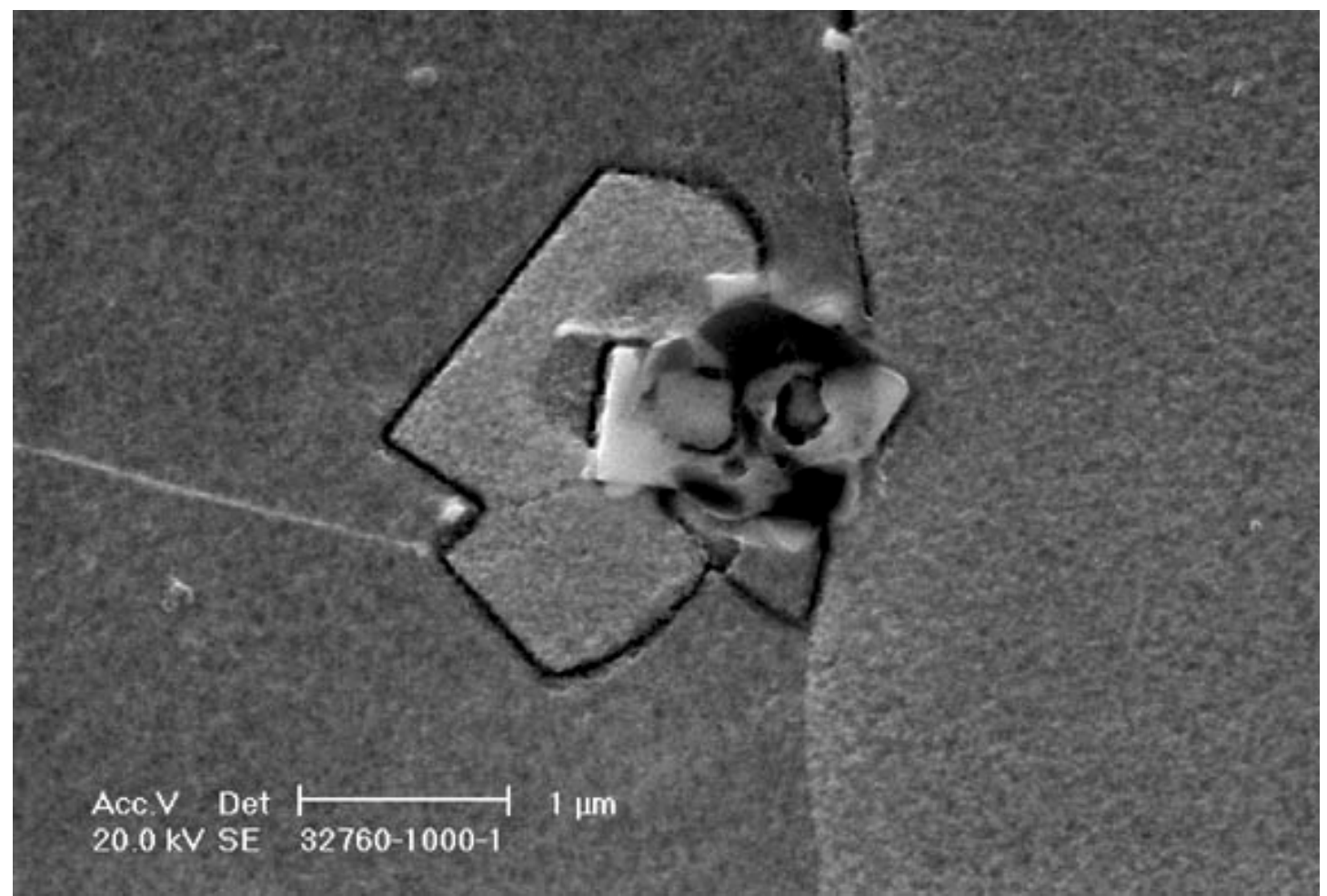

Figura 140: Precipitação de $\gamma_{2}$ intragranular a partir de uma inclusão rica em $\mathrm{O}, \mathrm{Al}, \mathrm{Mg}$ e Ce. AISD UNS S32760. MEV-EC.

\subsubsection{Soldas Reais}

Foram preparadas seções transversais das juntas soldadas dos cinco AIDs executadas com três diferentes energias de soldagem.

No caso da energia de soldagem mais baixa $(0,6 \mathrm{~kJ} / \mathrm{mm})$ foi bastante difícil obter juntas isentas de falta de penetração e de fusão. Isto foi devido à baixa energia de soldagem e ao fato de se manter os parâmetros de soldagem fixos.

Nas Figuras 141 a 143 são apresentadas as seções transversais dos cordões de solda dos cinco materiais, cada um deles soldado com três energias de soldagem diferentes, sendo estas de 0,$6 ; 0,8$ e $1,0 \mathrm{~kJ} / \mathrm{mm}$. 


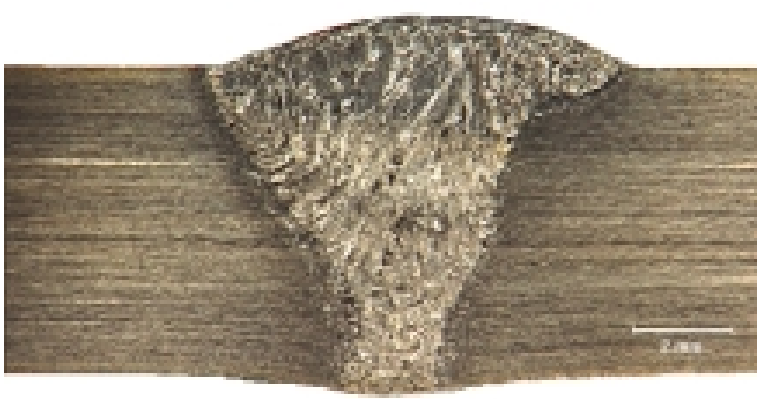

a.

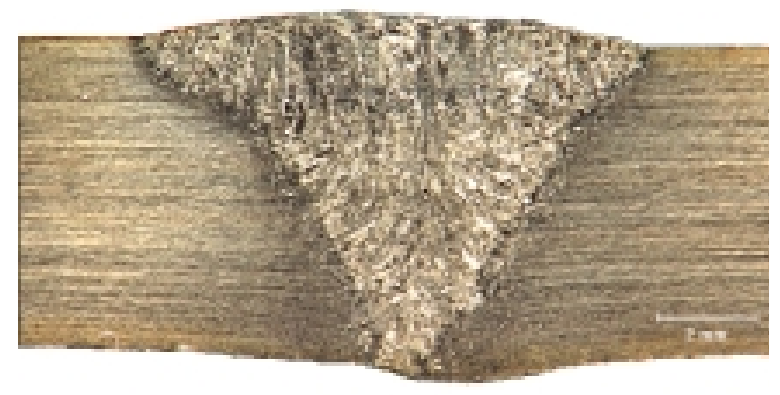

b.

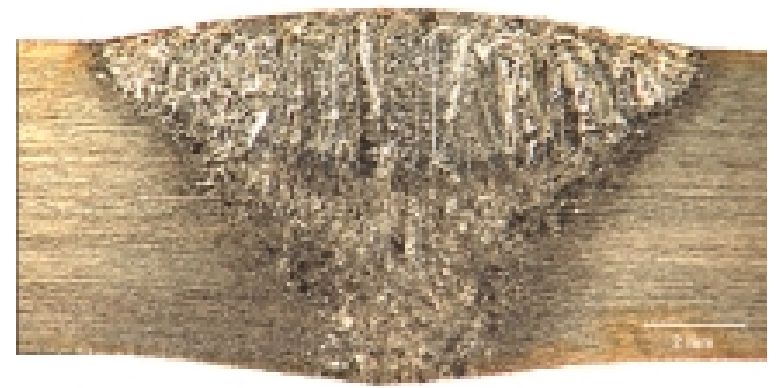

c.

Figura 141: Seção transversal das soldas reais de: a. UNS S32205-0,6 kJ/mm; b. UNS S32205-0,8 $\mathrm{kJ} / \mathrm{mm}$; c. UNS S32205-1,0 kJ/mm; d. UNS S32304-0,6 kJ/mm; e. UNS $\mathrm{S} 32304-0,8$ $\mathrm{kJ} / \mathrm{mm}$; f. UNS S32304-1,0 kJ/mm.

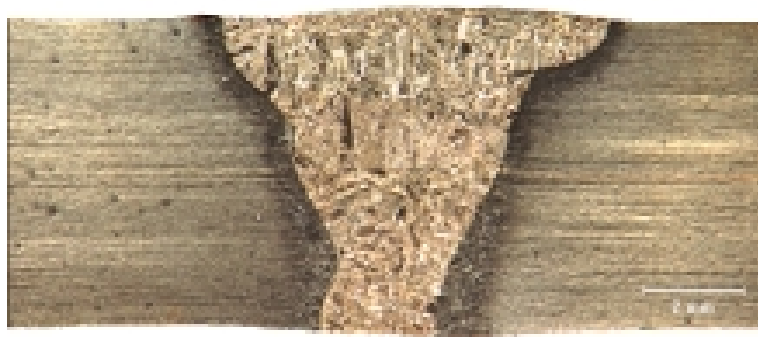

d.

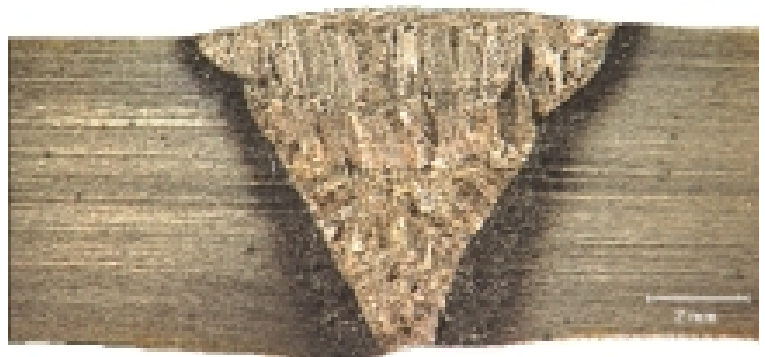

e.

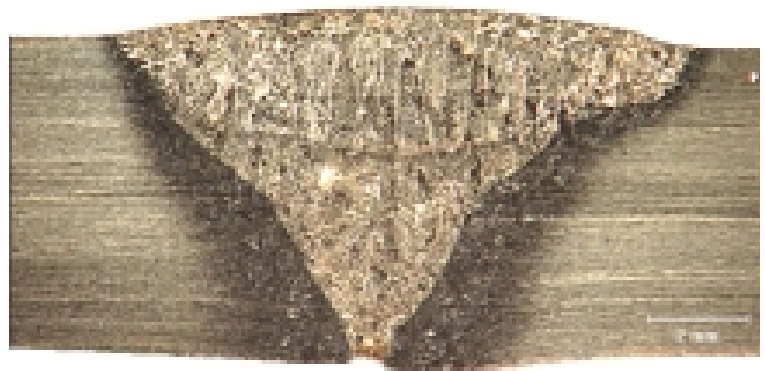

f. 

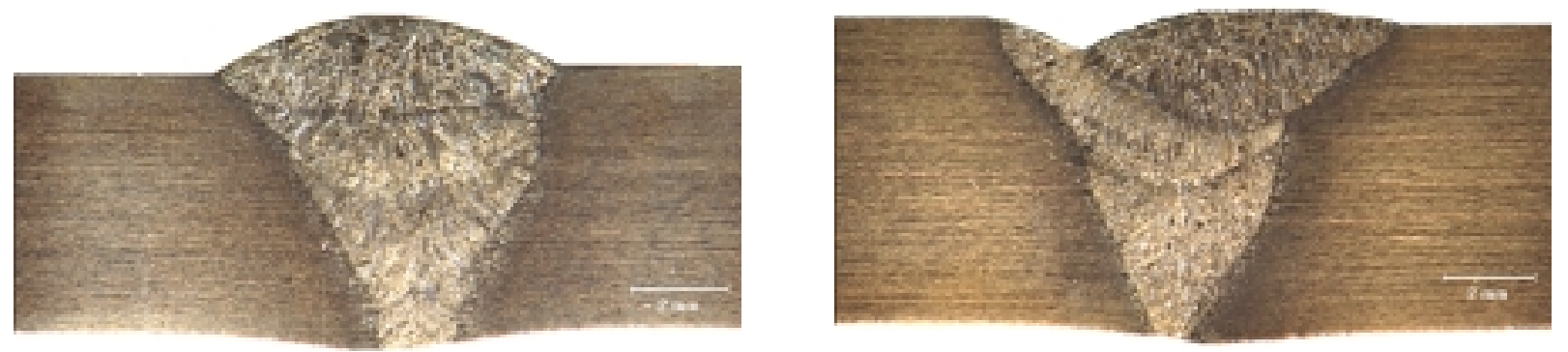

a.

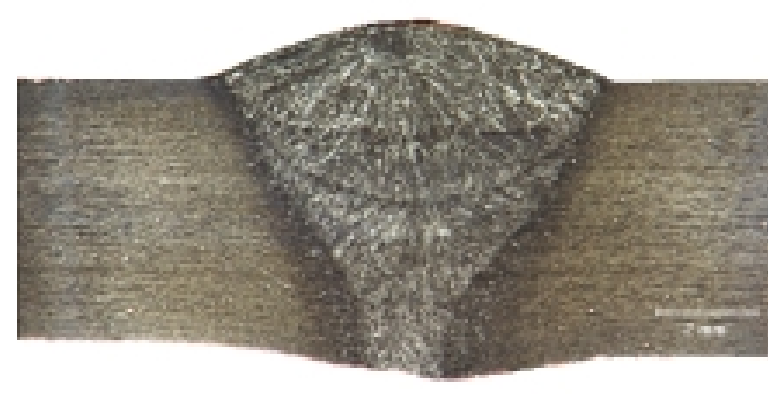

b.

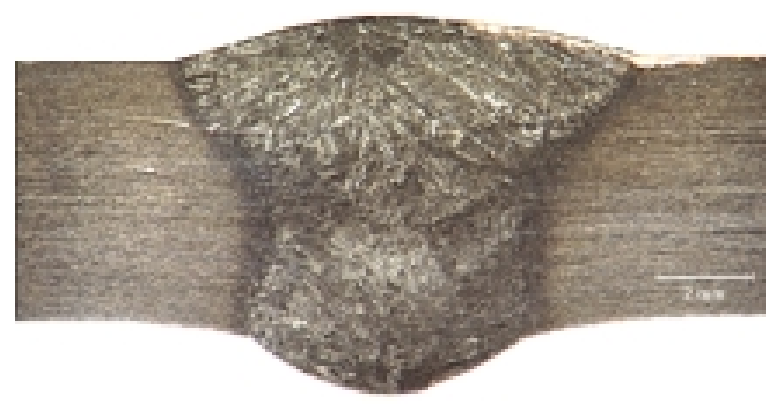

C.

Figura 142: Seção transversal das soldas reais de: a. UNS S32550-0,6 kJ/mm; b. UNS S32550-0,8 $\mathrm{kJ} / \mathrm{mm}$; c. UNS S32550-1,0 kJ/mm; d. UNS S32570-0,6 kJ/mm; e. UNS S32570-0,8 $\mathrm{kJ} / \mathrm{mm}$; f. UNS S32570-1,0 kJ/mm.

Como mostram estas macrografias, à medida que aumenta a energia de soldagem, aumenta a largura do cordão de solda, tanto na raiz como na face. No entanto, deve ser levado em conta que, neste caso, somente foi preparada uma seção transversal do cordão e que esta muda de um lugar do cordão para outro. Portanto, nesta pesquisa não foi feito nenhum tipo de trabalho relacionado com o formato do cordão de solda.

É importante ressaltar que no caso dos AISDs UNS S32550 e S32750 foram soldadas chapas com uma espessura de 5,3 e $6,5 \mathrm{~mm}$, respectivamente, diferente dos outros materiais, onde as chapas tinham $6 \mathrm{~mm}$ de espessura. 


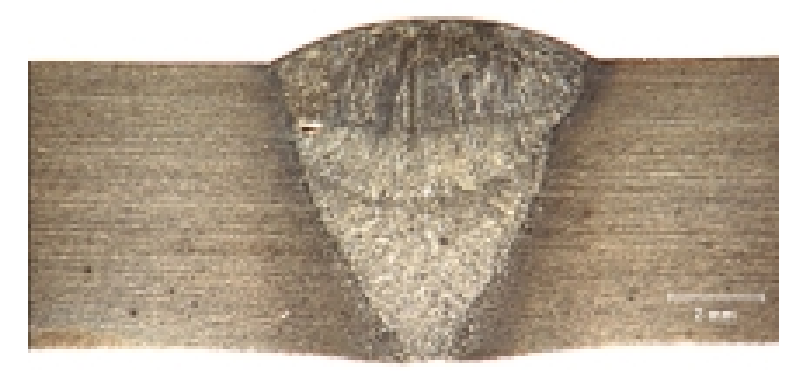

a.

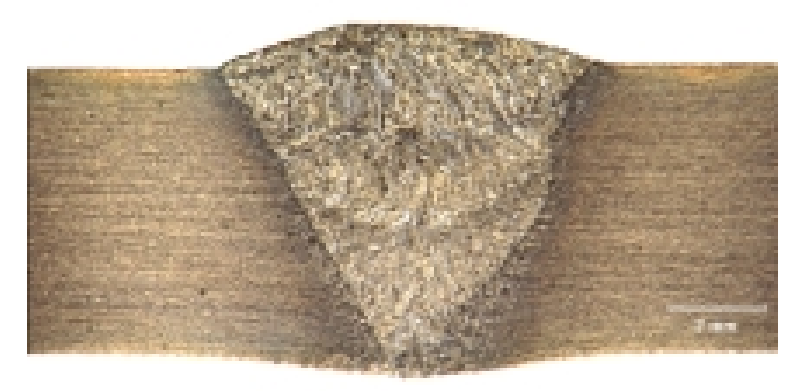

b.

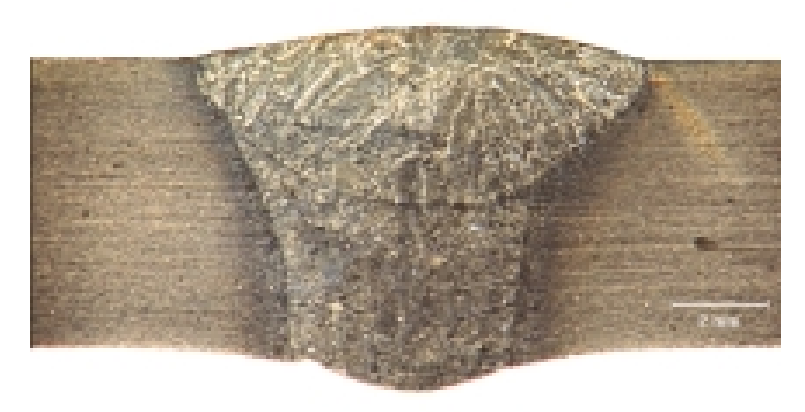

c.

Figura 143: Seção transversal das soldas reais de: a. UNS S32760-0,6 kJ/mm; b. UNS S 32760-0,8 $\mathrm{kJ} / \mathrm{mm}$; c. UNS S 32760-1,0 kJ/mm.

Nas Figuras 144 a 146 são mostrados os detalhes da microestrutura da ZACTE na região da raiz das cinco ligas estudadas. É evidente nestas microestruturas a precipitação de austenita intragranular e o aumento na fração de austenita com o aumento da energia de soldagem. Estas microestruturas serão posteriormente comparadas com as simuladas. 


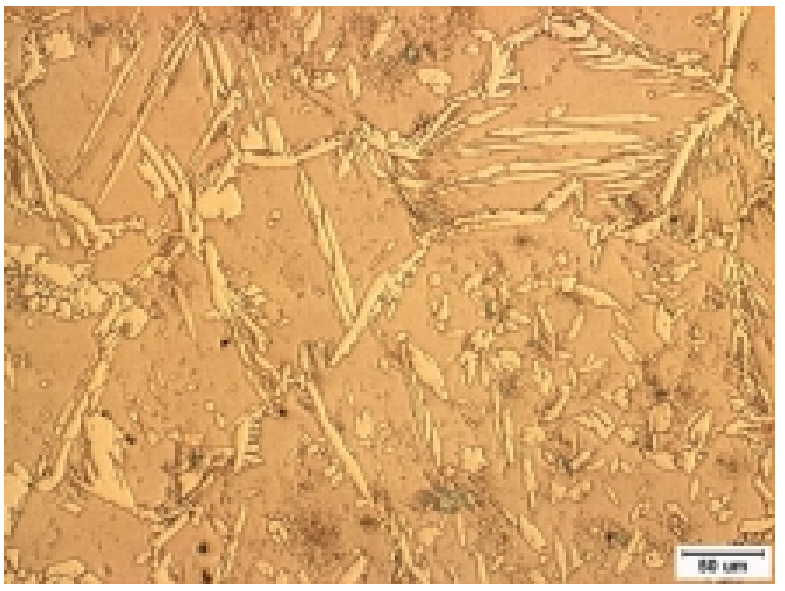

UNS S32304-0,6 kJ/mm

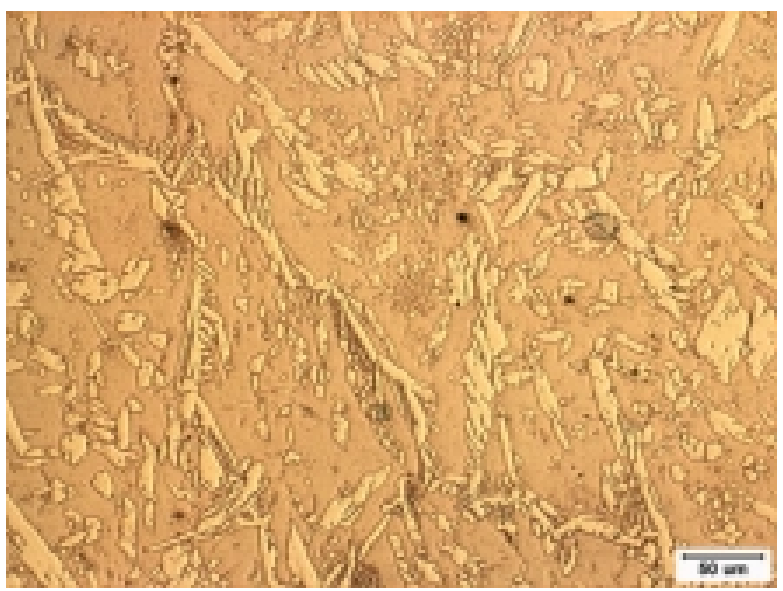

UNS S32304 - 0,8 kJ/mm

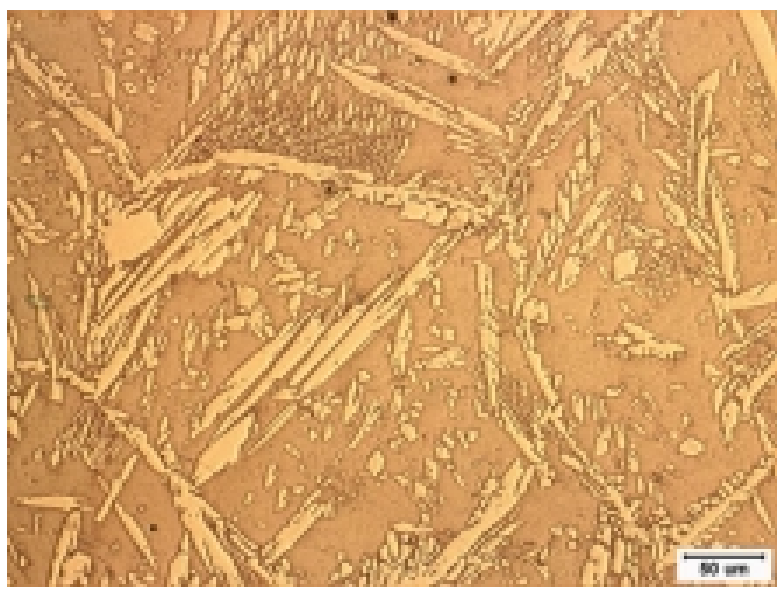

UNS S32304 - 1,0 kJ/mm

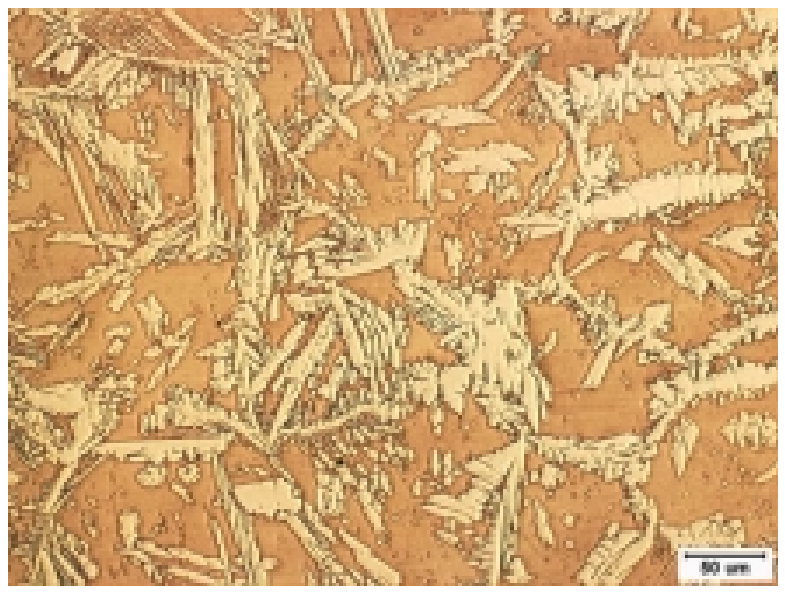

UNS S32205 - 0,6 kJ/mm

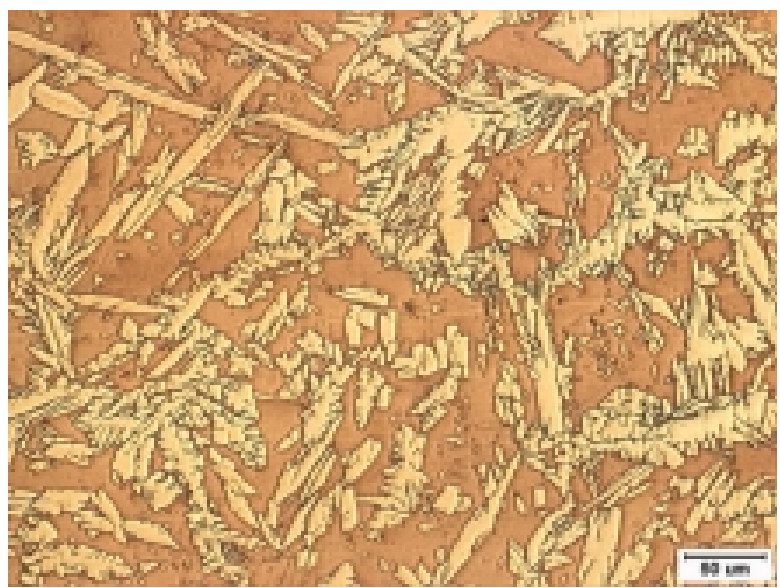

UNS S32205 - 0,8 kJ/mm

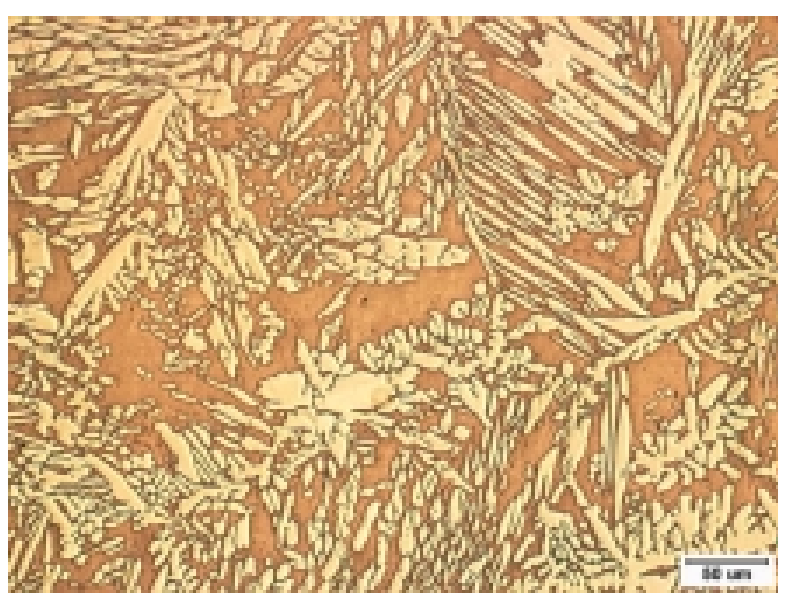

UNS S32205 - 1,0 kJ/mm

Figura 144: Microestrutura da ZACTE na região da raiz na junta soldada dos AIDs UNS S32304 e S32205. Energias de soldagem de 0,6-0,8-1,0 kJ/mm. MO. 


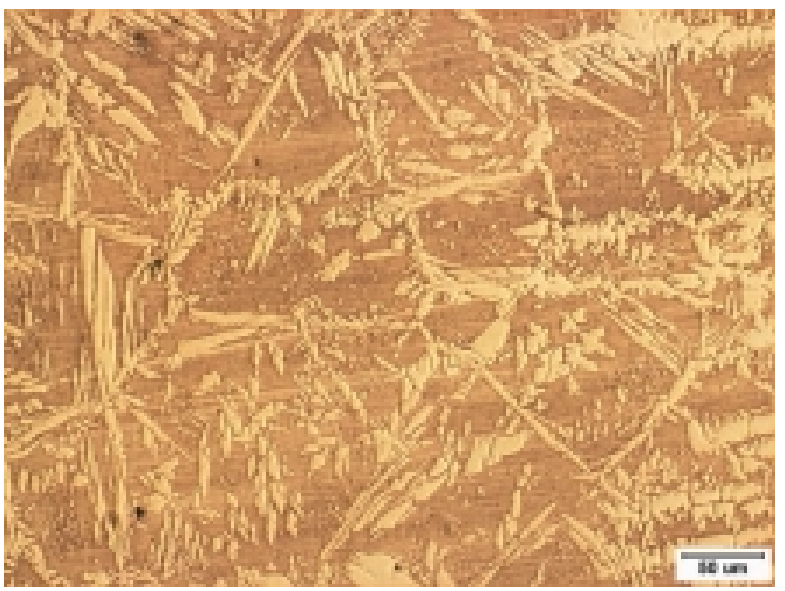

UNS S32550 - 0,6 kJ/mm

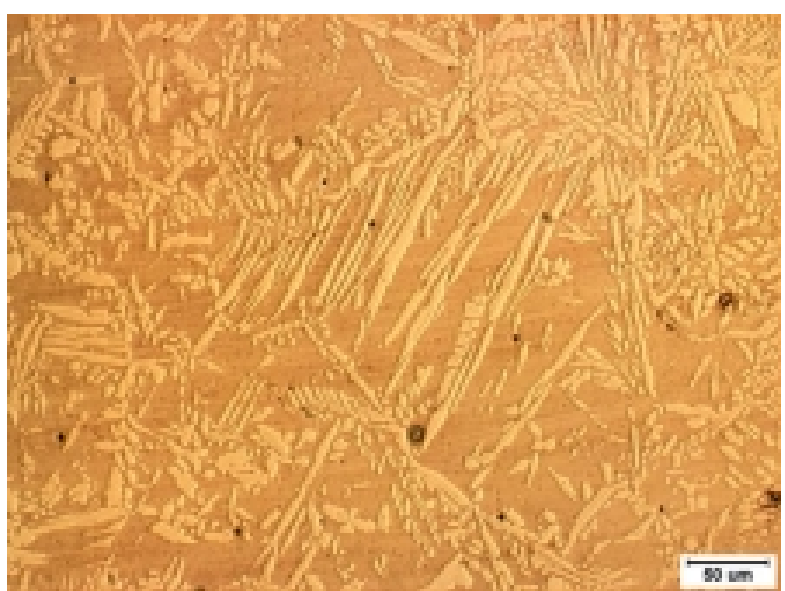

UNS S32550 - 0,8 kJ/mm

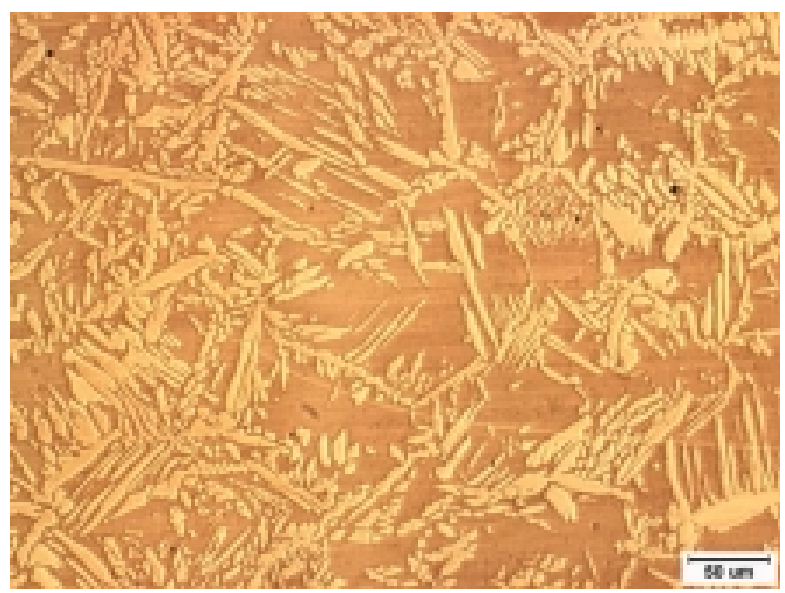

UNS S32550 - 1,0 kJ/mm

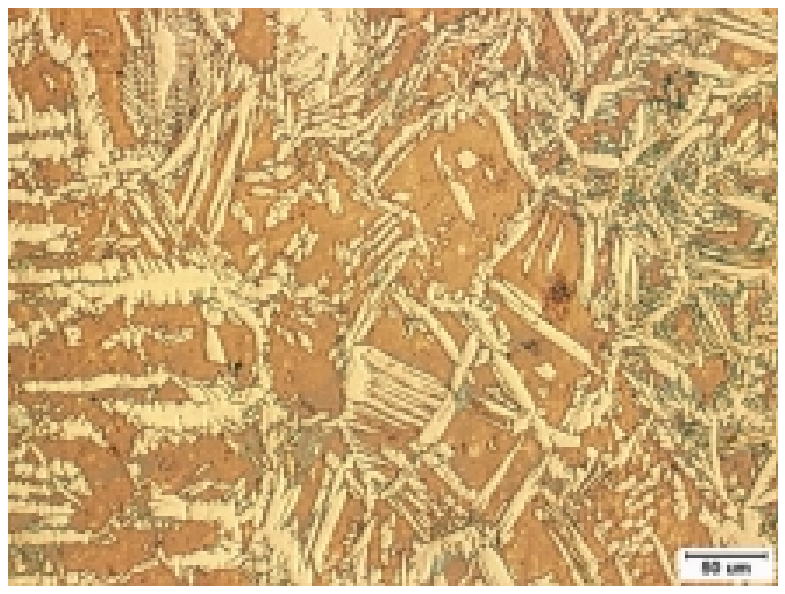

UNS S32750 - 0,6 kJ/mm

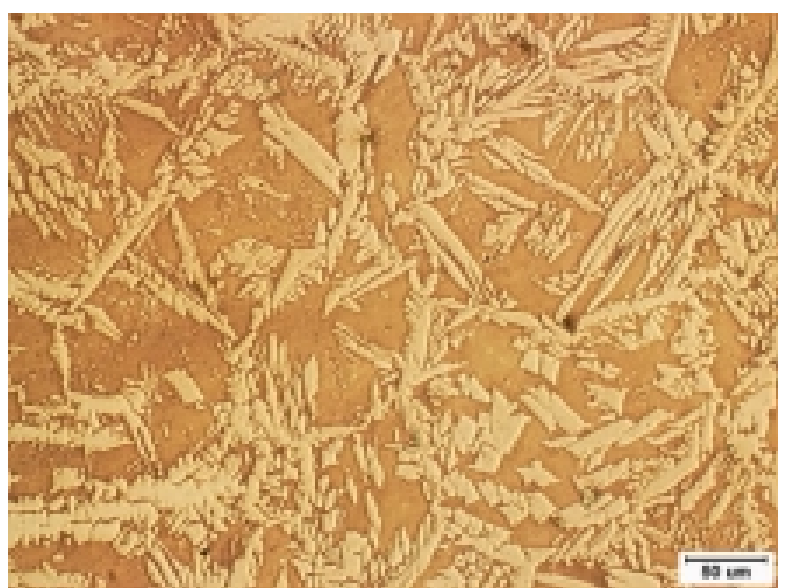

UNS S32750 - 0,8 kJ/mm

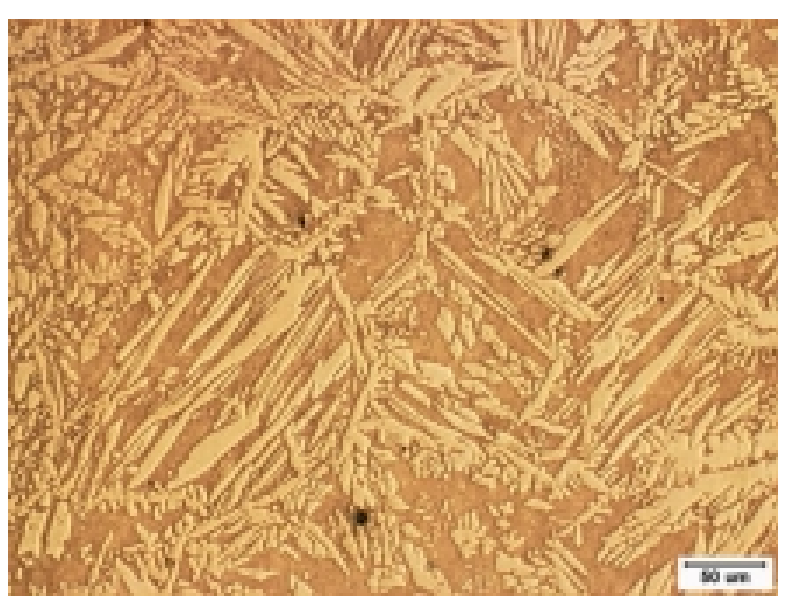

UNS S32750 - 1,0 kJ/mm

Figura 145: Microestrutura da ZACTE na região da raiz na junta soldada dos AISDs UNS S32550 e S32750. Energias de soldagem de 0,6-0,8-1,0 kJ/mm. MO. 


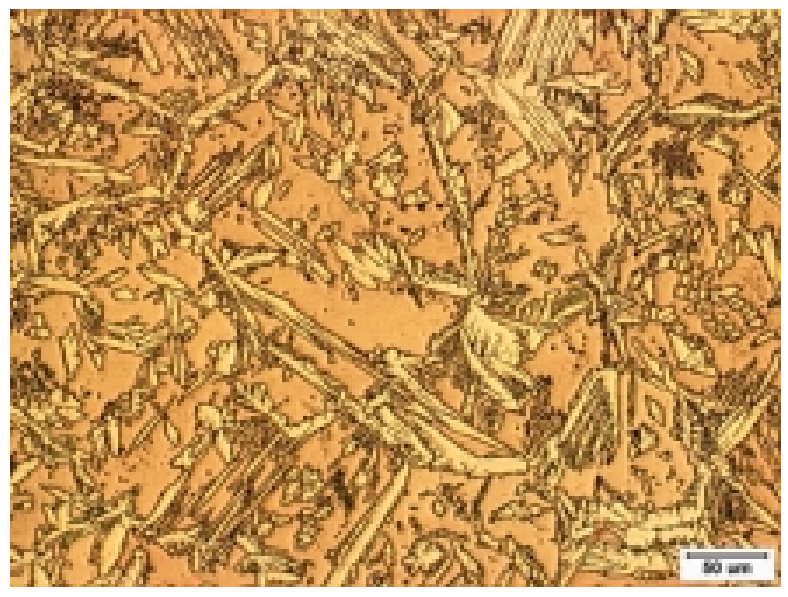

UNS S32760 - 0,6 kJ/mm

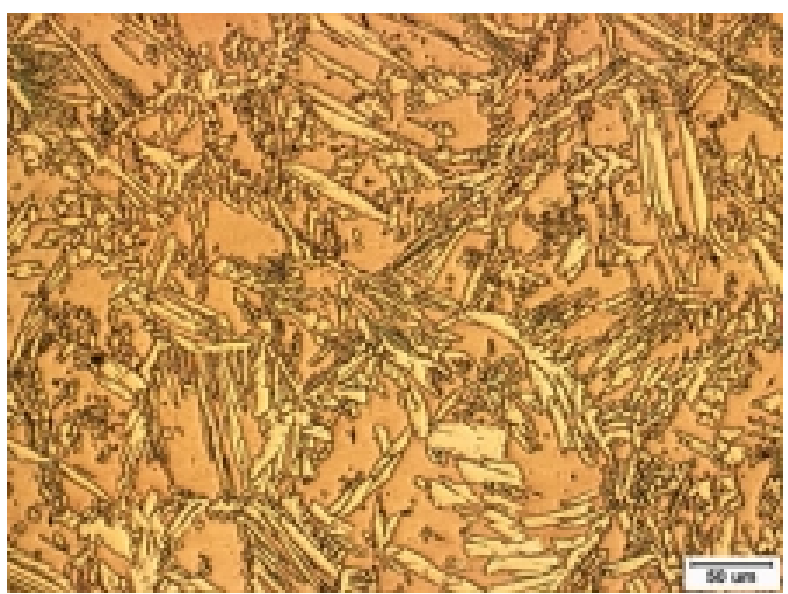

UNS S32760 - 0,8 kJ/mm

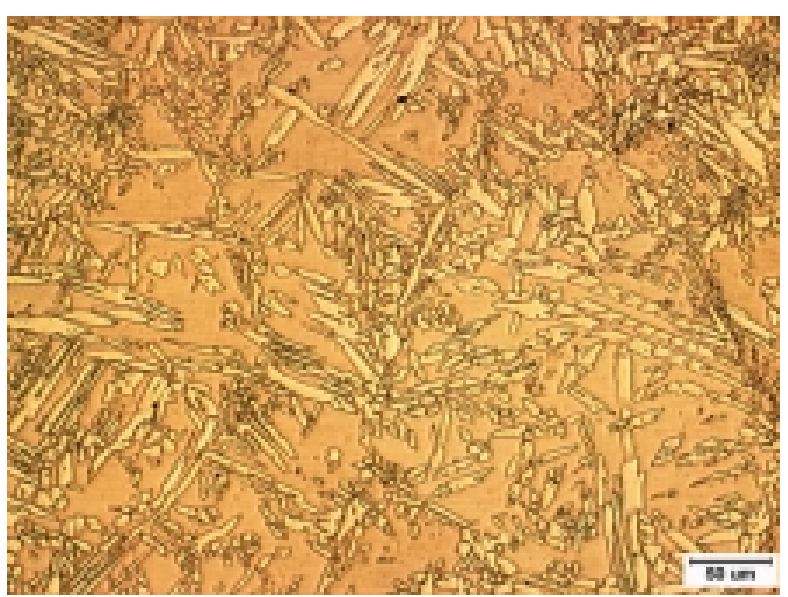

UNS S32760 - 1,0 kJ/mm

Figura 146: Microestrutura da ZACTE na região da raiz na junta soldada do AISD UNS S32760. Energias de soldagem de 0,6-0,8-1,0 kJ/mm. MO. 


\subsubsection{Simulação da ZACTE no Equipamento Gleeble ${ }^{\circledR}$}

Inicialmente foram realizadas algumas experiências para determinar as melhores condições para simular os ciclos térmicos de soldagem. Na Figura 147 são apresentadas duas simulações do mesmo ciclo com uma mudança de 20 para $30 \mathrm{~mm}$, no espaçamento entre as "garras" do sistema de fixação do corpo de prova (Ver Figura 26). Vale a pena mencionar que a redução deste espaçamento possibilita velocidades de resfriamento maiores. Mas, por outro lado, aumenta o gradiente térmico no $\mathrm{CP}$, causando uma redução na região útil do $\mathrm{CP}$.
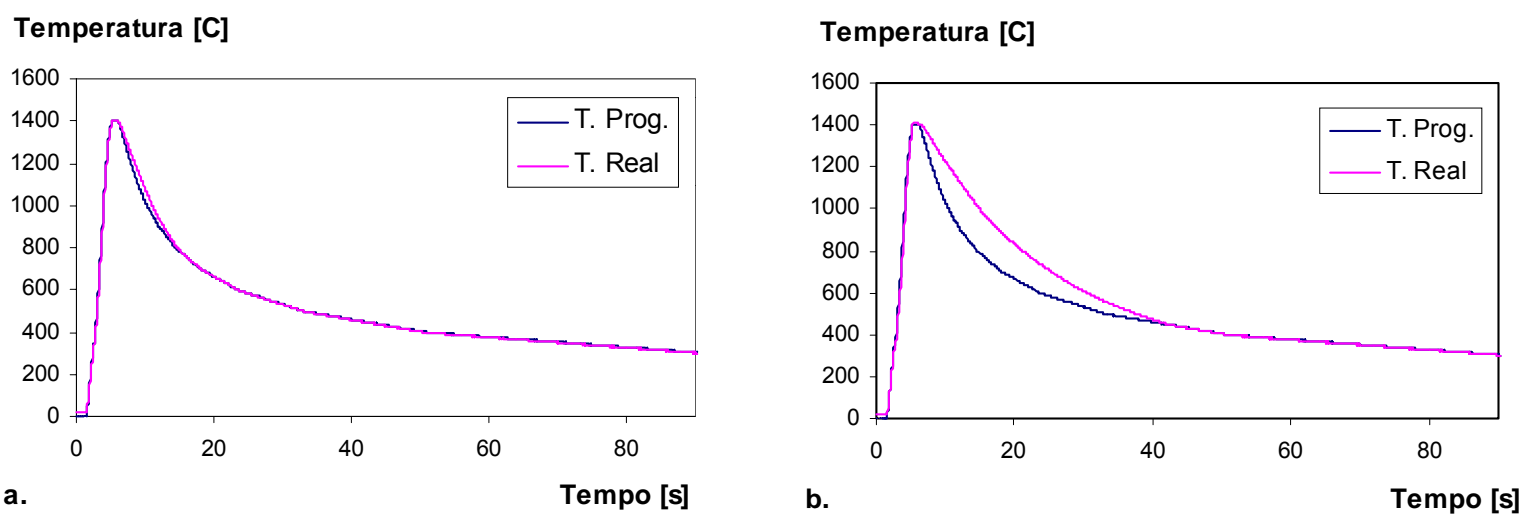

Figura 147: Efeito do espaçamento entre as "garras" do sistema de fixação do CP na taxa de resfriamento durante a simulação no equipamento Gleeble ${ }^{\circledR}$. (a.) Espaçamento de $20 \mathrm{~mm}$; (b.) Espaçamento de $30 \mathrm{~mm}$.

Assim como foi ajustado o parâmetro espaçamento entre as "garras" para obter uma adequada velocidade de resfriamento, outros parâmetros como, por exemplo, a potência disponível teve que ser ajustada para obter as taxas de aquecimento e temperaturas máximas programadas.

Uma vez otimizados os parâmetros de programação do equipamento Gleeble ${ }^{\circledR}$, foi realizada a experiência de simulação da ZACTE correspondente ao primeiro passe com uma energia de soldagem de $0,6 \mathrm{~kJ} / \mathrm{mm}$ (06-1P - segundo código na Tabela 6) com temperatura máxima de $1400{ }^{\circ} \mathrm{C}$. Inicialmente foi utilizada esta energia de soldagem, pois se com ela fosse possível obter a ferritização total dos diversos materiais, com a energias maiores, seria ainda mais fácil. Na Figura 148 é apresentado o ciclo térmico simulado correspondente ao AID UNS S32205. Como é mostrado nesta figura, a reprodução do ciclo térmico programado foi bastante boa. 


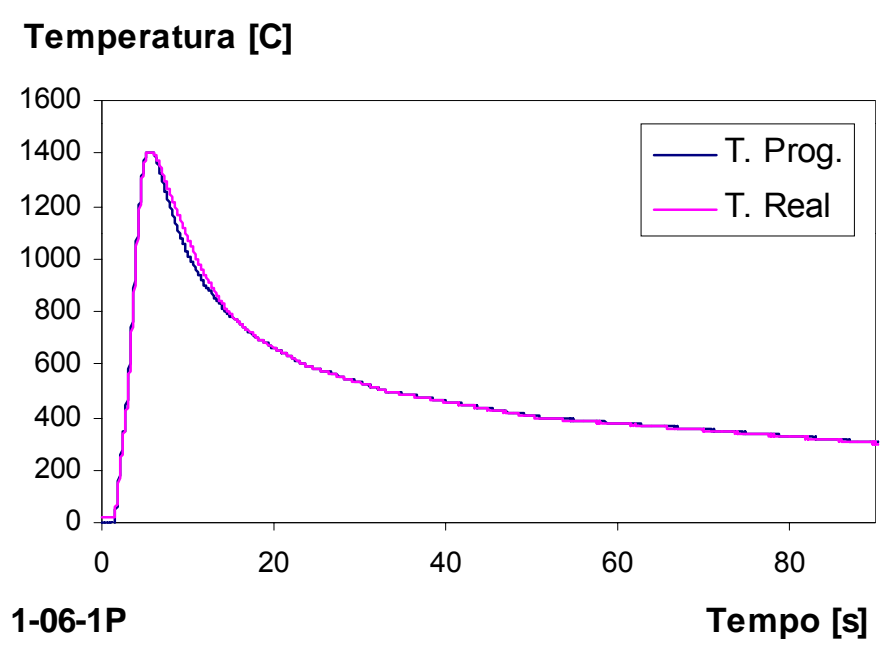

Figura 148: Experiência de simulação da ZACTE 2-06-1P com temperatura máxima de $1400{ }^{\circ} \mathrm{C}$.

Apesar das dificuldades inerentes em se trabalhar em temperaturas acima da TRN, o que normalmente não é feito no equipamento Gleeble ${ }^{\circledR}$, no caso dos AIDs UNS S32304 e S32205 as simulações foram realizadas sem grandes dificuldades. Por outro lado, quando os AISDs UNS S32550, S32750 e S32760 foram submetidos à simulação anteriormente descrita, apresentaram trincas e microtrincas no meio da região simulada. No caso das microtrincas foi possivel observar que estas se desenvolveram ao longo dos contornos de grão ferríticos. Este fenômeno revela a presença de filme líquido nos contornos de grão devido à elevada temperatura de ensaio. Estas trincas viriam a interferir na preparação de corpos de prova para microscopia eletrônica e com os ensaios mecânicos e de corrosão.

Desta forma, foi testada a região da ZACTE com temperatura máxima de $1380^{\circ} \mathrm{C}$, simulando o ciclo térmico de soldagem 06-1P para as cinco ligas. Apresentaram-se também algumas microtrincas, mas tanto o seu tamanho como incidência foram bem menores. Poder-se-ia pensar em simular uma região submetida a temperaturas máximas menores durante 0 primeiro passe. Neste caso a simulação seria de uma região fora da ZACTE e, além disso, o reaquecimento devido aos segundo e terceiro passes estaria fora da faixa de temperatura de precipitação de $\gamma_{2}$. Portanto, decidiu-se realizar o trabalho de simulação na região da ZACTE submetida a uma temperatura máxima de $1380{ }^{\circ} \mathrm{C}$ durante o primeiro passe (Ver Tabela 6).

\subsubsection{Caracterização Microestrutural da ZACTE}

Nas Figuras 149 a 153 são mostradas as microestruturas dos materiais submetidos à simulação térmica da região da ZACTE na raiz do cordão, após o primeiro, segundo e terceiro passes, para as energias de soldagem de 0,6 e 1,0 kJ/mm. 


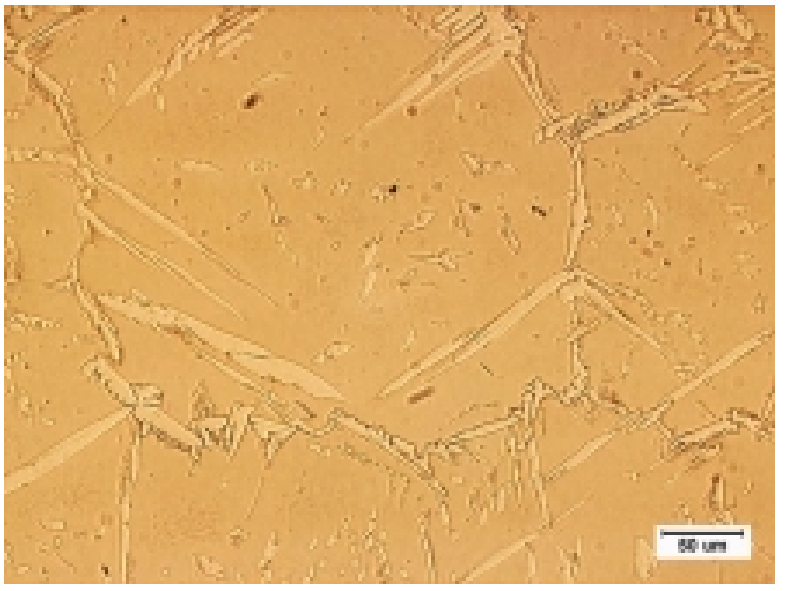

$0,6 \mathrm{~kJ} / \mathrm{mm}$ - Após o $1^{\circ}$ passe

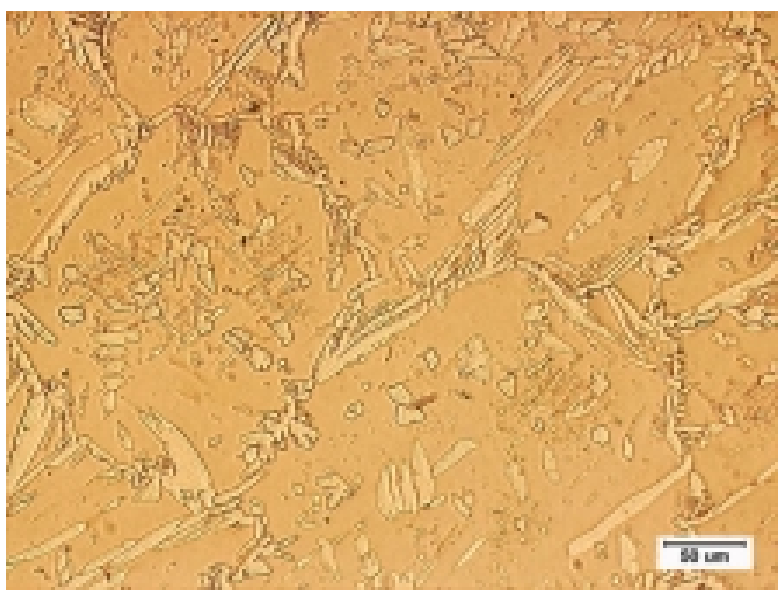

$0,6 \mathrm{~kJ} / \mathrm{mm}$ - Após o $2^{\circ}$ passe

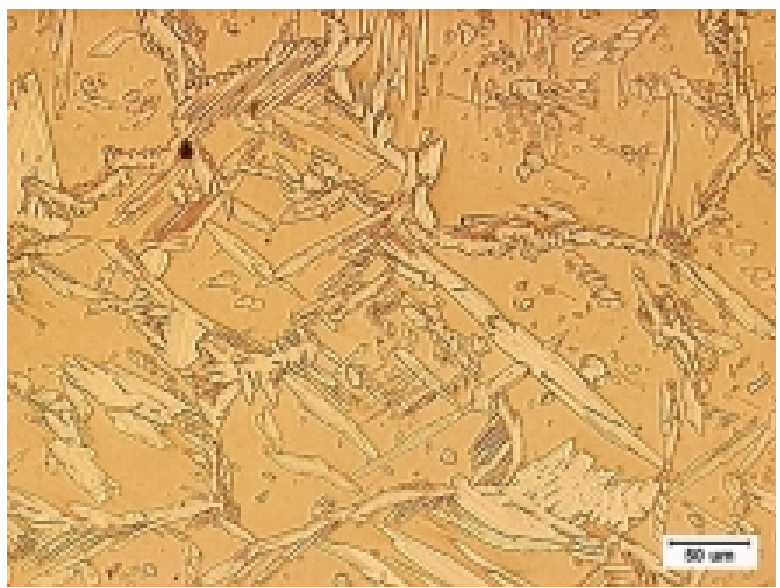

$0,6 \mathrm{~kJ} / \mathrm{mm}$ - Após o $3^{\circ}$ passe

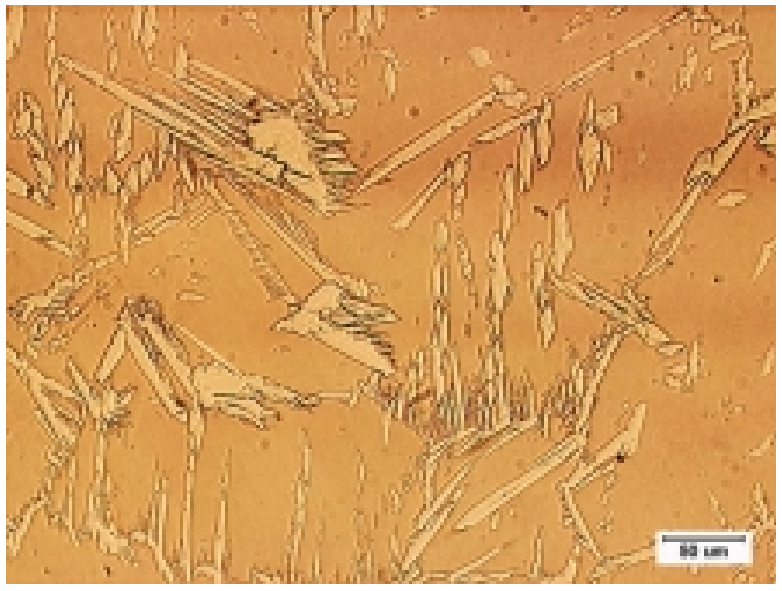

$1,0 \mathrm{~kJ} / \mathrm{mm}$ - Após o $1^{\circ}$ passe

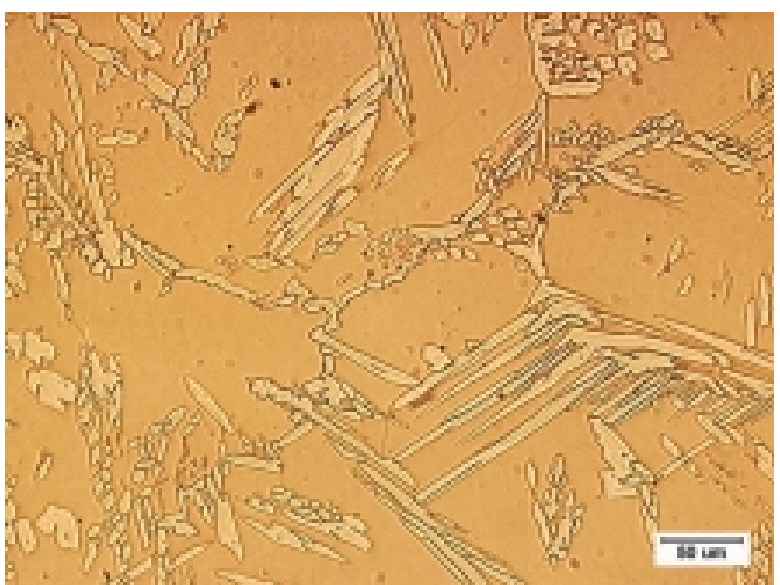

$1,0 \mathrm{~kJ} / \mathrm{mm}$ - Após o $2^{\circ}$ passe

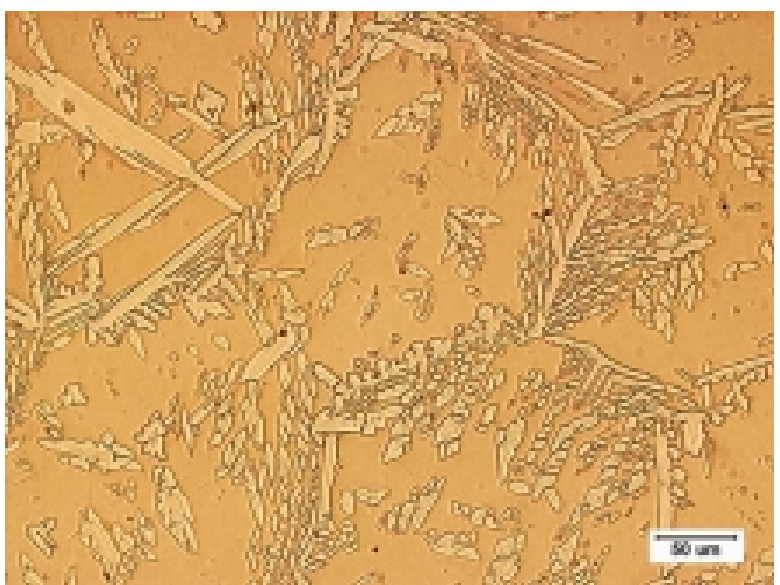

$1,0 \mathrm{~kJ} / \mathrm{mm}$ - Após o $3^{\circ}$ passe

Figura 149: Microestruturas do AID UNS S32304, correspondentes à simulação da ZACTE na raiz do cordão, realizado com energias de soldagem de 0,6 e 1,0 kJ/mm. 


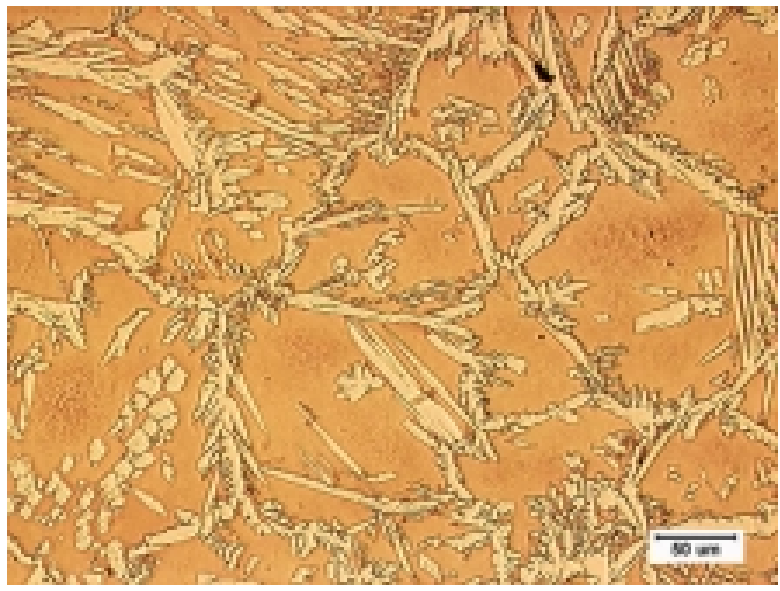

$0,6 \mathrm{~kJ} / \mathrm{mm}$ - Após o $1^{\circ}$ passe

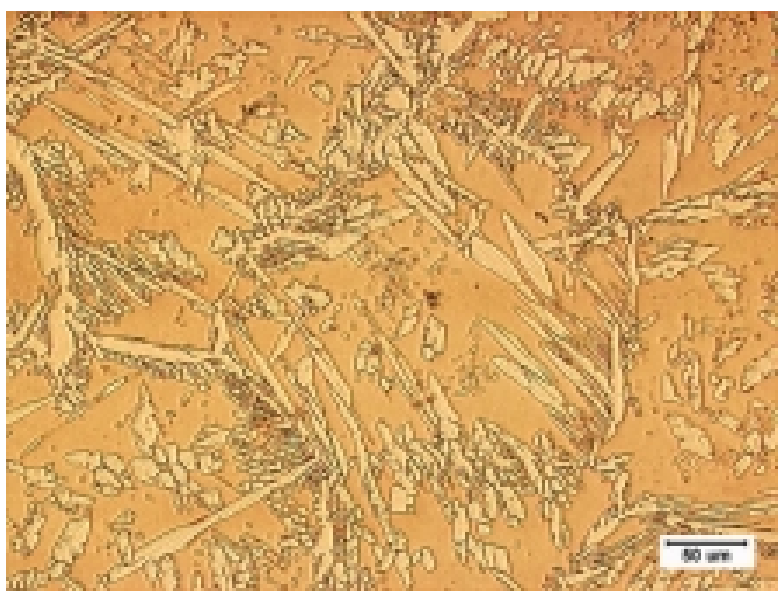

$0,6 \mathrm{~kJ} / \mathrm{mm}$ - Após o $2^{\circ}$ passe

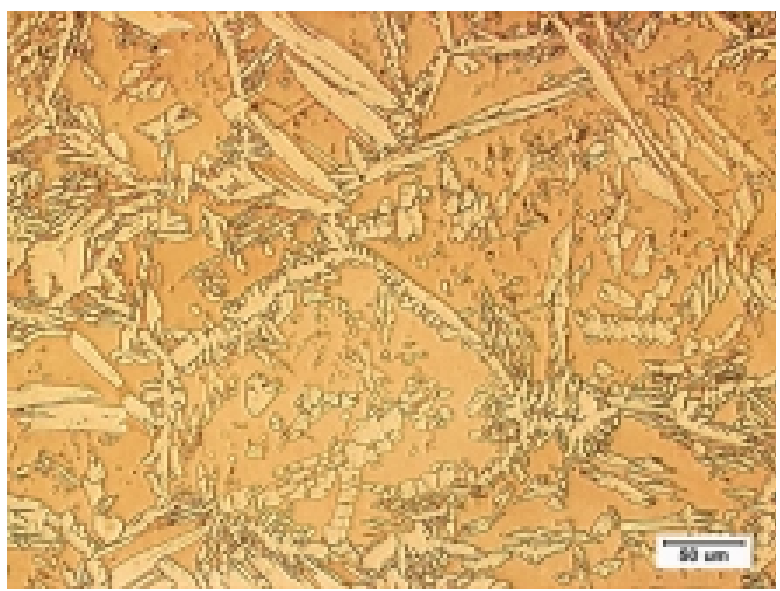

$0,6 \mathrm{~kJ} / \mathrm{mm}-$ Após o $3^{\circ}$ passe

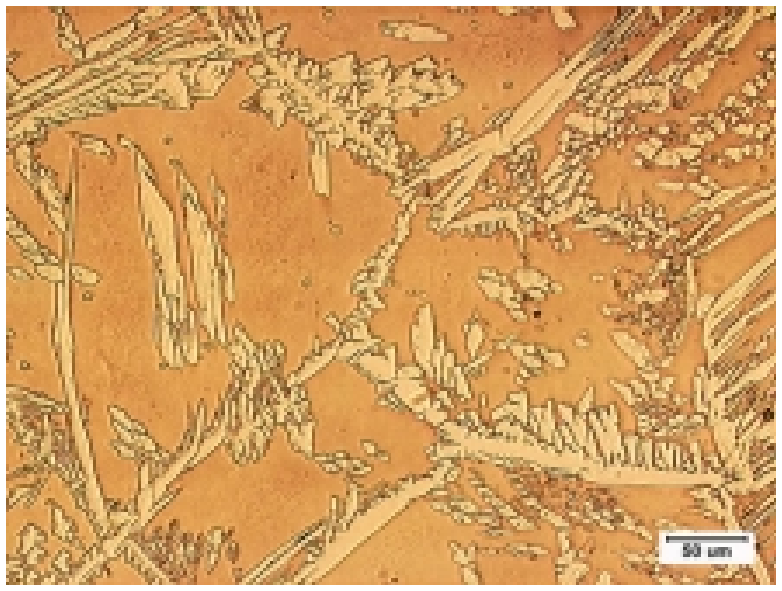

$1,0 \mathrm{~kJ} / \mathrm{mm}$ - Após o $1^{\circ}$ passe

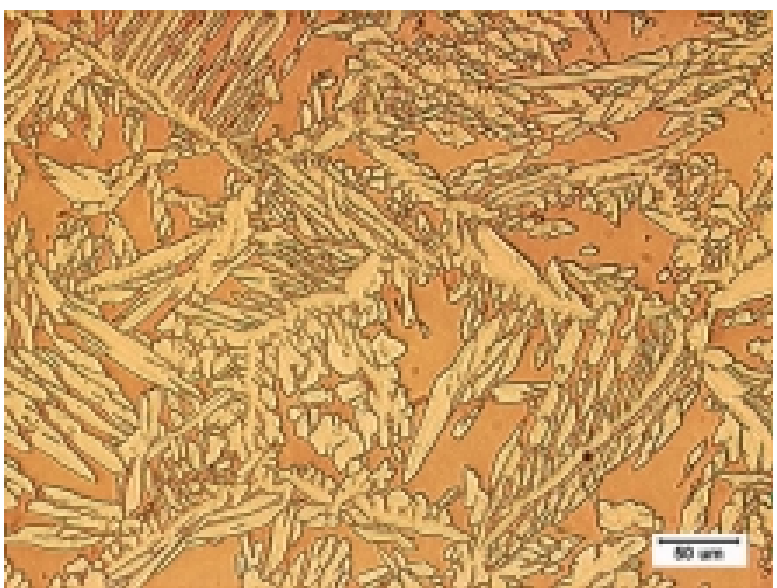

$1,0 \mathrm{~kJ} / \mathrm{mm}$ - Após o $2^{\circ}$ passe

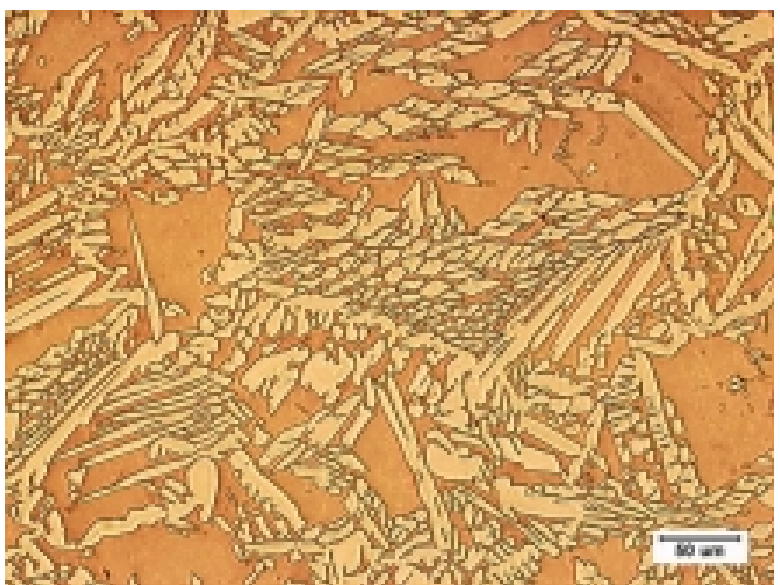

$1,0 \mathrm{~kJ} / \mathrm{mm}$ - Após o $3^{\circ}$ passe

Figura 150: Microestruturas do AID UNS S32205, correspondentes à simulação da ZACTE na raiz do cordão, realizado com energias de soldagem de 0,6 e 1,0 kJ/mm. 


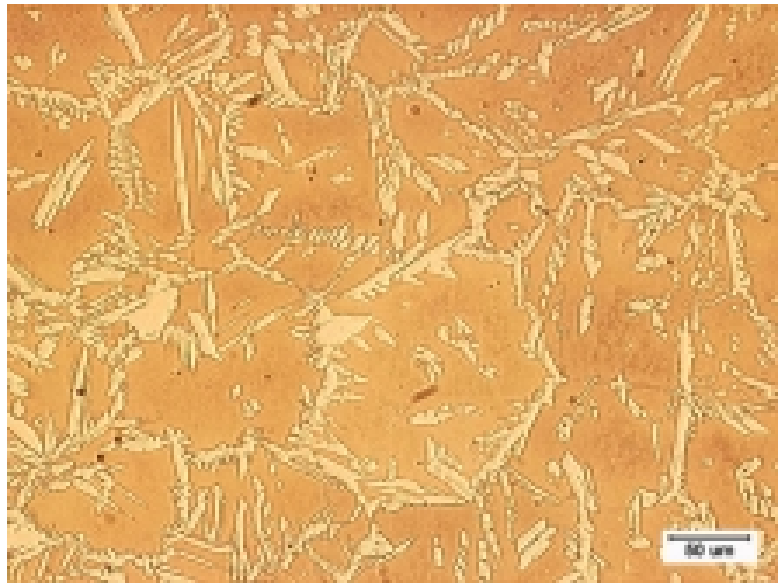

$0,6 \mathrm{~kJ} / \mathrm{mm}$ - Após o $1^{\circ}$ passe

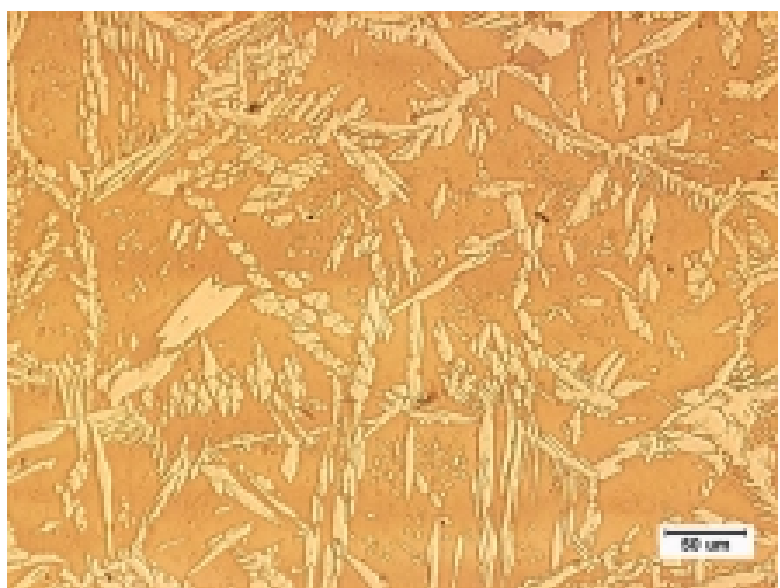

$0,6 \mathrm{~kJ} / \mathrm{mm}$ - Após o $2^{\circ}$ passe

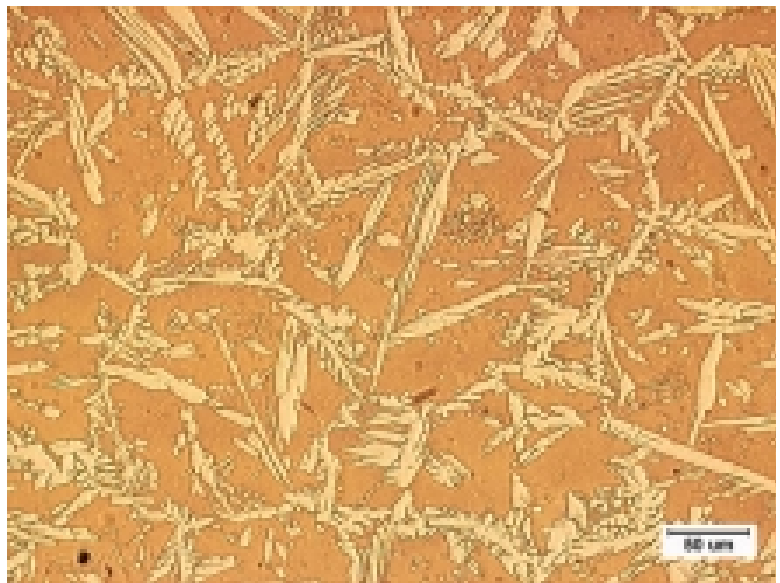

$0,6 \mathrm{~kJ} / \mathrm{mm}$ - Após o $3^{\circ}$ passe

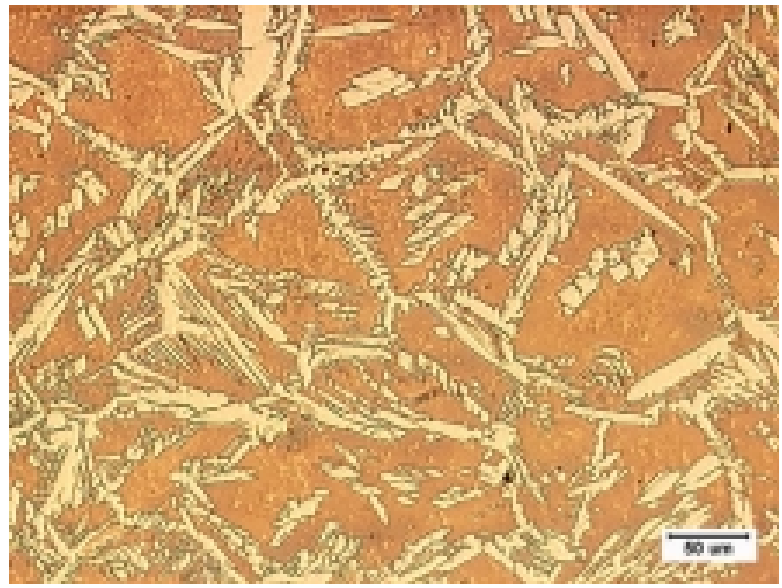

$1,0 \mathrm{~kJ} / \mathrm{mm}$ - Após o $1^{\circ}$ passe

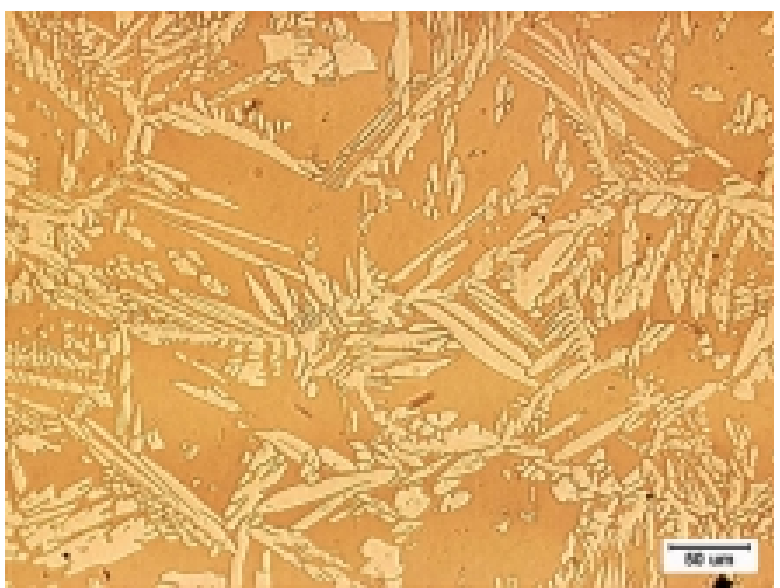

$1,0 \mathrm{~kJ} / \mathrm{mm}$ - Após o $2^{\circ}$ passe

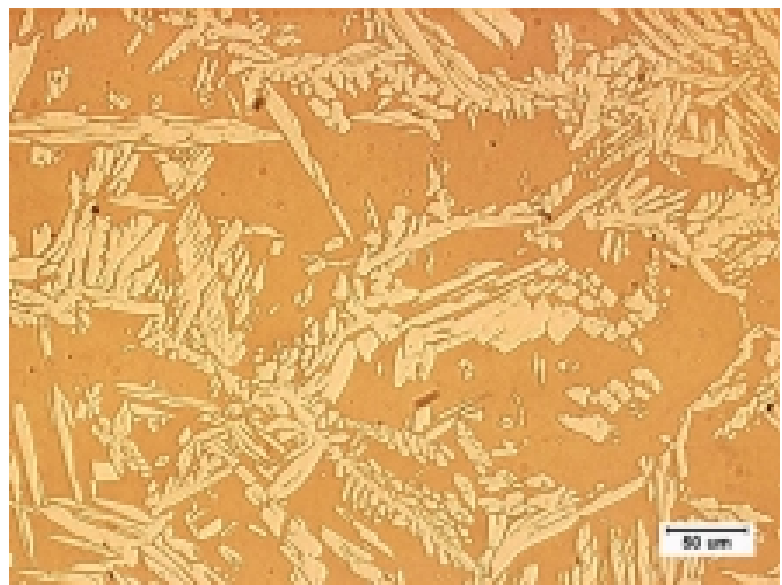

$1,0 \mathrm{~kJ} / \mathrm{mm}-$ Após o $3^{\circ}$ passe

Figura 151: Microestruturas do AISD UNS S32550, correspondentes à simulação da ZACTE na raiz do cordão, realizado com energias de soldagem de 0,6 e 1,0 kJ/mm. 


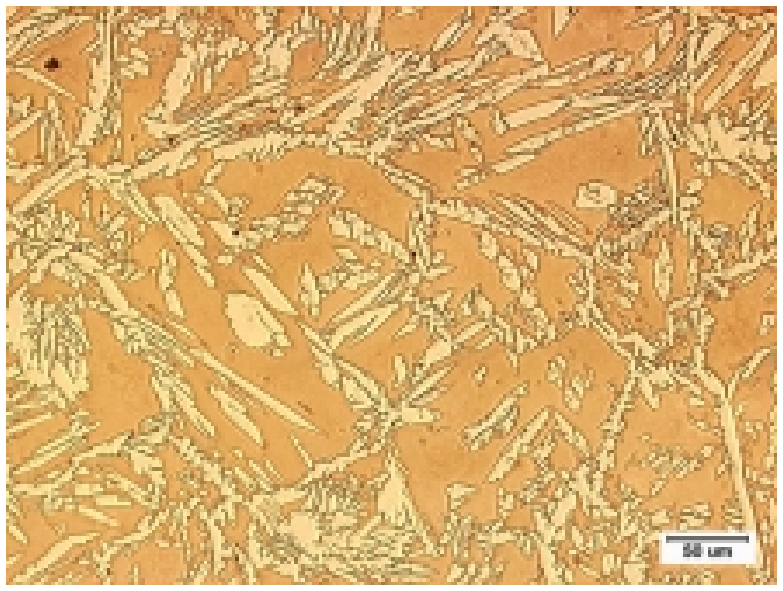

$0,6 \mathrm{~kJ} / \mathrm{mm}$ - Após o $1^{\circ}$ passe

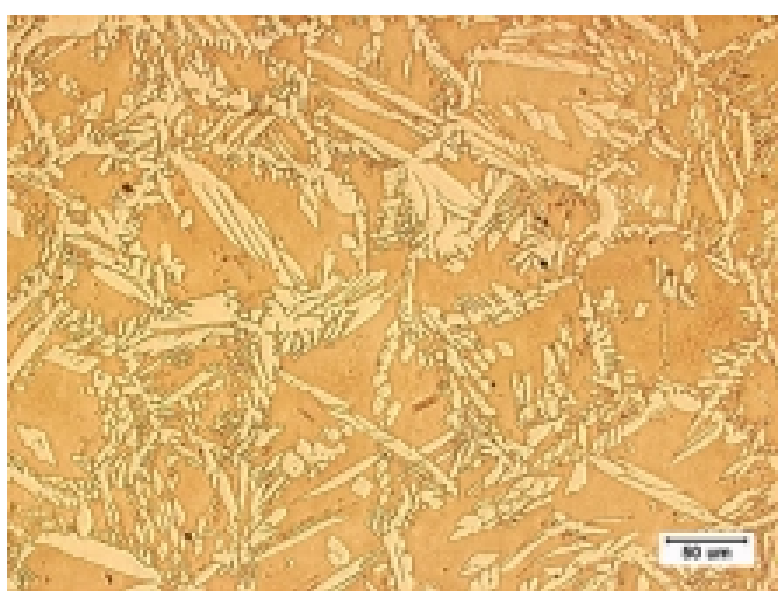

$0,6 \mathrm{~kJ} / \mathrm{mm}$ - Após o $2^{\circ}$ passe

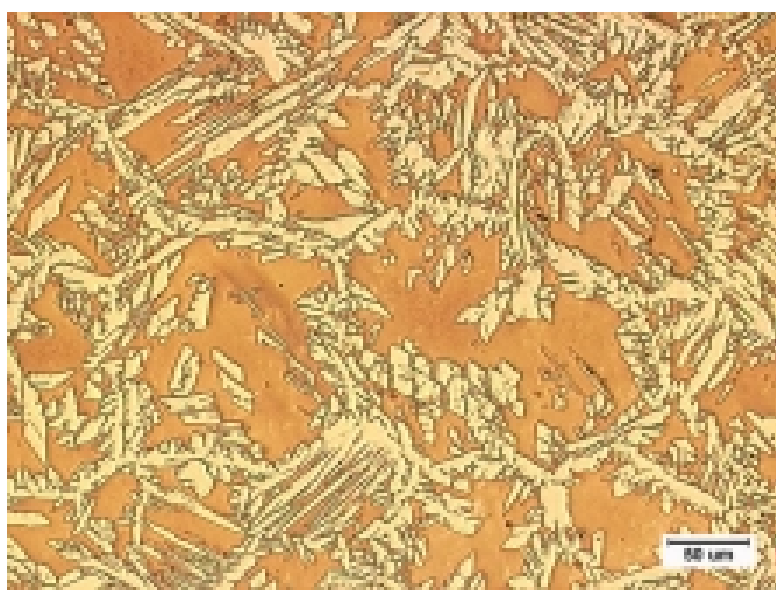

$0,6 \mathrm{~kJ} / \mathrm{mm}$ - Após o $3^{\circ}$ passe

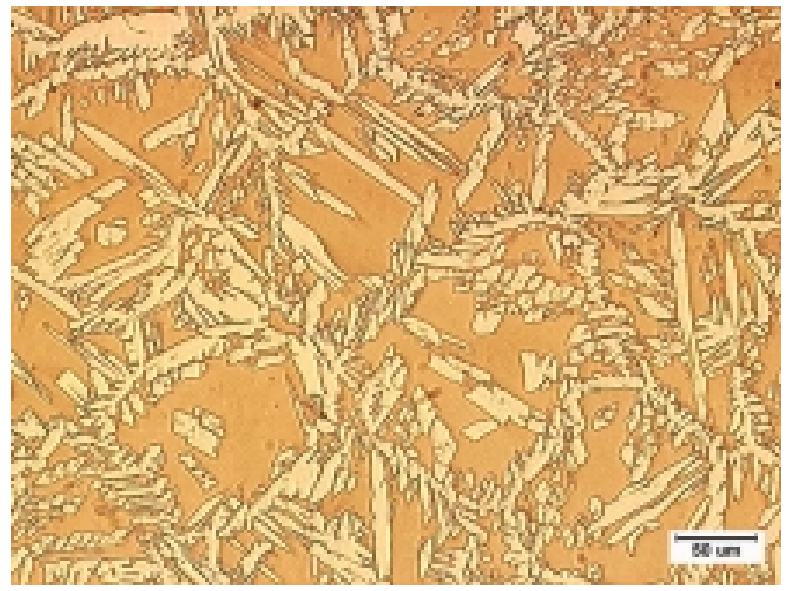

$1,0 \mathrm{~kJ} / \mathrm{mm}$ - Após o $1^{\circ}$ passe

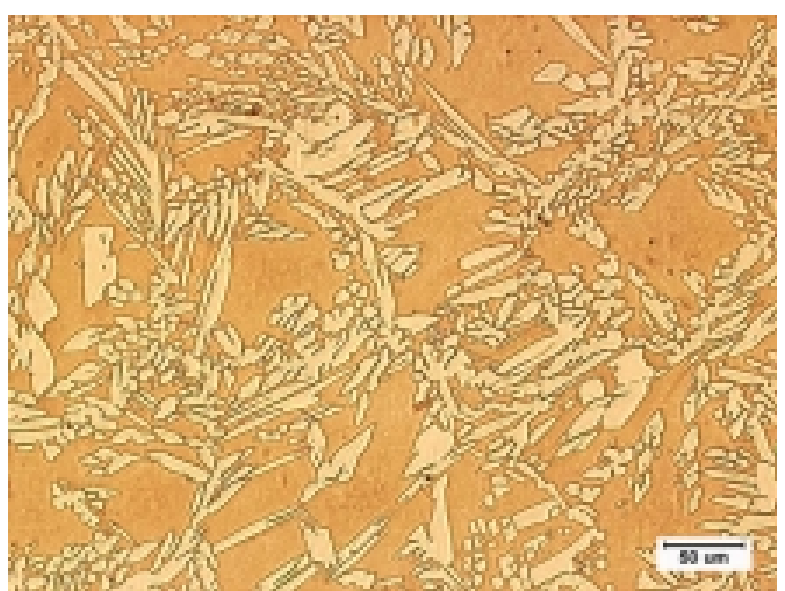

$1,0 \mathrm{~kJ} / \mathrm{mm}$ - Após o $2^{\circ}$ passe

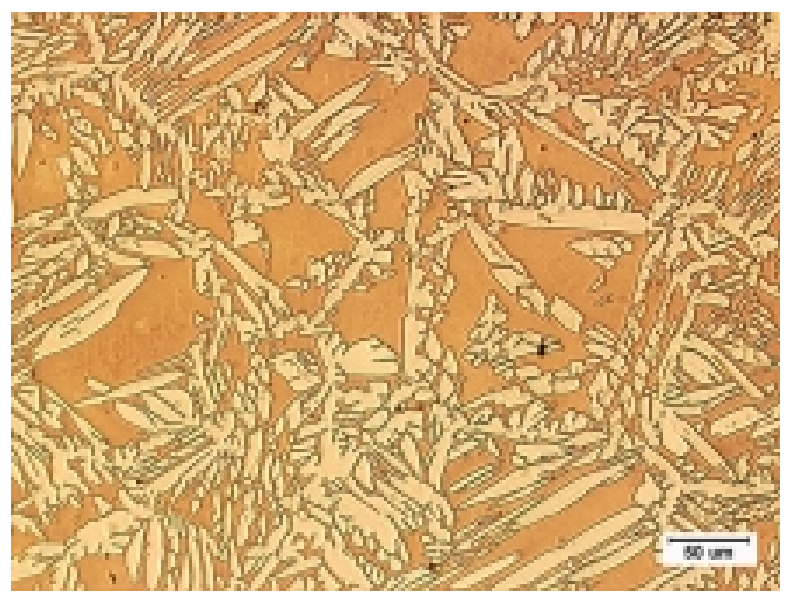

$1,0 \mathrm{~kJ} / \mathrm{mm}-$ Após o $3^{\circ}$ passe

Figura 152: Microestruturas do AID UNS S32750, correspondentes à simulação da ZACTE na raiz do cordão, realizado com energias de soldagem de 0,6 e 1,0 kJ/mm. 


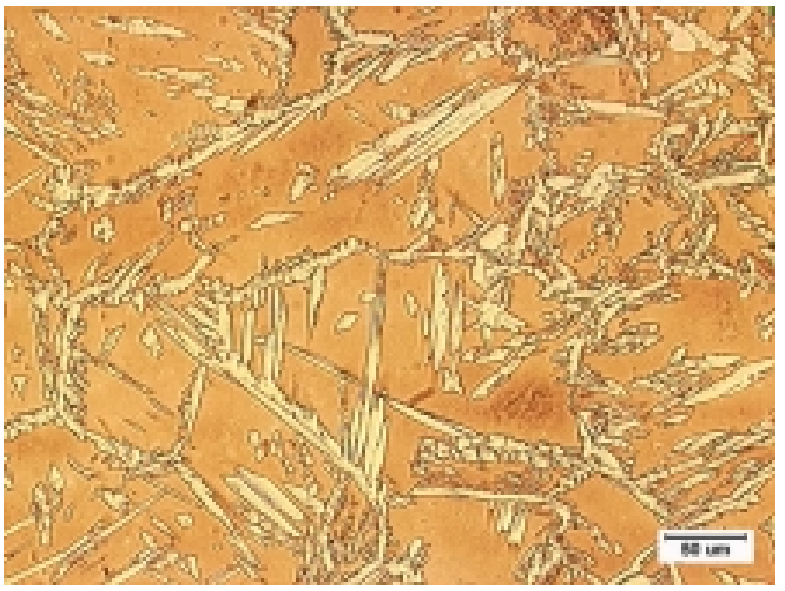

$0,6 \mathrm{~kJ} / \mathrm{mm}$ - Após o $1^{\circ}$ passe

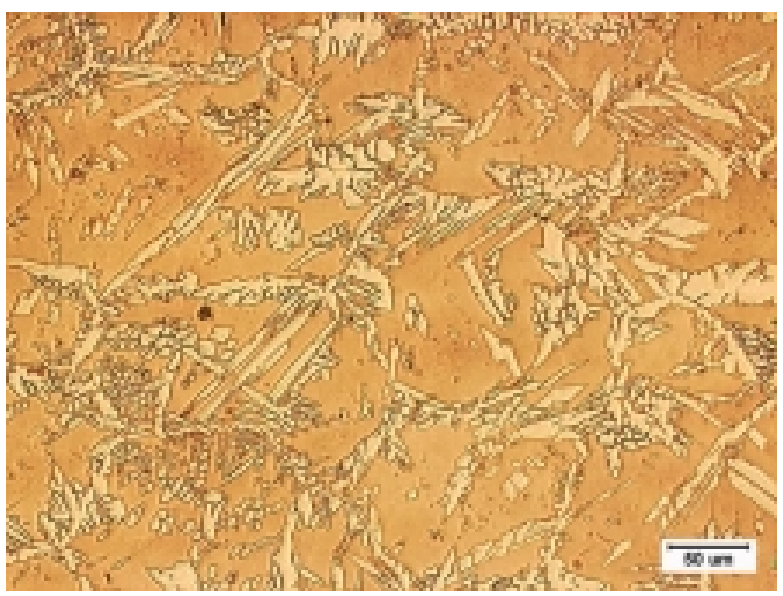

\section{$0,6 \mathrm{~kJ} / \mathrm{mm}$ - Após o $2^{\circ}$ passe}

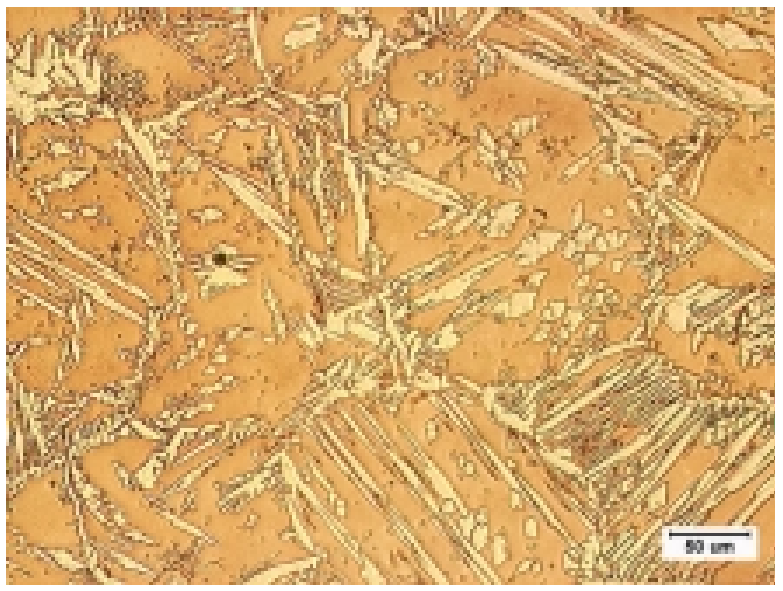

0,6 kJ/mm - Após o $3^{\circ}$ passe

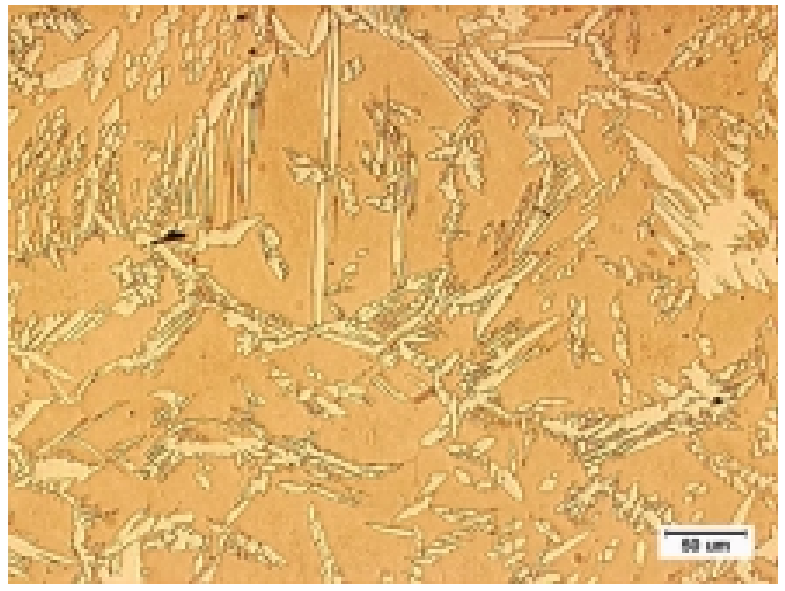

$1,0 \mathrm{~kJ} / \mathrm{mm}$ - Após o $1^{\circ}$ passe

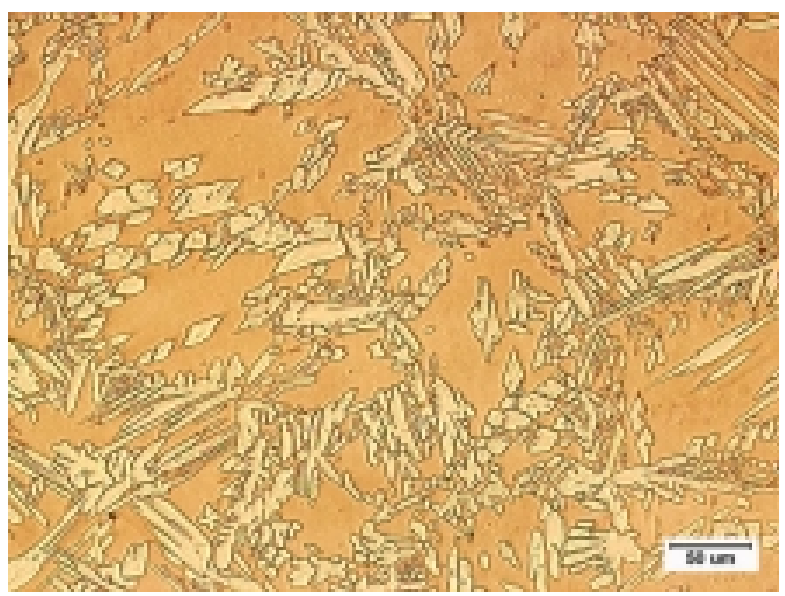

\section{$1,0 \mathrm{~kJ} / \mathrm{mm}$ - Após o $2^{\circ}$ passe}

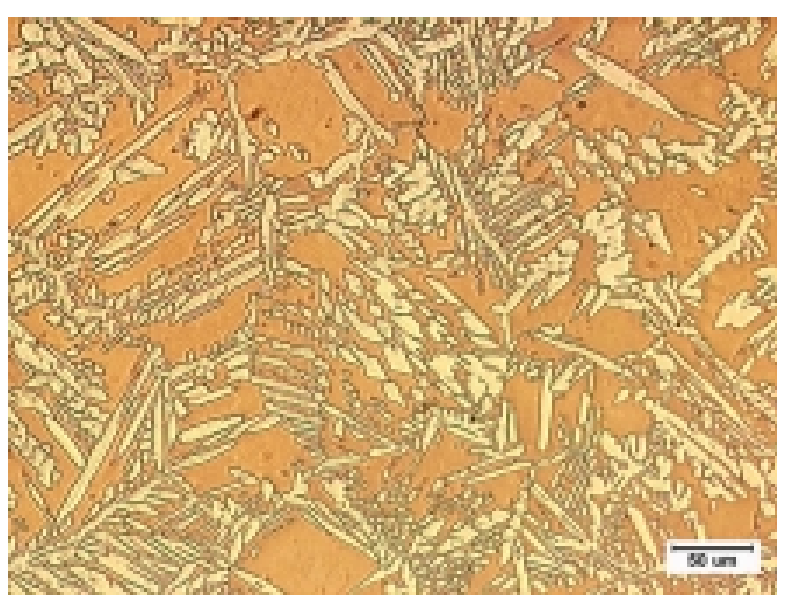

$1,0 \mathrm{~kJ} / \mathrm{mm}$ - Após o $3^{\circ}$ passe

Figura 153: Microestruturas do AID UNS S32760, correspondentes à simulação da ZACTE na raiz do cordão, realizado com energias de soldagem de 0,6 e $1,0 \mathrm{~kJ} / \mathrm{mm}$. 
A comparação das microestruturas apresentadas nas Figuras 149 a 153, correspondentes às simulações após o terceiro passe, com as microestruturas da ZACTE da raiz das soldas reais (Figuras 144 a 146) mostra a boa reprodutibilidade obtida da ZACTE mediante a simulação térmica no equipamento Gleeble ${ }^{\circledR}$.

Quanto a análise dos CPs simulados termicamente, a Tabela 40 mostra os resultados da medição do tamanho de grão ferrítico após o primeiro passe de soldagem na ZACTE das diversas ligas. Nesta mesma tabela é apresentado o resultado da análise de variância das referidas medidas. Para facilitar a visualização, estes resultados são apresentados graficamente na Figura 154. Da análise destes dados verifica-se que a energia de soldagem tem uma importante influência no tamanho de grão ferrítico da ZACTE dos AIDs UNS S32304 e S32205. Esta influência é moderada no caso do AISD UNS S32760 e finalmente é praticamente desprezível nos AISD UNS S32550 e S32750.

O aumento da energia de soldagem significa um incremento no tempo de permanência em temperaturas elevadas, portanto era de se esperar um aumento do tamanho de grão com a energia de soldagem. Porém, a microestrutura dos materiais na faixa de temperaturas elevadas às quais foram submetidos, nem sempre foi monofásica. Assim, a quantidade de liquido presente na microestrutura na temperatura máxima durante o primeiro passe, que neste caso é $1380{ }^{\circ} \mathrm{C}$ (Ver Tabela 29 na página 85), condicionou o crescimento de grão. Portanto, para o AID UNS S32304, que não apresenta líquido nesta temperatura e além disso encontra-se no campo monofásico $(\alpha)$, o aumento do tempo de permanência em temperaturas elevadas causou um considerável crescimento de grão. No caso do AID UNS S32205, a quantidade de líquido presente a $1380{ }^{\circ} \mathrm{C}(8 \%$ vol $)$ já é suficiente para reduzir o crescimento de grão. Finalmente no caso dos AISDs a quantidade de líquido é tal (UNS S32550 = $28 \%$ vol; UNS S32750 = $26 \%$ vol; UNS S32760 = $23 \%$ vol ) que o crescimento de grão é praticamente suprimido.

Tabela 40: Variação do tamanho de grão ferrítico com a energia de soldagem utilizada, na ZACTE das diferentes ligas.

\begin{tabular}{|c|c|c|c|c|c|}
\hline \multirow{2}{*}{$\begin{array}{c}\text { Energia de } \\
\text { Soldagem }\end{array}$} & \multicolumn{5}{|c|}{ Tamanho de Grão $[\mu \mathrm{m}]$} \\
\cline { 2 - 6 } & UNS S32304 & UNS S32205 & UNS S32550 & UNS S32750 & UNS S32760 \\
\hline $0,6 \mathrm{~kJ} / \mathrm{mm}$ & $162 \pm 9$ & $120 \pm 10$ & $95 \pm 5$ & $95 \pm 6$ & $101 \pm 8$ \\
\hline $0,8 \mathrm{~kJ} / \mathrm{mm}$ & $185 \pm 14$ & $143 \pm 7$ & $98 \pm 4$ & $97 \pm 5$ & $111 \pm 4$ \\
\hline $1,0 \mathrm{~kJ} / \mathrm{mm}$ & $227 \pm 18$ & $169 \pm 12$ & $99 \pm 5$ & $97 \pm 6$ & $120 \pm 9$ \\
\hline ANOVA - F & $\mathbf{2 1}$ & $\mathbf{2 5}$ & $\mathbf{1}$ & $\mathbf{0 , 3}$ & $\mathbf{7}$ \\
\hline
\end{tabular}

Nota: ANOVA-F: Fator de análise de variância, onde o $F_{\text {crítico }}=5,2$. Nível de significância de $1 \%$. Vermelho: $F<F_{\text {crítico }}$ 


\section{Tamanho de Grão $[\mu \mathrm{m}]$}

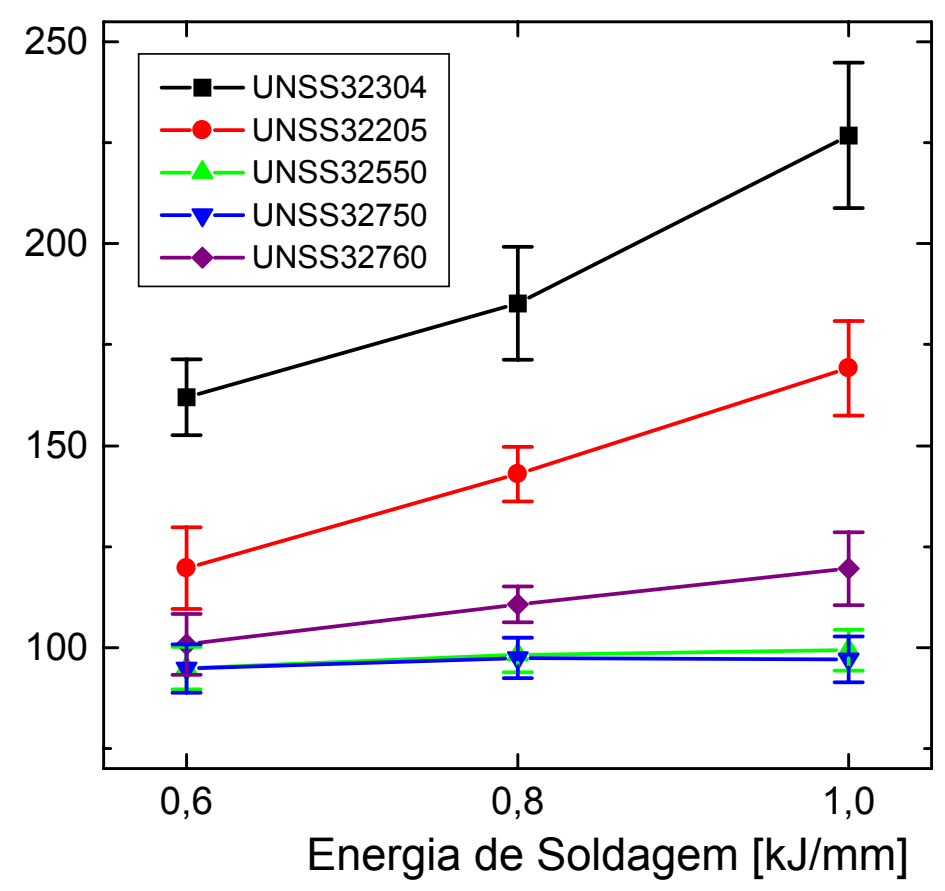

Figura 154: Variação do tamanho de grão ferrítico com a energia de soldagem utilizada, na ZACTE das diferentes ligas.

Observou-se uma correspondência entre a largura da ZACTE nas soldas reais e o crescimento de grão obtido nos CPs simulados. Isto é, os AIDs UNS S32304 e S32205, que apresentaram o maior crescimento de grão durante as simulações, também foram os materiais com as ZACTE mais largas.

Os resultados das medidas das frações volumétricas de austenita na ZACTE após o primeiro, segundo e terceiro passes de soldagem nestes mesmos CPs são apresentadas na Tabela 41. Estes mesmos resultados são apresentados graficamente nas Figuras 155 a 157 . A análise de variância destes resultados mostra que, com exceção do AID UNS S32205 soldado com energia de soldagem de $1,0 \mathrm{~K} / \mathrm{mm}$ e o AISD UNS $\$ 32750$ soldado com energias de soldagem de 0,6 e $0,8 \mathrm{~kJ} / \mathrm{mm}$, em todos os outros casos foi registrada uma mudança na fração de austenita na ZACTE, conforme foram executados os diversos passes de soldagem.

Também foi verificado para todas as ligas um aumento muito pequeno, por não dizer desprezível, na fração final de austenita com o aumento da energia de soldagem. Isto é, no caso desta soldagem multipasse, o aumento da energia da soldagem (dentro da faixa aqui estudada) tem uma influência mínima na fração final de austenita na ZACTE da raiz da solda. Portanto, neste caso, a fração final de austenita da região estudada não deve ser o fator decisivo para a seleção da energia de soldagem a ser utilizada. Este comentário não deve 
ser generalizado e deve-se tomar bastante cuidado quando se soldem chapas muito grossas com energias de soldagem muito baixas. Nestes casos, mudanças nas energias de soldagem poderão ter um efeito significativo na fração final de austenita.

Tabela 41: Fração volumétrica de austenita dos corpos de prova simulados correspondentes à ZACTE das diversas ligas. Resultados da análise de variância.

\begin{tabular}{|c|c|c|c|c|c|c|}
\hline \multirow{2}{*}{$\begin{array}{l}\text { Energia de } \\
\text { Soldagem }\end{array}$} & \multirow{2}{*}{ Passe } & \multicolumn{5}{|c|}{ Fração de Austenita [\% $\%_{\text {vol] }}$} \\
\hline & & UNS S32304 & UNS S32205 & UNS S32550 & UNS S32750 & UNS S32760 \\
\hline \multirow{4}{*}{$0,6 \mathrm{~kJ} / \mathrm{mm}$} & 1 & $14 \pm 1$ & $30 \pm 2$ & $27 \pm 2$ & $39 \pm 3$ & $25 \pm 2$ \\
\hline & 2 & $24 \pm 2$ & $36 \pm 2$ & $35 \pm 2$ & $41 \pm 2$ & $29 \pm 2$ \\
\hline & 3 & $27 \pm 3$ & $39 \pm 3$ & $36 \pm 2$ & $44 \pm 3$ & $30 \pm 2$ \\
\hline & ANOVA - F & 47,1 & 13,7 & 27,6 & 4,1 & 10,7 \\
\hline \multirow{4}{*}{$0,8 \mathrm{~kJ} / \mathrm{mm}$} & 1 & $17 \pm 2,4$ & $33 \pm 3,6$ & $27 \pm 2,2$ & $39 \pm 1,8$ & $25 \pm 1,1$ \\
\hline & 2 & $24 \pm 2,7$ & $39 \pm 2,8$ & $34 \pm 2,4$ & $42 \pm 3,1$ & $32 \pm 1,7$ \\
\hline & 3 & $28 \pm 1,7$ & $41 \pm 3,0$ & $37 \pm 1,9$ & $44 \pm 1,9$ & $32 \pm 2,7$ \\
\hline & ANOVA - F & 22,4 & 7,2 & 20,9 & 4,8 & 17,7 \\
\hline \multirow{4}{*}{$1,0 \mathrm{~kJ} / \mathrm{mm}$} & 1 & $22 \pm 3$ & $39 \pm 3$ & $32 \pm 2$ & $40 \pm 2$ & $26 \pm 3$ \\
\hline & 2 & $23 \pm 2$ & $41 \pm 3$ & $38 \pm 4$ & $43 \pm 3$ & $30 \pm 3$ \\
\hline & 3 & $31 \pm 3$ & $42 \pm 3$ & $41 \pm 3$ & $47 \pm 3$ & $37 \pm 3$ \\
\hline & ANOVA - F & 14,7 & 1,1 & 8,7 & 7,1 & 12,2 \\
\hline
\end{tabular}

Nota: ANOVA-F: Fator de análise de variância, onde o $F_{\text {critico }}=5,0$. Nível de significância de $1 \%$. Vermelho: $F<F_{\text {crítico }}$

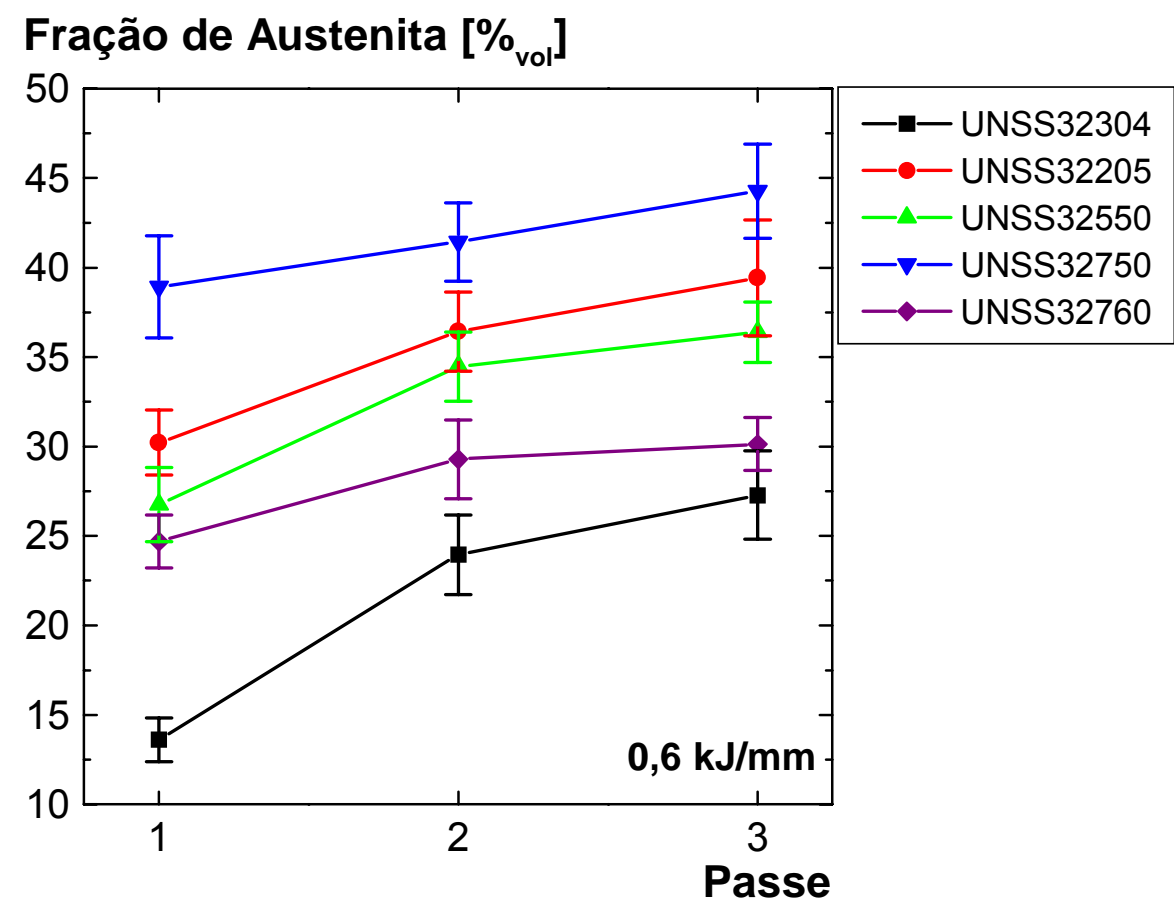

Figura 155: Evolução da fração volumétrica de austenita na ZACTE para energia de soldagem de 0,6 $\mathrm{kJ} / \mathrm{mm}$. Corpos de prova simulados das diversas ligas. 


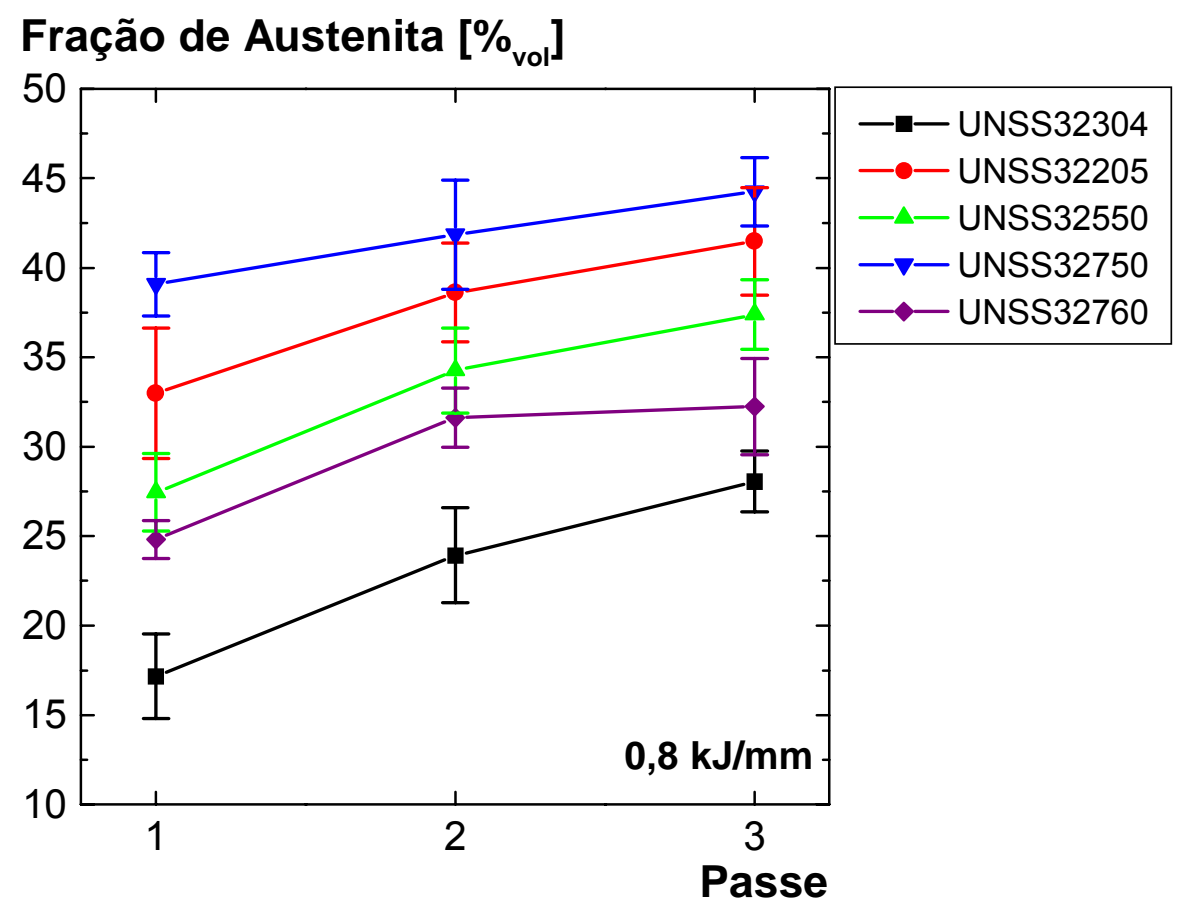

Figura 156: Evolução da fração volumétrica de austenita na ZACTE para energia de soldagem de 0,8 $\mathrm{kJ} / \mathrm{mm}$. Corpos de prova simulados das diversas ligas.

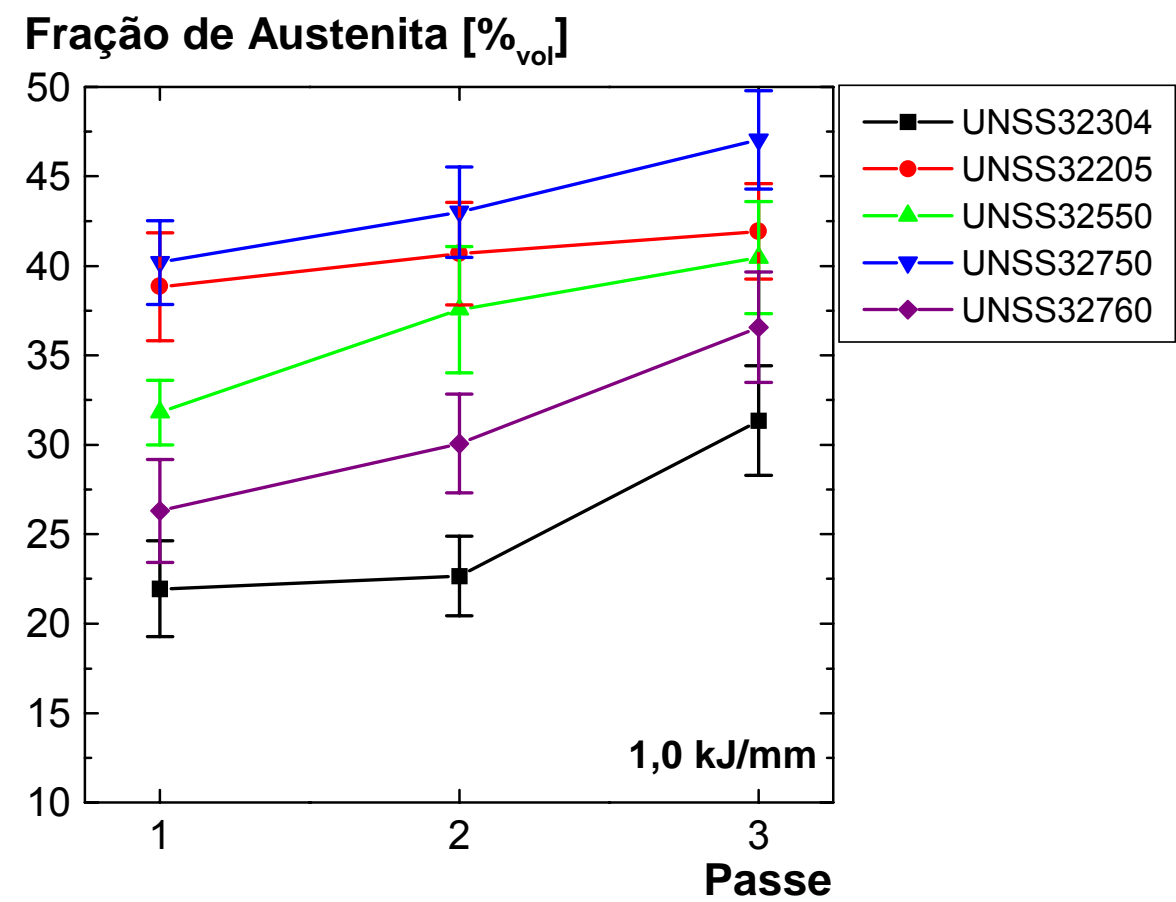

Figura 157: Evolução da fração volumétrica de austenita na ZACTE para energia de soldagem de 1,0 $\mathrm{kJ} / \mathrm{mm}$. Corpos de prova simulados das diversas ligas. 
De acordo com os dados apresentados de forma resumida na Tabela 42, ordenando-se as ligas segundo o seu tamanho de grão após a simulação térmica da ZACTE, para todas as energias de soldagem, a ordem do maior para o menor seria:

$$
\mathrm{S} 32304>\mathrm{S} 32205>\mathrm{S} 32760>\mathrm{S} 32550>\mathrm{S} 32750
$$

Esta ordem é mesma observada nos materiais tratados termicamente a $1350{ }^{\circ} \mathrm{C}$.

As ligas também podem ser ordenadas de acordo com a sua fração máxima final de austenita após as simulações térmicas da ZACTE. Neste caso, a ordem do maior para o menor é a seguinte:

$$
\mathrm{S} 32750>\mathrm{S} 32205>\mathrm{S} 32550>\mathrm{S} 32760>\mathrm{S} 32304
$$

De novo esta ordem é a mesma obtida para as frações máximas de austenita obtidas após os tratamentos térmicos de reaquecimento.

Tabela 42: Resumo dos dados de máximos tamanhos de grão de frações de austenita obtidas durante os tratamentos térmicos e as simulações da ZACTE.

\begin{tabular}{|c|c|c|c|c|c|c|}
\hline \multirow{2}{*}{$\begin{array}{c}\text { Designação } \\
\text { UNS }\end{array}$} & \multirow{2}{*}{$\mathrm{Cr}_{\mathrm{eq}} / \mathrm{Ni}_{\mathrm{eq}}$} & $\begin{array}{c}\text { Como- } \\
\text { Recebido }\end{array}$ & \multicolumn{2}{|c|}{ Tratamentos Térmicos } & \multicolumn{2}{|c|}{$\begin{array}{c}\text { Simulação da ZACTE } \\
\mathrm{kJ} / \mathrm{mm})\end{array}$} \\
\cline { 3 - 7 } & Espy $\left.^{(125)}\right)$ & $\begin{array}{c}\text { Fração de } \gamma \\
{[\%}\end{array}$ & TG [um] & $\begin{array}{c}\text { Máx. fração de } \\
\gamma\left[\%_{\text {vol }}\right]\end{array}$ & TG [um] & $\begin{array}{c}\text { Máx. fração de } \\
\gamma\left[\%_{\text {vol }}\right]\end{array}$ \\
\hline S32304 & 2,87 & $50,2 \pm 0,8$ & $238 \pm 23$ & $34 \pm 3$ & $227 \pm 18$ & $31 \pm 3$ \\
\hline S32205 & 2,24 & $59,8 \pm 1,2$ & $193 \pm 11$ & $49 \pm 3$ & $169 \pm 12$ & $42 \pm 3$ \\
\hline S32550 & 2,38 & $50,9 \pm 1,2$ & $167 \pm 9$ & $46 \pm 3$ & $99 \pm 5$ & $41 \pm 3$ \\
\hline S32750 & 2,24 & $61,3 \pm 1,0$ & $145 \pm 7$ & $53 \pm 3$ & $97 \pm 6$ & $47 \pm 3$ \\
\hline S32760 & 2,34 & $51,4 \pm 1,1$ & $173 \pm 20$ & $42 \pm 3$ & $120 \pm 9$ & $37 \pm 3$ \\
\hline
\end{tabular}

$\mathrm{Na}$ análise anterior verifica-se como os materiais com maior tamanho de grão, apresentam a menor fração final de austenita, o que é de se esperar pois os sítios para nucleação de $\gamma$ são poucos. Chama-se a atenção para a inversão das ordens das ligas, quando se muda o critério de tamanho de grão para o de fração final de austenita, o que também era esperado. O AID UNS S32205 é o único material que sai da ordem. Esta liga além de apresentar o segundo maior tamanho de grão, a sua fração final de austenita é a segunda mais elevada. Assim, o tamanho de grão não é o único fator que determina a fração final de $\gamma$.

A tendência de um material para formar $\gamma$, depende da sua composição química, isto é da relação entre elementos alfagênicos e gamagênicos, representada pela relação $\mathrm{Cr}_{\mathrm{eq}} / \mathrm{Ni}_{\mathrm{eq}}$, 
apresentada na Tabela 16 (página 63). Das diversas definições propostas para esta relação, está se empregando a de ESPY ${ }^{(125)}$, como sendo a mais adequada para as ligas estudadas, pois é esta que melhor representa o efeito do nitrogênio, que é um elemento de liga chave nos AIDs.

Desta forma, o fator $\mathrm{Cr}_{\text {eq }} / \mathrm{Ni}_{\text {eq }}$ pode predizer a tendência das ligas estudadas para formar austenita. No caso especifico do AID UNS S32205, espera-se que seu considerável tamanho de grão impeça um teor de austenita tão elevado. Por outro lado, a sua relação $\mathrm{Cr}_{\text {eq }} / \mathrm{Ni}_{\text {eq }}$ é tão baixa quanto a do AISD UNS S32750. Portanto, a composição química do AID UNS S32205 foi responsável pela fração elevada de $\gamma$.

Da mesma forma, o AID UNS S32304, apresenta o maior tamanho de grão e a maior relação $\mathrm{Cr}_{\text {eq }} / \mathrm{Ni}_{\text {eq. }}$. Estas duas condições propiciam uma fração menor de $\gamma$, como foi medido.

No caso do AISD UNS S32750, o seu tamanho de grão menor e a baixa relação $\mathrm{Cr}_{\mathrm{eq}} / \mathrm{Ni}_{\mathrm{eq}}$ explicam a fração final maior de $\gamma$, tanto após os tratamentos térmicos, como na simulação da ZACTE.

Comparando-se os AISD UNS S32550 e S32760, verifica-se que as suas relações $\mathrm{Cr}$ eq $/ \mathrm{Ni}_{\text {eq }}$ são bastante próximas. Portanto, neste caso o maior tamanho de grão do S32760 foi o fator determinante para que a fração final de $\gamma$ desta liga seja menor que a do $\$ 32550$.

Resumindo, utilizando-se como critérios a fração final de $\gamma$, a largura da ZACTE e o tamanho de grão nesta região, verifica-se que o AISD UNS S32750, é a liga que apresenta a melhor soldabilidade metalúrgica. Esta liga apresenta o menor tamanho de grão e uma ZACTE com menor largura. Ao mesmo tempo, após o primeiro passe de soldagem obteve-se frações de $\gamma$ bastante elevadas e próximas do material na condição como-recebido. Usando estes mesmos critérios, o AID UNS S32304 é o material com a pior soldabilidade metalúrgica. Porém, deve-se ter claro que estes não são os únicos parâmetros a serem levados em conta na avaliação da soldabilidade metalúrgica.

Quanto à evolução da fração de $\gamma$ com os diversos passes de soldagem, esta foi diferente para as energias de soldagem utilizadas. Em termos gerais, no caso das energias de soldagem menores $(0,6$ e $0,8 \mathrm{~kJ} / \mathrm{mm})$, a fração de austenita aumentou mais do primeiro para o segundo que do segundo para o terceiro passe. Isto foi devido a dois fatores:

- O potencial termodinâmico disponível para esta transformação foi em grande parte consumido durante o primeiro reaquecimento.

- As temperaturas máximas de reaquecimento durante o segundo passe foram de $1110 \mathrm{e}$ $1170{ }^{\circ} \mathrm{C}$ aproximadamente (Ver Tabela 14 na página 60) para as duas energias de soldagem. Nos resultados dos tratamentos térmicos de reaquecimento por $10 \mathrm{~s}$ notou-se que as maiores frações de $\gamma$ foram atingidas a $1100{ }^{\circ} \mathrm{C}$, devido a marcada queda da fração de $\gamma$ no equilíbrio para temperaturas maiores. 
Por outro lado, para a energia de soldagem de $1,0 \mathrm{~kJ} / \mathrm{mm}$, em termos gerais, obteve-se um incremento maior na fração de $\gamma$ do segundo para o terceiro passe. No entanto, o lógico era que isto acontecesse durante o segundo passe, devido ao consumo do potencial termodinâmico disponível. Porém, para esta energia de soldagem as temperaturas máximas atingidas durante o segundo e terceiros passes, foram de 1250 e $1150{ }^{\circ} \mathrm{C}$, respectivamente. Desta forma, a baixa fração de $\gamma$ no equilíbrio destas ligas a $1250^{\circ} \mathrm{C}$, limitou a formação de $\gamma$ durante o segundo passe. Já durante o terceiro passe, com temperatura máxima de 1150 ${ }^{\circ} \mathrm{C}$, o potencial termodinâmico disponível foi bem maior, levando a uma fração final maior de $\gamma$.

Além da metalografia quantitativa, foi realizada uma comparação detalhada das microestruturas da ZACTE a fim de estudar a evolução da microestrutura desta região durante os diversos passes de soldagem. Na Tabela 43 é apresentado um resumo com a observação dos CPs correspondentes à simulação da ZACTE.

Tabela 43: Resumo das mudanças microestruturais observadas nos CP simulados.

\begin{tabular}{|c|c|c|c|c|c|c|}
\hline \multirow{2}{*}{\begin{tabular}{|l|} 
Energia de \\
Soldagem
\end{tabular}} & \multirow{2}{*}{ Passe } & \multicolumn{5}{|c|}{ Evolução da Microestrutura } \\
\hline & & UNS S32304 & UNS S32205 & UNS S32550 & UNS S32750 & UNS S32760 \\
\hline \multirow{3}{*}{$0,6 \mathrm{~kJ} / \mathrm{mm}$} & 1 & $\gamma_{A}-\gamma_{W}-\gamma_{1 n t}-C_{2} N$ & $\gamma_{A}-\gamma_{W}-\mathrm{Cr}_{2} \mathrm{~N}$ & $\gamma_{A}-\gamma_{W}-\mathrm{Cr}_{2} \mathbf{N}$ & $\gamma_{A}-\gamma_{W}-\mathrm{Cr}_{2} \mathrm{~N}$ & $\gamma_{A}-\gamma_{W}-\gamma_{i n t}-C_{2} N$ \\
\hline & 2 & $\gamma_{A}-\gamma_{W}-\gamma_{\text {Int }}$ & $\gamma_{A}-\gamma_{W}-C_{2} N-\gamma_{i n t}$ & $\gamma_{A}-\gamma_{W}-C_{2} N-\gamma_{\text {Int }}$ & $\gamma_{A}-\gamma_{W}-C_{2} N-\gamma_{1 n t}$ & $\gamma_{A}-\gamma_{W}-\gamma_{\mathrm{Int}}-\mathrm{Cr}_{2} \mathbf{N}$ \\
\hline & 3 & $\gamma_{A}-\gamma_{W}-\gamma_{\mathrm{Int}}$ & $\gamma_{A}-\gamma_{W}-\gamma_{\operatorname{lnt}}$ & $\gamma_{A}-\gamma_{W}-C_{2} N-\gamma_{i n t}$ & $\gamma_{\mathrm{A}}-\gamma_{\mathrm{W}}-\mathrm{Cr}_{2} \mathrm{~N}-\gamma_{\mathrm{Int}}$ & $\gamma_{\mathrm{A}}-\gamma_{\mathrm{W}}-\gamma_{\mathrm{Int}}-\mathrm{Cr}_{2} \mathrm{~N}$ \\
\hline \multirow{3}{*}{$0,8 \mathrm{~kJ} / \mathrm{mm}$} & 1 & $\gamma_{A}-\gamma_{W}-\gamma_{1 n t}-C_{2} N$ & $\gamma_{A}-\gamma_{W}-C_{2} \mathbf{N}$ & $\gamma_{A}-\gamma_{W}-\mathrm{Cr}_{2} \mathbf{N}$ & $\gamma_{A}-\gamma_{W}-C_{2} N$ & $\gamma_{A}-\gamma_{W}-C_{2} N$ \\
\hline & 2 & $\gamma_{A}-\gamma_{W}-\gamma_{1 n t}-\mathrm{Cr}_{2} \mathrm{~N}$ & $\gamma_{A}-\gamma_{W}-C_{2} N-\gamma_{i n t}$ & $\gamma_{A}-\gamma_{W}-C_{2} \mathbf{N}-\gamma_{\text {Int }}$ & $\gamma_{A}-\gamma_{W}-C_{2} N-\gamma_{1 n t}$ & $\gamma_{A}-\gamma_{W}-C_{2} \mathbf{N}-\gamma_{i n t}$ \\
\hline & 3 & $\gamma_{A}-\gamma_{W}-\gamma_{\mathrm{Int}}$ & $\gamma_{A}-\gamma_{W}-\gamma_{\mathrm{Int}}$ & $\gamma_{A}-\gamma_{W}-C_{2} N-\gamma_{1 n t}$ & $\gamma_{\mathrm{A}}-\gamma_{\mathrm{W}}-\mathrm{Cr}_{2} \mathrm{~N}-\gamma_{\mathrm{Int}}$ & $\gamma_{\mathrm{A}}-\gamma_{\mathrm{W}}-\mathrm{Cr}_{2} \mathrm{~N}-\gamma_{\mathrm{Int}}$ \\
\hline \multirow{4}{*}{$1,0 \mathrm{~kJ} / \mathrm{mm}$} & 4 & & & & & \\
\hline & 1 & $\gamma_{A}-\gamma_{W}-\gamma_{1 n t}-C_{2} N$ & $\gamma_{A}-\gamma_{W}-C_{2} N$ & $\gamma_{A}-\gamma_{W}-C_{2} N$ & $\gamma_{A}-\gamma_{W}-C_{2} N$ & $\gamma_{A}-\gamma_{W}-\mathrm{Cr}_{2} \mathrm{~N}$ \\
\hline & 2 & $\gamma_{A}-\gamma_{W}-\gamma_{I n t}-C_{2} N$ & $\gamma_{A}-\gamma_{W}-\mathrm{Cr}_{2} \mathrm{~N}$ & $\gamma_{A}-\gamma_{W}-\mathbf{C r}_{2} \mathbf{N}$ & $\gamma_{\mathrm{A}}-\gamma_{\mathrm{W}}-\mathrm{Cr}_{2} \mathrm{~N}$ & $\gamma_{A}-\gamma_{W}-\mathrm{Cr}_{2} \mathbf{N}$ \\
\hline & 3 & $\gamma_{A}-\gamma_{W}-\gamma_{\mathrm{int}}$ & $\gamma_{\mathrm{A}}-\gamma_{\mathrm{W}}-\mathrm{Cr}_{2} \mathrm{~N}$ & $\gamma_{\mathrm{A}}-\gamma_{\mathrm{W}}-\mathrm{Cr}_{2} \mathrm{~N}$ & $\gamma_{A}-\gamma_{W}-\mathrm{Cr}_{2} \mathrm{~N}$ & $\gamma_{\mathrm{A}}-\gamma_{\mathrm{W}}-\mathrm{Cr}_{2} \mathrm{~N}$ \\
\hline
\end{tabular}

Desta observação detalhada deve-se chamar a atenção para o incremento na fração final de $\gamma$ com o aumento da energia de soldagem. Porém, isto não levou à dissolução total dos nitretos de cromo. Somente no caso do AID UNS S32304 os nitretos foram totalmente dissolvidos após o terceiro passe, para todas a as energias de soldagem. No caso do AID UNS S32205 os nitretos somente dissolveram-se totalmente para as duas energias de soldagem menores, durante o terceiro passe. Finalmente a microestrutura dos três AISD 
apresentou nitretos de cromo após o terceiro passe, para todas as energias de soldagem estudadas.

Esta persistência dos nitretos de cromo após os reaquecimentos do segundo e terceiro passes, para a energias de soldagem maiores, não é geralmente esperada. Na soldagem, em geral, o aumento da energia de soldagem leva a resfriamentos mais lentos, favorecendo a precipitação da austenita nos AIDs. Como conseqüência, a precipitação de nitretos é reduzida. Além disso, reaquecimentos a temperaturas maiores e velocidades de resfriamento menores (que são conseqüência de energias de soldagem maiores), espera-se que leve à dissolução total dos nitretos. No entanto, esta linha de raciocínio é muito simplista e esquece que nos AIDs os nitretos tornam-se estáveis em temperaturas abaixo de 850 a $1100{ }^{\circ} \mathrm{C}$ aproximadamente (Ver Tabela 17 na página 66). Portanto, uma boa parte dos nitretos precipitados na ZACTE durante o resfriamento do primeiro passe dissolve durante os reaquecimentos posteriores. Porém, dependendo da composição química da liga e dos tempos de permanência nas faixas de temperatura de estabilidade do $\mathrm{Cr}_{2} \mathrm{~N}$, nem todos $\mathrm{O}$ nitretos dissolverão e até novas partículas poderão precipitar.

Por exemplo no caso do AID UNS S32205, para as menores energias de soldagem, as condições dos reaquecimentos foram suficientes para dissolver os nitretos, mas no caso da energia de soldagem maior, onde ainda eram observados nitretos, os tempos de permanência em temperaturas elevadas foram tais que esta fase tornou-se estável. Além disto, existe um outro fator que influencia no fato de energias de soldagem maiores gerarem microestruturas contendo nitretos. Como foi mencionado anteriormente, a temperatura de reaquecimento do segundo passe aumenta com a energia de soldagem, chegando a atingir temperaturas nas quais a fração $\gamma$ no equilíbrio são bastante baixas. Desta forma, este reaquecimento não chega a promover um crescimento suficientemente da fração da $\gamma \mathrm{e}$, desta forma, a quantidade de nitretos ainda continua elevada. Assim, o reaquecimento devido ao terceiro passe, não é suficiente para dissolver o restante dos nitretos ou, como já foi mencionado, pelo tempo de permanência do material em temperaturas relativamente elevadas, pode ser suficiente para aproximar o material do seu estado de equilíbrio, onde os mencionados nitretos são estáveis.

No caso dos AISD, a persistência dos nitretos de cromo parece estar relacionada com a maior faixa de temperatura de estabilidade desta fase.

A energia de soldagem influenciou principalmente na morfologia predominante da austenita secundária precipitada durante o segundo e terceiros passes. A maior energia de soldagem $(1,0 \mathrm{~kJ} / \mathrm{mm})$ levou ao crescimento das austenitas alotrimórficas e de Widmanstätten já precipitadas durante o primeiro passe. A exceção foi o AID UNS S32304, no qual também se teve uma mínima precipitação e crescimento das $\gamma_{2}$ intragranulares para a energia de soldagem maior. Por outro lado, no caso das energias de soldagem menores $(0,6$ e 0,8 
$\mathrm{kJ} / \mathrm{mm}$ ) além do crescimento das $\gamma$ alotrimórficas e de Widmanstätten, teve-se também a precipitação e crescimento de $\gamma_{2}$ intragranulares.

A precipitação de $\gamma_{2}$ intragranular foi importante nos AIDs UNS S32304 e S32205 soldados com energias de 0,6 e $0,8 \mathrm{~kJ} / \mathrm{mm}$. Já nos AISDs UNS S32550 soldado com energia de 0,6 $\mathrm{kJ} / \mathrm{mm}$, e no UNS S32760, soldado com energia de $0,8 \mathrm{~kJ} / \mathrm{mm}$, notou-se alguma precipitação de $\gamma_{2}$ intragranular, mas em quantidade bem menor que nos casos mencionados anteriormente. Finalmente, todas as outras condições em que se menciona (Tabela 43) a presença de $\gamma$ intragranular na microestrutura, a sua fração volumétrica foi muito baixa.

A precipitação da $\gamma_{2}$ intragranular aconteceu, do mesmo modo que nos CPs tratados termicamente, no interior dos grãos ferríticos, onde se encontravam as colônias de nitretos de cromo. Isto é, nas regiões livres de austenitas alotrimórficas e de Widmanstätten.

A morfologia destas $\gamma_{2}$ intragranulares também mudou com a energia de soldagem. Nos AIDs UNS S32304 e S32205 onde se obteve a mais importante precipitação de $\gamma_{2}$ intragranular, as partículas observadas após o segundo passe para a energia de soldagem de $0,6 \mathrm{~kJ} / \mathrm{mm}$ eram bem aciculares, ao contrário das observadas nos CPs correspondentes à energia de soldagem de $0,8 \mathrm{~kJ} / \mathrm{mm}$, as quais apresentavam um aspecto bem mais arredondado. Finalmente, em todos os casos, após o terceiro passe, todas as $\gamma_{2}$ intragranulares mostraram uma aparência arredondada bastante similar. Este comportamento deve estar relacionado com a influência das velocidades de resfriamento no super-resfriamento gerado. Foi sugerido por AARONSON et al. ${ }^{(139)}$ que a relação entre as velocidades de migração das interfaces incoerentes e semicoerentes depende do superresfriamento. Assim, super-resfriamentos maiores geram estruturas de Widmanstätten mais aciculares, como no caso de energias de soldagem menores.

Uma observação muito importante que merece ser registrada, é como as microestruturas com as maiores frações de $\gamma_{2}$ intragranular (AIDs UNS S32304 e S32205 soldados com energias de 0,6 e $0,8 \mathrm{~kJ} / \mathrm{mm}$ ), apresentaram frações finais menores de $\mathrm{Cr}_{2} \mathrm{~N}$. Isto pode ser devido ao fato das regiões dos grãos de ferrita onde ainda poderiam subsistir os nitretos terem sido povoados por $\gamma_{2}$ intragranulares. Desta forma, verifica-se o possível efeito benéfico da $\gamma_{2}$ intragranular quanto à redução na quantidade de nitretos, que são fases ricas em cromo. Porém, deve-se tomar cuidado com esta afirmação pois existem dados na literatura que reportam efeitos deletérios da $\gamma_{2}$ intragranular na resistência à corrosão. Ao mesmo tempo, é importante lembrar que o nitreto de cromo por si mesmo não é prejudicial para a resistência à corrosão e sim a região empobrecida em cromo ao seu redor. Portanto, se as condições de reaquecimento da ZACTE são tais que não se consegue a dissolução dos nitretos, mas permite uma certa homogeneização na composição química da ferrita ao redor dos nitretos, a resistência à corrosão não deve ser tão seriamente afetada. Por outro 
lado quanto ao comportamento mecânico da junta soldada, a mera presença dos nitretos pode afetar a tenacidade ${ }^{(58)}$.

\subsection{AVALIAÇÃO DE DESEMPENHO DA ZACTE}

\subsubsection{Tenacidade}

A tenacidade da ZACTE foi avaliada mediante o ensaio Charpy em corpos de prova reduzidos de $5 \times 5 \times 55 \mathrm{~mm}$, com entalhe em "V", segundo a norma ASTM E-23, realizado a $-40{ }^{\circ} \mathrm{C}$. A orientação do plano da trinca segundo a norma AWS B 4.0 (92) é LT, que é a direção na qual são normalmente ensaiadas as juntas soldadas.

Devido a reprodutibilidade usual dos resultados Charpy de CP simulados no equipamento Gleeble $^{\circledR}$, foram testados quatro CP para cada uma das condições. Na Tabela 44 e na Figura 158 são apresentados estes resultados.

Em termos gerais pode-se notar que esta região da ZACTE atinge tenacidades maiores para a maior energia de soldagem. Este resultado é esperado porque nestas condições tem-se uma precipitação mais intensa de austenita, como se pode observar na Tabela 41.

Tabela 44: Energia absorvida no ensaio Charpy da região da ZACTE simulada e dos materiais no estado como-recebido.

\begin{tabular}{|c|c|c|c|c|c|c|c|}
\hline \multirow{2}{*}{\multicolumn{3}{|c|}{ Condição }} & \multicolumn{5}{|c|}{ Energia Absorvida no Ensaio Charpy [J] } \\
\hline & & & UNS S32304 & UNS S32205 & UNS S32550 & UNS S32750 & UNS S32760 \\
\hline \multicolumn{3}{|c|}{ Metal de base } & $43 \pm 1$ & $44 \pm 1$ & $39 \pm 0,2$ & $27 \pm 1$ & $37 \pm 1$ \\
\hline \multirow{9}{*}{$\begin{array}{c}\text { Simulação } \\
\text { ZACTE }\end{array}$} & $\begin{array}{l}\text { Energia de } \\
\text { Soldagem }\end{array}$ & Passe & & & & & \\
\hline & \multirow{4}{*}{$0,6 \mathrm{~kJ} / \mathrm{mm}$} & 1 & $33 \pm 2$ & $35 \pm 8$ & $10 \pm 5$ & $20 \pm 8$ & $11 \pm 3$ \\
\hline & & 2 & $39 \pm 0,3$ & $34 \pm 8$ & $16 \pm 2$ & $31 \pm 8$ & $22 \pm 2$ \\
\hline & & 3 & $38 \pm 1$ & $24 \pm 19$ & $15 \pm 2$ & $18 \pm 2$ & $35 \pm 2$ \\
\hline & & ANOVA - F & 21,9 & 1,0 & 3,1 & 4,3 & 90,1 \\
\hline & \multirow{4}{*}{$1,0 \mathrm{~kJ} / \mathrm{mm}$} & 1 & $37 \pm 1$ & $32 \pm 8$ & $16 \pm 2$ & $24 \pm 3$ & $28 \pm 4$ \\
\hline & & 2 & $37 \pm 1$ & $27 \pm 4$ & $19 \pm 5$ & $24 \pm 4$ & $29 \pm 3$ \\
\hline & & 3 & $39 \pm 0,1$ & $43 \pm 2$ & $20 \pm 2$ & $28 \pm 10$ & $29 \pm 5$ \\
\hline & & ANOVA - F & 4,0 & 9,7 & 1,1 & 0,6 & 0,1 \\
\hline
\end{tabular}

Nota: ANOVA-F: Fator de análise de variância, onde o $F_{\text {critico }}=8,0$. Nível de significância de $1 \%$. Vermelho: $F<F_{\text {critico }}$ 
Energia Absorvida - Charpy [J]

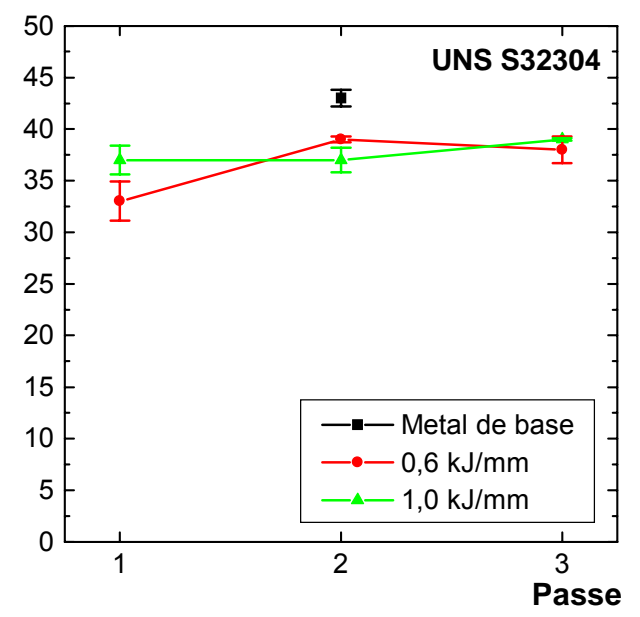

Energia Absorvida - Charpy [J]

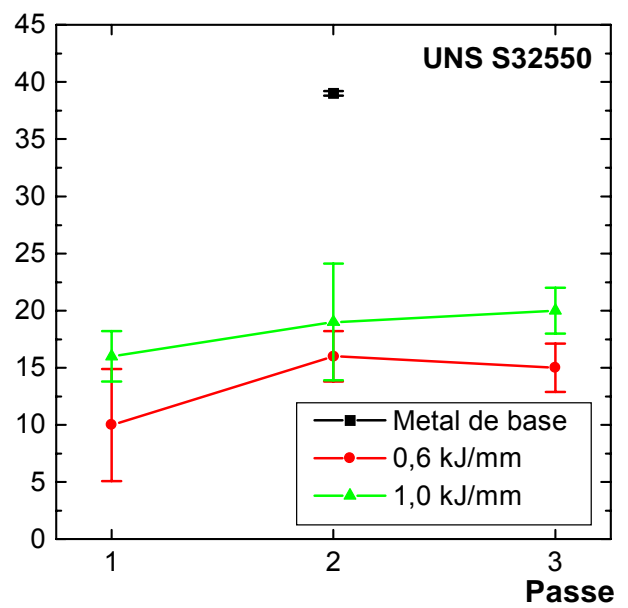

Energia Absorvida - Charpy [J]

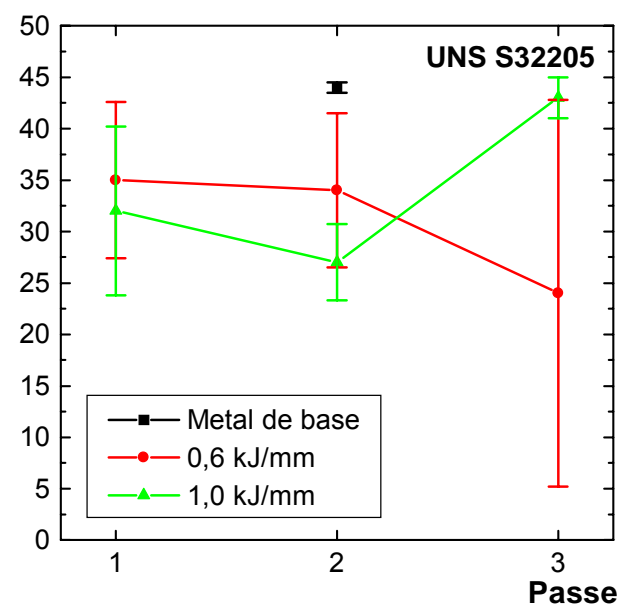

Energia Absorvida - Charpy [J]

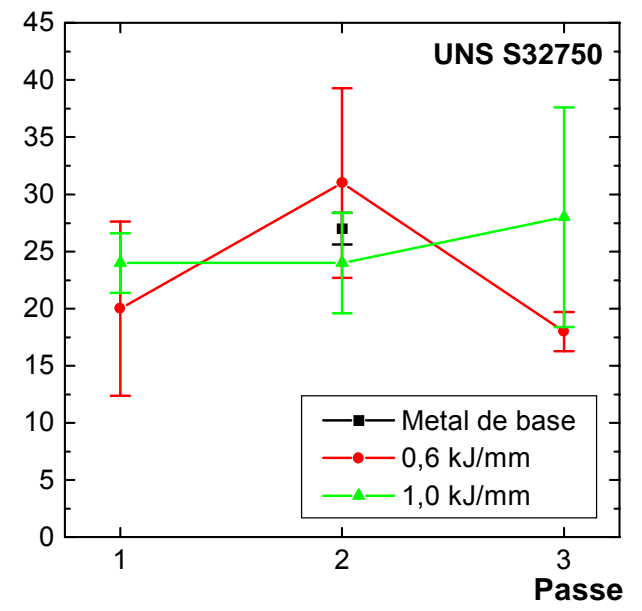

Energia Absorvida - Charpy [J]

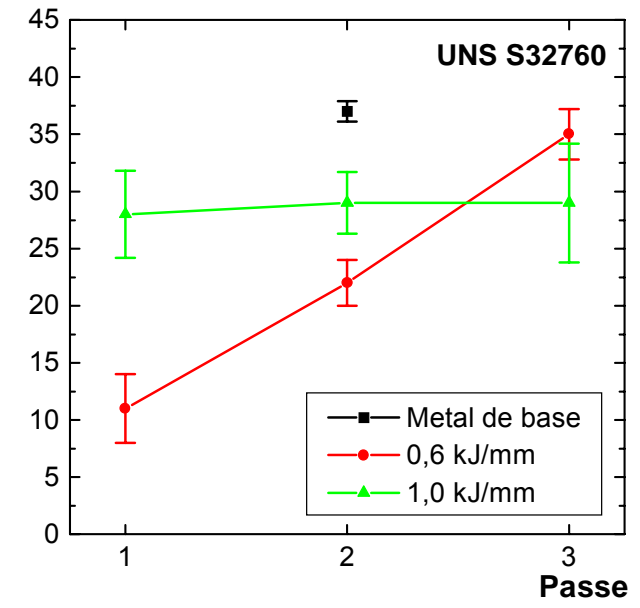

Figura 158: Energia absorvida no ensaio Charpy da região da ZACTE simulada e dos materiais no estado como-recebido. 
Quanto à tenacidade do metal de base, vale a pena ressaltar a menor energia absorvida pelo AISD UNS S32750. Este comportamento foi devido à segregação no centro da espessura da chapa, que produziu a precipitação excessiva de fases intermetálicas.

As ligas UNS S32205 e S32750 apresentaram desvios maiores nas medidas. Nestes casos foi impossível observar qualquer tendência clara no comportamento destes materiais. A análise de variância destes dados mostrou que a média da energia absorvida nas seis diferentes condições não foi diferente.

No restante dos casos observa-se uma leve tendência ao aumento da energia absorvida, à medida que a junta multipasse é preenchida. Esta tendência foi um pouco mais marcante no caso das soldas realizadas com a energia de soldagem de $0,6 \mathrm{~kJ} / \mathrm{mm}$. Isto pode ser explicado pela maior precipitação de austenita secundária que acontece para esta energia de soldagem.

Em todas as ligas, com exceção da UNS S32550, foram alcançadas tenacidades comparáveis com a do metal de base, após o terceiro passe. Já no caso do AISD UNS S32550, a tenacidade final foi de aproximadamente $50 \%$ do seu valor inicial.

Levando-se em conta os resultados anteriores, verifica-se que a melhoria na tenacidade da região estudada com os passes sucessivos variou de mínima a moderada, com exceção do AISD UNS S32760, soldado com uma energia de $0,6 \mathrm{~kJ} / \mathrm{mm}$. Neste caso, a tenacidade cresceu consideravelmente durante o segundo e o terceiro passe.

Nas Figuras 159 a 163 são mostradas as fotografias das superfícies de fratura dos CP Charpy, obtidas no MEV. Em termos gerais, pode-se verificar a presença de trincas normais ao plano principal de fratura em alguns CP, principalmente nos AISD UNS S32550 e S32750. Estas trincas secundárias são paralelas ao plano de laminação das chapas, o que é bastante comum em materiais laminados. No caso geral de materiais laminados, este fenômeno de formação de trincas secundárias normais ao plano principal de fratura (splitting delamination) pode ser devido a fenômenos $\operatorname{como}^{(140)}$ :

- Segregação, que pode ocasionar precipitação de terceiras fases, ou segregação de elementos para os contornos de grão.

- Gradiente térmico durante o processamento, que pode produzir microestruturas diferentes.

- Concentração de tensões.

- Clivagem. 


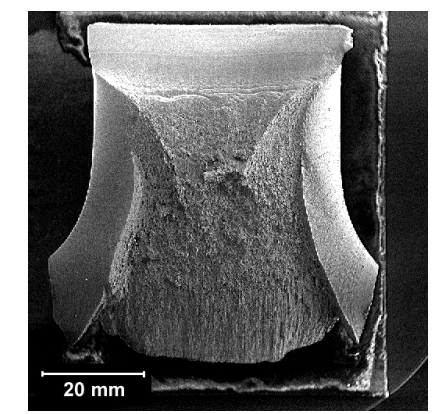

Metal de Base

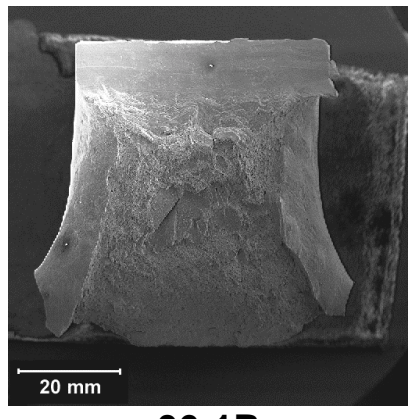

06-1P

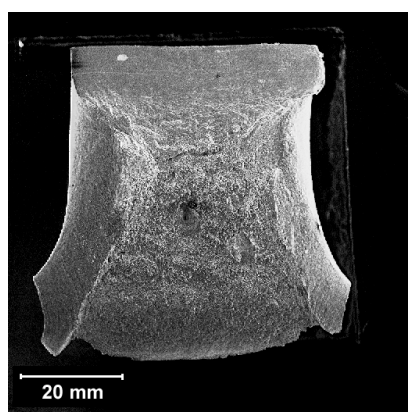

10-1P

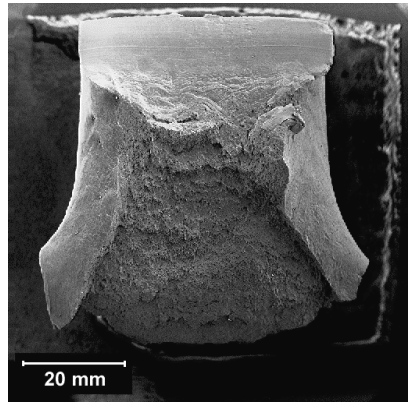

06-2P

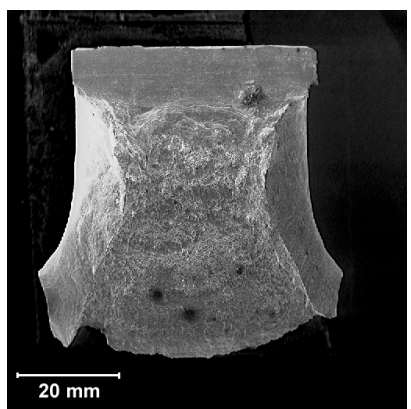

$10-2 P$

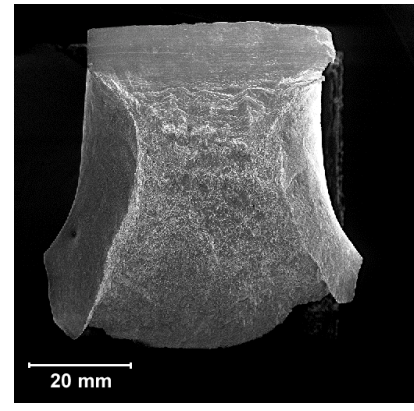

06-3P

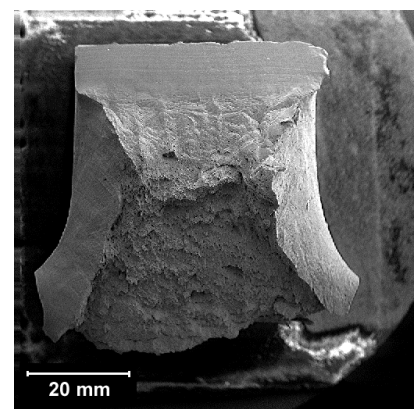

10-3P

Figura 159: Vista geral das superfícies de fratura dos CP Charpy do AID UNS S32304. MEV.

No caso especifico aqui apresentado, este fenômeno foi observado nos AISDs UNS S32750 e UNS S32760, no estado como-recebido. Em estudo complementar do AISD UNS S32750 verificou-se a presença de uma terceira fase na região do meio da espessura da chapa, acreditando-se que se trata de fase sigma. Além disso, como pode ser observado na Figura 164, a fratura na região da trinca secundária apresenta aspecto típico de clivagem, o que vem a reforçar a teoria da presença de uma fase bastante frágil nesta região do CP. Como mostra a Figura 165, a trinca secundária formada no material AISD UNS S32760 no estado como-recebido, apresenta um aspecto misto de clivagem e alvéolos (dimples).

A energia absorvida para gerar estas delaminações, que estão perpendiculares ao plano de propagação da trinca principal, é superposta a energia absorvida pelo corpo de prova para a 
propagação da trinca principal. Desta forma, a interpretação destes resultados torna-se bastante difícil, geralmente apresentando valores muito superiores ao do material na condição de ensaio.

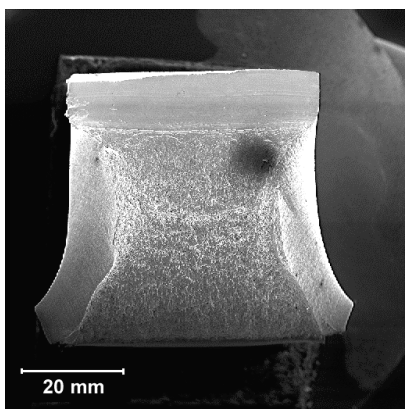

Metal de Base

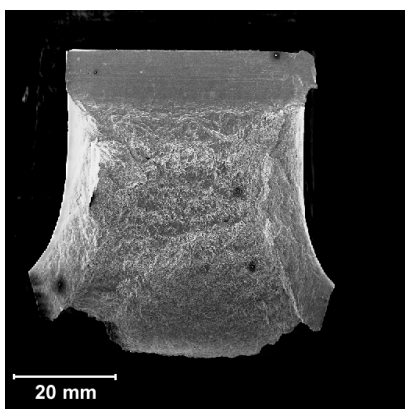

06-1P

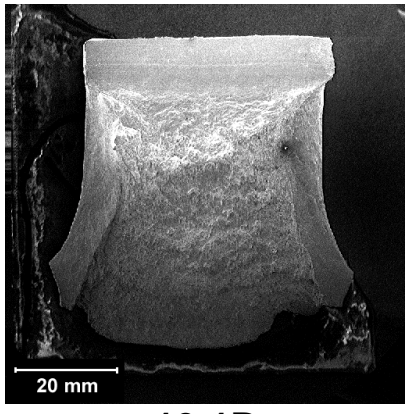

10-1P

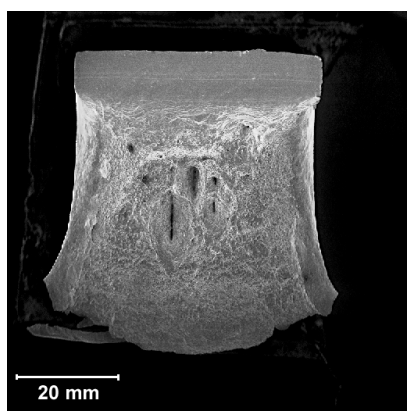

06-2P

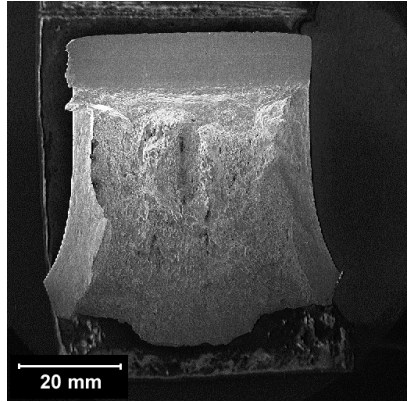

$10-2 P$

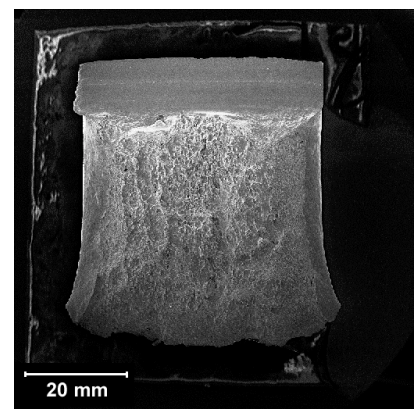

06-3P

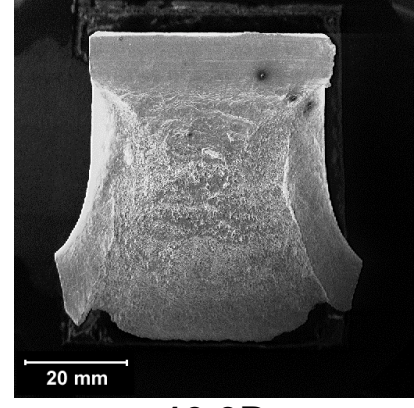

10-3P

Figura 160: Vista geral das superfícies de fratura dos CP Charpy do AID UNS S32205. MEV. 


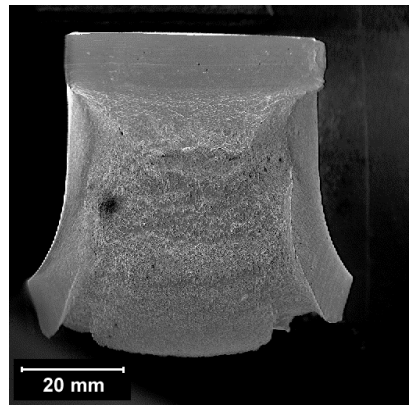

Metal de Base

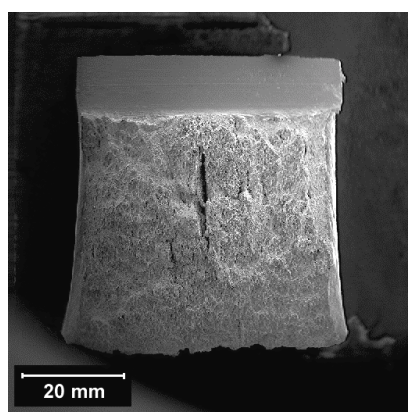

06-1P

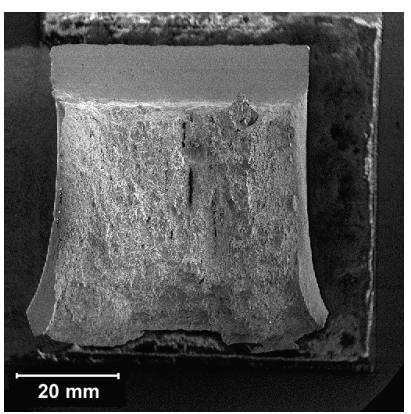

10-1P

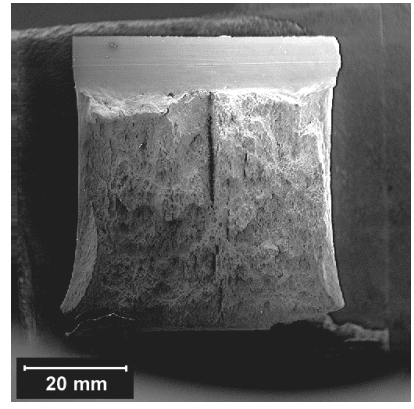

06-2P

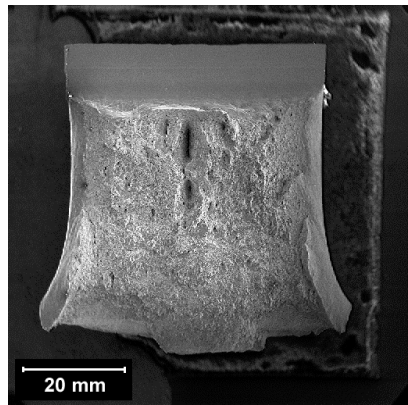

$10-2 P$

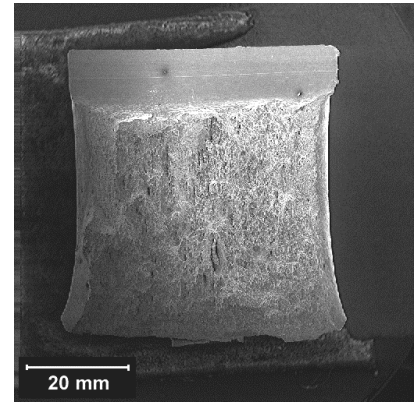

06-3P

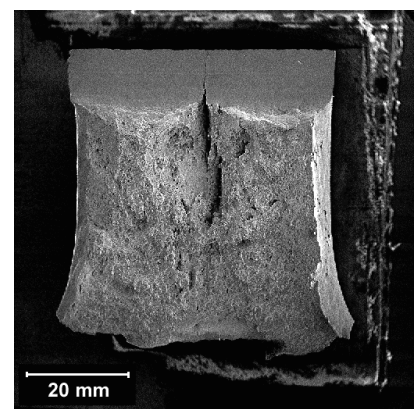

10-3P

Figura 161: Vista geral das superfícies de fratura dos CP Charpy do AISD UNS S32550. MEV.

Já durante a realização das experiências preliminares de simulação dos ciclos térmicos de soldagem foi detectada a formação de algumas microtrincas de liquação no interior dos CPs. Como conseqüência, foram selecionados parâmetros que minimizassem a ocorrência das mesmas. Porém, a observação no MEV das superfícies de fratura dos CPs simulados posteriormente submetidos ao ensaio Charpy, revelou a presença de trincas de liquação. Estas trincas foram formadas durante a simulação, mas a sua abertura durante o ensaio Charpy pode ter implicado em um consumo extra de energia. Além disto, quando a trinca principal cruza com uma desta trincas preexistentes, o raio na ponta da trinca se torna muito grande. Desta forma, tem-se um aumento fictício da tenacidade.

A Figura 166 mostra claramente a aparência destas trincas de liquação, que apresentam uma estrutura bruta de fusão na sua superfície. Estas trincas são paralelas ao plano de 
laminação da chapa, o que confirma a teoria de macro-segregação. Isto é, a composição química do material no centro da espessura da chapa é tal que a sua temperatura de fusão é ligeiramente menor que a do resto do material. Assim, durante a simulação formaram-se microtrincas de liquação nesta região.

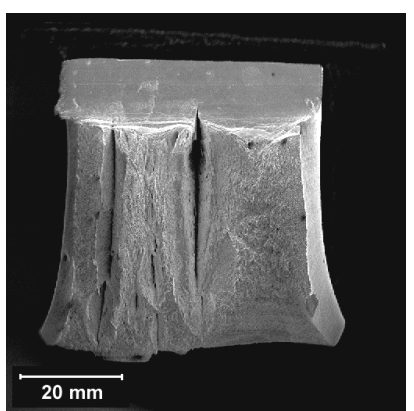

Metal de Base

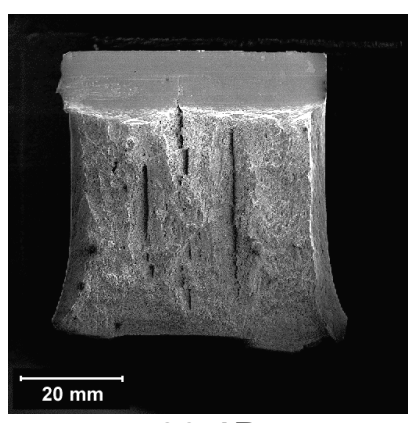

06-1P

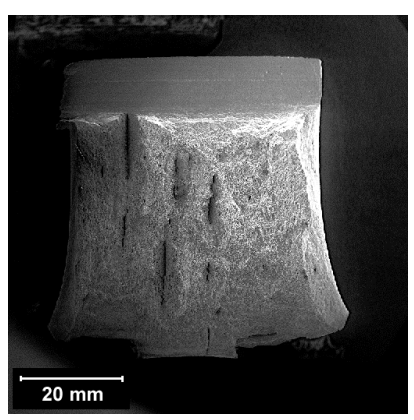

10-1P

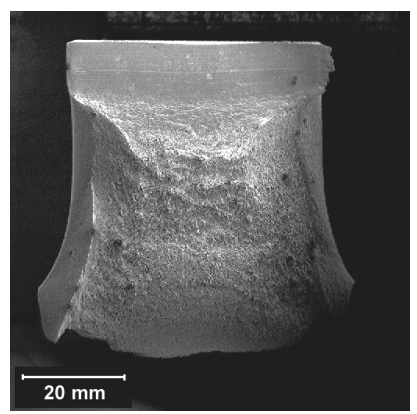

06-2P

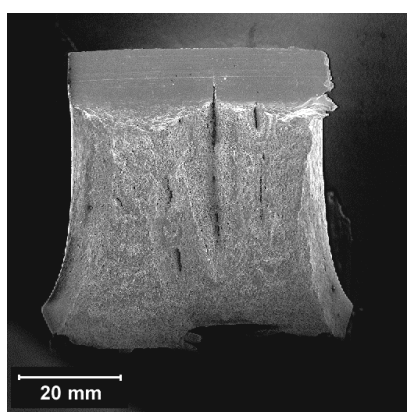

$10-2 P$

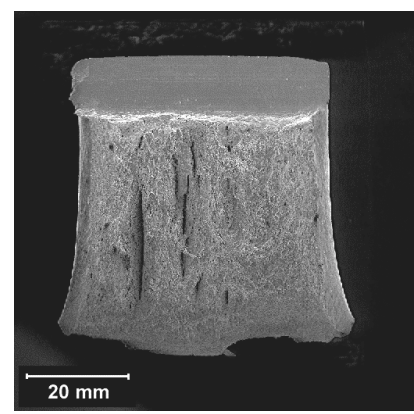

06-3P

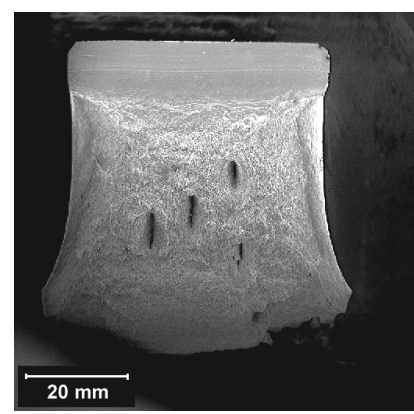

10-3P

Figura 162: Vista geral das superfícies de fratura dos CP Charpy do AISD UNS S32750. MEV. 


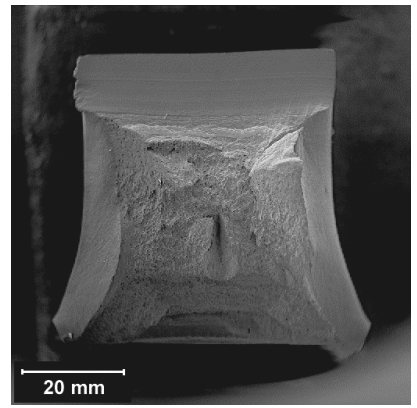

Metal de Base

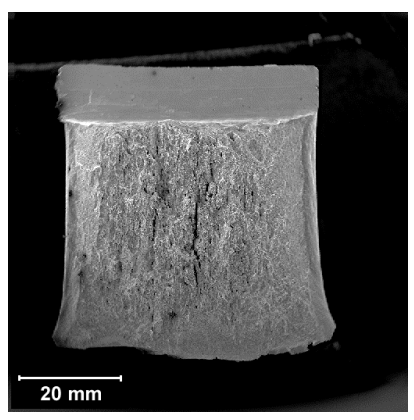

06-1P

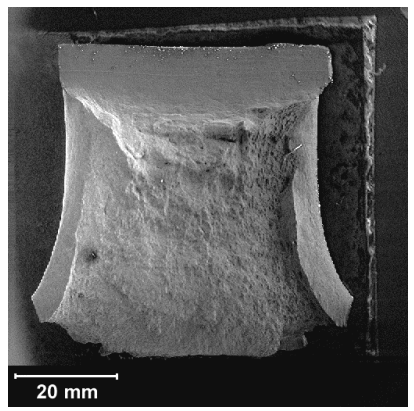

10-1P

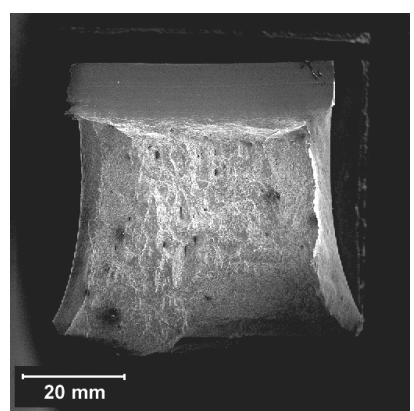

06-2P

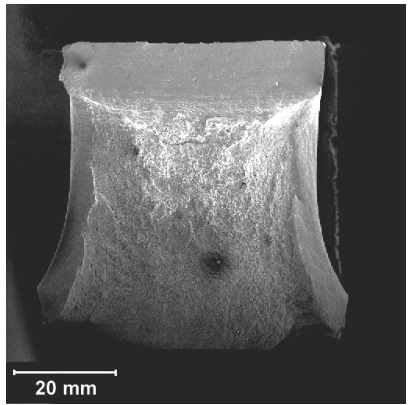

$10-2 P$

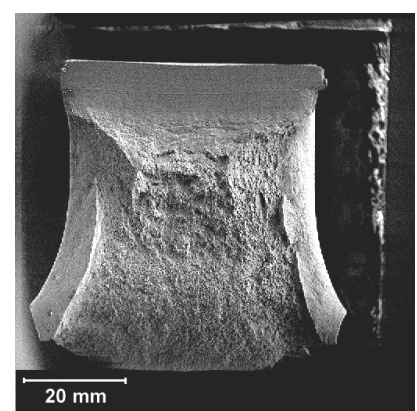

06-3P

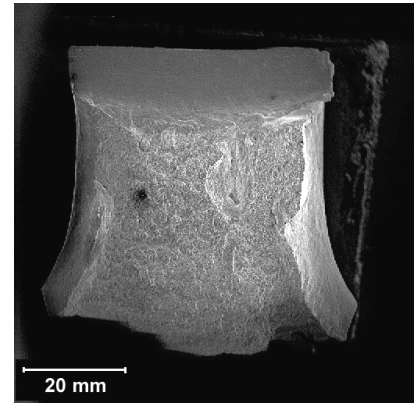

10-3P

Figura 163: Vista geral das superfícies de fratura dos CP Charpy do AISD UNS S32760. MEV.

Em termos gerais, as aparências macroscópica e microscópica das fraturas estudadas relacionam-se facilmente com a energia absorvida no ensaio Charpy. Sempre que se teve uma energia absorvida menor do que a esperada, encontrou-se algum elemento fragilizante, que foi facilmente identificado mediante o tipo de fratura. 


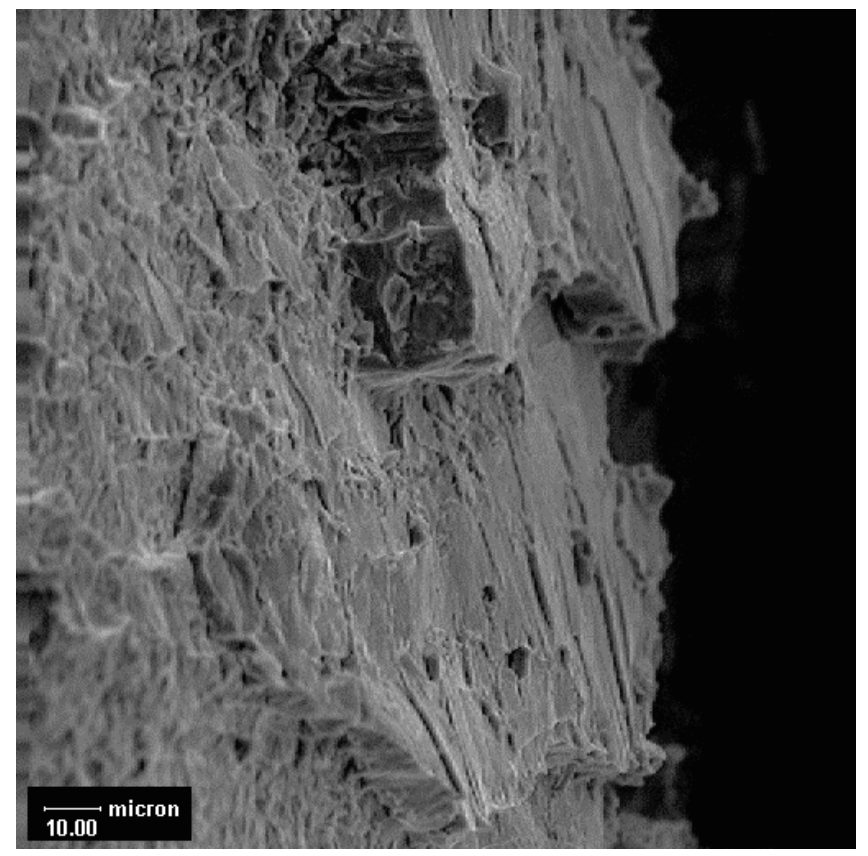

Figura 164: Aspecto da superfície de fratura da trinca secundária formada por splitting no CP Charpy do AISD UNS S32750 no estado como-recebido. MEV.

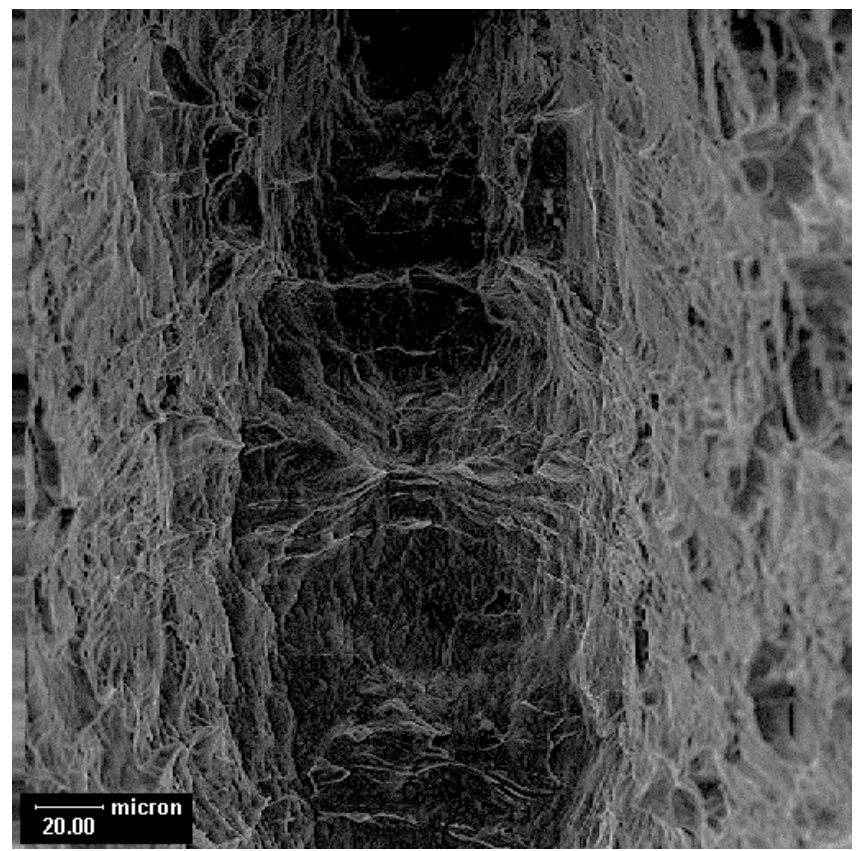

Figura 165: Aspecto da superfície de fratura da trinca secundária formada por splitting no CP Charpy do AISD UNS S32760 no estado como-recebido. MEV. 
A grande maioria das condições estudadas apresentaram uma fratura dúctil formada por micro-cavidades ou alvéolos, mais conhecidas como dimples (por simplicidade de aqui para frente este termo será usado neste texto). Como no ensaio Charpy a ruptura é por rasgamento, os dimples formados geralmente não coalescem uns com os outros, mas são interceptados e coalescem com o vértice da trinca que está propagando. Desta forma os dimples formados apresentam um formato parabólico.

O tamanho e a distribuição de tamanhos dos dimples depende principalmente ${ }^{(141)}$ :

- Da quantidade, distribuição e tamanho das partículas de segunda fase, ou inclusões, e das propriedades destas fases e de suas interfaces.

- Da ductilidade do material ou das fases que o compõem.

- Do mecanismo ou mecanismos atuantes no processo de formação dos dimples.

Geralmente, materiais mais dúcteis e com poucas descontinuidades formam dimples mais profundos com traços de cizalhamento nas suas bordas. Já em materiais com muitas descontinuidades e baixa ductilidade forma-se uma quantidade elevada de dimples pequenos. No entanto, dimples grandes e bastante planos podem-se formar em materiais com ductilidade muito baixa ${ }^{(142)}$. Quanto ao mecanismo de formação, dimples maiores são associados a grandes descontinuidades, enquanto os pequenos são formados mediante o acumulo de deformação em bandas de escorregamento, nas quais numerosos dimples são nucleados a partir de descontinuidades muito pequenas ${ }^{(141)}$.

Como uma forma de classificar dimples observados neste trabalho, segundo o seu tamanho, serão chamados de micro-dimples aqueles que apresentam um diâmetro menor de $5 \mu \mathrm{m}$ e os maiores serão chamados de macro-dimples. Os macro-dimples geralmente apresentam diâmetros acima dos $15 \mu \mathrm{m}$. No caso dos dimples serem alongados, como são a grande maioria dos observados neste trabalho, o tamanho supracitado refere-se à menor medida destes. Na Figura 167 é mostrado, a título de exemplo, a fratura do CP Charpy do AISD UNS S32750 simulado na condição 10-3P. Nesta fratura são facilmente diferenciáveis os dimples de tamanhos diferentes.

$\mathrm{Na}$ Tabela 45 é apresentado o resumo da observação das superfícies de fratura dos CP Charpy. A seguir será feita uma análise desta evolução para cada uma das ligas estudadas:

Tabela 45: Evolução do aspecto da fratura dos CP Charpy. 


\begin{tabular}{|c|c|c|c|c|c|c|}
\hline \multirow{2}{*}{\multicolumn{2}{|c|}{ Condição }} & \multicolumn{5}{|c|}{ Aspecto da fratura } \\
\hline & & UNS S32304 & UNS S32205 & UNS S32550 & UNS S32750 & UNS S32760 \\
\hline \multicolumn{2}{|c|}{ Metal de base } & MaD - MiD & MaD - MiD & MaD - MiD & Sp - MaD - MiD & MaD - Sp - MiD \\
\hline $\begin{array}{l}\text { Energia de } \\
\text { Soldagem }\end{array}$ & Passe & & & & & \\
\hline \multirow{3}{*}{$0,6 \mathrm{~kJ} / \mathrm{mm}$} & 1 & $\begin{array}{c}\text { MaD - MiD - Cv } \\
\text { QCv }\end{array}$ & MaD - MiD & $\begin{array}{c}\text { FCG }- \text { TLq - MiD } \\
\text { RsD - MaD }\end{array}$ & TLq - MiD - MaD & $\begin{array}{c}\text { FCG }- \text { MaD }- \text { TLq } \\
\text { MiD }\end{array}$ \\
\hline & 2 & MaD - MiD & MaD - MiD & $\begin{array}{c}\text { FCG - TLq - MaD } \\
\text { MiD - RsD }\end{array}$ & MaD - MiD & MaD - MiD - TLq \\
\hline & 3 & MaD - MiD & MaD - FCG - MiD & MaD - FCG - MiD & $\begin{array}{c}\text { TLq }- \text { MiD - MaD } \\
\text { QCv }\end{array}$ & MaD - MiD \\
\hline \multirow{3}{*}{$1,0 \mathrm{~kJ} / \mathrm{mm}$} & 1 & MaD - MiD & MaD - MiD & $\begin{array}{c}\text { MiD - MaD - TLq } \\
\text { FCG }\end{array}$ & TLq - MaD - MiD & MaD - MiD \\
\hline & 2 & MaD - MiD & MaD - MiD & MaD - MiD - TLq & MiD - MaD - TLq & MaD - MiD \\
\hline & 3 & MaD - MiD - RsD & MaD & $\begin{array}{c}\text { TLq - MaD- MiD } \\
\text { FCG - RsD }\end{array}$ & MiD - MaD - TLq & MaD - MiD \\
\hline
\end{tabular}

Nota: $\quad$ Sp: Splitting - MaD: Macro-dimples - MiD: Micro-dimples RsD: Rasgamento dúctil - Cv: Clivagem - QCv: QuaseClivagem - FCG: Fusão dos contornos de grão - TLq: Trinca de Liquação

Escala de Predominância

\begin{tabular}{|l|l|l|l|}
\hline Máxima & & Mínima \\
\hline
\end{tabular}

UNS S32304: Como este material apresenta a maior fração de ferrita após o primeiro passe, para a energia de soldagem de $0,6 \mathrm{~kJ} / \mathrm{mm}$, observou-se fratura do tipo frágil, como mostra a Figura 168. Isto não é devido somente à maior fração de ferrita, mas também à maior quantidade de $\mathrm{Cr}_{2} \mathrm{~N}$, precipitada no seu interior. Estes nitretos facilitam a fratura por clivagem $^{(58)}$. Já durante os passes sucessivos teve-se uma importante precipitação de austenita e dissolução de $\mathrm{Cr}_{2} \mathrm{~N}$, portanto, a ausência de fratura frágil.

UNS S32205: Esta liga apresentou uma queda inesperada de tenacidade na condição 063P $(0,6 \mathrm{~kJ} / \mathrm{mm}$ após o terceiro passe). A observação dos CP no MEV revelou que isto foi devido à fusão dos contornos de grão, o que ocasionou fratura intergranular, como pode ser visto na Figura 169. No entanto, dos quatro CP ensaiados, somente um esteve livre deste problema e, neste caso, a energia absorvida foi de $42 \mathrm{~J}$. Desta forma, fica claro como este material na verdade tem um comportamento similar aos outros, isto é, o aumento da tenacidade à medida que são realizados os passes sucessivos. Para as duas energias de soldagem avaliadas, após o terceiro passe, a energia absorvida no ensaio Charpy foi aproximadamente a mesma do metal de base.

UNS S32550: A baixa tenacidade deste material foi devido à fusão dos contornos de grão ocorrida durante as simulações. Esta fusão localizada reduziu a seção resistente e causou trincamento intergranular frágil. Nas Figuras 170 e 171 pode ser visto o aspecto destas fraturas. Assim, a incidência desta fusão nos contornos, junto com as trincas de liquação, 
evitaram o registro adequado da mudança da tenacidade do material. Por outro lado, a grande incidência destes problemas de fusão neste material pode ser explicada pela sua menor temperatura solidus (ao redor de $1274{ }^{\circ} \mathrm{C}$ ), como foi mostrado na Tabela 17 . Mesmo com os problemas de fusão, a aparência da fratura nas regiões não fundidas foi tipicamente dúctil.

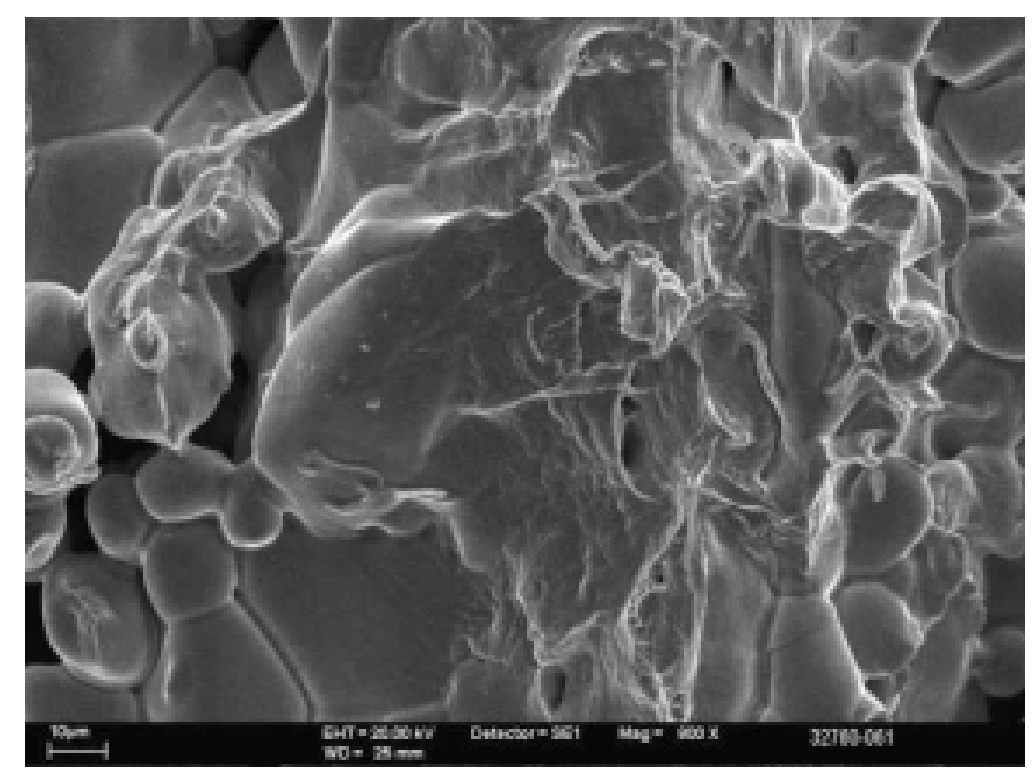

Figura 166: Trinca de liquação no CP submetido a simulação térmica. AISD UNS S32760, simulação 06-1P $(0,6 \mathrm{~kJ} / \mathrm{mm}$ após o primeiro passe). MEV.

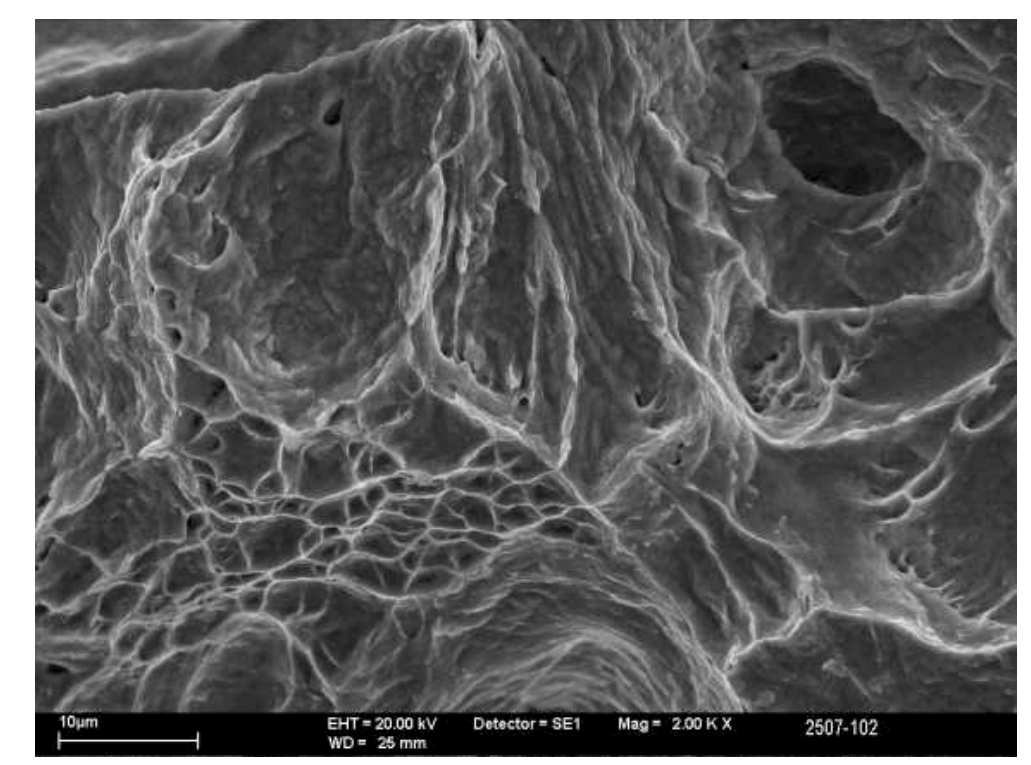

Figura 167: Aspecto dúctil da fratura do CP Charpy do AISD UNS S32750 após o segundo passe para uma energia de soldagem de $1,0 \mathrm{~kJ} / \mathrm{mm}$. Observam-se dimples de tamanhos diferentes. MEV. 


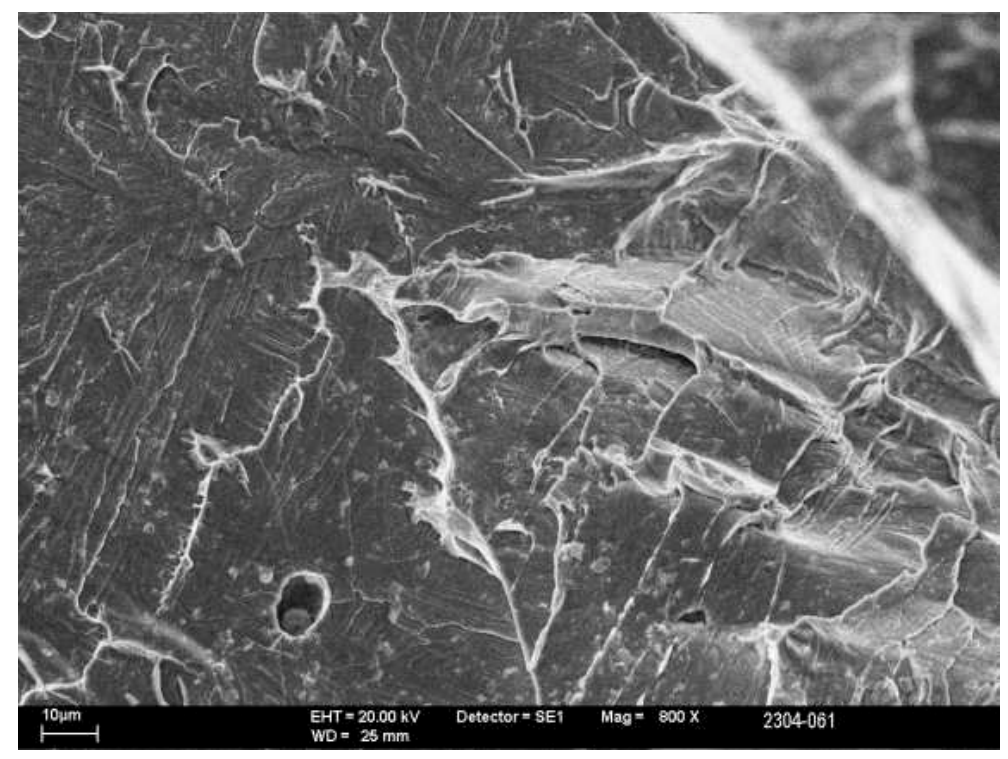

Figura 168: Aspecto da fratura do CP Charpy do AID UNS S32304 após o primeiro passe para uma energia de soldagem de $0,6 \mathrm{~kJ} / \mathrm{mm}$. MEV.

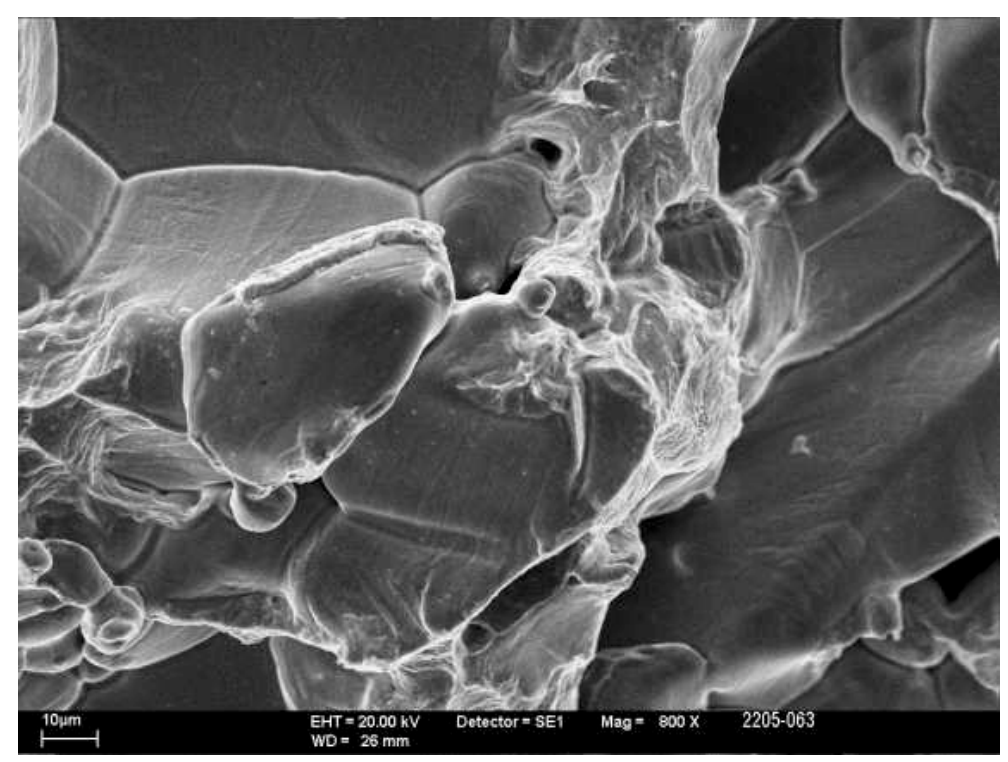

Figura 169: Aspecto da fratura do CP Charpy do AID UNS S32205 após o terceiro passe para uma energia de soldagem de $0,6 \mathrm{~kJ} / \mathrm{mm}$. Detalhe de região que sofreu fusão dos contornos de grão. MEV.

UNS S32750: De forma similar ao AISD UNS S32550, também foi observada a formação de trincas de liquação. Esta fusão foi principalmente observada na região do centro da espessura da chapa. Isto leva a pensar que esta fusão esteja diretamente relacionada com a segregação previamente mencionada. Conservando o mesmo padrão de comportamento, a temperatura solidus deste material $\left(1304^{\circ} \mathrm{C}\right.$, segundo a Tabela 17$)$ também é bastante baixa 
se comparada com a máxima temperatura de simulação $\left(1380^{\circ} \mathrm{C}\right)$. Apesar deste problema de trincas de liquação, o aspecto geral do restante das superfícies de fratura foi dúctil.

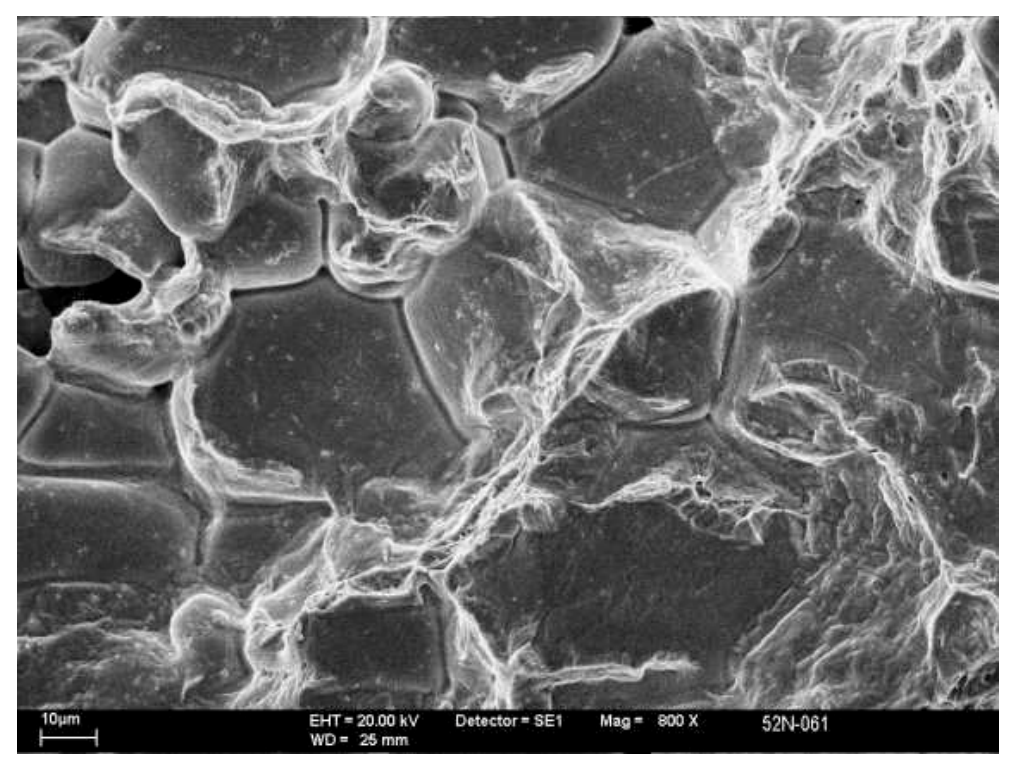

Figura 170: Aspecto da fratura do CP Charpy do AID UNS S32550 após o primeiro passe para uma energia de soldagem de $0,6 \mathrm{~kJ} / \mathrm{mm}$. Fratura intergranular, devido à fusão dos contornos de grão. MEV.

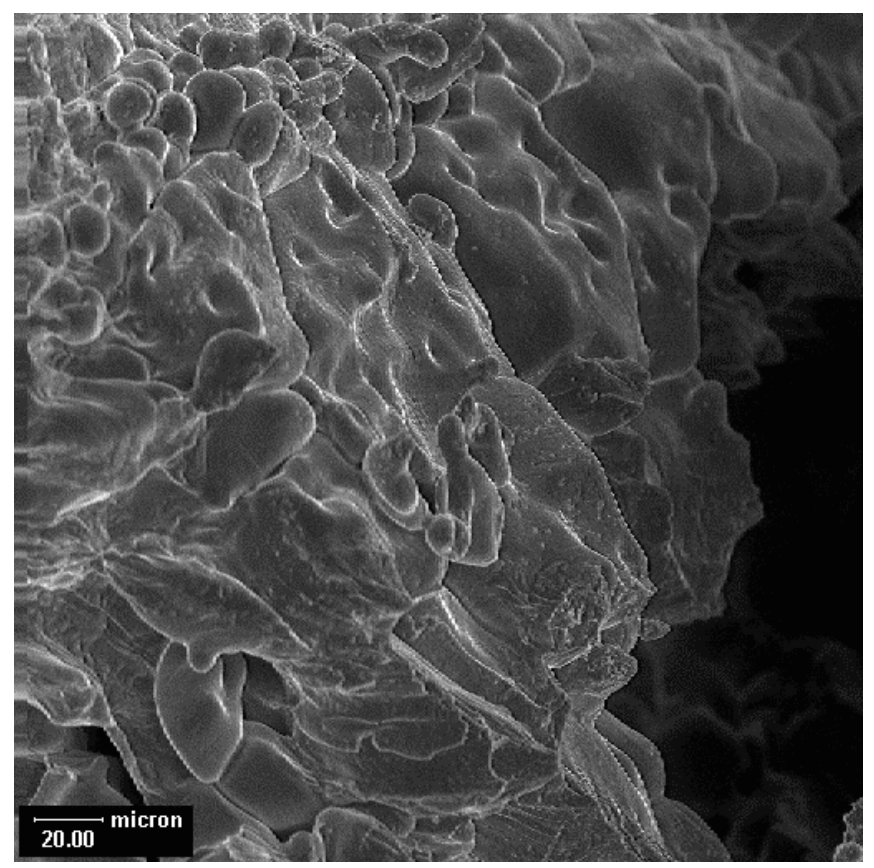

Figura 171: Aspecto da fratura do CP Charpy do AID UNS S32550 após o terceiro passe para uma energia de soldagem de $1,0 \mathrm{~kJ} / \mathrm{mm}$. Trinca de liquação formada durante a simulação. MEV. 


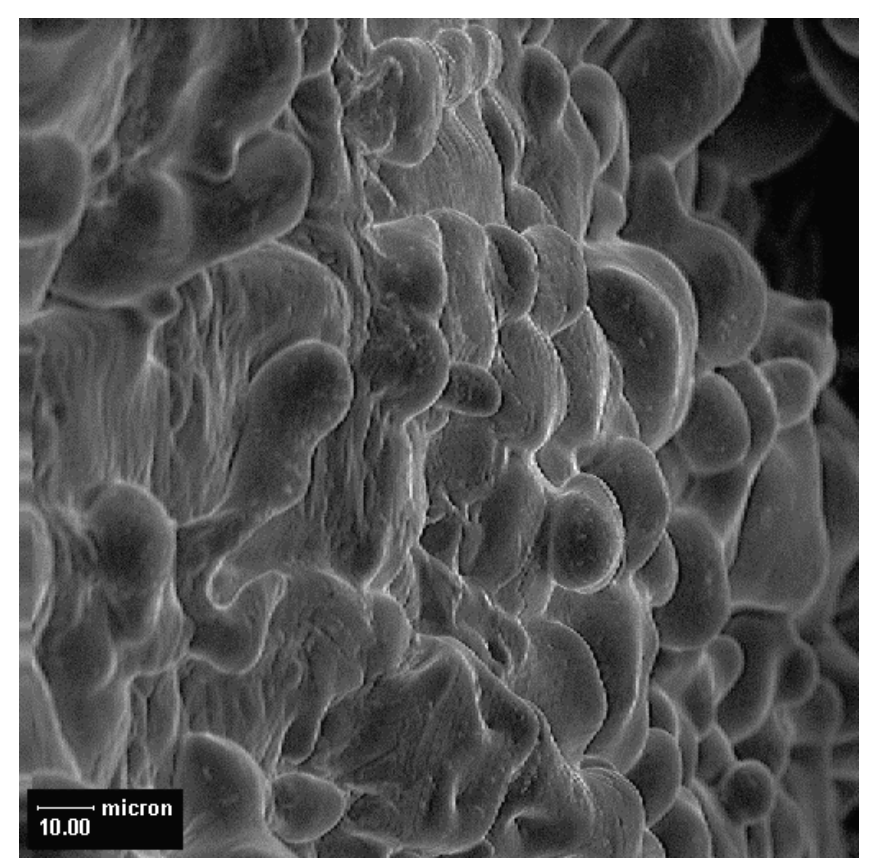

Figura 172: Aspecto da fratura do CP Charpy do AID UNS S32750 após o terceiro passe para uma energia de soldagem de $0,6 \mathrm{~kJ} / \mathrm{mm}$. Trinca de liquação formada durante a simulação. MEV.

UNS S32760: Esta liga, como as duas anteriores, também apresentou problemas de fusão dos contornos de grão, e de formação de trincas de liquação. Tendo uma temperatura solidus de $1301{ }^{\circ} \mathrm{C}$, segundo a Tabela 17 , a segunda menor de todas as ligas estudadas, este comportamento era esperado. No caso da energia de soldagem de $1,0 \mathrm{~kJ} / \mathrm{mm}$, teve-se um aumento da fração de austenita após o primeiro passe. No entanto, não houve um aumento da energia absorvida no ensaio Charpy. Nem após o terceiro passe foi atingida a energia absorvida pelo metal de base, o que pode estar relacionado também com o conteúdo de nitretos na microestrutura. Deve-se ressaltar que apesar dos problemas de fusão, uma parte importante das superfícies de fratura apresentou um aspecto dúctil.

\subsubsection{Resistência à Corrosão Localizada}

A avaliação da resistência à corrosão por pites, que é um tipo de corrosão localizada, foi realizada mediante ensaios de polarização cíclica numa solução aquosa naturalmente aerada de $3,5 \%$ peso de $\mathrm{NaCl}$, nas temperaturas de $25,35,50$ e $75{ }^{\circ} \mathrm{C}$. Posteriormente aos ensaios de corrosão os CPs foram polidos para a sua observação no $\mathrm{MO}$ e, desta forma, poder determinar os lugares de nucleação dos pites. Foram estudados os materiais de base no seu estado como-recebidos, os CPs tratados termicamente e os materiais submetidos à simulação da ZACTE. A seguir são apresentados e discutidos estes resultados para cada um dos grupos mencionados. 


\subsubsection{Metais de Base}

Inicialmente foram realizados testes nos metais de base, no estado como-recebido a $25^{\circ} \mathrm{C}$. Todos os materiais com exceção do AID UNS S32304, apresentaram potenciais de pite acima dos $1000 \mathrm{mV}$. Esta diferença de comportamento desta liga é explicada pela menor quantidade de elementos de liga, principalmente $\mathrm{Mo}$ e $\mathrm{N}$ neste material.

Por outro lado, devido à elevada resistência à corrosão do restante das ligas estudadas, o seu potencial de pite é muito elevado, com o que o fenômeno de aumento da densidade de corrente devido à formação e crescimento do pite fica sobreposto com a reação eletroquímica de geração de oxigênio a partir do íon $\mathrm{OH}^{-}\left(4 \mathrm{HO}^{-}=\mathrm{O}_{2}+2 \mathrm{H}_{2} \mathrm{O}+4 \mathrm{e}^{-}\right)$. Desta forma, fica bastante difícil determinar o potencial de pite. Portanto optou-se por realizar testes em temperaturas maiores, com o que o potencial de pite pode ser reduzido e desta forma o problema acima descrito é menos intenso.

Foi assim que se optou por ensaiar os dois AIDs (UNS S32304 e S32205) na temperatura de $35{ }^{\circ} \mathrm{C}$ e os três AISD (UNS S32550, UNS S32750 e UNS S32760), por serem ligas com propriedades de corrosão superiores, na temperatura de $50^{\circ} \mathrm{C}$.

No caso dos ensaios a $35{ }^{\circ} \mathrm{C}$, o AID UNS S32304, apresentou queda no seu potencial de pite, mas no caso do AID UNS S32205, este se manteve acima dos $1000 \mathrm{mV}$. Desta forma, passou-se a testar todos os materiais a $50{ }^{\circ} \mathrm{C}$, com exceção do AID UNS S32304. Nesta temperatura verificou-se uma queda no potencial de pite do AID UNS S32205, mas os outros materiais mantiveram potenciais de pite elevados.

Passou-se então a testar os materiais a $75^{\circ} \mathrm{C}$. Mas não se obteve queda no potencial de pite dos três AISD. O que foi observado foi uma aumento bastante considerável da dispersão dos resultados para as temperaturas de 50 e $75^{\circ} \mathrm{C}$. Este aumento na dispersão deve-se a fatores como a convecção na solução, que começam a ser importantes nestas temperaturas.

Um comportamento que foi bastante claro, foi uma tendência à redução do potencial de proteção, de todas as ligas, com o aumento da temperatura de ensaio.

Deve-se chamar atenção para o fato da utilização de uma eletrodo de referência diferente para os ensaios a 50 e $75^{\circ} \mathrm{C}$. Dado que o eletrodo saturado de calomelano não deve ser utilizado em temperaturas elevadas, nestes casos foi utilizado o eletrodo saturado de $\mathrm{Ag} / \mathrm{AgCl}$. No entanto, todos os potenciais aqui apresentados, incluindo os gráficos, foram corrigidos e todos são apresentados com relação ao eletrodo de calomelano.

$\mathrm{Na}$ Tabela 46 são apresentados os resultados dos ensaios realizados nas temperaturas de $25,35,50$ e $75^{\circ} \mathrm{C}$. Nas Figuras 173 a 175 são mostradas a título de exemplo algumas das curvas de polarização dos ensaios supracitados. A partir destes ensaios foram determinados os potenciais de pite e de proteção. O potencial de pite é aquele no qual a corrente cresce 
abruptamente, o que geralmente é bastante evidente, mas teve-se alguns ensaios nos quais a sua determinação não foi tão simples como, por exemplo, o ensaio do AID UNS S32304 a $35^{\circ} \mathrm{C}$ mostrado na Figura 174. Pela sua vez o potencial de proteção é aquele no qual o pite repassiva e portanto deixa de crescer. Para a determinação do potencial de proteção existem vários critérios. O mais tradicionalmente utilizado é o potencial no qual a curva de descida cruza com a curva de subida do potencial. Porém, este critério está em desuso. Um outro critério, atualmente com maior aceitação, para a determinação do potencial de proteção, é aquele potencial no qual a corrente se torna catódica. Foi este último critério o aplicado neste trabalho.

Em geral as curvas de polarização cíclica mostram um comportamento típico de materiais passivos. Em algumas das curvas, principalmente nas do AID UNS S32304, no seu trecho de subida, observam-se flutuações na corrente, as quais são originadas pela formação de pites instáveis, isto é a quebra da película passiva dando lugar a formação de pites, os quais repassivam rapidamente.

Finalmente, levando-se em conta os potenciais de pite e a forma mais comportada das curvas dos ensaios, optou-se pela realização do restante dos ensaios a $50{ }^{\circ} \mathrm{C}$. Porém, devese chamar a atenção para o fato do AID UNS S32304 não ser testado na temperatura de 50 ${ }^{\circ} \mathrm{C}$, pois isto levaria a um achatamento dos dados medidos, dificultando a detecção de diferença de comportamento entre os CP submetidos a ciclos térmicos diferentes.

Tabela 46: Potenciais de pite de proteção (ECS) dos materiais de base, determinados mediante ensaio de polarização cíclica.

\begin{tabular}{|c|c|c|c|c|c|c|c|c|}
\hline Temperatura & \multicolumn{2}{|c|}{$\mathbf{2 5}^{\circ} \mathbf{C}$} & \multicolumn{2}{c|}{$\mathbf{3 5}^{\circ} \mathbf{C}$} & \multicolumn{2}{c|}{$\mathbf{5 0}^{\circ} \mathbf{C}$} & \multicolumn{2}{c|}{$\mathbf{7 5}^{\circ} \mathbf{C}$} \\
\hline $\begin{array}{c}\text { Designação } \\
\text { UNS }\end{array}$ & Epit [mV] & Eprot [mV] & Epit [mV] & Eprot [mV] & Epit [mV] & Eprot [mV] & Epit [mV] & Eprot [mV] \\
\hline S32304 & $535 \pm 52$ & $-65 \pm 66$ & 332 & -192 & & & & \\
\hline S32205 & $1070 \pm 31$ & $407 \pm 63$ & 1060 & 338 & $796 \pm 76$ & $-116 \pm 60$ & 355 & -156 \\
\hline S32550 & $1034 \pm 4$ & $598 \pm 72$ & & & $1065 \pm 44$ & $336 \pm 51$ & $1003 \pm 69$ & $154 \pm 237$ \\
\hline S32750 & $1048 \pm 18$ & $432 \pm 58$ & & & $1069 \pm 70$ & $122 \pm 116$ & $1149 \pm 131$ & $45 \pm 178$ \\
\hline S32760 & $1063 \pm 4$ & $526 \pm 85$ & & & $1038 \pm 39$ & $290 \pm 75$ & $1103 \pm 17$ & $-55 \pm 12$ \\
\hline
\end{tabular}

Notas: Epit: Potencial de pite (ECS).

Eprot: Potencial de proteção (ECS).

Intervalo de confiança da média de $95 \%$.

Quanto à comparação dos potenciais de pite dos materiais, fica bastante claro que o material com a menor resistência à corrosão localizada é o AID UNS S32304, seguido pelo AID UNS S32205 e finalmente os três AISD (UNS S32550, S32750 e S32760) apresentam resistências bem mais elevadas, mas sem diferenças apreciáveis entre eles. Este ordenamento das ligas segundo a sua resistência à corrosão localizada, é a mesma predita pelo fator PREW apresentado na Tabela 16 (página 63). Como pode ser visto nesta tabela, os valores de PREW dos AISD são bastante próximos, mas a sua ordem corresponde com a apresentada 
pelos materiais quando testados a $75^{\circ} \mathrm{C}$. A menor resistência à corrosão localizada do AID UNS S32304 é um comportamento esperado devido à menor quantidade de elementos de liga neste material. O valor intermédio de resistência à corrosão localizada do AID UNS S32205 também é explicado pela sua composição química.
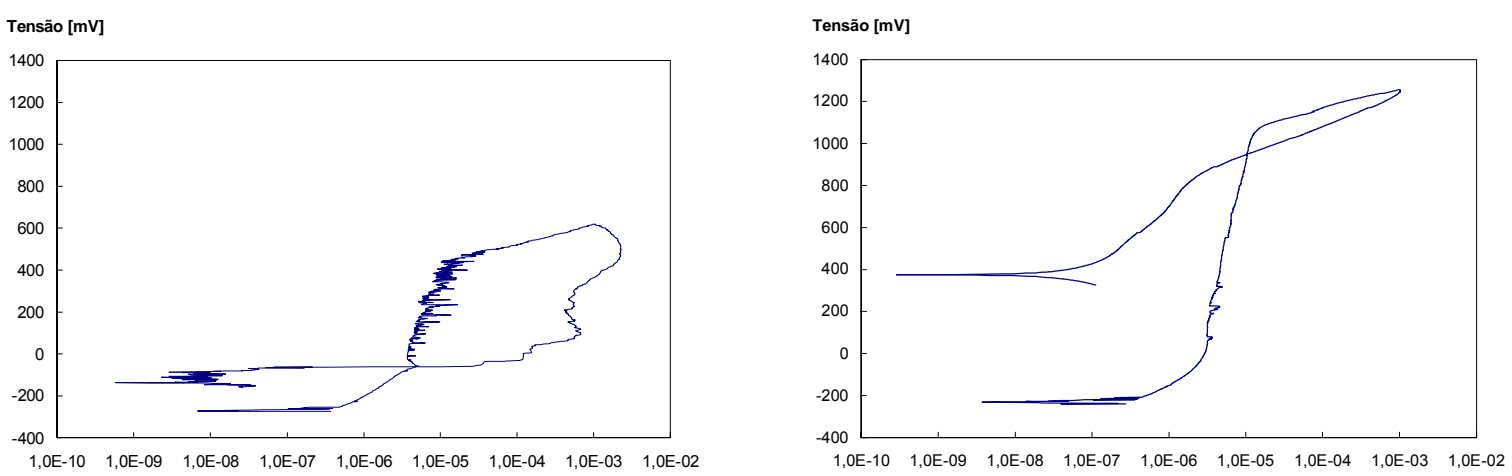

UNS $\$ 32304-25^{\circ} \mathrm{C}$

Corrente/Área $\left[\mathrm{A} / \mathrm{cm}^{2}\right]$

UNS $\$ 32205-25^{\circ} \mathrm{C}$

Corrente/Área $\left[\mathbf{A} / \mathrm{cm}^{2}\right]$
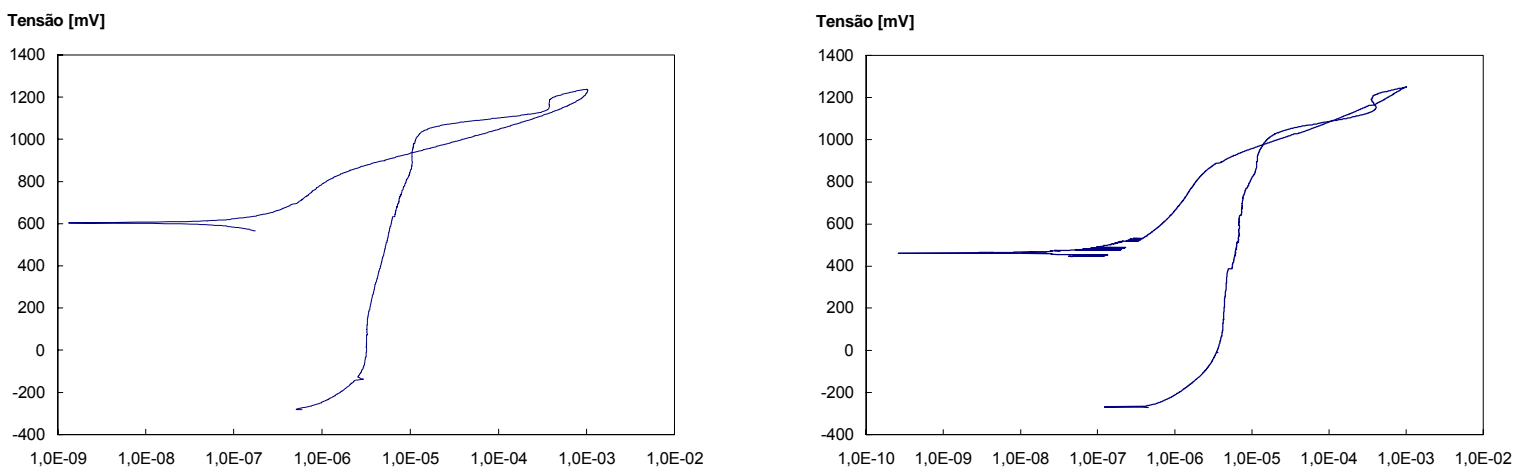

UNS $\$ 32550-25^{\circ} \mathrm{C}$

Corrente/Área $\left[\mathbf{A} / \mathrm{cm}^{2}\right]$

UNS $\$ 32750-25^{\circ} \mathrm{C}$

Corrente/Área $\left[\mathbf{A} / \mathrm{cm}^{2}\right]$

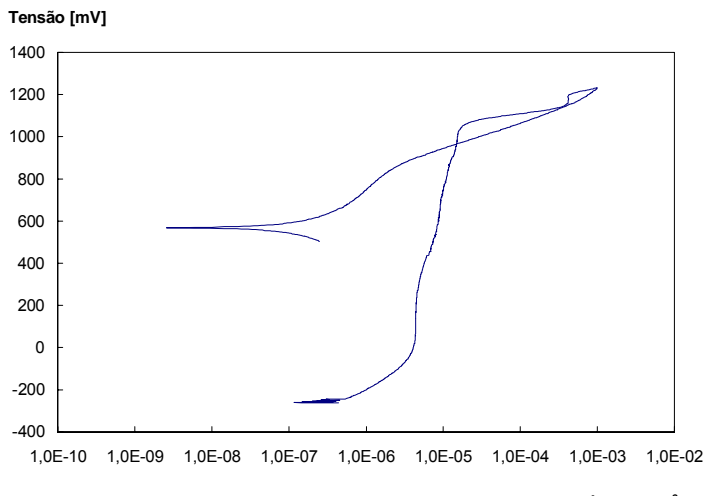

UNS $\$ 32760-25^{\circ} \mathrm{C}$

Corrente/Área $\left[\mathbf{A} / \mathrm{cm}^{2}\right]$

Figura 173: Curvas de polarização dos materiais de base, levantadas mediante ensaio potenciodinâmico realizado numa solução aquosa naturalmente areada de $3,5 \%$ peso de $\mathrm{NaCl}$, na temperatura de $25^{\circ} \mathrm{C}$. 


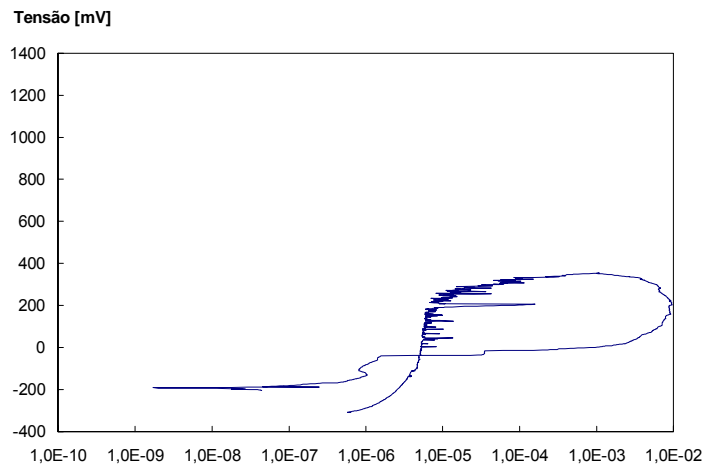

UNS $\$ 32304-35^{\circ} \mathrm{C}$

Corrente/Área $\left[\mathbf{A} / \mathrm{cm}^{2}\right]$

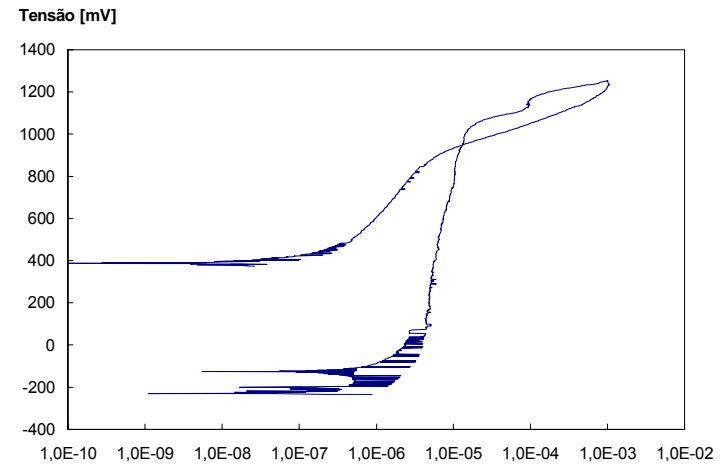

UNS $\$ 32205-35^{\circ} \mathrm{C}$

Corrente/Área $\left[\mathbf{A} / \mathrm{cm}^{2}\right]$

Figura 174: Curvas de polarização dos materiais de base, levantadas mediante ensaio potenciodinâmico realizado numa solução aquosa naturalmente areada de $3,5 \%_{\text {peso }}$ de $\mathrm{NaCl}$, na temperatura de $35^{\circ} \mathrm{C}$.

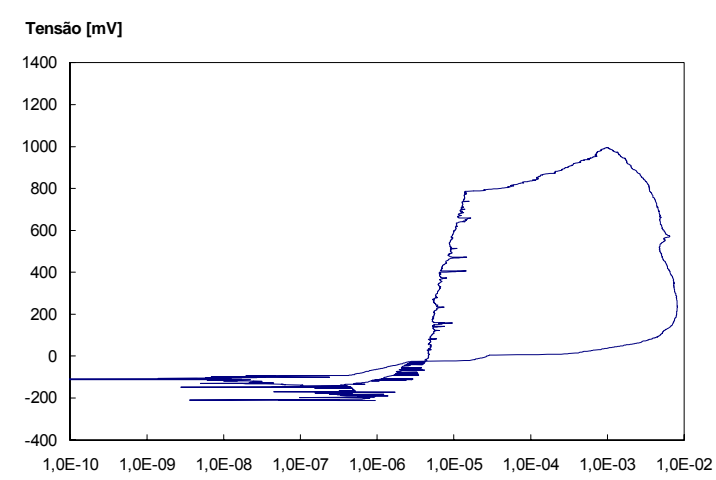

UNS $\$ 32205-50^{\circ} \mathrm{C}$

Tensão [mV]

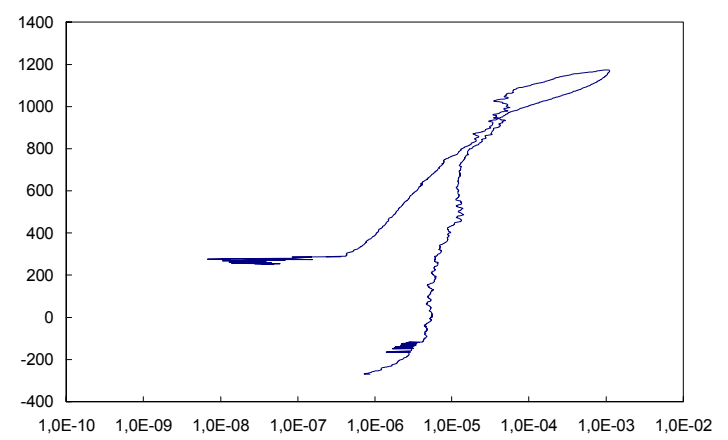

UNS $\$ 32750-50{ }^{\circ} \mathrm{C}$
Corrente/Área $\left[\mathrm{A} / \mathrm{cm}^{2}\right]$

Corrente/Área $\left[\mathrm{A} / \mathrm{cm}^{2}\right]$

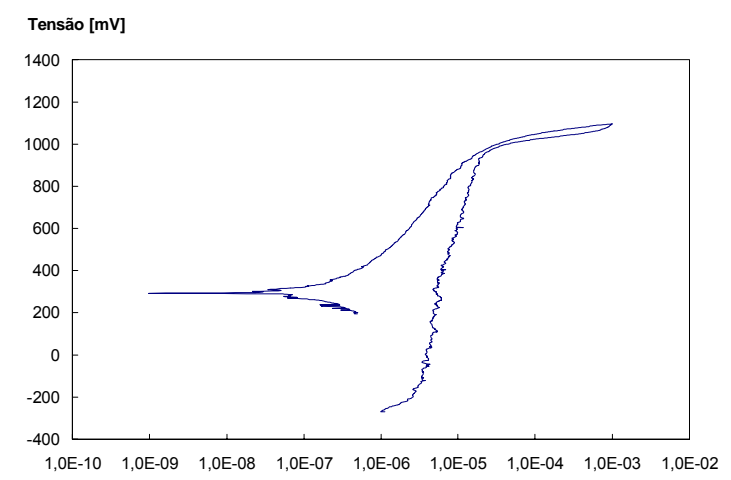

UNS $\$ 32550-50^{\circ} \mathrm{C}$

Corrente/Área $\left[\mathbf{A} / \mathrm{cm}^{2}\right]$

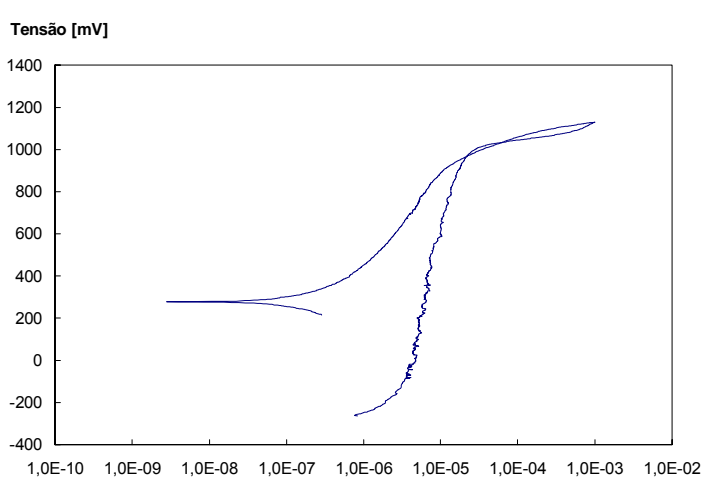

UNS $\$ 32760-50^{\circ} \mathrm{C}$

Corrente/Área $\left[\mathrm{A} / \mathrm{cm}^{2}\right]$

Figura 175: Curvas de polarização dos materiais de base, levantadas mediante ensaio potenciodinâmico realizado numa solução aquosa naturalmente areada de $3,5 \%_{\text {peso }}$ de $\mathrm{NaCl}$, na temperatura de $50^{\circ} \mathrm{C}$.

Na Figura 177 é apresentada graficamente a relação existente entre o PREW e os potenciais de pite medidos nas ligas estudadas no estado como-recebido. Segundo a regressão linear dos dados, a relação PREW-Potencial de Pite muda com a temperatura de ensaio, sendo que, com o aumento da temperatura, o efeito do PREW no potencial de pite se faz maior. 


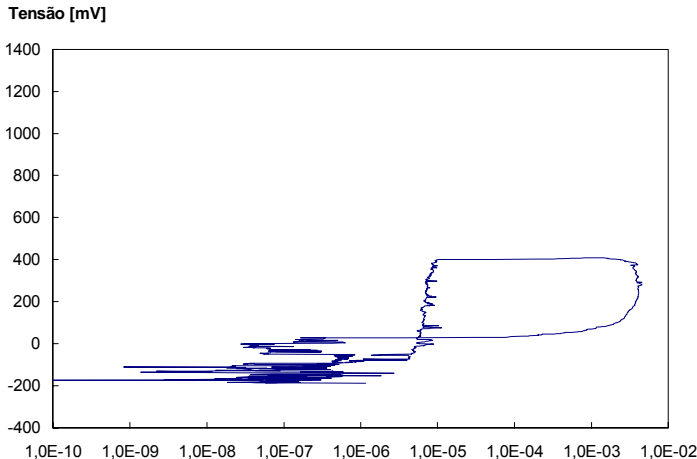

UNS $\$ 32205-75^{\circ} \mathrm{C}$

Corrente/Área $\left[\mathrm{A} / \mathrm{cm}^{2}\right]$

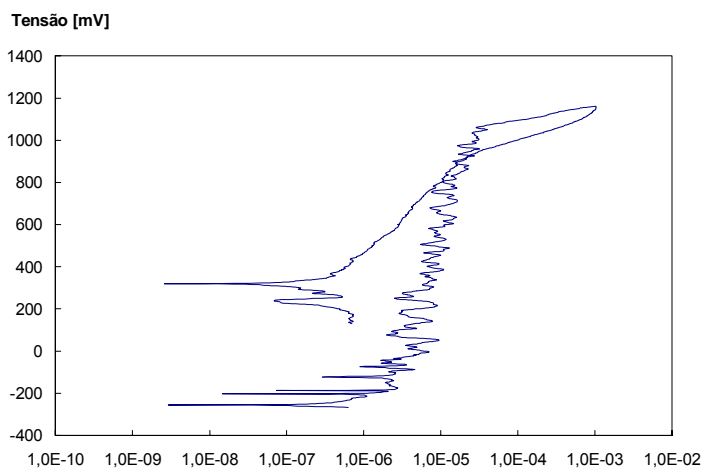

UNS $\mathrm{S} 32550-75^{\circ} \mathrm{C}$

Corrente/Área $\left[\mathrm{A} / \mathrm{cm}^{2}\right]$

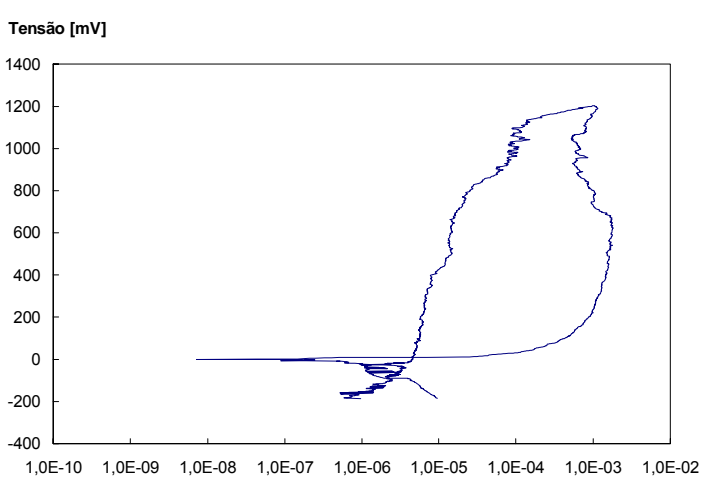

UNS $\$ 32750-75^{\circ} \mathrm{C}$

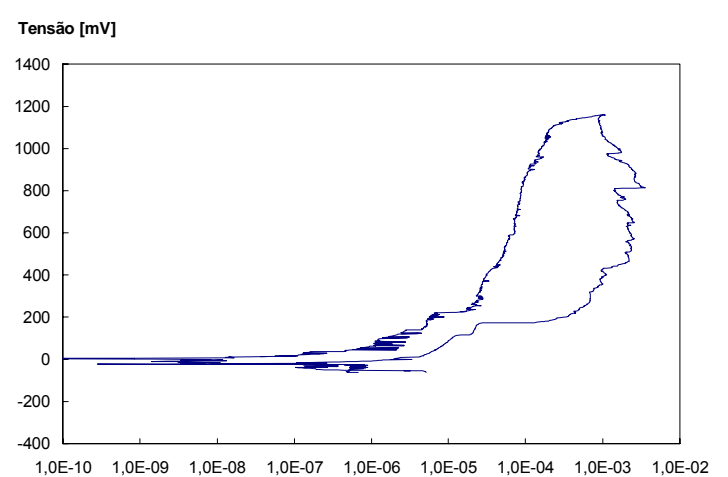

UNS $\$ 32760-75^{\circ} \mathrm{C}$
Corrente/Área $\left[\mathrm{A} / \mathrm{cm}^{2}\right]$

Figura 176: Curvas de polarização dos materiais de base, levantadas mediante ensaio potenciodinâmico realizado numa solução aquosa naturalmente areada de $3,5 \%$ peso de $\mathrm{NaCl}$, na temperatura de $75^{\circ} \mathrm{C}$.

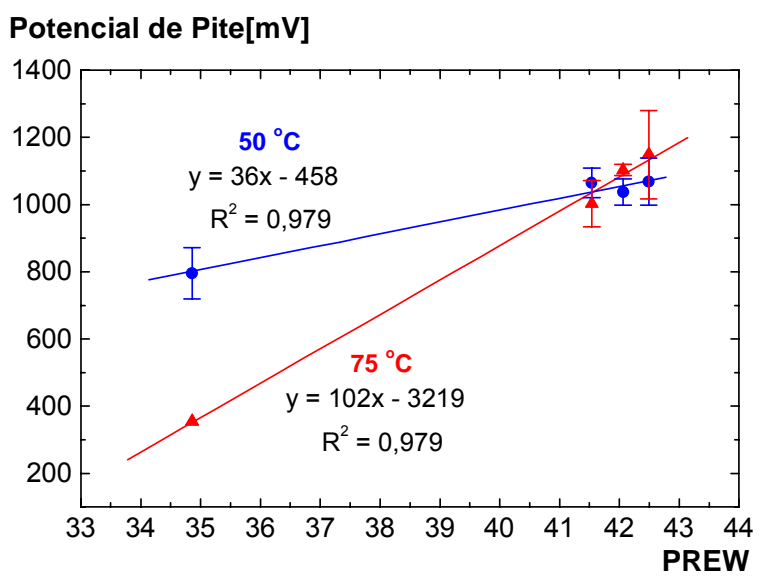

Figura 177: Relação entre o potencial de pite e o PREW para duas diferentes temperaturas de ensaio. 


\subsubsection{Materiais Tratados Termicamente}

Os materiais submetidos aos tratamentos térmicos de ferritização e reaquecimento foram submetidos ao mesmo ensaio de polarização cíclica, utilizando as mesmas condições estabelecidas para os metais de base. Isto é, o AID UNS S32304 foi testado a $25{ }^{\circ} \mathrm{C}$ e as outras ligas foram testadas a $50{ }^{\circ} \mathrm{C}$. Nas Tabelas 47 e 48 são apresentados os resultados destes ensaios. Foram feitos em média 5 ensaios para cada condição, mas devido à sua grande dispersão, foram descartados os resultados maiores e menores e somente foram utilizados 3 deles para o cálculo da média. Na Tabela 49 são apresentados os valores de potencial de pite dos diversos materiais após os tratamentos térmicos, em valores relativos ao potencial de pite do material no seu estado como-recebido. Esta tabela permite visualizar melhor a evolução da resistência a corrosão por pite dos materiais quando submetidos aos diferentes tratamentos térmicos.

Em termos gerais todos materiais apresentaram uma queda importante no seu potencial de pite quando tratados a $1350{ }^{\circ} \mathrm{C}$, isto com relação ao estado como-recebido.

No caso dos AIDs UNS S32304 e S32205, notou-se uma queda importante do potencial de pite, mas não no potencial de proteção. Assim, para estes dois materiais o formato geral das curvas de polarização mostradas na Figura 178 não mudou com este tratamento, tendo-se um potencial de pite muito bem definido. Mas, após o tratamento a $1350{ }^{\circ} \mathrm{C}$, os pites instáveis chegaram a crescer muito mais que nos metais de base, antes de se repassivarem.

Por outro lado no caso dos três AISD (UNS S32550, S32750 e S32760) tanto os potenciais de pite como de proteção caíram substancialmente com o tratamento a $1350{ }^{\circ} \mathrm{C}$. Porém a queda do potencial de pite deles foi bem menor que a sofrida pelas duas ligas anteriormente comentadas (UNS S32304 e S32205). Além disso, os formatos das curvas de polarização mudaram drasticamente. O formato das curvas para os materiais no estado como-recebido é o típico de um material altamente resistente a corrosão por pite, no qual, uma vez permitido que o pite cresça um pouco (densidade de corrente de $10^{-3} \mathrm{~A} / \mathrm{cm}^{2}$ ), logo que o potencial aplicado é diminuído um pouco, a densidade de corrente cai para os valores anteriores à formação do pite, como pode ser visto na Figura 175. Após o tratamento a $1350{ }^{\circ} \mathrm{C}$, o formato das curvas destes três materiais mudou bastante (Ver Figura 177), sendo que o potencial aplicado teve que ser drasticamente reduzido para alcançar as densidades de corrente que se tinham antes da formação dos pites. Este comportamento foi mais marcado no AISD UNS S32760, seguido pelo S32550 e finalmente do S32750, que também é o material com o maior PREW, no qual este efeito foi bem menos importante. 
Tabela 47: Potenciais de pite (ECS) dos materiais submetidos aos tratamentos térmicos de ferritização e reaquecimento. Ensaio de polarização cíclica.

\begin{tabular}{|c|c|c|c|c|c|c|c|c|c|}
\hline \multirow{2}{*}{$\begin{array}{c}\text { Designação } \\
\text { UNS }\end{array}$} & \multirow{2}{*}{$\begin{array}{c}\text { Como- } \\
\text { Recebido }\end{array}$} & \multirow{2}{*}{\multicolumn{2}{|c|}{ 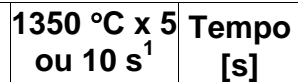 }} & \multicolumn{4}{|c|}{ Temperatura de Reaquecimento $\left[{ }^{\circ} \mathrm{C}\right]$} & \multicolumn{2}{|c|}{ ANOVA } \\
\hline & & & & 900 & 1000 & 1100 & 1200 & $F_{\text {critico }}$ & $\mathbf{F}$ \\
\hline \multirow{3}{*}{ S32304 } & \multirow{3}{*}{$535 \pm 52$} & \multirow{3}{*}{$332 \pm 30$} & 1 & $366 \pm 36$ & $403 \pm 21$ & $361 \pm 16$ & $433 \pm 42$ & 7,6 & 4,6 \\
\hline & & & 10 & $401 \pm 27$ & $376 \pm 15$ & $457 \pm 34$ & $443 \pm 30$ & 7,6 & 7,1 \\
\hline & & & $\mathbf{F}$ & 2,3 & 4,0 & 25,1 & 0,1 & 21,2 & \\
\hline \multirow{3}{*}{ S32205 } & \multirow{3}{*}{$796 \pm 76$} & \multirow{3}{*}{$508 \pm 32$} & 1 & $458 \pm 17$ & $408 \pm 49$ & $558 \pm 46$ & $554 \pm 43$ & 7,6 & 12,5 \\
\hline & & & 10 & $494 \pm 36$ & $511 \pm 43$ & $577 \pm 20$ & $568 \pm 58$ & 7,6 & 3,7 \\
\hline & & & $\mathbf{F}$ & 3,1 & 9,5 & 0,5 & 0,1 & 21,2 & \\
\hline \multirow{3}{*}{ S32550 } & \multirow{3}{*}{$1065 \pm 44$} & \multirow{3}{*}{$877 \pm 92$} & 1 & $971 \pm 21$ & $1027 \pm 25$ & $1033 \pm 50$ & $1015 \pm 7$ & 7,6 & 3,4 \\
\hline & & & 10 & $968 \pm 28$ & $1012 \pm 18$ & $1048 \pm 3$ & $991 \pm 59$ & 7,6 & 3,8 \\
\hline & & & $\mathbf{F}$ & 0,02 & 1,0 & 0,4 & 0,7 & 21,2 & \\
\hline \multirow{3}{*}{ S32750 } & \multirow{3}{*}{$1069 \pm 70$} & \multirow{3}{*}{$919 \pm 12$} & 1 & $1022 \pm 45$ & $1035 \pm 28$ & $1026 \pm 44$ & $1061 \pm 60$ & 7,6 & 0,6 \\
\hline & & & 10 & $1031 \pm 16$ & $1038 \pm 32$ & $1040 \pm 48$ & $1047 \pm 7$ & 7,6 & 0,2 \\
\hline & & & $\mathbf{F}$ & 0,1 & 0,02 & 0,2 & 0,2 & 21,1 & \\
\hline \multirow{3}{*}{ S32760 } & \multirow{3}{*}{$1038 \pm 39$} & \multirow{3}{*}{$879 \pm 65$} & 1 & $976 \pm 28$ & $1045 \pm 26$ & $1035 \pm 10$ & $1045 \pm 25$ & 7,6 & 7,6 \\
\hline & & & 10 & $1013 \pm 38$ & $1017 \pm 55$ & $1023 \pm 3$ & $1016 \pm 36$ & 7,6 & 0,04 \\
\hline & & & $F$ & 2,4 & 0,8 & 5,3 & 1,7 & 21,2 & \\
\hline
\end{tabular}

Nota: $\quad$ 1: UNS S32304, S32205, S32550 e S32760 tratados a $1350^{\circ} \mathrm{C}$ por $5 \mathrm{~s}$. UNS S32750 tratado a $1350{ }^{\circ} \mathrm{C}$ por $10 \mathrm{~s}$. UNS S32304 testado a $25^{\circ} \mathrm{C}$. UNS S32205, S32550, S32750 e S32760 testados a $50^{\circ} \mathrm{C}$.

ANOVA: Análise de variância - Nível de significância de $1 \%$.

F: Fator de variância.

Vermelho: $\mathrm{F}<\mathrm{F}_{\text {critico }}$

O intervalo de confiança das médias é de $95 \%$

Tabela 48: Potenciais de proteção (ECS) dos materiais submetidos aos tratamentos térmicos de ferritização e reaquecimento. Ensaio de polarização cíclica.

\begin{tabular}{|c|c|c|c|c|c|c|c|}
\hline \multirow{2}{*}{$\begin{array}{c}\text { Designação } \\
\text { UNS }\end{array}$} & \multirow{2}{*}{$\begin{array}{c}\text { Como- } \\
\text { Recebido }\end{array}$} & \multirow{2}{*}{$\begin{array}{c}1350{ }^{\circ} \mathrm{C} \times 5 \\
\text { ou } 10 \mathrm{~s}^{1}\end{array}$} & \multirow{2}{*}{$\begin{array}{c}\text { Tempo } \\
\text { [s] }\end{array}$} & \multicolumn{4}{|c|}{ Temperatura de Reaquecimento $\left[{ }^{\circ} \mathrm{C}\right]$} \\
\hline & & & & 900 & 1000 & 1100 & 1200 \\
\hline \multirow{2}{*}{ S32304 } & \multirow{2}{*}{$-65 \pm 66$} & \multirow{2}{*}{$-137 \pm 51$} & 1 & $-135 \pm 117$ & $-65 \pm 22$ & $-64 \pm 44$ & $-110 \pm 65$ \\
\hline & & & 10 & $-137 \pm 114$ & $-157 \pm 139$ & $-54 \pm 57$ & $-98 \pm 61$ \\
\hline \multirow{2}{*}{ S32205 } & \multirow{2}{*}{$-116 \pm 60$} & \multirow{2}{*}{$-82 \pm 42$} & 1 & $-147 \pm 46$ & $-144 \pm 91$ & $-75 \pm 89$ & $-89 \pm 75$ \\
\hline & & & 10 & $-131 \pm 55$ & $-157 \pm 30$ & $-48 \pm 48$ & $-59 \pm 121$ \\
\hline \multirow{2}{*}{ S32550 } & \multirow{2}{*}{$336 \pm 51$} & \multirow{2}{*}{$-111 \pm 85$} & 1 & $66 \pm 446$ & $187 \pm 279$ & $563 \pm 125$ & $-88 \pm 102$ \\
\hline & & & 10 & $104 \pm 233$ & $356 \pm 63$ & $346 \pm 129$ & $79 \pm 288$ \\
\hline \multirow{2}{*}{ S32750 } & \multirow{2}{*}{$122 \pm 116$} & \multirow{2}{*}{$-124 \pm 39$} & 1 & $15 \pm 280$ & $399 \pm 33$ & $409 \pm 44$ & $118 \pm 233$ \\
\hline & & & 10 & $290 \pm 38$ & $386 \pm 104$ & $282 \pm 305$ & $352 \pm 47$ \\
\hline \multirow{2}{*}{ S32760 } & \multirow{2}{*}{$290 \pm 75$} & \multirow{2}{*}{$-113 \pm 39$} & 1 & $295 \pm 83$ & $275 \pm 164$ & $255 \pm 153$ & $195 \pm 300$ \\
\hline & & & 10 & $246 \pm 220$ & $158 \pm 232$ & $354 \pm 128$ & $166 \pm 247$ \\
\hline
\end{tabular}

Nota: 1: UNS S32304, S32205, S32550 e S32760 tratados a $1350^{\circ} \mathrm{C}$ por $5 \mathrm{~s}$. UNS S 32750 tratado a $1350^{\circ} \mathrm{C}$ por $10 \mathrm{~s}$.

UNS S32304 testado a $25^{\circ} \mathrm{C}$. UNS S32205, S32550, S32750 e S32760 testados a $50{ }^{\circ} \mathrm{C}$.

O intervalo de confiança das médias é de $95 \%$

Analisando-se os resultados apresentados dos CPs submetidos a tratamentos a $1350{ }^{\circ} \mathrm{C} \mathrm{em}$ termos práticos, todos os materiais estudados apresentaram uma considerável redução na sua resistência à corrosão por pites após o tratamento a $1350{ }^{\circ} \mathrm{C}$. A maior perda de resistência foi sofrida pelos AIDs UNS S32205 e S32304. Um material submetido a este 
tratamento é equivalente à ZACTE de uma soldagem executada com um baixo insumo de energia. Portanto, estas condições de soldagem devem ser evitadas.

Tabela 49: Fração do potencial de pite no estado como-recebido após o tratamentos térmicos para todas as ligas estudadas.

\begin{tabular}{|c|c|c|c|c|c|c|c|}
\hline \multirow{3}{*}{$\begin{array}{c}\text { Designação } \\
\text { UNS }\end{array}$} & \multirow{2}{*}{$\begin{array}{c}\text { Como- } \\
\text { Recebido }\end{array}$} & \multirow{2}{*}{$\begin{array}{c}1350{ }^{\circ} \mathrm{C} \times 5 \\
\text { ou } 10 \mathrm{~s}^{1}\end{array}$} & \multirow{2}{*}{$\begin{array}{c}\text { Tempo } \\
{[\mathbf{s}]}\end{array}$} & \multicolumn{4}{|c|}{ Temperatura de Reaquecimento $\left[{ }^{\circ} \mathrm{C}\right]$} \\
\hline & & & & 900 & 1000 & 1100 & 1200 \\
\hline & \multicolumn{7}{|c|}{ Fração do Potencial de Pite no Estado Como-Recebido [\%] } \\
\hline \multirow{2}{*}{ S32304 } & \multirow{2}{*}{$100 \pm 10$} & \multirow{2}{*}{$64 \pm 4$} & 1 & $68 \pm 7$ & $75 \pm 4$ & $67 \pm 3$ & $81 \pm 8$ \\
\hline & & & 10 & $75 \pm 5$ & $70 \pm 3$ & $85 \pm 6$ & $83 \pm 6$ \\
\hline \multirow{2}{*}{ S32205 } & \multirow{2}{*}{$100 \pm 10$} & \multirow{2}{*}{$62 \pm 6$} & 1 & $58 \pm 2$ & $51 \pm 6$ & $70 \pm 6$ & $70 \pm 5$ \\
\hline & & & 10 & $62 \pm 4$ & $64 \pm 5$ & $72 \pm 3$ & $71 \pm 7$ \\
\hline \multirow{2}{*}{ S32550 } & \multirow{2}{*}{$100 \pm 4$} & \multirow{2}{*}{$82 \pm 9$} & 1 & $91 \pm 2$ & $96 \pm 2$ & $97 \pm 5$ & $95 \pm 1$ \\
\hline & & & 10 & $91 \pm 3$ & $95 \pm 2$ & $98 \pm 0,3$ & $93 \pm 6$ \\
\hline \multirow{2}{*}{ S32750 } & \multirow{2}{*}{$100 \pm 7$} & \multirow{2}{*}{$86 \pm 1$} & 1 & $96 \pm 4$ & $97 \pm 3$ & $96 \pm 4$ & $99 \pm 6$ \\
\hline & & & 10 & $96 \pm 2$ & $97 \pm 3$ & $97 \pm 4$ & $98 \pm 1$ \\
\hline \multirow{2}{*}{ S32760 } & \multirow{2}{*}{$100 \pm 4$} & \multirow{2}{*}{$85 \pm 6$} & 1 & $94 \pm 3$ & $101 \pm 3$ & $100 \pm 1$ & $101 \pm 2$ \\
\hline & & & 10 & $98 \pm 4$ & $98 \pm 5$ & $99 \pm 0,3$ & $98 \pm 3$ \\
\hline
\end{tabular}

Nota: 1: UNS S32304, S32205, S32550 e S32760 tratados a $1350^{\circ} \mathrm{C}$ por $5 \mathrm{~s}$. UNS S 32750 tratado a $1350^{\circ} \mathrm{C}$ por $10 \mathrm{~s}$.

UNS S32304 testado a $25^{\circ} \mathrm{C}$. UNS S32205, S32550, S32750 e S32760 testados a $50^{\circ} \mathrm{C}$.

O intervalo de confiança das médias é de $95 \%$

Quanto aos tratamentos de reaquecimento, eles tiveram efeito mais ou menos importante na resistência à corrosão localizada, dependendo da liga, da temperatura e do tempo. Em geral, os tratamentos de reaquecimento levaram a um aumento no potencial de pite (PPit) dos materiais. Era de se esperar que aumentos de tempo de tratamento e de temperatura também levariam a aumentos no PPit. Em termos gerais isto foi assim, mas existem algumas exceções. Desta forma, a evolução da resistência à corrosão de cada um dos aços será comentada separadamente:

UNS S32304: O tratamento térmico (TT) a $900{ }^{\circ} \mathrm{C}$ por $1 \mathrm{~s}$, não levou a nenhuma mudança apreciável no PPit. Isto era de se esperar devido à cinética limitada das transformações de fase nesta temperatura, que já foi verificada na microestrutura. Já no tratamento por $10 \mathrm{~s}$ nesta mesma temperatura, observou-se uma certa recuperação do PPit. Como foi verificado no item 6.2.2.2, as mudanças microestruturais causadas pelo aumento de tempo de tratamento de 1 para $10 \mathrm{~s}$ a 900 foram mínimas, não sendo observado um aumento na fração de austenita, nem a diminuição na quantidade de $\mathrm{Cr}_{2} \mathrm{~N}$ intragranular e, pelo contrário, foi verificada a precipitação de $\mathrm{Cr}_{2} \mathrm{~N}$ nas interfaces $\alpha / \gamma$. Assim, a recuperação verificada no PPit não é devida a grandes mudanças na microestrutura. Portanto, esta recuperação deve estar diretamente relacionada com o grau de homogeneização química alcançado, principalmente ao redor dos nitretos precipitados durante o resfriamento rápido a partir dos 
$1350{ }^{\circ} \mathrm{C}$. No caso do TT a $1000^{\circ} \mathrm{C}$, teve-se uma inesperada queda no PPit do material quando o tempo de tratamento passou de 1 para $10 \mathrm{~s}$, apesar do crescimento da fração de $\gamma$ e da dissolução quase total dos nitretos de cromo. Uma mudança microestrutural bastante importante notada nesta temperatura foi a abundante precipitação e crescimento de $\gamma_{2}$ intragranular, após o tratamento por $10 \mathrm{~s}$. Assim, acredita-se que seja a precipitação desta fase a responsável pela queda do PPit.
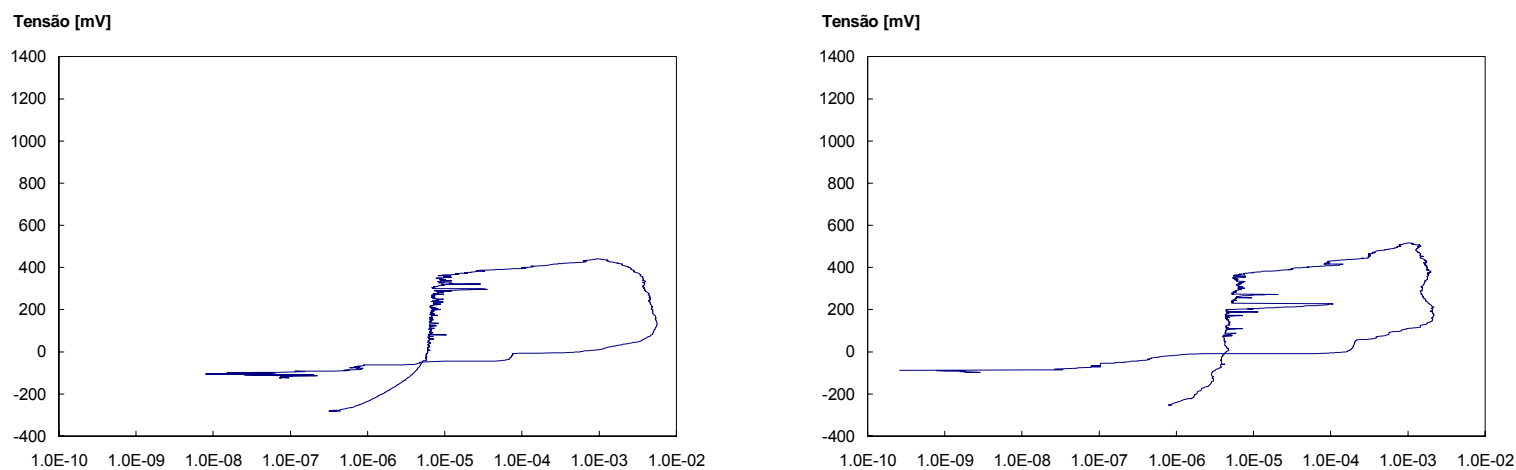

UNS S32304 - Ferritizado

Corrente/Área $\left[\mathrm{A} / \mathrm{cm}^{2}\right]$

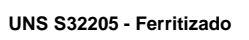

Corrente/Área $\left[\mathbf{A} / \mathrm{cm}^{2}\right]$

Tensão $[\mathrm{mV}]$

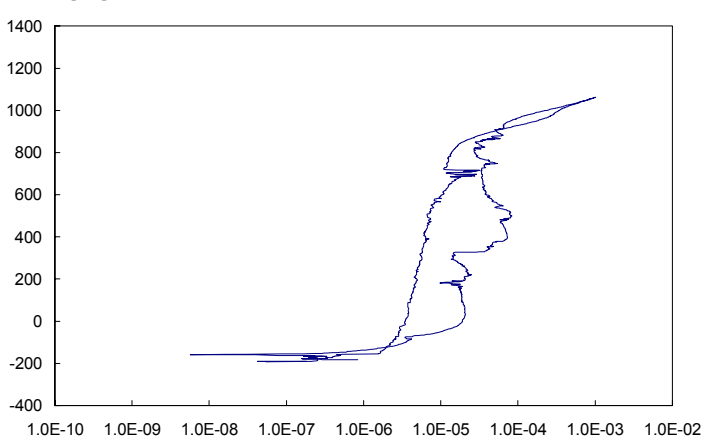

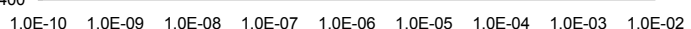

UNS S32550 - Ferritizado

Corrente/Área $\left[\mathbf{A} / \mathrm{cm}^{2}\right]$

Tensão [mV]

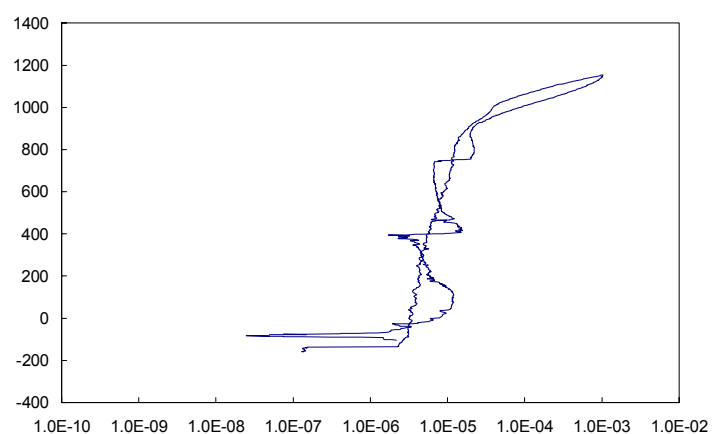

UNS S32750 - Ferritizado

Corrente/Área $\left[\mathrm{A} / \mathrm{cm}^{2}\right]$

Tensão [mV]

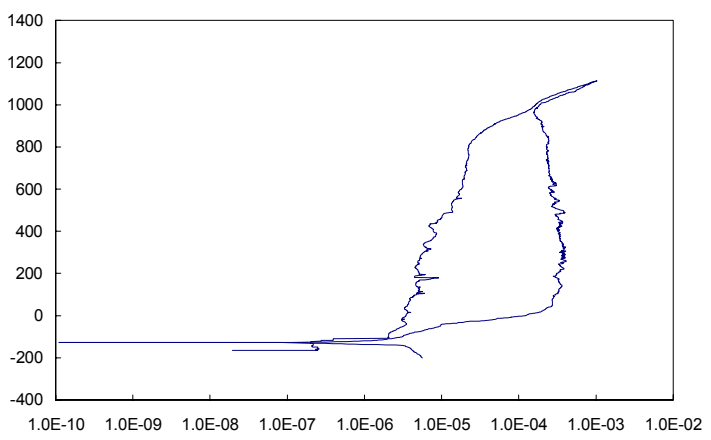

UNS $\mathbf{3 2 7 6 0}$ - Ferritizado

Corrente/Área $\left[\mathrm{A} / \mathrm{cm}^{2}\right]$

Figura 178: Curvas de polarização do AIDs UNS S32304, S32205, S32550, S32750, S32760 submetido a tratamentos térmicos a $1350^{\circ} \mathrm{C}$ por 5 e $10 \mathrm{~s}$. 
A afirmação de ser a precipitação da $\gamma_{2}$ intragranular a responsável pela queda no PPit no AID UNS S32304 é reforçada pela observação dos pites no MO. Como é mostrado na Figura 179 , os pites se formaram preferencialmente nas colônias de $\gamma_{2}$ intragranular.

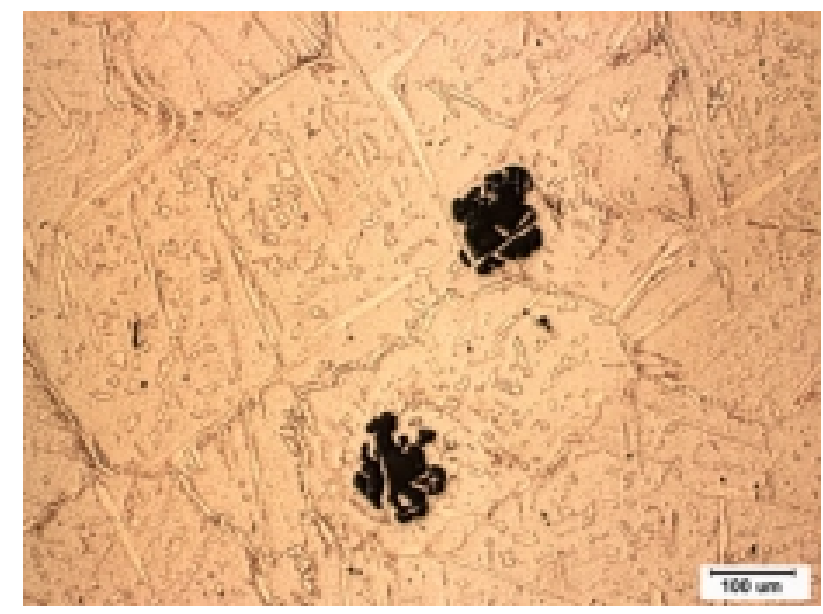

$1000^{\circ} \mathrm{C}$ por $1 \mathrm{~s}$

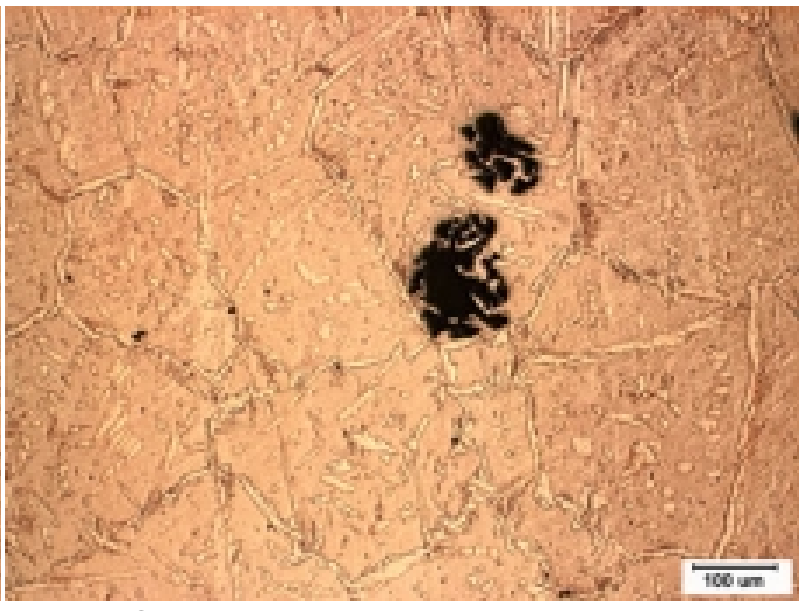

$1100{ }^{\circ} \mathrm{C}$ por $1 \mathrm{~s}$

Figura 179: Aparência dos pites formados nos ensaios de polarização cíclica nos CPs submetidos a tratamento térmicos de reaquecimento no AID UNS S32304.

No caso dos tratamentos a $1100^{\circ} \mathrm{C}$ por $1 \mathrm{~s}$, registrou-se um PPit bastante baixo. Neste caso teve-se tambem uma razoável precipitação de $\gamma_{2}$ intragranular. O tratamento por $10 \mathrm{~s}$ nesta mesma temperatura levou a uma importante recuperação no PPit do material, mas as $\gamma_{2}$ intragranulares cresceram. Desta forma, verifica-se que não é simples presença das $\gamma_{2}$ intragranulares que leva a uma diminuição do PPit e sim a sua composição química. Portanto, o que deve ter acontecido durante este TT mais longo foi uma certa mudança na composição química da $\gamma_{2}$ ou da matriz ferrítica ao seu redor, de tal forma que o material tornou-se mais resistente à corrosão por pites.

Os TTs a $1200{ }^{\circ} \mathrm{C}$ por 1 e $10 \mathrm{~s}$ levaram ao aumento do PPit deste material. O tempo de tratamento não teve influência no PPit, o que pode estar relacionado com a elevada difusividade e cínetica das trasnformações nesta temperatura.

Na Figura 180 são apreentadas as curvas de polarização, correspondentes aos TT de reaquecimento do AID UNS S32304. Verifica-se que não se teve uma mudança no formato destas curvas com os tratamentos de reaquecimento.

UNS S32205: Nos TTs a $900{ }^{\circ} \mathrm{C}$ teve-se um leve aumento na fração de $\gamma$, mas não se teve recuperação no PPit. Já após o TT a $1000{ }^{\circ} \mathrm{C}$ por $1 \mathrm{~s}$ teve-se uma importante precitação de $\gamma_{2}$ intragranular e, similar ao AID UNS S32304, isto coincidiu com uma queda razoável no PPit do material. Porém, após o tratamento por $10 \mathrm{~s}$ nesta mesma temperatura o material recuperou em parte o PPit. Acredita-se que esta recuperação também esteja relacionada com a redistribuição de elementos químicos e com a total disolução dos nitretos de cromo. 


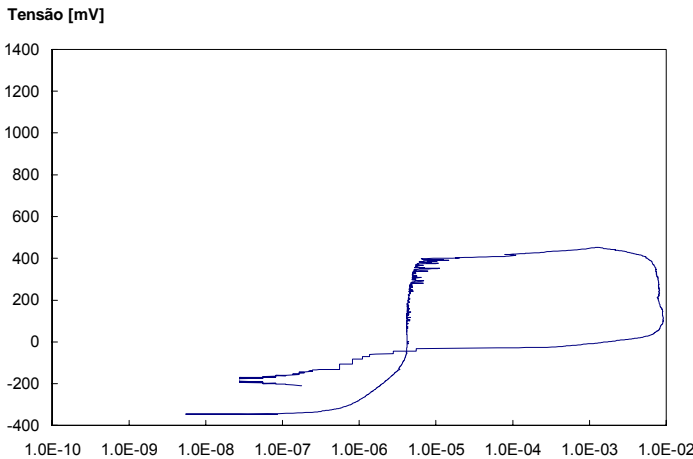

UNS \$32304 - 900x1

Tensão [mV]

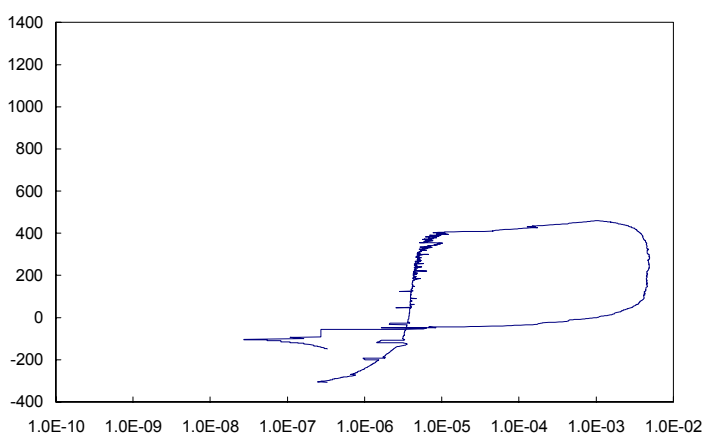

UNS S32304 - 1000x1

Corrente/Área $\left[\mathbf{A} / \mathrm{cm}^{2}\right]$

Tensão [mV]

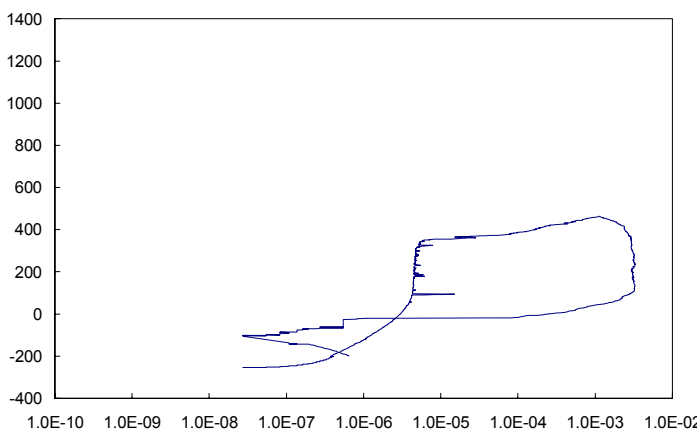

UNS \$32304 - 1100x1

Corrente/Área $\left[\mathrm{A} / \mathrm{cm}^{2}\right]$

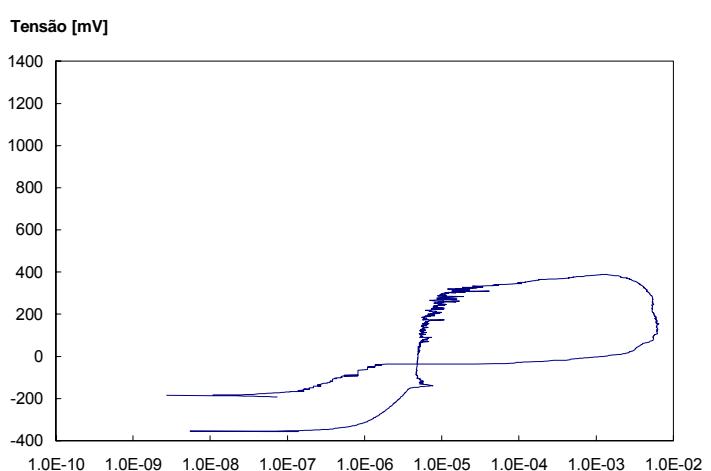

UNS S32304 - 1200x1
Tensão [mV]

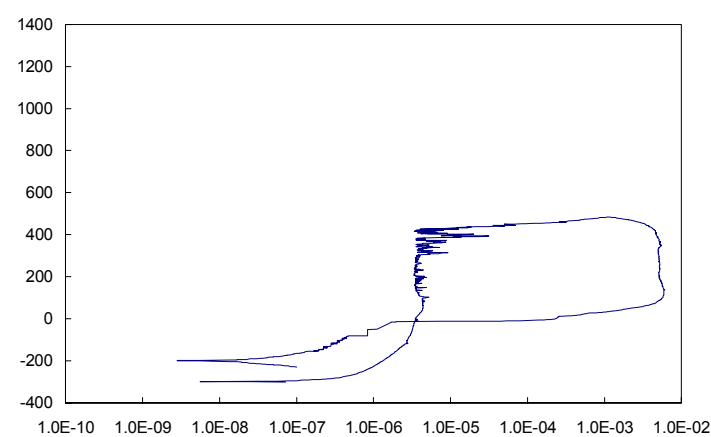

UNS \$32304 - 900×10

Corrente/Área $\left[\mathrm{A} / \mathrm{cm}^{2}\right]$

Tensão [mV]

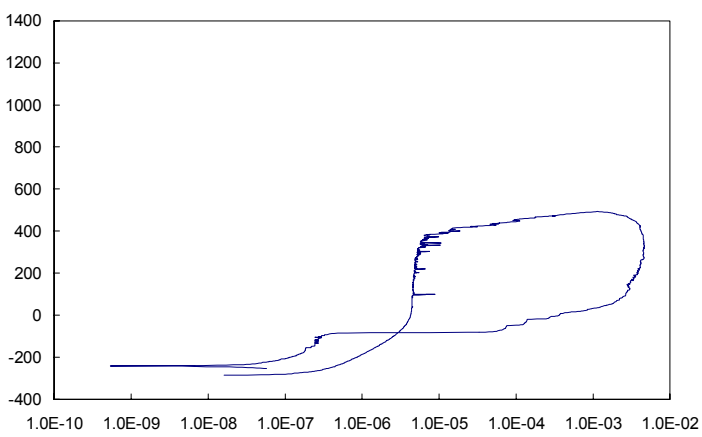

UNS S32304 - 1000×10

Corrente/Área $\left[\mathrm{A} / \mathrm{cm}^{2}\right]$

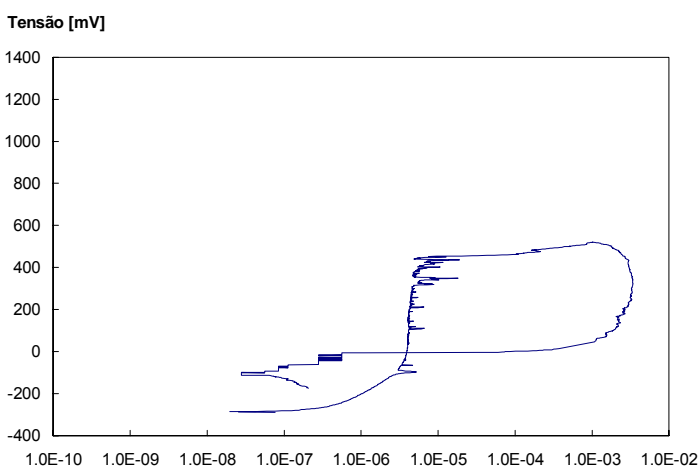

UNS S32304 - 1100x10

Corrente/Área $\left[\mathrm{A} / \mathrm{cm}^{2}\right]$

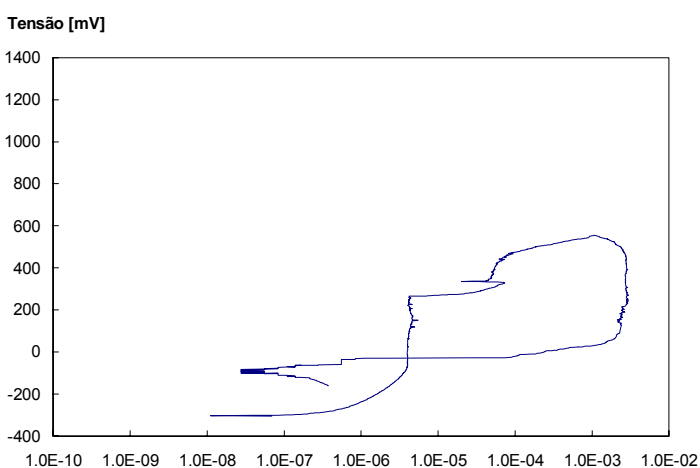

UNS S32304 - 1200x10

Figura 180: Curvas de polarização do AID UNS S32304 submetido a tratamentos térmicos de reaquecimento. 
Na Figura 181 são mostrados alguns dos pites formados durante os ensaios desta liga a $1000{ }^{\circ} \mathrm{C}$, onde observou-se uma profusa formação de $\gamma_{2}$ intragranular. Como pode ser visto, os pites são formados preferencialmente no interior dos grãos ferríticos, que é onde se encontram tanto os nitretos como as colônias de $\gamma_{2}$ intragranular.

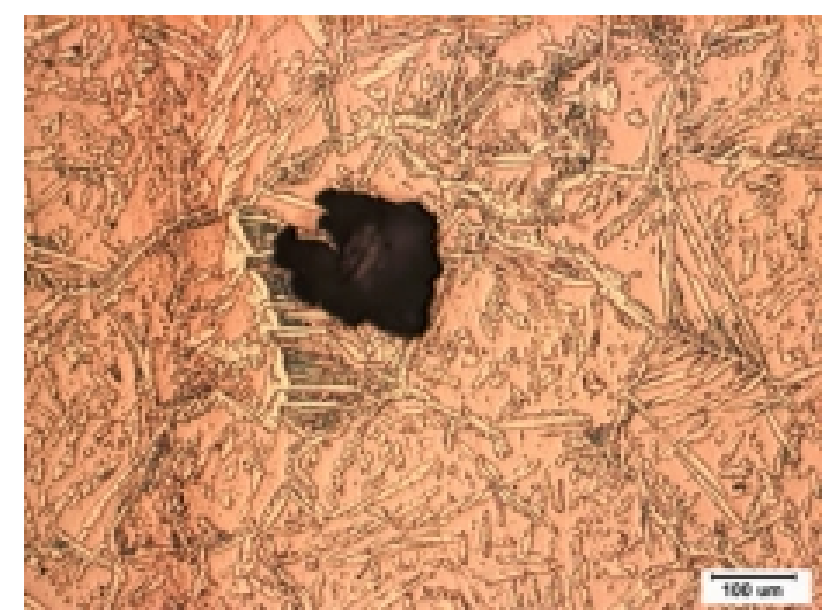

$1000^{\circ} \mathrm{C}$ por $1 \mathrm{~s}$

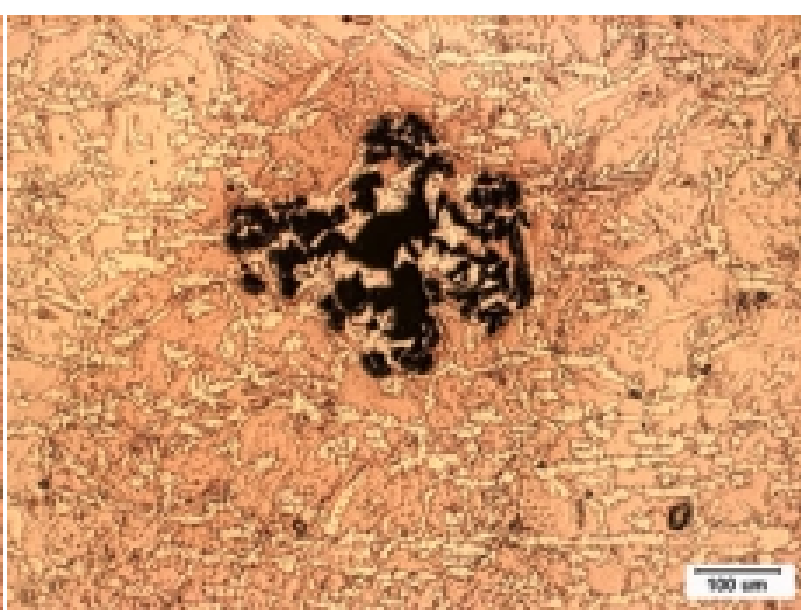

$1000^{\circ} \mathrm{C}$ por $10 \mathrm{~s}$

Figura 181: Aparência dos pites formados nos ensaios de polarização cíclica nos CPs submetidos a tratamento térmicos de reaquecimento no AID UNS S32205.

Os TTs a 1100 e $1200{ }^{\circ} \mathrm{C}$ levaram a uma importante recuperação no PPit do material, chegando ao $70 \%$ do valor alcançado pelo metal de base. Esta melhora está relacionada com o aumento da fração de $\gamma$, a dissolução dos nitretos e a redistribuição de elementos químicos.

Com relação as curvas de polarização dos ensaios no AID UNS S32205, mostradas na Figura 182, também não se teve mudanças importantes no formato destas curvas.

UNS S32550: Os tratamentos a $900{ }^{\circ} \mathrm{C}$ não causaram quase nenhuma mudança na microestrutura deste liga, mas levaram a um incremento no PPit, que deve estar relacionada com a redistribuição dos elementos de liga, principalmente ao redor do nitretos. Pela sua parte os TTs a 1000 e $1100{ }^{\circ} \mathrm{C}$ levaram a uma recuperação quase total do PPit do material com relação à sua condição como-recebido, o que está relacionado com o crescimento da fração de $\gamma$, a dissolução dos nitretos, a baixa precipitação de $\gamma_{2}$ intragranular e a redistribuição dos elementos de liga. Já no caso do tratamento a $1200^{\circ} \mathrm{C}$, a queda na fração final de $\gamma$ levou a uma conseqüente queda no PPit do material.

Os pites formados nesta liga foram bem menores e em menor quantidade que no caso dos dois AIDs anteriormente tratados. Na Figura 183 são mostrados alguns dos maiores pites formados nesta liga. 


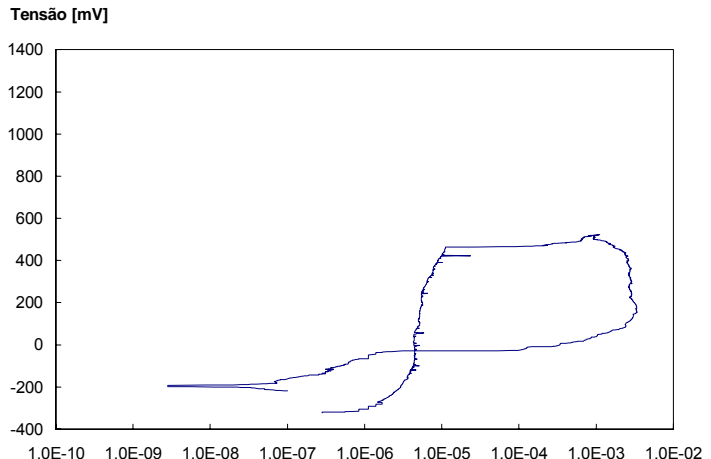

UNS S32205 - 900x1

Tensão [mV]

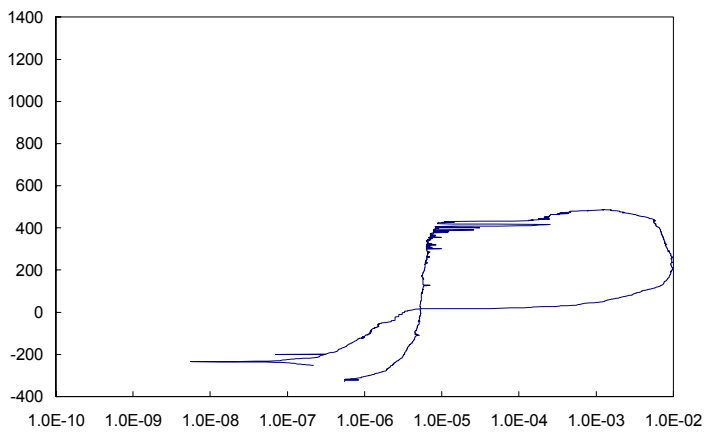

UNS S32205 - 1000x1

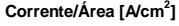

Tensão [mV]

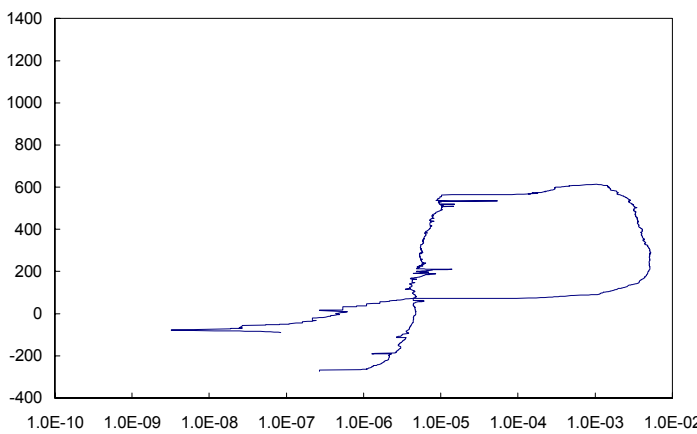

UNS S32205 - 1100x1

Corrente/Área $\left[\mathrm{A} / \mathrm{cm}^{2}\right]$

\section{Tensão [mV]}

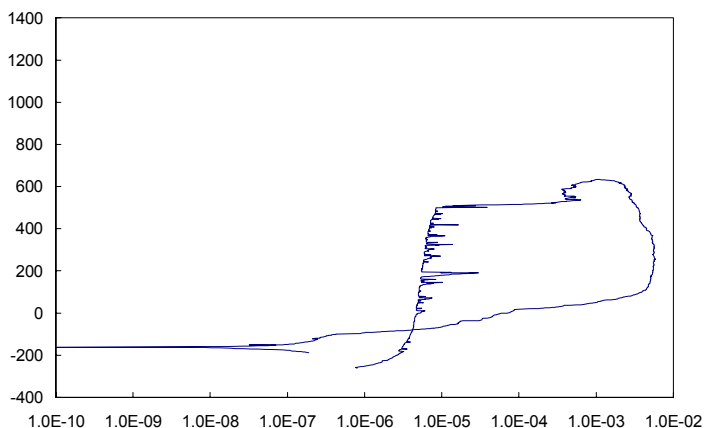

UNS S32205 - 1200x 1

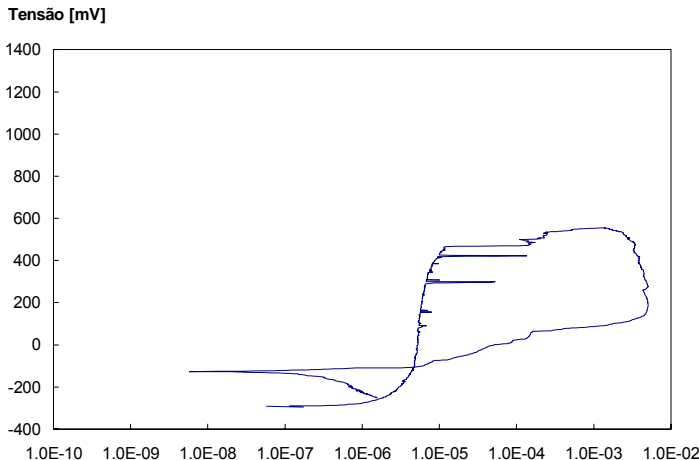

UNS S32205 - 900x10

Corrente/Área $\left[\mathrm{A} / \mathrm{cm}^{2}\right]$

Tensão [mV]

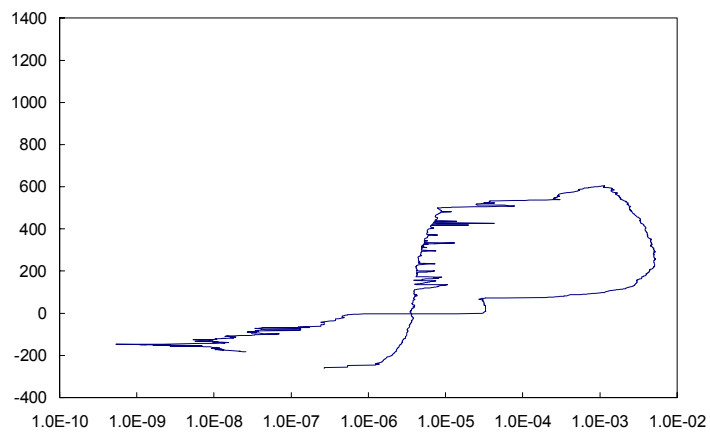

UNS S32205 - 1000x10

Corrente/Área $\left[\mathrm{A} / \mathrm{cm}^{2}\right]$

Tensão [mV]

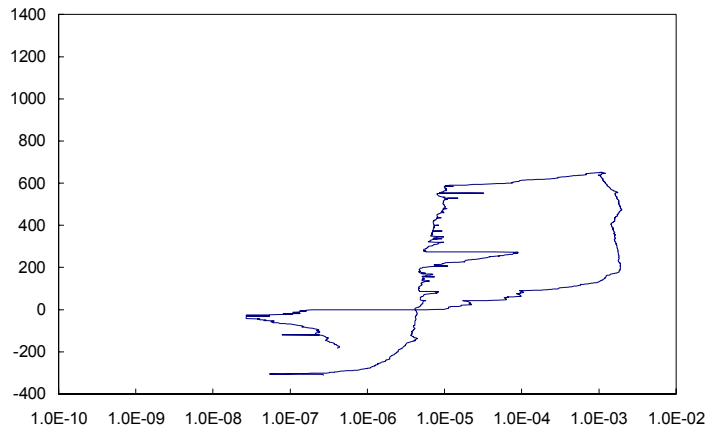

UNS S32205 - 1100×10

Corrente/Área $\left[\mathrm{A} / \mathrm{cm}^{2}\right]$

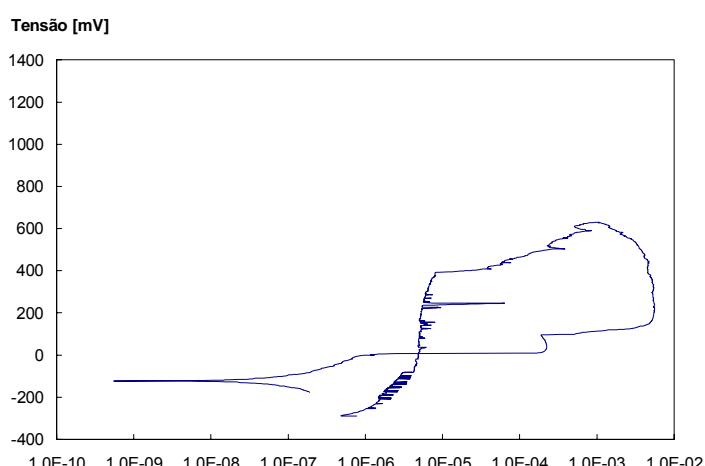

UNS S32205 - 1200x10

Corrente/Área $\left[\mathrm{A} / \mathrm{cm}^{2}\right]$

Figura 182: Curvas de polarização do AID UNS S32205 submetido a tratamentos térmicos de reaquecimento. 


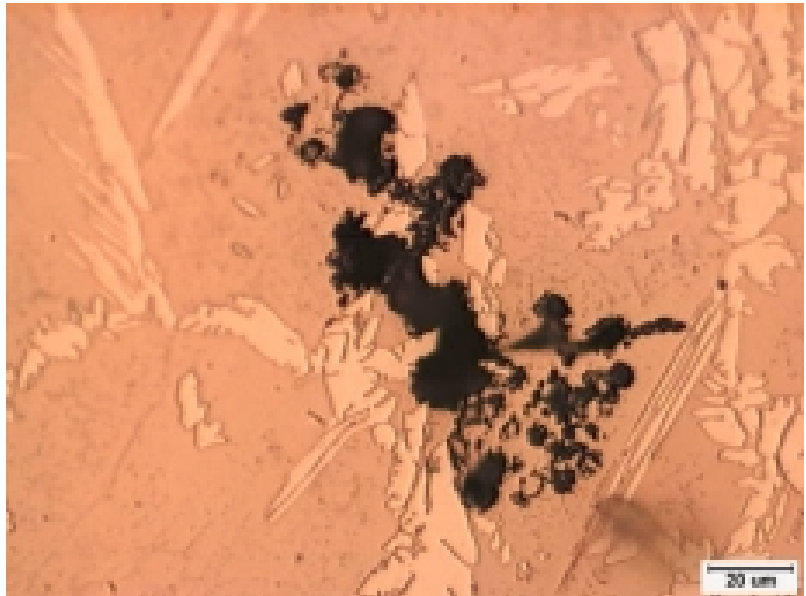

$900{ }^{\circ} \mathrm{C}$ por $1 \mathrm{~s}$

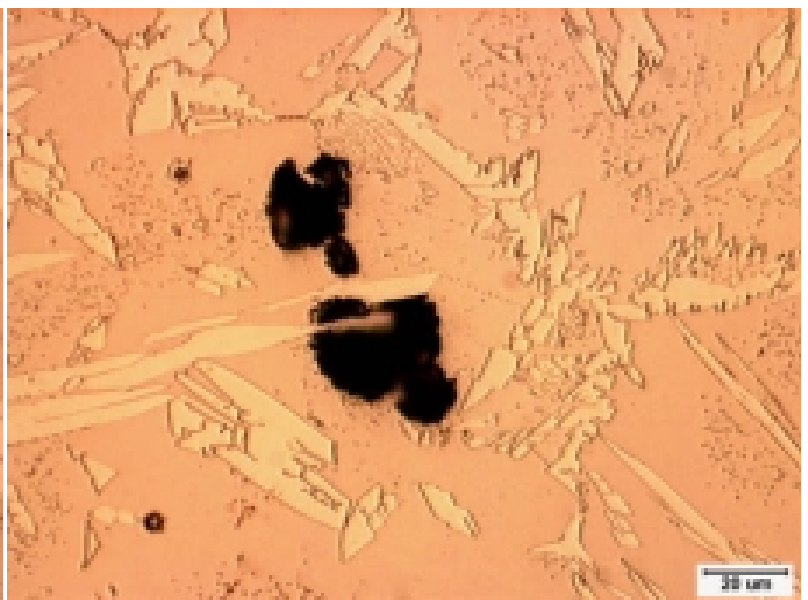

$1000^{\circ} \mathrm{C}$ por $1 \mathrm{~s}$

Figura 183: Aparência dos pites formados nos ensaios de polarização cíclica nos CPs submetidos a tratamento térmicos de reaquecimento no AID UNS S32550.

As curvas de polarização correspondentes ao AISD UNS S32550 apresentaram um formato bastante diferente do apresentado pelas curvas dos dois AIDs previamente discutidos. Para as condições em que se teve os menores PPit $\left(900^{\circ} \mathrm{C}\right.$ por $1 \mathrm{~s} \mathrm{e} 1200^{\circ} \mathrm{C}$ por $\left.10 \mathrm{~s}\right)$ registrouse uma curva similar à apresentada após o TT a $1350{ }^{\circ} \mathrm{C}$. No restante dos casos as curvas de potencial são similares as do material no estado como-recebido. Comportamento que era de se esperar, pois nestes casos se atingiram PPit bastante próximos.

UNS S32750: Para todos o tratamentos obteve-se uma recuperação do PPit do material para o seu estado como-recebido. Isto é explicado pelas elevadas frações de $\gamma$ obtidas neste material para todos os tratamentos térmicos o qual pela sua vez leva a quantidades mínimas de nitretos.

O TT neste material que levou a maior precipitação de $\gamma_{2}$ intragranular foi a $1000{ }^{\circ} \mathrm{C}$ por $10 \mathrm{~s}$. Porém, não foi identificada nenhuma influência prejudicial desta $\gamma_{2}$ intragranular no PPit destes CPs. Deve-se chamar a atenção que neste caso, esta fase precipitou em tempos de TT mais longos. Portanto, teve-se mais tempo para a difusão, com o qual a composição química das $\gamma_{2}$ intragranulares ou da matriz ao redor delas chegou a ser tal que, a resistência a corrosão por pites não foi prejudicada. Este resultado indica que não é a presença da $\gamma_{2}$ intragranular que prejudica a resistência à corrosão por pites dos AIDs e sim deve ser a sua composição química ou à da matriz ao redor dela, nos estágios iniciais da sua precipitação. 


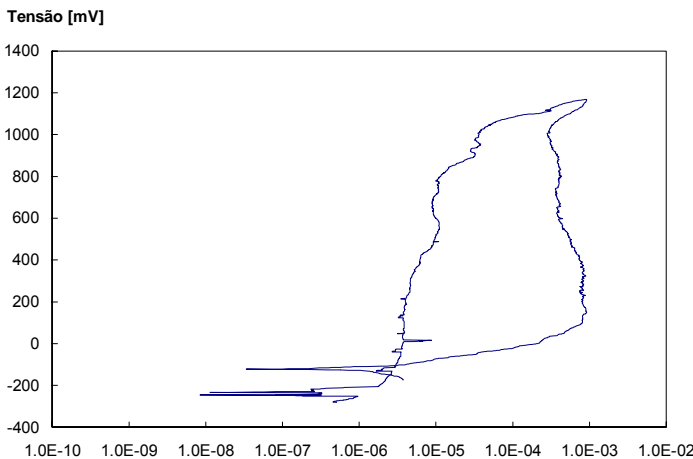

UNS S32550 - 900x1

Tensão [mV]

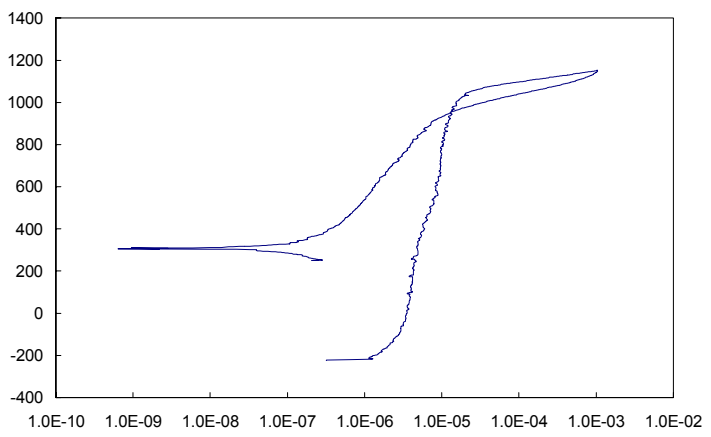

UNS S32550 - 1000x1

Corrente/Área $\left[\mathrm{A} / \mathrm{cm}^{2}\right]$

Tensão [mV]

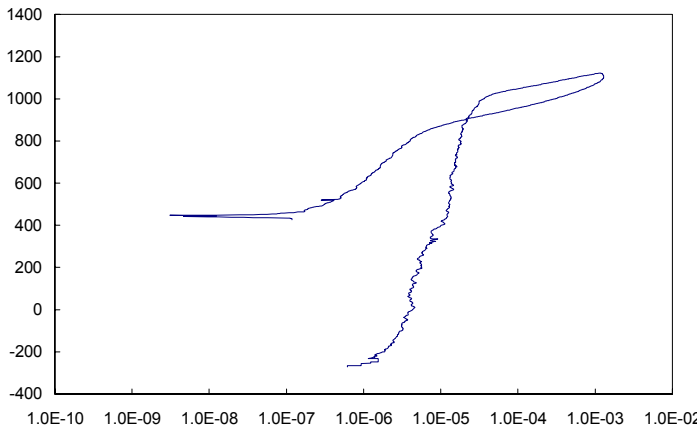

UNS S $32550-1100 \times 1$

Corrente/Área $\left[\mathrm{A} / \mathrm{cm}^{2}\right]$

Tensão [mV]

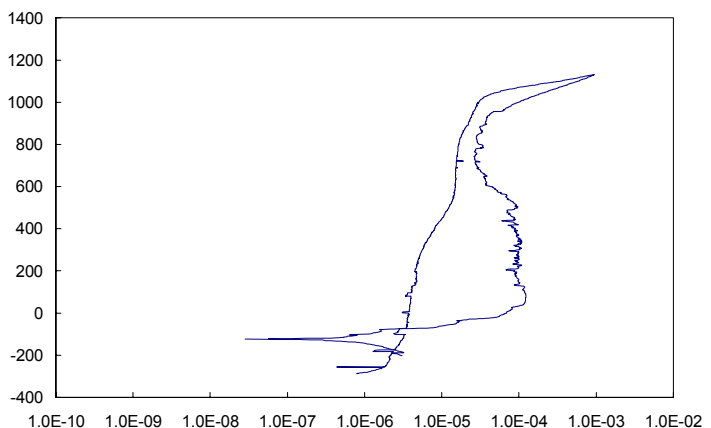

UNS S32550 - 1200x1
Tensão [mV]

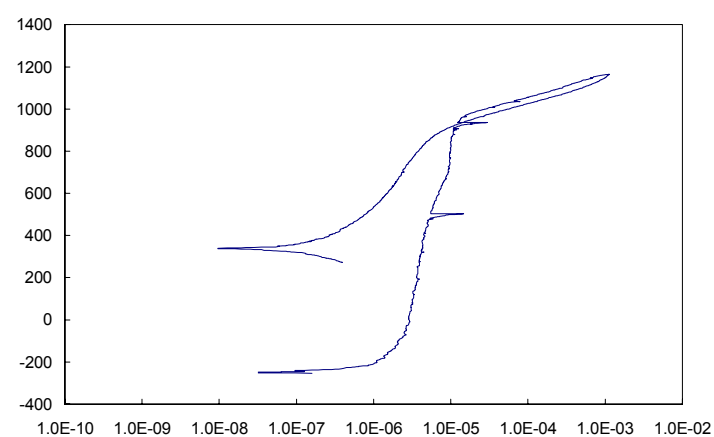

UNS S32550 - 900×10

Corrente/Área $\left[\mathbf{A} / \mathrm{cm}^{2}\right]$

Tensão [mV]

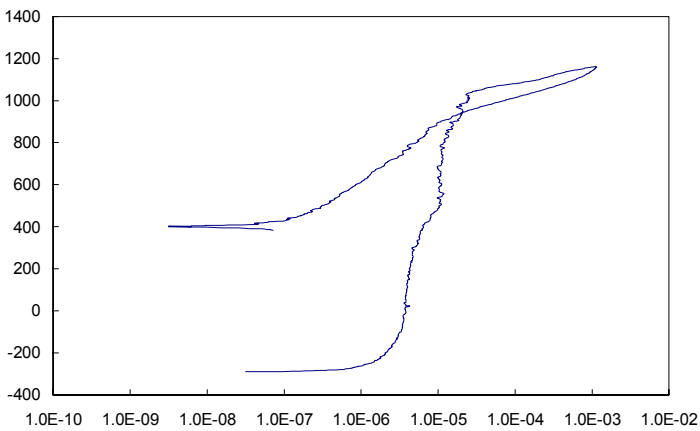

UNS S32550 - 1000×10

Corrente/Área [A/cm $\left.{ }^{2}\right]$

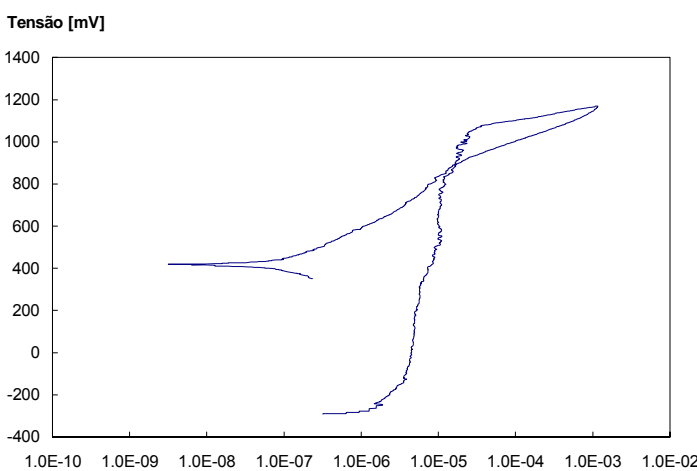

UNS S32550 - 1100×10

Corrente/Área $\left[\mathrm{A} / \mathrm{cm}^{2}\right]$

Tensão [mV]

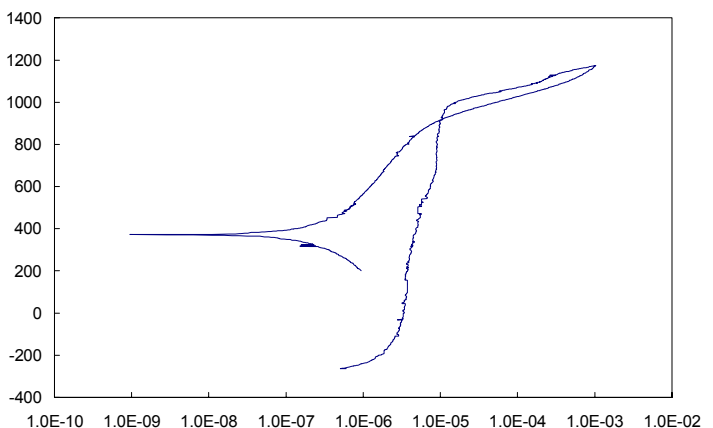

UNS S32550 - 1200x10

Corrente/Área $\left[\mathrm{A} / \mathrm{cm}^{2}\right]$

Figura 184: Curvas de polarização do AID UNS S32550 submetido a tratamentos térmicos de reaquecimento. 
Portanto se a $\gamma_{2}$ intragranular tiver tempo para homogeneizar a sua composição química e a da matriz ao seu redor, o seu efeito prejudicial na resistência à corrosão do material pode ser evitado e, desta forma, será possível utilizar as suas vantagens para aumentar a fração total de $\gamma$ e reduzir o conteúdo de nitretos do material. Assim, são beneficiadas tanto a resistência à corrosão como a tenacidade.

Durante os testes de corrosão destes materiais formaram-se pites bastante pequenos e em pouca quantidade. Na Figura 185 são mostrados alguns destes pites.

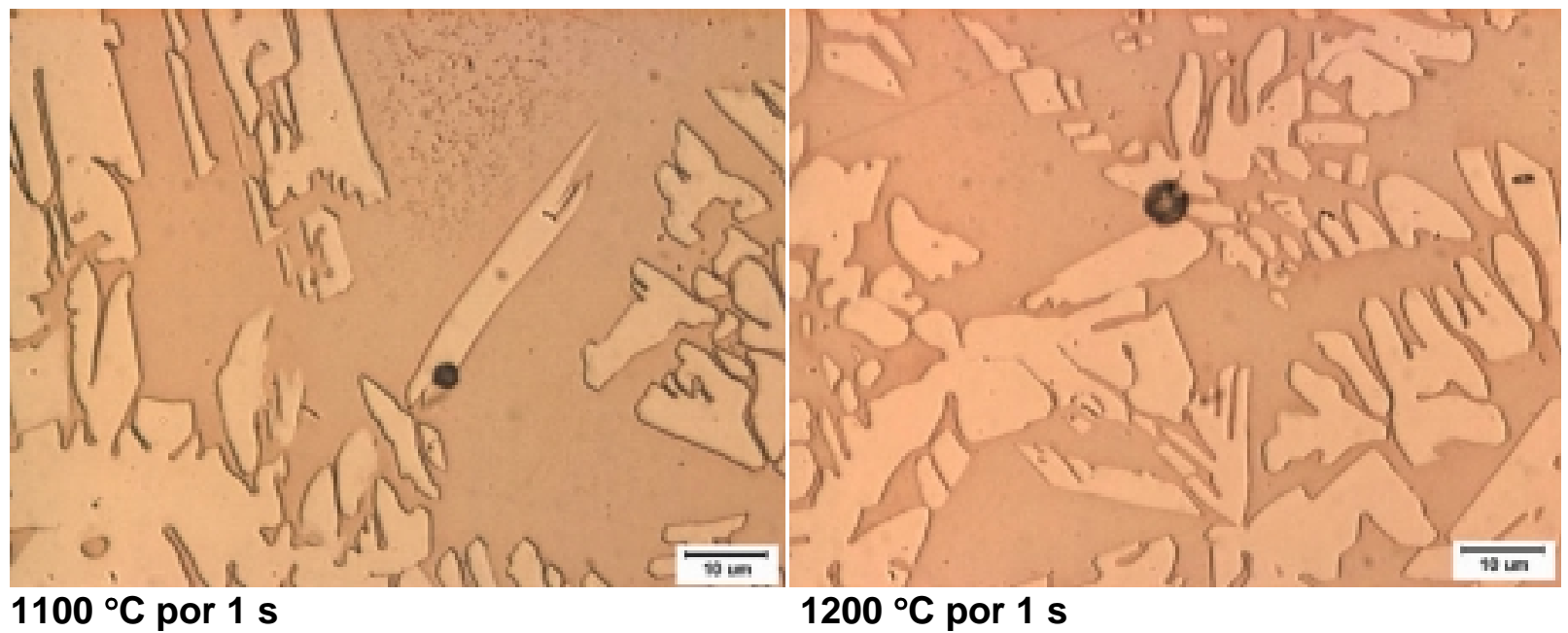

Figura 185: Aparência dos pites formados nos ensaios de polarização cíclica nos CPs submetidos a tratamento térmicos de reaquecimento no AID UNS S32750.

Na Figura 187 são mostradas as curvas de polarização correspondentes aos testes com o material UNS S32750. Como pode ser visto nesta figura, todas as curvas, com exceção de duas, apresentam um formato igual à curva do teste deste mesmo material no estado comorecebido. Este comportamento é esperado devido à recuperação quase total do PPit, causada por estes tratamentos. Quanto às curvas correspondentes aos TTs a 900 e $1200{ }^{\circ} \mathrm{C}$ por $1 \mathrm{~s}$, o seu formato é um pouco diferente. São estes mesmos CPs os que apresentam uma maior quantidade de nitretos, o qual pode estar relacionado com o formato diferente das curvas.

UNS S32760: Os TTs neste material levaram a um aumento considerável da fração de $\gamma$, porém, menor que o observado no UNS S32750. Consequentemente, teve-se uma recuperação total do PPit, se comparado com o do material no estado como-recebido. A única condição que apresentou um PPit um pouco menor foi o $\mathrm{CP}$ tratado a $900{ }^{\circ} \mathrm{C}$ por $1 \mathrm{~s}$. Este comportamento que deve estar relacionado com a baixa fração de $\gamma$ e grande quantidade de nitretos tanto intragranulares como intergranulares. Chama a atenção o CP 
tratado a $1000{ }^{\circ} \mathrm{C}$ por $1 \mathrm{~s}$, no qual não se teve aumento nenhum na fração de $\gamma$, mas foi observada uma recuperação total do PPit, o que pode ser explicado pela diminuição na quantidade de nitretos e pela redistribuição dos elementos de liga.

No CP tratado a $1100{ }^{\circ} \mathrm{C}$ por $1 \mathrm{~s}$, teve-se uma importante precipitação de $\gamma_{2}$ intragranular, mas o PPit foi o mesmo do material no estado como-recebido. Poderia-se pensar que isto contradiz o anteriormente exposto quanto à susceptibilidade à corrosão da microestrutura que apresenta $\gamma_{2}$ intragranular no seu estágio inicial de precipitação. No entanto, isto só reforça o anteriormente exposto, neste caso, a transformação aconteceu numa temperatura mais elevada e, portanto, não foram necessários tempos longos para a redistribuição dos elementos de liga na $\gamma_{2}$ e/ou na matriz, de modo que a resistência à corrosão fosse recuperada. Assim, verifica-se de novo, como a simples presença da $\gamma_{2}$ intragranular pode não ser prejudicial para a resistência à corrosão do material. Neste estudo ela se mostrou prejudicial no estágio inicial de precipitação, quando isto acontece em temperaturas suficientemente baixas, para que a redistribuição de elementos de liga seja dificultada.

Os pites formados neste material foram pequenos, mas ainda bem maiores que os formados no AISD UNS S32750. Na Figura 186 são mostrados alguns dos pites formados no AISD UNS S32760.

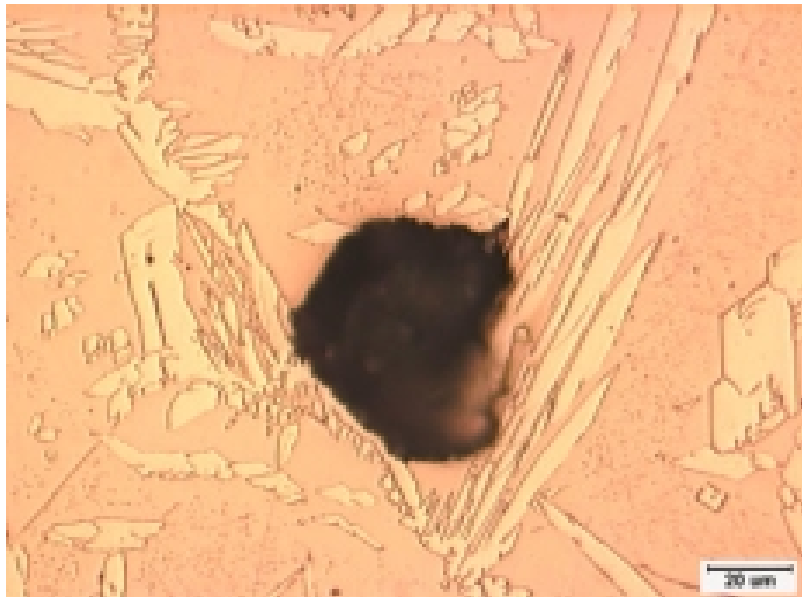

$900{ }^{\circ} \mathrm{C}$ por $1 \mathrm{~s}$

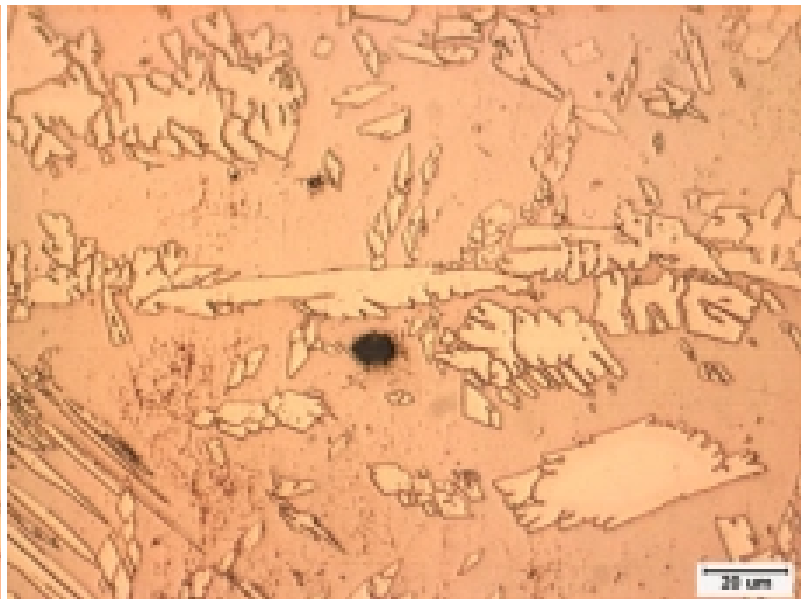

$1100{ }^{\circ} \mathrm{C}$ por $1 \mathrm{~s}$

Figura 186: Aparência dos pites formados nos ensaios de polarização cíclica nos CPs submetidos a tratamento térmicos de reaquecimento no AID UNS S32760.

Todas as curvas de polarização dos CPs reaquecidos do UNS S32760, mostradas na Figura 188 , apresentaram o mesmo formato das curvas de polarização do material quando testado no estado como-recebido, o que era de esperar devido à total recuperação da resistência à corrosão por pites. 


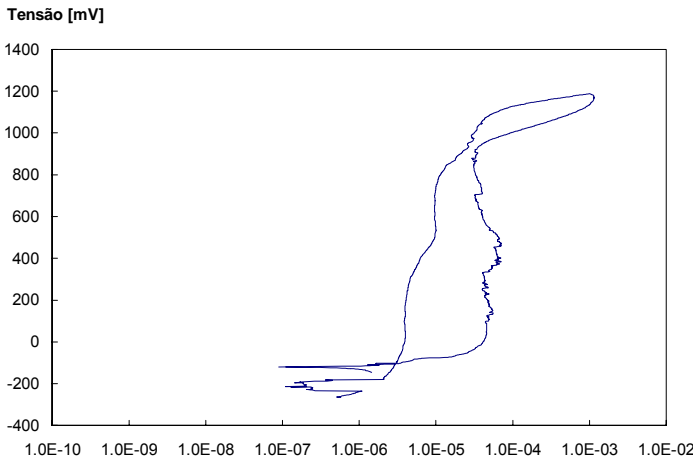

UNS S32750 - 900x1

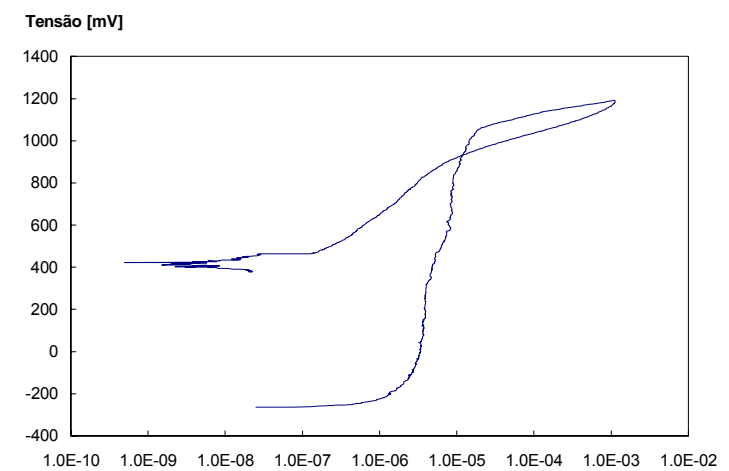

UNS S32750 - 1000x1

Corrente/Área $\left[\mathrm{A} / \mathrm{cm}^{2}\right]$

Tensão [mV]

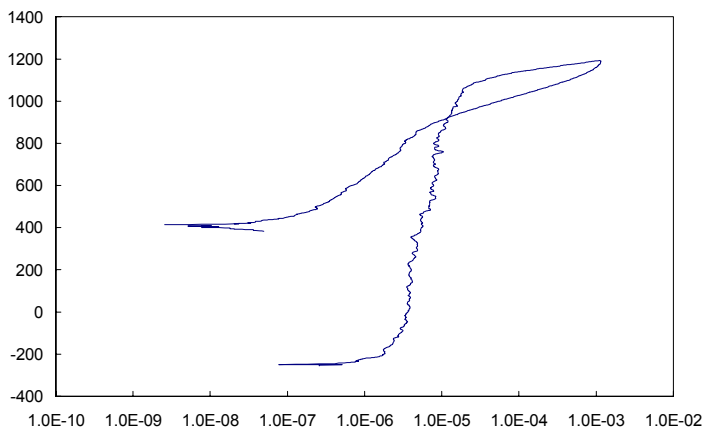

UNS S32750 - 1100x1

Corrente/Área $\left[\mathrm{A} / \mathrm{cm}^{2}\right]$

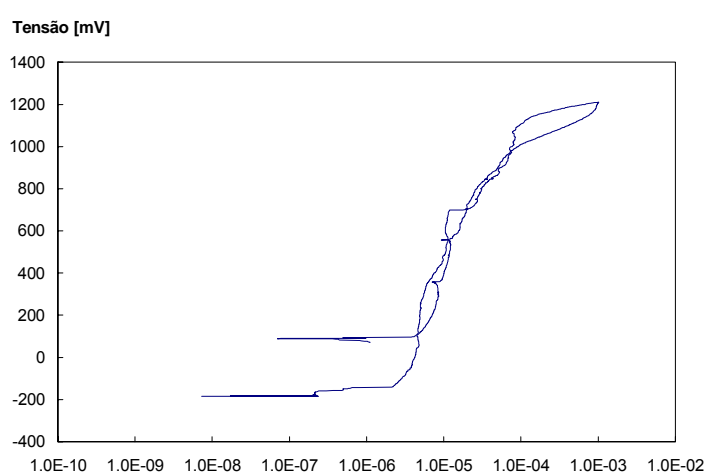

UNS $\$ 32750$ - 1200x1

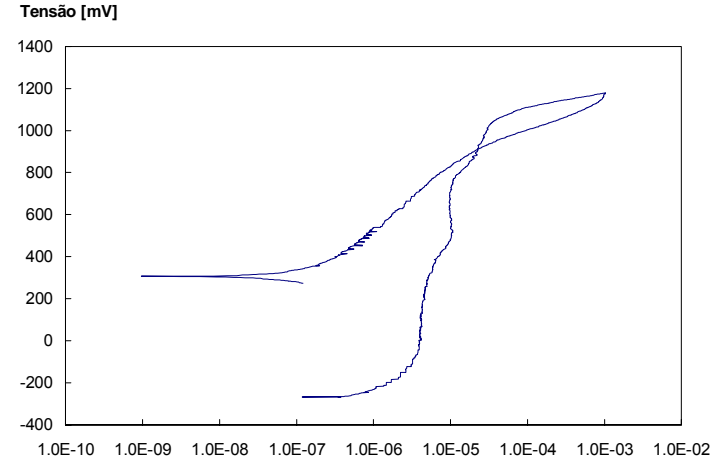

UNS $\$ 32750$ - 900x10

Corrente/Área $\left[\mathbf{A} / \mathrm{cm}^{2}\right]$

Tensão [mV]

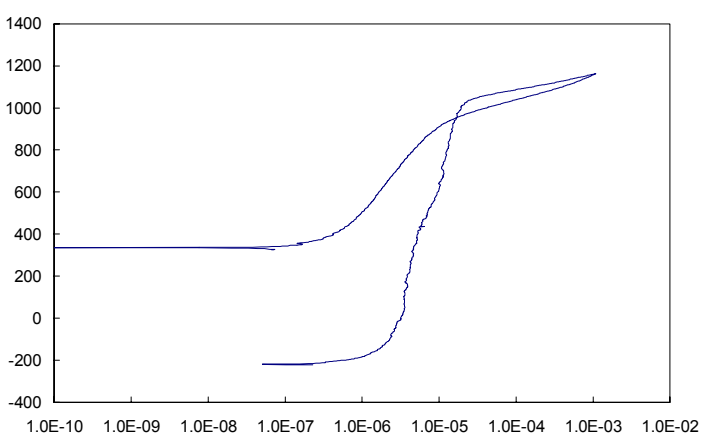

UNS S32750 - 1000x10

Corrente/Área $\left[\mathrm{A} / \mathrm{cm}^{2}\right]$

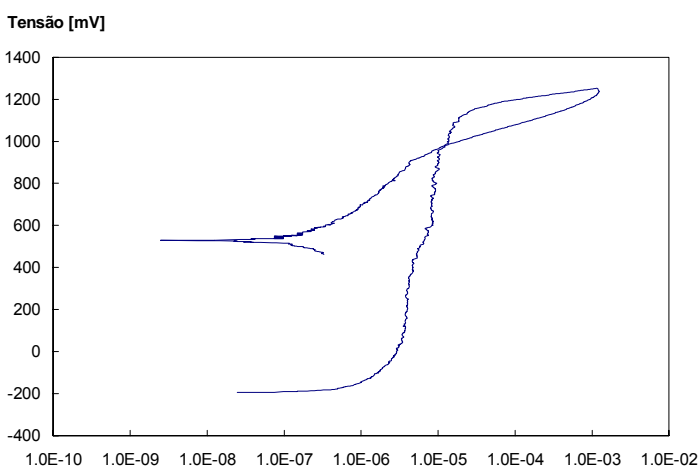

UNS S32750 - 1100x10

Corrente/Área $\left[\mathrm{A} / \mathrm{cm}^{2}\right]$

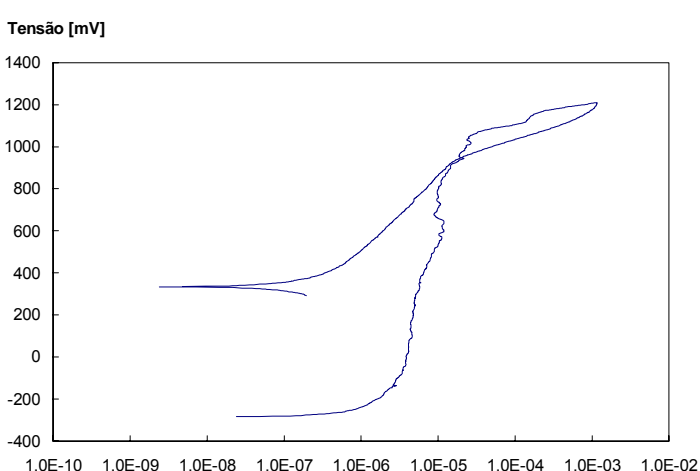

UNS S32750 - 1200x10

Corrente/Área $\left[\mathrm{A} / \mathrm{cm}^{2}\right]$

Figura 187: Curvas de polarização do AID UNS S32750 submetido a tratamentos térmicos de reaquecimento. 


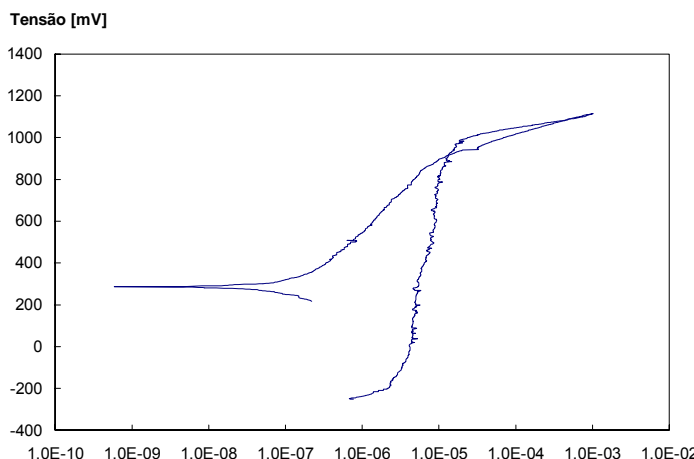

UNS $\$ 32760$ - 900x1

Tensão [mV]

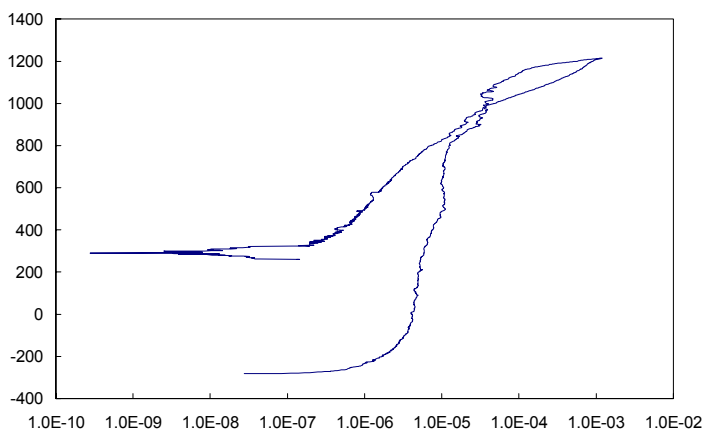

UNS S32760 - 1000x1

Corrente/Área [A $\left.\mathrm{Acm}^{2}\right]$

Tensão [mV]

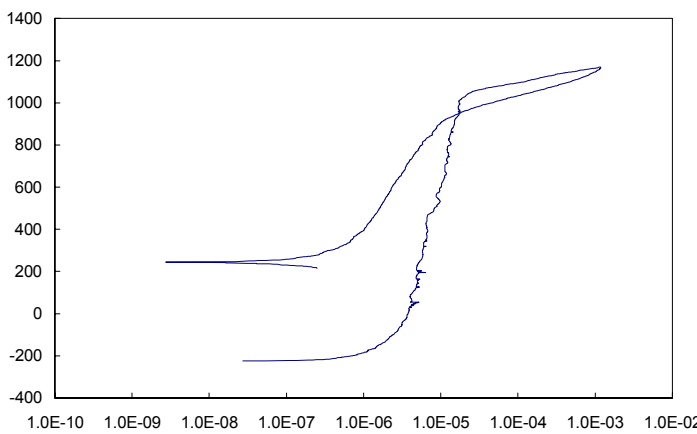

UNS S32760 - 1100x1

Corrente/Área $\left[\mathrm{A} / \mathrm{cm}^{2}\right]$

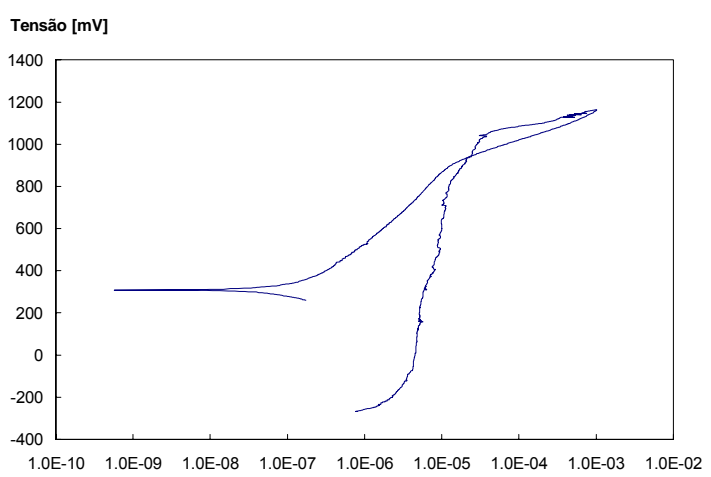

UNS $\mathrm{S} 32760$ - 1200x1

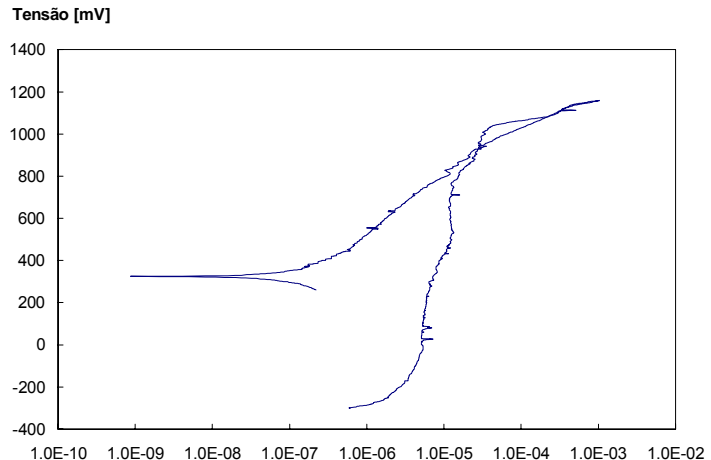

UNS $\$ 32760$ - 900x10

Corrente/Área $\left[\mathrm{A} / \mathrm{cm}^{2}\right]$

Tensão [mV]

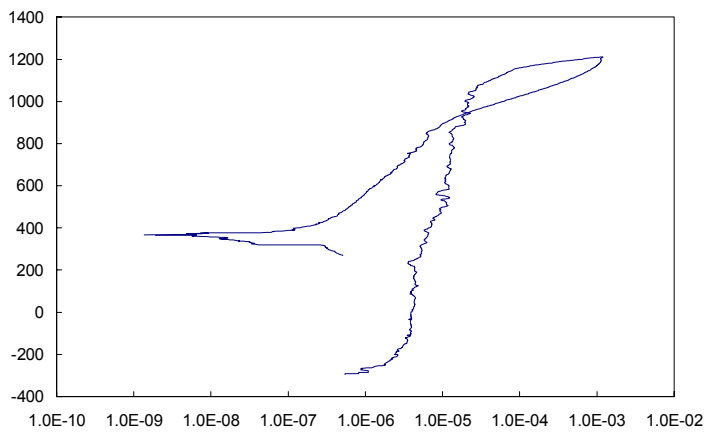

UNS S32760 - 1000×10

Corrente/Área $\left[\mathrm{A} / \mathrm{cm}^{2}\right]$

Tensão [mV]

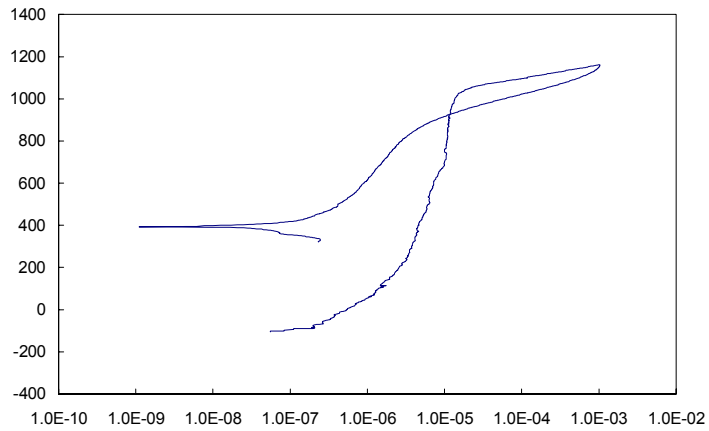

UNS S32760 - 1100×10

Corrente/Área $\left[\mathrm{A}_{\mathrm{cm}} \mathrm{cm}^{2}\right]$

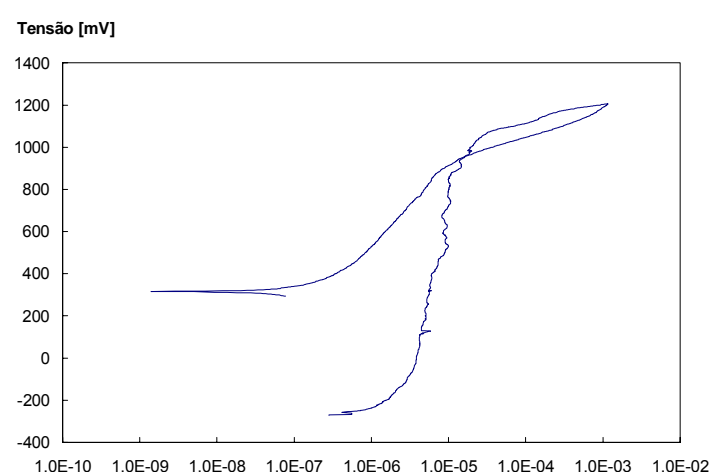

UNS $\$ 32760$ - 1200×10

Corrente/Área $\left[\mathrm{A} / \mathrm{cm}^{2}\right]$

Figura 188: Curvas de polarização do AID UNS $\$ 32760$ submetido a tratamentos térmicos de reaquecimento. 
Resumindo, os dois AIDs (UNS S32304 e S32205) tiveram um comportamento similar, não obtendo-se a recuperação total do PPit após os TTs de reaquecimento e sofreram o que pareceu ser o efeito adverso dos estágios iniciais da precipitação da $\gamma_{2}$ intragranular em temperaturas mais baixas $\left(1000^{\circ} \mathrm{C}\right.$ ). Do outro lado, os três AISDs (UNS S32550, S32750 e S32760) mostraram uma recuperação quase total do PPit após os TTs de reaquecimento.

Verificou-se também que o simples crescimento da fração de $\gamma$ não garante a recuperação do PPit dos aços. O fenômeno que parece ter uma maior influência no aumento da resistência à corrosão localizada do material, é o crescimento da fração de $\gamma$, acompanhado da dissolução dos nitretos e da redistribuição dos elementos de liga.

Quanto aos pites observados, verificou-se que a fase que dissolveu preferencialmente foi a ferrita. Esta fase apresenta teores maiores de $\mathrm{Cr}$ e Mo do que a austenita, porém o elevado teor de nitrogênio da austenita é suficiente para faze-la a fase mas resistente à corrosão. A nucleação dos pites pareceu ter acontecido nas interfaces $\alpha / \gamma$, como mostrado na Figura 185.

\subsubsection{Materiais Submetidos à Simulação da ZACTE}

Os CPs correspondentes à região da raiz da ZACTE, também foram submetidos ao teste de polarização cíclica, sob as mesmas condições que os materiais no estado como-recebido e tratados termicamente. Estes testes visaram verificar o verdadeiro efeito da soldagem multipasse na resistência à corrosão por pites da ZACTE.

Foram realizados seis testes para cada condição e foram descartados os testes com os maiores e menores valores de PPit. $\mathrm{Na}$ Tabela 50 são apresentadas as médias dos resultados obtidos. Como pode ser visto na tabela, os resultados foram submetidos a teste de variância (nível de significância de 1\%) para determinar se existem diferenças estatisticamente relevantes entre as médias apresentadas. Nesta tabela, o fator de variância (F) é apresentado em azul quando as médias são diferentes e em vermelho quando estas são iguais. Assim, verifica-se que a única mudança estatisticamente significativa foi sofrida pelo AISD UNS S32550 quando soldado com uma energia de $1,0 \mathrm{~kJ} / \mathrm{mm}$, tendo-se um importante aumento do potencial de pite do primeiro para o terceiro passe.

No caso do potencial de proteção (PProt), os resultados foram tão aleatórios que não se considerou pertinente submeter estes a testes de variância. Deve-se ressaltar que este comportamento dos resultados do PProt não é incomum.

Na Tabela 51 são apresentados os resultados de PPit em termos relativos ao PPit de cada liga no seu estado como-recebido. Desta forma são mais facilmente visualizadas as mudanças. 
Tabela 50: Potenciais de pite e proteção (ECS) dos materiais submetidos a simulação térmica. Ensaio de polarização cíclica.

\begin{tabular}{|c|c|c|c|c|c|c|c|c|}
\hline \multirow{3}{*}{$\begin{array}{c}\text { Designação } \\
\text { UNS }\end{array}$} & \multicolumn{5}{|c|}{ Potencial de Pite [mV] } & \multicolumn{3}{|c|}{ Potencial de Proteção [mV] } \\
\hline & \multirow{2}{*}{$\begin{array}{l}\text { Como- } \\
\text { Recebido }\end{array}$} & \multirow[t]{2}{*}{ Passes } & \multicolumn{2}{|c|}{$\begin{array}{c}\text { Energia de Soldagem } \\
{[\mathrm{kJ} / \mathrm{mm}]}\end{array}$} & \multirow{2}{*}{$\begin{array}{c}\text { Anova } \\
\mathrm{F}\end{array}$} & \multirow{2}{*}{$\begin{array}{l}\text { Como- } \\
\text { Recebido }\end{array}$} & \multicolumn{2}{|c|}{$\begin{array}{c}\text { Energia de Soldagem } \\
{[\mathrm{kJ} / \mathrm{mm}]}\end{array}$} \\
\hline & & & 0,6 & 1,0 & & & 0,6 & 1,0 \\
\hline \multirow{3}{*}{ S32304 } & \multirow{3}{*}{$535 \pm 52$} & 1 & $436 \pm 58$ & $414 \pm 67$ & 0,24 & \multirow{3}{*}{$-65 \pm 66$} & $-67 \pm 12$ & $-151 \pm 15$ \\
\hline & & 3 & $461 \pm 37$ & $463 \pm 50$ & 0,01 & & $-154 \pm 45$ & $-91 \pm 58$ \\
\hline & & $\mathbf{F}$ & 0,55 & 1,33 & & & & \\
\hline \multirow{3}{*}{ S32205 } & \multirow{3}{*}{$796 \pm 76$} & 1 & $406 \pm 84$ & $448 \pm 49$ & 0,48 & \multirow{3}{*}{$-116 \pm 60$} & $-39 \pm 73$ & $-94 \pm 193$ \\
\hline & & 3 & $531 \pm 92$ & $631 \pm 95$ & 2,11 & & $-109 \pm 32$ & $-115 \pm 63$ \\
\hline & & $\mathbf{F}$ & 3,82 & 8,9 & & & & \\
\hline \multirow{3}{*}{ S32550 } & \multirow{3}{*}{$1065 \pm 44$} & 1 & $1033 \pm 56$ & $986 \pm 43$ & 1,69 & \multirow{3}{*}{$336 \pm 51$} & $-105 \pm 79$ & $-124 \pm 51$ \\
\hline & & 3 & $1040 \pm 14$ & $1074 \pm 24$ & 5,41 & & $393 \pm 104$ & $30 \pm 168$ \\
\hline & & $\mathbf{F}$ & 0,06 & 11,94 & & & & \\
\hline \multirow{3}{*}{ S32750 } & \multirow{3}{*}{$1069 \pm 70$} & 1 & $937 \pm 83$ & $998 \pm 31$ & 0,73 & \multirow{3}{*}{$122 \pm 116$} & $621 \pm 122$ & $564 \pm 114$ \\
\hline & & 3 & $1050 \pm 27$ & $1024 \pm 54$ & 1,82 & & $402 \pm 29$ & $372 \pm 176$ \\
\hline & & $\mathbf{F}$ & 6,74 & 0,67 & & & & \\
\hline \multirow{3}{*}{ S32760 } & \multirow{3}{*}{$1038 \pm 39$} & 1 & $1049 \pm 51$ & $1067 \pm 15$ & 0,44 & \multirow{3}{*}{$290 \pm 75$} & $-75 \pm 48$ & $-98 \pm 79$ \\
\hline & & 3 & $1054 \pm 57$ & $1066 \pm 56$ & 0,08 & & $170 \pm 207$ & $93 \pm 105$ \\
\hline & & $\mathbf{F}$ & 0,02 & 0,01 & & & & \\
\hline lota: & & & $\begin{array}{l}\text { NS S32205 } \\
\text { titico }=11,25\end{array}$ & $\begin{array}{l}50, \text { S327 } \\
\text { de signi }\end{array}$ & $\begin{array}{l}\text { S3276C } \\
\text { ia de } 1\end{array}$ & & & \\
\hline
\end{tabular}

Tabela 51: Fração do potencial de pite no estado como-recebido após o tratamento térmico a $1350^{\circ} \mathrm{C}$ e a simulação da ZACTE, para todas as ligas estudadas.

\begin{tabular}{|c|c|c|c|c|c|}
\hline \multirow{3}{*}{$\begin{array}{l}\text { Designação } \\
\text { UNS }\end{array}$} & \multicolumn{5}{|c|}{ Fração do Potencial de Pite no Estado Como-Recebido [\%] } \\
\hline & \multirow{2}{*}{$\begin{array}{l}\text { Como- } \\
\text { Recebido }\end{array}$} & \multirow{2}{*}{$\begin{array}{c}\text { Tratamento } \\
\text { Térmico }^{1} \\
1350^{\circ} \mathrm{C}\end{array}$} & \multirow[t]{2}{*}{ Passes } & \multicolumn{2}{|c|}{$\begin{array}{c}\text { Energia de Soldagem } \\
{[\mathrm{kJ} / \mathrm{mm}]}\end{array}$} \\
\hline & & & & 0,6 & 1,0 \\
\hline \multirow{2}{*}{ S32304 } & \multirow{2}{*}{$100 \pm 10$} & \multirow{2}{*}{$64 \pm 4$} & 1 & $81 \pm 11$ & $77 \pm 13$ \\
\hline & & & 3 & $86 \pm 7$ & $87 \pm 9$ \\
\hline \multirow{2}{*}{ S32205 } & \multirow{2}{*}{$100 \pm 10$} & \multirow{2}{*}{$62 \pm 6$} & 1 & $51 \pm 11$ & $56 \pm 6$ \\
\hline & & & 3 & $67 \pm 12$ & $79 \pm 12$ \\
\hline \multirow{2}{*}{$\mathrm{S} 32550$} & \multirow{2}{*}{$100 \pm 4$} & \multirow{2}{*}{$82 \pm 9$} & 1 & $97 \pm 5$ & $93 \pm 4$ \\
\hline & & & 3 & $98 \pm 1$ & $101 \pm 2$ \\
\hline \multirow{2}{*}{ S32750 } & \multirow{2}{*}{$100 \pm 7$} & \multirow{2}{*}{$86 \pm 1$} & 1 & $88 \pm 8$ & $93 \pm 3$ \\
\hline & & & 3 & $98 \pm 2$ & $96 \pm 5$ \\
\hline \multirow{2}{*}{ S32760 } & \multirow{2}{*}{$100 \pm 4$} & \multirow{2}{*}{$85 \pm 6$} & 1 & $101 \pm 5$ & $103 \pm 1$ \\
\hline & & & 3 & $102 \pm 5$ & $103 \pm 5$ \\
\hline
\end{tabular}

Nota: $\quad 1-$ UNS S32304, S32205, S32550 e S 32760 tratados a $1350{ }^{\circ} \mathrm{C}$ por 5 s. AISD UNS S32760 tratado a $1350{ }^{\circ} \mathrm{C}$ por $10 \mathrm{~s}$.

UNS S32304 testado a $25^{\circ} \mathrm{C}$. UNS S32205, S32550, S32750 e S32760 testados a 50 ${ }^{\circ} \mathrm{C}$. 
Em termos gerais verificou-se um leve aumento no PPit do primeiro para o terceiro passe. Este resultado era esperado, pois durante a execução do segundo e terceiros passes constatou-se o aumentou da fração de $\gamma$, a diminuição da quantidade de nitretos e a redistribuição dos elementos de liga.

Os três AISD (UNS S32550, S32750 e S32760) apresentaram uma recuperação total do seu PPit com relação ao valor inicial do metal de base, após o $3^{\circ}$ passe, isto para as duas energias de soldagem estudadas. Após o primeiro passe, o AISD UNS S32550 apresentou uma recuperação de aproximadamente $95 \%$ do seu PPit inicial. Por sua vez, o AISD UNS S32750 recuperou aproximadamente $90 \%$ do PPit. Finalmente, o UNS S32760 recuperou $100 \%$ do seu potencial de pite original. Desta forma, em termos reais de soldagem os três AISD apresentaram um comportamento exemplar quanto a sua recuperação total da resistência à corrosão da ZACTE após o terceiro passe, sendo que esta recuperação já foi quase total após o primeiro passe. Estes melhores resultados de corrosão da ZACTE simulada, em relação aos CPs tratados termicamente, são sem dúvida devidos às menores velocidades de resfriamento da ZACTE, com o qual são facilitadas as mudanças microestruturais, previamente mencionadas, que favorecem a resistência à corrosão.

No caso dos dois AIDs (UNS S32304 e S32205), a resistência à corrosão por pites da região estudada da ZACTE foi prejudicada pela realização da soldagem. Para o AID UNS S32304 o PPit foi recuperado até aproximadamente $85 \%$ do seu valor inicial, sem serem notadas diferenças entre as duas energias de soldagem. No AID UNS S32205 o PPit foi recuperado até 70 ou $80 \%$ do seu valor inicial, tendo-se uma recuperação um pouco maior para a energia de soldagem maior. Neste último material, teve-se uma recuperação maior do $1^{\circ}$ para o $3^{\circ}$ passe, para as duas energias de soldagem.

Todos estes resultados mostram como a resistência a corrosão por pite das soldas multipasse não foi modificada com a energia de soldagem utilizada.

Nas Figuras 189 a 193 são mostradas as curvas de polarização das cinco ligas estudadas, correspondentes à região da ZACTE estudada.

Como pode ser visto nas Figuras 189 e 190, o formato das curvas de polarização correspondentes aos ensaios de polarização cíclica na ZACTE dos AIDs UNS S32304 e S32205, são os mesmos mostrados por estes materiais no estado como-recebido e não mostram nenhuma mudança importante de uma energia de soldagem para a outra nem de um passe para três passes. Verifica-se em todas estas curvas um loop bastante grande, que é compatível com a menor resistência à corrosão localizada destas ligas nas temperaturas de ensaio e, consequentemente, com o grande tamanho dos pites encontrados nestes materiais. Outra caraterística bastante evidente destas curvas é a instabilidade da corrente na subida do potencial, o que pode ser explicado como a formação de pites instáveis. 

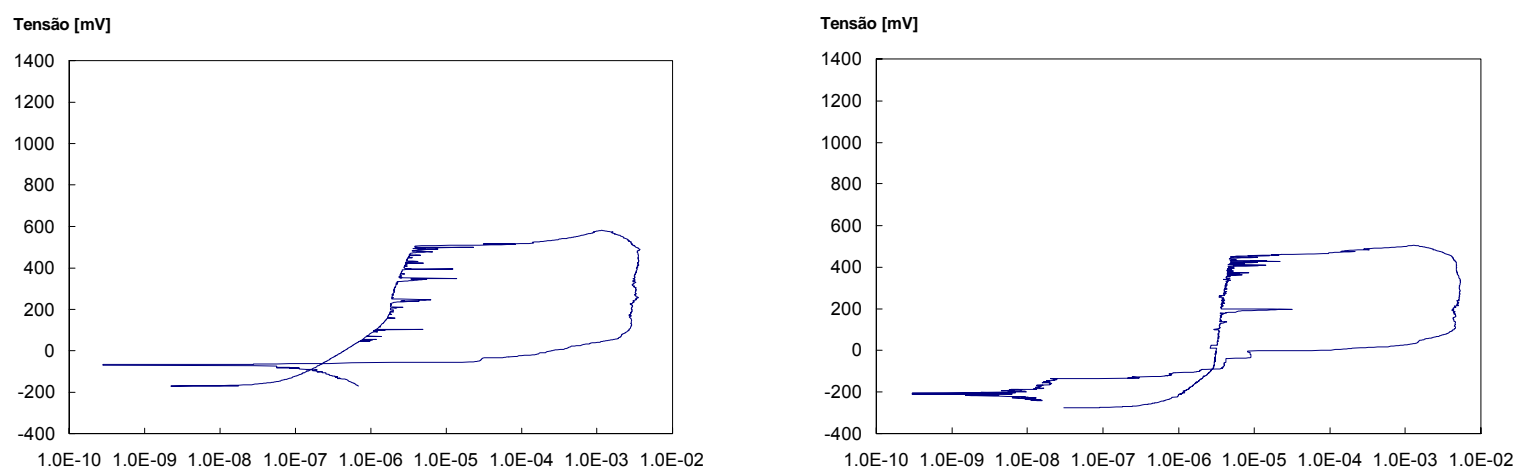

UNS $\$ 32304-0,6 \mathrm{~kJ} / \mathrm{mm}-1$ passe

Corrente/Área $\left[\mathrm{A} / \mathrm{cm}^{2}\right]$

UNS $\mathrm{S} 32304-0,6 \mathrm{~kJ} / \mathrm{mm}-3$ passes

Corrente/Área $\left[\mathrm{A} / \mathrm{cm}^{2}\right]$

Tensão [mV]

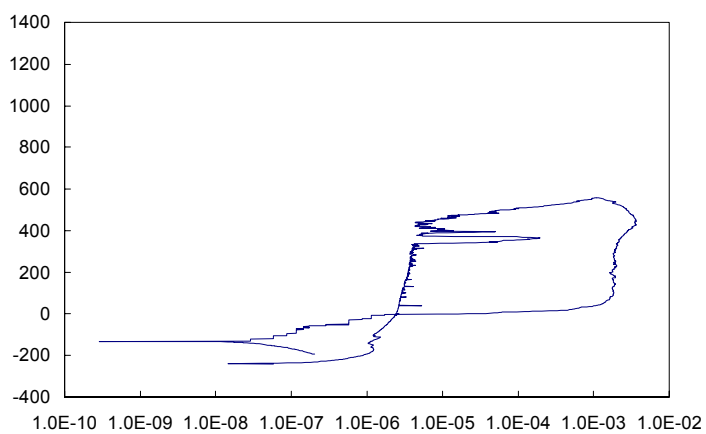

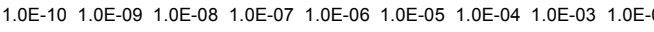

UNS S32304 - 1,0 kJ/mm - 1 passe

Corrente/Área $\left[\mathrm{A} / \mathrm{cm}^{2}\right]$

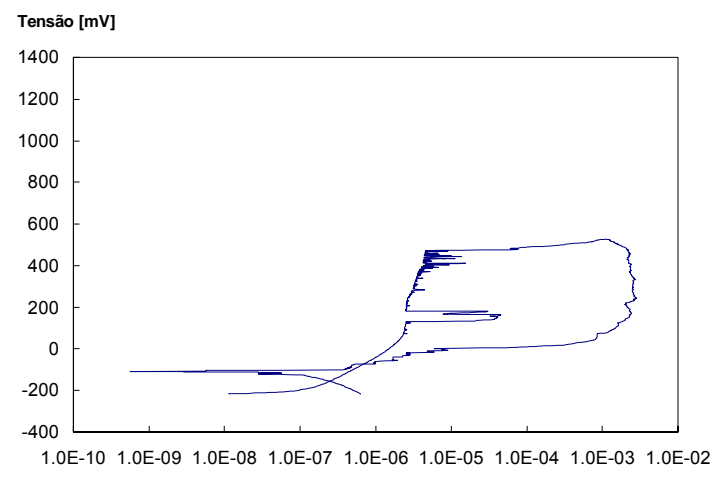

UNS $\mathrm{S} 32304-1,0 \mathrm{~kJ} / \mathrm{mm}-3$ passes

Corrente/Área $\left[\mathrm{A} / \mathrm{cm}^{2}\right]$

Figura 189: Curvas de polarização dos CPs submetidos a simulação térmica da região da raiz da ZACTE do AID UNS S32304.

Por outro lado Nas Figuras 191 e 193 são mostradas as curvas de polarização correspondentes aos ensaios de polarização cíclica da ZACTE dos AISDs UNS S32550 e S32760. Observa-se nestas figuras que as curvas dos CPs após a realização do primeiro passe, isto para as duas energias de soldagem, apresentam um formato diferente daquele do metal de base. Nestes casos, as curvas apresentam loops maiores e potencial de proteção bem menores, o que indica pites de tamanho maior. O potencial de proteção, pela sua parte, é bastante dependente da composição química da matriz, pois tem a ver com a capacidade do pite de se repassivar. Portanto, após o primeiro passe se tem uma maior quantidade de ferrita, com o qual o seu conteúdo de $\mathrm{Cr}$ e Mo é menor e, desta forma, a sua capacidade de repassivar um pite é menor, o que é claramente observado nas curvas. 

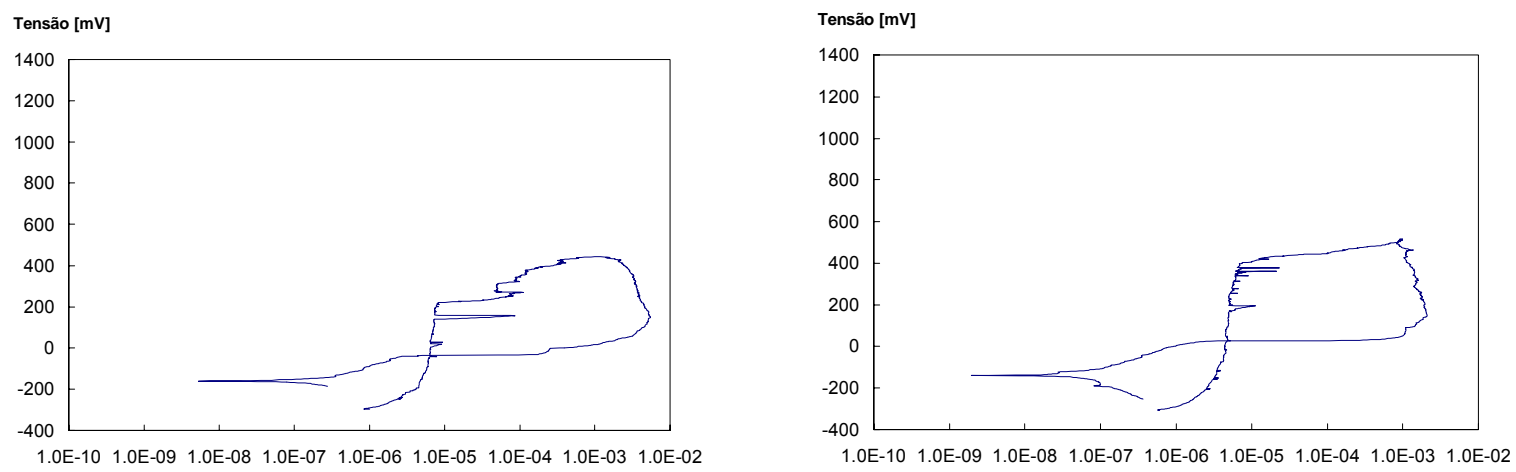

UNS $\$ 32205-0,6 \mathrm{~kJ} / \mathrm{mm}-1$ passe

Corrente/Área $\left[\mathbf{A} / \mathrm{cm}^{2}\right]$

Tensão [mV]

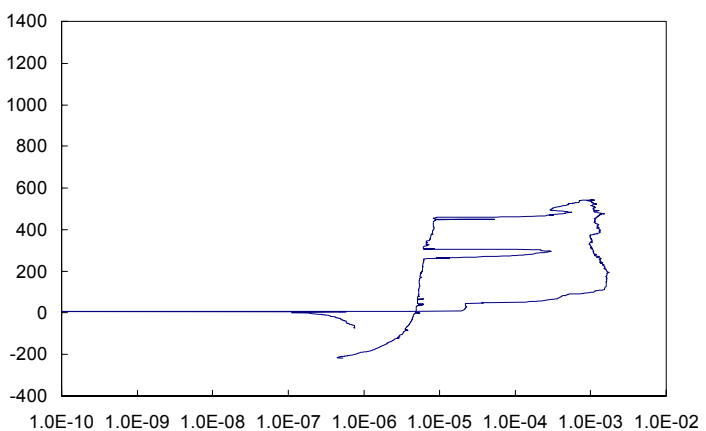

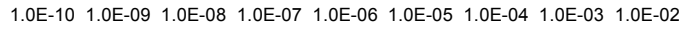

UNS $\$ 32205-1,0 \mathrm{~kJ} / \mathrm{mm}-1$ passe

Corrente/Área $\left[\mathrm{A} / \mathrm{cm}^{2}\right]$

Tensão [mV]

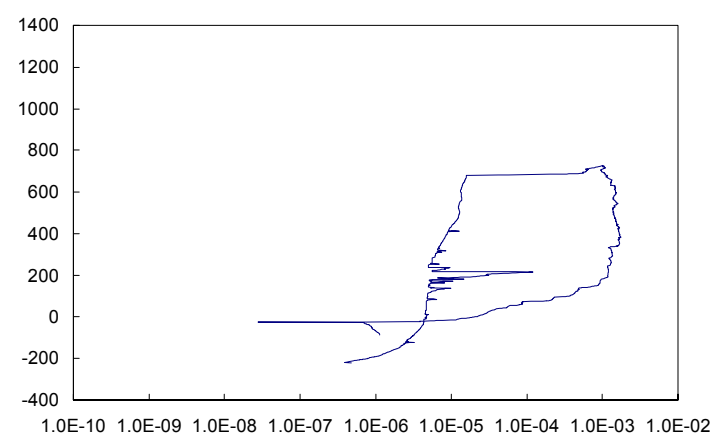

UNS $\$ 32205-1,0 \mathrm{~kJ} / \mathrm{mm}-3$ passes

Figura 190: Curvas de polarização dos CPs submetidos a simulação térmica da região da raiz da ZACTE do AID UNS S32205.

Finalmente, na Figura 192 são mostradas as curvas de polarização correspondentes à ZACTE do AISD UNS S32750. Como pode ser observado nesta figura também não se teve nenhuma mudança importante no formato das curvas tanto com relação aos metais de base, como entre as diversas energias de soldagem. O pequeno loop formado nestas curvas indica pites não muito grandes. Assim, este material, que mostrou o melhor comportamento com relação a sua resistência à corrosão localizada, nos testes de corrosão dos CPs tratados termicamente, vem a se mostrar de novamente na ZACTE simulada como o material com o melhor comportamento do ponto de vista de resistência à corrosão localizada. 

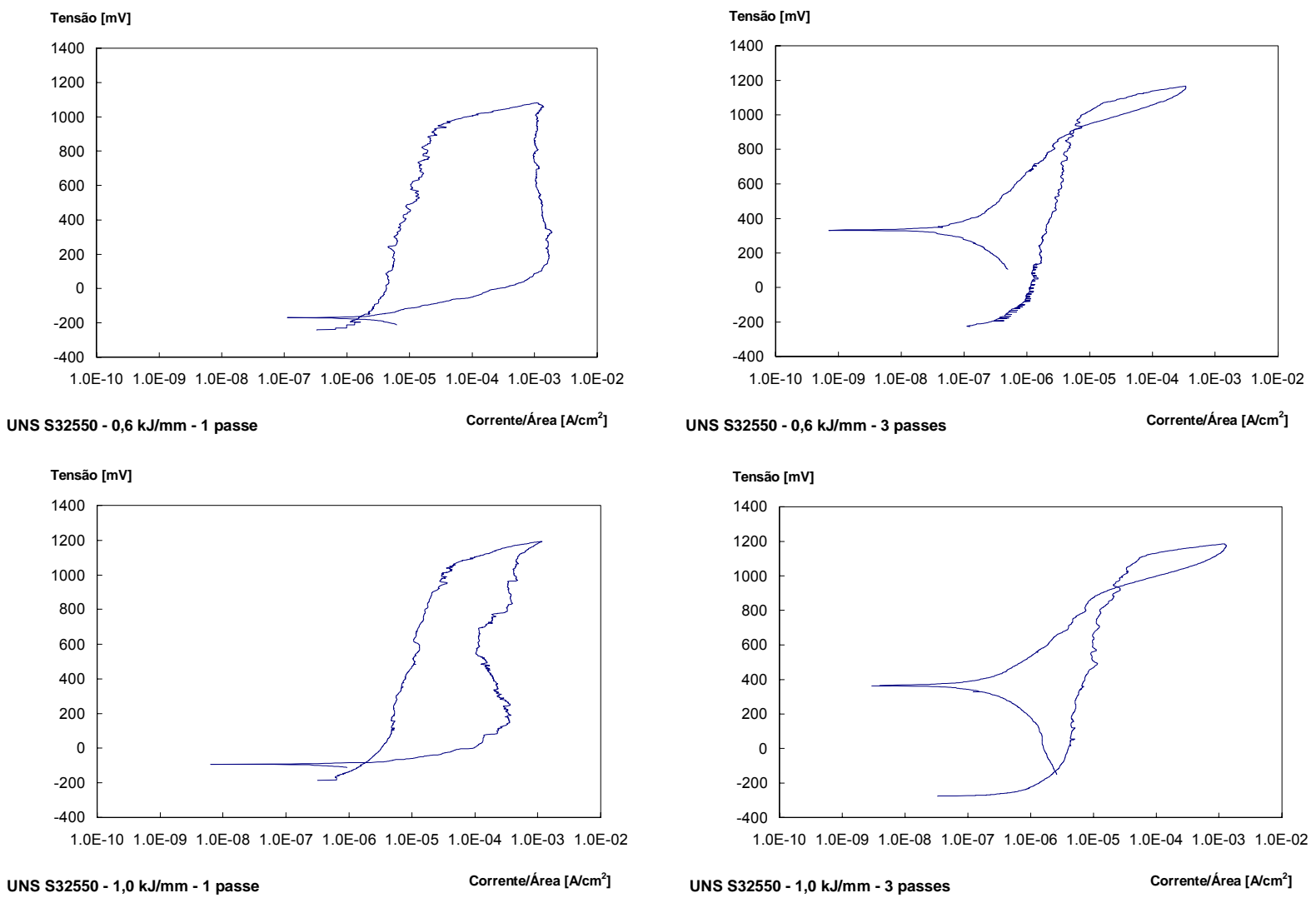

UNS $\mathrm{S} 32550-1,0 \mathrm{~kJ} / \mathrm{mm}-1$ passe

Corrente/Área $\left[\mathrm{A} / \mathrm{cm}^{2}\right]$

UNS S32550 - 1,0 kJ/mm - 3 passes

Corrente/Área $\left[\mathrm{A}^{\mathrm{cm}}{ }^{2}\right]$

Figura 191: Curvas de polarização dos CPs submetidos a simulação térmica da região da raiz da ZACTE do AID UNS S32550.

Uma parte importante dos ensaios de corrosão realizados é a observação dos pites para a determinação de:

- Os lugares de início dos mesmos;

- As (s) fases que dissolvem preferencialmente;

- O tamanho dos pites formados.

Nas Figuras 194 a 198 são mostrados alguns dos pites formados na ZACTE das cinco ligas estudadas. Os pites mostrados são do tamanho típico observado em cada um dos CPs.

Através da observação dos pites verificou-se como o tamanho do loop na curva de polarização correspondeu bastante bem com o tamanho dos pites observados para cada um dos ensaios. A título de exemplo, é interessante observar as curvas de polarização correspondentes ao AISD UNS S32750 (Figura 192) e ao AID UNS S32304 (Figura 189) e comparar com os tamanhos dos pites formados nestes corpos de prova, mostrados nas Figuras 194 e 197. 
Verificou-se nestas figuras que a fase que dissolveu preferencialmente nos pites foi a $\alpha$, sendo que as agulhas de $\gamma$ permaneceram praticamente intocadas dentro dos pites.
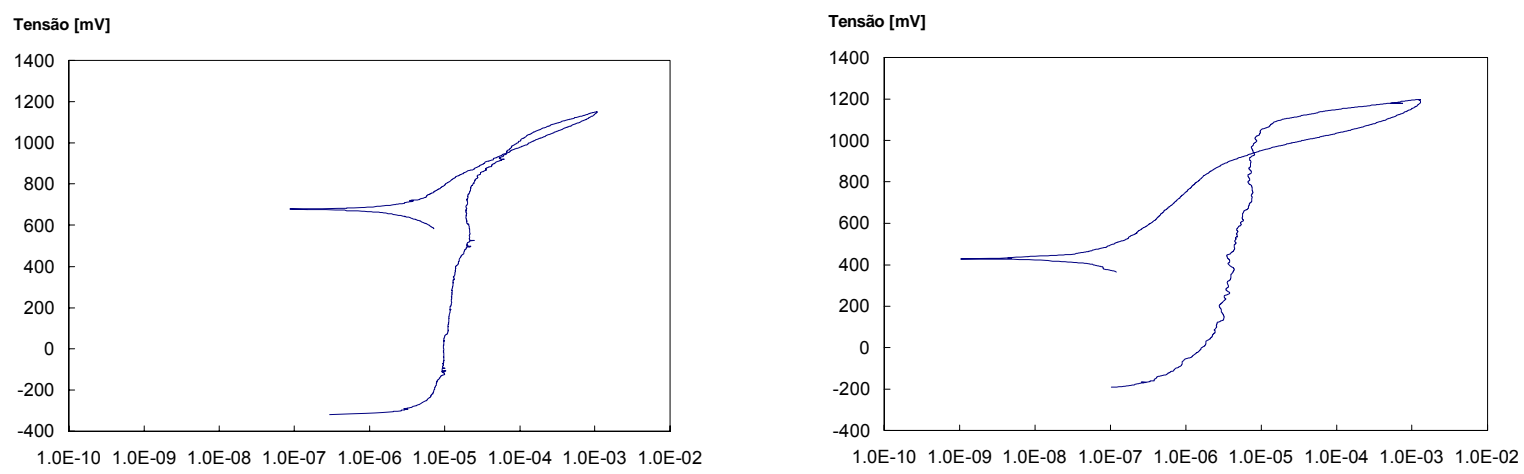

UNS $\$ 32750-0,6 \mathrm{~kJ} / \mathrm{mm}-1$ passe

Corrente/Área $\left[\mathrm{A} / \mathrm{cm}^{2}\right]$

UNS $\$ 32750-0,6 \mathrm{~kJ} / \mathrm{mm}-3$ passes

Corrente/Área [A/ $\left.\mathrm{cm}^{2}\right]$

Tensão [mV]

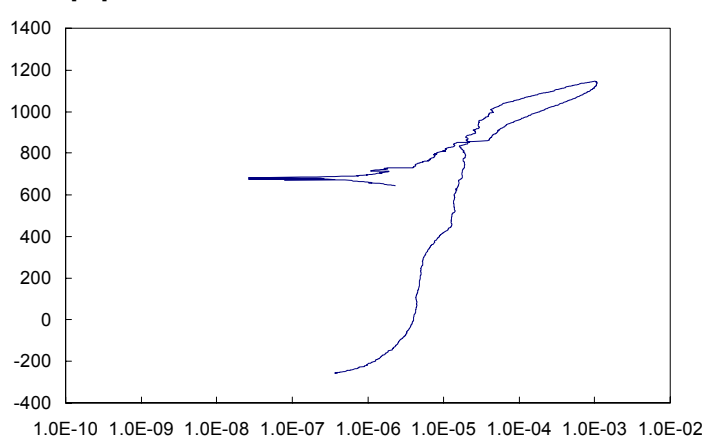

$\begin{array}{lllllllll}1.0 \mathrm{E}-10 & 1.0 \mathrm{E}-09 & 1.0 \mathrm{E}-08 & 1.0 \mathrm{E}-07 & 1.0 \mathrm{E}-06 & 1.0 \mathrm{E}-05 & 1.0 \mathrm{E}-04 & 1.0 \mathrm{E}-03 & 1.0 \mathrm{E}-02\end{array}$

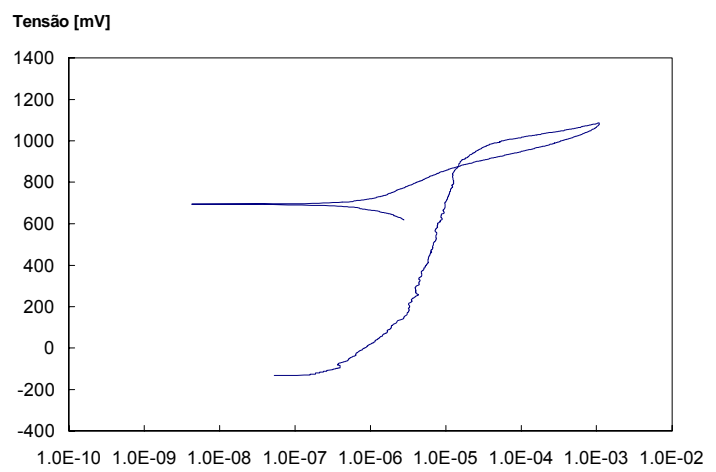

UNS $\$ 32750-1,0 \mathrm{~kJ} / \mathrm{mm}-1$ passe

Corrente/Área $\left[\mathrm{A} / \mathrm{cm}^{2}\right]$

UNS $\mathrm{S} 32750-1,0 \mathrm{~kJ} / \mathrm{mm}-3$ passes

Corrente/Área $\left[\mathrm{A} / \mathrm{cm}^{2}\right]$

Figura 192: Curvas de polarização dos CPs submetidos a simulação térmica da região da raiz da ZACTE do AID UNS S32750. 


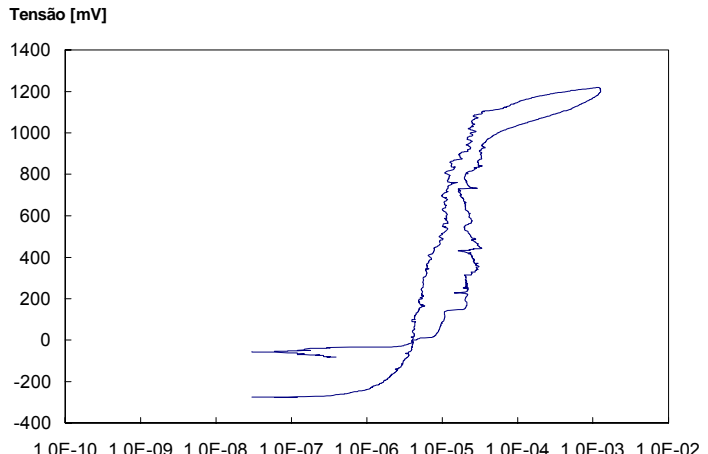

UNS S32760 - 0,6 $\mathrm{kJ} / \mathrm{mm}-1$ passe

Tensão [mV]

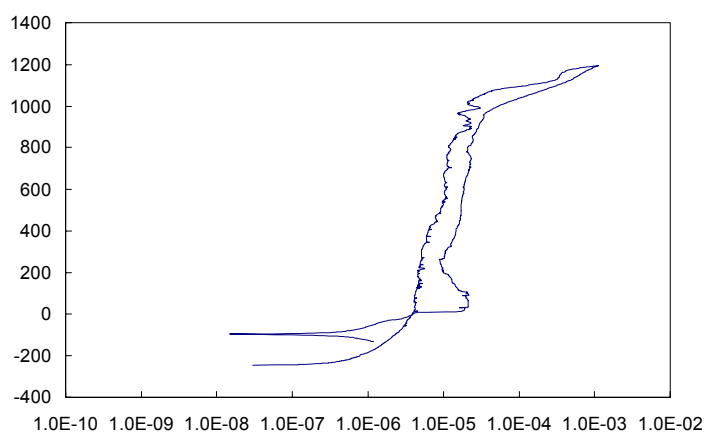

UNS $\$ 32760$ - 1,0 kJ/mm - 1 passe

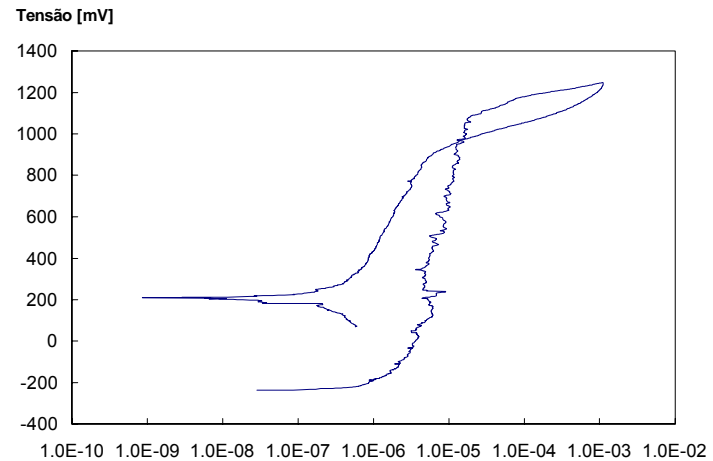

UNS $\mathrm{S} 32760-0,6 \mathrm{~kJ} / \mathrm{mm}-3$ passes

Corrente/Área $\left[\mathrm{A} / \mathrm{cm}^{2}\right]$

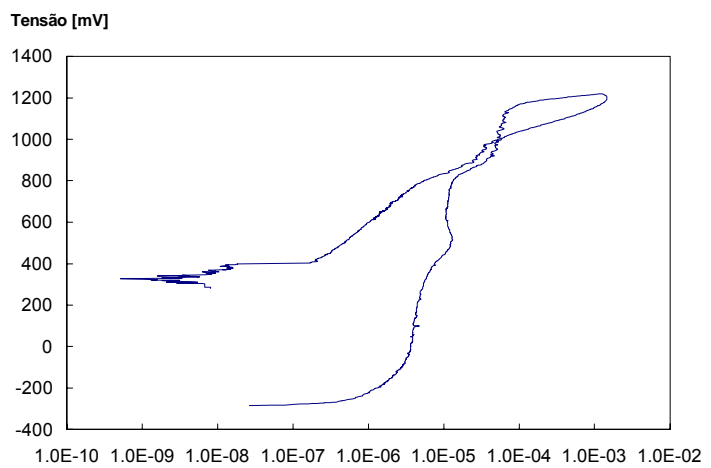

UNS S32760 - 1,0 kJ/mm - 3 passes

Corrente/Área $\left[\mathrm{A} / \mathrm{cm}^{2}\right]$

Figura 193: Curvas de polarização dos $C P s$ submetidos a simulação térmica da região da raiz da ZACTE do AID UNS S32760.

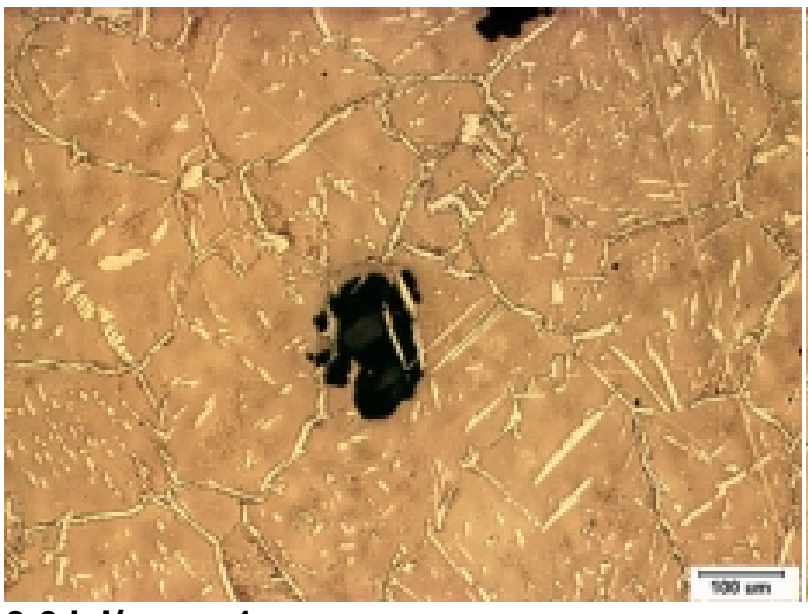

$0,6 \mathrm{~kJ} / \mathrm{mm}-1$ passe

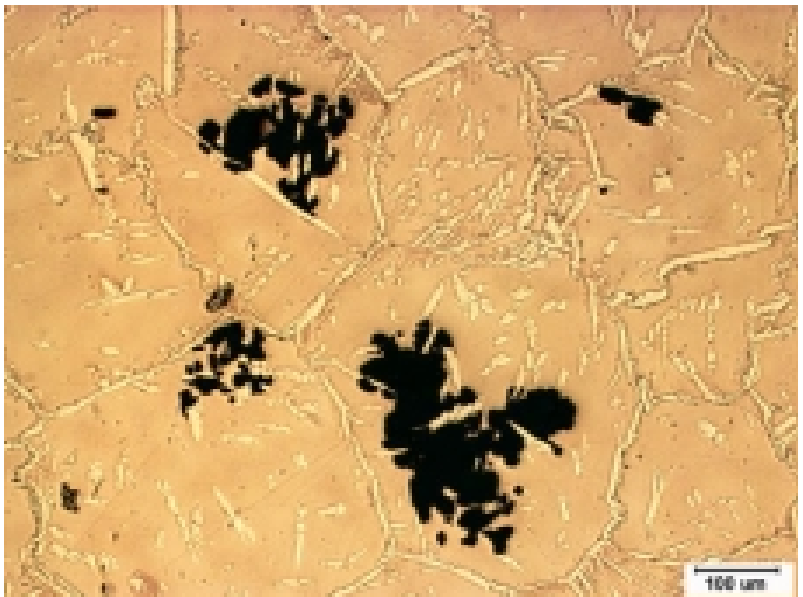

$1,0 \mathrm{~kJ} / \mathrm{mm}-1$ passe

Figura 194: Aparência dos pites formados na ZACTE do AID UNS S32304. 


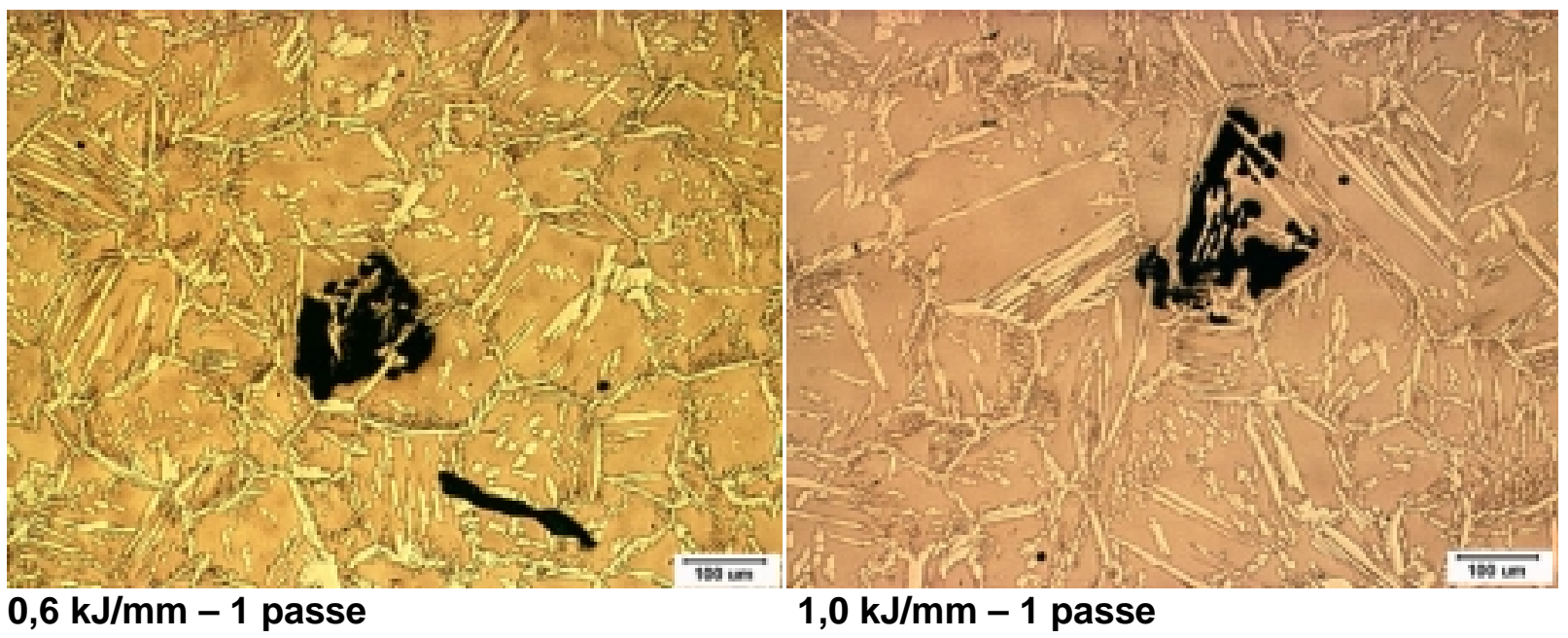

Figura 195: Aparência dos pites formados na ZACTE do AID UNS S32205.

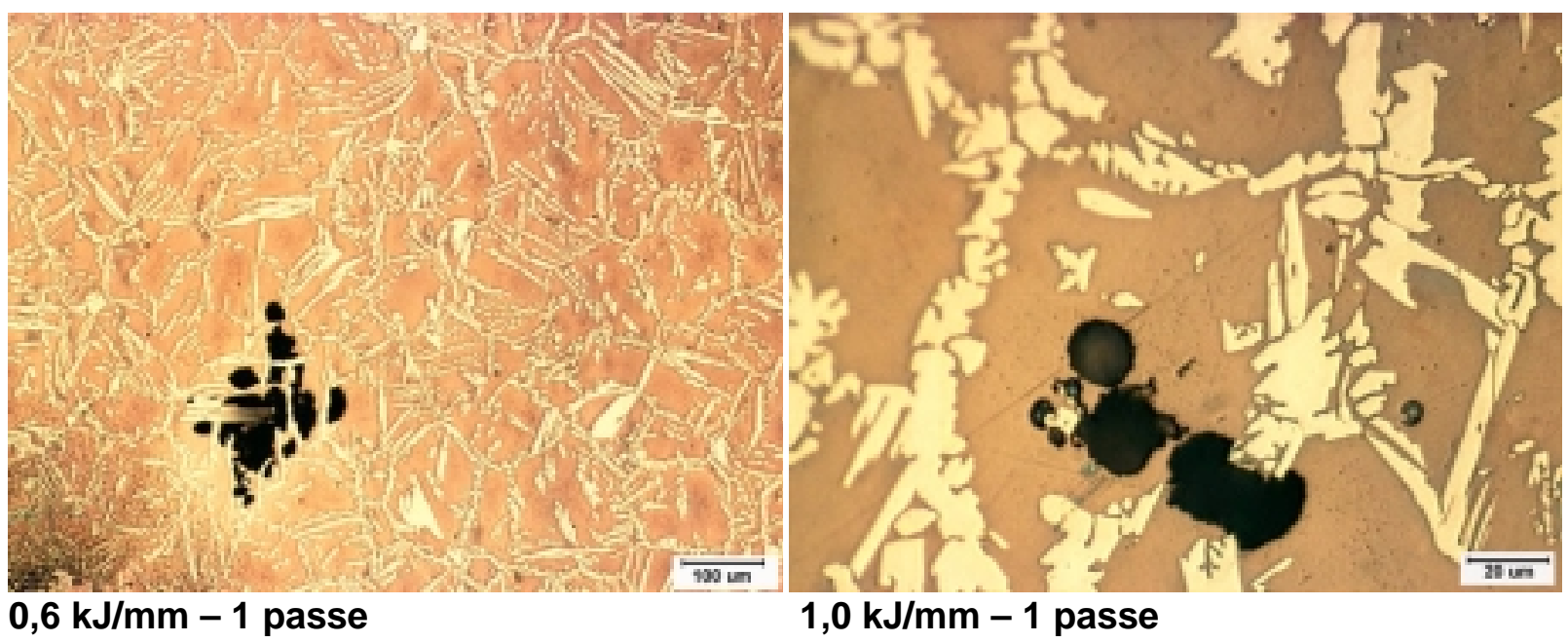

Figura 196: Aparência dos pites formados na ZACTE do AID UNS S32550.

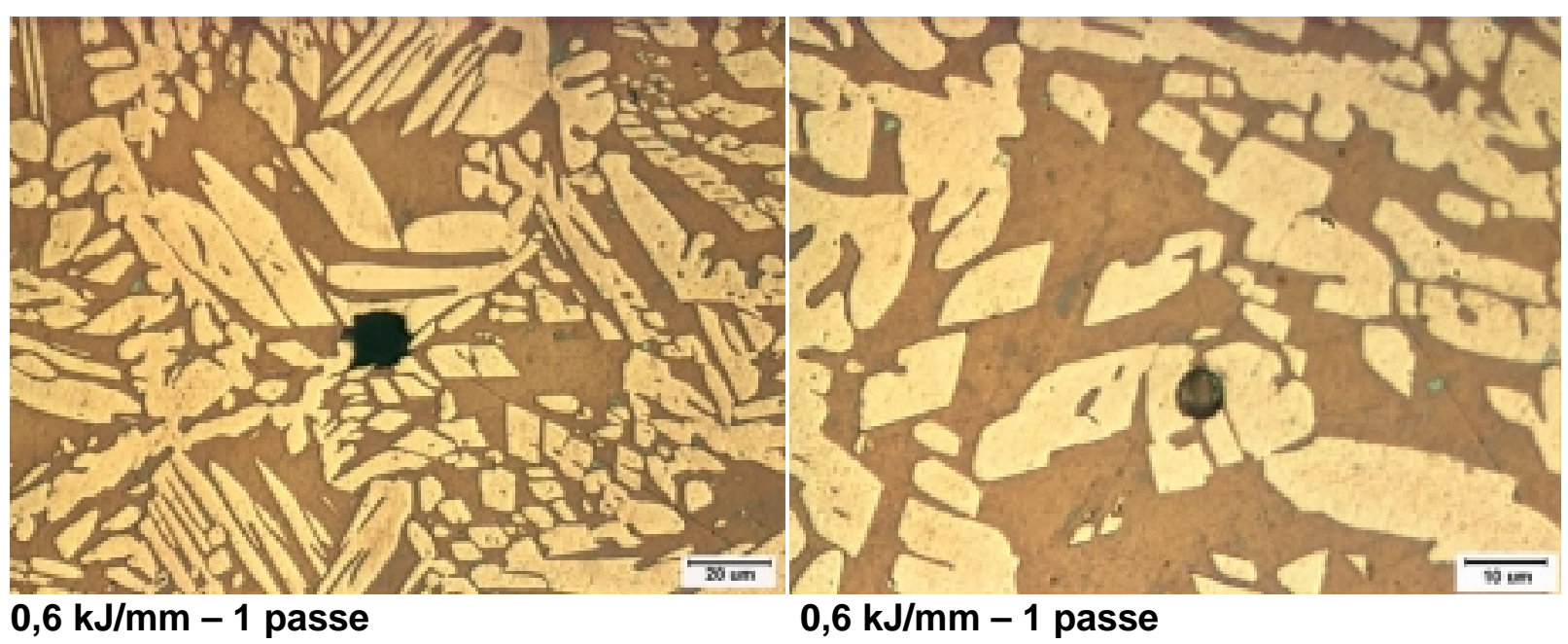

Figura 197: Aparência dos pites formados na ZACTE do AID UNS S32750. 


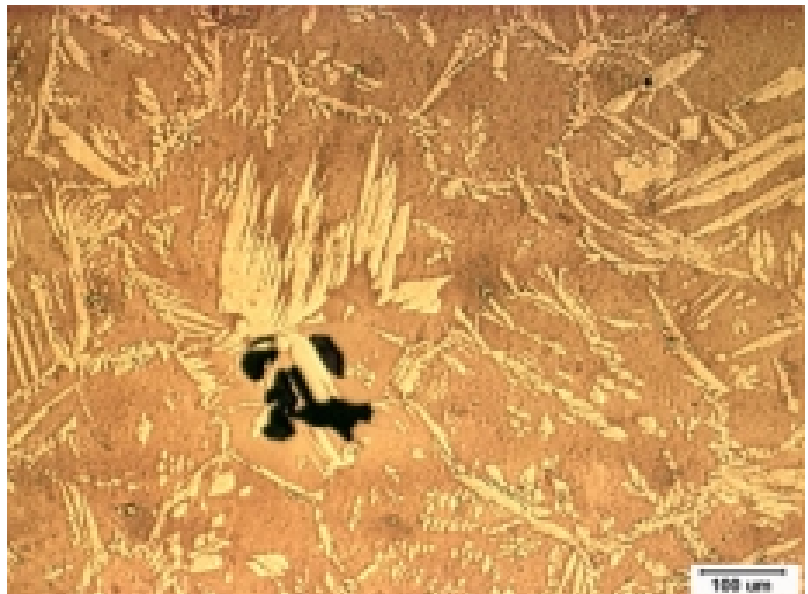

$0,6 \mathrm{~kJ} / \mathrm{mm}-1$ passe

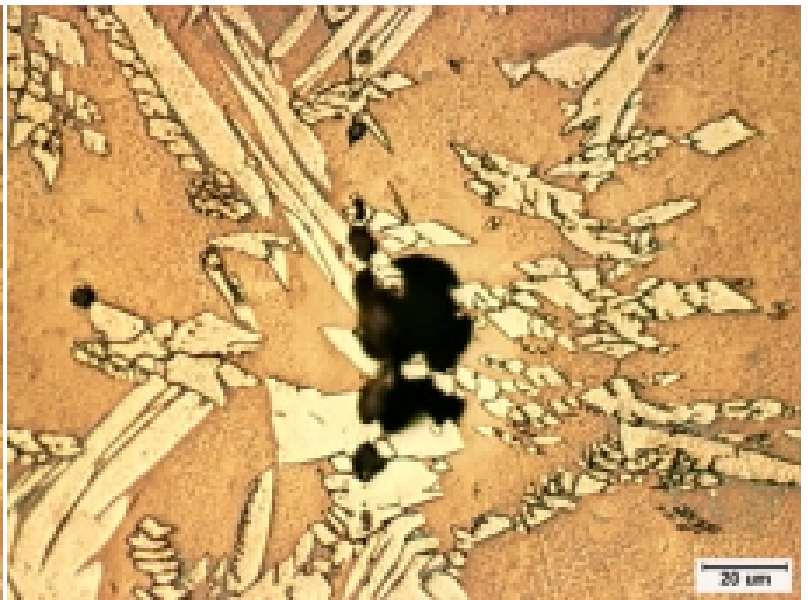

$1,0 \mathrm{~kJ} / \mathrm{mm}-1$ passe

Figura 198: Aparência dos pites formados na ZACTE do AID UNS S32760.

Quanto aos lugares de início dos pites, nas Figuras 197 e 199 são apresentados detalhes de pites que começaram a se formar na ZACTE. Como pode ser visto nestas figuras, os pites se formam preferencialmente nas interfaces $\alpha / \gamma$. Também foi observado com alguma freqüência a formação de pites nas colônias de $\gamma_{2}$ intragranular e nas inclusões, a partir das quais precipitaram austenitas intragranulares.

Resumindo, o comportamento dos CPs correspondentes à ZACTE nos testes de corrosão foi bastante parecido com o observado nos CPs submetidos a TTs. Os ensaios dos CPs submetidos a TTs foi de bastante ajuda para o entendimento do comportamento da ZACTE, o que dificilmente se teria logrado somente com o estudo das soldas reais ou simuladas.

Finalmente, vale a pena ressaltar que o fato da $\gamma_{2}$ intragranular não ter prejudicado o PPit da ZACTE é explicado pelas velocidades de resfriamento mais lentas e pelo posterior reaquecimento das $\gamma_{2}$ intragranulares (formadas durante o segundo passe) no decorrer do terceiro passe. Desta forma, os dois grupos de ensaios se complementaram muito bem e em nenhum momento se apresentam resultados contraditórios. 

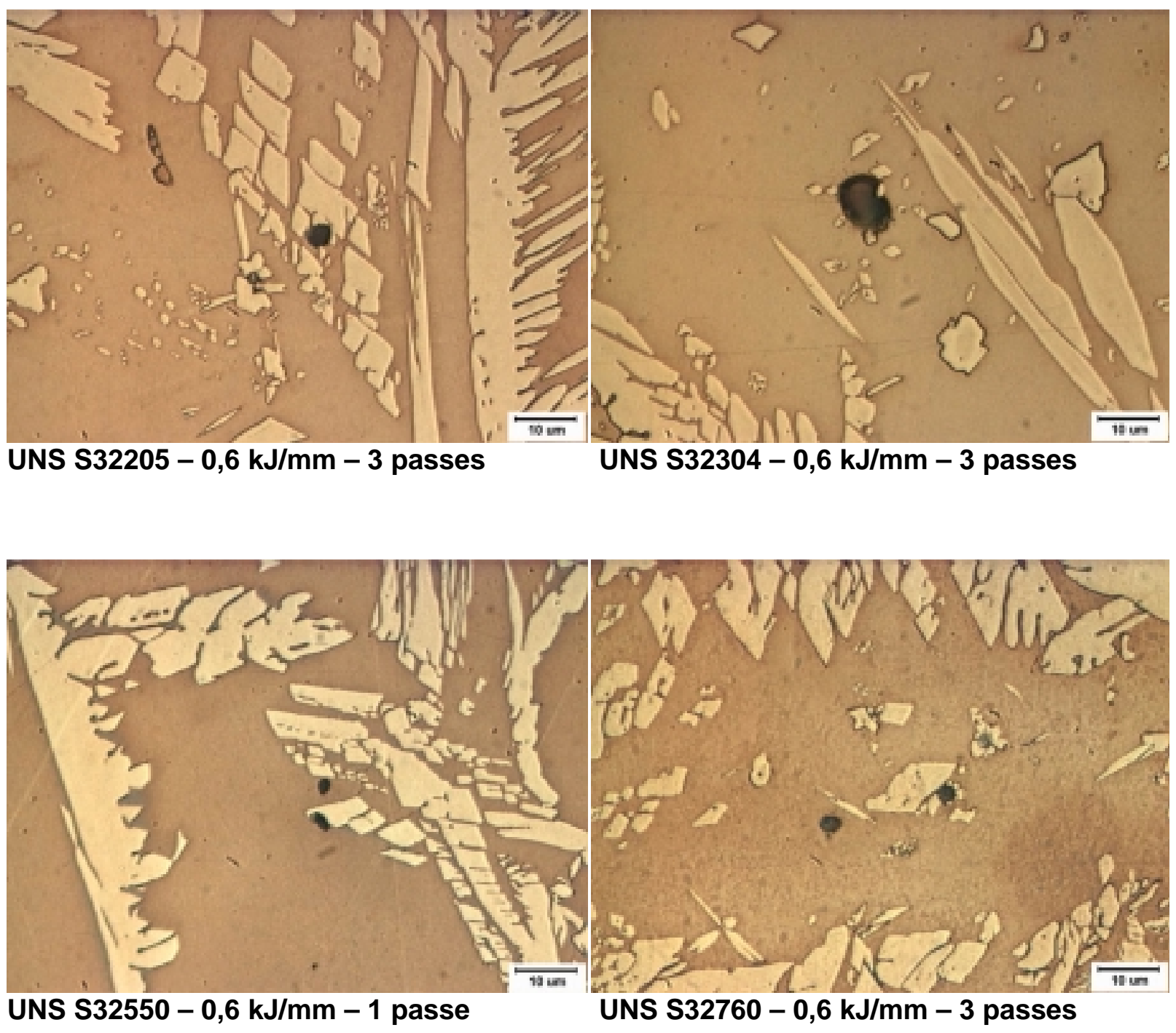

Figura 199: Lugares preferenciais de formação de pites durante o ensaio de polarização cíclica. 


\section{CONCLUSÕES}

Tendo em vista os materiais e as técnicas experimentais utilizadas é possível concluir que:

\section{Modelagem do Fluxo de Calor na Soldagem:}

1. Para a solda multipasse que foi estudada, o fluxo de calor encontra-se no regime intermediário entre bidimensional e tridimensional.

2. O modelo analítico de fluxo de calor que foi proposto representa bem a história térmica da zona afetada pelo calor de uma solda multipasse.

\section{Mudancas Microestruturais na Zona Afetada pelo Calor Submetida a Temperatura Elevada (ZACTE):}

3. Os cálculos termodinâmicos realizados com o programa de computador Thermo-Calc permitiram verificar que nem todos os aços inoxidáveis duplex (AIDs) são completamente ferritizáveis. Das cinco ligas estudadas, somente o AID UNS S32304 atinge uma estrutura $100 \%$ ferrítica. O restante das ligas apresentam uma solidificação ferríticoaustenítica.

4. Existe uma relação muito bem definida entre a temperatura de resistência nula (TRN) e a temperatura solidus (TS) dos AIDs. Desta forma, verificou-se a possibilidade de inferir a TRN de um AID a partir da TS calculada com o Thermo-Calc ${ }^{\circledR}$.

\section{Tratamentos Térmicos a $1350^{\circ} \mathrm{C}:$}

5. As partículas precipitadas no interior da ferrita, após um resfriamento brusco (a partir de $1350{ }^{\circ} \mathrm{C}$ ), foram identificadas inequivocamente, mediante difração de elétrons no MET, como sendo $\mathrm{Cr}_{2} \mathrm{~N}$. Estes nitretos de cromo intragranulares possuíam um formato de bastonete. Os precipitados maiores apresentaram uma bifurcação nas suas extremidades.

6. Em todos os casos observados, os nitretos intragranulares apresentaram relações de orientação com a ferrita, onde os planos mais compactos de ambas estruturas são paralelos:

$$
\text { (110) } \alpha / /(0001) \mathrm{Cr}_{2} \mathrm{~N} \text {. }
$$

A relação de orientação $\alpha / \mathrm{Cr}_{2} \mathrm{~N}$ predominante foi: 


$$
\begin{aligned}
& (110)_{\alpha} \mathrm{II}(0001)_{\mathrm{Cr}_{2} \mathrm{~N}} \\
& {[\overline{1} 11]_{\alpha} \|[\overline{1} 100]_{\mathrm{Cr}_{2} \mathrm{~N}}}
\end{aligned}
$$

Esta relação de orientação, que é equivalente à relação de Burgers, permite a formação de uma interface semicoerente ao longo do comprimento dos bastonetes.

7. A composição química dos nitretos intragranulares muda de uma liga para outra. Mas em todos os casos esta fase é rica em $\mathrm{Cr}, \mathrm{Fe}, \mathrm{Mo}, \mathrm{V}$ e pobre em Ni e Cu.

8. Partículas de segunda fase precipitadas nas interfaces $\alpha / \gamma$ foram identificadas inequivocamente mediante difração de elétrons no MET como nitretos de cromo do tipo $\mathrm{Cr}_{2} \mathrm{~N}$. Estes nitretos apresentam uma relação de orientação com a ferrita e a austenita, onde os planos mais compactos das três fases são paralelos:

$$
\text { (111) } \gamma / /(110) \alpha / /(0001) \mathrm{Cr}_{2} \mathrm{~N}
$$

Esta relação de orientação mantém a relação de K-S entre a ferrita e a austenita, a relação de Burgers entre a ferrita e o nitreto e uma outra relação previamente reportada entre o nitreto e austenita. Assim, a relação de orientação $\alpha / \gamma / \mathrm{Cr}_{2} \mathrm{~N}$ é:

$$
\begin{aligned}
& (111) \gamma\|(110) \alpha\|(0001) \mathrm{Cr}_{2} \mathrm{~N} \\
& {[\overline{1} 10] \gamma\|[\overline{1} 11] \alpha\|[\overline{1} 100] \mathrm{Cr}_{2} \mathrm{~N}}
\end{aligned}
$$

Tratamentos Térmicos de Reaquecimento Subsequentes ao Tratamento a $1350{ }^{\circ} \mathrm{C}$ :

9. O ataque eletrolítico desenvolvido permitiu a identificação inequívoca das austenitas primárias $\left(\gamma_{1}\right)$ e secundárias $\left(\gamma_{2}\right)$ no microscópio eletrônico de varredura.

10. A temperatura de predominância de precipitação de $\gamma_{2}$ intragranular muda de uma liga para a outra. No AID UNS S32304, teve-se a precipitação de $\gamma_{2}$ intragranular no intervalo de 1000 a $1200{ }^{\circ} \mathrm{C}$, tendendo para uma maior quantidade ao redor de $1000{ }^{\circ} \mathrm{C}$. Nos AIDs UNS S32205, S32550 e S32750, a maior quantidade desta fase precipitou a 1000 ${ }^{\circ} \mathrm{C}$. No AISD UNS $S 32760$ a temperatura de máxima precipitação da $\gamma_{2}$ intragranular foi ao redor de $1100^{\circ} \mathrm{C}$.

11. A precipitação de $\mathrm{Cr}_{2} \mathrm{~N}$ nas temperaturas de reaquecimento de 900 e $1000{ }^{\circ} \mathrm{C}$, em algumas das interfaces $\alpha / \gamma$, antecede o crescimento da $\gamma_{2}$. Existe um mecanismo de colaboração, onde o nitreto retira o $\mathrm{Cr}$, Mo e $\mathrm{V}$ da ferrita e enriquece esta em $\mathrm{Ni}$ e $\mathrm{Cu}$, facilitando o crescimento da $\gamma$ na forma de $\gamma_{2}$. O nitrogênio necessário para ambas transformações é suprido pela dissolução dos nitretos de cromo intragranulares da ferrita.

12. A íntima coexistência observada entre os nitretos de cromo intragranulares e as austenitas intragranulares, tanto primárias como secundárias, junto com a relação de 
epitaxia que se desenvolve entre a austenita e o nitreto, sugere a nucleação destas austenitas a partir dos nitretos.

\section{Simulação da ZACTE:}

13. As microestruturas logradas com as simulações da ZACTE são muito parecidas com as das regiões equivalentes nas soldas reais.

14. O aumento da energia de soldagem levou ao aumento da fração final de austenita na ZACTE de uma soldagem multipasse. Porém, este efeito foi bastante reduzido. Além disso, o aumento da energia de soldagem não levou a total dissolução dos nitretos. Desta forma, para a faixa de energia de soldagem utilizada, a fração final de austenita não deve ser um fator de peso na seleção da energia de soldagem.

15. A energia de soldagem influenciou as morfologias predominantes da $\gamma_{2}$. Para as energias de soldagem menores $(0,6$ e $0,8 \mathrm{~kJ} / \mathrm{mm})$ verificou-se o crescimento das $\gamma$ alotrimórficas e de Widmanstätten e a precipitação de $\gamma_{2}$ intragranulares. Por outro lado, para a energia de soldagem maior $(1,0 \mathrm{~kJ} / \mathrm{mm})$, somente foi registrado o crescimento das austenitas alotrimórficas e de Widmanstätten.

16. O tamanho de grão ferrítico da ZACTE aumenta com a energia de soldagem utilizada. A maior influência foi observada nos AIDs UNS S32304 e S32205. No AISD UNS S32760 este efeito foi moderado. Finalmente, nos AISD UNS S32550 e S32750, esta influência foi nula. Desta forma, a energia de soldagem é um parâmetro importante no controle do tamanho de grão da ZACTE nos AIDs UNS S32304 e S32205.

17. A evolução da fração de austenita com os sucessivos passes de soldagem mudou de uma energia de soldagem para a outra. Para a energia de soldagem menor, o maior crescimento da fração de austenita ocorreu durante o segundo passe. Já para a energia de soldagem maior, o maior crescimento da fração de austenita aconteceu durante o terceiro passe. Este comportamento está relacionado com os potenciais termodinâmicos disponíveis e com os intervalos de temperatura alcançados durante os reaquecimentos.

\section{Avaliação de Desempenho da ZACTE:}

18. A energia absorvida no ensaio Charpy pela ZACTE tende a ser menor que a do material no estado como-recebido.

19. O potencial de pite dos AIDs quando tratados termicamente a $1350{ }^{\circ} \mathrm{C}$, seguido de resfriamento rápido, apresentou uma queda considerável com relação ao estado comorecebido. Este potencial apresentou uma recuperação variável quando as ligas foram submetidas a tratamentos térmicos de reaquecimento, entre 900 e $1200{ }^{\circ} \mathrm{C}$. Os AIDs 
UNS S32304 e S32205 recuperaram até 85 e $72 \%$, respectivamente, do seu potencial de pite original, quando tratados a $1100{ }^{\circ} \mathrm{C}$. No caso dos AISDs UNS S32550, S32750 e S32760, apresentaram uma recuperação total do seu potencial de pite quando tratados entre 1000 e $1200^{\circ} \mathrm{C}$. Este comportamento também foi observado na ZACTE simulada.

20. A recuperação do potencial de pite durante os tratamentos de reaquecimento não segue uma relação direta com o aumento da fração de austenita durante estes tratamentos. Portanto, acredita-se que sejam outros fatores como a redistribuição de elementos de elementos de liga e a dissolução dos nitretos de cromo, que controlam esta recuperação do potencial de pite.

21. A $\gamma_{2}$ intragranular tem um efeito deletério na resistência à corrosão localizada somente nos estágios iniciais da sua precipitação, quando esta acontece em temperaturas mais baixas $\left(1000{ }^{\circ} \mathrm{C}\right)$. Quando a precipitação acontece em temperaturas ao redor de 1100 ${ }^{\circ} \mathrm{C}$, ou o tratamento de reaquecimento, que leva à precipitação desta fase, tem uma duração considerável, o efeito prejudicial da $\gamma_{2}$ intragranular não é mais detectado pelo ensaio.

22. A energia de soldagem não teve efeito sobre o potencial de pite da ZACTE, para a faixa de energia de soldagem estudada. 


\section{SUGESTÃO DE TRABALHOS FUTUROS}

- Continuar o estudo de MET para procurar partículas de $\gamma$ intragranular contendo nitretos de cromo no seu interior e desta forma fazer todas as análises que permitam corroborar o modelo proposto de precipitação de $\gamma$ intragranular a partir dos nitretos.

- Ampliar o estudo de MET para o restante das condições de tratamento térmico. Principalmente para os TTs a 900 e $1000{ }^{\circ} \mathrm{C}$ para estudar melhor a relação entre precipitação dos nitretos de cromo e a austenita secundária nas interfaces $\alpha / \gamma$.

- Fazer estudos com tratamentos térmicos de maior duração para verificar as faixas de temperatura, nas quais se tem a total dissolução dos nitretos de cromo tanto intragranulares como intergranulares.

- Estudar a evolução da composição química (mediante EELS) da $\gamma_{2}$ intragranular com os tratamentos térmicos de reaquecimento

- Realizar estudos mais completos sobre a evolução da tenacidade e da resistência à corrosão da ZACTE, principalmente utilizando-se um intervalo mais amplo de energias de soldagem, para desta forma poder estabelecer janelas operacionais de soldagem dos AIDs. 


\section{BIBLIOGRAFIA}

1 TSAI, N.S.; EAGAR, T.W. Distribution of the heat and current fluxes in gas tungsten arcs. Metallurgical Transactions B. v. 16B, n. 4, p. 841-846, 1985.

${ }^{2}$ GLICKSTEIN, S.S. et al. Heat flow in welding. In: AMERICAN WELDING SOCIETY. The Welding Handbook. v. 1, $8^{\text {a }}$ Ed., USA, 1987. Cap. 3, p. 65-87.

${ }^{3}$ GLICKSTEIN, S.S.; FRIEDMAN, E. Weld modeling applications. Welding Journal. v. 63, n. 9, p. 3842, 1984.

${ }^{4}$ GHENT, H.W. et al. Arc Efficiencies in TIG welds. In: Conference Arc Physics and Weld Pool Behavior, London, 1979. Proceedings. London, The Welding Institute, 1980, p. 17-23.

${ }^{5}$ DuPONT, J.N.; MARDER, A.R. Thermal efficiency of arc welding processes. Welding Journal. v. 74, n. 12, p. 406s-416s, 1995.

${ }^{6}$ BRANDI, S. Estudo da soldabilidade do Aço Inoxidável Duplex DIN W. Nr. 1.4462 (UNS S31803). São Paulo, 1992, 265p. Tese (Doutorado) - Departamento de Eng. Metalúrgica, Escola Politécnica, Universidade de São Paulo.

${ }^{7}$ GRANJON, H. Fundamentals of Welding Metallurgy. Abinton Publishing, England, 1991.

${ }^{8}$ LANCASTER, J.F. Metallurgy of Welding. Ed. Chapman \& Hall, London, fifth ed., p. 389, 1993.

${ }^{9}$ KRAUS, H.G. Experimental measurement of stationary SS 304 , SS $316 \mathrm{~L}$ and 8630 GTAW weld pool surface temperatures. Welding Journal. v. 68, n. 7, p. 269s-279s, 1989.

${ }^{10} \mathrm{KUO}, \mathrm{S}$.; SUN, D.K. Fluid flow and weld penetration in stationary arc welds. Metallurgical Transactions A. v. 16A, n. 2, p. 203-213, 1985.

11 GLICKSTEIN, S.S.; FRIEDMAN, E.; YENISCAVICH, W. Investigation of alloy 600 welding parameters. Welding Journal. v. 54, n. 4, p. 113s-122s, 1975.

${ }^{12} \mathrm{KEY}$, J.F. Anode/cathode geometry and shielding gas interrelationship in GTAW. Welding Journal. v. 59 , n. 12 , p. 364s-370s, 1980.

${ }^{13}$ WELLS, A.A. Heat flow in welding. Welding Journal. v. 31, n. 5, p. 263s-267s, 1952.

${ }^{14}$ EASTERLING, K. Introduction to the Physical Metallurgy of Welding. Ed. Butterworths, London, p. 231, 1983.

15 TSAI, C.L.; TSO, C.M. Heat flow in fusion welding. In: Welding, Brazing and soldering, ASM Handbook, v. 6, 10 ed, ASM International, USA, p. 7-18, 1993.

${ }^{16}$ ROSENTHAL, D. The theory of moving sources of heat and its application to metal treatments. Transactions of the ASME. v. 68, November, p. 849-866, 1946.

${ }^{17}$ GRONG, O. Metallurgical Modeling of Welding. The Institute of Materials, London, p. 77-80, 1994.

${ }^{18}$ ADAMS, C.M. Cooling rates and peak temperatures in fusion welding. Welding Journal. v. 37, n. 5 , p. 210s-215s, 1958.

19 JHAVERI, P.; MOFFATT W.G.; ADAMS, C.M. The effect of plate thickness and radiation on heat flow in welding and cutting. Welding Journal. v. 41, n. 1, p. 12s-16s, 1962.

${ }^{20}$ SOLOMON, H.D.; DEVINE, T.M. A tale of two phases. In: Conference Duplex Stainless Steels'82, St. Louis-USA, 1982. Proceedings. Ohio, American Society of Metals, 1983, p. 693-756.

${ }^{21}$ CHARLES, J. Structure and mechanical properties of duplex stainless steels. In Conference Duplex Stainless Steels'94, Glasgow-Scotland, 1994. Proceedings. England, TWI, 1994, paper K1.

${ }^{22}$ CHARLES, J. Why and where duplex stainless steels. In: Conference Duplex Stainless Steels'97, Maastrisht-The Netherlands, 1997. Proceedings. The Netherlands, 1997, p. $29-42$.

${ }^{23}$ SOUTHWICK, P.D.; HONEYCOMBE, W.K. Decomposition of ferrite to austenite in $26 \% \mathrm{Cr}-5 \% \mathrm{Ni}$ stainless steel. Metal Science. v. 14, n. 7, p. 253-261, 1980.

${ }^{24}$ ATAMERT, S.; KING, J.E. Elemental partitioning and microstructural development in duplex stainless steel weld metal. Acta Metall. Mater. v.39, n. 3, p. 273-285, 1991.

${ }^{25}$ CHARLES, J. Super duplex stainless steels: structure and properties. In: Conference Duplex Stainless Steels'91, Beaune Bourcogne-France, 1991. Proceedings. France, 1991, p. 3-48. 
${ }^{26}$ NORBERG, P. Applicability of duplex stainless steels above $300^{\circ} \mathrm{C}$. In: Conference Duplex Stainless Steels'86, The Hauge-The Netherlands, 1986. Proceedings. The Netherlands, Nederlands Institut Voor Lastechniek, 1986, p. 298-302.

${ }^{27}$ RAVINDRANATH, K.; MALHOTRA, S.N. The influence of aging on the intergranular corrosion of 22 Cr-5Ni duplex stainless steel. Corrosion Science. v. 37, n. 1, p. 121-132, 1995.

${ }^{28}$ BERNHARDSSON, S. The corrosion resistance of duplex stainless steels. In: Conference Duplex Stainless Steels'91, Beaune Bourcogne-France, 1991. Proceedings. France, 1991, p. 185-210.

${ }^{29}$ NILSSON, J.O. Superduplex stainless steels. Materials Sc. and Tech. v. 8, n. 8, p. 685-700, 1992.

${ }^{30}$ NICHOLLS, J.M. Corrosion properties of duplex stainless steels: General corrosion, pitting and crevice corrosion. In: Conference Duplex Stainless Steels'94, Glasgow-Scotland, 1994. Proceedings. England, TWI, 1994, paper KIII.

${ }^{31}$ BAVAY, J.C.; BOULET, J.M.; CASTEL, J. Laboratory tests showing the high corrosion resistance of new cold rolled duplex stainless steels. In: Conference Duplex Stainless Steels'86, The HaugeThe Netherlands, 1986. Proceedings. The Netherlands, Nederlands Institut Voor Lastechniek, 1986, p. 407-415.

${ }^{32}$ CHARLES, J. Structure and mechanical properties of duplex stainless steels. In Conference Duplex Stainless Steels'94, Glasgow-Scotland, 1994. Proceedings. England, TWI, 1994, paper K1.

${ }^{33}$ NILSSON, J.O.; JONSSON, P.; WILSON, A. Formation of secondary austenite in superduplex stainless steel weld metal and its dependence on chemical composition. In: Conference Duplex Stainless Steels'94, Glasgow-Scotland, 1994. Proceedings. England, TWI, 1994, paper 39.

${ }^{34}$ NILSSON, J.O.; KARLSSON, L.; ANDERSSON, J.O. Formazione ed effetto dell'austenite secondaria nei cordoni di saldatura di acciai inossidabili duplex e superduplex. L' acciaio Inossidabile. $n$. 1, p. 18-22, 1994.

${ }^{35}$ SOLOMON, H.D. Age hardening in a duplex stainless steel. In: Conference Duplex Stainless Steels'82, St. Louis-USA, 1982. Proceedings. Ohio, American Society of Metals, 1983, p. 4169.

${ }^{36}$ ATAMERT, S.; KING, J.E. Intragranular nucleation of austenite. Z. Metallkde. v. 82, n. 3, p. 230239, 1991.

37 THORVALDSSON, T. et al. Influence of microstructure on mechanical properties of a duplex stainless steel. In: Conference Stainless steels'84, Göteborg, 1984. Proceedings. London, The Institute of Metals, 1985, p. 101-105.

${ }^{38}$ KIM, S.J.; MARQUART, T.; FRANZEN, H.F. Structure refinement of $\mathrm{Cr}_{2} \mathrm{~N}$. Journal of Less-Common Metals. v. 158, p. L9-L10, 1990.

${ }^{39}$ BYWATER, K.A.; DYSON, D.J. The precipitation of $\mathrm{Cr}_{2} \mathrm{~N}$ in $17 \% \mathrm{Cr}$ steel. Metal Science. v. 9, p. 155-162, 1975.

40 TURKDOGAN, E.T.; IGNATOWICZ, S. The solubility of nitrogen in iron-chromium alloys. Journal Iron Steel Institute. v. 188, n. 3, p. 242-247, 1958.

${ }^{41}$ HERTZMAN, S.; ROBERTS, W.; LINDENMO, M. Microstructure and properties of nitrogen alloyed duplex stainless steel after welding treatments. In: Conference Duplex Stainless Steels'86, The Hauge-The Netherlands, 1986. Proceedings. The Netherlands, Nederlands Institut Voor Lastechniek, 1986, p. 257-267.

${ }^{42}$ NILSSON, J.O.; LIU, P. Aging at $400-600^{\circ} \mathrm{C}$ of submerged arc welds of $22 \mathrm{Cr}-3 \mathrm{Mo}-8 \mathrm{Ni}$ duplex stainless steel and its effect on toughness and microstructure. Materials Sc. and Tech. v. 7, n. 9, p. 853-862, 1991.

${ }^{43}$ WEISS, B.; STICKLER, R. Phase Instabilities during high temperature exposure of 316 austenitic stainless steel. Metallurgical Transactions. v. 3, n. 4, p. 851-866, 1972.

${ }^{44}$ LEWIS, H.; HATTERSLEY, B. Precipitation of $\mathrm{M}_{23} \mathrm{C}_{6}$ in austenitic steels. Acta Metallurgica. v. 13, n. 11, p. 1159-1168.

${ }^{45}$ HALL, E.O.; ALGIE, S.H. The sigma phase. Metallurgical Reviews. v. 11, p. 61-88, 1966.

${ }^{46}$ BERGMAN, B.G.; SHOEMAKER, D.P. The space group of the $\sigma-\mathrm{FeCr}$ crystal structure. Journal of the Chemical Physics. v. 19, n. 4, p. 515, 1951. 
${ }^{47}$ SOYLU, B.; HONEYCOMBE, W.K. Microstructural refinement of duplex stainless steels. Materials Sc. and Tech. v. 7, n. 2, p. 137-145, 1991.

${ }^{48}$ VRINAT, M.; COZAR, R.; MEYZAUD, Y. Precipitated phases in the ferrite of aged cast duplex stainless steels. Scripta Metallurgica. v. 20, n. 8, p. 1101-1106, 1986.

${ }^{49}$ REDJAIMIA, A.; METAEUR, G.; GANTOIS, M. Decomposition of delta ferrite in a Fe-22Cr-5Ni-3Mo$0.03 \mathrm{C}$ duplex stainless steel. A morphological and structural study. In: Conference Duplex Stainless Steels'91, Beaune Bourcogne-France, 1991. Proceedings. France, 1991, p. 119-126.

${ }^{50}$ KOMURA, Y.; SLY, W.; SHOEMAKER, D.P. The crystal structure of the R phase, Mo-Co-Cr. Acta Crystallographica. v. 13, n. 8, p. 575-585.

${ }^{51}$ REDJAIMIA, A. et al. Identification and characterization of a novel intermetallic compound in a Fe$22 \% \mathrm{Cr}-5 \% \mathrm{Ni}-3 \% \mathrm{Mo}-0,3 \% \mathrm{C}$ duplex stainless steel. Philosophical Magazine A. v. 67, n. 5 , p. 1277-1286, 1993.

${ }^{52}$ RAMÍREZ-LONDOÑO, A.J. Estudo da Precipitação de Nitreto de Cromo e Fase Sigma por Simulação Térmica da Zona Afetada Pelo Calor na Soldagem Multipasse de Aços Inoxidáveis Duplex. São Paulo, 1997. Dissertação (Mestrado) - Departamento de Eng. Metalúrgica, Escola Politécnica, U. de São Paulo.

${ }^{53}$ NILSSON, J.O.; WILSON, A. Influence of isothermal phase transformations on toughness and pitting corrosion of super duplex stainless steel SAF 2507. Materials Science and Technology. v. 9, n. 7, p. 545-554, 1993.

${ }^{54}$ VAN-NASSAU, L.; MEELSKER, H.; NEESSEN, F.; HILKES, J. Welding duplex and superduplex stainless steel. In: Conference Duplex Stainless Steels'97, Maastrisht-The Netherlands, 1997. Proceedings. The Netherlands, 1997, p. 17-28.

${ }^{55}$ GINN, B.J.; GOOCH, T.G. Effect of intermetallic content on pitting resistance of ferritic-austenitic stainless steels. TWI Document. \# IX-H-444-99 - IX-1946-99, p.p. 9, 1999.

${ }^{56}$ SIMMONS, J.W. Overview: high-nitrogen alloying of stainless steels. Materials Science and Engineering A. v. A207, p. 159-169, 1996.

${ }^{57}$ SERVI, I.S.; FORGENG, W.D. Metallurgical observations of nitrides in chromium. Journal of the Institute of Metals. v. 88, n. 4, p. 164-167, 1959.

${ }^{58}$ KOKAWA, H.; TSORY, E.; NORTH, T.H. Nitride precipitation in duplex stainless steels weld metal. ISIJ International. v. 35, n. 10, p. 1277-1283, 1995.

${ }^{59}$ SIMMONS, J.W. et al. Effect of nitride $\left(\mathrm{Cr}_{2} \mathrm{~N}\right)$ precipitation on the mechanical, corrosion and wear properties of austenitic stainless steel. ISIJ International. v. 36, n. 7, p. 846-854, 1996.

${ }^{60} \mathrm{KIKUCHI}, \mathrm{M}$.; KAJIHARA, M.; FRISK, K. Solubility of nitrogen in austenitic stainless steels. In: Conference high nitrogen steels'88, Lille-France, 1988. Proceedings. Ed. J. Foct - A. Hendry, France, 1989, p. 63-74.

${ }^{61}$ BRANDI, S.D.; RAMÍREZ, A.J. Precipitation of intermatallic phases in the HAZ of multipass welding of duplex and superduplex stainless steels. In: International Conference Duplex Stainless Steels'97, Maastricht-The Netherlands, 1997. Proceedings. The Netherlands, KCl, 1997, p. 411-418.

62 RAMÍREZ, A.J; BRANDI, S.D. Intermetallic phases precipitation in simulated multipass low temperature heat-affected zone of Duplex Stainless Steels In: 79th American Welding Society Annual Meeting, April 26-30, 1998, Detroit, Michigan, Proceedings. USA, AWS, 1998, p. 220221.

${ }^{63}$ RADEMAKERS, P.L.F.; VUIK, J. Factors influencing microstructure and properties of weldments in duplex stainless steels. In: Conference Joining/Welding 2000, The Hauge-The Netherlands, 1991. Proceedings. London, IIW, 1991, p. 253-270.

${ }^{64}$ LILJAS, M.; QVARFORT, R. Influence of nitrogen on weldments in UNS S 31803. In: Conference Duplex Stainless Steels'86, The Hauge-The Netherlands, 1986. Proceedings. The Netherlands, Nederlands Institut Voor Lastechniek, 1986, p. 244-256.

${ }^{65}$ VAN-NASSAU, L.; MEELKER, H.; HILKES, J. Welding duplex and superduplex stainless steels. In: Conference Duplex Stainless Steels'91, Beaune Bourcogne-France, 1991. Proceedings. France, 1991, p. 303-323. 
${ }^{66}$ FOCT, J.; MAGNIN, T.; PERROT, P.; VOGT, J.B. Nitrogen alloying of duplex stainless steels. In: Conference Duplex Stainless Steels'91, Beaune Bourcogne-France, 1991. Proceedings. France, 1991, p. 49-65.

${ }^{67}$ KOMIZO, Y.; OGAWA, K.; AZUMA, S. HAZ embrittlement in high Cr-Mo duplex stainless steel and the effects of $\mathrm{Ni}$ and $\mathrm{N}$. Welding International. v. 5, n. 4, p. 277-282, 1991.

68 JOSEFSSON, B.; NILSSON, J.O.; WILSON, A. Phase transformations in duplex steels and the relation between continuous cooling and the isothermal heat treatment. In: Conference Duplex Stainless Steels'91, Beaune Bourcogne-France, 1991. Proceedings. France, 1991, p. 67-78.

${ }^{69}$ CHUNG, H.M.; LEAX, T.R. Embrittlement of laboratory and reactor aged CF3, CF8 and CF8M duplex stainless steels. Materials Science and Technology . v. 6, n. 3, p. 249-262, 1990.

${ }^{70}$ KAJIMURA, H.; OGAWA, K.; NAGANO, $\mathrm{H}$. Effects of $\alpha / \gamma$ phase ratio and $\mathrm{N}$ addition on the corrosion resistance of Si-bearing duplex stainless steel in nitric acid. ISIJ International. v. 31, n. 2, p. 216-222, 1991.

${ }^{71}$ RAMÍREZ, A.J; BRANDI, S.D.; TANIGUCHI, C. Simulação da ZAC de uma solda multipasse de aços inoxidáveis duplex: Estudo da precipitação de fases e sua influência no desempenho da junta soldada. In: 23 Seminário de Inspeção de Equipamentos - COTEQ'97, IBP, Rio de JaneiroBrasil, 1997. Proceedings. Brasil, IBP, 1997, p. 201-204.

${ }^{72}$ HOFFMEISTER, H.; LOTHONGKUM, G. Quantitative effects of nitrogen contents and cooling cycles on $\delta$ - $\gamma$ transformation, chromium nitride precipitation and pitting corrosion after weld simulation of duplex stainless steels. In: Conference Duplex Stainless Steels'94, Glasgow-Scotland, 1994. Proceedings. England, TWI, 1994, paper 55.

73 LUNDGVIST, B.; NORBERG, P.; OLSSON, K. Influence of different welding conditions on mechanical properties and corrosion resistance of Sandvik SAF 2205 (UNS S31803). In: Conference Duplex Stainless Steels'86, The Hauge-The Netherlands, 1986. Proceedings. The Netherlands, Nederlands Institut Voor Lastechniek, 1986, p. 16-29.

${ }^{74}$ HOCHOERTLER, G.; KRISZT, K. Effect of sensitization on pitting corrosion of duplex stainless steels. In: Conference Duplex Stainless Steels'86, The Hauge-The Netherlands, 1986. Proceedings. The Netherlands, Nederlands Institut Voor Lastechniek, 1986, p. 114-120.

${ }^{75} \mathrm{UME}, \mathrm{K}$. et al. Influence of thermal history on the corrosion resistance of duplex stainless steel linepipe. Materials Performance. v. 26, n. 8, p. 25-31, 1987.

${ }^{76}$ ATAMERT, S.; KING, J.E. Super duplex stainless steels - part 1 heat affected zone microstructures. Materials Science and Technology. v. 8, n. 10, p. 896-911, 1992.

${ }^{77}$ CAO, H.L.; HERTZMAN, S. The relationship between impact properties and welding simulated microstructures in three duplex stainless steels. In: Conference Duplex Stainless Steels'91, Beaune Bourcogne-France, 1991. Proceedings. France, 1991, p. 363-372.

${ }^{78}$ LIPPOLD, J.C.; VAROL, I.; BAESLACK III, A. The influence of composition and microstructure on the $\mathrm{HAZ}$ toughness of duplex stainless steels at $-20^{\circ} \mathrm{C}$. Welding Journal. v. 73 , n. 4 , p. $75 \mathrm{~s}-79 \mathrm{~s}$, 1994.

${ }^{79}$ ENJO, T.; KURODA, T.; IMANISHI, R. Microstructure and toughness in weld heat-affected zone of duplex stainless steel. Transactions of JWRI. v. 17, n. 2, p. 105-111, 1988.

${ }^{80}$ MERINO, C. et al. Kinetic study of eutectoid transformation to $24 \% \mathrm{Cr} / 7 \% \mathrm{Ni}$ duplex stainless steel. In: Conference Duplex Stainless Steels'94, Glasgow-Scotland, 1994. Proceedings. England, TWI, 1994, paper 41.

${ }^{81}$ ATAMERT, S; KING, J.E. Sigma phase formation and its prevention in duplex stainless steels. Journal of Materials Science Letters. v. 12, p. 1144-1147, 1993.

${ }^{82}$ VITEK, J.M.; DAVID, S.A. The sigma phase transformation in austenitic stainless steels. Welding Journal. v. 65, n. 4, p. 106s-111s, 1986.

${ }^{83}$ SRUTT, A.J.; LORIMER, G.W. Structure property relationships of Zeron 100. In: Conference Duplex Stainless Steels'86, The Hauge-The Netherlands, 1986. Proceedings. The Netherlands, Nederlands Institut Voor Lastechniek, 1986, p. 310-318. 
${ }^{84}$ BRANDI, S.; PADILHA, A.F. Precipitação de fase sigma em aços inoxidáveis ferríticos-austeníticos com microestrutura duplex. In: II Seminário Brasileiro do Aço Inoxidável - Inox-90, Brasil, 1990. Proceedings. Brasil, 1990, p. 135-152.

${ }^{85}$ HERTZMAN, T. et al. Microstructure-property relations of Mo- and W-alloyed super duplex stainless weld metals. Materials Science and Technology. v. 13, n. 7, p. 604-613, 1997.

${ }^{86}$ NILSSON, J.O. et al. Structural stability of super duplex stainless weld metals and its dependence on tungsten and copper. Metallurgical and Materials Transactions A. v. $27^{A}$, n. 8 , p. 2196-2208, 1996.

${ }^{87}$ OKAMOTO, $\mathrm{H}$. The effect of tungsten and molybdenum on the performance of superduplex stainless steels. In: Conference applications of stainless steels'92, Stockholm, 1992. Proceedings. Stockholm, 1992, p. 360-369.

${ }^{88}$ KONDO, K.; UEDA, M.; OGAWA, K.; OKAMOTO, H.; IGARASHI, M. Precipitation behavior of sigmarelated phases in $25 \% \mathrm{Cr}$ based super duplex stainless steels. In: Conference Innovation stainless steel, Florence-Italy, 1993. Proceedings. p. 2.191-2.197.

${ }^{89}$ OH, B.W.; KIM, J.I.; JEONG, S.W.; KWON, H.S.; HONG, S.H.; KIM, Y.G. The influence of W on Corrosion resistance and sigma phase formation in duplex stainless steels. In: : Conference Innovation stainless steel, Florence-Italy, 1993. Proceedings. p. 3.59-3.64.

${ }^{90}$ SHIRLEY, H.T. Microstructural characteristics of acid corrosion in $18 \% \mathrm{Cr}, 8-14 \% \mathrm{Ni}, 3 \% \mathrm{Mo}$ steels. Journal of the Iron steel Institute. v. 174, n. 3, p. 242-249, 1953.

91 TRUMAN, J.E.; PIRT, K.R. Properties of a duplex stainless steel and effects of thermal history. In: Conference Duplex Stainless Steels'82, St. Louis-USA, 1982. Proceedings. Ohio, American Society of Metals, 1983, p. 113-141.

${ }^{92}$ KOLTS, J. Properties of ferralium alloy 255 duplex austenitic-ferritic stainless steel for sour gas well applications. In: Conference Duplex Stainless Steels'82, St. Louis-USA, 1982. Proceedings. Ohio, American Society of Metals, 1983, p. 233-246.

${ }^{93}$ HAGEN, V.; KELLER, M. Interrelation between fabrication processes and mechanical properties of AF 22 duplex stainless steel tubes. In: Conference Duplex Stainless Steels'82, St. Louis-USA, 1982. Proceedings. Ohio, American Society of Metals, 1983, p. 325-353.

${ }^{94}$ NORSTRÖM, L.A.; PETTERSSON, S.; NORDIN, S. $\sigma$-Phase embrittlement in some ferritic-austenitic stainless steels. Z. Werkstofftech. v. 12, p. 229-234, 1981.

${ }^{95}$ RAMIREZ, A.J.; BRANDI, S.D.; LIPPOLD, J.C. HAZ Precipitação de austenita secundária na ZAC de soldas multipasse de aços inoxidáveis duplex: Estudo a partir de microestruturas simuladas. In: XXV Encontro Nacional de Técnologia da Soldagem, Curitiba-PR, 2000. Proceedings. Brazil, ABS, 2000.

${ }^{96}$ RAMIREZ, A.J.; BRANDI, S.D.; LIPPOLD, J.C. HAZ secondary austenite formation in duplex stainless steels during multipass welding. In: 81th Annual AWS Convention, Chicago-IL, 2000. Proceedings. USA, AWS, 2000.

${ }^{97}$ BRANDI, S.D.; LIPPOLD, J.C.; LIN, W. The corrosion resistance of simulated multipass welds of duplex and super-duplex stainless steels. In: Conference Duplex Stainless Steels'97, MaastrishtThe Netherlands, 1997. Proceedings. The Netherlands, 1997, p. 411-418.

${ }^{98}$ LIPPOLD, J.C.; AL-RUMAIH, A.M. Toughness and pitting corrosion of duplex stainless steel weld heat-affected zone microstructures containing secondary austenite. In: Conference Duplex Stainless Steels'97, Maastrisht-The Netherlands, 1997. Proceedings. The Netherlands, 1997, p. 1005-1010.

${ }^{99}$ LEE, K.M.; CHO, H.S.; CHOI, D.C. Effect of isothermal treatment of SAF 2205 duplex stainless steel on migration of $\alpha / \gamma$ interface boundary and growth of austenite. Journal of Alloys and Compounds. v. 285, p. 156-161, 1999.

100 OHMORI, Y.; MAEHARA, Y. Precipitation of $\mathrm{M}_{23} \mathrm{C}_{6}$ and $\sigma$-phase in $\delta / \gamma$ duplex stainless steels. Transactions ISIJ. v. 24, p. 60-68, 1984.

101 KURODA, T.; MATSUDA, F. Role of secondary austenite on corrosion and stress corrosion cracking of sensitized duplex stainless steel weldments. Transactions JWRI. v. 23, n. 2, p. 205-211, 1994. 
${ }^{102}$ NILSSON, J.O.; KARLSSON, L.; ANDERSSON, J.O. Secondary austenite formation and its relation to pitting corrosion in duplex stainless steel weld metal. Materials Sc. and Tech. v. 11, n. 3, p. 276-283, 1995.

${ }^{103}$ AL-RUMAIH, A.M. Secondary Austenite Formation in Duplex Stainless Steel Welds and Its Influence on Toughness and Corrosion. Columbus(OH), 1997. 162p. M.Sc. Thesis - Welding Eng. Program, The Ohio State University.

${ }^{104}$ AARONSON, H.I. The proeutectoid ferrite and the proeutectoid cementite reactions. In: Symposium Decomposition of Austenite by Difusional Processes, Philadelphyia-USA, 1960. Proceedings. Easton-USA, American Institute of Mining, Metallurgical and Petroleum Eng., 1962, p. 387-546.

105 MENON, E.S.K; AARONSON, H.I. Morphology, crystallography and kinetics of simpathetic nucleation. Acta Metall. v. 35, n. 3, p. 549-563, 1987

${ }^{106}$ ROSCOE, C.V.; GRADWELL, K.J.; LORIMER, G.W. Structure/property relationships in a series of duplex stainless steels. In: Conference Stainless steels'84, Göteborg, 1984. Proceedings. London, The Institute of Metals, 1985, p. 563-577.

107 VAROL, I.; LIPPOLD, J.C.; BAESLACK III, W.A. Welding of duplex stainless steels. Key Engineering Materials. v. 69-70, p. 217-252, 1992.

${ }^{108}$ RAMÍREZ-LONDOÑO, A.J.; BRANDI, S.D. Estudo da adição de nitrogênio no gás de proteção na soldagem de aço inoxidável duplex UNS S31803. In: XXII Encontro Nacional de Tecnologia da Soldagem, Blumenau-Brasil, 1996. Proceedings. São Paulo-Brasil, Associação Brasileira de Soldagem, 1996, p. 277-287.

${ }^{109}$ RAMÍREZ, A.J.; BRANDI, S.D. Efeito da adição de nitrogênio no gás de proteção na soldagem do aço inoxidável duplex UNS S31803. Soldagem \& Inspeção - Suplemento Técnico. v. 3, n. 4, p. 1-9, 1997.

${ }^{110}$ BONNEFOIS, B.; SOULIGNAC, P.; CHARLES, J. Some aspects of nitrogen introduction in duplex weld pool. In: Conference Duplex Stainless Steels'91, Beaune Bourcogne-France, 1991. Proceedings. France, 1991, p. 469-478.

${ }^{111}$ ATAMERT, S.; KING, J.E. Super duplex stainless steels - part 1 heat affected zone microstructures. Materials Sc. and Tech.. v. 8, n. 10, p. 896-911, 1992.

112 LILJAS, M. The welding metallurgy of duplex stainless steels. In: Conference Duplex Stainless Steels'94, Glasgow-Scotland, 1994. Proceedings. England, TWI, 1994, paper KV.

113 VAROL, I. Microstructure/Property Relationships in the Weld Heat Afected Zone of Duplex stainless Steels. Columbus $(\mathrm{OH}), 1992$, p. 261. Dissertation (Ph.D.) - Department of Welding Engineering, The Ohio State University.

114 KIVINEA, E.I.; HANNERZ, N.E. The properties of Gleeble simulated heat affected zone of SAF 2205 and SAF 2507 duplex stainless steels. In: Conference Duplex Stainless Steels'94, GlasgowScotland, 1994. Proceedings. England, TWI, 1994, paper 7.

115 SVENSSON, L.E.; GRETOFT, B. Properties-microstructure relationship for duplex stainless steel weld metals. In: Conference Duplex Stainless Steels'86, The Hauge-The Netherlands, 1986. Proceedings. The Netherlands, Nederlands Institut Voor Lastechniek, 1986, p. 288-294.

116 SERNA, C.P.; RAMIREZ, A.J.; BRANDI, S.D. Precipitação de fases intermetálicas e Cr2N na ZACTB durante a soldagem multipasse dos aços inoxidáveis duplex UNS S32304, UNS S32750 e UNS S32760. In: XXV Encontro Nacional de Técnologia da Soldagem, Curitiba-PR, 2000. Proceedings. Brazil, ABS, 2000.

117 SAVAGE, W.F. et al. Microsegragation in partially melted regions of $70 \mathrm{Cu}-30 \mathrm{Ni}$ weldments. Welding Journal. v. 55, n. 7, p. 181s-187s, 1976.

118 SAVAGE, W.F.; ARONSON, A.H. Preferred orientation in the weld fusion zone. Welding Journal. v. 45, n. 2, p. 85s-89s, 1966.

119 ATAMERT, S.; KING, J.E.; REED, R.C. Reheated regions in duplex stainless weldments. In: Conference International Trends in welding Science and Technology, Gatlinburg-TennesseeUSA, 1992. Proceedings. USA, ASM, 1992, p. 241-245.

${ }^{120}$ RAMÍREZ, A.J.; BRANDI, S.D. Estudo da precipitação de fases intermetálicas na ZAC de soldas multipasse de aços inoxidáveis duplex e superduplex. In: V Seminário Brasileiro do Aço 
Inoxidável - Inox'96, São Paulo-Brasil, 1996. Proceedings. Brasil, Núcleo Inox, 1996, p. 187200.

${ }^{121}$ VAN NASSAU, L. et al. Welding duplex and super-duplex stainless steel piping and components. In: Conference Joining/Welding 2000, The Hauge-The Netherlands, 1991. Proceedings. London, IIW, 1991, p. 271-284.

${ }^{122}$ BRANDI, S.D.; LIPPOLD, J.C.; LIN W. Effect of interpass temperature on the heat-affected zone performance of simulated multipass welds in duplex and superduplex stainless steels. EWI Sumary Report No. SR 9707. Edison Welding Institute, Columbus-Ohio, November, 1997.

${ }^{123}$ RYKALIN, N.N. Berechnung der Wärmevorgänge beim Schweissen. VEB Verlag Technik, Berlin, 1953.

${ }^{124}$ HULL, F.C. Delta ferrite and martensite formation in stainless steels. Welding Journal. v. 52, n. 5 , p. 193s-203s, 1973.

${ }^{125}$ ESPY, R.H. Weldability of nitrogen-strengthened stainless steels. Welding Journal. v. 61, n. 5, p. 149s-156s, 1982.

${ }^{126}$ KOTECKI, D.J.; SIEWERT, T.A. WRC-1992 constitution diagram for stainless steel weld metal. Welding Journal. v. 52, n. 7, p. 171s-178s, 1992.

127 SAVAGE, W.F.; NIPPES, E.F.; GOODWIN, G.M. Effect of minor elements on hot-cracking tendencies of Inconel 600. Welding Journal. v. 56, n. 8, p.245s-253s, 1977.

${ }^{128}$ SAVAGE, W.F.; NIPPES, E.F.; MUSHALA, M.C. Copper -contamination cracking in the weld heataffected zone. Welding Journal. v. 57, n. 5, p. 145s-152s, 1978.

${ }^{129}$ SAVAGE, W.F.; NIPPES, E.F.; MUSHALA, M.C. Copper-contamination cracking in the weld heataffected zone. Welding Journal. v. 57, n. 8, p. 237s-245s, 1978.

${ }^{130}$ DAHMEN, U. Orientation relationships in precipitation systems. Acta Metallurgica. v. 30, n. 1, p. 6373, 1982.

${ }^{131}$ KOBAYASHI, S.; NAKAI, K.; OHMORI, Y. Isothermal decomposition of ferrite in a $25 \mathrm{Cr}-7 \mathrm{Ni}-0.14 \mathrm{~N}$ stainless steel. Acta Materialia. v. 49, p. 1891-1902, 2001.

132 SERNA-GIRALDO, C.P. Precipitação de Fases Intermetálicas na Zona Afetada Pelo Calor de Baixa Temperatura na Soldagem Multipasse de Aços Inoxidáveis Duplex. São Paulo, 2001. Dissertação (Mestrado) - Departamento de Eng. Metalúrgica, Escola Politécnica, U. de São Paulo.

133 RAYAPROLU, D.B.; HENDRY, A. Cellular precipitation in a nitrogen alloyed stainless steel. Materials Science and Technology. v. 5, n. 4, p. 328-332, 1989.

${ }^{134}$ PORTER, D.A.; EASTERLING, K.E. Phase Transformations in Metals and Alloys. $2^{\text {nd }}$ Edition, Ed. Chapman \& Hall, Great Britain, p. 514, 1992.

${ }^{135}$ DEVINE, T.M. Influence of carbon content and ferrite morphology on the sensitization of duplex stainless steel. Metallurgical Transactions A. v. 11A, n. 5, p. 791-880, 1980.

${ }^{136}$ SOUTHWICK, P.D.; HONEYCOMBE, W.K. Precipitation of $\mathrm{M}_{23} \mathrm{C}_{6}$ at austenite/ferrite interfaces in duplex stainless steel. Metal Science. v. 16, n. 10, p. 475-481, 1982.

137 GAVRILJUK, V.G.; BERNS, H. High Nitrogen Steels: Structure, Properties, Manufacture, Applications. Ed. Springer, Germany, p. 378, 1999.

138 HONEYCOMBE, R.W.K.; BHADESHIA, H.K.D.H. Steels Microstructure and Properties. 2on Edition. Ed. Arnold, Great Britain, p. 145, 1995.

${ }^{139}$ AARONSON, H.I.; LAIRD, C.; KINSMAN, K.K. Phase Transformations. American Society of Metals, Metals Park-OH, USA, Chapter 8, 1970

140 VANDER VORT, G.F. Visual Examination and Light Microscopy. In: Fractography, Metals Handbook, v. 12, $9^{\text {th }}$ ed. ASM International, USA, p. 104-105, 1987.

${ }^{141}$ CETLIN, P.R.; PEREIRA, P.S. Análise de Fraturas. 2a. reimpressão, ed. ABS, Brasil, p. 229, 1979.

142 FLÜGGE, J. et. al. The Appearance of Cracks and Fractures in Metallic Materials. Ed. Stahleisen, Germany, p. 176, 1996. 